\title{
Floods of June 1964 in \\ Northwestern Montana
}

GEOLOGICAL SURVEY WATER-SUPPLY PAPER 1840-B

Prepared in cooperation with the State of Montana and agencies of the $F$ ederal Government

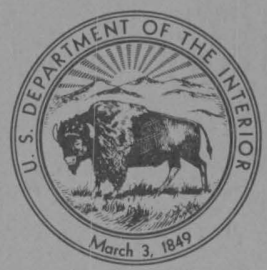




\section{Floods of June 1964 in Northwestern Montana}

By F C BONER and FRANK STERMITZ

FLOODS OF 1964 IN THE UNITED STATES

GEOLOGICAL SURVEY WATER-SUPPLY PAPER 1840-B

Prepared in cooperation with the State of Montana and agencies of the Federal Government

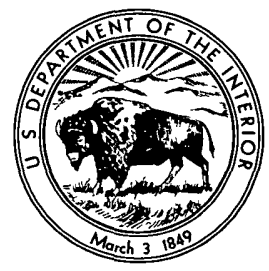




\section{UNITED STATES DEPARTMENT OF THE INTERIOR}

STEWART L. UDALL, Secretary

\section{GEOLOGIGAL SURVEY}

William T. Pecora, Director

For sale by the Superintendent of Documents, U S Government Printing Office Washington, D C 20402 - Price $\$ 150$ (paper cover) 


\section{CONTENTS}

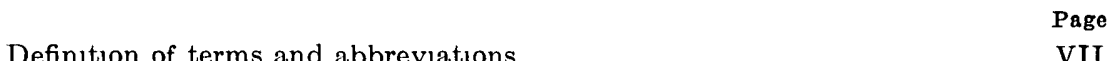

Abstract

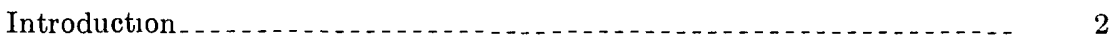

Acknowledgments. . . . .

Antecedent hydrologic conditions.

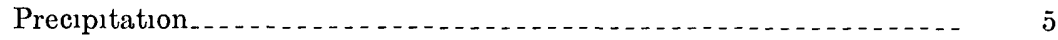

Temperature

Snow cover

Soll moisturc

Streamflow

Meteorological developments contributing to the flood, by R A Dightman.- 16

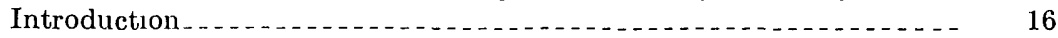

Synoptic features.

Rainfall pattern

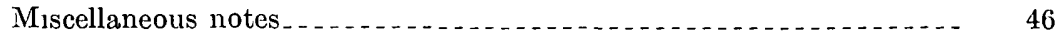

Meteorological comparison with previous floods_............. 47

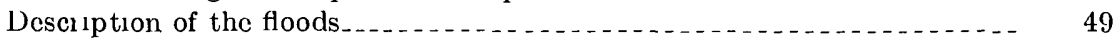

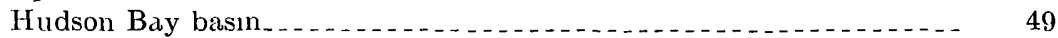

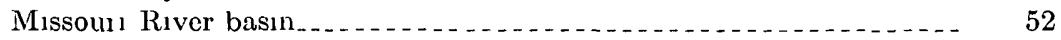

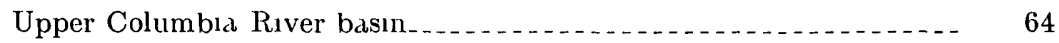

Evaluation of flood damage . . .

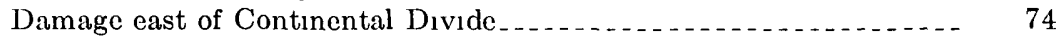

Rural damage

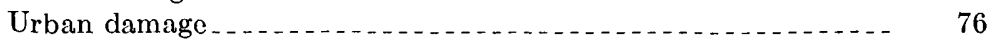

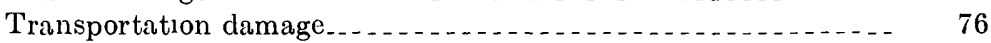

Damage west of Contınental Divide $\ldots \ldots \ldots$

Flood-crest stages . . .

Storage regulation

Records of previous floods........ 98

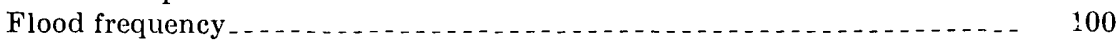

Erosion and deposition caused by floods of June $1964 \mathrm{~m}$ northwestern

Montana, by Richard F Hadley . . . . 115

Intioduction . . . . .

Ficldwork _......

General features of the flood area.

Location . . . . . .

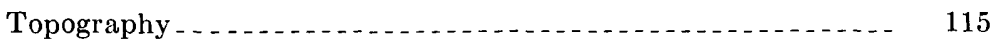

Geology

Physiography ......... 116

Erosional effects of the flood

Upland areas .

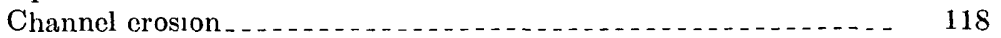


Erosion and deposition, etc - Continued Page

Detalled description of channel changes . . . . . . . . . . . . . . . B118

Skyland Creek near Essex, Mont...................... 118

Bear Creek near Essex, Mont . . . . . . . . . . . . . . . . . . 121

Middle Fork Flathead River at Essex, Mont_._._.

Two Medicine River near East Glacier, Mont._. . . . _... 124

North Fork Sun River near Augusta, Mont_........... 127

Teton River near Dutton, Mont_... . . . . . . . . . . . . . . 128

Deposition caused by falure of Swift Dam on Birch Creek . . . . . . 128

Determination of flood discharges............ 130

Summary of flood stages and discharges

Explanation of station data

Station data. . .

Selected references.

Index $\ldots \ldots \ldots 1$

\section{ILLUSTRATIONS}

Plate 1 Flood inundation map of Flathead River between Columbia Falls and Flathead Lake, Mont . . . . . . In pocket

FIGURE 1 Map showing area covered by this report ........ B2

2 Map of flood area showing location of flood-data sites.-- 3

3 Graph of accumulation of precipitation at four weather stations, May 1 to June 6, 1964.............

4 Chart of maximum and minimum temperatures at three weather stations, April to June 1964 ...............

5 Chart of mean dally and dally normal temperature, accumulated departure of mean dally and dally normal temperature from $32^{\circ} \mathbf{F}$, and dally precipitation, at Summit, March to June 1964 . . . . . . . . . . . . . . . . .

Map showing approximate locations of snow courses...-

7 Graph showing water equivalent of snow at selected snow courses.........................................

8 Hydrograph of discharge of Middle Fork Flathead River near West Glacier, March to June 1964 . . . . . . . . . . -

9 Hydrographs of discharge at selected gaging stations east of the Continental Divide, March to June 1964..-

10-12 Map showing-

10 500-millibar surface and sea-level pressure, 1700 hours, June 7, 1964....................

11500 -millibar surface and sea-level pressure, 0500 hours, June, 8 1964....................

12500 -millibar surface and sea-level pressure, 1700

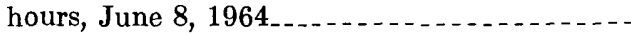

13 Isohyetal chart for June 7-8, 1964_. . . . . . . . . . . . .

14 Plot of windflow from Gulf of Mexico into Montana..--

15 Mass curves of accumulation of precipitation 
Figure 16 Diagram showing concept of a precipitation-releasing

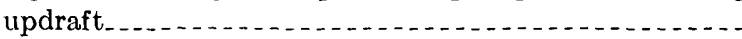

17 Plot of Glasgow radiosonde observation, 1700 hours, June 7, 1964 ......................................

18 Aerial photograph of silt and debris deposits by Divide Creek at resort town of St Mary ................

19 Hydrographs of discharge at selected gaging stations in Hudson Bay basin...........................

20 Aerial photograph of flow over parapet of Gibson Dam on June 9, 1964

21 Aerial photograph of inundation of the town of Sun River on June 10, 1964

23 Aerial photograph of city of/Great Falls at 1010 hours, June 10, 1964 ............ 57

24 Stage hydrographs of Missouri and Sun Rivers.........

25 Flood mundation map of Choteau . . . . . . . . . . . .

26 Acrial photograph of city of Choteau.

27-30 Aerial photograph showing-

27 Remains of Swift Dam lookıng downstream from reservolr area.....................

28 Remains of Lower Two Medicıne Lake Dam ...

29 Damage to Badger Creek bridge on US Highway 89

30 Marias River flooding US Highway 91 south of Shelby .....

31-33 Hydrograph showing-

31 Discharge at selected gaging stations in Missourı River basin . . . . . . . . . . . . . . . . .

32 Discharge at selected gaging stations on the Missouri River........................

33 Discharge at selected gaging stations on Blackfoot River and Clark Fork..............

34-37 Act ial photograph showing-

34 Damage to U S Highway 2 along Bear Creck - -

35 Great Northern Railway tunncl along Middle Fork Flathead River.....................

36 Debris deposits at mouth of Moccasin Creek near West Glacier . . . . . . . . . . . . . .

37 Flooded Evergreen area east 'of Kalıspell.......

38 Hydrographs of discharge at selected gaging stations in

Flathead River basın........................

39-45 Profile of flood-crest elevations

39 Sun River basin ....................... 91

40 Teton River. 92

41 Flathead Rivel

42 Middle Fork Flathead River basın........... 93

43 Stillwater River basin . . . . . . . . . . . . . . . . . 94

44 Swan River.

45 Flathead River between Columbic Falls and Flathead Lake.....................

46 Map showing flood-frequency regions and hydrologic areas 
Figdre 47-56 Graph showing relation of 1964 peak discharge to 10Pago and 50-year floods

47 Hudson Bay basın

48 Region $\mathrm{A}$, area 1

49 Region $A$, area 2

105

50 Region $\mathrm{A}$, area 4

105

51 Region $\mathrm{B}$, area 1

106

52 Region $\mathrm{B}$, area 2

107

53 Region B, area 3

108

54 Region B, area 4

109

55 Region $\mathrm{B}$, area 8

110

56 Missourı River main stem

110

57 Flood-frequency curves for selected stations in upper Columbia River basin

58-60 Graph showing relation of unit discharge to drainage area

58 Hudson Bay and Missourı River basıns.........

59 Upper Columbia River basın.................

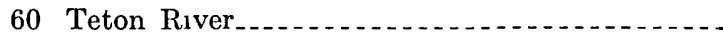

61 Photograph of Moccasin Creek near West Glacier, Mont, showing debris moved down steep mountain slopes by flood.

62 Channel cross section on Moccasin Creek near West

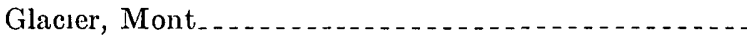

63 Channel cross sections on Skyland Creck near Essex, Mont, and on Bear Creek near Essex ...........

64-67 Photograph of

64 Gaging station on Skyland Creek near Essex,

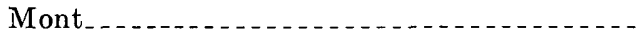

65 Gaging station on Bear Creek near Essex, Mont, lookıng upstream, June 26, 1948 . . . . . . . . .

66 Beal Creck near the gaging-station site on September 5, 1964, showing erosion along channel sides

67 Flood plain of Middle Fork Flathead River at Essex, Mont, showing deposition of finegrained material in Forest Service campground . . . . . . . . . . . . . . .

68 Channel cross section on Two Medicıne River near East Glacier, Mont.

69 Photographs of gaging station on Two Medicine River near East Glacier, Mont.

70 Closeup photograph of cobbles that were transported onto flood plain of Two Medicine River near East Glacier, Mont, by the flood.

71 Channel cross section on North Fork Sun River near

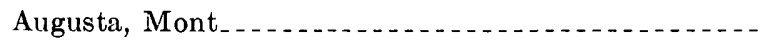

72 Channel cross section on Teton River near Dutton,

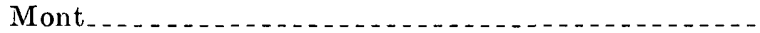

73 Photograph of block of earthfill material from Swift Dam on Birch Creek that was carried intact from the damsite about one-half mile by the flood 


\section{TABLES}

TABLE 1 Water equivalent of snow, in inches, at selected snow courses by basins.

Page

2 Water equivalent of snow by drainage basin, March-June 1964, as percentage of 1943-57 average.............

3 Precipitation data at U S Weather Bureau gages, storm of June 7-8, 1964

4 Supplementary precipitation data, storm of June $7-8$, 1964

5 Supplemental precipitation data from the Alberta, Canada, area north of the Montana boundary, storm of June $7-8,1964$.

6 Hourly precepitation data at U S Weather Bureau weighing rain gages, storm of June $7-8,1964 \ldots$

7 Summary of flood damage east of the Continental Divide.

8 Rural flood damage east of the Contınental Divide......

0 Urban flood damage east of the Contınental Divide......

10 Transportation flood damage east of the Continental

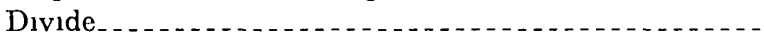

77

11 Summary of flood damage west of the Continental Divide -

12-17 Flood-crest stages -

12 Sun River basin . . .

13 Teton River......... 82

14 Flathead River......... 84

15 Middle Fork Flathead River basın........... 87

16 Stillwatel River basin.................... 89

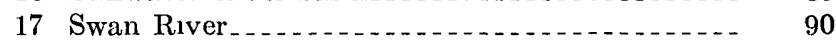

18 Flood-crest elevations on the Flathead River between

Kalispell and Flathead Lake.................. 90

19 Summary of flood stages and discharges. $\ldots \ldots \ldots \ldots . . . . . . .134$

\section{DEFINITION OF TERMS AND ABBREVIATIONS}

The terms and abbreviations of streamflow and other hydrologic data, as used in this report, are defined as follows

Gaging station is a particular site on a stream, canal, lake, or reservoir where sy stematic observations of gage height or discharge are obtained When used in connection with a discharge iecord, the term is apphed only to gaging stations where a continuous record of discharge is obtained

Crest-stage station is a particular site where limited streamflow data are collected systematically over a period of years for use in hydrologic analyses

Cubic foot per second (cfs) is the rate of discharge of a stream whose channel is 1 square foot in cross-sectional area and whose average velocity is 1 foot per second The volume of water represented by a flow of 1 cubic foot per second for 24 hours is equivalent to 86400 cublc feet 1983471 acre-feet, or 646317 gallons 
Cubic feet per second per square mile (cfs per $\mathrm{sq} \mathrm{ml}$ ) is the average number of cubic feet of watei flowing per second from each square mile of area drained, ascuming that the 1 unoff is distributed uniformly in time and area

Acre-foot (acre-ft) is the quantity of water required to cover an acre to a depth of 1 foot and in equiralent to 43.560 cubic feet or 325,851 gallons The term is usually used in relation to storage and rolume of 1 unoff

Runoff, in inches (in) is the depth to which the dranage area would be covered if all the 1 umoff tor a given time penod were uniformlv distributed on its surface

Drainage area of a stieam at a specified location is that area, measured in a hor izontal plane which $1>$ so enclosed bv a topographic divide that direct surface lunoff from precipitation nomalls would drain by gravity into the stream above the specified point Drandge area is expressed in square miles in this report

Contents is the volume of water in a reservoir or lake and is expressed in acre-feet Volume in computed on the bass of a lerel pool and does not include bank stor age

Stage-discharge relation is the relation between gage height and the iate of How

Time of das is expressed in 24-hour time, for example 1230 a m is 0030,130 l) 11 is 1330 All tmen noted are Mountain Standard Time 


\title{
FLOODS OF 1964 IN THE UNITED STATES
}

\section{FLOODS OF JUNE 1964 IN NORTHWESTERN MONTANA}

\author{
By F C Boner and Frank Stermitz
}

\begin{abstract}
Northwestern Montana had the most severe floods of record along both sides of the Continental Divide following heavy rains of June 7-8, 1964 Precipitation during the 36-hour storm period was as much as 14 inches Streams were already high from late snow melt iunoff Soll moisture was also favorable for high runoff rates

The principal streams aftected by the floods were the St Mary, Belly, and Waterton Rivers in the Hudson Bay basin, the Dearborn, Sun, Teton, and Marias Rivers in the Missouri River basin, and the Flathead River upstream from Flathead Lake in the Columbia River basin

Peak discharges on streams in the flood area ranged from about 2 to 115 times the probable 50-year flood The peak discharge of 5,740 cfs (cubic feet per second) of Street Creek at the international boundary, from 60 square miles of drainage area, was 103 times the 50-year flood On Teton River near Farmington the peak discharge $(54,600 \mathrm{cfs})$ was 115 times the 50-year flood from a drainage area of 105 square miles Maxımum discharge of Middle Fork Flathead River at Essex (75,300 cfs) was 39 times the 50-year flood and was 4 times the maximum discharge during the previous 25 years of record

The operation of irrigation and flood-control reservoirs did much to reduce flood peaks and damage, however, the fallure of Swift Dam on Birch Creek and Lower Two Medicine Dam on Two Medicine Creek caused complete destruction of numerous buldings and bridges along downstream reaches

Total flood damage in Montana was estımated at $\$ 55$ millon Thirty lives were lost, 350 persons were injured, and about 8,700 persons were evacuated during the highwater period Damage in excess of $\$ 1$ millon in Canada was reported

This report has been pı epared to furnish hydrologic data for detalled planning Included are discussions of antecedent hydrology and the meteorology of the storm, a description of the floods, information on flood damage, maps of pincipal urban inundation, flood profiles, discussions of storage regulation pievious floods, flood frequency, deposition and degradation of stream channels, and detailed information of stage, discharge, and reservoir contents for the May-June period
\end{abstract}




\section{INTRODUCTION}

Past records of peak flow, loss of life, and property damage were gieatly exceeded in the brief floods of June 1964 in northwestern Montalld Streams rose rapidly following precipitation of as much as 14 inches 11 a 36-hour period on June 7-8 The melt of mountam snow contributed to the peak flows The flood area, which lies along both sides of the Contmental Divide, is outlined in figure 1

'The legion of highest runoff is a rugged timbered mountain area that, on the eastern tront, rises abruptly from grassy glaciated plains and lon foothills of about 4,500 feet altitude to the Contmental Divide in a distance of 20 to 30 miles Sheer cliffs, hundreds of feet high, he just east of the crest. The western slopes are generally not as steep Numerous peaks of 7,000 teet to more than 9,000 feet altitude are tound throughout the entrre mountain area Marias Pass, lying at the southern edge of Glacier National Park, has an altitude of $., 2: 36$ feet The principal streams affected by the floods were the Iearborn, Sun, Teton, and Marıas Rivers in the Missourı River basin; the Flathead River above Flathead Lake in the Columbia River basm, and the St Mary, Belly, and Waterton Rivers in the Hudson Bay basin (fig 2)

Thity persons lost theil lives, nearly all durmg the rapid ise of streams on the mornmg of June 8 Damage to transpor tation facilit les accounted for more than half of the total damage of $\$ 55$ million.

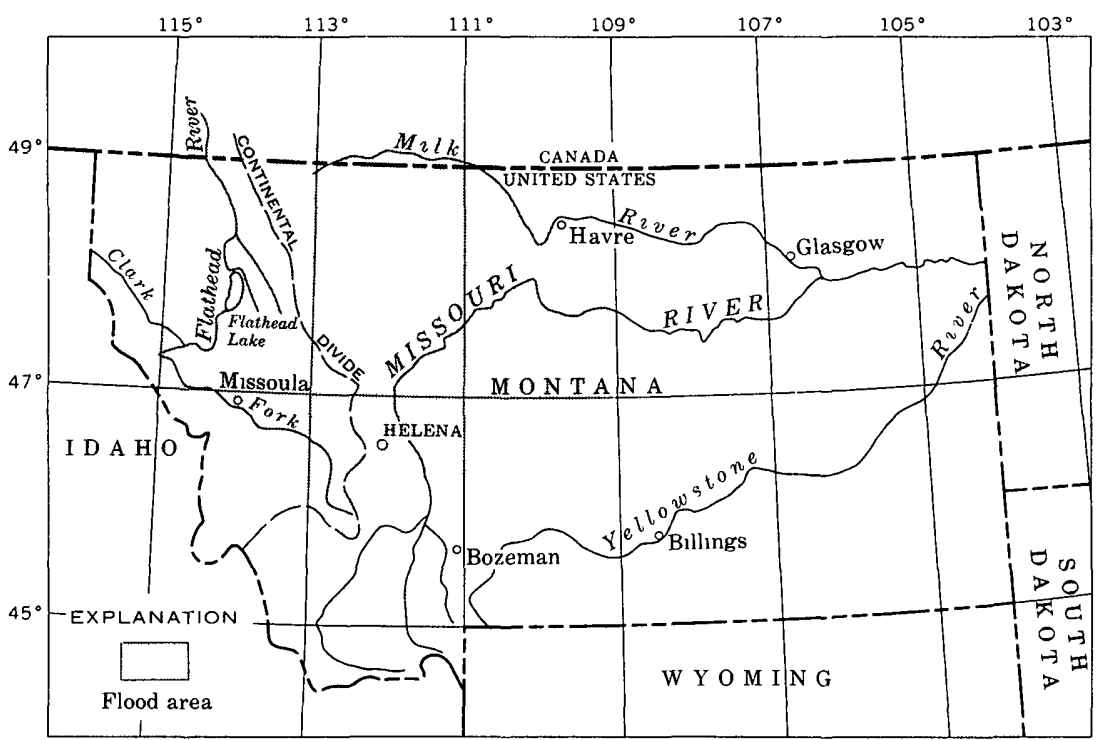

Frgure 1 -Aled coveled by this report 


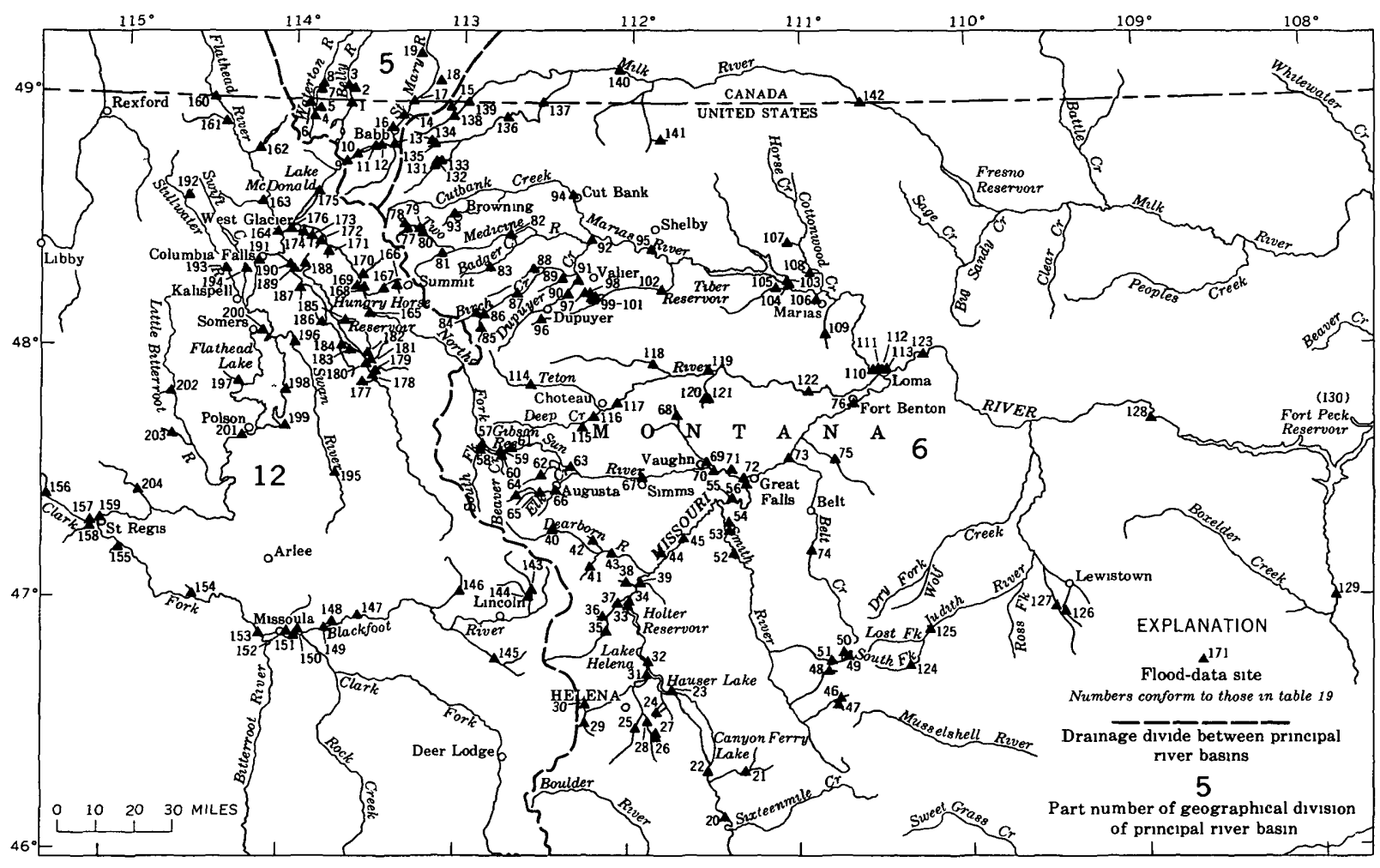


The amount of damage prevented by reservon storage and flood control systems has been estımated to be greater than the damage actually caused by the flood

The need for documentation of this outstanding flood prompted an interagency meeting at Great Falls, Mont, on June 12 to arrange tor the coordinated gathering and exchange of hydrologic information and its presentation in a comprehensive and readily avalable report This resulting report includes discussions of antecedent hydrology and the meteor ology of the intense storm, a description of the floods, information on flood damage, maps of puncipal urban inundation, flood profiles, discussions of storage regulation, previous floods, flood frequency, deposition and degradation of stream channels, and detarled information of stage, discharge, and reservoir contents for the May-.June period

\section{ACKNOWLEDGMENTS}

The ald of the many individuals, corporations, and governmental agencies who furnished data and assistance for this report is gratefully acknowledged The Bureau of Reclamation, the Corps of Engineers of the Department of the Army, and the U S Forest Service assigned men and equipment for the collection of supplementary precipitation data under the direction of the US Weather Bureau, for the indirect discharge measurement surveys conducted by the US Geological Survey, and for the quantitatire measurements of remaining snow cover conducted by the Soll Conservation Service Collection of field dita necessary for the computation of peak discharge by indirect methods and the calculation of detanled records of discharge were greatly anded by the work of technical personnel of the Water Resources Division of the US Geological Sur vey from other States detaled to the flood area Data furnished by all governmental agencies are specifically acknowledged where they appear in the text

\section{ANTECEDENT HYDROLOGIC CONDITIONS}

The pilmary cause of the record floodflows was the intense highi olume ram of June 7-8, although antecedent streamflow, mountain cnowmelt, and abundant soll moisture had some bearng Streams were still at high stages on June $6 \mathrm{in}$ most of the mountain area because of snowmelt 1 unoff and scattered 1 ains of late May There was considerable snow cover in the high mountains and some snow in wellsheltered areas at slightly lower altitudes prior to the heavy rams. Snow measurements and observations made after the flood indicate the net snowmelt contribution to flooding from the higher mountains 
may not have been highly significant. The rain-mduced snowmelt at shightly lower altitudes and in shaded areas may have been a significant factor in some drainage basins

Soll moisture was near field capacity in areas recently bared of snow and was presumably above normal in the toothill areas because of cool weather and above-average precipitation $\mathrm{m}$ April and May The meteorological features of the storm of June 7-8 are covered in detal by the US Weather Bureau $m$ a separate section of the report (p B16) Five major factors affecting antecedent conditions are discussed in the tollowing sections

\section{PRECIPITATION}

Precipitation during January to April 1964 was nearly equal to the 4-month normal for the standard period 1931-60, but that for May was nearly double the normal. The January-May monthly precipitation totals for 1964 and nor mals, shown in par entheses, for six Weather Bureau stations are shown, in inches, in the following table

\begin{tabular}{|c|c|c|c|c|c|c|}
\hline Weather station & $\underset{(\mathrm{ft})}{\text { Altitude }}$ & January & February & March & April & May \\
\hline Great Falls. & 3,664 & \multirow{6}{*}{ 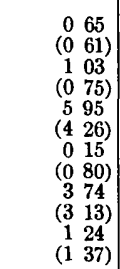 } & \multirow{6}{*}{ 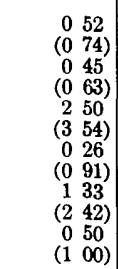 } & \multirow{6}{*}{ 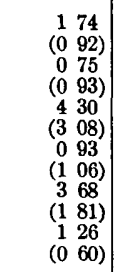 } & \multirow{6}{*}{ 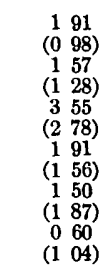 } & \multirow{6}{*}{$\begin{array}{rr}3 & 36 \\
(2 & 10) \\
6 & 19 \\
(2 & 63) \\
7 & 15 \\
(2 & 86) \\
5 & 61 \\
(2 & 58) \\
4 & 62 \\
(2 & 36) \\
2 & 56 \\
(1 & 97)\end{array}$} \\
\hline Gibson Dam.. & 4,590 & & & & & \\
\hline Summit.... & 5,213 & & & & & \\
\hline Babb $6 N E_{-}$ & 4,300 & & & & & \\
\hline West Glacier..... & 3,154 & & & & & \\
\hline Kalispell..... & 2,965 & & & & & \\
\hline
\end{tabular}

The gener al snowfall of May 2-3 was the heaviest on record for May at Kalispell and Missoula and near record at Helena (US Weather Bureau, 1964) Precipitation in that storm ranged from about 2 to 4 inches There was little precipitation thereafter untıl May 27-29 when significant amounts of ram fell along the summit and east of the Continental Divide The higher mountains may have received some snow in the storm of May 27-29. There was little or no ram in June untıl the storm of June 7-8, which is treated in detall in a separate section Cumulative precipitation at West Glacier in the Flathead River dramage basin, Summit on the Contınental Divide at Marıas Pass, and Gibson Dam and Great Falls in the Sun River dramage tor May 1 to June 6 is shown in figure 3 The dally precipitation at Summit tor March through June is shown as a bar graph in the lower part of figure 5 


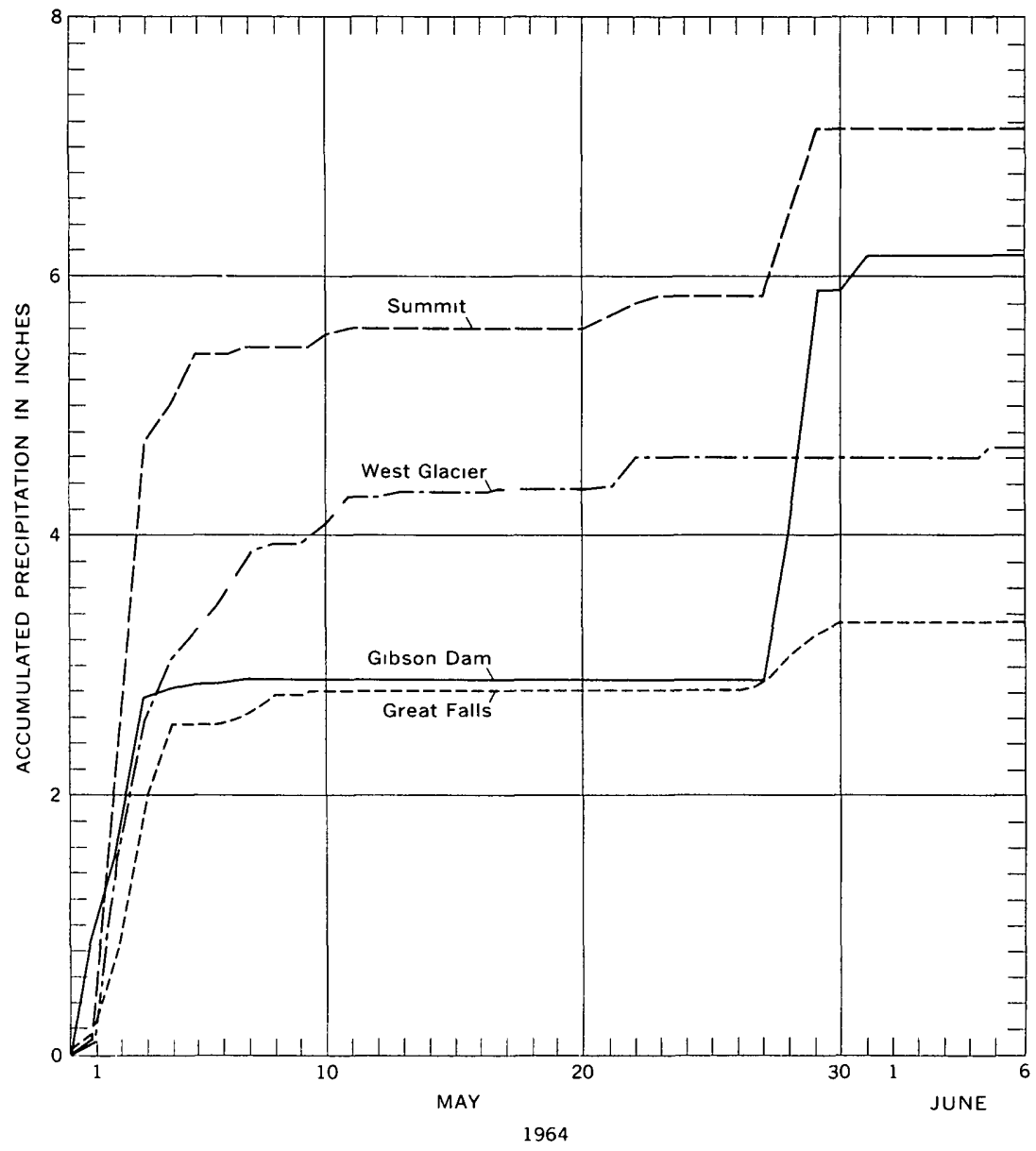

Figure 3 -Accumulation of precipitation at four weather stations May 1 to June 6,1964

\section{TEMPERATURE}

Below-normal temperatures of March to May delayed the usual mountan snowmelt pattern As a result, many stıeams were at a high level and theie still was a significant amount of high-alititude snow when the intense rans began The January-May mean monthly temperatures tor $196+$ and departure trom normal, in parentheses, for six Weather Bureau stations in the mountan and foothll area are shown, in degrees Fahrenhelt, in the following table 


\begin{tabular}{|c|c|c|c|c|c|c|}
\hline Weather station & $\underset{\text { (ft) }}{\text { Altitude }}$ & January & February & March & Aprll & May \\
\hline Great Falls. & 3,664 & \multirow{6}{*}{ 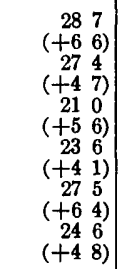 } & \multirow{6}{*}{$\left.\begin{array}{rr}33 & 0 \\
(+9 & 2 \\
29 & 9 \\
(+5 & 4) \\
24 & 1 \\
(+6 & 1 \\
30 & 2 \\
(+9 & 3 \\
27 & 7 \\
(+3 & 4 \\
23 & 9 \\
(-0 & 6\end{array}\right)$} & \multirow{6}{*}{ 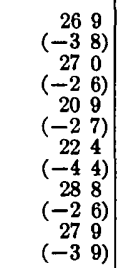 } & \multirow{6}{*}{ 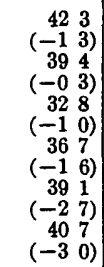 } & \multirow{6}{*}{$\left.\begin{array}{rl}54 & 8 \\
(+1 & 8) \\
47 & 6 \\
(-0 & 6 \\
40 & 8 \\
(-2 & 8 \\
-46 & 2 \\
(-1 & 4 \\
48 & 8 \\
(-2 & 3 \\
49 & 7 \\
(-2 & 5\end{array}\right)$} \\
\hline Gibson Dam & 4,590 & & & & & \\
\hline Summit..... & 5,213 & & & & & \\
\hline Babb 6NE . & 4,300 & & & & & \\
\hline West Glacier..... & 3,154 & & & & & \\
\hline Kalıspell... & 2,965 & & & & & \\
\hline
\end{tabular}

Temperatures of January and February had little or no effect on the flood Although temperatures of early March were sufficiently high to melt much of the snow in the plains and the exposed foothill area, the March mean temperatures were genreally lower than those of the 2 prior months The below-normal temperatures of late March delayed the progress of mountain snowmelt and may have contributed to the above-normal soll moisture that existed when the heavy rains began Dally maximum and minimum temperatures for Gibson Dam, Babb $6 \mathrm{NE}$, and West Glacier are shown in figure 4 for Aprll through June 1964 These stations are in mountain valleys near the Contınental D1vide The weather station at Summit, on the Continental Divide, is at a higher altitude $(5,213 \mathrm{ft})$ than any other station in the flood area. Dally mean and dally normal temperatures at Summit for March to June 1964 are shown on figure 5 with a graph of cumulative departure from $32^{\circ} \mathrm{F}$ The base of $32^{\circ}$ for mean dally temperatures is sufficiently high to indicate snowmelt conditions during parts of the day at this altitude and reasonably continuous melt at lower altitudes The relative coolness of the last half of April and early May is very evident

\section{SNOW COVER}

Snow survey data are collected for their index value in making forecasts of volume runoff from mountain areas These surveys are made in mountain areas where precipitation data are not generally avallable The successive surveys made during the season supply data of accretion and depletion of the snowpack However, they cannot be more than an approximate measure of the snow-water supply in a watershed at any given time because of wide variations in snow cover due to altitude, orographic effects, and susceptibility to melt In general, the last regular snow sur veys are made about May 1, subsequent data are too few to be fully representative Following the flood, the Soll Conservation Service, with the assistance of various Federal agencies, supervised the snow surveys of June 16-18, 1964 

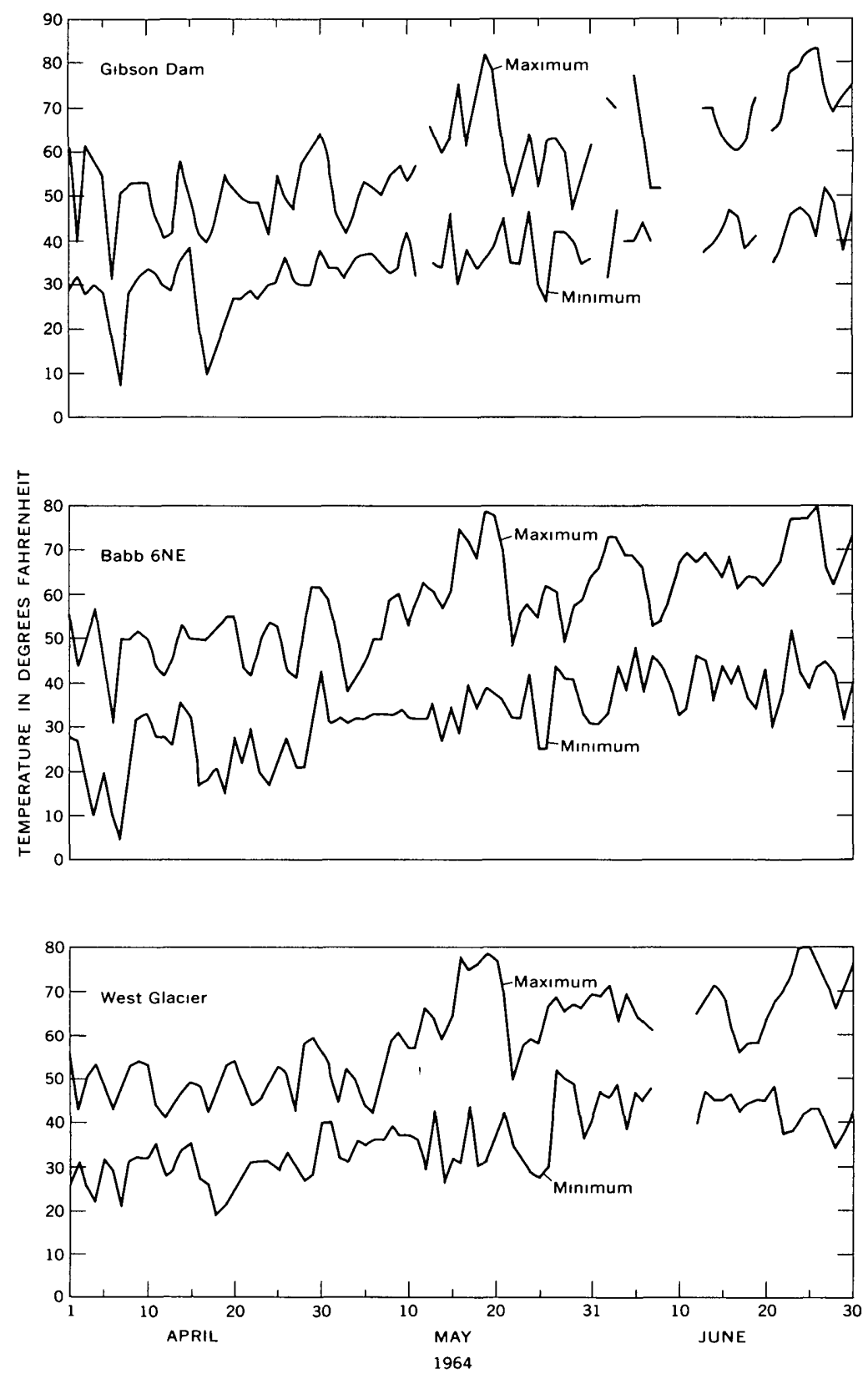

Figure 4-Maximum and minmum temperatures at thiee weather statrons April to June 1964 


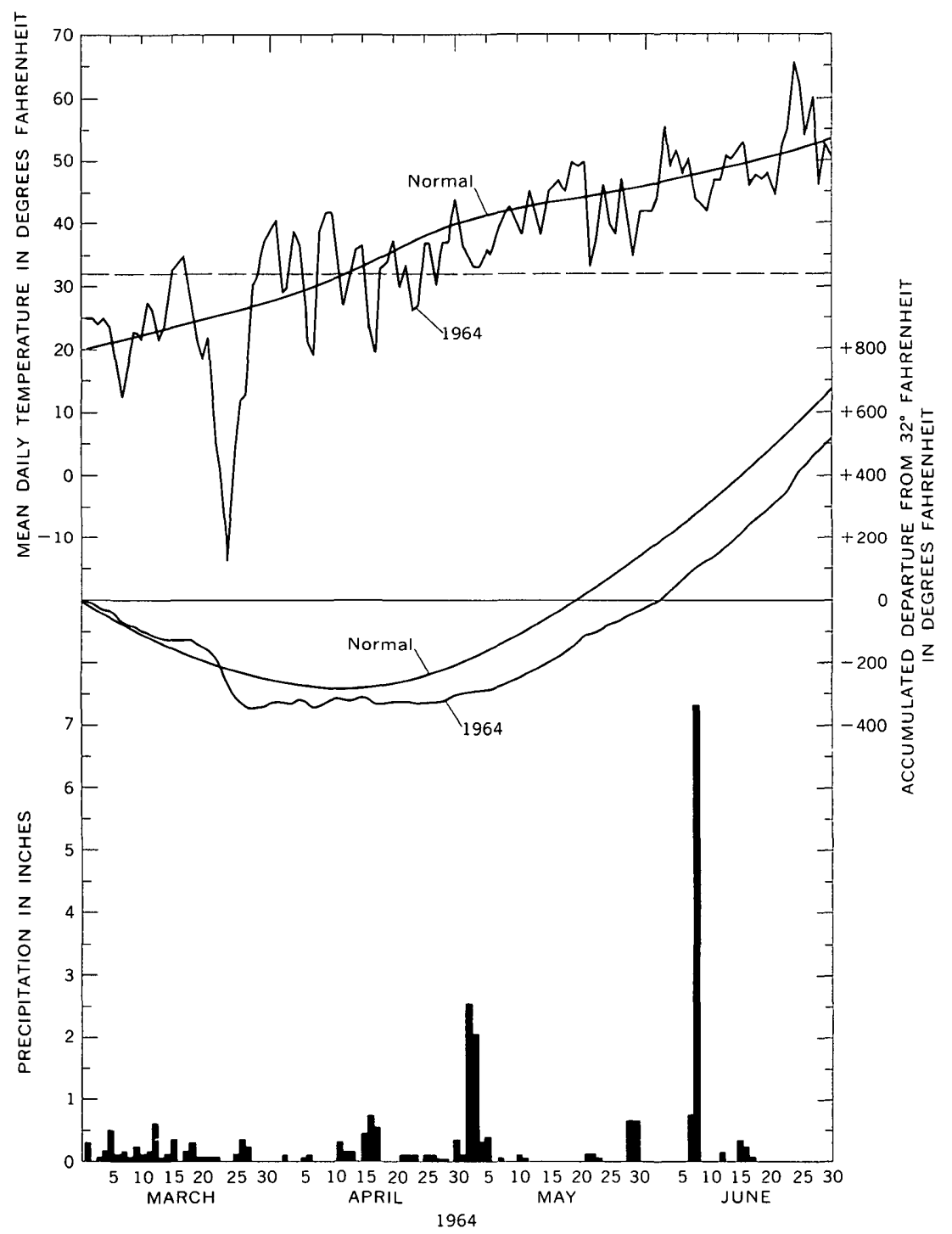

FIGURE 5-Mean daily and daily normal temperature, accumulated departure of mean dally and dally normal temperature from $32^{\circ} \mathrm{F}$, and daily precipitation at Summit, March to June 1964

The locations of the snow courses are shown on figure 6 The identification numbers used are those assigned by the Soll Conservation Service Table 1 lists the average water equivalent of the snow at 


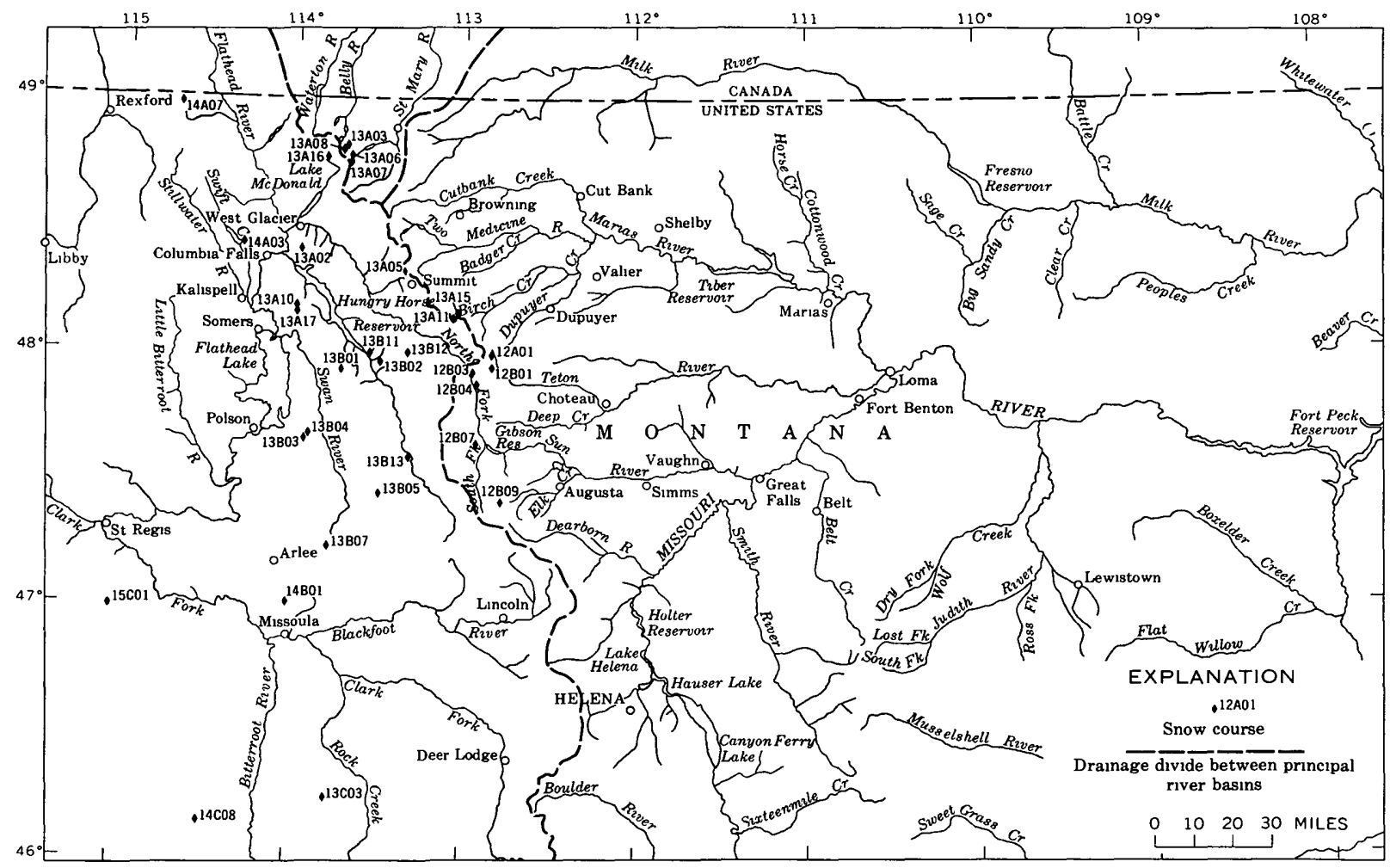

Figure 6-Approximate location of snow courses Snow-course numbers conform with those on table 1 
each snow course as determined by the monthly or semimonthly snow surveys made by many Federal, State, and private organizations The water equivalents of the snow expressed as percentage of the 194357 average, are given by watersheds, in table 2

TABLE 1 -Water equivalent of snow, in inches, at selected snow courses by basins, March-June 1964

[Figures in parentheses are 1943-57 average water equivalent of snow, in inches]

\begin{tabular}{|c|c|c|c|c|c|c|c|c|}
\hline \multicolumn{2}{|c|}{ Snow course } & \multirow{2}{*}{$\begin{array}{l}\text { Alti- } \\
\text { tude } \\
\text { (ft) }\end{array}$} & \multirow{2}{*}{ March 1} & \multirow{2}{*}{ April 1} & \multirow{2}{*}{ May 1} & \multirow{2}{*}{ May 15} & \multirow{2}{*}{ June 1} & \multirow{2}{*}{ June 15} \\
\hline No & Name & & & & & & & \\
\hline
\end{tabular}

Flathead River above Middle Fork Flathead River

\begin{tabular}{|c|c|c|c|c|c|c|c|c|}
\hline $14 \mathrm{~A} 03$ & Hell Roaring Divide....... & 5,770 & $\begin{array}{ll}23 & 8 \\
\end{array}$ & 358 & 388 & 425 & 282 & 15 \\
\hline $14 \mathrm{~A} 07$ & Weasel Divide.. & 5,450 & $\left.\begin{array}{cc}30 & 7 \\
(29 & 6\end{array}\right)$ & $\left.\begin{array}{rr}36 & 8 \\
(33 & 4\end{array}\right)$ & $\left.\begin{array}{rr}37 & 8 \\
(34 & 7\end{array}\right)$ & $\left.\begin{array}{rr}36 & 4 \\
(31 & 4\end{array}\right)$ & 218 & 50 \\
\hline
\end{tabular}

Middle Fork Flathead River

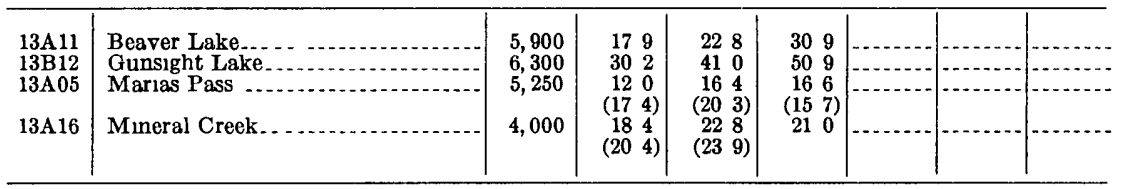

South Fork Flathead River

\begin{tabular}{|c|c|c|c|c|c|c|c|c|}
\hline $13 \mathrm{~A} 02$ & Desert Mountain................... & 5,600 & $\begin{array}{lll}12 & 2\end{array}$ & $\begin{array}{ll}17 & 2 \\
16\end{array}$ & $\begin{array}{ll}16 & 5 \\
\end{array}$ & $-\cdots$ & 15 & $\ldots$ \\
\hline $13 B 13$ & Holbrook & 4,530 & $\begin{array}{rrr}14 & 1 \\
9 & 8 \\
9\end{array}$ & $\left(\begin{array}{ll}10 & 0 \\
13 & 8 \\
\end{array}\right.$ & $\begin{array}{rll}15 & 0 \\
5 & 0\end{array}$ & & & \\
\hline 13B02 & Spotted Bear Mountain & 7,000 & $\begin{array}{ll}11 & 3 \\
11 & 8\end{array}$ & 173 & $\begin{array}{ll}16 & 5\end{array}$ & & & 0 \\
\hline $13 \mathrm{~A} 10$ & Strawberry Lake...... & 5,600 & $\left(\begin{array}{lll}14 & 0\end{array}\right)$ & 448 & $\begin{array}{lll}53 & 6\end{array}$ & & & $-\ldots$ \\
\hline 13B11 & 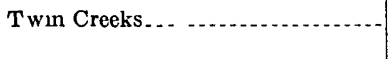 & 3,580 & 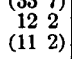 & $\left.\begin{array}{cc}(42 & 5 \\
16 & 0 \\
(10 & 6\end{array}\right)$ & $\begin{aligned}\left(\begin{array}{ll}0 & 0 \\
9 & 8 \\
(0 & 8\end{array}\right)\end{aligned}$ & & & \\
\hline
\end{tabular}

Swan River

\begin{tabular}{|c|c|c|c|c|c|c|c|c|}
\hline $13 \mathrm{~B} 04$ & Fatty Creek & 5,500 & 204 & 266 & 280 & & 118 & \\
\hline $13 \mathrm{~B} 01$ & Trunkus Lake & 6,100 & $\left.\begin{array}{cc}35 & 3 \\
(36 & 3\end{array}\right)$ & $\left.\begin{array}{cc}46 & 3 \\
(41 & 5\end{array}\right)$ & $\left.\begin{array}{rr}55 & 2 \\
(41 & 4\end{array}\right)$ & 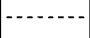 & - n- n & $\cdots$ \\
\hline $13 \mathrm{~B} 05$ & Upper Holland Lake.. & 7,000 & $\left.\begin{array}{cc}28 & 0 \\
(28 & 4\end{array}\right)$ & $\left.\begin{array}{cc}39 & 0 \\
(34 & 3\end{array}\right)$ & $\left.\begin{array}{cc}46 & 8 \\
(36 & 8\end{array}\right)$ & & & 200 \\
\hline
\end{tabular}

Flathead River below Middle Fork Flathead River

\begin{tabular}{|c|c|c|c|c|c|c|c|c|}
\hline $13 \mathrm{~B} 03$ & 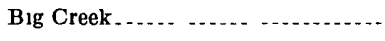 & 6,750 & 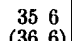 & $\begin{array}{rr}47 & 4 \\
43 & 4\end{array}$ & $\begin{array}{rr}51 & 6 \\
(48 & 4\end{array}$ & -....... & $\begin{array}{rr}48 & 4 \\
30 & 7\end{array}$ & \\
\hline 13A17 & Camp Misery ................. & 6,400 & $\begin{array}{rl}37 & 0\end{array}$ & 511 & $\begin{array}{cc}140 & 4 \\
57 & 0\end{array}$ & & 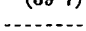 & 380 \\
\hline $13 \mathrm{~B} 07$ & North Fork Jocko River . . . . . ... & 6,330 & $\left.\begin{array}{cc}41 & 0 \\
(38 & 3\end{array}\right)$ & $\left.\begin{array}{rl}53 & 3 \\
(44 & 4\end{array}\right)$ & $\left.\begin{array}{rl}58 & 1 \\
(44 & 7\end{array}\right)$ & 592 & $\left.\begin{array}{cc}41 & 8 \\
(28 & 1\end{array}\right)$ & 242 \\
\hline
\end{tabular}


TABLE 1 -Water equivalent of snow, in inches, at selected snow courses by basins, March-June 1964-Contınued

\begin{tabular}{|c|c|c|c|c|c|c|c|c|}
\hline \multicolumn{2}{|c|}{ Snow course } & \multirow{2}{*}{$\begin{array}{c}\text { Alt1- } \\
\text { tude } \\
\text { (ft) }\end{array}$} & \multirow{2}{*}{ March 1 } & \multirow{2}{*}{ April 1} & \multirow{2}{*}{ May 1} & \multirow{2}{*}{ May 15} & \multirow{2}{*}{ June 1} & \multirow{2}{*}{ June 15} \\
\hline No & Name & & & & & & & \\
\hline
\end{tabular}

St Mary River

\begin{tabular}{|c|c|c|c|c|c|c|c|c|}
\hline $13 \mathrm{~A} 03$ & 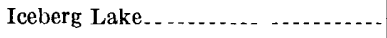 & 5,600 & -..... & $-\ldots . .-$ & $\begin{array}{lll}39 & 4\end{array}$ & & -- & $-\cdots$ \\
\hline $13 \mathrm{~A} 07$ & Mount Allen $\ldots \ldots$ & 5,700 & & & 508 & -...... & & \\
\hline $13 \mathrm{~A} 06$ & Pregan Pass $\ldots$ & 5,500 & -....... & $-\ldots \ldots$ & $\begin{array}{ll}45 & 2 \\
4 & 2\end{array}$ & $-\ldots$ & $\ldots$. & $-\ldots$. \\
\hline 13A08 & Ptarmigan & 5,800 & & $-\cdots$ & $\left.\begin{array}{cc}46 & 6 \\
(37 & 8\end{array}\right)$ & $-\cdots$ & $\ldots$ & $\ldots$ \\
\hline
\end{tabular}

Marias River

\begin{tabular}{|c|c|c|c|c|c|c|c|c|}
\hline $13 \mathrm{~A} 15$ & Badger Pass $\ldots$ & 6,900 & 294 & 396 & 464 & 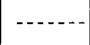 & $-\ldots$ & $\ldots+\ldots$ \\
\hline \multicolumn{9}{|c|}{ Teton River } \\
\hline $\begin{array}{l}12 \mathrm{~A} 01 \\
12 \mathrm{~B} 01\end{array}$ & $\begin{array}{l}\text { Freight Creek } \\
\text { West Fork }\end{array}$ & $\begin{array}{l}6,000 \\
6,000\end{array}$ & $\left.\begin{array}{rl}11 & 2 \\
(14 & 9\end{array}\right)$ & $\left.\begin{array}{rl}15 & 2 \\
(17 & 4\end{array}\right)$ & $\begin{array}{l}196 \\
183\end{array}$ & $\cdots \cdots$ & $-\ldots$ & $\begin{array}{c}0 \\
\cdots-\cdots\end{array}$ \\
\hline
\end{tabular}

Sun River

\begin{tabular}{|c|c|c|c|c|c|c|c|c|}
\hline 12B09 & Five-Bull . $\ldots$ & 5,700 & $\begin{array}{cc}5 & 4 \\
(6 & 2)\end{array}$ & $\left.\begin{array}{cc}5 & 8 \\
(7 & 5\end{array}\right)$ & 66 & & & \\
\hline 12B07 & Goat Mountaln $\ldots \ldots$ & 7,000 & $\left.\begin{array}{rr}9 & 8 \\
9 & 8 \\
(10 & 7\end{array}\right)$ & $\begin{array}{cc}11 & 5 \\
(12 & 4)\end{array}$ & $\left.\begin{array}{ll}12 & 6 \\
(9 & 2\end{array}\right)$ & -........ & $-\cdots--$ & 0 \\
\hline $12 \mathrm{~B} 04$ & 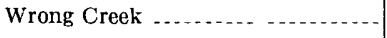 & 5,700 & 135 & 168 & 174 & & $\ldots \ldots$ & 0 \\
\hline $12 B 03$ & Wrong Ridge... & 6,800 & $\left.\begin{array}{cc}17 & 3 \\
(20 & 4\end{array}\right)$ & $\left.\begin{array}{cc}22 & 0 \\
(23 & 1\end{array}\right)$ & 256 & $\ldots$ & & 26 \\
\hline
\end{tabular}

\section{Others}

\begin{tabular}{|c|c|c|c|c|c|c|c|c|}
\hline $15 \mathrm{C} 01$ & IIoodoo Creek $\ldots$ & 5,900 & 374 & 498 & 552 & $\ldots$ & & 183 \\
\hline $13 \mathrm{C} 03$ & Skalkaho Summit.. & 7,260 & 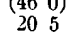 & $\left(\begin{array}{ll}3 & 2\end{array}\right)$ & $\left.\begin{array}{cl}(46 & 9\end{array}\right)$ & 288 & 196 & 86 \\
\hline $14 \mathrm{~B} 01$ & TV Mountain $\ldots \ldots \ldots$ & 6,800 & 140 & $\left(\begin{array}{ll}27 & 1 \\
19 & 6 \\
10 & 0\end{array}\right)$ & $\left(\begin{array}{cc}25 & 8\end{array}\right)$ & & & 36 \\
\hline $14 \mathrm{C} 08$ & Twill Lakes. _. . . . . . . . . & 3,580 & 364 & 476 & 549 & $\ldots$ & $\ldots+\ldots$ & 274 \\
\hline
\end{tabular}

T \BLE 2-Wateı equivalent of snow by drainage basın, Maıch-June 1964, as percentage of 1943-57 average

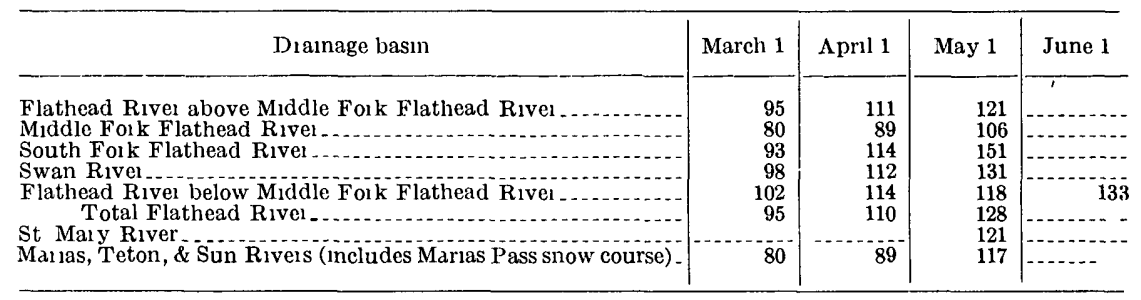


P E. Farnes, Soll Conservation Service, Snow Survey Supervisor for Montana (written commun ), gave the following résumé of snow cover in the flood area

Snow surveys made near the first of March indicated the water accumulated in the snow pack was about 5 percent below the $1943-57$ av erage in the Flathead River dranage above Flathead Lake and 20 percent below average in the Marias, Teton, and Sun River drainages ** Snow-water equivalent near the first of April was 110 percent of average $m$ the Flathead [basin], and 89 percent of average in the Marias, Teton, and Sun River headwaters Many courses at high elerations, particularly in the Flathead Rivel dramage, showed increases of 10 to 14 inches of water during March

During Apill 1964 there was very little melt even at lower elevations and almost all courses showed an increase in water equvalent during April Many low elevation courses had the highest May 1 water equivalent since record began As of May 1, the water equralent in the Flathead River drainage is estimated at 128 percent of the 1943-57 ar erage and that in the Marıas, Teton, and Sun River diamages at 117 percent of that average Very little melt occurred to May 15 and the few higher courses then measured showed increases in water equiralent Melting on a large scale began in mid-May, dropped off somewhat a week later, and resumed at a sustained high rate in the last few days of May Saturated mountain solls and a ripe snow pack contributed to the rapid response of streamflow to the heavy precipitation of June 7-8 The snow-melt contribution to the peak flows was greatest on the west slopes of the Continental Divide because of heavier snow cover

The accumulation and depletion of snow water is depicted in figure 7 for a few of the snow courses listed in table 1

Knowledge of the snow cover immediately prior and subsequent to the heavy 1 ains of June $7-8$ is vague Streamflow records, presented in a later discussion, indicate that a substantial amount of snowmelt had occurred in the lower and middle altitudes US Geological Survey engineeis s epor ted that there appeared to be little melt of highaltitude snow in the Flathead River dramage basm as late as June 2. In the course of an aerial reconnassance of June 11 to appraise flood damage to stream gaging stations, one of the authors made some general observations of mountam snow cover when visibility permitted The highest mountains in the Middle Fork Flathead River drainage basm had considerable snow cover and there was more extensive snow cover in the South Fork Flathead River dramage basm The highest mountam peaks in the Dearborn and Sun River dramage basins were largely snow covered and some snow appeared to be newly fallen $\mathbf{A}$ brief glımpse into the Swiftcun ent Creek dramage basin above Many Glacier gave the impression of complete snow cover. Farnes and Cook (1964) noted that the mountain snowpack remaining on June 16-18 was still above normal and could contribute to further flooding 

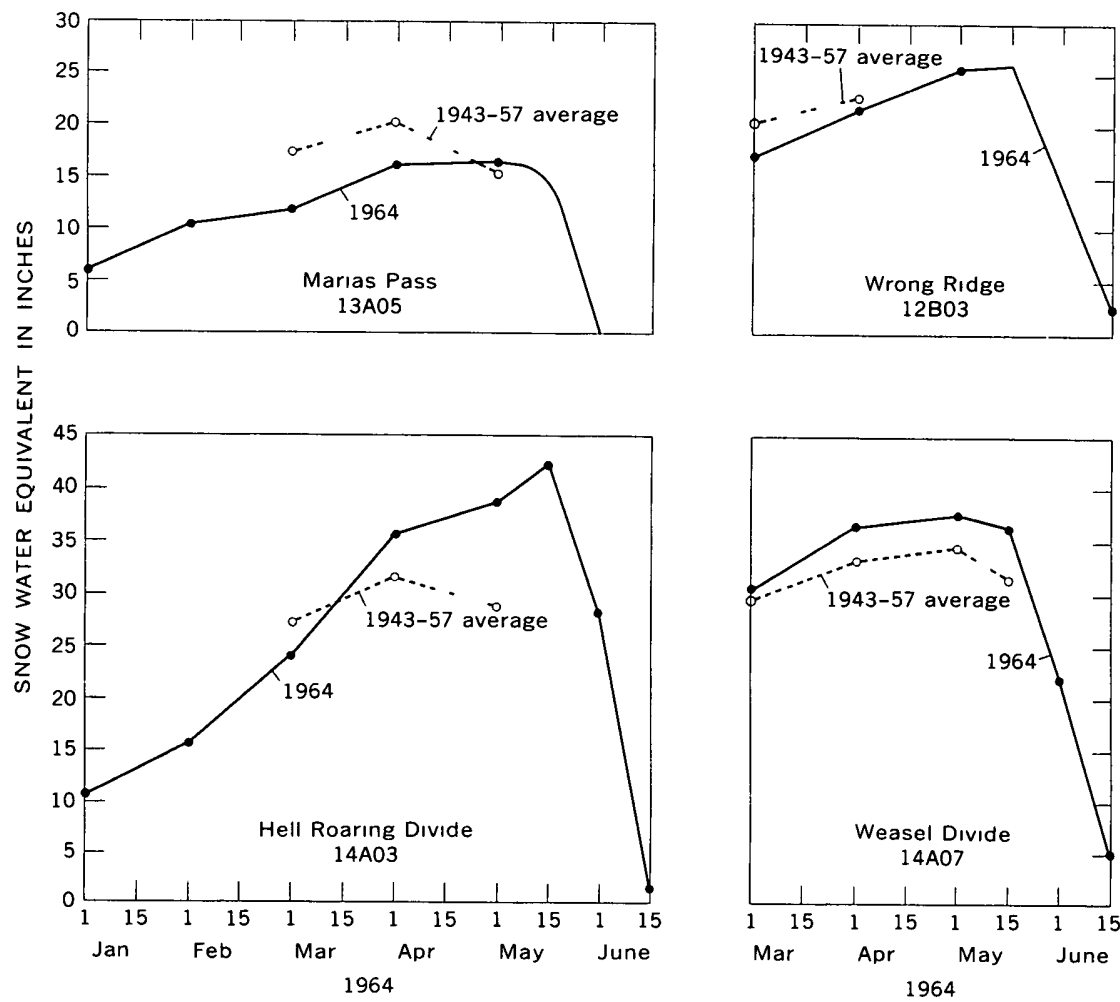

Figure 7 - Water equivalent of snow at selected snow courses

\section{SOIL MOISTURE}

The soil mantle in most of the mountam area is relatively thin, and soll morsture was piobably near field capacity just proo to the flood The widespread snow and ram of the first few days of May, the general prevalence of snow cover untll about May 20, and substantial rains along and east of the Continental Divide on May $27-29$ support the ،ssumption

Sorl-morsture data are being collected at Desert Mountam near Col am, in the Flathead River basin, and at Summit, on the Contmental Divide, by the Soll ('onservation Service (1964) Sorl-moisture content in a profile depth of 54 mches for the Desert Mountam and Summit stations is shown in the following table 


\begin{tabular}{|c|c|c|c|c|c|}
\hline \multirow{3}{*}{ Station } & \multirow{3}{*}{ Period of record } & \multicolumn{4}{|c|}{ Water content of sols (inches) } \\
\hline & & \multirow{2}{*}{$\begin{array}{c}\text { Field } \\
\text { capactty }\end{array}$} & \multicolumn{3}{|c|}{ June 1} \\
\hline & & & Normal & $\begin{array}{l}\text { Range of data } \\
\text { of record }\end{array}$ & 1964 \\
\hline Desert Mountain ........ & $1957-59$ & 84 & 86 & $84-88$ & 89 \\
\hline Summit_. & $\begin{array}{c}1950-52 \\
1957-63\end{array}$ & 65 & 58 & $\begin{array}{lll}5 & 4-6 & 1\end{array}$ & 61 \\
\hline
\end{tabular}

On July 1 the soil moisture at these two stations was approximately normal

The general rain and snow of May 2-3, and above-average precip1tation for May, probably resulted in at least normal soll moisture in the foothll area before the June 7 storm

\section{STREAMFLOW}

Streamflow was well below average in the flood area prior to winter and continued to be relatively low through May 1964. Monthly flows of the Marias River near Shelby for the months of January through May were 59,54, 26, 31, and 81 percent, respectively, of the 1948-62 averages The March flow was the second lowest for that month since 1902 and the April flow was the fifth lowest. Monthly flows of the Middle Fork Flathead River near West Glacier for the months of January to May were $62,55,52,42$, and 84 percent, r espectively, of the 1948-62 averages. The March flow was the second lowest since records began in 1940 and the April flow was the third lowest

The 1964 dally discharge and 1948-62 approximate average dally flow of Middle Fork Flathead River near West Glacier for the period of March through June are plotted in figure 8 The three hydrographs of figure 9 lllustrate the same general discharge pattern east of the Continental Divide Further reference to figures 3, 4, and 5 may be helpful in visualizing the effect of curent precipitation and temperature upon streamflow The greater response of Middle Fork Flathead River and Swiftcurrent Creek to the warmer weather that began about May 30 may indicate relatively greater areal snow cover in those basins at that time Moist solls, high streamflow, and substantial snow cover at high altitudes accentuated the effect of the intense storm of June 7-8 


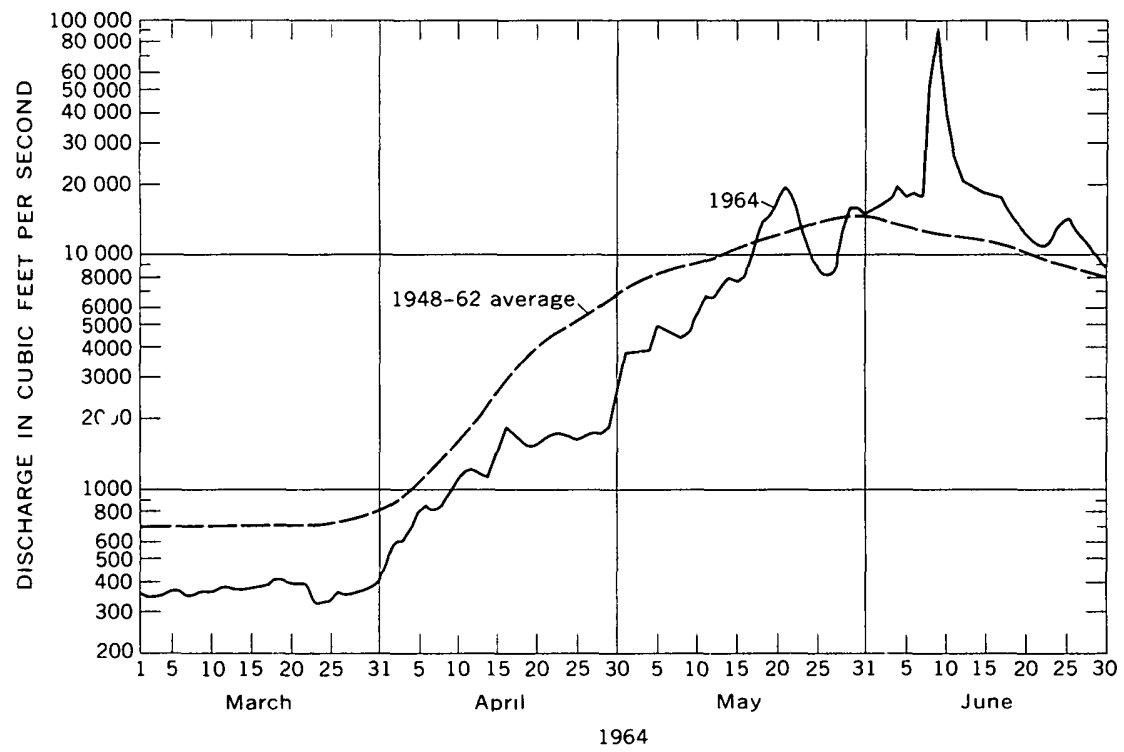

Figure 8-Discharge of Middle Fork Flathead River near West Glacier, March to June 1964

\section{METEOROLOGICAL DEVELOPMENTS CONTRIBUTING TO THE FLOOD}

By R A Dightman, U S Weather Bueau

\section{INTRODUCTION}

Any attempt to describe the meteorology of a storm of sufficient magnitude to produce the extremely heavy rans obselved June $7-8$, 1964, along the north half of the Contmental Divide in Montana, involves the problem of describing complex atmospherıc motions and processes Large-scale motions controlling the Montanc storm covered large parts of the Northern Hemısphere Medium-scale features included general or ogiaphic effects and wind patten ns nea the surface Small-scale effects were local $\mathrm{m}$ extent (limited to small areas) and included effects of wind channeling in "dead-end" mountam valleys, local instability, and others In view of the many-faceted importance of this storm and the resulting floods, these features will be treated $m$ some detall

The physical processes of the atmosphere that produce the upward all motion which finally causes precipitation are well known They are summarized in some detall in a US Weather Bureau (1960b) technical paper, and are covered in texts by Petterssen (1956), Haltıneı and Martin (1957), and others. Accordingly, this summary of storm meteorology is limited to brief descriptions of some of the 


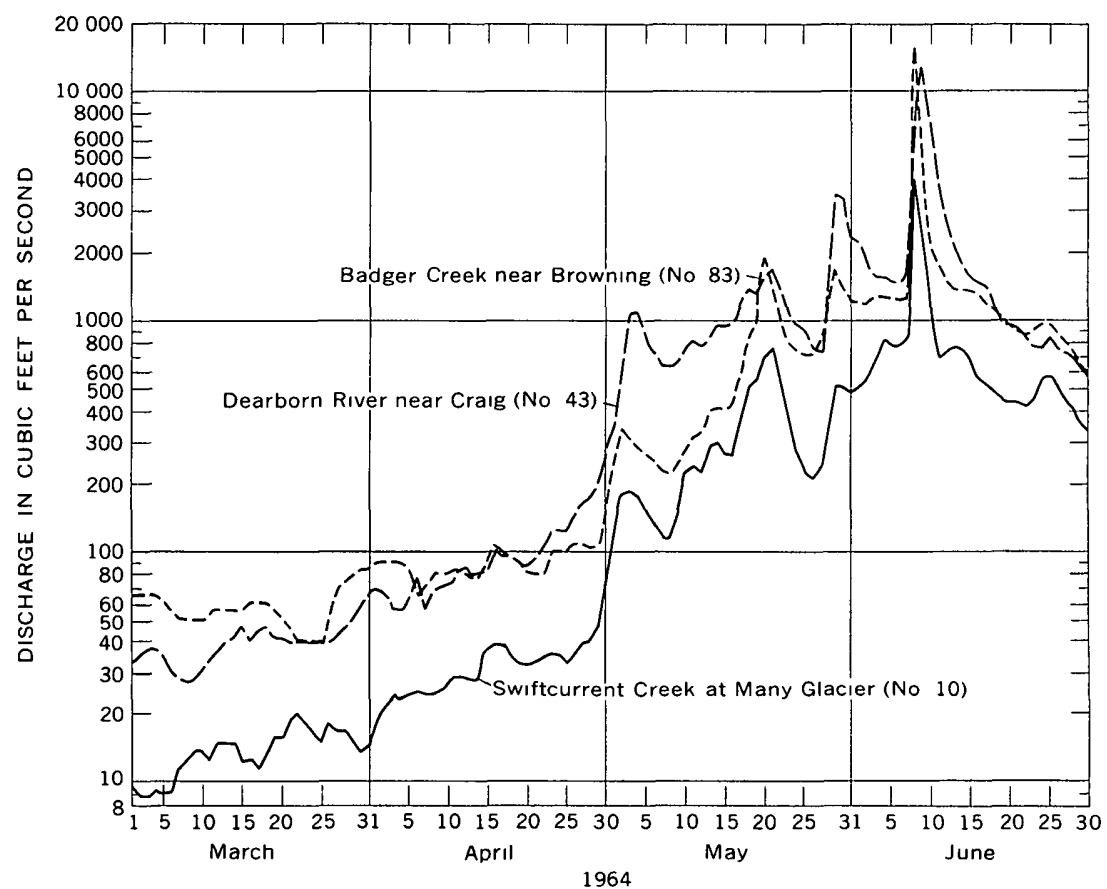

Figure 9-Discharge at selected gaging stations east of the Continental Divide, March to June 1964 Numbers in parentheses conform with those in table 19 and on figure 2

atmospheric processes involved, to their interrelationships and dimensions, and to an areal depiction of the resulting precipitation. For i more complete discussion of the physical mechanisms involved, use of the references at the end of this report is recommended.

\section{SYNOPTIC FEATURES}

The climatic history of Montana (US Weather Bureau, 1960a) points to an amnual ramy season from about May 20 to June 30, during which nearly all the heavy east-slope rainstorms of record have occur red Obviously then, it is during this 40-day period that general atmospheric conditions are most likely to be favorable for producing rains in central Montana. Seasonally, by early June, the southern half of the United States has warmed much more rapidly than has northern Canada Circulations resulting from this annual thermal gradient have lost little of their late-winter and early-spring energy by early June, whlle aurmasses trom southern latitudes (Gulf of Mexico sources in particular) may carry larger quantities of water vapor than is possible earlier in the season at lower temperatures Meteorological developments of early June 1964 fit this general pattern 
At the beginning of June 1964, moist anr from the Gulf of Mexico was spreading north and north-northwest over the westem plams and central Rocky Mountams, carried northward on generally southerly (from south quadrant) w inds ahead of a series of low-pressure centers over and just east of the Contmental Divide This moist air, becoming involved in a series of slow-moving but quite energetic circulations, caused the first half of June to be very wet over much of the West These and other larger scale features are discussed by Dickson (1964) By the atternoon of June 7, when rams associated directly with the flood disaster started, the arrmass still carrying much of its origmal Gulf of Mexico-source moisture was entering the northeast quadrant of a low-pressure area, which centered over Wyoming but corered most of the Rocky Mountam area of the United States This cyclonic circulation extended vertically mito the upper levels of the troposphere, with the vortex at $500 \mathrm{mb}$ (millibar), about 18,000 ft msl (feet above mean sea level) and by 1700 hours, June 7, was centered just northeast of Bolse, Idaho

By 1700 hours, June 7, ram had become general over the affected anea Surface and 500-mb maps for that time are shown in figure 10 The most important large-scale features are the circulations, shown by these two maps, involving the strong westward tilt of the vortex between surface (about $900 \mathrm{mb}$ ) and the $500-\mathrm{mb}$ level, the tilt suggests flow from easterly directions over north-central Montana This phenomenon was observed at this time at all levels to well above 500$\mathrm{mb}$ Dewpoints neal ground surface were very high for the season, they ranged trom about $55^{\circ} \mathrm{F}$ in easter $n$ and central Montana to about $60^{\circ} \mathrm{F}$ in northeast, Wyommg and the I)akotas and mdicated the high water-rapor content of the armass Precipitable water (US Weather Bureau, 1961) from the surface to $500-\mathrm{mb}$ had reached 109 mches at Glasgow and probably exceeded 1 inch over most of northern Montana north and east of Great Falls-a very large amount for this altitude (3,000-4,000 ft msl), latitude, and season

All the teatures described above were involved in the early phases of the storm and were magnified to a considerable extent by the fact that the observed easterly flow was traveling upslope in the affected ar ea-sharply upslope the last 10 miles or so just east of the Rocky Mountam ridge For 1700 hours, June 7, figure 10 (bottom) shows a well-defined cold fi ont at about $5^{\circ}$ latitude north of the Canada-Montana border This front entered the circulation system late in the storm (figs 11,12) with significant effects, as will be noted By 0500 hours, June 8 , exceedingly heary ram had become general on the high eastern slopes along the Contmental Divide In the very hard hit area between Browning and West Glacrer, some of the heaviest rams 

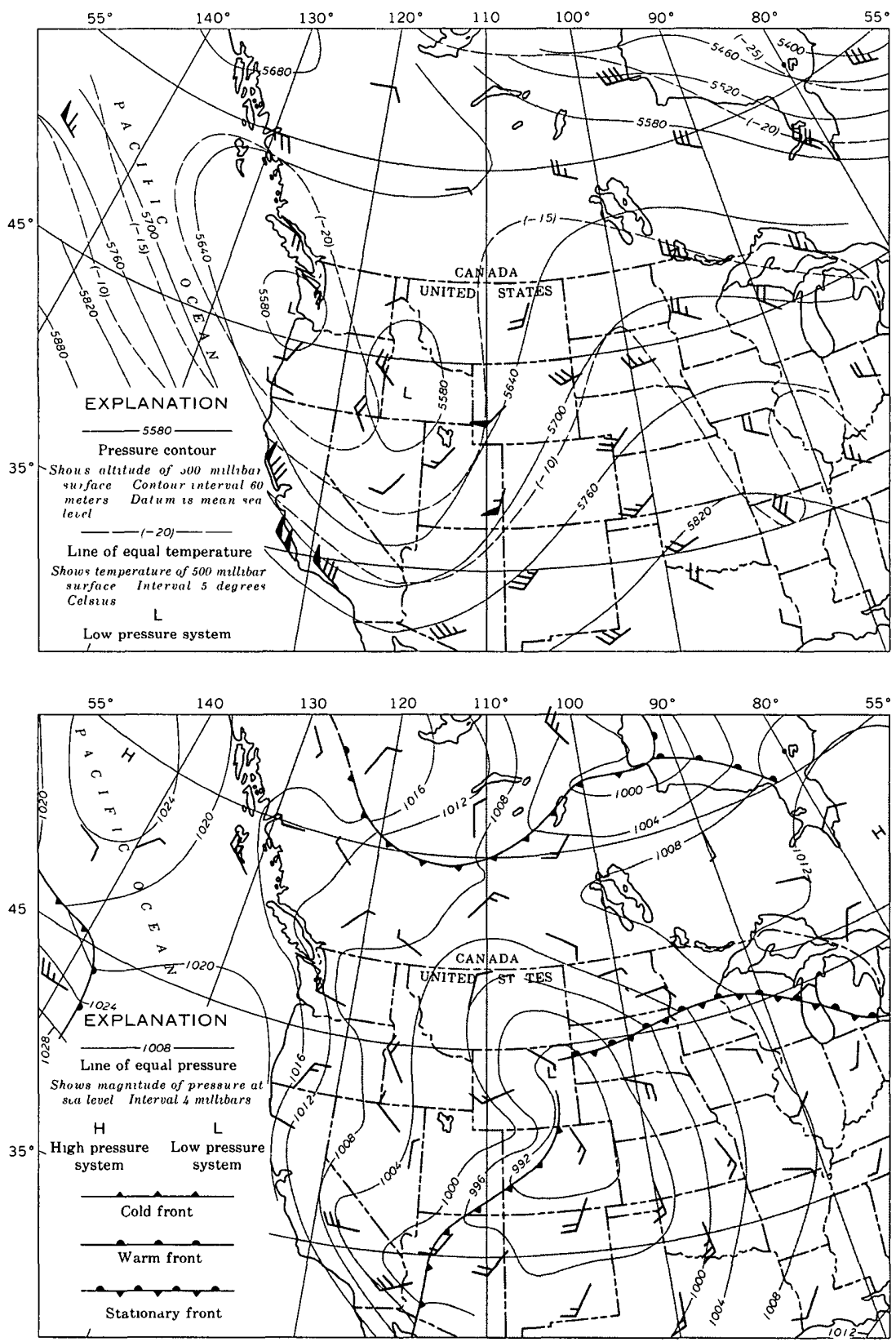

Figure 10 -The 500-millbar surface (top) and sea-level pressure (bottom), 1700 hour June 7, 1964 Note position of arctic front north of international boundary between Alberta and Montana Note also the sea-level to 500-millibai westraid tilt of rortex structure which is associated with a deep flow of moist dil from the east over northem Montana Wind-velocity symbol shafts are oriented with the wind disection, each flag represents 50 knots each full barb represents 10 knots, and each half barb represents 5 knots 
reached into enough drainage area of the Middle Fork Flathead River to produce the highest discharge rates on record for the Flathead River at Columbia Falls and other points The physical processes involved in the atmosphere had changed very little by the morning of June 8, but between sea level and the 500-mb level (fig 11) there was an even stronger westward tilt of the vortex than 12 hours earlier, this indicated that a deep and farrly strong easterly flow had persisted during the night Figure 11 (bottom) shows the cold front from the north entering the nothern edge of the area of heavjest rains. This cold front, as it moved southward, undoubtedly played a key role by imparting an important upward-motion component to the alrmass during the last several hours of the storm, as well as sustaining the upslope wind pattern In general, the rain ended about 4 hours earlier in the northern part of the storm near Browning and East Glacier, than in southern areas about 100 miles away near Gibson Dam and Augusta

By 1700 hours, June 8, rains had ended in the flood area except for a few light showers By that time, the surface low-pressure center had moved to central South Dakota and Nebraska (fig 12, bottom) The primary circulation at $500 \mathrm{mb}$ (fig 12, top) had also moved eastward, but with considerable weakening A new 500-mb low had appeared to the southwest over northern Calıfornia These phenomenona had reduced the effectiveness of the easterly flow over north-central Montana early in the day; but as the easterly flow dimm1shed, the cold wedge from the north continued to supply storm winds from the northeast and continued vertical lifting of the airmass and thus extended the duration of heavy precipitation by about 4 hours

All ingredients necessary for rain in the affected area were present c large supply of relatively warm moist arr, lifting of this air by sevcral methods, and large-scale atmospheric motions that sustained these overlapping effects for several hours The sustained vertical motion necessary to produce the rates of precipitation observed in this storm may be estimated roughly by use of a method attributed to Fulks (1935), later modıfied and condensed by Petterssen (1956), Thompson and Collins (1953), and others Assuming that (1) precipitation rates were 0 50-100 inch per hour (rates of 0 50-0 60 in per hr were actually measured on recorders at Summit and Gibson Dam), (2) the precipitating layer was about 16,000 feet thick $(4,000-20,000 \mathrm{ft} \mathrm{msl})$, (3) the surface temperature was $50^{\circ} \mathrm{F}$ and decreased vertically at about $333^{\circ} \mathrm{F}$ per 1,000 feet (the saturated adiabatıc rate at lower levels), and (4) the rate of condensation was approximately equal to the 1 ate of precipitation, then vertical speeds from about 75 to $150 \mathrm{~cm}$ per sec (centmeters per second) would be required (Petterssen, 

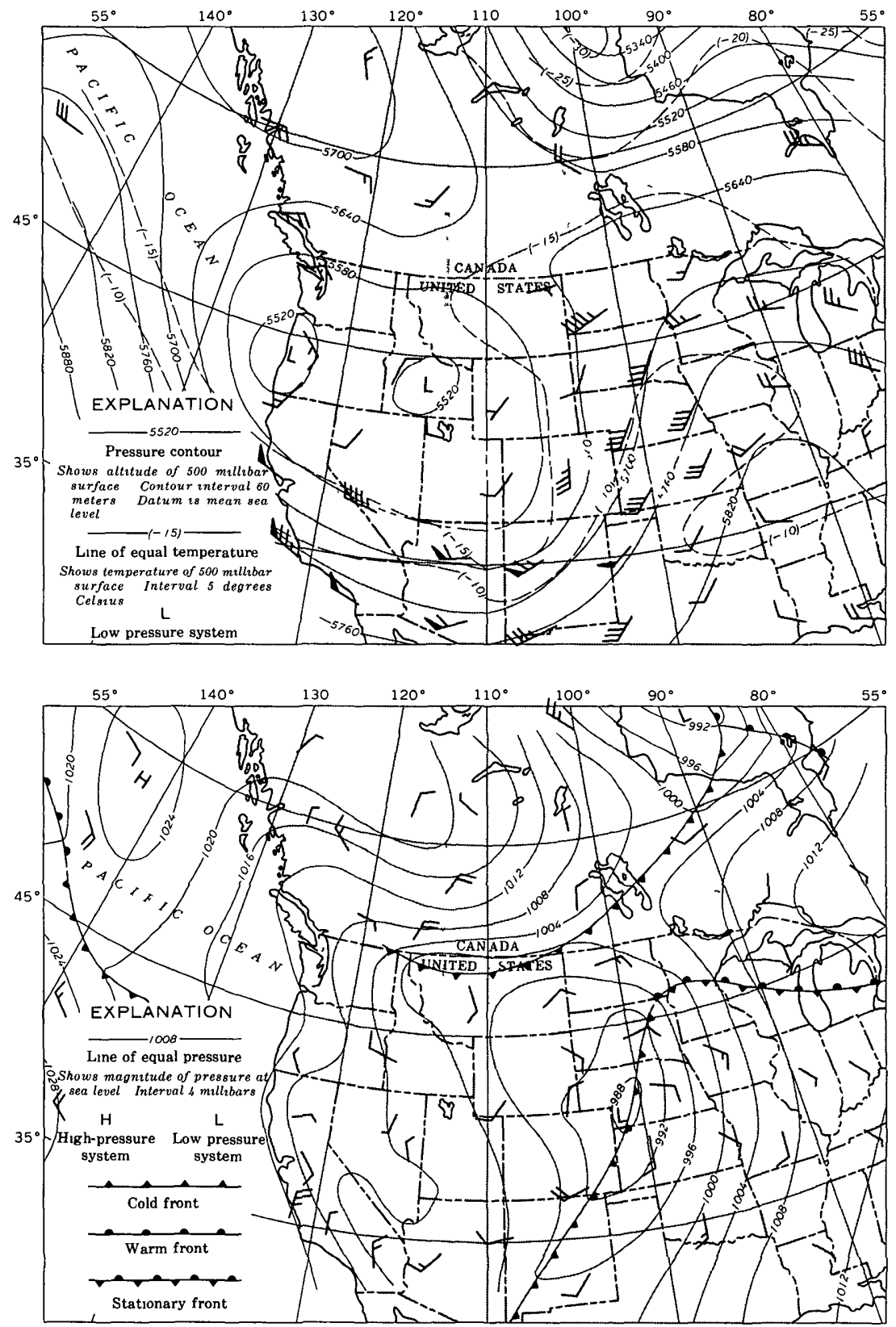

Figure 11 -The 500-millubar surface (top) and sea-level pressure (bottom), 0500 hours, June 8, 1964, after heavy rain had persisted about 12-16 hours ove1 flood headwaters Note (1) The advance to the arctic front into northern Montana, (2) The maintenance of depth and strength of the flow of moist air from the east Wind-velocity symbol shafts are oriented with the wind direction, each flag represents 50 knots, each full barb represents 10 knots, and each half barb represents 5 knots 

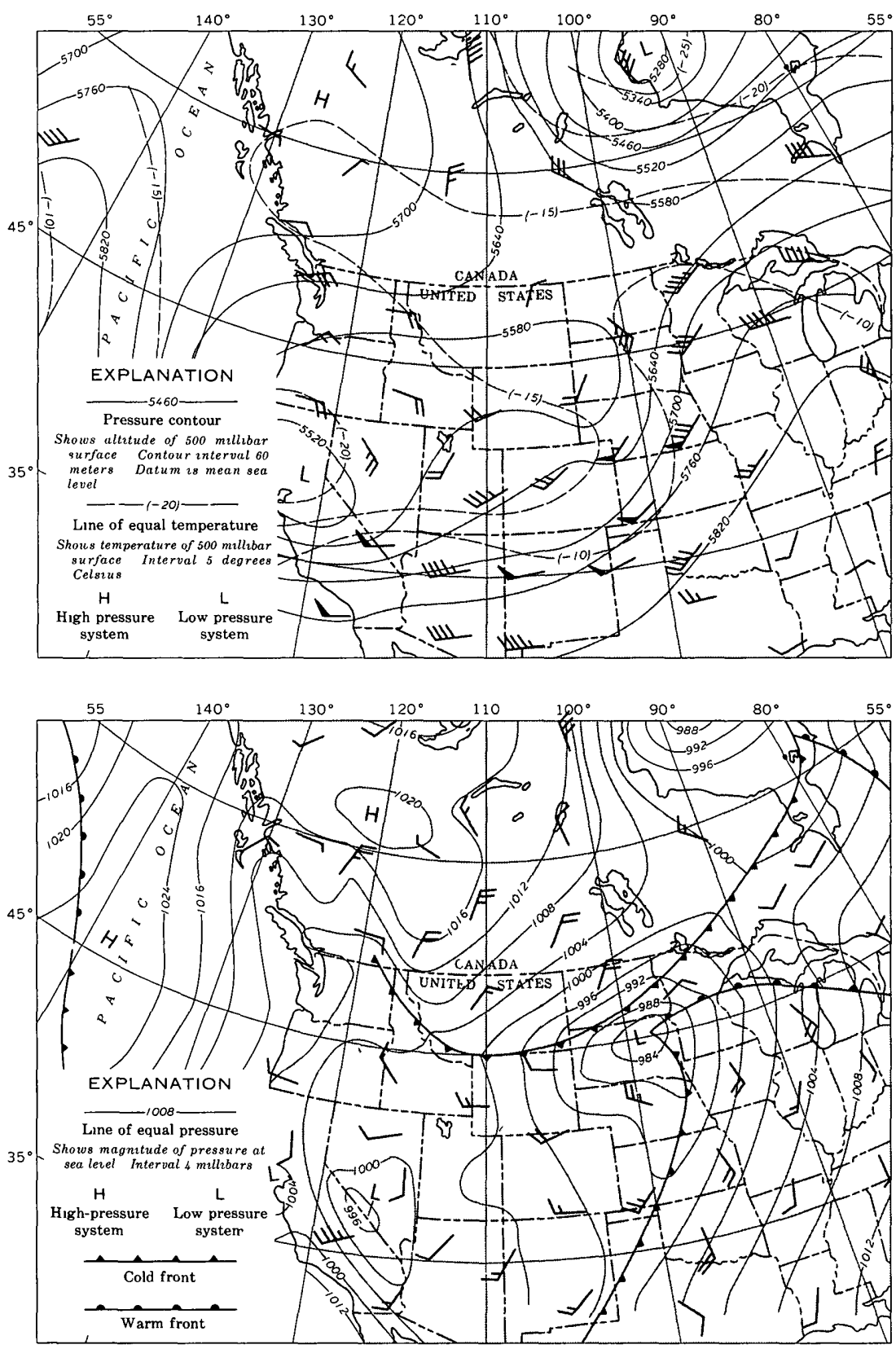

Figure 12 - The 500-millibar surface (top) and sea-lerel pressue (bottom), 1700 hour, June 81964 By this tume, rams had elther stopled or diminished to light as the cold-front wedge effectively cut off the low-lerel flow of morst in from the edst Wind-relocity simbol shafts de onented with the wind direction each flag represents 50 hnots each full barb represents 10 linots, and each half barb represents 5 knot 
(1956). If we assume that winds in the precipitating layer were easterly at about 30 knots, air involved would have to rise orographlcally from about 4,000 feet to the average altitude of the Continental Divide in this area, or to about $8,000^{\prime}$ feet-a rise of about 4,000 feet in about 20 statute miles The largest part of the lift could be expected at, or just east of, the ridge line, and this actually is the location of the centers of heaviest storm precipitation If we use a lift of 200 feet per statute mile at a speed of 30 knots normal to the ildge line, by simple arithmetic, we arrive at an orographic component of $194 \mathrm{ft}$ per sec (feet per second), or $59 \mathrm{~cm}$ per sec. Orographic lifting was probably most strong in the lower few thousand feet of the precipitating layer and was probably replaced, to an indeterminate extent, by convection in middle and upper parts of the layer.

Orographic lifting therefore appears to have been an extremely important factor In the rugged areas in the northern center of heaviest iain (fig 13), where lifting of 1,000 feet is possible in less than 5 miles, the orographlc lift component was undoubtedly greater than $59 \mathrm{~cm}$ per sec and possibly exceeded $100 \mathrm{~cm}$ per sec by a considerable margin Other factors contributing to upward motion include vertical variation of vorticity advection, the Laplacian of temperature advection, the Laplacian of the latent heat of condensation, and low-level friction effects With an orographic hft of $60-100 \mathrm{~cm}$ per sec to buld upon, these factors could account for the lifting necessary for rains with rates of up to an inch per hour in the heaviest ranfall areas (fig. 13).

Many of the medium-scale atmospheric processes and motions of this storm have been touched upon in preceding paragraphs Upslope, for example, sometimes is considered to be medium scale; but in this storm, it was part of large-scale motions on a front more than 100 miles wide Vorticity, convergence, and instability also were important parts of the general circulation in the heavy-storm area The general flow pattern of the atmosphere at lower levels is shown in figure 14 The maps (depicting winds at about 2,000 ft above the surface and at 5,000 ft msl at 1700 hours, June 7) show very clearly the trajectory of the anrmass involved in the storm The arrmass moved northward, then westward over northern Montana inito the storm circulation It was this moisture-laden air at the lower levels of the troposphere that fed the vertical motions in the storm centers The flow of water vapor was strong and steady in the early stages of the storm, but was cut off by the action of the cold front (figs 10,11) in the storm's later stages.

A few medium-scale features require comment The channeling effect of mountain valleys, the angle of flow incidence to mountain ridges, and the effects of nearly parallel ridges almost normal to the 


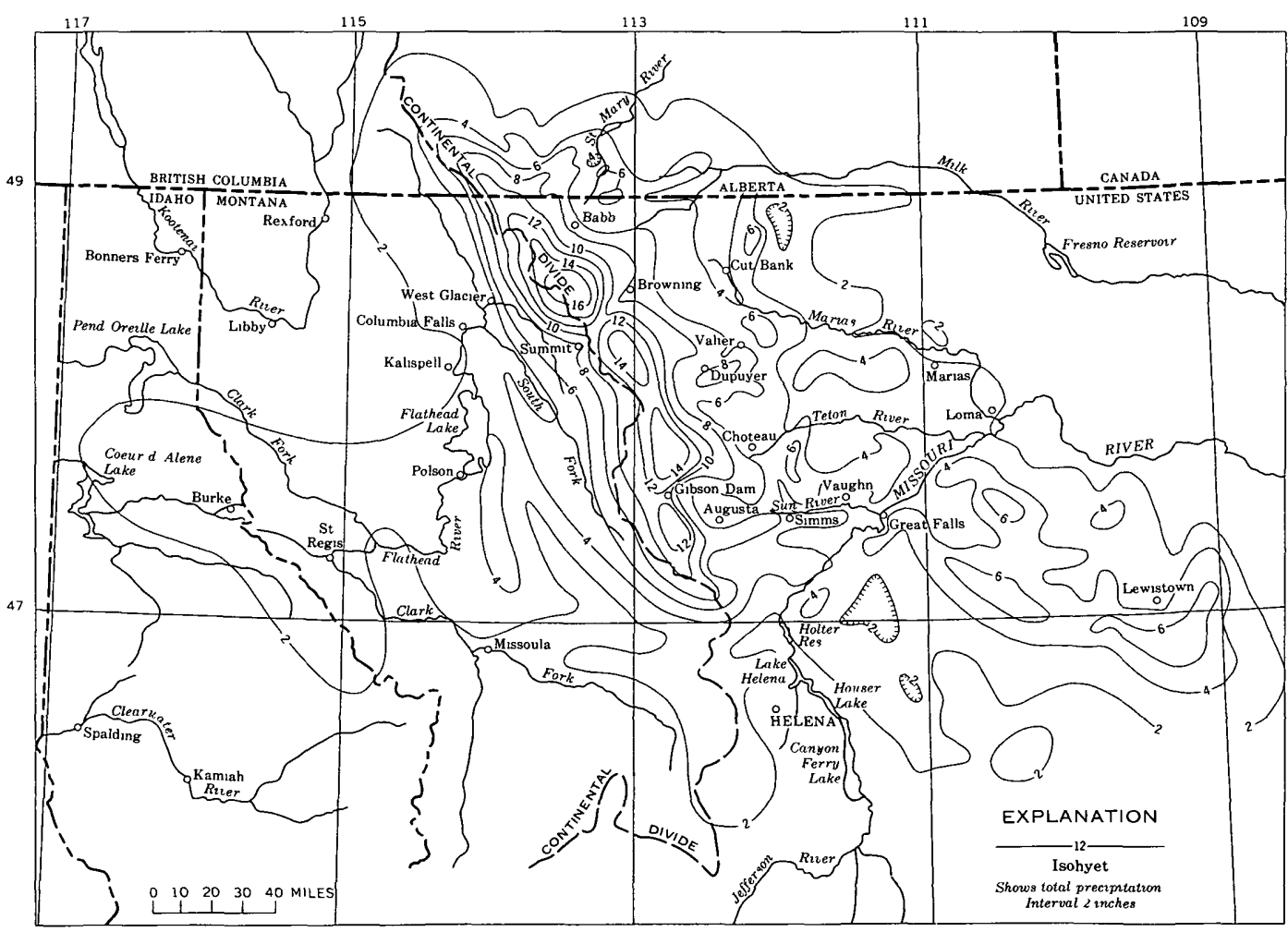

FIGURE 13 -Total precipitation for June 7-8, 1964 Note centers of high intensity ranfall near crest of Contunental Divide Highest centers estımated because of lack of measurements in mountains Owing to the natural variability of rainfall in rugged mountain country such as this, caution is recommended in interpolating from this chart 

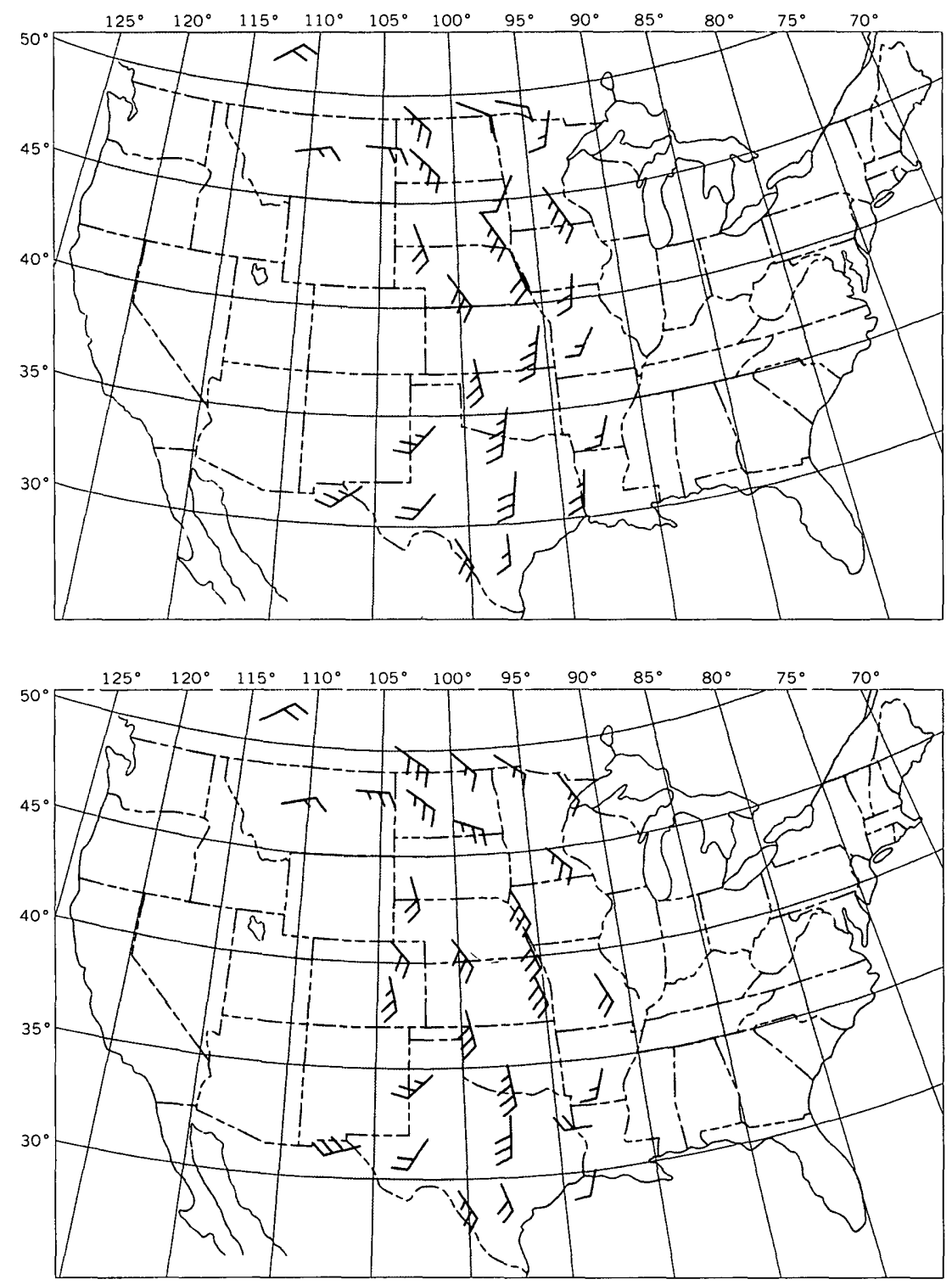

Figure 14 -Windflow at about 5,000 feet above mean sea level (top) and 2,000 feet above land surface (bottom) into Montana from the Gulf of Mexico at 1700 hours, June 7, 1964 Wind-velocity symbol shafts are oriented with the wind direction, each full barb represents 10 knots, each half barb, 5 knots 
general flow no doubt caused important local variations in rainfall rates However, observations and measurements were not sensitive enough or were too sparse to detect such local variations with certainty Mass ramtall cur ves for ser eral stations withm the storni's boundaries, but still some distance from the heaviest centers, show a remarkable steadiness in the rates at which precipitation accumulated (fig 15) Thus, although the degree to which each factor acted to produce precipitation varied during the storm, the integrated effect changed little during the principal 30-hour storm period

The flood-producing precipitation os es the Flathead River basin and other basins to the west of the Contmental Divide appears to have exceeded the magnitudes that can be accounted for by the drift, with the wind, of snow and lam formed in the rising anr above the eastem

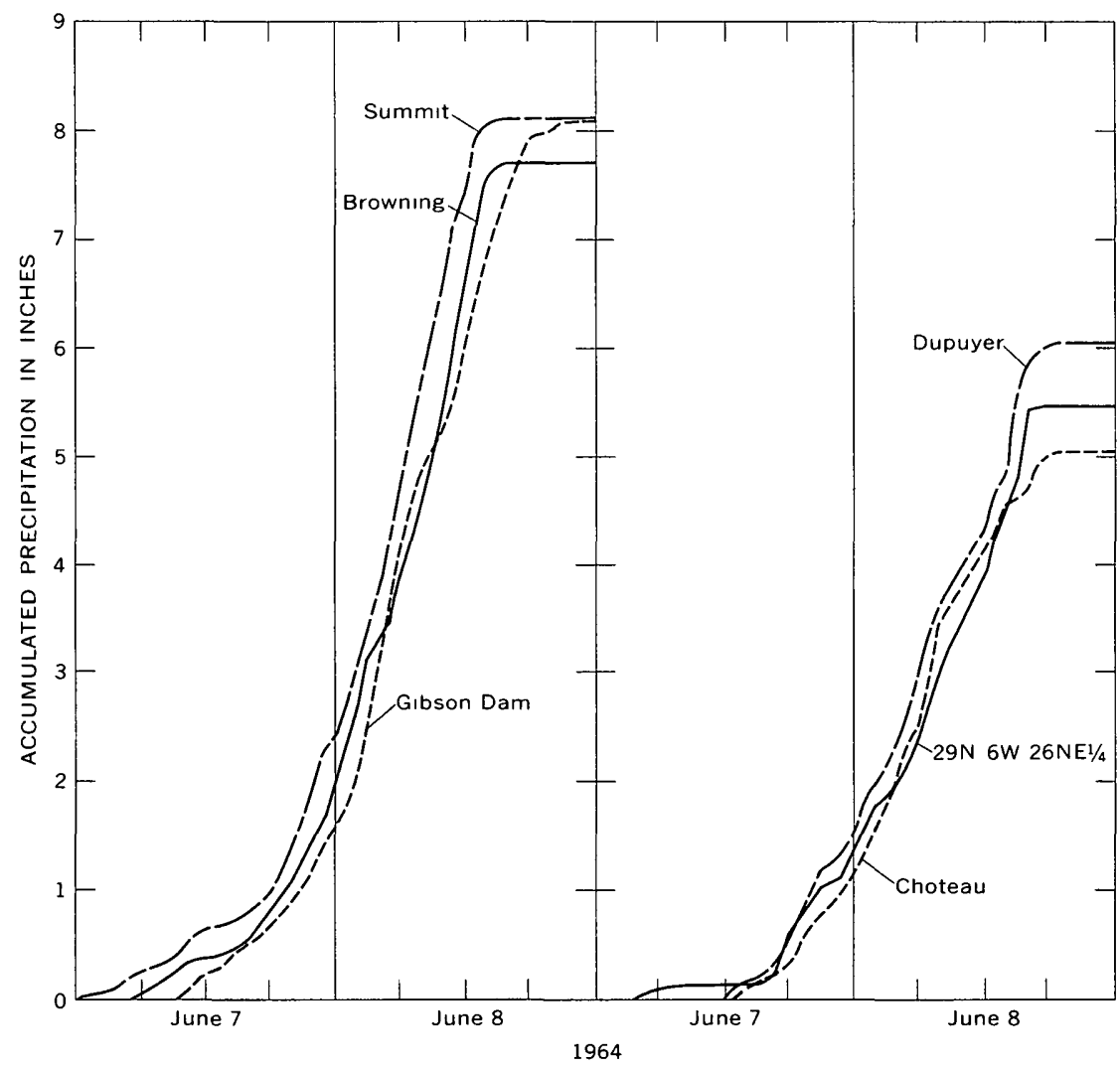

Figure 15-Mass curres of accumulation of precipitation with time fiom 1 cording precipitation gages in (or on edge of) storm area, June 7-8, 1964 
slopes, though no calculations have been made to confirm this. It is surmised that this heavy lee-side precipitation was, in part, the result of convective cells, which were set off by the windward lift but which sloped with the wind and extended to the lee side This concept is depicted schematically in figure 16

\section{RAINFALL PATTERN}

With the moist easterly flow impinging upon the eastern slopes along the Continental Divide where the orographic lift was large and steady, it should not be surprising that the area of heaviest rains was along or just east of the divide ridge for a north-south distance of more than 100 miles The impact of the storm was staggering (the magnitude of the resulting flood disaster is covered elsewhere in this report), determination of precipitation amounis was delayed several days because of disrupted travel facilities and communications. With cooperation from US Army Corps of Engineers, Bureau of Reclamation, U.S. Forest Service, U.S. Geological Survey, and U S Weather Bureau, a survey of the area was conducted during the week of June 15 to find sources of precipitation measurements which might help to reconstruot the storm and to outline the areas of heaviest rain-
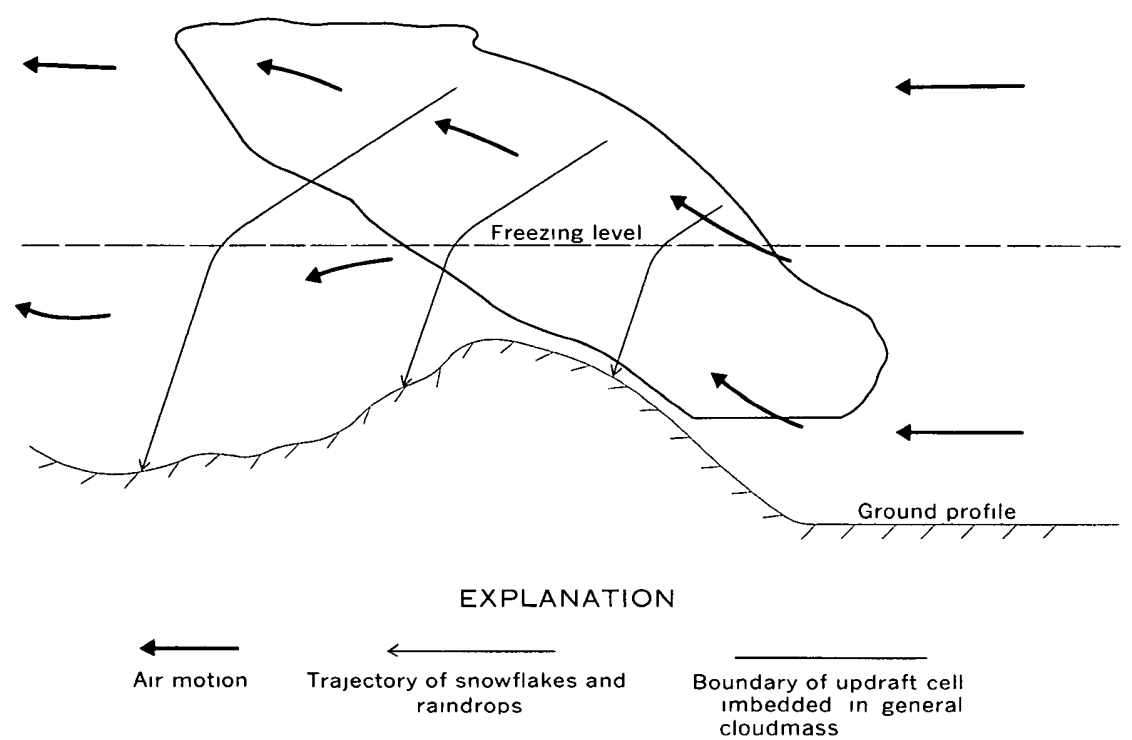

Figure 16 - Concept of a precipitation-releasing updraft cell that is formed on a windward slope and leans with the wind Upper part of cell lies above lee ralley 
fall Hundreds of good-quality measurements were reported However, the scarcity of observers severely limited information for the mountain areas where the heaviest precipitation occurred Through the generous help of the Canada Department of Agriculture, Regina, Saskatchewan, about 200 measurements were made avallable for the southern Albeita al ea of the storm All these measur ements are listed in tables $3,4,5$, and 6 , and were used in preparmg the isohyetal chart for the storm (fig 13)

Table 3 lists precipitation measurements from regular weather observing stations, table 4 lists supplementary reports from privately owned gages or other receptacles, table $\breve{5}$ contams precipitation data from the Canada Department of Agriculture and the Canada Department of Transport measurements, table 6 gives amounts of precipitation, taken hourly, some of which are shown graphically in figure 15 Most of these amounts were plotted and used in locating isohyets. The heavy-precipitation centers were rery well located but their magnitude and extent are partly based upon peak stream discharges of 500 cfs per sq $\mathrm{ml}$ or more and several precipitation measurements of 10 inches or more The altitude of the freezing level remaned highei than mountain ridges throughout the storm area, and the effect upon snowmelt runoff was an important consideration It appears that the snowmelt contribution to peak discharge was probably mmor in the hardest hit areas 


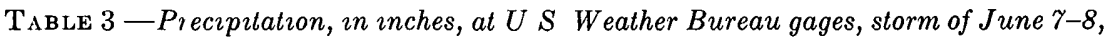
1964

I(A) indicates 6-hr-reporting station, $24 \mathrm{hr}$ begins at $0500 \mathrm{hr} \quad(\mathrm{R})$ indicates recording rain gage station, $24 \mathrm{hr}$ ends at $2400 \mathrm{hr}$ )

Cascade County

Cascade $5 \mathrm{~S}$

Cascade $20 \mathrm{SSE}$

Great Falls WB Airport (A)

Kings Hill (R)

Millegan (R)

Power $6 \mathrm{SE}$

Sun River $5 \mathrm{SW}$

Ulm 8 SE (Truly)

Chouteau County

Brady (Aznoe)

Fort Benton -

Fort Benton $20 \mathrm{~N}(\mathrm{R})$

Geraldine

Highwood (R)

Highwood $7 \mathrm{NE}$

Loma 1 WNW

Lonesome Lake.

Shonkın $7 \mathrm{~S}$

Fergus County

Denton.

Hewer

Flathead County

Creston

Hungry Horse Dam

Kalıspell WB Arrport (A)

Kila_.

Olney $1 \mathrm{SE}$

Pleasant Vallcy $4 \mathrm{SE}$

Summit (R)

West Glacier

Whitefish $5 \mathrm{~N} \overline{\mathrm{W}}$

Polebridge.

Glacier County

Babb 6 NE

Browning (R)

Cut Bank Arport (R)

Del Bonita

East Glaciel

Santa Rita $14 \mathrm{~N}$

Granite County

Drummond Aviation (A) . ...............

Philipsburg ranger station

Judith Basin County

Hobson..-

Moccasin experiment station

Raynesford $1 \mathrm{~W}$

Stanford 2 NE

Lake County

Bigfork $10 \mathrm{~S}$

Polson Airport

Polson Kerr Dam.

St Ignatius

Swan Lake ( $\mathrm{R}$ )

Swan lake $(R)$

$\frac{\text { Preciputat ion collected on- }}{\text { June } 7}$ June $8 \quad \begin{gathered}\text { Total } \\ \text { preciputa- } \\ \text { tion }\end{gathered}$

112

58

202

77

67

01

93

68

46

18

92

26

69

178

34

23

53

84

53

1 12

51

58

64

41

149

22

78

47

63

63
58

106

203

82

78

115

41

70

10

90

210

60

95

68

64

43

73

84

24
195

142

133

136

52

370

254

228

$\begin{array}{ll}3 & 07\end{array}$

200

335

213

119

371

\begin{tabular}{ll}
347 \\
\hline
\end{tabular}

296

192
2

276

169

285

252

206

99

81

499

238

294

261

311

321

384

133

104

243

162

186

552

$\begin{array}{ll}3 & 27\end{array}$

215

298

180

231

222

117

100

31

88

731

$\begin{array}{lll}3 & 47\end{array}$

$\begin{array}{ll}3 & 11\end{array}$

202

280

181

141

180

110

$\begin{array}{lll}1 & 8 & 09\end{array}$

394

374

260

297

403

565

229

293

680

262

2768

$\begin{array}{ll}3 & 11\end{array}$

371

795

303

\section{9}

149

144

154

$\begin{array}{llll}2 & 85 & 375\end{array}$

170

380

$517 \quad 577$

$\begin{array}{lll}2 & 85 & 380\end{array}$

$\begin{array}{llll}3 & 39 & 4 & 07\end{array}$

$\begin{array}{llll}2 & 20 & 2 & 84\end{array}$

$250 \quad 293$

$170 \quad 143$

$256 \quad 340$

$\begin{array}{llll}3 & 44 & 3 & 68\end{array}$

See footnotes at end of table 
T IBLE 3 - Precipitalion, in inches, at $U S$ Weather Bur eau gages, slorm of June 7-8, 1964-Continued

[(A) indicates 6-hr-reporting station, $24 \mathrm{hr}$ begins at $0500 \mathrm{hr} \quad(\mathrm{R})$ indicates recording rain gage station, $24 \mathrm{hr}$ ends at $2400 \mathrm{hr}$ ]

Lewis and Clark County

County and station $\quad \frac{\text { Prectptation collected on- }}{\text { June } 7 \quad \text { June } 8} \begin{gathered}\text { Total } \\ \text { prectpita- } \\ \text { tron }\end{gathered}$

Augusta . . . . .

Augusta $11 \mathrm{~W} \mathrm{~N} \mathrm{~W}_{-}$

Austin $1 \mathrm{~W}$

$\begin{array}{llll}0 & 97 & 3 & 71\end{array}$

468

$\begin{array}{llllll}2 & 39 & 4 & 08 & 6 & 47\end{array}$

Canyon Creek

Canyon Ferry power house.

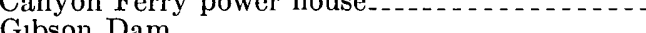

Helena 6 N

Helena WB Airport

Holte Dam

Lincoln 14 NE_...

Lincoln rangel station.

Marysville.

Liberty County

Tiber Dam

Lincoln County

Fortine $1 \mathrm{~N}$

Meagher County

Fort Logan 3 ESE

$\begin{array}{ll}6 & 47 \\ 2 & 05\end{array}$

$\begin{array}{lll}41 & 1 & 64 \\ 37 & 1 & 72\end{array}$

$\begin{array}{lll}2 & 09 \\ 2 & 09\end{array}$

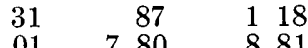

101

25

54

61

780

77

102

$\begin{array}{lll}49 & 1 & 03\end{array}$

$\begin{array}{llll}149 & 2 & 12\end{array}$

$\begin{array}{lllll}73 & 3 & 74 & 4 & 47\end{array}$

$\begin{array}{lllll}22 & 2 & 27 & 2 & 49\end{array}$

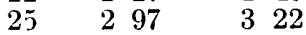

Lennep $5 \mathrm{SW}$

Martinsdale $3 \mathrm{NN}$

$162 \quad 193$

White Sulphur Springs

White Sulphur Springs $10 \mathrm{~N}$

31

69

68

137

Missoula County

Missoula WB Airport

Missoula 2 WNW

Missoula 2 WNW -

Seeley Lake ranger station $(\mathrm{R})$

Pondera County

Conrad

Dupuyer (R)

Valier

Powell County

Deer Lodge $3 \mathrm{~W}$

Elliston

Ovando $1 \mathrm{SW}$

Ovando $7 \mathrm{WNW}$

Silver Lake.

Sanders County

Lonepine 1. WNW (R)

Teton County

Blackleaf

Bynum 4 SSE

Choteau (R)

Dutton $6 \mathrm{E}(\mathrm{R})$

Faurfield.

Pendroy

Toole County

Ethridge

Galata 16 SS W

184

185

50

116

160

64

123

173

55

68

132

40

110

165

70

147

187

$55 \quad 125$

20

359

379

155

$\begin{array}{lll}4 & 48\end{array}$

\begin{tabular}{ll}
6 & 03 \\
\hline &
\end{tabular}

33

03

450

485

Shelby Airport

Sweetgrass

$\begin{array}{lllll}03 & 1 & 07 & 1 & 10\end{array}$

$\begin{array}{lllll}50 & 2 & 05 & 2 & 55\end{array}$

$\begin{array}{lllll}18 & 1 & 02 & 1 & 20\end{array}$

$\begin{array}{llll}19 & 87 & 1 & 06\end{array}$

$\begin{array}{lllll}00 & 1 & 63 & 1 & 63\end{array}$

$\begin{array}{lllll}40 & 1 & 83 & 2 & 23\end{array}$

$124 \quad 470 \quad 594$

$\begin{array}{lllll}53 & 4 & 12 & 4 & 65\end{array}$

$\begin{array}{llllll}1 & 14 & 3 & 89 & 5 & 03\end{array}$

$\begin{array}{llll}83 & 1 & 88 & 2\end{array}$

$\begin{array}{lllll}62 & 5 & 76 & 6 & 38\end{array}$

$\begin{array}{lllll}12 & 5 & 26 & 5 & 38\end{array}$

$\begin{array}{llllll}2 & 05 & 170 & 375\end{array}$

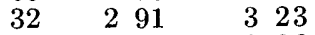

$\begin{array}{lllll}38 & 2 & 70 & 3 & 08\end{array}$

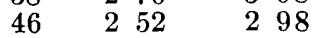

I $24 \mathrm{hr}, 1700$ hours to 1700 hours

2 Manual gage total, 805 mches 
TABLE 4 -Supplemental precipitation data from privately owned gages, or other receptacles, storm of June 7-8, 1964

\begin{tabular}{c|c|c|c|c}
\hline \multicolumn{2}{c|}{ Location } & $\begin{array}{c}\text { Precipita- } \\
\text { tion } \\
\text { (inches) }\end{array}$ & Type of gage & $\begin{array}{c}\text { Evaluation } \\
\text { of record }\end{array}$ \\
\hline
\end{tabular}

\begin{tabular}{|c|c|c|c|c|c|}
\hline \multicolumn{6}{|c|}{ Cascade County } \\
\hline $\begin{array}{l}8 \\
22 \\
420 \\
24\end{array}$ & $\begin{array}{l}22 \\
22 \\
22 \\
22 \\
22\end{array}$ & $\begin{array}{l}1 \text { E } \\
1 \\
2 \\
2 \\
2 \\
2 \\
2\end{array}$ & $\begin{array}{ll}4 & 8 \\
4 & 9 \\
6 & 0 \\
5 & 25 \\
4 & 0\end{array}$ & \begin{tabular}{|c|}
\multicolumn{2}{|c|}{ Glass tube } \\
do
\end{tabular} & $\begin{array}{l}\text { Fair } \\
\text { Good } \\
\text { Fair } \\
\text { Good } \\
\text { Do }\end{array}$ \\
\hline (3) & $\begin{array}{l}22 \\
22 \\
22 \\
22 \\
22\end{array}$ & $\begin{array}{l}3 \mathrm{E} \\
4 \mathrm{E} \\
4 \mathrm{E} \\
4 \mathrm{E} \\
5 \mathrm{E}\end{array}$ & $\begin{array}{ll}4 & 75 \\
4 & 1 \\
4 & 1 \\
4 & 0 \\
3 & 6\end{array}$ & $\begin{array}{l}\text { Wedge type } \\
\text { Rectangular.y. } \\
\text { Glass tube }\end{array}$ & $\begin{array}{l}\text { Do } \\
\text { Do } \\
\text { Do } \\
\text { Do } \\
\text { Do }\end{array}$ \\
\hline $\begin{array}{l}9 \\
9 \\
13 \\
13\end{array}$ & $\begin{array}{l}21 \\
21 \\
21 \\
21 \\
21\end{array}$ & $\begin{array}{l}2 \mathrm{~W} \\
2 \mathrm{~W} \\
1 \mathrm{~W} \\
3 \mathrm{E} \\
3 \mathrm{E}\end{array}$ & $\begin{array}{ll}4 & 3 \\
3 & 8 \\
2 & 5 \\
6 & 3 \\
3 & 5\end{array}$ & \begin{tabular}{|c|} 
Straight-sided bucket \\
Sto do
\end{tabular} & $\begin{array}{l}\text { Do } \\
\text { Fair } \\
\text { Do } \\
\text { Good } \\
\text { Fair }\end{array}$ \\
\hline $\begin{array}{l}21 \\
27 \\
25 \\
35\end{array}$ & $\begin{array}{l}21 \\
21 \\
21 \\
20 \\
20\end{array}$ & $\begin{array}{l}3 \underset{\mathrm{E}}{3} \\
4 \underset{\mathrm{E}}{\mathrm{E}} \\
3 \mathrm{~W} \\
2 \mathrm{~W}\end{array}$ & $\begin{array}{ll}4 & 0 \\
4 & 25 \\
3 & 65 \\
5 & 5 \\
4 & 0\end{array}$ & 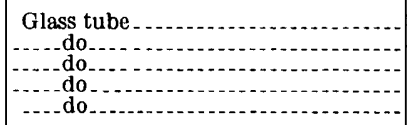 & $\begin{array}{l}\text { Good } \\
\text { Fair } \\
\text { Good } \\
\text { Do } \\
\text { Do }\end{array}$ \\
\hline $\begin{array}{l}71 \\
71 \\
12 \\
32\end{array}$ & $\begin{array}{l}20 \\
20 \\
20 \\
20 \\
20\end{array}$ & $\begin{array}{l}1 \mathrm{~W} \\
2 \mathrm{~W} \\
2 \mathrm{~W} \\
2 \mathrm{~W} \\
1 \mathrm{E}\end{array}$ & $\begin{array}{ll}4 & 5 \\
4 & 7 \\
4 & 1 \\
4 & 2 \\
3 & 85\end{array}$ & $\begin{array}{l}\text { Coffee can } \\
\text { Glass tube... }\end{array}$ & $\begin{array}{l}\text { Fair } \\
\text { Good } \\
\text { Do } \\
\text { Do } \\
\text { Do }\end{array}$ \\
\hline $\begin{array}{l}\text { Great Falls } \\
26 \\
22\end{array}$ & $\begin{array}{l}20 \\
20 \\
19 \\
19 \\
19\end{array}$ & $\begin{array}{ll}4 & \mathrm{E} \\
4 & \mathrm{E} \\
3 & \mathrm{~W} \\
2 & \mathrm{E} \\
4 & \mathrm{E}\end{array}$ & $\begin{array}{ll}3 & 65 \\
4 & 8 \\
3 & 5 \\
3 & 5 \\
4 & 7\end{array}$ & $\begin{array}{l}\text { Various } \\
\text { Glass tube. } \\
\text { Wedge type }\end{array}$ & $\begin{array}{l}\text { Do } \\
\text { Do } \\
\text { Fair } \\
\text { Good } \\
\text { Do }\end{array}$ \\
\hline $\begin{array}{l}26 \\
71 \\
79\end{array}$ & $\begin{array}{l}19 \\
19 \\
19 \\
19 \\
18\end{array}$ & $\begin{array}{l}4 \underset{\mathrm{E}}{4} \\
4 \mathrm{E} \\
5 \mathrm{E} \\
7 \underset{\mathrm{W}}{\mathrm{W}}\end{array}$ & $\begin{array}{ll}3 & 2 \\
4 & 4 \\
3 & 94 \\
3 & 2 \\
5 & 0\end{array}$ & $\begin{array}{l}\text { Glass tube. } \\
\text { Glass tube type } \\
\text { Wedge typ. }\end{array}$ & $\begin{array}{l}\text { Fair } \\
\text { Good } \\
\text { Do } \\
\text { Do } \\
\text { Do }\end{array}$ \\
\hline $\begin{array}{l}8 \\
\text { Cascade } \\
30 \\
18\end{array}$ & $\begin{array}{l}18 \\
18 \\
18 \\
18 \\
18\end{array}$ & $\begin{array}{l}1 \mathrm{~W} \\
1 \mathrm{~W} \\
2 \mathrm{E} \\
4 \mathrm{E} \\
4 \mathrm{E}\end{array}$ & $\begin{array}{ll}3 & 5 \\
5 & 5 \\
3 & 0 \\
3 & 25 \\
3 & 5\end{array}$ & $\begin{array}{l}\text { Glass tube. } \\
\text { Glass tube. }\end{array}$ & $\begin{array}{l}\text { Do } \\
\text { Fair } \\
\text { Do } \\
\text { Good } \\
\text { Do }\end{array}$ \\
\hline 11 & $\begin{array}{l}16 \\
16 \\
16 \\
15\end{array}$ & $\begin{array}{l}2 \underset{\mathrm{W}}{2} \\
2 \underset{\mathrm{E}}{\mathrm{E}} \\
7 \mathrm{E}\end{array}$ & $\begin{array}{ll}4 & 00 \\
2 & 20 \\
3 & 9 \\
3 & 80\end{array}$ & 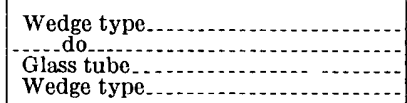 & $\begin{array}{l}\text { Do } \\
\text { Do } \\
\text { Do } \\
\text { Do }\end{array}$ \\
\hline
\end{tabular}

Chouteau County

\begin{tabular}{|c|c|c|c|c|c|}
\hline $\begin{array}{l}27 \\
4 \\
19 \\
34 \\
12\end{array}$ & $\begin{array}{l}27 \\
26 \\
26 \\
25 \\
25\end{array}$ & $\begin{array}{l}10 \mathrm{E} \\
9 \mathrm{E} \\
10 \mathrm{E} \\
3 \mathrm{E} \\
6 \mathrm{E}\end{array}$ & $\begin{array}{ll}1 & 68 \\
3 & 5 \\
2 & 75 \\
3 & 75 \\
2 & 3\end{array}$ & \begin{tabular}{|c|c|} 
\\
Glass tube \\
do
\end{tabular} & $\begin{array}{l}\text { Good } \\
\text { Do } \\
\text { Do } \\
\text { Fair } \\
\text { Good }\end{array}$ \\
\hline $\begin{array}{l}35 \\
30 \\
31 \\
34 \\
8\end{array}$ & $\begin{array}{l}25 \\
25 \\
25 \\
24 \\
24\end{array}$ & $\begin{array}{l}7 \mathrm{E} \\
8 \mathrm{E} \\
14 \mathrm{E} \\
3 \mathrm{E} \\
5 \mathrm{E}\end{array}$ & $\begin{array}{ll}3 & 2 \\
2 & 5 \\
0 & 7 \\
3 & 90 \\
3 & 0\end{array}$ & 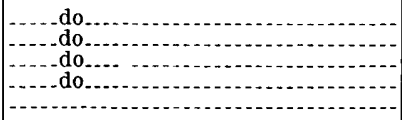 & $\begin{array}{c}\text { Do } \\
\text { Do } \\
\text { Do } \\
\text { Do } \\
\text { Fair }\end{array}$ \\
\hline $\begin{array}{l}3_{5} \ldots \\
27 \\
28\end{array}$ & $\begin{array}{l}24 \\
24 \\
24\end{array}$ & $\begin{array}{l}6 \mathrm{E} \\
6 \mathrm{E} \\
7 \mathrm{E}\end{array}$ & $\begin{array}{ccc}3 & 0-3 & 2 \\
3 & 4 \\
3 & 0\end{array}$ & \begin{tabular}{|} 
Glass tube. \\
\hdashline do
\end{tabular} & $\begin{array}{r}\text { Do } \\
\text { Good } \\
\text { Do }\end{array}$ \\
\hline
\end{tabular}


TABLE 4-Supplemental precipitation data from privately owned gages, or othen receptacles, storm of June 7-8, 1964-Continued

\begin{tabular}{|c|c|c|c|c|c|}
\hline \multicolumn{3}{|c|}{ Location } & \multirow{2}{*}{$\begin{array}{l}\text { Precipita- } \\
\text { tlon } \\
\text { (mches) }\end{array}$} & \multirow{2}{*}{ Type of gage } & \multirow[b]{2}{*}{$\begin{array}{l}\text { Evaluation } \\
\text { of record }\end{array}$} \\
\hline Section & $\begin{array}{l}\text { Town- } \\
\text { ship } \\
\text { north }\end{array}$ & Range & & & \\
\hline \multicolumn{6}{|c|}{ Chouteau County-Continued } \\
\hline $15-25$ & $\begin{array}{l}23 \\
23\end{array}$ & $\begin{array}{l}3 \mathrm{E} \\
3 \mathrm{E}\end{array}$ & $\begin{array}{l}4 \underset{4}{2} 25 \\
4\end{array}$ & $\begin{array}{l}\text { Wedge type } \\
\text { Glass tube. }\end{array}$ & $\begin{array}{l}\text { Good } \\
\text { Do }\end{array}$ \\
\hline $\begin{array}{l}36 \\
30 \\
30 \\
33\end{array}$ & $\begin{array}{l}23 \\
23 \\
23 \\
23 \\
23\end{array}$ & $\begin{array}{ll}3 & \mathrm{E} \\
5 & \mathrm{E} \\
6 & \mathrm{E} \\
6 & \mathrm{E} \\
7 & \mathrm{E}\end{array}$ & $\begin{array}{ll}4 & 35 \\
5 & 35 \\
3 & 4 \\
3 & 5 \\
4 & 0\end{array}$ & \begin{tabular}{l} 
Glass tube. \\
\hdashline do
\end{tabular} & $\begin{array}{l}\text { Do } \\
\text { Do } \\
\text { Do } \\
\text { Fair } \\
\text { Good }\end{array}$ \\
\hline $\begin{array}{l}\text { Ft Benton........ } \\
933\end{array}$ & $\begin{array}{l}23 \\
23 \\
23 \\
22 \\
22\end{array}$ & $\begin{array}{l}8 \mathrm{E} \\
10 \mathrm{E} \\
11 \mathrm{E} \\
6 \mathrm{E} \\
7 \mathrm{E}\end{array}$ & $\begin{array}{ll}3 & 55 \\
2 & 7 \\
1 & 9 \\
3 & 8 \\
4 & 10\end{array}$ & 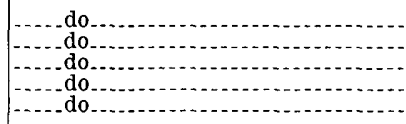 & $\begin{array}{l}\text { Do } \\
\text { Fair } \\
\text { Good } \\
\text { Do } \\
\text { Do }\end{array}$ \\
\hline $\begin{array}{l}32 \\
6 \\
15 \\
26\end{array}$ & $\begin{array}{l}22 \\
22 \\
21 \\
21 \\
21\end{array}$ & $\begin{array}{l}7 \mathrm{E} \\
9 \mathrm{E} \\
7 \mathrm{E} \\
9 \mathrm{E} \\
12 \mathrm{E}\end{array}$ & $\begin{array}{ll}3 & 6 \\
5 & 0 \\
3 & 8 \\
6 & 5 \\
3 & 5\end{array}$ & \begin{tabular}{|c} 
do \\
Glass tube
\end{tabular} & $\begin{array}{l}\text { Do } \\
\text { Do } \\
\text { Do } \\
\text { Do } \\
\text { Do }\end{array}$ \\
\hline $\begin{array}{l}7 \\
18 \\
18\end{array}$ & $\begin{array}{l}21 \\
20 \\
20 \\
20\end{array}$ & $\begin{array}{l}14 \mathrm{E} \\
8 \mathrm{E} \\
9 \mathrm{E} \\
12 \mathrm{E}\end{array}$ & $\begin{array}{ll}3 & 0 \\
3 & 0 \\
4 & 2 \\
4 & 10\end{array}$ & \begin{tabular}{|l} 
do \\
\hdashline do \\
\hdashline do
\end{tabular} & $\begin{array}{l}\text { Do } \\
\text { Do } \\
\text { Do } \\
\text { Do }\end{array}$ \\
\hline
\end{tabular}

Fergus County

\begin{tabular}{|c|c|c|c|c|c|}
\hline $\begin{array}{l}26 \ldots+\ldots \\
22 \\
7 \\
7 \\
3 \\
2\end{array}$ & $\begin{array}{l}19 \\
19 \\
19 \\
18 \\
18\end{array}$ & $\begin{array}{l}12 \mathrm{E} \\
13 \mathrm{E} \\
15 \mathrm{E} \\
13 \mathrm{E} \\
14 \mathrm{E}\end{array}$ & 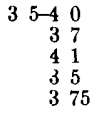 & $\begin{array}{l}\text { Glass tube } \\
\text { Rectangular. } \\
\text { Glass tube }\end{array}$ & $\begin{array}{l}\text { Fair } \\
\text { Do } \\
\text { Do } \\
\text { Good } \\
\text { Fair }\end{array}$ \\
\hline 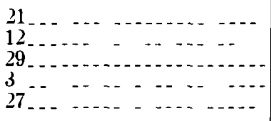 & $\begin{array}{l}18 \\
18 \\
18 \\
18 \\
17\end{array}$ & $\begin{array}{ll}15 & \mathbf{E} \\
21 & \mathbf{E} \\
21 & \mathbf{E} \\
23 & \mathbf{E} \\
15 & \mathrm{E}\end{array}$ & $\begin{array}{ll}3 & 5 \\
1 & 9 \\
4 & 10 \\
1 & 65 \\
3 & 85\end{array}$ & $\begin{array}{c}\text { Glass tube }{ }^{2} \\
\text { do }\end{array}$ & $\begin{array}{l}\text { Good } \\
\text { Do } \\
\text { Do } \\
\text { Do } \\
\text { Do }\end{array}$ \\
\hline $\begin{array}{l}23 \ldots \ldots \\
31 \\
28\end{array} 2$ & $\begin{array}{l}17 \\
16 \\
16 \\
16 \\
15\end{array}$ & $\begin{array}{l}18 \mathrm{E} \\
16 \mathrm{E} \\
18 \mathrm{E} \\
23 \mathrm{E} \\
16 \mathrm{E}\end{array}$ & $\begin{array}{ll}2 & 5 \\
4 & 82 \\
3 & 4 \\
1 & 25 \\
4 & 0\end{array}$ & 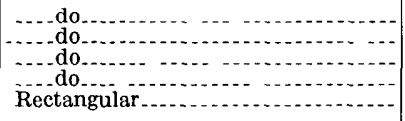 & $\begin{array}{l}\text { Do } \\
\text { Do } \\
\text { Do } \\
\text { Do } \\
\text { Do }\end{array}$ \\
\hline 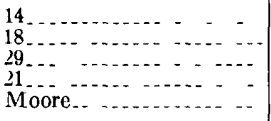 & $\begin{array}{l}15 \\
15 \\
15 \\
15 \\
14\end{array}$ & $\begin{array}{l}17 \mathbf{E} \\
19 \mathrm{E} \\
21 \mathrm{E} \\
22 \mathrm{E} \\
16 \mathrm{E}\end{array}$ & $\begin{array}{ll}3 & 8 \\
4 & 0 \\
7 & 25 \\
3 & 5 \\
4 & 32\end{array}$ & 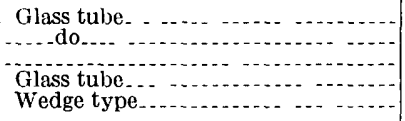 & $\begin{array}{l}\text { Fair } \\
\text { Good } \\
\text { Do } \\
\text { Fair } \\
\text { Good }\end{array}$ \\
\hline 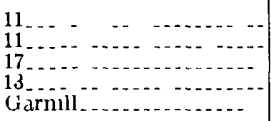 & $\begin{array}{l}14 \\
14 \\
14 \\
12 \\
11\end{array}$ & $\begin{array}{ll}19 & \mathrm{E} \\
21 & \mathrm{E} \\
21 & \mathrm{E} \\
24 & \mathrm{E} \\
16 & \mathrm{E}\end{array}$ & $\begin{array}{ll}5 & 5 \\
3 & 5 \\
5 & 9 \\
2 & 0 \\
3 & 5\end{array}$ & $\begin{array}{l}\text { Glass tube } \ldots \text { do } \\
\text { Glass tube }\end{array}$ & $\begin{array}{l}\text { Do } \\
\text { Do } \\
\text { Good } \\
\text { Do }\end{array}$ \\
\hline
\end{tabular}

Flathead County

\begin{tabular}{|c|c|c|c|c|c|}
\hline $\begin{array}{l}63 \\
28 \\
\text { Lake Mclonald } \\
\text { Apgar. }\end{array}$ & $\begin{array}{l}37 \\
35 \\
33 \\
33 \\
32\end{array}$ & $\begin{array}{l}22 \mathrm{~W} \\
21 \mathrm{~W} \\
20 \mathrm{~W} \\
18 \mathrm{~W} \\
19 \mathrm{~W}\end{array}$ & $\begin{array}{rl}3 & 25 \\
3 & 18 \\
2 & 25 \\
10 & 0 \\
3 & 51\end{array}$ & $\begin{array}{l}\text { Tohacco can } \\
\text { 8-1n standard rain gage }\end{array}$ & $\begin{array}{l}\text { Fair } \\
\text { Good } \\
\text { Do } \\
\text { Fair }\end{array}$ \\
\hline
\end{tabular}


TABLE 4-Supplemental precıpitation data from privately owned gages, or other receptacles, storm of June 7-8, 1964-Contınued

\begin{tabular}{|c|c|c|c|c|c|}
\hline \multicolumn{3}{|c|}{ Location } & \multirow{2}{*}{$\begin{array}{l}\text { Precipita- } \\
\text { tion } \\
\text { (inches) }\end{array}$} & \multirow{2}{*}{ Type of gage } & \multirow{2}{*}{$\begin{array}{l}\text { Evaluation } \\
\text { of record }\end{array}$} \\
\hline Section & $\begin{array}{l}\text { Town- } \\
\text { ship } \\
\text { north }\end{array}$ & Range & & & \\
\hline
\end{tabular}

Flathead County-Contınued

\begin{tabular}{|c|c|c|c|c|c|}
\hline & & $21 \mathrm{~W}$ & & Glass tuhe & Cond $>$ \\
\hline 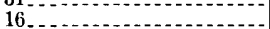 & $\begin{array}{l}51 \\
30\end{array}$ & $20 \mathrm{~W}$ & $\begin{array}{ll}2 & 40 \\
3 & 40\end{array}$ & 8-1n standard rain gage. & $\begin{array}{l}\text { Goud } \\
\text { Do }\end{array}$ \\
\hline $8 \ldots \ldots$ & 30 & $19 \mathrm{~W}$ & 313 & do. & Do \\
\hline 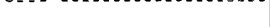 & 29 & $19 \mathrm{~W}$ & 45 & $3-\times 6-1 n$ & Do \\
\hline $36 \ldots$ & 27 & $20 \mathrm{~W}$ & 242 & 8-in standard rain gage & Do \\
\hline & 27 & $19 \mathrm{~W}$ & 40 & Gallon can & Do \\
\hline 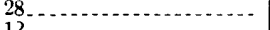 & 27 & $13 \mathrm{~W}$ & 555 & 8-in standard rain gage........... & Do \\
\hline $12 \ldots \ldots \ldots$ & 26 & $20 \mathrm{~W}$ & $\begin{array}{ll}25 \\
2 & 4\end{array}$ & 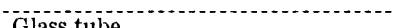 & Do \\
\hline $\begin{array}{lll}3 \\
5\end{array}$ & $\begin{array}{l}26 \\
25\end{array}$ & $\begin{array}{l}19 \mathrm{~W} \\
19 \mathrm{~W}\end{array}$ & $\begin{array}{l}24 \\
30\end{array}$ & $\begin{array}{l}\text { Glass tube } \\
\text { do do... }\end{array}$ & $\begin{array}{l}\text { Do } \\
\text { Do }\end{array}$ \\
\hline 17 & $\begin{array}{l}25 \\
24\end{array}$ & $\begin{array}{l}15 \mathrm{~W} \\
19 \mathrm{~W}\end{array}$ & $\begin{array}{ll}4 & 49 \\
3 & 6\end{array}$ & $\begin{array}{l}\text { 8-in standard rain gage } \\
6 \text {-in plastic } \ldots\end{array}$ & $\begin{array}{l}\text { Do } \\
\text { Do }\end{array}$ \\
\hline
\end{tabular}

Glacier County

\begin{tabular}{|c|c|c|c|c|c|}
\hline \begin{tabular}{|l|l|}
3 \\
3 \\
1
\end{tabular} & $\begin{array}{l}37 \\
37\end{array}$ & $\begin{array}{l}16 \mathrm{~W} \\
14 \mathrm{~W}\end{array}$ & $\begin{array}{r}+65 \\
48\end{array}$ & Bucket, sloping sides & Fair \\
\hline 21,23 & $\begin{array}{l}37 \\
36 \\
36\end{array}$ & $\begin{array}{l}14 \mathrm{~W} \\
14 \mathrm{~W} \\
14 \mathrm{~W}\end{array}$ & $\begin{array}{ll}6 & 0 \\
7 & 40 \\
7 & 29\end{array}$ & $\begin{array}{l}\text { Glass tube... } \\
\text { Wedge type. }\end{array}$ & $\begin{array}{l}\text { Good } \\
\text { Do } \\
\text { Do }\end{array}$ \\
\hline $\begin{array}{l}\text { Duck Lake.. } \\
32 \\
21 \\
14 \\
3\end{array}$ & $\begin{array}{l}36 \\
36 \\
35 \\
33 \\
33\end{array}$ & $\begin{array}{l}13 \mathrm{~W} \\
12 \mathrm{~W} \\
16 \mathrm{~W} \\
9 \mathrm{~W} \\
7 \mathrm{~W}\end{array}$ & $\begin{array}{ll}5 & 0 \\
6 & 0 \\
5 & 5 \\
4 & 5 \\
4 & 2\end{array}$ & $\begin{array}{l}\text { Barrel } \\
\text { Coffee can, 6-in deep. } \\
\text { USGS tipping bucket. } \\
51,2-1 \text { g glass tube. }\end{array}$ & $\begin{array}{l}\text { Fair } \\
\text { Good } \\
\text { Do } \\
\text { Do } \\
\text { Fair }\end{array}$ \\
\hline 13 & $\begin{array}{l}33 \\
32\end{array}$ & $\begin{array}{l}5 \mathrm{~W} \\
13 \mathrm{~W}\end{array}$ & $\begin{array}{r}53 \\
145\end{array}$ & 50-gal drum & Fair to \\
\hline 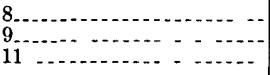 & $\begin{array}{l}32 \\
32 \\
32\end{array}$ & $\begin{array}{l}12 \mathrm{~W} \\
12 \mathrm{~W} \\
5 \mathrm{~W}\end{array}$ & $\begin{array}{rl}9 & 0 \\
10 & 0+ \\
4 & 9\end{array}$ & $\begin{array}{l}\text { 5-gal pall } \\
\text { 35-gal oil drum } \\
6-1 n \text { glass tube. }\end{array}$ & $\begin{array}{l}\text { Good } \\
\text { Fair } \\
\text { Good }\end{array}$ \\
\hline 6 & $\begin{array}{l}31 \\
31\end{array}$ & $\begin{array}{l}12 \mathrm{~W} \\
8 \mathrm{~W}\end{array}$ & $\begin{array}{rr}11 & 0 \\
4 & 5\end{array}$ & $\begin{array}{l}\text { 5-gal bucket } \\
6-\text { in glass tube. }\end{array}$ & $\begin{array}{l}\text { Falr } \\
\text { Good }\end{array}$ \\
\hline
\end{tabular}

Granite County

\begin{tabular}{|c|c|c|c|c|c|}
\hline $30 \ldots$ & $\begin{array}{l}6 \\
5\end{array}$ & $\begin{array}{l}15 \mathrm{~W} \\
14 \mathrm{~W}\end{array}$ & $\begin{array}{ll}1 & 65 \\
1 & 60\end{array}$ & Glass tube & $\begin{array}{r}\text { Good } \\
\text { Do }\end{array}$ \\
\hline
\end{tabular}

Judith Basin County

\begin{tabular}{|c|c|c|c|c|c|}
\hline $\begin{array}{l}5 \\
24 \\
34 \\
3 \\
12 \\
12 \ldots-\ldots-2\end{array}$ & $\begin{array}{l}18 \\
18 \\
18 \\
18 \\
18\end{array}$ & $\begin{array}{l}8 \mathbf{E} \\
8 \mathbf{E} \\
9 \underset{\mathbf{E}}{9} \\
10 \mathbf{E}\end{array}$ & $\begin{array}{ll}3 & 5 \\
4 & 8 \\
2 & 9 \\
4 & 0 \\
4 & 5\end{array}$ & \begin{tabular}{|c|c|} 
Glass tube & \\
$2-1 b$ &
\end{tabular} & $\begin{array}{l}\text { Fair } \\
\text { Good } \\
\text { Fair } \\
\text { Good } \\
\text { Do }\end{array}$ \\
\hline 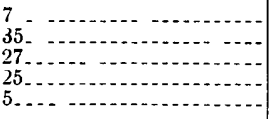 & $\begin{array}{l}18 \\
18 \\
17 \\
17 \\
16\end{array}$ & $\begin{array}{l}10 \mathrm{E} \\
11 \mathrm{E} \\
9 \mathrm{E} \\
10 \mathrm{E} \\
8 \mathrm{E}\end{array}$ & $\begin{array}{ll}4 & 0 \\
5 & 0 \\
5 & 0 \\
4 & 9 \\
6 & 0\end{array}$ & 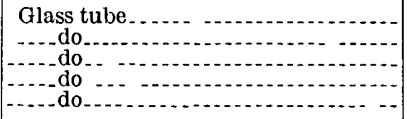 & $\begin{array}{l}\text { Fair } \\
\text { Do } \\
\text { Do } \\
\text { Do } \\
\text { Do }\end{array}$ \\
\hline 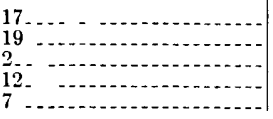 & $\begin{array}{l}16 \\
16 \\
16 \\
15 \\
15\end{array}$ & $\begin{array}{l}9 \mathrm{E} \\
13 \mathrm{E} \\
14 \mathrm{E} \\
12 \mathrm{E} \\
13 \mathrm{E}\end{array}$ & $\begin{array}{ll}7 & 25 \\
4 & 5 \\
3 & 6 \\
4 & 5 \\
4 & 05\end{array}$ & 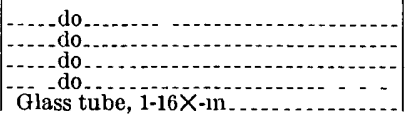 & $\begin{array}{l}\text { Good } \\
\text { Fair } \\
\text { Good } \\
\text { Do } \\
\text { Do }\end{array}$ \\
\hline
\end{tabular}


$\mathrm{T}_{\mathrm{ABLE}} 4$-Supplemental precipttation data from privately owned gages, or other receptacles, storm of June 7-8, 1964-Continued

\begin{tabular}{|c|c|c|c|c|c|}
\hline \multicolumn{3}{|c|}{ Location } & \multirow{2}{*}{$\begin{array}{c}\text { Precipita- } \\
\text { t1on } \\
\text { (inches) }\end{array}$} & \multirow{2}{*}{ Type of gage } & \multirow[b]{2}{*}{$\begin{array}{l}\text { Evaluation } \\
\text { of record }\end{array}$} \\
\hline Section & $\begin{array}{l}\text { Town- } \\
\text { ship } \\
\text { north }\end{array}$ & Range & & & \\
\hline
\end{tabular}

Judith Basın County-Contınued

\begin{tabular}{|c|c|c|c|c|c|}
\hline 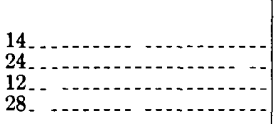 & $\begin{array}{l}15 \\
14 \\
14 \\
14 \\
14\end{array}$ & $\begin{array}{l}14 \mathrm{E} \\
12 \underset{\mathrm{E}}{\mathrm{E}} \\
15 \mathrm{E} \\
15 \mathrm{E}\end{array}$ & $\begin{array}{ll}4 & 2 \\
5 & 75 \\
4 & 3 \\
6 & 0 \\
7 & 0\end{array}$ & 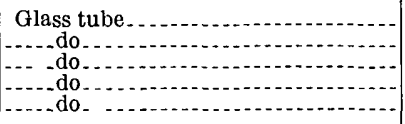 & $\begin{array}{l}\text { Good } \\
\text { Do } \\
\text { Do } \\
\text { Do } \\
\text { Fair }\end{array}$ \\
\hline \begin{tabular}{|l}
8 \\
$89_{1}$
\end{tabular} & $\begin{array}{l}13 \\
13 \\
12\end{array}$ & $\begin{array}{l}12 \mathrm{E} \\
14 \mathrm{E} \\
14 \mathrm{E}\end{array}$ & $\begin{array}{ll}4 & 5 \\
4 & 6 \\
3 & 5\end{array}$ & 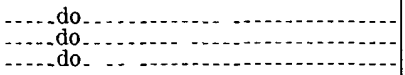 & $\begin{array}{l}\text { Do } \\
\text { Good } \\
\text { Fair }\end{array}$ \\
\hline
\end{tabular}

Lake County

\begin{tabular}{|c|c|c|c|c|c|}
\hline $\begin{array}{l}20 \ldots \\
30 \\
29 \\
30 \\
19\end{array}$ & $\begin{array}{l}26 \\
25 \\
25 \\
24 \\
24\end{array}$ & $\begin{array}{l}19 \mathrm{~W} \\
20 \mathrm{~W} \\
19 \mathrm{~W} \\
21 \mathrm{~W} \\
21 \mathrm{~W}\end{array}$ & $\begin{array}{ll}2 & 75 \\
2 & 97 \\
2 & 35 \\
3 & 00 \\
3 & 25\end{array}$ & Wedge type & Good \\
\hline $\begin{array}{l}2 \\
9 \\
9 \\
21 \\
33 \\
15\end{array}$ & $\begin{array}{l}24 \\
24 \\
24 \\
24 \\
23\end{array}$ & $\begin{array}{l}19 W \\
19 W \\
19 W \\
19 W \\
19 W\end{array}$ & $\begin{array}{ll}4 & 0 \pm \\
3 & 6 \\
4 & 5 \pm \\
4 & 2 \\
3 & 5\end{array}$ & \begin{tabular}{|l} 
Wedge type \\
do do
\end{tabular} & $\begin{array}{l}\text { Do } \\
\text { Do } \\
\text { Do } \\
\text { Do } \\
\text { Do }\end{array}$ \\
\hline $\begin{array}{l}4 \\
49\end{array}$ & $\begin{array}{l}22 \\
22\end{array}$ & $\begin{array}{l}19 \mathrm{~W} \\
17 \mathrm{~W}\end{array}$ & $\begin{array}{rl}14 & 40 \\
2 & 2\end{array}$ & Pail, sloping sides & Faur \\
\hline
\end{tabular}

Lewis and Clark County

\begin{tabular}{|c|c|c|c|c|c|}
\hline $\begin{array}{l}31 \\
27 \\
35 \\
23 \\
12\end{array}$ & $\begin{array}{l}22 \\
21 \\
21 \\
20 \\
20\end{array}$ & $\begin{array}{l}8 W \\
8 W \\
7 W \\
10 W \\
8 W\end{array}$ & $\begin{array}{rl}8 & 0 \\
6 & 47 \\
5 & 1 \\
10 & 0 \\
6 & 1\end{array}$ & $\begin{array}{l}\text { 5-gal pall } \\
\text { 8-in standard rain gage. } \\
\text { Glass tube. }\end{array}$ & $\begin{array}{l}\text { Fair } \\
\text { Good } \\
\text { Fair } \\
\text { Do } \\
\text { Do }\end{array}$ \\
\hline $\begin{array}{l}13 \\
135 \\
85 \\
8 \\
8\end{array}$ & $\begin{array}{l}20 \\
20 \\
20 \\
20 \\
19\end{array}$ & $\begin{array}{l}8 W \\
7 W \\
5 W \\
4 W \\
8 W\end{array}$ & $\begin{array}{rl}6 & 0 \\
5 & 75 \\
5 & 0 \\
7 & 4 \\
12 & 75\end{array}$ & $\begin{array}{l}\text { Rectangular } \\
\text { Glass tube. }\end{array}$ & $\begin{array}{l}\text { Do } \\
\text { Good } \\
\text { Do } \\
\text { Fair } \\
\text { Good }\end{array}$ \\
\hline 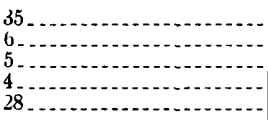 & $\begin{array}{l}19 \\
19 \\
19 \\
19 \\
19\end{array}$ & $\begin{array}{l}8 \mathrm{~W} \\
8 \mathrm{~W} \\
8 \mathrm{~W} \\
8 \mathrm{~W} \\
7 \mathrm{~W}\end{array}$ & $\begin{array}{l}83 \\
13+ \\
1125 \\
10+ \\
58\end{array}$ & $\begin{array}{l}\text { Coffee can } \\
\text { Glass tube }\end{array}$ & $\begin{array}{l}\text { Do } \\
\text { Fair } \\
\text { Do } \\
\text { Do } \\
\text { Good }\end{array}$ \\
\hline $\begin{array}{l}32 \\
13 \\
24 \\
70 \\
20\end{array}$ & $\begin{array}{l}19 \\
18 \\
18 \\
18 \\
17\end{array}$ & $\begin{array}{l}7 \mathrm{~W} \\
8 \mathrm{~W} \\
7 \mathrm{~W} \\
6 \mathrm{~W} \\
6 \mathrm{~W}\end{array}$ & $\begin{array}{ll}8 & 0 \\
8 & 0 \\
5 & 5 \\
6 & 0 \\
4 & 5+\end{array}$ & $\begin{array}{l}\text { 2-lb coffee can } \\
\text { Glass tube. }\end{array}$ & $\begin{array}{l}\text { Fair } \\
\text { Do } \\
\text { Do } \\
\text { Good } \\
\text { Poor }\end{array}$ \\
\hline $\begin{array}{l}1 \\
4 \\
4 \\
4\end{array}{ }^{4}$ & $\begin{array}{l}16 \\
16 \\
15 \\
15 \\
14\end{array}$ & $\begin{array}{l}6 \mathrm{~W} \\
5 \mathrm{~W} \\
7 \mathrm{~W} \\
3 \mathrm{~W} \\
2 \mathrm{~W}\end{array}$ & $\begin{array}{ll}6 & 1 \\
4 & 3 \\
8 & 0 \\
1 & 97 \\
3 & 8\end{array}$ & $\begin{array}{l}\text { 5-gal can do } \\
\text { 8-in standard rain gage. } \\
\text { Glass tube.. }\end{array}$ & $\begin{array}{l}\text { Good } \\
\text { Fair } \\
\text { Good } \\
\text { Do } \\
\text { Do }\end{array}$ \\
\hline
\end{tabular}

Liberty County

\begin{tabular}{|c|c|c|c|c|c|}
\hline $\begin{array}{l}15 \\
22 \\
25 \\
4\end{array}$ & $\begin{array}{l}33 \\
33 \\
33 \\
31\end{array}$ & $\begin{array}{l}4 \mathrm{E} \\
5 \mathrm{E} \\
5 \\
4 \mathrm{E}\end{array}$ & $\begin{array}{ll}1 & 4 \\
& 85 \\
0 & 8 \\
1 & 8\end{array}$ & $\begin{array}{l}\text { Funnel gage } \\
\text { Wedge type } \\
\text { Glass tube } \\
\text { 5-1n glass tube. }\end{array}$ & $\begin{array}{l}\text { Good } \\
\text { Do } \\
\text { Do } \\
\text { Do }\end{array}$ \\
\hline
\end{tabular}

See tootnote at end of table 
TABLE 4-Supplemental preciptation data from privately owned gages, or other receptacles, storm of June 7-8, 1964-Continued

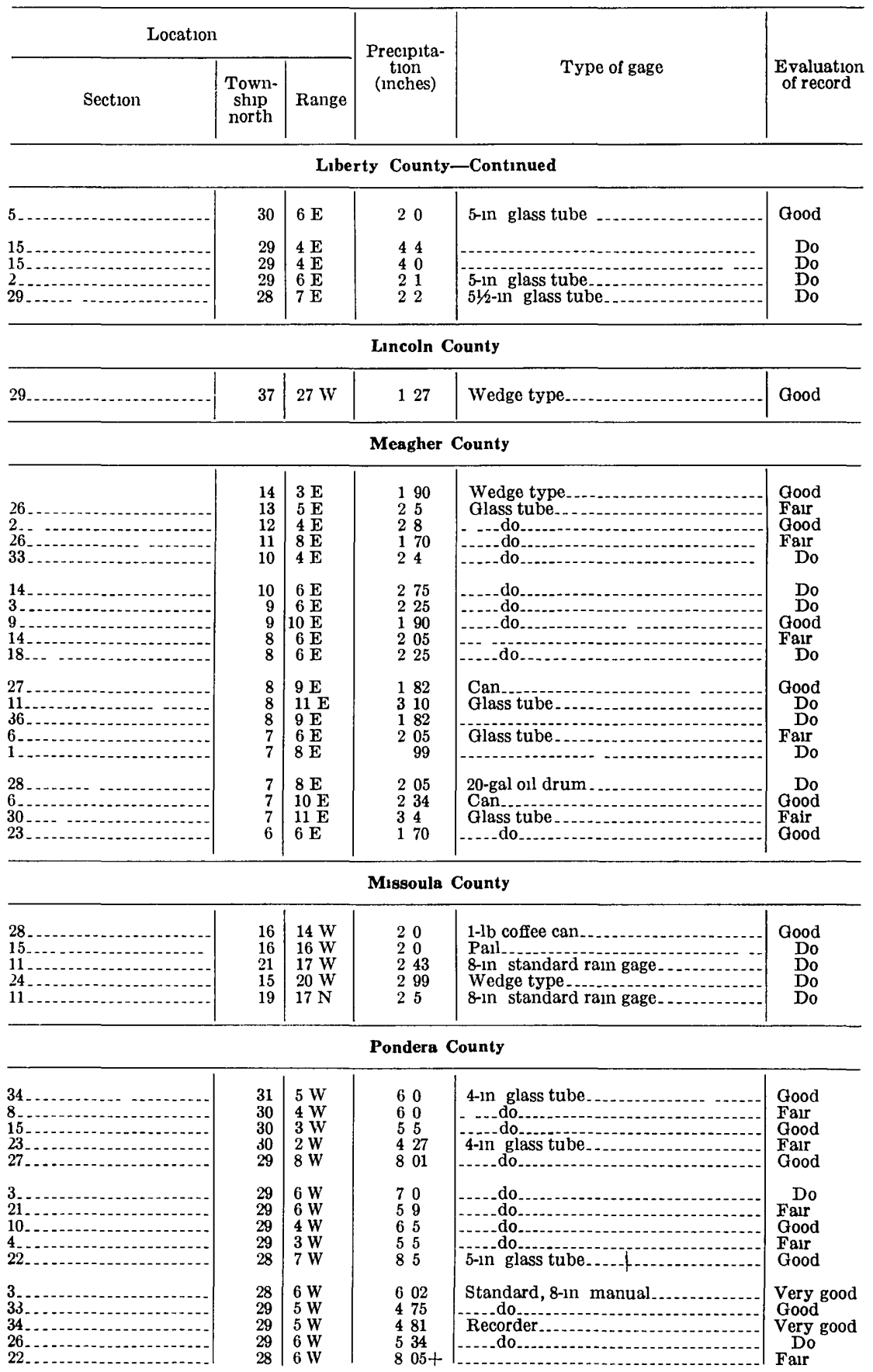


TABLE 4-Supplemental precipitation data from privately owned gages, on other receptacles, storm of June 7-8, 1964-Continued

\begin{tabular}{|c|c|c|c|c|c|}
\hline \multicolumn{3}{|c|}{ Location } & \multirow{2}{*}{$\begin{array}{l}\text { Precipita- } \\
\text { tion } \\
\text { (mches) }\end{array}$} & \multirow{2}{*}{ Type of gage } & \multirow{2}{*}{$\begin{array}{l}\text { Evaluation } \\
\text { of record }\end{array}$} \\
\hline Section & $\begin{array}{l}\text { Town- } \\
\text { ship } \\
\text { north }\end{array}$ & Range & & & \\
\hline
\end{tabular}

Pondera County-Contınued

\begin{tabular}{|c|c|c|c|c|c|}
\hline $\begin{array}{l}28 \\
12 \\
36 \\
6 \\
15\end{array}$ & $\begin{array}{l}28 \\
28 \\
28 \\
28 \\
28\end{array}$ & $\begin{array}{l}4 W \\
2 W \\
2 W \\
1 W \\
1\end{array}$ & $\begin{array}{ll}4 & 5 \\
4 & 1 \\
4 & 3 \\
4 & 80 \\
4 & 20\end{array}$ & \begin{tabular}{|c|} 
5-1n glass tube. \\
4-in glass tube do do
\end{tabular} & $\begin{array}{l}\text { Good } \\
\text { Fair } \\
\text { Do } \\
\text { Do } \\
\text { Good }\end{array}$ \\
\hline $\begin{array}{l}15 \\
29 \\
21 \\
28\end{array}$ & $\begin{array}{l}28 \\
27 \\
26 \\
27 \\
27\end{array}$ & $\begin{array}{l}2 \mathbf{E} \\
3 \mathbf{W} \\
2 \mathbf{W} \\
2 \mathbf{W} \\
1 \mathbf{W}\end{array}$ & $\begin{array}{ll}3 & 50 \\
5 & 5 \\
3 & 5 \\
4 & 7 \\
2 & 9\end{array}$ & 5-m glass tube & $\begin{array}{l}\text { Fair } \\
\text { Do } \\
\text { Good } \\
\text { Fair } \\
\text { Do }\end{array}$ \\
\hline 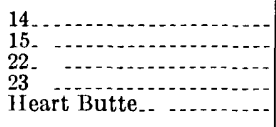 & $\begin{array}{l}27 \\
27 \\
27 \\
26 \\
29\end{array}$ & $\begin{array}{ll}1 & \mathrm{E} \\
2 & \mathrm{E} \\
2 & \mathrm{E} \\
1 & \mathrm{E} \\
10 \mathrm{WW}\end{array}$ & $\begin{array}{rr}3 & 5 \\
4 & 0 \\
4 & 6 \\
3 & 0 \\
11 & 0\end{array}$ & $\begin{array}{l}\text { 11/4-1n tube } \\
\text { 5-1n glass tube } \\
\text { Washtub. - - }\end{array}$ & $\begin{array}{l}\text { Good } \\
\text { Do } \\
\text { Do } \\
\text { Fair } \\
\text { Do }\end{array}$ \\
\hline
\end{tabular}

Powell County

\begin{tabular}{|c|c|c|c|c|}
\hline $\begin{array}{l}4 \\
41 \\
22\end{array}$ & $\begin{array}{l}15 \\
15 \\
15 \\
15 \\
15\end{array}$ & $\begin{array}{l}13 \mathrm{~W} \\
12 \mathrm{~W} \\
11 \mathrm{~W} \\
11 \mathrm{~W} \\
10 \mathrm{~W}\end{array}$ & $\begin{array}{ll}1 & 5 \\
1 & 3 \\
2 & 2 \\
2 & 04 \\
3 & 0\end{array}$ & 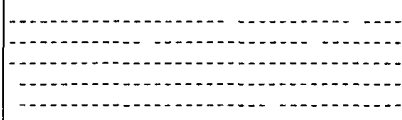 \\
\hline $28 \ldots \ldots \ldots$ & 15 & $10 \mathrm{~W}$ & 165 & 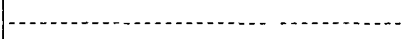 \\
\hline
\end{tabular}

Sanders County

\begin{tabular}{|c|c|c|c|c|}
\hline 30 & 22 & $23 \mathrm{~W}$ & 340 & 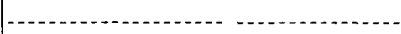 \\
\hline
\end{tabular}

Teton County

\begin{tabular}{|c|c|c|c|c|c|}
\hline $\begin{array}{l}13 \\
26\end{array}$ & $\begin{array}{l}27 \\
27 \\
27 \\
27 \\
26\end{array}$ & $\begin{array}{l}8 \mathrm{~W} \\
7 \mathrm{~W} \\
5 \mathrm{~W} \\
4 \mathrm{~W} \\
8 \mathrm{~W}\end{array}$ & $\begin{array}{ll}7 & 5 \\
6 & 4 \\
6 & 5 \\
6 & 5 \\
6 & 7\end{array}$ & 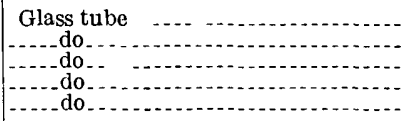 & $\begin{array}{l}\text { Fair } \\
\text { Do } \\
\text { Good } \\
\text { Do } \\
\text { Do }\end{array}$ \\
\hline 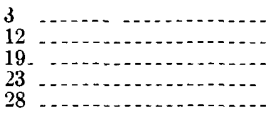 & $\begin{array}{l}26 \\
26 \\
26 \\
26 \\
26\end{array}$ & $\begin{array}{l}6 \mathrm{~W} \\
5 \mathrm{WV} \\
5 \mathrm{~W} \\
4 \mathrm{~W} \\
3 \mathrm{~W}\end{array}$ & $\begin{array}{ll}6 & 0 \\
4 & 0 \\
4 & 75 \\
4 & 7 \\
4 & 5\end{array}$ & \begin{tabular}{|c|c|} 
Rectangular. \\
Glass tube
\end{tabular} & $\begin{array}{l}\text { Do } \\
\text { Fair } \\
\text { Good } \\
\text { Do } \\
\text { Do }\end{array}$ \\
\hline 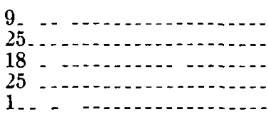 & $\begin{array}{l}25 \\
25 \\
25 \\
25 \\
25\end{array}$ & $\begin{array}{l}8 \mathrm{~W} \\
7 \mathrm{~W} \\
5 \mathrm{~W} \\
3 \mathrm{~W} \\
2 \mathrm{~W}\end{array}$ & $\begin{array}{ll}9 & 0 \\
8 & 0 \\
4 & 65 \\
4 & 0 \\
4 & 85\end{array}$ & \begin{tabular}{|c|c|} 
Wedge type \\
Glass tube.
\end{tabular} & $\begin{array}{l}\text { Do } \\
\text { Fair } \\
\text { Good } \\
\text { Do } \\
\text { Do }\end{array}$ \\
\hline $\begin{array}{l}12 \\
13 \\
25 \\
14\end{array}$ & $\begin{array}{l}24 \\
24 \\
24 \\
24\end{array}$ & $\begin{array}{l}5 \mathrm{~W} \\
5 \mathrm{~W} \\
5 \mathrm{~W} \\
4 \mathrm{~W}\end{array}$ & $\begin{array}{ll}4 & 73 \\
5 & 5 \\
5 & 21 \\
5 & 0\end{array}$ & Gin standard ram gage & $\begin{array}{l}\text { Do } \\
\text { Fair } \\
\text { Good } \\
\text { Do }\end{array}$ \\
\hline
\end{tabular}


TABLE 4 -Supplemental precıptation data from privately owned gages, or other receptacles, storm of June 7-8, 1964-Continued

\begin{tabular}{c|c|c|c|c}
\hline \multicolumn{2}{c|}{ Location } & $\begin{array}{c}\text { Precipita- } \\
\text { tion } \\
\text { (nches) }\end{array}$ \\
\hline Section & $\begin{array}{c}\text { Town- } \\
\text { ship } \\
\text { north }\end{array}$ & Range & Type of gage & Evaluation \\
of record
\end{tabular}

\begin{tabular}{l|r|l|r|l|l|l}
\hline \multicolumn{7}{|c|}{ Teton County-Continued } \\
\hline 1
\end{tabular}

Toole County

\begin{tabular}{|c|c|c|c|c|c|}
\hline Galata & 31 & $3 \mathrm{E}$ & 20 & 5-1n glass tube & Good \\
\hline Sunburst. & 36 & $2 \mathrm{~W}$ & 20 & - do & Fair \\
\hline 0 & 37 & $2 \mathrm{~W}$ & 21 & Glass tube. & Do \\
\hline $28,25-10$ & $\begin{array}{l}36 \\
36\end{array}$ & $\begin{array}{l}4 \mathrm{~W} \\
3 \mathrm{~W}\end{array}$ & $\begin{array}{ll}2 & 2 \\
2 & 0\end{array}$ & - do do do & $\begin{array}{l}\text { Good } \\
\text { Falr }\end{array}$ \\
\hline $\begin{array}{l}2 \\
33 \\
21 \\
16 \\
11\end{array}$ & $\begin{array}{l}35 \\
35 \\
35 \\
34 \\
34\end{array}$ & $\begin{array}{l}4 \underset{\mathrm{W}}{\mathrm{W}} \\
2 \underset{\mathrm{W}}{1} \mathrm{E} \\
4 \underset{\mathrm{W}}{\mathrm{W}} \\
3 \mathrm{~W}\end{array}$ & $\begin{array}{ll}6 & 4 \\
2 & 5 \\
1 & 5 \\
4 & 0 \\
3 & 0\end{array}$ & 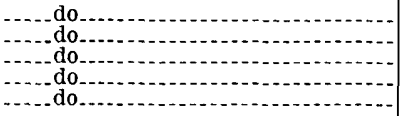 & $\begin{array}{l}\text { Good } \\
\text { Fair } \\
\text { Good } \\
\text { Fair } \\
\text { Do }\end{array}$ \\
\hline $\begin{array}{l}2 \\
6 \\
6 \\
6 \\
6 \\
26 \\
19\end{array}$ & $\begin{array}{l}34 \\
33 \\
33 \\
33 \\
33\end{array}$ & $\begin{array}{l}1 \mathrm{w} \\
3 \underset{\mathrm{W}}{3} \\
2 \mathrm{~W} \\
2 \mathrm{~W}\end{array}$ & $\begin{array}{ll}1 & 5 \\
3 & 1 \\
3 & 25 \\
3 & 0 \\
2 & 5\end{array}$ & Glass tube & $\begin{array}{l}\text { Do } \\
\text { Good } \\
\text { Fair } \\
\text { Good }\end{array}$ \\
\hline $\begin{array}{l}22 \\
18 \\
35 \\
34 \\
4\end{array}$ & $\begin{array}{l}33 \\
32 \\
32 \\
32 \\
32\end{array}$ & $\begin{array}{l}3 \mathrm{E} \\
4 \mathrm{~W} \\
4 \mathrm{~W} \\
3 \mathrm{~W} \\
2 \mathrm{E}\end{array}$ & $\begin{array}{ll}1 & 7 \\
4 & 6 \\
5 & 3 \\
4 & 0 \\
2 & 0\end{array}$ & Glass tube & $\begin{array}{l}\text { Do } \\
\text { Good } \\
\text { Fair } \\
\text { Good }\end{array}$ \\
\hline
\end{tabular}


TABLE 4-Supplemental precıpıtation data from privately owned gages, or other receptacles, storm of June 7-8, 1964-Contınued

\begin{tabular}{c|c|c|c|c}
\hline \multicolumn{2}{c|}{ Location } & $\begin{array}{c}\text { Precipita- } \\
\text { tion } \\
\text { (inches) }\end{array}$ & Type of gage & $\begin{array}{c}\text { Evaluation } \\
\text { of record }\end{array}$ \\
\hline
\end{tabular}

Toole County-Contınued

\begin{tabular}{|c|c|c|c|c|c|}
\hline $\begin{array}{l}34 \\
16 \\
26 \\
4 \\
27\end{array}$ & $\begin{array}{l}32 \\
31 \\
31 \\
31 \\
31\end{array}$ & $\begin{array}{ll}3 & \mathbf{E} \\
2 & \mathbf{W} \\
2 & \mathbf{W} \\
1 & \mathbf{W} \\
1 & \mathbf{E}\end{array}$ & $\begin{array}{ll}3 & 85 \\
4 & 7 \\
4 & 1 \\
3 & 5 \\
2 & 25\end{array}$ & \begin{tabular}{|c|} 
Glass Tube \\
do
\end{tabular} & $\begin{array}{l}\text { Good } \\
\text { Do } \\
\text { Fair } \\
\text { Do } \\
\text { Good }\end{array}$ \\
\hline $\begin{array}{l}30 \\
7 \\
3 \\
3\end{array}$ & $\begin{array}{l}30 \\
30 \\
30 \\
29\end{array}$ & $\begin{array}{l}1 \mathbf{W} \\
2 \underset{\mathbf{E}}{3} \\
2 \mathbf{E}\end{array}$ & $\begin{array}{ll}3 & 3 \\
2 & 25 \\
2 & 0 \\
3 & 2\end{array}$ & 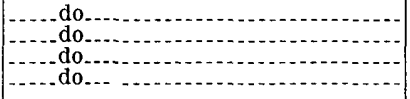 & $\begin{array}{l}\text { Do } \\
\text { Do } \\
\text { Do } \\
\text { Do }\end{array}$ \\
\hline
\end{tabular}

1 About 
T IBLE 5 - Supplemental preciptation data from the Alberta, Canada, area north of the Montana boundary, storm of June 7-8, 1964

Canada Department of Agriculture measurements

\begin{tabular}{|c|c|c|c|c|c|c|}
\hline Section or locality & $\begin{array}{l}\text { Town- } \\
\text { ship } \\
\text { north }\end{array}$ & Range & $\begin{array}{l}\text { June } 7-8 \\
\text { duration } \\
\text { (hours) }\end{array}$ & $\begin{array}{l}\text { Total } \\
\text { precipl- } \\
\text { tation } \\
\text { (1nches) }\end{array}$ & Gage & $\underset{\text { Evalua- }}{\text { tion }}$ \\
\hline 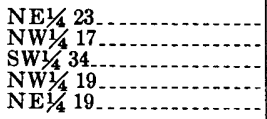 & $\begin{array}{l}3 \\
3 \\
2 \\
3 \\
2\end{array}$ & $\begin{array}{l}25 \\
24 \\
24 \\
24 \\
23\end{array}$ & $\begin{array}{l}25 \\
24 \\
23 \\
24 \\
24\end{array}$ & $\begin{array}{ll}4 & 0 \\
4 & 0 \\
5 & 0 \\
5 & 0 \\
4 & 5\end{array}$ & $\begin{array}{l}11-\text { by } 15-1 n \text { pall } \\
12-\text { by } 15-1 n \text { pan } \\
\text { 5/8-1n glass }\end{array}$ & $\begin{array}{l}\text { Good } \\
\text { Do } \\
\text { Do } \\
\text { Do } \\
\text { Do }\end{array}$ \\
\hline $\begin{array}{l}\text { NW1/4 } 36 \ldots \ldots \\
\text { NW1/4 } 29 \ldots \ldots \\
\text { SW } 1 / 416 \ldots \ldots \\
\text { SW1/4 } 16 \ldots \ldots\end{array}$ & $\begin{array}{l}1 \\
1 \\
1 \\
1\end{array}$ & $\begin{array}{l}24 \\
24 \\
23 \\
23\end{array}$ & $\begin{array}{l}24 \\
241 / 2 \\
24 \\
24\end{array}$ & $\begin{array}{ll}5 & 5 \\
5 & 5 \\
5 & 2 \\
3 & 9\end{array}$ & $\begin{array}{l}\text { Department of Transport } \\
\text { B/8-1n glass } . . . d o \\
\text { Department of Transport. }\end{array}$ & $\begin{array}{l}\text { Do } \\
\text { Do } \\
\text { Do } \\
\text { Do }\end{array}$ \\
\hline 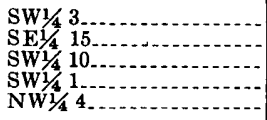 & $\begin{array}{l}1 \\
1 \\
1 \\
2 \\
3\end{array}$ & $\begin{array}{l}22 \\
24 \\
25 \\
25 \\
24\end{array}$ & $\begin{array}{l}25 \\
25 \\
24 \\
24 \\
24\end{array}$ & $\begin{array}{ll}4 & 2 \\
6 & 5 \\
6 & 5 \\
6 & 5 \\
5 & 5\end{array}$ & 5/8-1n glass & $\begin{array}{l}\text { Do } \\
\text { Do } \\
\text { Do } \\
\text { Do } \\
\text { Do }\end{array}$ \\
\hline $\begin{array}{l}\text { NW1/4 } 20 \ldots \ldots \\
\text { SW1/4 } 3 \ldots \\
\text { NW1/4 } 28 \ldots \ldots \\
\text { NE1/4 32 } \\
\text { SE1/4 } 13 \ldots \ldots\end{array}$ & $\begin{array}{l}3 \\
4 \\
4 \\
3 \\
4\end{array}$ & $\begin{array}{l}23 \\
23 \\
23 \\
24 \\
25\end{array}$ & $\begin{array}{l}24 \\
24 \\
24 \\
24 \\
24\end{array}$ & $\begin{array}{ll}3 & 4 \\
3 & 5 \\
2 & 5 \\
4 & 5 \\
4 & 5\end{array}$ & $\begin{array}{l}1 / 2-\text { by } 4-1 n \text { glass. } \\
5 / 8-10 \text { glass } \\
6 / 8-1 n \text { glass }\end{array}$ & $\begin{array}{l}\text { Fair } \\
\text { Do } \\
\text { Good } \\
\text { Do } \\
\text { Do }\end{array}$ \\
\hline $\begin{array}{l}\text { SE1/4 } 19 \\
\text { NW1/4 25 } \\
\text { SW1/4 } 1 \\
\text { Magrath, Alberta. } \\
\text { NE1/4 } 7\end{array}$ & $\begin{array}{r}3 \\
4 \\
4 \\
-5\end{array}$ & $\begin{array}{l}24 \\
23 \\
23 \\
21\end{array}$ & $\begin{array}{l}24 \\
24 \\
24 \\
24 \\
24\end{array}$ & $\begin{array}{ll}3 & 8 \\
3 & 0 \\
4 & 5 \\
1 & 13 \\
1 & 65\end{array}$ & 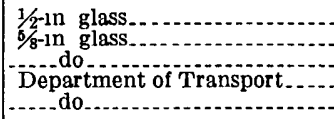 & $\begin{array}{l}\text { Do } \\
\text { Do } \\
\text { Do } \\
\text { Do } \\
\text { Do }\end{array}$ \\
\hline 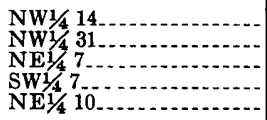 & $\begin{array}{l}4 \\
2 \\
2 \\
2 \\
1\end{array}$ & $\begin{array}{l}22 \\
21 \\
21 \\
20 \\
21\end{array}$ & $\begin{array}{l}24 \\
24 \\
24 \\
24 \\
24\end{array}$ & $\begin{array}{ll}3 & 4 \\
3 & 25 \\
3 & 6 \\
4 & 5 \\
2 & 5\end{array}$ & 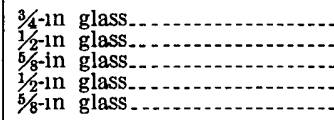 & $\begin{array}{l}\text { Do } \\
\text { Do } \\
\text { Do } \\
\text { Do } \\
\text { Do }\end{array}$ \\
\hline $\begin{array}{l}\text { NW1/4 } 16 \ldots \ldots \\
\text { NE1/4 } 23 \ldots \ldots \\
\text { SW1/4 } 7 \ldots \ldots \\
\text { SW1 } 1 / 42 \ldots \\
\text { NE1/4 } 14 \ldots \ldots\end{array}$ & $\begin{array}{l}1 \\
1 \\
1 \\
2 \\
1\end{array}$ & $\begin{array}{l}20 \\
20 \\
19 \\
17 \\
17\end{array}$ & $\begin{array}{l}24 \\
24 \\
24 \\
24 \\
24\end{array}$ & $\begin{array}{ll}4 & 0 \\
3 & 25 \\
3 & 75 \\
2 & 63 \\
4 & 75\end{array}$ & $\begin{array}{l}3 / 4-1 n \text { glass } \\
5 / 8-1 n \text { glass. } \\
1 / 4-\text { by } 6-1 n \text { glass. }\end{array}$ & $\begin{array}{l}\text { Do } \\
\text { Do } \\
\text { Do } \\
\text { Do } \\
\text { Do }\end{array}$ \\
\hline 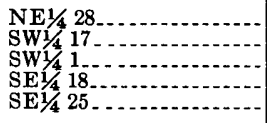 & $\begin{array}{l}1 \\
1 \\
1 \\
1 \\
1\end{array}$ & $\begin{array}{l}17 \\
17 \\
17 \\
16 \\
16\end{array}$ & $\begin{array}{l}24 \\
24 \\
24 \\
24 \\
24\end{array}$ & $\begin{array}{ll}3 & 0 \\
3 & 0 \\
4 & 5 \\
4 & 5 \\
3 & 5\end{array}$ & 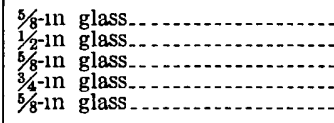 & $\begin{array}{l}\text { Do } \\
\text { Do } \\
\text { Do } \\
\text { Do } \\
\text { Do }\end{array}$ \\
\hline $\begin{array}{l}\text { SE1/4 } 1 \\
\text { NE1/47 } \\
\text { SW1/4 } 11 \\
\text { NE1/4 } 19 \ldots \ldots \\
\text { SW } 1 / 416 \ldots\end{array}$ & $\begin{array}{l}3 \\
3 \\
3 \\
3 \\
4\end{array}$ & $\begin{array}{l}17 \\
16 \\
17 \\
17 \\
18\end{array}$ & $\begin{array}{l}24 \\
24 \\
24 \\
24 \\
34\end{array}$ & $\begin{array}{ll}3 & 2 \\
3 & 0 \\
3 & 5 \\
3 & 0 \\
2 & 8\end{array}$ & $\begin{array}{l}1 / 2 \text { in glass } \\
1 / 2 \text { in glass. } \\
3 / 4 \text {-in glass } \ldots\end{array}$ & $\begin{array}{l}\text { Do } \\
\text { Do } \\
\text { Do } \\
\text { Do } \\
\text { Do }\end{array}$ \\
\hline 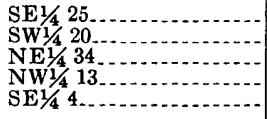 & $\begin{array}{l}4 \\
3 \\
4 \\
5 \\
5\end{array}$ & $\begin{array}{l}19 \\
19 \\
20 \\
21 \\
21\end{array}$ & $\begin{array}{l}24 \\
24 \\
24 \\
24 \\
24\end{array}$ & $\begin{array}{ll}3 & 32 \\
4 & 0 \\
2 & 5 \\
2 & 7 \\
3 & 0\end{array}$ & 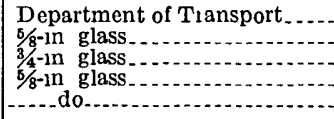 & $\begin{array}{l}\text { Do } \\
\text { Do } \\
\text { Do } \\
\text { Do } \\
\text { Do }\end{array}$ \\
\hline $\begin{array}{l}\text { NE1/49. } \\
\text { NW1/4 28 } \\
\text { Glenwood, Alberta. } \\
\text { NW1/4 20. } \\
\text { NE1/4 14 }\end{array}$ & $\begin{array}{r}4 \\
5 \\
-5 \\
-5\end{array}$ & $\begin{array}{r}22 \\
25 \\
23 \\
30\end{array}$ & $\begin{array}{l}24 \\
24 \\
24 \\
24 \\
24\end{array}$ & $\begin{array}{ll}3 & 25 \\
2 & 3 \\
2 & 44 \\
4 & 42 \\
1 & 92\end{array}$ & $\begin{array}{l}\text { 1/2-in glass } \\
3 / 4-\text { glass } \\
\text { Department of Transport }\end{array}$ & $\begin{array}{l}\text { Do } \\
\text { Do } \\
\text { Do } \\
\text { Do } \\
\text { Do }\end{array}$ \\
\hline $\begin{array}{l}\text { NW1/4 } 17 \ldots \ldots \\
\text { NW1/4 31 } \\
\text { NE1/46 } 6 \ldots \\
\text { SE1/414 } 14 \ldots \\
\text { NE1/4 35 }\end{array}$ & $\begin{array}{l}4 \\
1 \\
5 \\
5 \\
2\end{array}$ & $\begin{array}{l}29 \\
18 \\
28 \\
29 \\
28\end{array}$ & $\begin{array}{l}24 \\
24 \\
24 \\
25 \\
251 / 2\end{array}$ & $\begin{array}{ll}4 & 0 \\
3 & 5 \\
2 & 5 \\
2 & 9 \\
5 & 5\end{array}$ & 5/8-1n glass $\ldots$ do & $\begin{array}{l}\text { Do } \\
\text { Do } \\
\text { Do } \\
\text { Do } \\
\text { Fair }\end{array}$ \\
\hline
\end{tabular}


TABLE 5-Supplemental precıpitatıon data from the Alberta, Canada, area north of the Montana boundary, storm of June 7-8, 1964-Continued

Canada Department of Agriculture measurements-Contınued

\begin{tabular}{|c|c|c|c|c|c|c|}
\hline Section or locality & $\begin{array}{l}\text { Town } \\
\text { ship } \\
\text { north }\end{array}$ & Range & $\begin{array}{l}\text { June } 7-8 \\
\text { duration } \\
\text { (hours) }\end{array}$ & $\begin{array}{l}\text { Total } \\
\text { precip1- } \\
\text { tation } \\
\text { (inches) }\end{array}$ & Gage & $\begin{array}{c}\text { Evalua- } \\
\text { tion }\end{array}$ \\
\hline $\begin{array}{l}\text { NE1/4 } 26 \ldots \ldots \\
\text { NE1/4 } 23 \ldots \ldots \\
\text { NE } 1 / 414 \ldots \\
\text { SE1/4 } 19 \ldots \ldots \\
\text { SE1/4 } 4 \ldots \ldots\end{array}$ & $\begin{array}{l}2 \\
2 \\
2 \\
2 \\
2\end{array}$ & $\begin{array}{l}28 \\
28 \\
28 \\
27 \\
27\end{array}$ & $\begin{array}{l}251 / 2 \\
26 \\
26 \\
261 / 2 \\
32\end{array}$ & $\begin{array}{ll}5 & 48 \\
6 & 0 \\
6 & 49 \\
7 & 25 \\
6 & 75\end{array}$ & 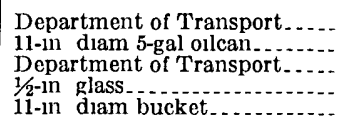 & $\begin{array}{l}\text { Good } \\
\text { Do } \\
\text { Do } \\
\text { Do } \\
\text { Fair }\end{array}$ \\
\hline 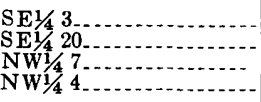 & $\begin{array}{l}2 \\
2 \\
2 \\
2\end{array}$ & $\begin{array}{l}27 \\
27 \\
28 \\
28\end{array}$ & $\begin{array}{l}251 / 2 \\
27 \\
30 \\
271 / 2\end{array}$ & $\begin{array}{ll}6 & 50 \\
7 & 75 \\
6 & 36 \\
7 & 5\end{array}$ & $\begin{array}{l}\text { 5/8-1n glass. } \\
11-11 \text { diam pail } \\
\text { Department of Transport. } \\
1 / 2-1 n \text { glass. . }\end{array}$ & $\begin{array}{l}\text { Good } \\
\text { Do } \\
\text { Do } \\
\text { Do }\end{array}$ \\
\hline $\begin{array}{l}\text { Belly River ranger } \\
\text { station }\end{array}$ & & $\ldots \ldots$ & 30 & 85 & Department of Transport_... & Do \\
\hline $\begin{array}{l}\text { NW } 1 / 422 \ldots \\
\text { SE1/46 } \\
\text { NW1/4 } 1 \ldots \\
\text { SW } 1 / 410\end{array}$ & $\begin{array}{l}2 \\
3 \\
3 \\
3\end{array}$ & $\begin{array}{l}27 \\
26 \\
27 \\
27\end{array}$ & $\begin{array}{l}261 / 2 \\
26 \\
26 \\
291 / 2\end{array}$ & $\begin{array}{ll}7 & 0 \\
5 & 5 \\
6 & 5 \\
7 & 0\end{array}$ & $\begin{array}{l}\text { 11-in diam pail. } \\
1 / 2-1 n \text { glass }\end{array}$ & $\begin{array}{l}\text { Do } \\
\text { Do } \\
\text { Do } \\
\text { Do }\end{array}$ \\
\hline $\begin{array}{l}\text { NE1/4 } 9 \ldots \ldots \\
\text { NE1/4 } 7 \ldots \ldots \\
\text { NE1/4 } 36 \ldots \ldots \\
\text { NE1 } 1 / 415 \ldots \\
\text { SE1/4 } 17 \ldots \ldots\end{array}$ & $\begin{array}{l}3 \\
3 \\
2 \\
2 \\
2\end{array}$ & $\begin{array}{l}26 \\
27 \\
26 \\
26 \\
26\end{array}$ & $\begin{array}{l}251 / 2 \\
25 \\
24 \\
261 / 2 \\
30\end{array}$ & $\begin{array}{ll}7 & 0 \\
3 & 5 \\
4 & 0 \\
6 & 5 \\
7 & 0\end{array}$ & $\begin{array}{l}\text { 5/8-1n glass } \\
11-1 n \text { diam pail }\end{array}$ & $\begin{array}{l}\text { Do } \\
\text { Do } \\
\text { Do } \\
\text { Do } \\
\text { Do }\end{array}$ \\
\hline $\begin{array}{l}\text { NE1/4 } 12 \ldots \\
\text { NE1/4 } 24 \ldots \\
\text { SE1/4 10 } \\
\text { SW } 1 / 4 \text { 14 } 14 \ldots \\
\text { SE1/4 } 14\end{array}$ & $\begin{array}{l}2 \\
1 \\
1 \\
1 \\
1\end{array}$ & $\begin{array}{l}27 \\
27 \\
27 \\
27 \\
27\end{array}$ & $\begin{array}{l}28 \\
321 / 2 \\
32 \\
26\end{array}$ & $\begin{array}{ll}6 & 75 \\
8 & 5 \\
7 & 5 \\
7 & 0 \\
7 & 0\end{array}$ & 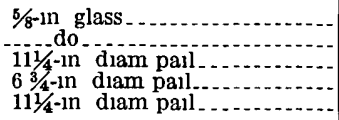 & $\begin{array}{l}\text { Do } \\
\text { Do } \\
\text { Do } \\
\text { Do } \\
\text { Do }\end{array}$ \\
\hline 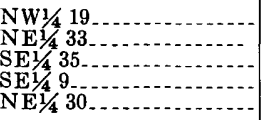 & $\begin{array}{l}1 \\
1 \\
1 \\
2 \\
2\end{array}$ & $\begin{array}{l}26 \\
26 \\
26 \\
25 \\
24\end{array}$ & $\begin{array}{l}27 \\
25 \\
271 / 2 \\
24\end{array}$ & $\begin{array}{ll}6 & 5 \\
4 & 5 \\
5 & 5 \\
6 & 0 \\
6 & 0\end{array}$ & $\begin{array}{l}\text { 5/8-1n glass } \\
\text { 5/4-1n pail } \\
\text { 4-1n diam can } \\
\text { 11-1n glass } \\
\text { 11-1n diam pail }\end{array}$ & $\begin{array}{l}\text { Do } \\
\text { Do } \\
\text { Fair } \\
\text { Do } \\
\text { Good }\end{array}$ \\
\hline $\begin{array}{l}\text { NE1/4 } 12 \ldots \ldots \\
\text { NE1/4 32 } \\
\text { SW1/4 35 } \\
\text { SE1/4 23 } \\
\text { SW1/4 20 } \ldots \ldots \ldots\end{array}$ & $\begin{array}{l}3 \\
2 \\
1 \\
2 \\
1\end{array}$ & $\begin{array}{l}26 \\
25 \\
23 \\
25 \\
25\end{array}$ & $\begin{array}{l}25 \\
27 \\
26 \\
24\end{array}$ & $\begin{array}{ll}5 & 0 \\
4 & 0 \\
5 & 0 \\
5 & 0 \\
5 & 0\end{array}$ & 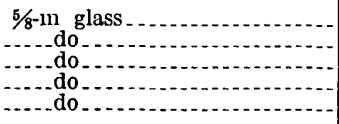 & $\begin{array}{l}\text { Do } \\
\text { Do } \\
\text { Do } \\
\text { Do } \\
\text { Do }\end{array}$ \\
\hline $\begin{array}{l}\text { SW1/4 } 23 \ldots \ldots \\
\text { NE1/4 } 20 \ldots \\
\text { NE1/4 } 24 \ldots \\
\text { NW1/4 } 21 \ldots \ldots \\
\text { NW1/4 } 12 \ldots \ldots\end{array}$ & $\begin{array}{l}1 \\
3 \\
3 \\
2 \\
2\end{array}$ & $\begin{array}{l}25 \\
29 \\
29 \\
29 \\
26\end{array}$ & $\begin{array}{l}27 \\
24 \\
30 \\
23\end{array}$ & $\begin{array}{ll}5 & 3 \\
3 & 87 \\
5 & 25 \\
7 & 5 \\
5 & 5\end{array}$ & $\begin{array}{l}\text { Department of Transport. } \\
\text { b/8-1n glass }\end{array}$ & $\begin{array}{l}\text { Do } \\
\text { Do } \\
\text { Do } \\
\text { Do } \\
\text { Do }\end{array}$ \\
\hline $\begin{array}{l}\text { SW1/4 } 19 \ldots \\
\text { SW1/4 } 3 \ldots \\
\text { NW1/4 } 4 \ldots \\
\text { SW1/42 }\end{array}$ & $\begin{array}{l}2 \\
1 \\
4 \\
1\end{array}$ & $\begin{array}{l}25 \\
27 \\
29 \\
25\end{array}$ & $\begin{array}{l}26 \\
29 \\
271 / 2 \\
31\end{array}$ & $\begin{array}{ll}5 & 25 \\
8 & 0 \\
4 & 5 \\
4 & 63\end{array}$ & $\begin{array}{l}\text { 3-1n diam can } \\
11-1 n \text { diam bucket } \\
3 / 4-1 n \text { glass } \\
\text { Department of Transport }\end{array}$ & $\begin{array}{l}\text { Do } \\
\text { Do } \\
\text { Do } \\
\text { Do }\end{array}$ \\
\hline
\end{tabular}


TABLE 5-Supplemental preciptation data from the Alberta, Canada, area north of the Montana boundary, storm of June 7-8, 1964-Contınued

Canada Department of 'Transport measurements

\begin{tabular}{|c|c|c|c|}
\hline Location & $\begin{array}{l}\text { Total pre- } \\
\text { clpitation } \\
\text { (inches) }\end{array}$ & Location & $\begin{array}{l}\text { Total pre- } \\
\text { clpitation } \\
\text { (inches) }\end{array}$ \\
\hline $\begin{array}{l}\text { Caldwell } \\
\text { Carway } \\
\text { Mountain View } \\
\text { Wountain View bridge } \\
\text { Waterton Lakes Belly River } \\
\text { Waterton Lakes Red Rock } \\
\text { Waterton Lakes ranger cabin } \\
\text { Waterton Park headquarters } \\
\text { Waterton Dam }\end{array}$ & 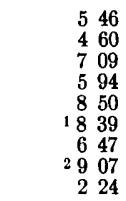 & $\begin{array}{l}\text { St Mary Dam } \\
\text { Beaver Mines } \\
\text { Carbondale lookout station. } \\
\text { Cardston. } \\
\text { Castle ranger station } \\
\text { Halstone Butte. } \\
\text { Kananaskia lookout station. } \\
\text { Magrath. } \\
\text { Pincher Creek West }\end{array}$ & $\begin{array}{ll}2 & 96 \\
3 & 16 \\
1 & 91 \\
3 & 44 \\
3 & 07 \\
1 & 68 \\
3 & 70 \\
1 & 93 \\
1 & 87\end{array}$ \\
\hline
\end{tabular}

1101 in also fell June 5-6

2045 in fell June 5-6 
TABLE $6-$ Hourly precıpıtatıon, in inches, at $U S$

$[\mathrm{Tr}$,

\begin{tabular}{|c|c|c|c|c|c|c|c|c|c|c|c|c|}
\hline June & 0100 & 0200 & 0300 & 0400 & 0500 & 0600 & 0700 & 0800 & 0900 & 1000 & 1100 & 1200 \\
\hline
\end{tabular}

24-1202 Browning.

\begin{tabular}{|c|c|c|c|c|c|c|c|c|c|c|c|c|c|c|}
\hline $\begin{array}{l}7- \\
8\end{array}$ & - & . & 031 & 025 & {$\left[\begin{array}{ll}0 & 51\end{array}\right.$} & 025 & $\begin{array}{lll}0 & 10\end{array}$ & $\begin{array}{rl}0 & 03 \\
& 35\end{array}$ & $\begin{array}{rrr}0 & 03 \\
& 38\end{array}$ & $\begin{array}{rr}0 \quad 09 \\
\quad 34\end{array}$ & $\begin{array}{rr}0 & 05 \\
& 43\end{array}$ & $\begin{array}{rr}0 & 06 \\
54\end{array}$ & \begin{tabular}{|rr}
0 & 09 \\
& 48
\end{tabular} & 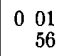 \\
\hline
\end{tabular}

24-1737-3 Choteau,

\begin{tabular}{|c|c|c|c|c|c|c|c|c|c|c|c|c|}
\hline $\begin{array}{l}7 . \\
8 .\end{array}$ & $\begin{array}{lll} & 0 & 18\end{array}$ & 026 & 016 & 026 & 033 & $0 \quad \overline{17}$ & 046 & 045 & 022 & 016 & 018 & $\begin{array}{lll}018 & 18\end{array}$ \\
\hline
\end{tabular}

24-2173 Cut Bank,

\begin{tabular}{|c|c|c|c|c|c|c|c|c|c|c|c|c|}
\hline $\begin{array}{l}7- \\
8 .\end{array}$ & 015 & $\begin{array}{lll}0 & 07\end{array}$ & 014 & $\begin{array}{lll}0 & 07\end{array}$ & 021 & 015 & 019 & 023 & $\begin{array}{ll}0 & 14\end{array}$ & 022 & $\begin{array}{lll}0 & 13\end{array}$ & $\begin{array}{lll}0 & 15\end{array}$ \\
\hline & & & & & & & & & & \multicolumn{3}{|c|}{$24-2571$} \\
\hline $\begin{array}{l}7 . \\
8 .\end{array}$ & 031 & 012 & 020 & $\begin{array}{ll}0 & 12\end{array}$ & 035 & 038 & $0 \overline{42}$ & 016 & 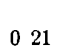 & 017 & $\begin{array}{ll}0 & 15\end{array}$ & 020 \\
\hline
\end{tabular}

24-2584 Dutton,

\begin{tabular}{|c|c|c|c|c|c|c|c|c|c|c|c|c|}
\hline $\begin{array}{l}7 . \\
8 .\end{array}$ & $\begin{array}{lll}0 & 02\end{array}$ & $\begin{array}{lll}0 & 02\end{array}$ & 014 & 024 & 023 & 013 & 002 & $\begin{array}{ll}005 \\
\end{array}$ & 005 & 004 & $\begin{array}{ll}009 \\
\end{array}$ & 004 \\
\hline
\end{tabular}

24-3119 Fort Benton,

\begin{tabular}{|c|c|c|c|c|c|c|c|c|c|c|c|c|}
\hline $\begin{array}{l}7- \\
8-\end{array}$ & 001 & $\begin{array}{ll}0 & 02\end{array}$ & $\begin{array}{lll}0 & 17\end{array}$ & $\overline{0} 07$ & 006 & 021 & 011 & $\begin{array}{ll}0 & 07\end{array}$ & $\begin{array}{lll}0 & 1\end{array}$ & 00 & 01 & 013 \\
\hline
\end{tabular}

24-3489 Gibson Dam.

\begin{tabular}{|c|c|c|c|c|c|c|c|c|c|c|c|c|}
\hline $\begin{array}{l}7 \\
8\end{array}$ & $\begin{array}{lll}0 & 18\end{array}$ & 022 & 052 & 056 & 061 & 048 & 034 & 035 & $\begin{array}{lll}0 & 17\end{array}$ & $\begin{array}{r}002 \\
\quad 19\end{array}$ & $\begin{array}{rr}0 & 06 \\
39\end{array}$ & $\begin{array}{ll}0 & 13 \\
& \end{array}$ \\
\hline
\end{tabular}

24-4120-3 Highwood,

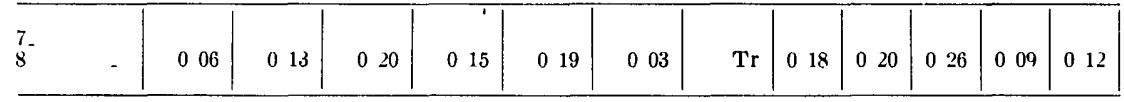

24-4143-4 Hılger,

\begin{tabular}{|c|c|c|c|c|c|c|c|c|c|c|c|c|}
\hline 7. & $\begin{array}{lll}0 & 0 \overline{5}\end{array}$ & 004 & 0 & $\begin{array}{lll}0 & 01\end{array}$ & 002 & 010 & 032 & $\begin{array}{ll}004 \\
\end{array}$ & 016 & 012 & $\begin{array}{rl}003 & 03 \\
14\end{array}$ & $\begin{array}{ll}0 & 05 \\
0 & 13\end{array}$ \\
\hline
\end{tabular}

24-4663-4 Kıngs Hıll,

\begin{tabular}{|c|c|c|c|c|c|c|c|c|c|c|c|c|}
\hline $\begin{array}{l}6 \\
7 \\
8\end{array}$ & 0 & 0 & 0 & 0 & 01 & 01 & $\begin{array}{rrr}0 & 01 \\
& 01\end{array}$ & $\begin{array}{l}002 \\
0\end{array}$ & $\begin{array}{lll}0 & 01 \\
0 & \end{array}$ & $\begin{array}{lll}0 & 01 \\
0\end{array}$ & $\begin{array}{rr}0 & 02 \\
& 01\end{array}$ & $\begin{array}{r}005 \\
\quad 26\end{array}$ \\
\hline
\end{tabular}


Weather Bureau werghing rain gages, storm of June 7-8, 1964 trace]

\begin{tabular}{|c|c|c|c|c|c|c|c|c|c|c|c|c|c|c|}
\hline 1300 & 1400 & 1500 & 1600 & 1700 & 1800 & 1900 & 2000 & 2100 & 2200 & 2300 & 2400 & $\begin{array}{c}\text { Daily } \\
\text { total } \\
\text { (Inches) }\end{array}$ & $\begin{array}{c}\text { Storm } \\
\text { total } \\
\text { (inches) }\end{array}$ & $\begin{array}{l}\text { Dur- } \\
\text { ation } \\
\text { (hours) }\end{array}$ \\
\hline & & & & & & & & & & & & & & \\
\hline
\end{tabular}

\section{Glacier County}

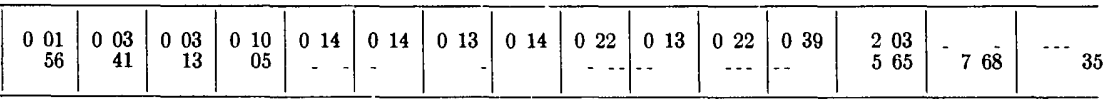

Teton County

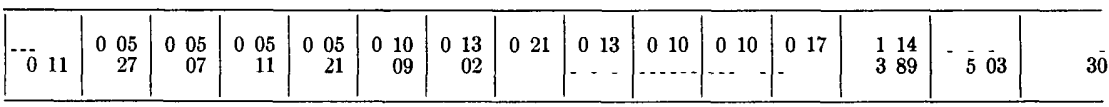

Aurport, Glacier County

\begin{tabular}{|c|c|c|c|c|c|c|c|c|c|c|c|c|c|}
\hline$\overline{0} 14$ & 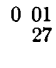 & $\begin{array}{r}003 \\
06\end{array}$ & 008 & $\begin{array}{rll}0 & 13 \\
- & \end{array}$ & & 010 & $\begin{array}{r}009 \\
-\quad\end{array}$ & $\begin{array}{cc}0 & 08 \\
-- & \end{array}$ & $\begin{array}{lll}0 & 11\end{array}$ & 006 & $\begin{array}{c}005 \\
-.\end{array}$ & $\begin{array}{r}82 \\
229\end{array}$ & $3 \overline{11}$ \\
\hline
\end{tabular}

\section{Pondera County}

\begin{tabular}{|c|c|c|c|c|c|c|c|c|c|c|c|c|c|c|}
\hline $\begin{array}{rr}0 & 07 \\
& 35\end{array}$ & $\begin{array}{ll}0 & 05 \\
& 15\end{array}$ & $\begin{array}{r}005 \\
\quad 71\end{array}$ & $\begin{array}{r}005 \\
29\end{array}$ & $\begin{array}{ll}0 & 13 \\
& 14\end{array}$ & $\begin{array}{ll}0 & 15 \\
& 03\end{array}$ & $\begin{array}{r}024 \\
\quad 02\end{array}$ & $\begin{array}{c}019 \\
-\end{array}$ & 027 & $\begin{array}{cc}0 & 05 \\
--\end{array}$ & \begin{tabular}{cc}
0 & 11 \\
\hdashline
\end{tabular} & 019 & $\begin{array}{ll}1 & 55 \\
4 & 48\end{array}$ & 603 & - 31 \\
\hline
\end{tabular}

\section{Teton County}

\begin{tabular}{|c|c|c|c|c|c|c|c|c|c|c|c|c|c|c|}
\hline $\begin{array}{rl}0 & 01 \\
& 05\end{array}$ & $\begin{array}{r}001 \\
08\end{array}$ & ${ }^{0} 07$ & $\begin{array}{rl}0 & 08 \\
& 10\end{array}$ & $\begin{array}{rr}0 & 09 \\
\quad 31\end{array}$ & $\begin{array}{r}008 \\
\quad 13\end{array}$ & $\begin{array}{l}011 \\
05\end{array}$ & $\begin{array}{ll}0 & 07 \\
& 01\end{array}$ & $\begin{array}{ll}0 & 01 \\
& 01\end{array}$ & $\begin{array}{lll}0 & 10\end{array}$ & \begin{tabular}{rl}
0 & 10 \\
\hdashline
\end{tabular} & $\begin{array}{ll}0 & 17 \\
- & -\end{array}$ & $\begin{array}{l}083 \\
188\end{array}$ & 271 & 33 \\
\hline
\end{tabular}

\section{Chouteau County}

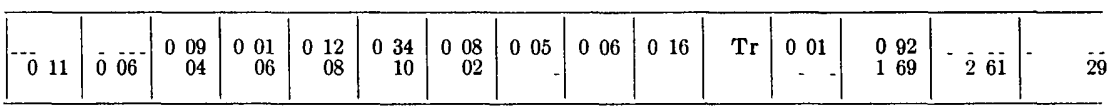

\section{Lewns and Clark County}

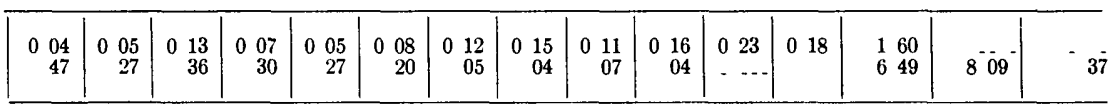

\section{Chouteau County}

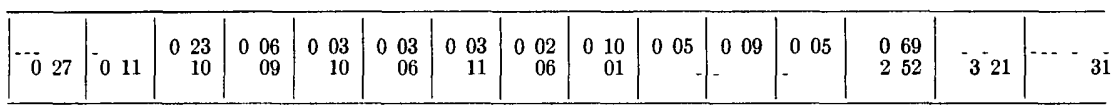

\section{Fergus County}

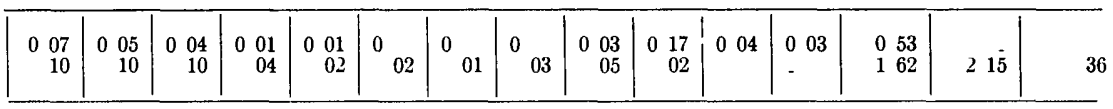

\section{Cascade County}

\begin{tabular}{|c|c|c|c|c|c|c|c|c|c|c|c|c|c|c|}
\hline $\begin{array}{r}003 \\
08 \\
24\end{array}$ & $\begin{array}{rr}0 & 01 \\
14 \\
16\end{array}$ & $\begin{array}{rr}0 \quad 09 \\
\quad 14\end{array}$ & $\begin{array}{ll}0 & 03 \\
& 16\end{array}$ & $\begin{array}{lll}0 & 01 \\
& 07\end{array}$ & $\begin{array}{r}003 \\
0\end{array}$ & $\begin{array}{r}002 \\
05\end{array}$ & $\begin{array}{r}003 \\
02 \\
06\end{array}$ & $\begin{array}{rr}0 & 06 \\
08 \\
06\end{array}$ & $\begin{array}{r}006 \\
12 \\
06\end{array}$ & $\begin{array}{l}03 \\
02\end{array}$ & $0^{-}$ & $\begin{array}{r}019 \\
\quad 77 \\
136\end{array}$ & $2 \overline{13}$ & ${ }^{-\cdots}$ \\
\hline
\end{tabular}


TABLE 6-Hourly precipitation, in inches, at US

\begin{tabular}{|c|c|c|c|c|c|c|c|c|c|c|c|c|}
\hline$\backslash$ Hour & 0100 & 0200 & 0300 & 0400 & 0500 & 0600 & 0700 & 0800 & 0900 & 1000 & 1100 & 1200 \\
\hline & & & & & & & & & \multicolumn{2}{|c|}{$24-4985$} & \multicolumn{2}{|c|}{ Lewistown } \\
\hline $\begin{array}{l}7- \\
8\end{array}$ & 048 & $\begin{array}{lll}0 & 15\end{array}$ & $\begin{array}{lll}0 & 12\end{array}$ & 012 & 010 & $\begin{array}{lll}0 & 10\end{array}$ & 005 & $\begin{array}{lll}0 & 07\end{array}$ & 011 & 011 & $\begin{array}{rr}0 & 04 \\
& 04\end{array}$ & $\begin{array}{l}012 \\
02\end{array}$ \\
\hline & & & & & & & & & \multicolumn{3}{|c|}{$24-7978-1$} & ummit \\
\hline 7 & 027 & $\begin{array}{r}002 \\
\quad 33\end{array}$ & $\begin{array}{rl}0 & 01 \\
& \end{array}$ & $\begin{array}{r}0 \quad 07 \\
\quad 40\end{array}$ & $\begin{array}{ll}0 & 07 \\
45\end{array}$ & $\begin{array}{rl}0 & 05 \\
& 54\end{array}$ & $\begin{array}{rl}0 & 03 \\
\quad 52\end{array}$ & $\begin{array}{r}005 \\
46\end{array}$ & $\begin{array}{r}003 \\
\quad 40\end{array}$ & $\begin{array}{rl}0 & 10 \\
46\end{array}$ & $\begin{array}{ll}013 \\
\quad 54\end{array}$ & $\begin{array}{rl}0 & 06 \\
30\end{array}$ \\
\hline
\end{tabular}

Grınnell Creek gagıng

\begin{tabular}{|c|c|c|c|c|c|c|c|c|c|c|c|c|}
\hline $8-$ & 02 & 02 & 02 & 02 & $\begin{array}{ll}01 \\
\quad 1\end{array}$ & $\begin{array}{ll}01 \\
\quad 1\end{array}$ & $\begin{array}{ll}0 & 1 \\
& 1\end{array}$ & $\begin{array}{ll}01 & 1 \\
& \end{array}$ & $\begin{array}{rl}01 & 1 \\
2\end{array}$ & $\begin{array}{ll}01 & 1 \\
& 1\end{array}$ & $\begin{array}{ll}01 & 1 \\
& \end{array}$ & $\begin{array}{l}01 \\
\quad 1\end{array}$ \\
\hline
\end{tabular}

NE 14 sec 34, T $29 \mathrm{~N}, \mathbf{R} 5 \mathrm{~W}$,

\begin{tabular}{|c|c|c|c|c|c|c|c|c|c|c|c|c|}
\hline $\begin{array}{l}7 . \\
8 .\end{array}$ & 021 & 006 & 016 & 027 & $\begin{array}{lll}0 & 01 \\
& 27\end{array}$ & $\begin{array}{ll}0 & 01 \\
& 26\end{array}$ & $\begin{array}{rr}0 & 01 \\
& 30\end{array}$ & 023 & 036 & 022 & 021 & 026 \\
\hline
\end{tabular}

NE $1 / 4 \sec 26, T 29 \mathrm{~N}, \mathrm{R} 6 \mathrm{~W}$,

\begin{tabular}{|c|c|c|c|c|c|c|c|c|c|c|c|c|}
\hline 8 & 015 & $\begin{array}{lll}0 & 19\end{array}$ & $\begin{array}{lll}0 & 09\end{array}$ & $\begin{array}{lll}0 & 09\end{array}$ & $\begin{array}{rr}0 & 04 \\
& 18\end{array}$ & $\begin{array}{r}004 \\
\quad 28\end{array}$ & $\begin{array}{rrr}0 & 01 \\
& 31\end{array}$ & $\begin{array}{rl}0 & 01 \\
& 01\end{array}$ & 028 & 016 & 030 & $\begin{array}{lll}018 & \end{array}$ \\
\hline
\end{tabular}

1 USGS tipping bucket on water-stage recorder 
Weather Bur eau weighing rain gagcs, storm of June 7-8, 1964-Contınued

\begin{tabular}{|c|c|c|c|c|c|c|c|c|c|c|c|c|c|c|}
\hline 1300 & 1400 & 1500 & 1600 & 1700 & 1800 & 1900 & 2000 & 2100 & 2200 & 2300 & 2400 & $\begin{array}{c}\text { Daily } \\
\text { total } \\
\text { (inches) }\end{array}$ & $\begin{array}{c}\text { Storm } \\
\text { total } \\
\text { (inches) }\end{array}$ & $\begin{array}{c}\text { Dur- } \\
\text { ation } \\
\text { (hours) }\end{array}$ \\
\hline
\end{tabular}

Arrport, Fergus County

\begin{tabular}{|c|c|c|c|c|c|c|c|c|c|c|c|c|c|c|}
\hline $\begin{array}{rr}0 & 10 \\
& 05\end{array}$ & $\begin{array}{rr}0 & 10 \\
& 04\end{array}$ & $\begin{array}{r}006 \\
01\end{array}$ & $\begin{array}{rr}0 & 05 \\
& 02\end{array}$ & $\begin{array}{rr}0 & 02 \\
& 02\end{array}$ & $\begin{array}{l}\mathrm{Tr} \\
01\end{array}$ & ${ }_{-}^{\mathrm{Tr}}$ & $\mathrm{Tr}$ & $\begin{array}{ll}0 & 02 \\
-\end{array}$ & $\begin{array}{r}034 \\
\end{array}$ & $\begin{array}{cc}008 \\
\ldots\end{array}$ & $\begin{array}{rr}0 & 19 \\
-\quad\end{array}$ & $\begin{array}{ll}1 & 12 \\
1 & 62\end{array}$ & 274 & $3 \overline{2}$ \\
\hline
\end{tabular}

\section{Flathead}

\begin{tabular}{|c|c|c|c|c|c|c|c|c|c|c|c|c|c|c|}
\hline $\begin{array}{rl}0 & 02 \\
& 44\end{array}$ & $\begin{array}{ll}0 & 03 \\
& 15\end{array}$ & $\begin{array}{ll}0 & 05 \\
& 07\end{array}$ & 006 & 006 & $\begin{array}{c}010 \\
\ldots\end{array}$ & $\begin{array}{l}022 \\
\ldots\end{array}$ & $\begin{array}{ll}0 & 19 \\
-\end{array}$ & $\begin{array}{c}032 \\
-.\end{array}$ & $\begin{array}{c}029 \\
-\end{array}$ & $\begin{array}{ll}0 & 29 \\
- & \ldots\end{array}$ & $\begin{array}{l}016 \\
-.\end{array}$ & $\begin{array}{ll}2 & 41 \\
5 & 68\end{array}$ & 809 & - \\
\hline
\end{tabular}

station, ${ }^{1}$ Glacier County

\begin{tabular}{|c|c|c|c|c|c|c|c|c|c|c|c|c|c|c|}
\hline $\begin{array}{ll}0 & 1 \\
& 1\end{array}$ & $\begin{array}{ll}0 & 1 \\
& 1\end{array}$ & 01 & 02 & $\begin{array}{r}02 \\
\quad-.\end{array}$ & 02 & {$\left[\begin{array}{ll}0 & 2 \\
-- & \end{array}\right.$} & $\begin{array}{r}02 \\
-\end{array}$ & $\begin{array}{lll}01 & 1\end{array}$ & $\begin{array}{ll}01 \\
0\end{array}$ & 01 & 01 & $\begin{array}{ll}2 & 5 \\
3 & 0\end{array}$ & $5 \overrightarrow{5}$ & 34 \\
\hline
\end{tabular}

Pondera County

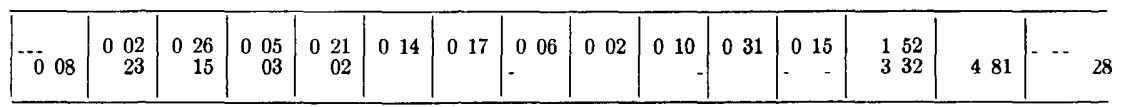

Pondera County

\begin{tabular}{|c|c|c|c|c|c|c|c|c|c|c|c|c|c|c|}
\hline$\ddot{0} \overline{41}$ & $\begin{array}{ll}0 & 01 \\
& 015\end{array}$ & $\begin{array}{r}003 \\
\quad 33\end{array}$ & $\begin{array}{r}003 \\
61\end{array}$ & $\begin{array}{l}012 \\
03\end{array}$ & $\begin{array}{l}029 \\
01 \\
\quad 01\end{array}$ & $\begin{array}{ll}0 & 12 \\
- & \ldots\end{array}$ & $\begin{array}{ll}0 & 17 \\
\ldots\end{array}$ & $\begin{array}{ll}0 & 15 \\
\cdot & \end{array}$ & 000 & $\begin{array}{r}002 \\
.\end{array}$ & $\begin{array}{l}032 \\
-\end{array}$ & $\begin{array}{ll}1 & 42 \\
4 & 02\end{array}$ & 534 & $-\quad \overline{29}$ \\
\hline
\end{tabular}




\section{MISCELLANEOUS NOTES}

In connection with the strong upslope winds along the Contmental Divide and the heavy spillover or lee-side precipitation (fig 16) previously described, it is worth noting that a large number of persons contacted for supplemental precipitation measurements commented upon the strength of the north to east w indflow toward the storm's centers At the Federal Aviation Agency station at the Cut Bank Airport (the nearest hourly observation station to any of the storm's heaviest ramfall centers), hourly wind leadings confirm the strength of the northeast windflow from midnight untıl after noon June 8 The observations show that the wind direction 1 anged from northeast to east-northeast during the storm's heaviest period, with speeds frequently gustmg to more than $40 \mathrm{mph}$ (miles per hour) The same set of observations also confirms that the cold front from the north entered the northern parts of the affected area at about the time the map measurements were taken (0500 hrr, June 8, fig 11)

Because Glasgow appears to have been near the center of the morst aurstream flowm into the stom area, upper an observations made there just before the storm and duing its early stages should reveal the general character of the arrmass involved The Glasgow radiosonde observation made at 1700 hours, June 7, is shown in figure 17 It shows, among other things, very high mixing ratios-from nearly 12 grams of watel vapor pel klogram of dry arr at the surface to 26 g per kg (grams per kllogram) at $500 \mathrm{mb}$ The observed lapse was conditionally unstable up to $500 \mathrm{mb}$, but the greatest degree of condrt 1 onal instability was between the surface and about 7,000 ft msl This layer of greatest instability was at the bottom of the larger layer (reaching to higher than the 500-mb level) that appeans to have been headmg for the storm activity a few hundred miles to the west The Glasgow sounding was used to calculate precipitable water (surface to $500 \mathrm{mb}$ ) content, which at that time was 109 mches, and the average relative humidity tor the same layer was 84 percent

An additional item of more than passing interest was the lack of thunderstorms in the heavy-precipitation areas In view of the sparsely populated nature of the areas where the heaviest 1 ans fell, it cannot be concluded that thunderstorms did not occur, but it is noteworthy that none was reported on .June 7 or 8 by any regular Weather Bureau station near any of the storm's several centers It seems likely that thunderstorms were widely scattered if they did occur, and that conditional instability release was mostly of a rather even intensity and farrly contmuous The steadmess of the ramfall rates shown in figure 15 support, at least m part, such a hypothesis 


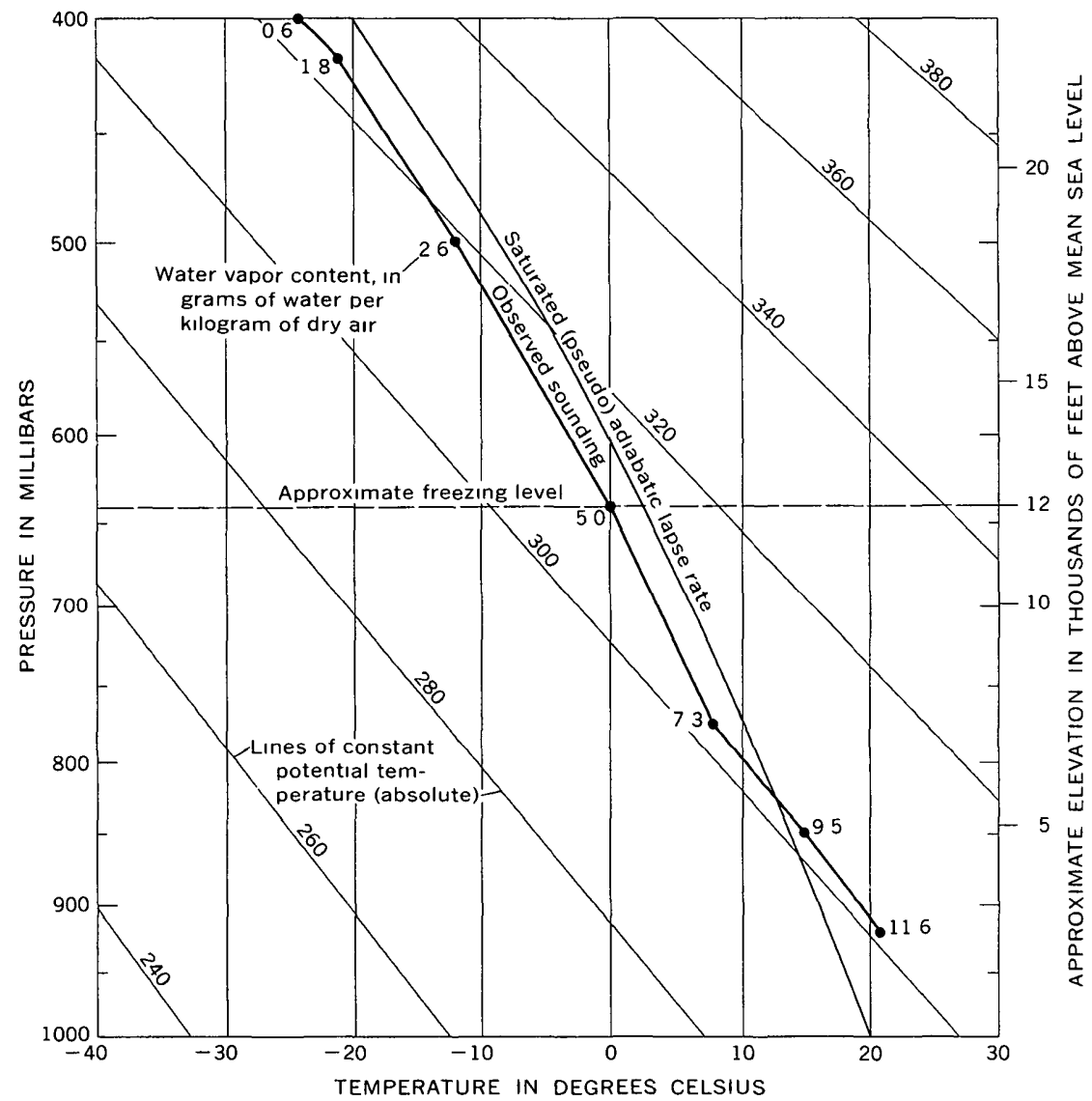

Figure 17 -Glasgow iadiosonde observation at 1700 hours, June 7, 1964, sampling moist air enroute westward into storm area The airmass was conditionally unstable from the surface (about $920 \mathrm{mb}$ ) to nearly $400 \mathrm{mb}$

\section{METEOROLOGICAL COMPARISON WITH PREVIOUS FLOODS}

The record-breaking floods of 1964 and most previous Montana floods occurred in June when seasonal large-scale meteorological conditions may have been similar Heary ramstorms along and near the eastein side of the Contmental Divide in late May and early June are clear ly associated with floods of 1894, 1906, 1908, 1916, 1927, 1938, 1948, and 1953 Mountam snowmelt has generally filled stream channels to near capacity in the same pel 1od, and the degiee to which floods have been rain induced is rarely as clear as in 1964 The noteworthy Springbrook storm of 1921 w as center ed a considerable distance from the mountains although general rams appeared to have had some effect on mountain runoff as well 
Precipitation data from regular stations for all these storms and a discussion of the flooding of June 1908 appear in the appropriate issues of the monthly publication "Climatological Data, Montana" by the US Weather Bureau Streamflow data, like precipitation data, are mole complete in later years and may be found in the yearly reports of the US Geological Survey entitled "Sur face Water Supply of the United States" Studies of the 1921 (Springbrook), 1906 (Warr ıck) and 1938 (Big Timber and Chessman Reservoir) storms have been discussed by the US Weather Bureau and Corps of Engineers (1945) Meteorological and hydrologic features of the Man las River flood of 1948 are discussed in the Monthly Weather Review (Dightman, 1950) The 1953 flood, which was felt particularly in Great Falls area, was documented 11 a report of the US Geological Survey (1957) An exammation of the data reveals a fauly strong climatological simılarity in the ram-induced floods that generally occur in .June, but which may begin to derelop in late May The major meteorological developments appear to be much the same While vertical motion maxima may be located in any part of the upper Missoun 1 River drainage basm, mcluding the Yellow stone River, depending on the parts of the general area travessed by the storm structures, all the storms received their moist air supply from the Gulf of Mexico as a result of general flow northward, then northwestward over the westem plans States

The principal differences between previous storms and the 1964 storm were

1 The maximum rertical motion centers in 1964 were apparently located above the steepest eastern slopes of the northern Rockies, and were reinforced by a larger orographic veitical-motion component than was possible in any of the earlier record floods

2 The flow of moist air from the gulf was unusually direct, broad, and undisturbed untıl its arrival in the ram area

3) The timing of the entry of the cold front from the north into the rain area was critical - its "wedging" and contmued upslope flow effects probably caused a few hours more of heavy ram than otherwise would have occurred

It would be difficult to design a combination of all factors more favor able for heavy rainfall than prevaled in this storm The timing of the interacting physical forces and other parameters could hardly be improved, and it is therefore not surprising that the dimensions of this storm closely approximate those of probable maximum precipitation descu ibed by the U S Weather Bureau (1960b) 


\section{DESCRIPTION OF THE FLOODS}

The disastrous floods of June 1964 in northwestern Montana struck parts of the Hudson Bay, Missour River, and the upper Columbia River basins The area of severe flooding extended about 200 miles northward along the Continental Divide from Helena to southern Alberta, Canada, in a band about 70 miles wide Flooding beyond this area was generally confined to the larger rivers having their sources along the Continental Divide.

The intense rain of about 30-hours duration, falling on the remains of the mountain snowpack, generally produced sharp peaks which were the highest of record at many gaging stations and greatly exceeded historical maximum stages on many streams The destruction of 200year-old trees at public campgrounds noted by U S. Forest Service personnel and the uprooting of old trees and the channel enlargernent described by others indicate the rare magnitude and extent of the 1964 floods The estimated flood damage of $\$ 55$ million in Montana was never previously approached Newspaper accounts indicate that damage in Canada was in excess of $\$ 1$ million

\section{HUDSON BAY BASIN}

The flood-producing area in the Hudson Bay basin is almost entirely in Glacier National Park in Montana and the adjoining Waterton Lakes National Park in Canada The principal streams in the flood area are the Belly, Waterton, and St Mary Rivers, which drain northeastward to the Saskatchewan River

Monetary damage in the Belly River drainage basin in the United States was light as there are no roads or habitations The peak stage on the Belly River near Mountam View, Alberta, was about half a foot lower than the previous known maximum stage of 1908 Severe flooding of the lowlands forced the evacuation of about 250 persons on the Blood Indian Reserve near Stand Off, Alberta. A Hutterite colony, north of Stand Off, was also threatened, and all 150 residents fled to higher ground No injuries to residents were reported, but more than 200 head of cattle and 300 sheep were believed drowned Flooding and bridge washouts closed most highways across the Belly River

Much of the town of Waterton Park, Alberta, bordering Waterton Lake, was inundated by flooding along the shorelne of Waterton Lake and by overbank flow of Cameron Creek The nearby Waterton Lakes National Park headquarters reported 907 inches of ram on June 7-8, and the 24-hour rainfall of 753 inches exceeded the previous record by 463 inches The lake level rose 4 feet in a 3-hour period 
early on June 8 The park was closed, and nearly 150 residents of the townsite were evacuated and housed $m$ the Prince of Wales Hotel A br ief $70-\mathrm{mph}$ north wind created waves that smashed boats at the Waterton Lake piers and blew down a wide strip of fir trees on the mountanside near the southern edge of the townsite Damage in the area was estimated at more than a millon dollars. The peak discharge of $25,700 \mathrm{cfs}$ on the Waterton River downstream from Waterton Lake exceeded the previous record of 1908 by 5 percent In Glacier National Park, runoff rates were probably as outstanding Street Creek, a tributary to the Waterton River with a dramage area of 6 square miles, had a peak flow of 5,740 cfs on June 8 Assignable monetary damage to the primitive United States dramage was light

Runoff' was extremely high in the upper reaches of the St Mary Ruver dramage basm The peak flow of Swiftcurrent Creek, a St Mary River tributay, at the outlet of Swiftcurrent Lake was treble the previous maximum of $2,250 \mathrm{cfs}$ for the period of record beginning in 1912 'The budge at the lake outlet was submerged, and so about 50 employees at Many Glacier Hotel were isolated Lake Sherburne, which held the upstream floodflow of Swiftcurrent Creek, had a peak inflow of about $10,000 \mathrm{cfs}$ from an area of 637 square miles The load between the town of Babb and the Many Glacier area was blocked by slides and gravel deposits and was washed out opposite the mouth of Boulder Creek The resort town of St Mary (fig 18) was evacuated when Divide Creek overflowed its banks Water was nearly 3 feet deep on the streets early on .June 8 A highway employee drowned at St Mary when a roadway, undermmed by Divide Creek, collapsed The peak discharge of 16,500 cfs on St Mary River downstream from Swiftcurrent Creek exceeded the previous maxımum. however, the collection of streamflow records at this station has been intermittent

Kennedy Creek washed out a bildge on US Highway 89 and a nearby section of the St Mary Canal on June 8 A Cardston, Alberta, man drowned after he drove his cal into the highway washout St Mary Canal diverts wạter from the St Mary River near Babb and, after discharge mto North Fork Milk River, serves 1rrigation needs along the Milk River in the United States A lımited temporary supply for the canal was obtained by diverting Kennedy Creek into the canal from June 19 to July 11 Reparrs to the canal were made and normal operation was resumed July 17 The peak flow of the St Mary River at the international boundary was $21,000 \mathrm{cfs}$, whereas the peak of 1908 was considered to be $40,000 \mathrm{cfs}$ Lee Creek, which 


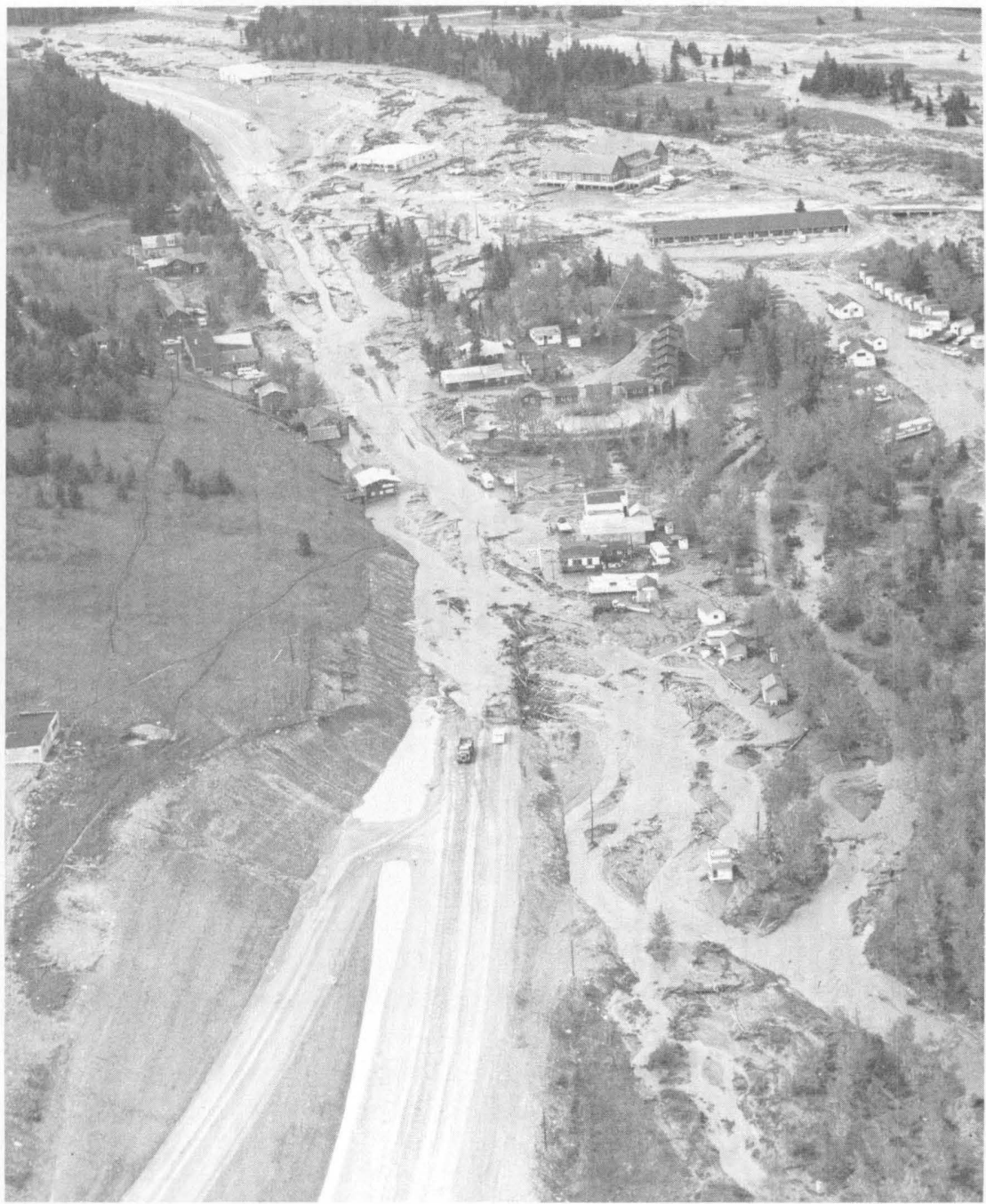

Figure 18.- Silt and debris deposits by Divide Creek at resort town of St. Mary. Photograph by Montana Highway Department.

heads in Glacier National Park, washed out the diversion dam for the municipal water supply at Cardston, Alberta, washed away six homes and several commercial buildings in Cardston, and drowned more than 100 cattle in a feed lot. Discharge hydrographs for selected gaging stations in the Hudson Bay basin are presented in figure 19. 


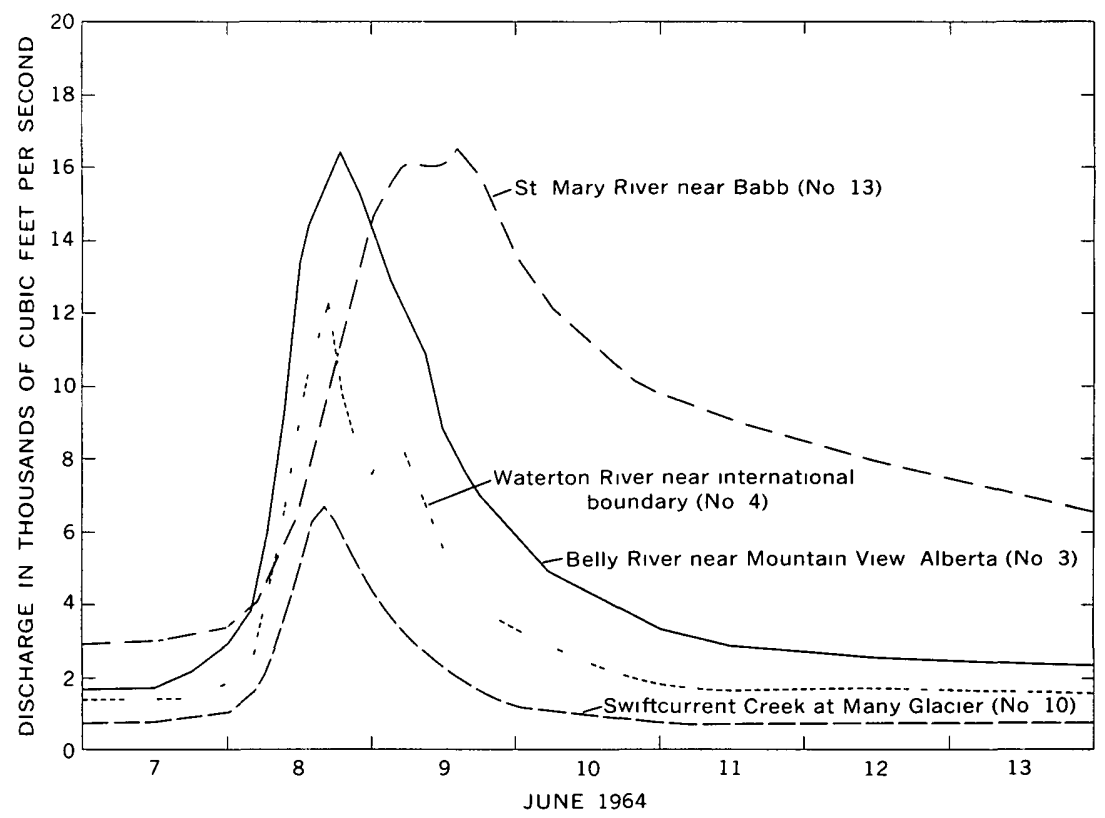

Figure 19 -Discharge at selected gaging stations in Hudson Bay basin, June 7-13. 1964 Number in parentheses conform with those given in table 19 and on figure 2

\section{MISSOURI RIVER BASIN}

The part of the Missourı Rivel basin covered in this report is the main stem and intervening tributary dramage areas from Toston to Fort Peck Dam, except for Musselshell River and Dry Creek dramage basins The Milk River basin upstream fiom Fresno Resel volr is also included The flooding which occurred in local areas outside the above boundaries was of a lesser magnitude or was in an area where discharge information is lacking

Peak flows of the Missour River and tributarles upstieam from Canyon Ferry Reservorr were not iecord high Although Canyon Ferry Reservoir was nearly full on June 6, it held nearly all the upstream flood flow untıl June 12 when the passage of inflow did not cause additional floodmg at Great Falls Tenmile, Serenmile, and Prickly Pear Creeks flooded adjacent lowlands in the Helena Valley and affected a few homes and ranches The peak discharge of Tenmıle Creek near Rımını was 556 cfs, whereas the peak of 1917 was $781 \mathrm{cfs}$

One bridge was washed away and sereral sections of State Seconday Highway 434 were damaged by Wolf Creek near the town of Wolf Creek The maximum flow of the Dearborn River apparently oc- 
curred near the mountain front and dimmished in a downstream direction because intervening tributaries had peaked earlier Somewhat hazy information from local residents indicates the peak stage and discharge of the Dearborn River in 1964 exceeded those of 1908 and intervening years throughout the river's length The sparsity of development along the narrow valleys of the Dearborn River and tributaries restricted property damage to a few ranches, approaches to a county bridge near Bean Lake, and the loss of two gaging stations Hardy Creek, a tributary to the Missourı River upstream from Cascade, undermined both piers of the bridge on U.S Highway 91, and closure of this bridge nearly doubled the road distance between Helena and Great Falls

Flooding along the Sun River was severe, particularly in the broader and more populous valley from Simms to Great Falls In the rather primitive area along the North and South Forks of Sun River above the Gibson Dam, summer homes, tralls, and a gaging station were damaged or destroyed The irrigation reservoir formed by Gibson Dam below the confluence of the two forks began to overflow at about 1400 hours on June 8. Water spilling over the parapet walls of the concrete dam (fig. 20) reached a maxımum depth of 323 feet between 1900 and 2000 hours on June 8. Beaver Creek, which enters the Sun River just below the dam, was also high and destroyed the access bridge to the dam and a large storage building

Much of the town of Augusta, on Elk Creek (locally called South Fork Sun River), was inundated Flooding, described as much worse than the "big flood of 1953," damaged 34 homes and 17 business establishments as water depths reached up to 3 feet The peak stage was 1eported to have occurred at about 2200 hours on June 8 An electrical powerline servicing the town was ripped out on the evening of June 9 Water over the road and the washed-out bridges on State Highways 287 and 20 nearly isolated the town untıl reparrs were made

The valley of the Sun River below the mouth of Elk Creek is appreciably wider and the gradient, flatter Overbank flow affected many farms and residences, however, ample warning and organized evacuation minimized property damage, and no lives were lost The town of Sun River (fig 21) was completely flooded, and the nearly 100 residents were evacuated A new suburban residental area on the flood plam at Vaughn was flooded to an average depth of about 8 feet, and a number of homes were washed away The small community of Manchester, about 3 miles west of Great Falls, was almost completely inundated to depths up to 7 feet 


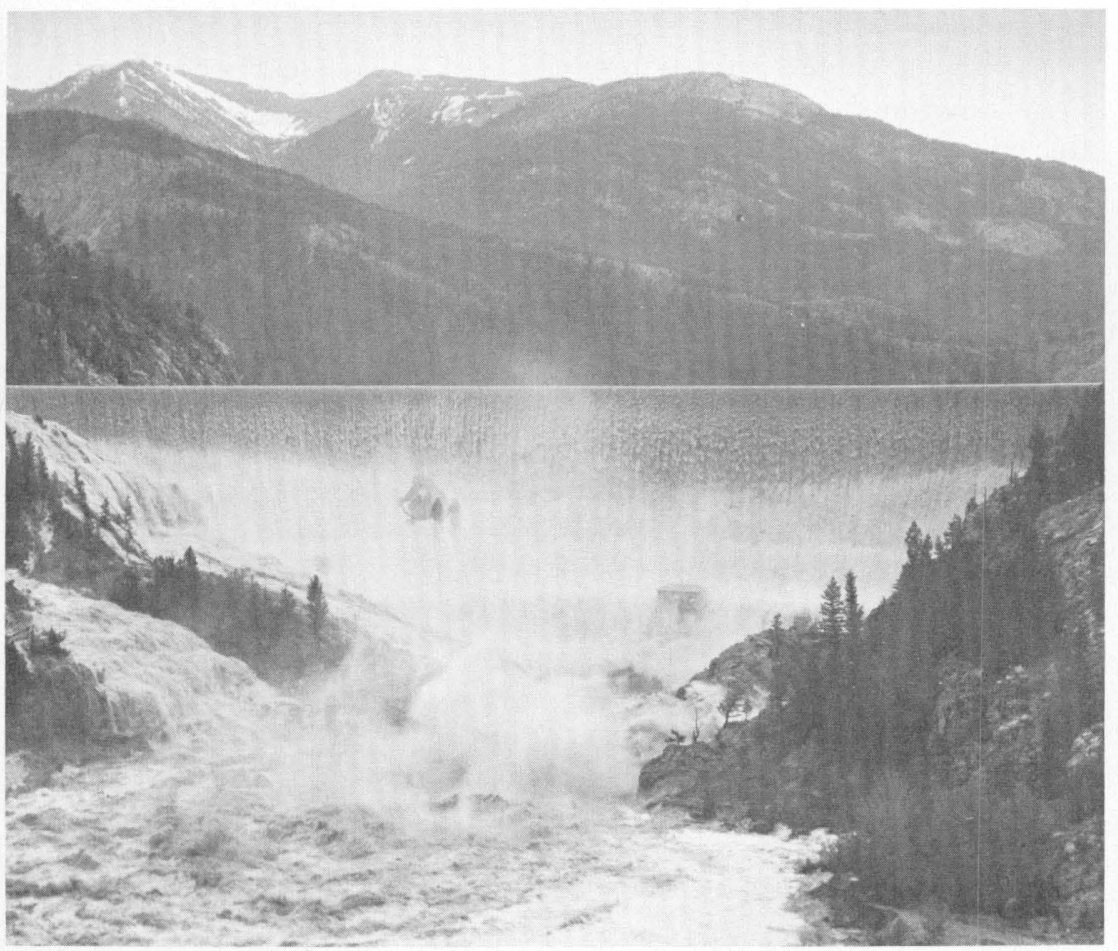

Figure 20.-Flow over parapet of Gibson Dam on June 9, 1964. Photograph by U.S. Forest Service.

The flat gradients of the Missouri River and Sun River at Great Falls caused considerable overbank flow of the low flood plains along both streams, and severe flooding lasted for several days. The Missouri River upstream from the Sun River held a fairly steady flow of about 22,000 cfs, which largely originated below Canyon Ferry Dam. Flood depths of 10-12 feet were noted on several homes in low-lying areas. Nearly 3,000 persons were evacuated from the flooded area, where 681 homes and 24 business establishments sustained various degrees of damage. At the 14th Street Bridge across the Sun River, the flood stage of 15 feet was exceeded from 2100 hours on June 8 to 0800 hours on June 15 , and the peak occurred at 0100 hours on June 10. The peak stage on the Missouri River at the city of Great Falls waterplant, just upstream from the mouth of the Sun River, held steady between 0400 and 1200 hours on June 10. The extent of flooding at Great Falls is shown in the inundation map of figure 22, and figure 23 is a view of much of the flooded area at 1010 hours on 


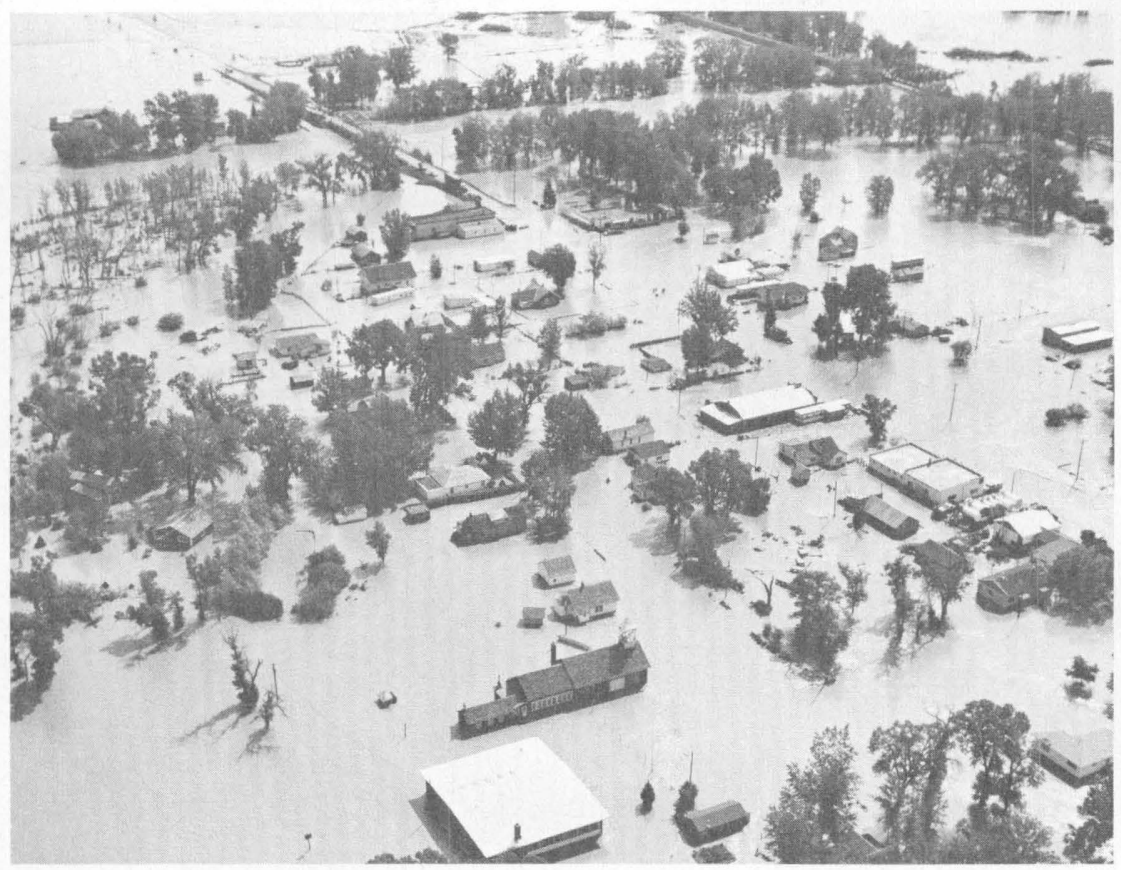

Figure 21.-Inundation of the town of Sun River on June 10, 1964. Photograph by United States Bureau of Reclamation.

June 10. Stage hydrographs for Sun River near Vaughn; Sun River at 14th Street Bridge, at Great Falls; and Missouri River above Sun River (at city waterplant), at Great Falls, are shown in figure 24.

The' Missouri River is well entrenched in a narrow valley from Great Falls to the mouth of the Marias River, and Fort Benton is the only city or town adjacent to the river in that reach. Erosion damage in the vicinity of the Fort Benton sewage lagoon required construction of an emergency dike. Flooding of some lowland hay meadows was probable as stages approached those of 1953 . Belt and Highwood Creeks, which are tributary in this reach, had peaks that were substantially less than the 1953 peaks. A washed-out railroad bridge lodged against the bridge on U.S. Highway 87 at Belt. Seventy youths at a camp in the upper Highwood Creek area were stranded because of several road washouts and the loss of more than 10 bridges.

Discharge and damage were high along the entire length of the Teton River, which enters the Marias River just above its mouth. A bridge, 1 mile downstream from the South Fork Teton River, was left high and dry when both approaches were eroded and the Teton River 


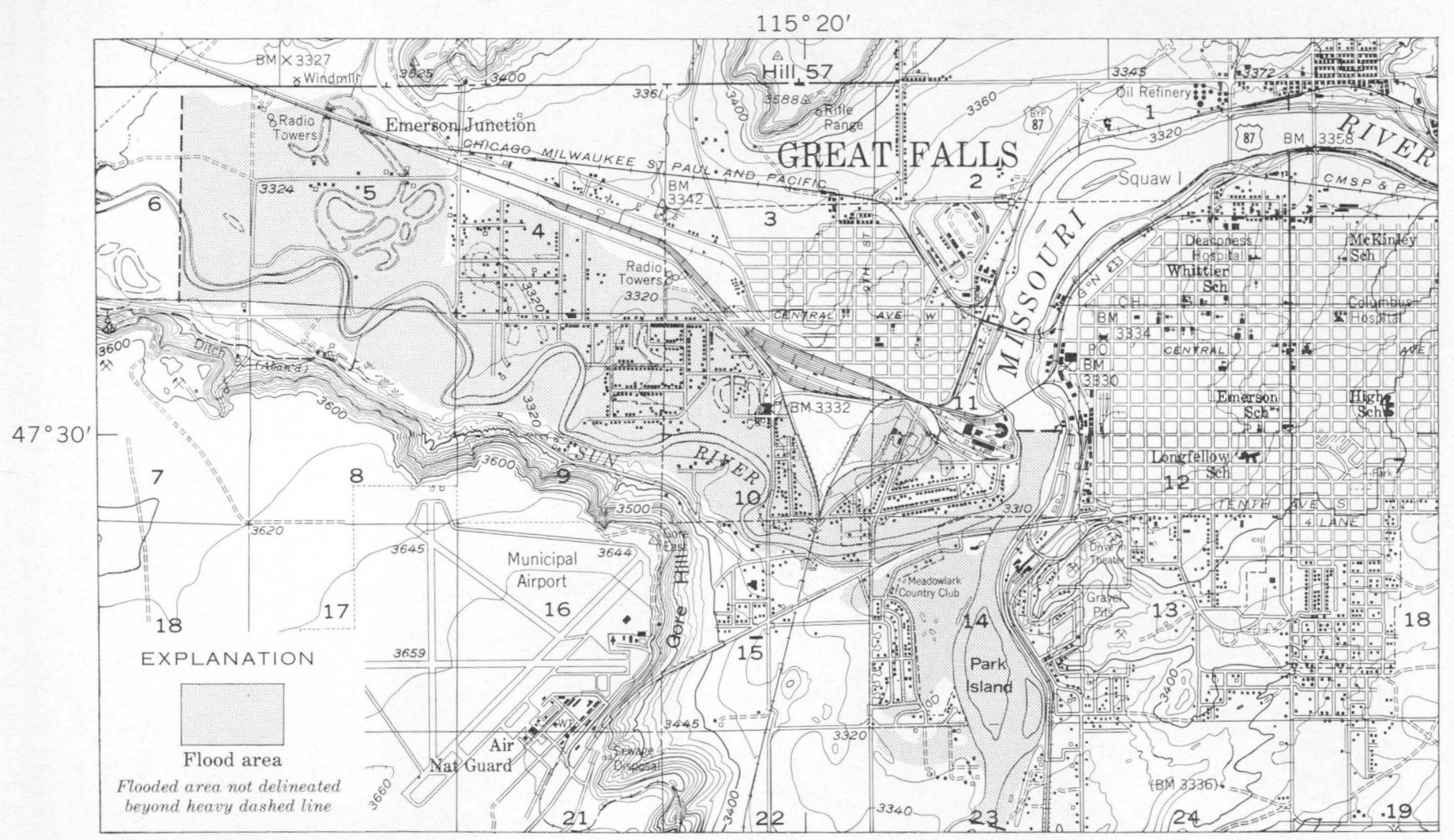

Figure 22.-Extent of flooding at Great Falls. Based on information furnished by the U.S. Army Corps of Engineers. 


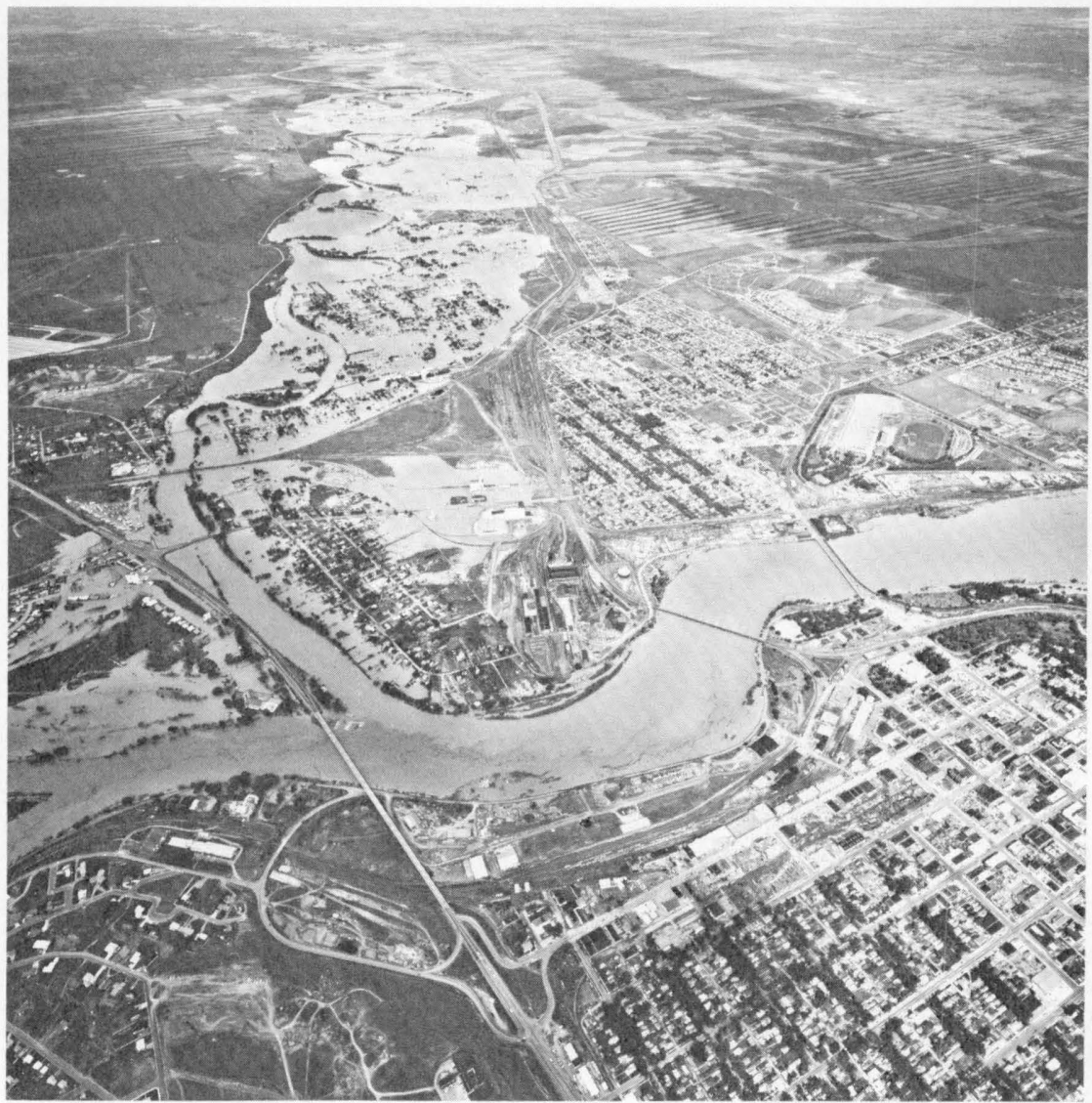

Figure 23.-View of city of Great Falls showing extent of flooding at 1010 hours, June 10, 1964. Photograph by Montana Highway Department.

cut a new channel several hundred feet south of the original channel. The many irrigation works along the river were destroyed, and there were several washouts on canals leading to offstream reservoirs. Floodwaters from the Teton River and a tributary, Spring Creek, combined to flood the town of Choteau (figs. 25, 26) on June 8. The entire population of nearly 2,000 residents was hastily evacuated as water as deep as 6 feet damaged 640 homes and business establishments. Deep Creek, which enters the Teton River downstream from Choteau, flooded low-lying areas and washed out the bridge on State Highway 287. U.S. Highway 89 was closed when one span of the Teton River bridge was destroyed. 


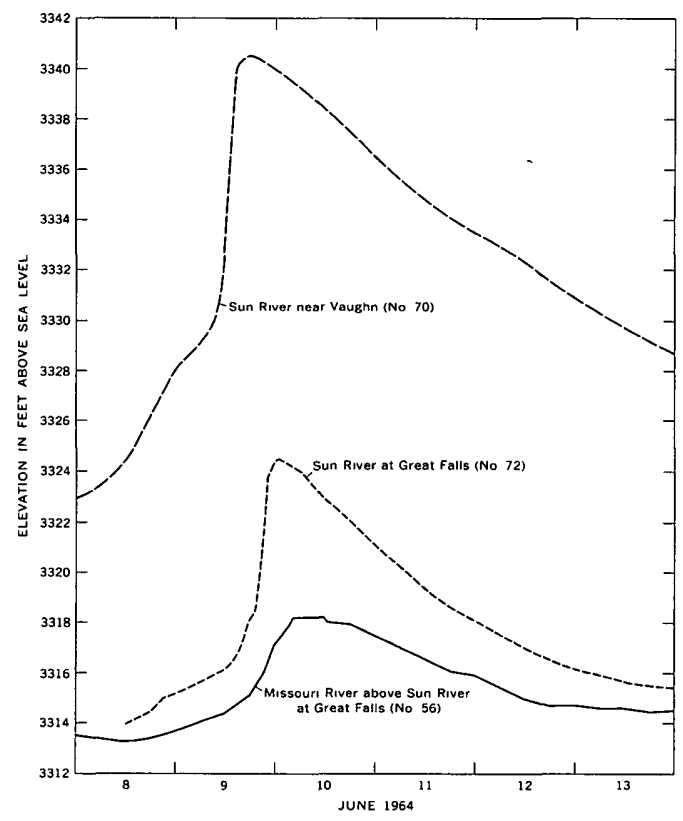

Figure 24 - Stage of Missouri River above Sun River at Great Falls, Sun River near Vaughn, and Sun River at Great Falls, June 8-13, 1964 Numbers in parentheses conform with those given in table 19 and on figure 2

The Teton River occupies a rather narrow valley downstream from Choteau, and the peak flow increased slightly through tributary contulbutions as it moved downstream The flood peak exceeded the normal channel capacity and flooded the bottom lands US Highway 91 was closed for several weeks after the bridge north of Dutton was destroyed, and overbank flow washed away much of the roadway across the valley Only three of about eight bridges across the Teton River remained, and these required repairs to approaches There was some damage to U S Highway 87 and the Great Northern Rallway, which parallel the Teton River for a few miles near Loma The scattered ranches in the narrow Teton River valley sustained considerable damage to lands, buldings, fences, and roads The residents of Loma, at the mouth of the Teton River, were evacuated although no residential flooding resulted at this point

Flooding in the Marias River basin upstieam from Tiber Reservon was widespread and extremely severe It was compounded by fallure of two irrigation dams and a community water supply dam The fallue of Swift Dam on Birch Creek (fig 27) released more than 30,000 acre-ft of stored water shortly after 1000 hours, June 8, in 


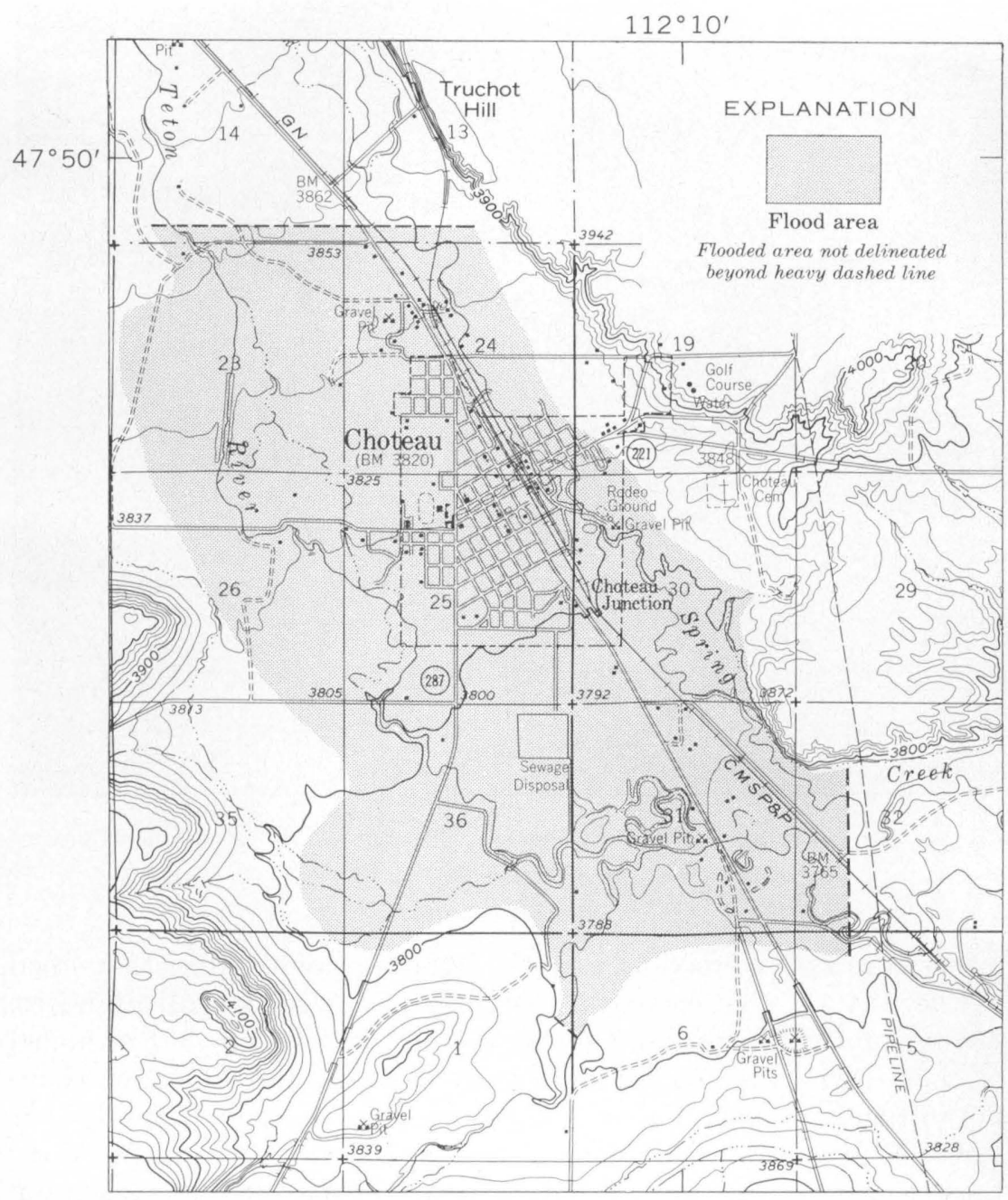

Figure 25.-Extent of flooding at Choteau. Based on information furnished by the U.S. Army Corps of Engineers.

what has been reported to be a very brief time. The instantaneous peak discharge of $881,000 \mathrm{cfs}$, calculated for an indirect measurement site 17 miles downstream from the dam, substantiates the reports of a sudden failure. The Birch Creek valley, downstream from the dam, presented a scene of vast devastation. All the trees and most of the 


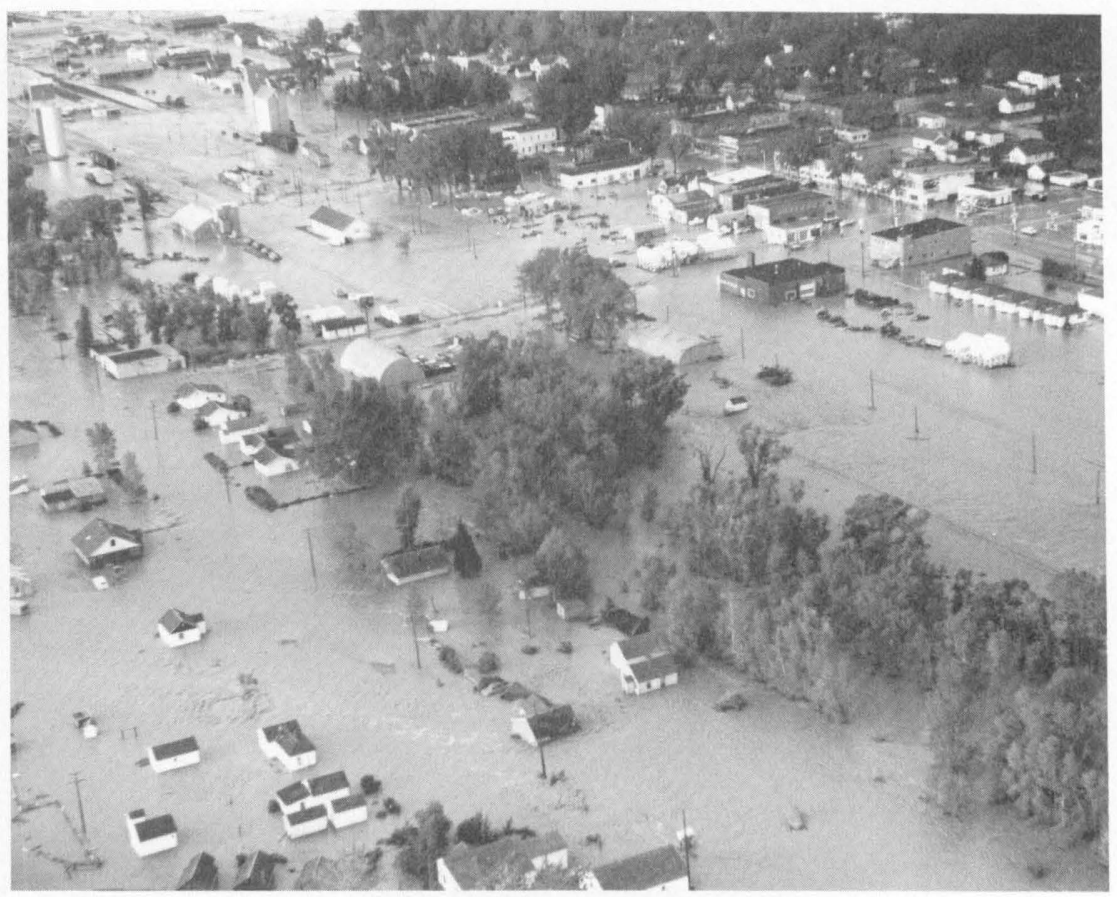

Figure 26.-Flooding in city of Choteau. Photograph by Montana Highway Department.

brush were swept away, as were the buildings and bridges that stood in the way of what has been described as a 20 -foot wall of water. Masses of tree stumps and other floating debris were left stranded or choked irrigation canals miles away from the normal stream channel in the vicinity of Valier. . The flood wave moved so rapidly that very few people received advance warning. In all, 19 residents along the creek lost their lives. Of those who perished, eight were members of one family. Another family of four was last seen floating down mile-wide Birch Creek on a $\log$ raft. During the first 6 hours after dawn on June 9, more than 100 persons were airlifted out of isolated areas along the creek. Dupuyer Creek, a Birch Creek tributary, washed out a bridge on U.S. Highway 89 , and water was a foot deep in the town of Dupuyer. Most basements were flooded, but the town's 125 residents did not evacuate.

The somewhat gradual failure of the dam on Lower Two Medicine Lake (fig. 28) in Glacier National Park released a flood wave on Two Medicine River on the afternoon of June 8. A radio station 


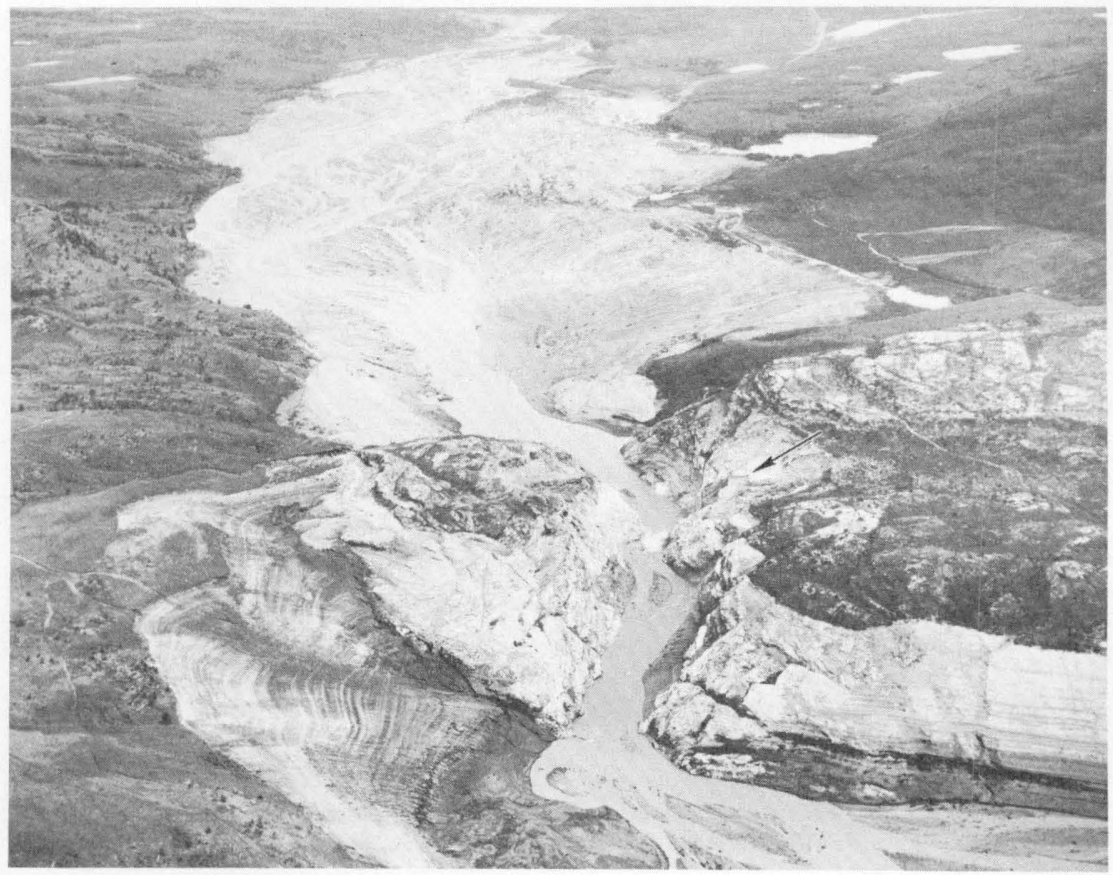

Figure 27.-Remains of Swift Dam looking downstream from the reservoir area. Arrow points to a part of the right end of the upstream face of the dam. Photograph by Bureau of Reclamation.

warning did not reach all residents because electric power was disrupted and many persons living in river-bottom areas had little time to evacuate. A pickup truck carrying 17 persons stalled when the driver missed the trail across an inundated meadow and drove into a depression. The driver left in search of help. Two persons were pulled to safety with a spare tire attached to fence wire, five were rescued by boat, and the remaining nine died. Midvale Creek, a tributary to Two Medicine River, flooded parts of East Glacier; and South Fork Two Medicine River caused considerable damage to U.S. Highway 2 between East Glacier and Summit. At the gaging station on Two Medicine River, 11 miles southeast of Browning and 30 miles downstream from Lower Two Medicine Lake, the peak flow occurred about 3 hours prior to the failure of Lower Two Medicine Lake Dam. Badger Creek, which enters Two Medicine River downstream from that gaging station, washed out bridges and overtopped the roadway of U.S. Highway 89 (fig. 29). Two Medicine River, which includes 


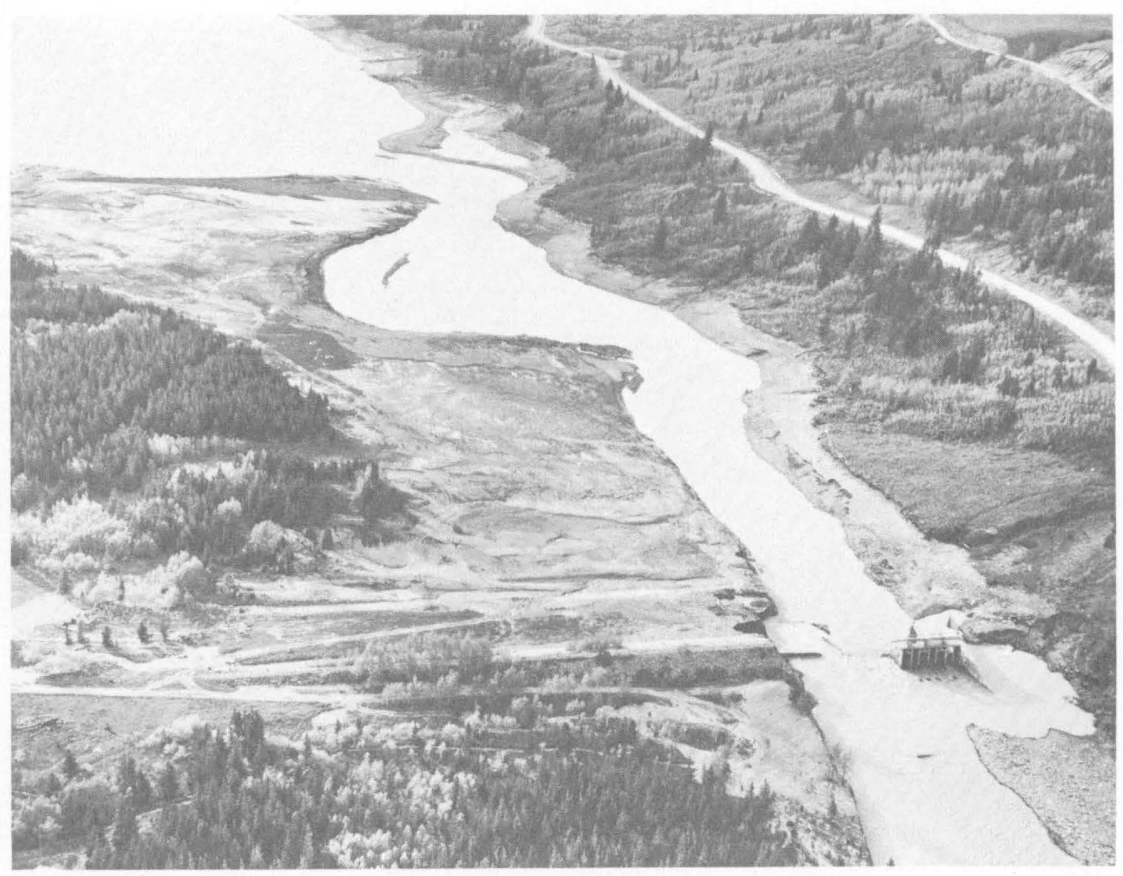

Figure 28.-Remains of Lower Two Medicine Lake Dam. Photograph by Bureau of Reclamation.

Birch Creek, joins Cut Bank Creek to form the Marias River. Willow Creek, a tributary to Cut Bank Creek, flooded many homes at Browning; and Cut Bank Creek washed out the bridge on State Secondary Highway 464.

The Marias River washed out a steel truss bridge on a county road north of Valier and the roadway to the south bridge approach on U.S. Highway 91 (fig. 30) south of Shelby. The flow of the Marias River was effectively stored in Tiber Reservoir until downstream floods had subsided. On June 8, Sullivan Reservoir, in an unnamed gulch about one-half mile from Shelby, breached and flooded a small part of the eity north of the Great Northern Railway tracks. Two other upstream reservoirs on the same gulch were brimful, and the northern third of Shelby was evacuated on June 11 when additional rainfall seemed imminent.

Flooding along the Missouri River from the mouth of Marias River to Fort Peck Reservoir was confined to a few ranches and left silt deposits up to 2 feet deep in the James Kipp State Park. Big Spring 


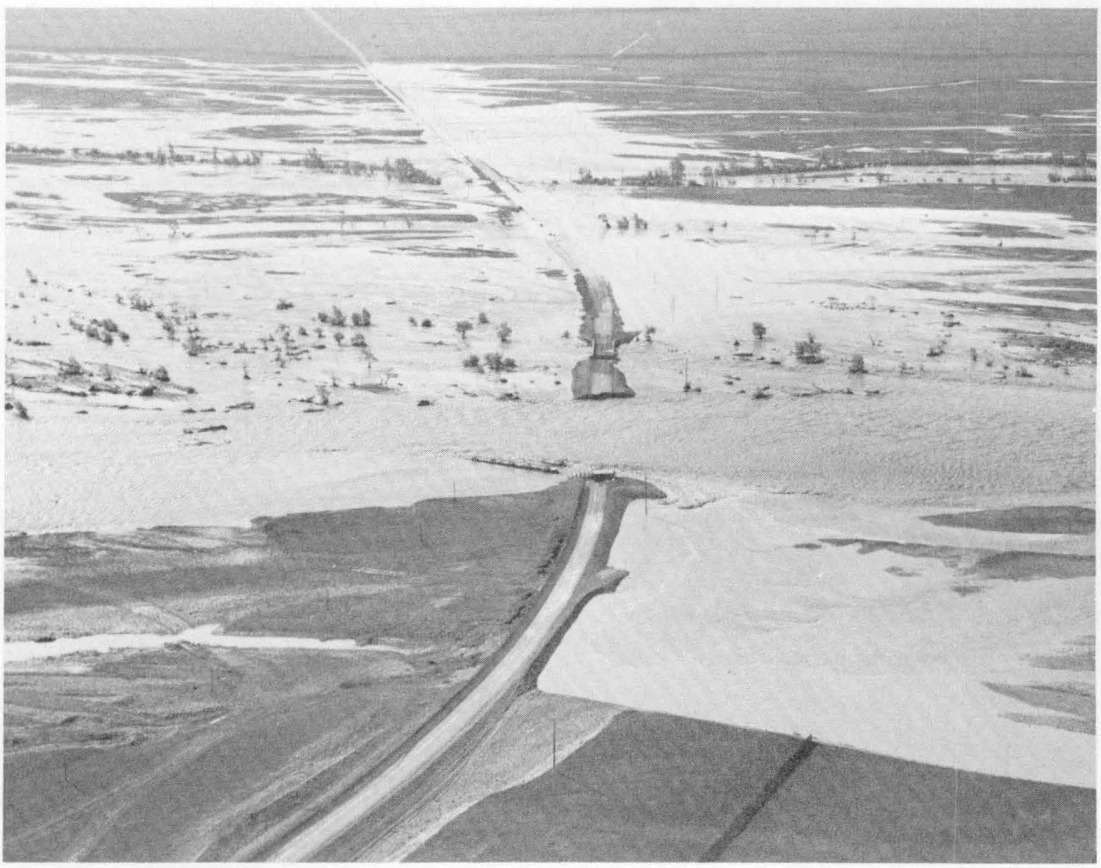

Figure 29.-Damage to Badger Creek bridge on U.S. Highway 89, typical of the many highway washouts caused by streams draining the eastern side of the Continental Divide. Photograph by Montana Highway Department.

Creek, a tributary of the Judith River, flooded 20 homes and 14 business establishments in a 3-block area of Lewistown. Cottonwood Creek, west of Lewistown, washed out the Glengarry bridge and a large culvert.

The Milk River basin flooded in the headwater area near Glacier National Park. State Secondary Highway 464 was closed for a time because several bridges and culverts and some roadway were lost. Low-lying ranch lands and a few other roads sustained some damage. Peak flows generally diminished below Del Bonita, and Fresno Reservoir near Havre prevented any downst ream damage.

Discharge hydrographs for selected gaging stations, on streams tributary to the Missouri River, are presented in figure 31. The time distribution and relative magnitude of peak discharges at selected gaging stations on the Missouri River main stem are illustrated by the hydrographs in figure 32 . 


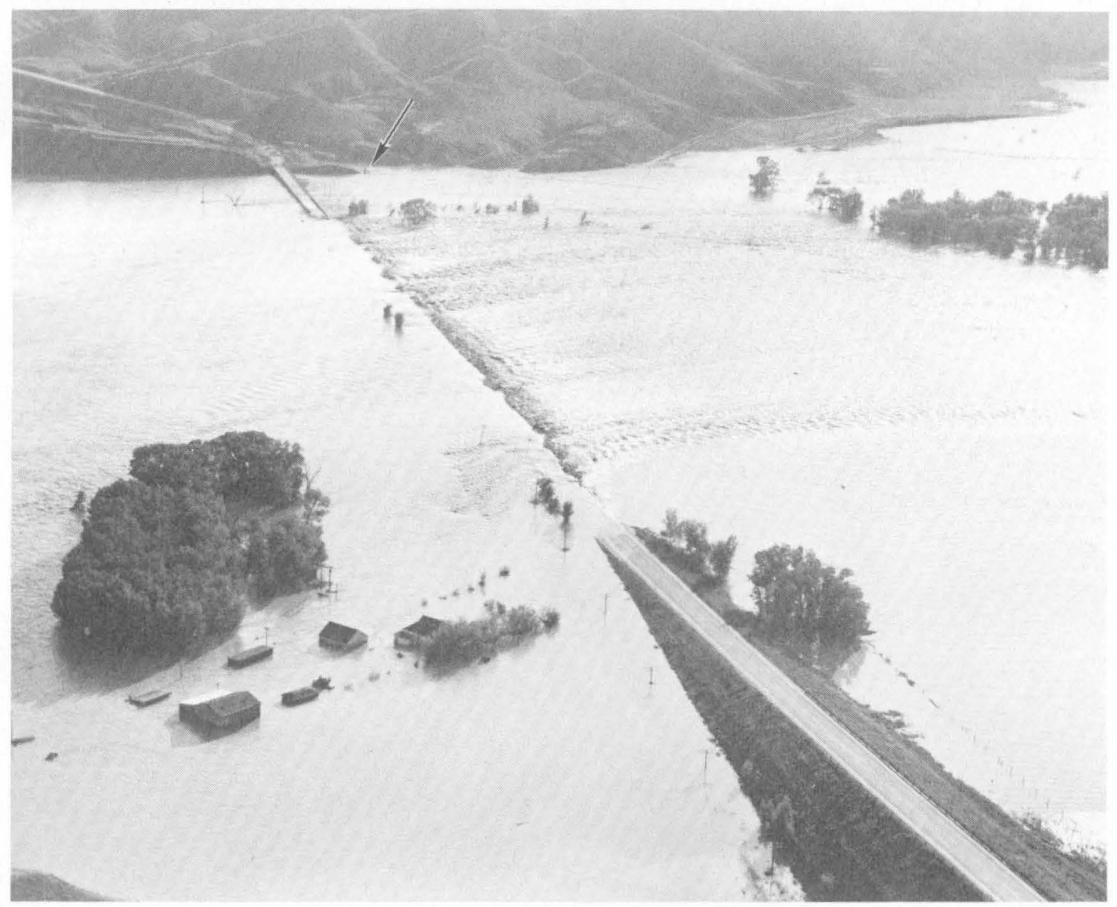

Frgure 30.-Marias River flooding U.S. Highway 91 south of Shelby. Arrow indicates gaging station on left bank downstream from bridge. Photograph by Montana Highway Department.

\section{UPPER COLUMBIA RIVER BASIN}

The chief flood-producing area of the Columbia River basin was that part of the Clark Fork drainage basin which lies near the Continental Divide in the northern half of Montana. Severe flooding was confined to the upper reaches of the Blackfoot River and Flathead River drainage areas. A noteworthy exception is local flooding at Deer Lodge, where Cottonwood Creek, a Clark Fork tributary, damaged 100 homes, destroyed 2 bridges, and prompted the man-caused destruction of 2 other bridges, when lodged debris aggravated overbank flooding.

The water was a foot deep in the east end of Lincoln, and several miles of the highway to the east were flooded as the Blackfoot River and tributaries overflowed. Several bridge approaches were lost and seven persons were isolated along Landers Fork. The North Fork Blackfoot River peaked at 11,800 cfs contrasted to a peak of $4,380 \mathrm{cfs}$ in 1948. Damage along the Blackfoot River, downstream from the 


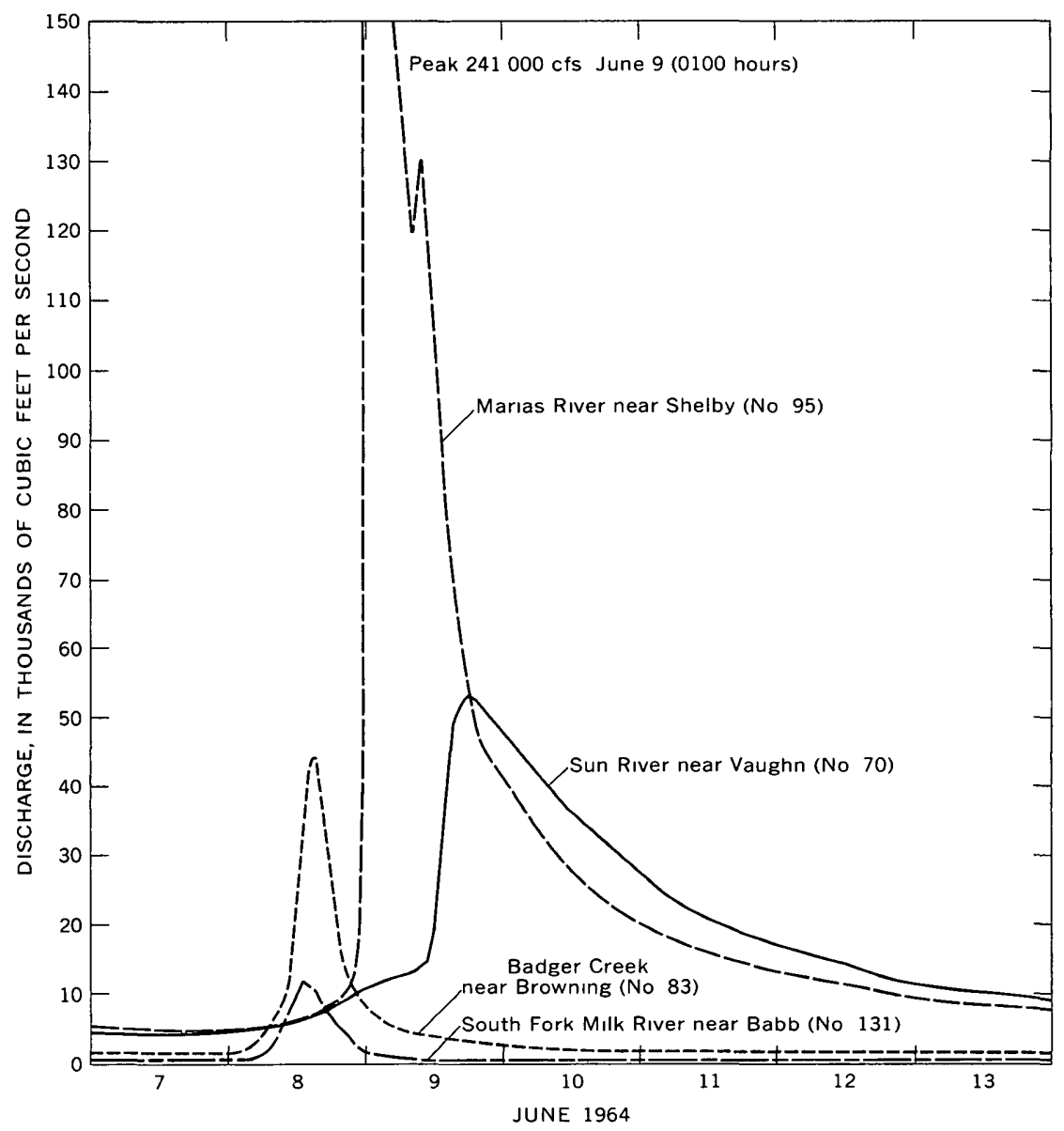

Figure 31 -Discharge at selected gaging stations in Missouı Rivel basin. June $7-13,1964$ Numbers in parentheses conform with those in table 19 and figure 2

North Fork, was not serere although the peak of 19,200 cfs near the mouth was the highest since iecord began in 1940 With the entrance of the Blackfoot Ru er flow, the peak of the Clark Fork abor e Missoula exceeded the 1948 peak by only $200 \mathrm{cfs}$ The peak of 1908 was considerably higher at Missould than either that of 1948 or $196+$ Rattlesnake Creek, which enters the Clark Fork in Missoula, flooded a number of homes and littered gardens and lawns with debris Dikes and sandbagging prevented flooding of the low-lying Orchard Homes area along the Clark Fork in the southwest part of Missoula The peak flow of the Bitterroot River, which enters the Clark Fork just west of Missoula, was about 5 percent higher in 1948 than $m 1964$ At 


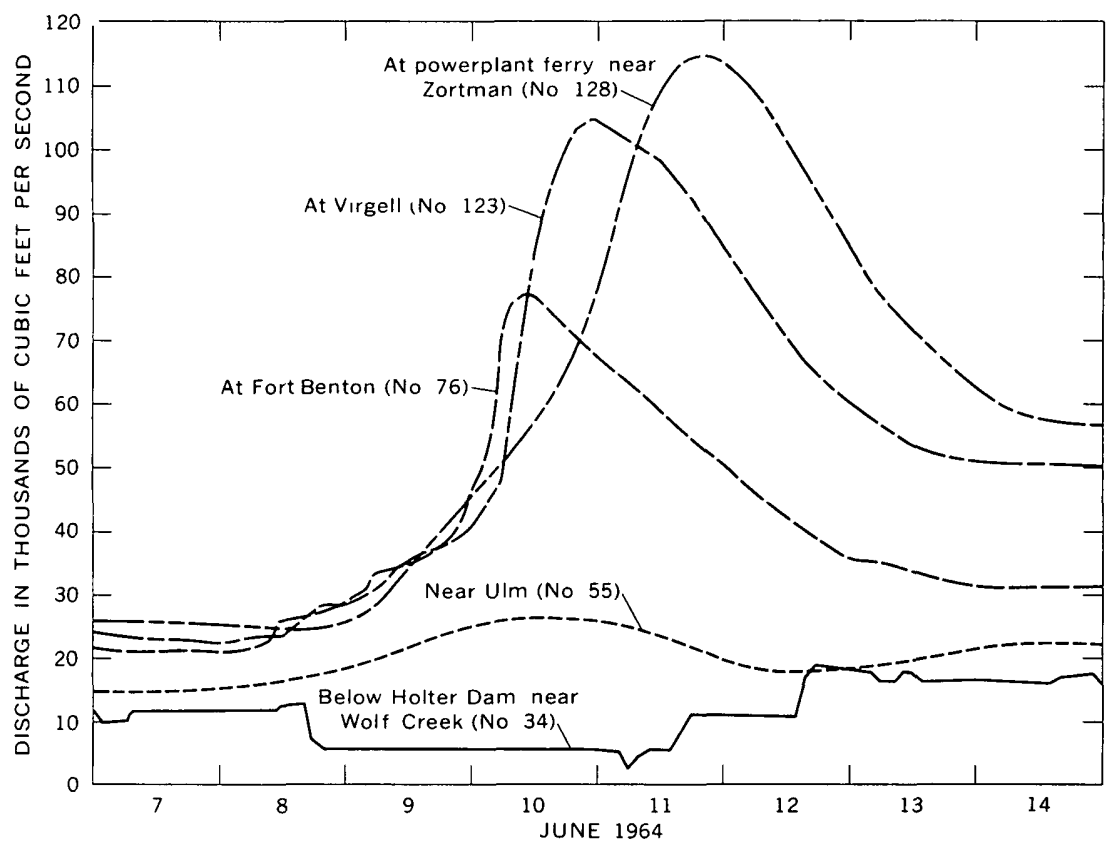

Figure 32 -Discharge at selected gaging stations on the Missouri River, June $7-14,1964$ Numbers in parentheses conform with those in table 19 and on figure 2

St. Regis, about 25 miles upstream from the Flathead River, the Clark Fork peak discharge was about 13 percent greater in 1948 Discharge hydrographs at selected gaging stations on the Blackfoot River and Clark Fork are shown in figure 33

The Flathead River basm upstıeam from Flathead Lake underwent the most severe flooding in modern times All mam bridges upstream fiom Columbia Falls were washed out or rendered unusable Upstieam from the Middle Fork Flathead River, the dranage of the man stem of the Flathead River is largely in public land that is sparsely settled Recreational camping facilities at Big Creek and Tuchuck were on the flood plam and were extensively damaged by scour, silt, and debris Nearly 70 percent of the damage reported in this dramage area was to roads and bridges Peak discharge of the Flathead River at Flathead, British Columbia, near the international boundary was $16,300 \mathrm{cfs}$, or 1,700 cfs greater than the highest peak recorded durng the past 35 years .Just upstream from the Middle Fork Flathead River, the 1964 peak flow was double the maximum peak of the previous 35 years of record Eastern tributaries from 


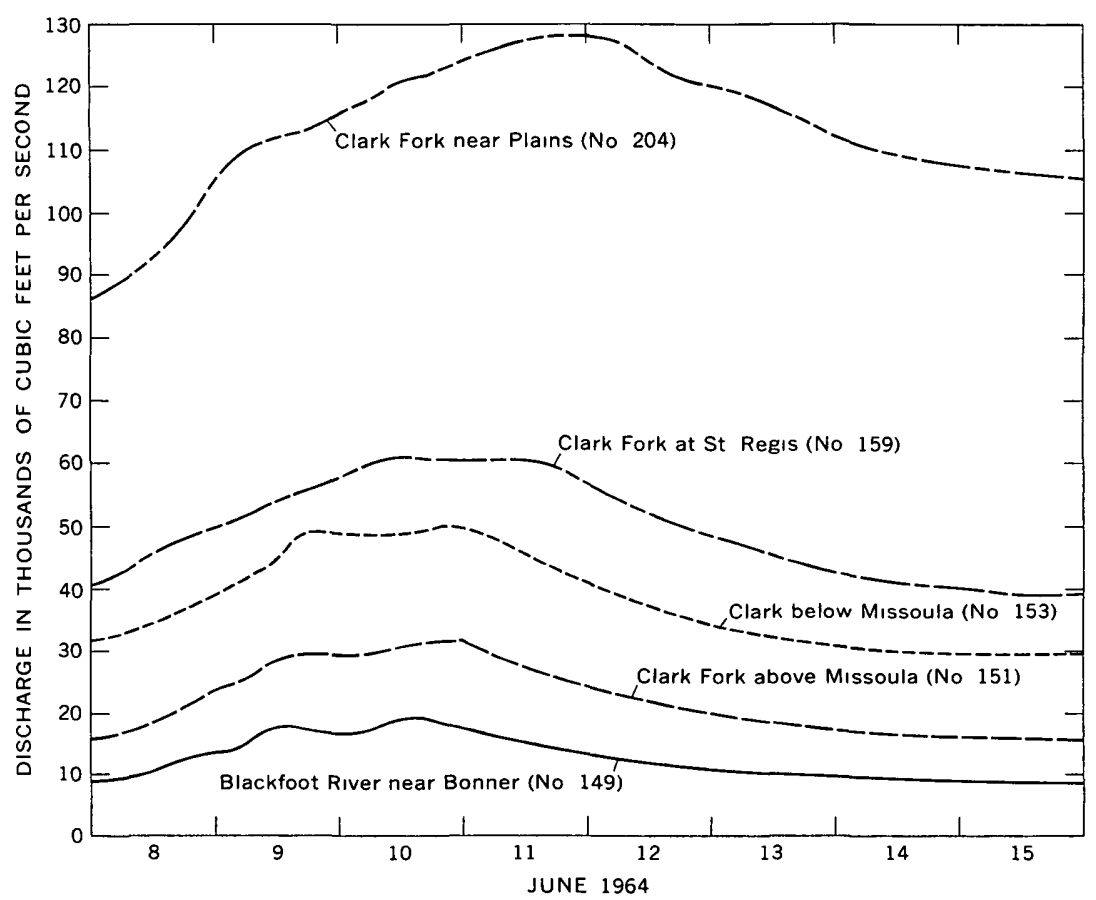

Figure 33 -Discharge at selected gagıng stations on Blackfoot River and Clark Fork, June 8-15, 1964 Numbers in parentheses conform with those in table 19 and on figure 2

Glacier National Park had higher unit r unoff than western tributares along the main stem Flathead River because of greater storm precıp1tation and snowmelt

Extremely high runott in the Middle Fork Flathead Rivel dramage basm caused extensive damage to highways and rallroads in narrow valleys along the southern edge of Glacier National Park A natural gash me was broken, and nearly 17 miles of U.S Highway 2 along both Bear Creek and the river literally disappeared (fig. 34). The peak dischange of Bear Creek near Essex was 8,380 cfs from a dramage alea of 207 square miles 1 steel bridge on US Highway 2 acıoss the Middle Fork Flathead Rwer at Essex was washed away The rivel at Essex peaked at 75,300 cfs an amount five times the maxımum discharge of the previous 25 years of record

The mamlme tracks of the Great Northern Ralway sustamed heavy damage from slides and washouts, principally by tributary streams; and at one point the Middle Fork Flathead River overtopped a tumnel portal (fig 35) Two freight trains were mar ooned near Essex Rall 


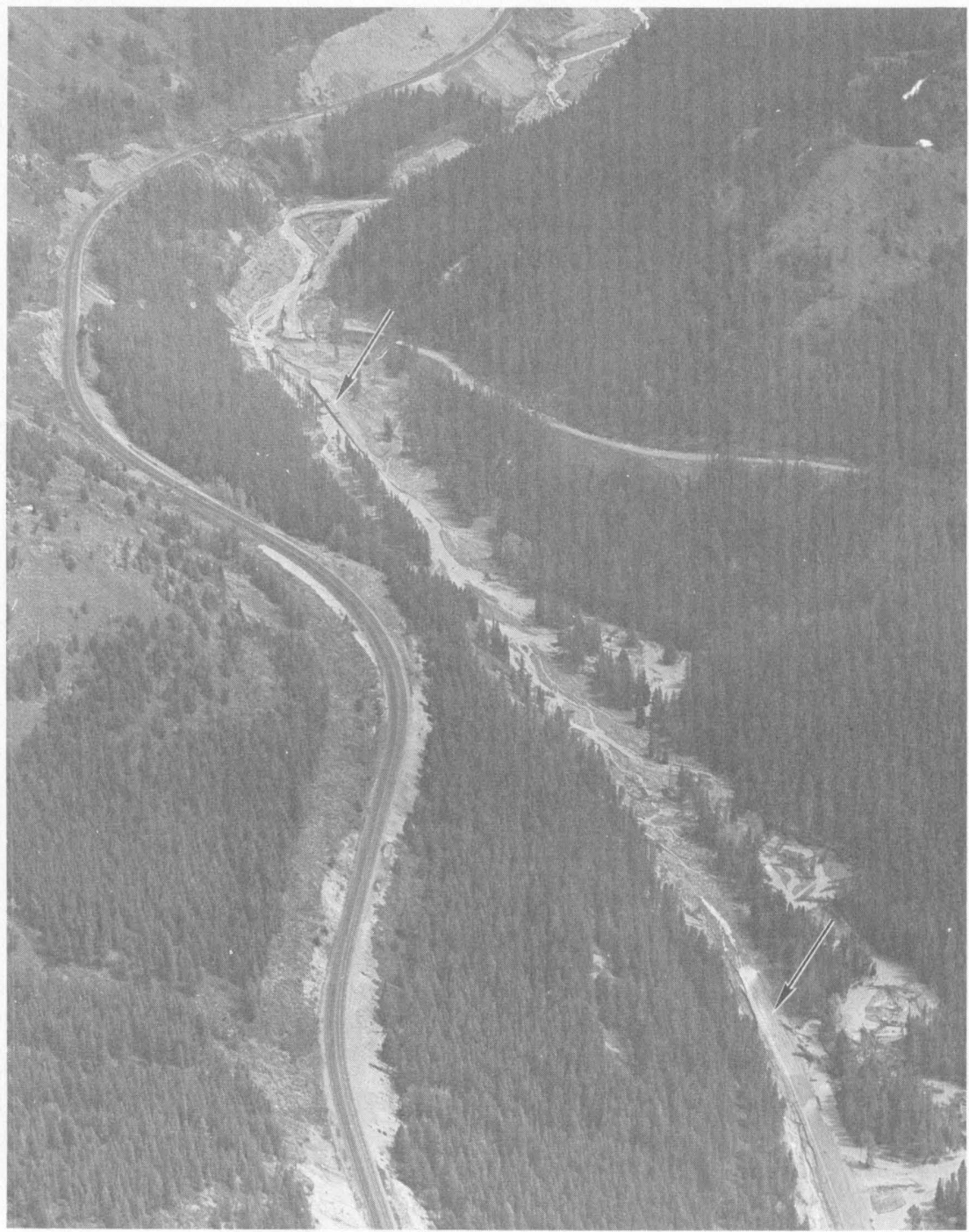

Figure 34.-Damage to U.S. Highway 2 (arrows) along Bear Creek. Photograph by Montana Highway Department.

traffic was rerouted through Helena on Northern Pacific Railway tracks for about a month while repairs were being made.

In the Nyack Flats area, along the Middle Fork Flathead River downstream from Essex, 30 residents were evacuated by air. Typical damage to transportation facilities by fill and debris from tributary streams is shown in figure 36. 


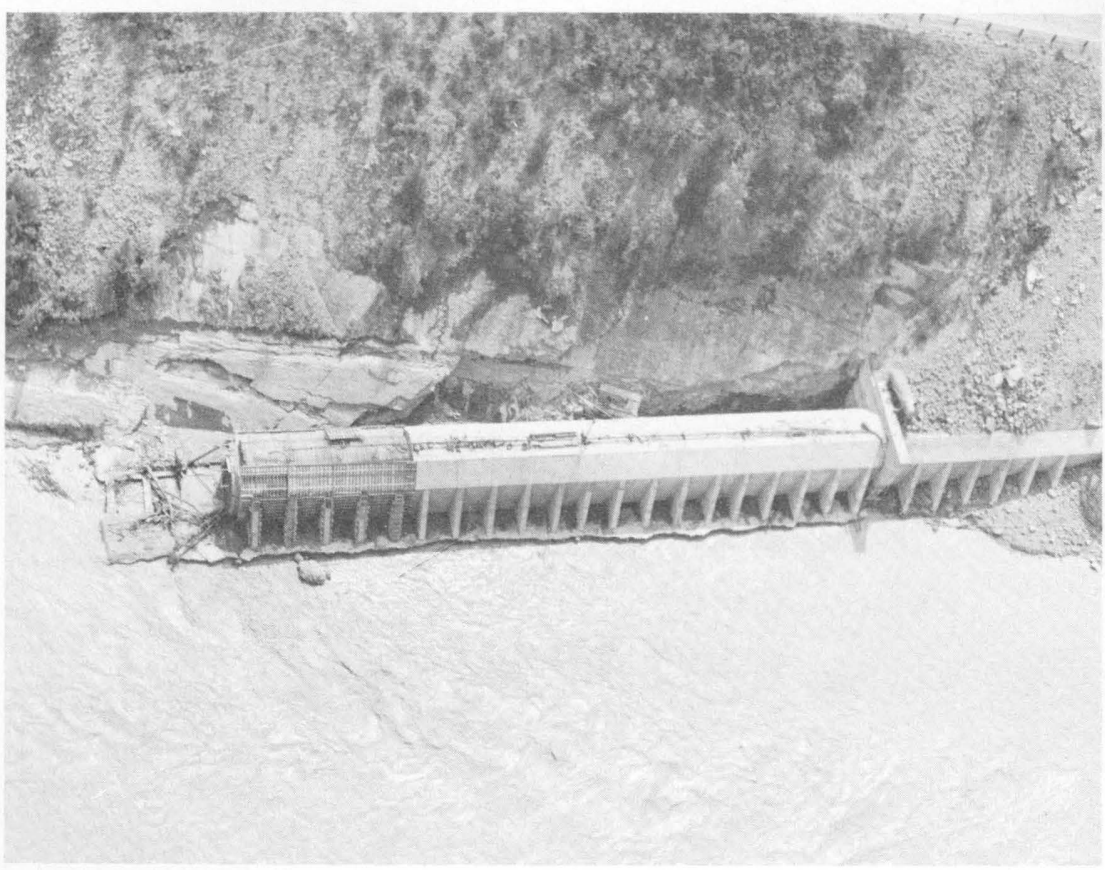

Figure. 35.-Great Northern Railway tunnel overtopped by Middle Fork Flathead River. Photograph by Guest Photo, Kalispell.

At West Glacier, the main highway bridge to the west entrance of Glacier National Park was damaged beyond repair. An old low single-arch concrete bridge was completely submerged, but the arch was not seriously damaged by drift. This bridge was redecked and restored for temporary use.

Downstream from West Glacier a rocky canyon constricted flow and, for a time, part of the Middle Fork Flathead River actually flowed upstream along McDonald Creek into Lake McDonald in Glacier National Park. Many homes, resorts, and lakeshore facilities were damaged. The peak flow of the Middle Fork Flathead River near West Glacier (downstream from McDonald Creek) reached about $140,000 \mathrm{cfs}$, or an amount four times the maximum peak of the previous 25 years of record.

Flow of the South Fork Flathead River was completely regulated at Hungry Horse Dam. Upstream from the dam widespread flooding damaged forest roads, trails, logging operations, and resort facilities. All roads in the area were closed because of washed-out bridges or approaches, slides, or roadway washouts. The previous peak of record 


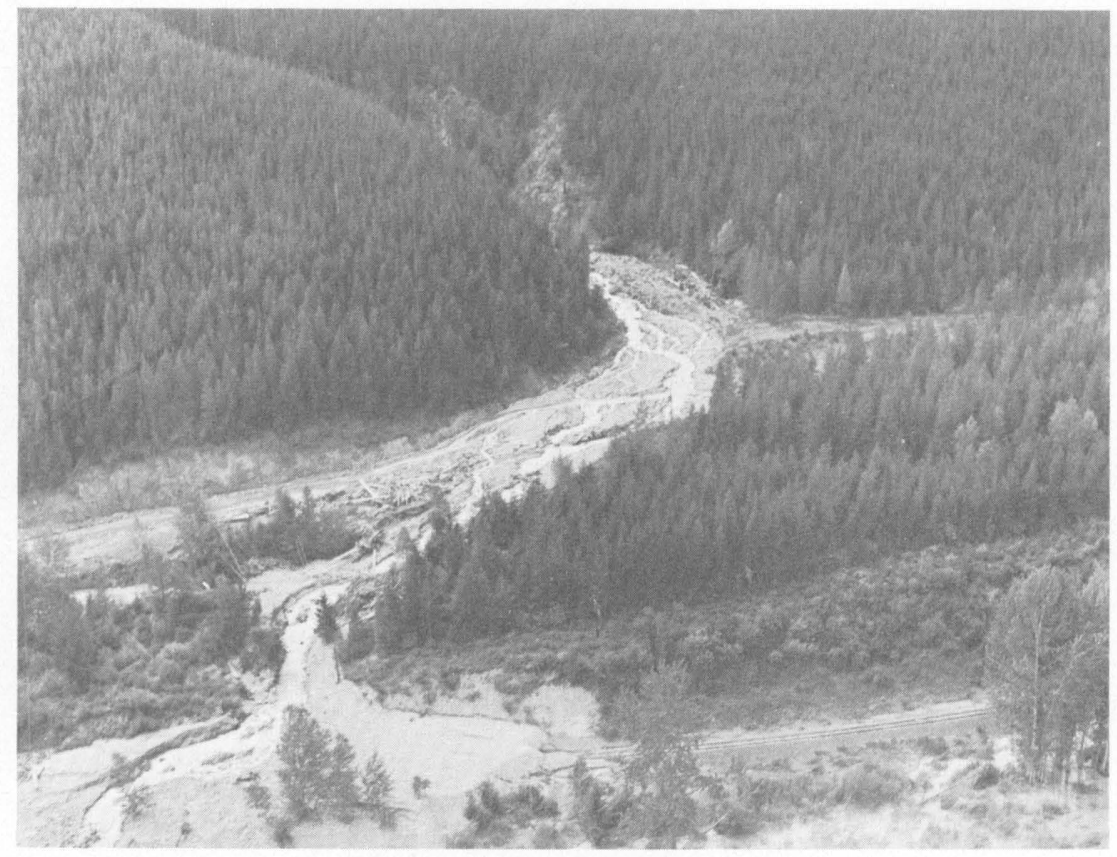

Figure 36.-Debris deposits at mouth of Moccasin Creek near West Glacier. Photograph by Guest Photo, Kalispell.

of South Fork Flathead River near the mouth, and prior to regulation, was 46,200 cfs in 1916. The computed 1964 peak inflow to Hungry Horse Reservoir was about 78,000 cfs.

The peak flow of the Flathead River at Columbia Falls, downstream from the three forks, was $176,000 \mathrm{cfs}$. Studies by the Corps of Engineers indicate that the peak at Columbia Falls would have been approximately 245,000 efs if the South Fork Flathead River had not been regulated. Prior to this regulation, the previously recorded maximum peak was $102,000 \mathrm{cfs}$ in 1948 , and the historic peak of 1894 was 142,000 cfs. About 50 homes in the Columbia Falls area were damaged. The Anaconda Co. aluminum reduction plant continued operation with standby fuel instead of natural gas and by pumping from three ground-water wells on high ground.

Between Columbia Falls and Flathead Lake, the Flathead River flooded an extensive area of lowlands totaling approximately 25,000 acres. More than 350 homes were flooded east of Kalispell in the Days Acres area and the Evergreen area (fig. 37). The Evergreen area also contains many small businesses such as motels, drive-ins, gas stations and nurseries, recreation facilities, and a city park. The 


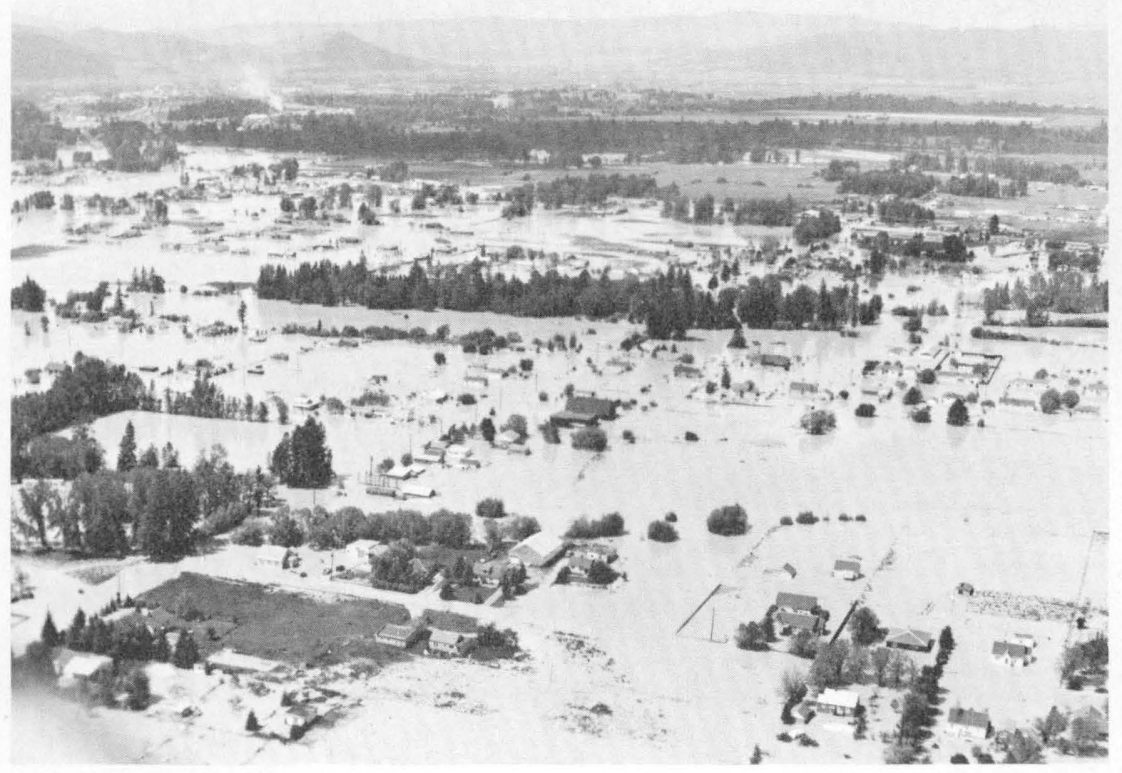

Figure 37.-Flooded Evergreen area east of Kalispell. Photograph by Guest Photo, Kalispell.

Days Acres area was flooded about 4 hours after the Evergreen area was by water backingup in the Stillwater River. Several thousand gallons of gasoline from ruptured bulk tanks of the Jet Oil Co. joined the floodwaters and created a fire hazard east of Kalispell. Dikes along the lower Flathead valley near the lake held, but were badly cut by the high flows. The flooded area from Columbia Falls to Flathead Lake is shown in plate 1. The peak flow of the Swan River, a direct tributary to Flathead Lake, was about 4 percent less than the previous record of 1948 at the gaging station near Bigfork. Upstream at Strom's Store, near Condon, the 1948 peak discharge was exceeded by about 20 percent.

The peak stage of Flathead Lake at Somers was $2,894.27$ feet, recorded at 1230 hours on June 12. This is the highest lake stage observed since upstream regulation by Hungry Horse Dam began in September 1951. The Corps of Engineers estimate a maximum stage of 2,896.8 feet would have occurred in 1964 if there had been uncontrolled outflow from Flathead Lake after May 1 and no flood-control storage in Hungry Horse Reservoir. The stage of 2,896.26 feet in 
1933 is the highest lake stage since contmuous record began in April 1909 The historic peak stage of 1894 was 2,900 feet All Flathead Lake elevations given are referenced to Somers datum To convert from Somers datum to datum of 1929, supplemental adjustment of 1947, subtract 100 feet Livestock losses in the Flathead River basin totaled nearly 1,200 with cattle, hogs, and pets making up the majority of drowned animals Three barge loads of animal carcasses were taken from Flathead Lake and burıed in a central disposal pit Not one horse was in the group

At the outlet of Flathead Lake, at Kerr Dam, the Flathead River had a peak of $66,800 \mathrm{efs}$ The highest previous peak since record began in 1910 occurred in 1928 and was 82,800 cfs The 1894 historic peak discharge was computed to be about $110,000 \mathrm{cfs}$ in a lake elevation-discharge study The relation of lake stages to inflow and outflow may be better understood if it is realized that a change of a foot in lake level is equivalent to a storage change of about 120,000 acre-ft

In the Jocko River Valley, US Highway 93, south of Arlee, was flooded in two places by Agency Creek Many small bridges on county roads were damaged, washed out, or sustained approach damage Nearly 300 feet of Northern Pacific Rallway track was washed out by the Jocko River near the Jocko Cabin Camp A local resident since 1915 reported he had never before seen flooding of this magnitude in the Jocko River Valley Revais Creek, a Flathead River tributary west of Dixon, washed out an approach to the bridge on US Highway $10 \mathrm{~A}$

Discharge hydrographs for selected gaging stations in the Flathead River basin are shown in figure 38

\section{EVALUATION OF FLOOD DAMAGE}

The rery rapid rise of stieams near the Contmental Divide left little time for protectrve measures Many of the 30 persons who lost then lis es had little or no warning, some per sshed while attempting to reach safety or to save a few possessions Farther downstream, the walnings of flood as much as a day in advance reduced casualties and peimitted saving of some property Nearly 350 persons were injured The Red Cross reported mass shelter and food were provided for about 8,700 persons during the highwater period Total damage in Montana was estimated by the Corps of Engmeers (1964a, 1964b), US Department of the Army, at $\$ 55$ million after prompt detaled surveys by various agencies No monetary damage was assigned to the effect of the extenswe scarring of stream channels upon fish and wildlife habitat Damage in excess of $\$ 1$ million occurred in Canada 


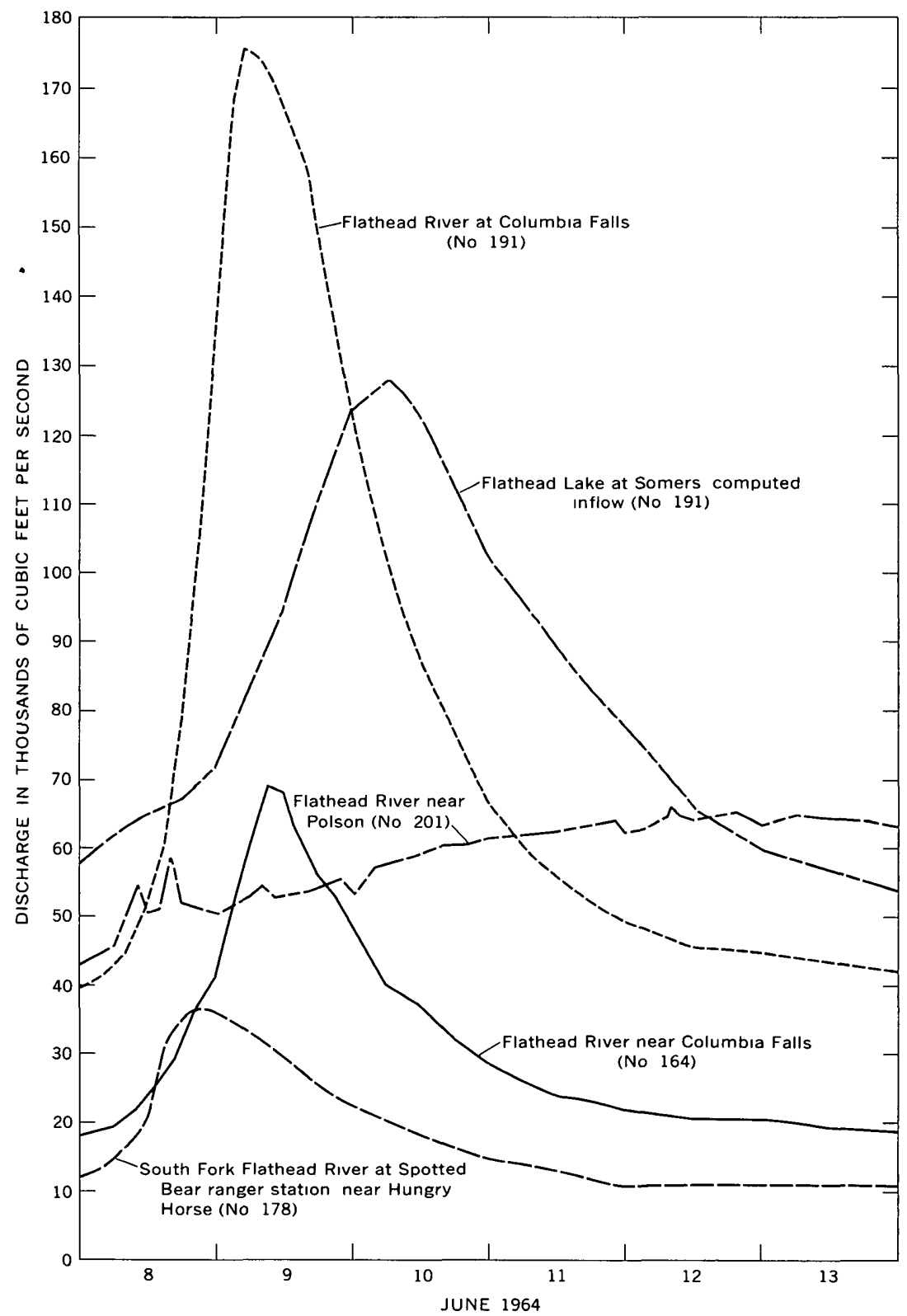

Figure 38 -Discharge at selected gaging stations in Flathead River basin, June 8-13, 1964 Numbers in parentheses conform with those in table 19 and on figure 2 
The statistical breakdown of losses by principal stream basins and by categories was generally avallable in the compllation of damage prepared by the Corps of Engmeers A major exception was in the extensive Lewis and Clark National Forest where subsequent breakdowns prepared by the US Forest Service were inserted in the Corps of Engineer listings No stream-basin breakdowns were avalable for public domain and publıc facilities in that part of Glacier National Park lying east of the Continental Divide This area includes much of the Hudson Bay draınage and small parts of the Marıas and Milk River basins

\section{DAMAGE EAST OF CONTINENTAL DIVIDE}

Flood damage east of the Contmental Divide (table 7) in the Hudson Bay and Missourı River basins totaled $\$ 30,714,500$ In the headwater areas, in the Lewis and Clark National Forest, almost all the fish habitat on 155 mules of major stream channels and 320 miles of minor stream channels sustained severe damage No monetary value was assigned to the loss of fish and wildlife habitat Alluvium, ranging from a few inches to several feet in depth, was deposited at the mouths of most small streams It was estimated that slightly more than 3,000 acres of flood plains was denuded in the Lewis and Clark National Forest Much of the heavy sediment load that reached the larger streams was deposited along the flatter reaches outside the National Forest

Downstream from the headwater areas, an estımated 120,400 acres of land was mundated by the flooding waters More than 5,500 persons were evacuated from their homes, and damage to 1,870 homes and 186 busmess establishments was reported

TABLE 7 -Summary of flood damage east of the Contrnental Divide by basins

[Based on damage estımates complled by the U S Army Corps of Engıneers and the U S Forest Service]

\begin{tabular}{|c|c|c|c|c|}
\hline Stream basin & Rural & Urban & Transportation & Total \\
\hline $\begin{array}{l}\text { Sun River } \\
\text { Marias River } \\
\text { Missour1 River main stem. } \\
\text { Others }{ }^{1}\end{array}$ & $\begin{array}{r}\$ 4,107,700 \\
9,220,000 \\
36,400 \\
372,900\end{array}$ & $\begin{array}{r}\$ 4,913,000 \\
1,262,900 \\
142,700 \\
132,500\end{array}$ & $\begin{array}{r}\$ 3,302,800 \\
5,037,200 \\
293,000 \\
1,893,400\end{array}$ & $\begin{array}{r}\$ 12,323,500 \\
15,520,100 \\
472,100 \\
2,398,800\end{array}$ \\
\hline Total & $13,737,000$ & $6,451,100$ & $10,526,400$ & $30,714,500$ \\
\hline
\end{tabular}

1 Includes public domain and facilities in Glacier National Park

\section{RURAL DAMAGE}

Rural damage (table 8) to crops, farmsteads, fences, 11 rigation works, national-forest facilities, and lands totaled nearly $\$ 14$ millon Damage to more than 300 farmsteads and rural nonfarm residences, stored feed and grain, and farm equipment and the loss of livestock 
represented about 25 percent of the total, or about $\$ 35$ million Flood damage to irrigation works throughout the area was about $\$ 3.7 \mathrm{mll}$ lion, about 50 percent of which was accounted for by the loss of Swift Dam on Birch Creek and Lower Two Medicine Lake Dam. Erosion and deposition of debris, silt, and weed seeds onto farmland account for 17 percent of the total rural damage Crop and pasture losses amounted to about 17 percent of the total, and the major part of the crop loss was in the irrigated areas Debris-laden streams caused nearly $\$ 700,000$ damage to fences in the stream valleys

The remaining 8 percent of the total rural damage was to gravel pits, recreation faclities, various U.S. Forest Service facilities, and rural schools The costs of evacuation and care of rural inhabitants, clearıng of debris jams from streams, and stabilization of streambanks at critical points, particularly at campgrounds $m$ the Lewis and Clark National Forest were also considered Forty-five percent of the Forest Service telephone lines were destroyed, and the remaining telephone lines sustained 10-50 percent damage In Glacier National Park damage to bullings, utilities, and campgrounds totaled nearly $\$ 400,000$

\section{TABLE 8 -Rural flood damage east of the Contrnental Divide}

[Based on damage estımates compled by the U S Army Corps of Engıneers and U S Forest Service]

\begin{tabular}{|c|c|c|c|c|}
\hline Stream & $\begin{array}{l}\text { Acres } \\
\text { flooded }\end{array}$ & Farmsteads & Fences & $\begin{array}{l}\text { Crop and } \\
\text { pasture }\end{array}$ \\
\hline $\begin{array}{l}\text { Sun River } \\
\text { Marias River } \\
\text { Teton River } \\
\text { Birch Creek } \\
\text { Two Medicine River } \\
\text { Cut Bank Creek } \\
\text { Main stem and tributaries. } \\
\text { Miscellaneous areas }{ }^{1} \text {... }\end{array}$ & $\begin{array}{r}32,600 \\
44,600 \\
16,670 \\
8,660 \\
8,680 \\
8,590 \\
600\end{array}$ & $\begin{array}{r}\$ 578,200 \\
743,800 \\
562,000 \\
1,109,000 \\
424,000 \\
79,000 \\
6,500\end{array}$ & $\begin{array}{r}\$ 324,400 \\
115,900 \\
146,800 \\
60,700 \\
41,000 \\
10,000 \\
600\end{array}$ & $\begin{array}{r}\$ 302,000 \\
1,136,800 \\
481,000 \\
153,900 \\
84,800 \\
171,500 \\
2,800\end{array}$ \\
\hline Total..... & 120,400 & $3,502,500$ & 699,400 & $2,332,800$ \\
\hline Stream & Land & $\begin{array}{l}\text { Irrigation } \\
\text { works }\end{array}$ & Other ${ }^{2}$ & Total \\
\hline $\begin{array}{l}\text { Sun River } \\
\text { Maris River } \\
\text { Teton River } \\
\text { Birch Creek } \\
\text { Two Medicine River } \\
\text { Cut Bank Creek } \\
\text { Man stem and tributaries. } \\
\text { Miscellaneous areas } 1 \text {. }\end{array}$ & $\begin{array}{r}\$ 1,222,900 \\
780,100 \\
156,900 \\
91,400 \\
44,200 \\
85,800 \\
100\end{array}$ & $\begin{array}{r}\$ 1,223,800 \\
7,000 \\
1,145,000 \\
1,300,000 \\
9,000 \\
20,000 \\
100\end{array}$ & $\begin{array}{r}\$ 456,400 \\
171,700 \\
17,200 \\
59,000 \\
11,500 \\
1,000 \\
399,200\end{array}$ & $\begin{array}{r}\$ 4,107,700 \\
2,955,300 \\
2,508,900 \\
2,774,000 \\
614,500 \\
367,300 \\
409,300\end{array}$ \\
\hline Total . & $2,381,400$ & $3,704,900$ & $1,116,000$ & $13,737,000$ \\
\hline
\end{tabular}

${ }^{1}$ Includes Missourı River main stem and minor tributarıes, St Mary River, Milk River, and Glacier National Park

2 Includes damage to U S Forest Service facilities and costs of stream channel clearıng and stabilization 


\section{URBAN DAMAGE}

The largest city flooded was Great Falls where damage was est1mated at $\$ 44$ million, of which nearly $\$ 3.2$ million was for residences and more than $\$ 1$ million was for streets and utilities. Overflow from the Sun and Missourı Rivers flooded the southwestern part of the city, requiring evacuation of about 3,000 persons

Choteau was almost completely flooded when the Teton River overflowed into Spring Creek, which courses through the town Hurried evacuation of the entire population of nearly 2,000 persons was necessary, and damage to homes, businesses, and municipal property exceeded $\$ 1$ million Damage to 14 other communities totaled about $\$ 1$ million Urban flood damage estımates are given in table 9.

T IBLE $9-U i b a n$ flood damages east of the Contınental Divide

[Compiled by U S Army Corps of Engineers]

\begin{tabular}{|c|c|c|c|c|c|c|c|}
\hline $\begin{array}{l}\text { Stream basin and } \\
\text { city or town }\end{array}$ & $\begin{array}{l}1960 \\
\text { Popula- } \\
\text { tion }\end{array}$ & $\begin{array}{c}\text { Resi- } \\
\text { dential }\end{array}$ & $\begin{array}{l}\text { Com- } \\
\text { mercial }\end{array}$ & Utilities & $\underset{\text { pal }}{\text { Municl- }}$ & Other & Total \\
\hline \multicolumn{8}{|l|}{ Sun River } \\
\hline August & 450 & $\$ 30,400$ & $\$ 32,400$ & & $\$ 2,800$ & & $\$ 66,600$ \\
\hline & 100 & 68,100 & 60,500 & 840000 & 10,000 & 9,000 & 147,600 \\
\hline $\begin{array}{l}\text { Vaug } \\
\text { Manc }\end{array}$ & (1) 265 & $\begin{array}{r}201,400 \\
46,600\end{array}$ & & $\begin{array}{l}\$+V, \\
200\end{array}$ & 500 & 200 & 47,500 \\
\hline Great Fal & 55,357 & $3,161,200$ & 199,700 & 456,000 & 546,000 & 47,000 & $4,409,900$ \\
\hline \multicolumn{8}{|l|}{ Marias River } \\
\hline $\begin{array}{l}\text { East Glacie } \\
\text { Dupuyer... }\end{array}$ & $\begin{array}{l}350 \\
125\end{array}$ & $\begin{array}{r}13,700 \\
5,600\end{array}$ & 1,200 & 65,000 & $\begin{array}{l}2,200 \\
1,000\end{array}$ & $\begin{array}{r}5,000 \\
500\end{array}$ & $\begin{array}{r}85,900 \\
8,300\end{array}$ \\
\hline Bro & 2,011 & 14,800 & 400 & & & 7,000 & 22,200 \\
\hline Shelb & 4,017 & 66,900 & 5,400 & 21,600 & 11,900 & 900 & 106,700 \\
\hline $\begin{array}{l}\text { Choteau } \\
\text { Loma }\end{array}$ & $\begin{array}{r}1,966 \\
110\end{array}$ & 558,600 & 339,300 & 42,000 & 90,500 & 7,800 & $1,038,200$ \\
\hline \multicolumn{8}{|l|}{ Missouri River } \\
\hline $\begin{array}{l}\text { (main stem) } \\
\text { Fort Benton. }\end{array}$ & 1,837 & & & 113,200 & & & 113,200 \\
\hline \multicolumn{8}{|l|}{$\begin{array}{l}\text { Fort Benton.- } \\
\text { Others }\end{array}$} \\
\hline $\begin{array}{l}\text { Raynesford - } \\
\text { Belt }\end{array}$ & (1) 757 & 1,500 & 500 & & & & 2,000 \\
\hline $\begin{array}{l}\text { Lewistown } \\
\text { St Mary }\end{array}$ & 7,408 & $\begin{array}{r}11,200 \\
3,700\end{array}$ & $\begin{array}{r}3,100 \\
95,800\end{array}$ & $\begin{array}{r}500 \\
2,500\end{array}$ & $\begin{array}{r}1,000 \\
500 \\
30,000\end{array}$ & $\begin{array}{l}200 \\
500\end{array}$ & $\begin{array}{r}15,500 \\
132,500\end{array}$ \\
\hline Total & $\ldots .$. & $\$ 4,183,700$ & $\$ 738,300$ & $\$ 741,000$ & $\$ 698,000$ & $\$ 90,100$ & 51,100 \\
\hline
\end{tabular}

1 Less than 100

TRANSPORTATION DAMAGE

The damage to transportation facilities (table 10) w as more than $\$ 10$ million, of which the county road system sustaned nearly $\$ 1$ millon and rallroads about $\$ 300,000$ Losses to the Federal and primary and secondary systems, exclusive of Glacier Natıonal Park and Forest Service roads in the area, account for nearly $\$ 26$ million Approximately 60 road bridge crossings were affected, as well as several culvert crossings and many miles of roadway Damage ranged from loss of approaches and abutments to complete destruction or loss of crossings. In the Iew is and Clark National Forest, 20 percent of the 112 miles 
of forest roads was destroyed and an additional 50 percent was so heavily damaged as to make reconstruction necessary Of the 15 bridges on forest roads, 5 were completely destroyed, 1 was damaged beyond repair, and 9 required extensive repair, replacement of approaches, or realmement of the channel The Pretty Prairıe airfield in the Sun River basin, was damaged beyond repair The Gates Park anfield, also in the Sun River basin, was severely damaged More than a third of the 977 miles of forest trall was completely destroyed and damage of 10 to 50 percent occurred to the rest. All major packhorse trall bridges were destroyed. The loss to public transportation facilities was estımated at $\$ 53$ million in the Lewis and Clark National Forest.

The National Park Service estımated the damage to roads and trails at nearly $\$ 1.5$ million for that part of Glacier National Park lying east of the Contmental Divide

TIBLE 10 - Transportation flood damage east of the Contınental Divide

[Based on damage estimates compiled by the U S Army Corps of Engineers and U S Forest Service]

\begin{tabular}{|c|c|c|c|c|}
\hline Stream basın & $\begin{array}{l}\text { County roads } \\
\text { and bridges }\end{array}$ & $\begin{array}{c}\text { State and federal } \\
\text { highways, } \\
\text { bridges and } \\
\text { arfields 1 }\end{array}$ & Raulroads & Total \\
\hline Sun Rivel _........ & $\$ 99,500$ & $\$ 3,129,300$ & $\$ 74,000$ & $\$ 3,302,800$ \\
\hline $\begin{array}{l}\text { rias River } \\
\text { Teton Rivel }\end{array}$ & 368,100 & $1,820,300$ & 69,100 & $2,257,500$ \\
\hline Birch Creek.... & 45,200 & $1,256,300$ & & $1,301,500$ \\
\hline Two Medicine River & 13,200 & 918,200 & & 931,400 \\
\hline Cut Bank Creek & 43,800 & 199,000 & & 242,800 \\
\hline $\begin{array}{l}\text { Main stem and tribu- } \\
\text { taries }\end{array}$ & 105,500 & 66,500 & 132,000 & 304,000 \\
\hline Miscellancous Areas ${ }^{2} \ldots$ & 205,300 & $1,962,800$ & 18,300 & $2,186,400$ \\
\hline Total_. & $\$ 880,600$ & $\$ 9,352,400$ & $\$ 293,400$ & $\$ 10,526,400$ \\
\hline
\end{tabular}

1 Includes damage estımates to roads, trails, and airfields in the Lewis and Clark National Forest

2 Includes Missouri River main stem and minor tributaries, St Mary River, Milk River and Glacier National Park

\section{DAMAGE WEST OF CONTINENTAL DIVIDE}

Flood damage west of the Contmental Divide was estimated at $\$ 245$ million, of which $\$ 176$ million was for transportation facilities The second highest category of damage, as reported by the Corps of Engineers, includes that to bulldings, contents and improvements, and so forth, for a total of $\$ 38$ million Damage to land, crops, livestock fences, and farm equipment was estimated at nearly $\$ 18$ million The remaining four categories of damage total $\$ 13$ million The 
damage estımate compiled by the Corps of Engineers is summarized in table 11 The breakdown by stream basins, or reaches, points up the preponderance of damage in the sparsely settled Middle Fork Flathead River drainage basin and the more populous area along the Flathead River from the Middle Fork Flathead River downstream to Flathead Lake.

Damage to transportation facilities accounted for about $\$ 126 \mathrm{mll}-$ lion, or nearly 95 percent of the total damage, in the Middle Fork Flathead River dramage basm where U.S Highway 2 and the Great Northern Ralway tracks were in the narrow valleys Earth slippage and the washout of bridges and trackage by tributary streams accounted for a large part of the rallroad damage The timber industry of the Flathead Valley depends greatly upon the forest roads, and it is reported that the road damage caused a setback of about a month in that industry Nearly 180 miles of tralls in the Flathead National Forest will require restoration, and several livestock and foot bridges that were destroyed will require replacement. Damage to trails and roads in Glacier National Park was severe

The category of buldings, contents and improvements, and automobiles and trucks covers rural and urban areas and does not distinguish between commercial and residential damage The fact that 50 homes near Columbia Falls and 350 homes near Kalispell were flooded indicates urban damage may represent a substantial part of the damage in this category for the area along the Flathead River below the Middle Fork Flathead River Facilities around Flathead Lake sustaned some damage when the level of Flathead Lake exceeded the upper limit for controlled regulation of 2,8930 feet elevation (Somers datum)

The chief agricultural area affected by the flood was along the Flathead River from Columbia Falls to Flathead Lake The rapid ise of flood waters contributed to a substantial livestock loss

Among the losses to utilities was damage to a natural-gas pipeline in the narrow valleys of Bear Creek and the Middle Fork Flathead River About 100 miles of forest telephone line needed reparr or replacement

The upper reaches of the Blackfoot River and its tributaries and most of the streams in the Flathead River basin, both in and outside Glacier National Park and the Flathead National Forest, are good trout habitat The US Forest Service estimated that 105 miles of main stream and about 240 miles of tributary streams of the Flathead River were scarred to the point of seriously affecting fish and wild- 
TABLE 11 - Summary of flood damage west of the Continental Divide by basins [Complled by U S Army Corps of Engineers]

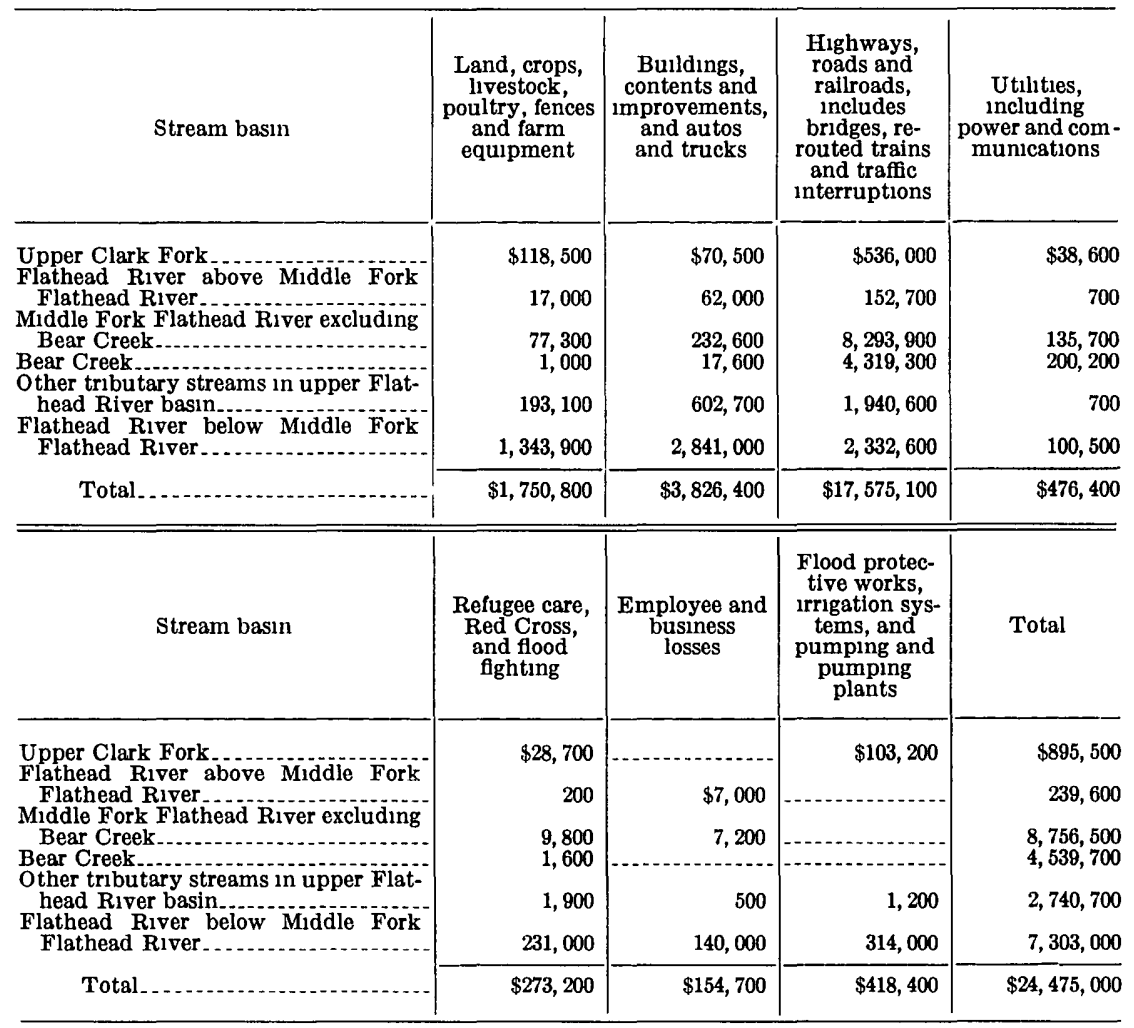

life habitat The loss of nesting areas for upland and migratory birds was also mentioned as serious in the Flathead National Forest No monetary value was placed on these items.

\section{FLOOD-CREST STAGES}

Flood-crest stages in the Missourı River basm are given for the Sun River and one of its major tilbutaries (table 12) and for the Teton River (table 13) in the area flooded during June 1964 In the uppes Columbia River basin, flood-crest stages are given for the Flathead River upstream from Flathead Lake (table 14), the Middle Fork Flathead River and one of its tributaries (table 15), the Stillwater River and one of its major tributaries (table 16), and the Swan River (table 17) Most of the information presented in the tables was furnished by Corps of Engineers 
TablF 12-Flood-cie'st stages, Sun Kiver basill, floods of Julle 1964

[Data mostly fuınıshed by U S Aımy Corps of Engineers]

\begin{tabular}{c|c|c}
\hline Stream, location, and time & $\begin{array}{c}\text { Miles above } \\
\text { mouth of } \\
\text { Sun Rivel }\end{array}$ & $\begin{array}{c}\text { Elevation } \\
\text { (feet) }\end{array}$ \\
\hline
\end{tabular}

June 8

Left bank Sun Rive1, approximately 4 miles north of Augusta, old telephone pole about $700 \mathrm{ft}$ west of State Highway 287 and $150 \mathrm{ft}$ northwest of old concrete bridge pier sec $27, \mathrm{~T} 21 \mathrm{~N}, \mathrm{R} 6 \mathrm{~W}$

Left bank Sun River, approximately 4 miles north of Augusta, $50 \mathrm{ft}$ north and $40 \mathrm{ft}$ east of State Highway 287 bridge abutment in sec $27, \mathrm{~T} 21 \mathrm{~N}, \mathrm{R} 6 \mathrm{~W}$

Left bank Elk Creek, approxımately 05 mile upstream from State Highway 287 bridge in Augusta, $260 \mathrm{ft}$ north of a steel truss road bridge in sec $17, \mathrm{~T} 20 \mathrm{~N}$, R $6 \mathrm{~W}$, at 2200 hours . . . . . . . .

Left bank Elk Creek, 04 mile south of Main St, Augusta, on State Highway 287 Northeast corner of timber bridge abutment in sec $17, T 20 \mathrm{~N}, \mathrm{R} 6 \mathrm{~W}$.

Left bank Elk Creek, on north gate of west entrance to Augusta rodeo grounds in sec 17, T $20 \mathrm{~N}, \mathrm{R} 6 \mathrm{~W}$

Left bank Elk Creek, on northeast corner of outside tollet at residence about $400 \mathrm{ft}$ south-southwest of American Legion building in Augusta in sec 17, T $20 \mathrm{~N}, \mathrm{R} 6 \mathrm{~W}$

Right bank Elk Creek, $1 / 4$ mile east of Augusta at Sofic Malataire residence Northwest corner of porch on television antenna polc in sec $17, T 20 \mathrm{~N}, \mathrm{R} 6 \mathrm{~W} \ldots$

715

3,97352

713

3,97021

734

4,08998

724

4, 07606

715

4,06828

714

4,06470

710

4,05680

June 9

Right bank Sun Riveı, approximately $450 \mathrm{ft}$ northeast of mile post 36, Great Northern Ralway, and $100 \mathrm{ft}$ west of communication marker pole in sec $8, T 20$ $\mathrm{N}, \mathrm{R} 5 \mathrm{~W}$

Right bank Sun River, $125 \mathrm{ft}$ northwest of Riebling Station rallroad siding sign in sec $8, T 20 \mathrm{~N}, \mathrm{R} 4 \mathrm{~W}$

Right bank Sun River, $40 \mathrm{ft}$ south of upstream abutment of Great Northern Rallway bridge at mile $273 \mathrm{~m} \mathrm{sec}$ $12, \mathrm{~T} 20 \mathrm{~N}, \mathrm{R} 4 \mathrm{~W}$

Right bank Sun River, on south side of Simms grain elevator in sec $12, \mathrm{~T} 20 \mathrm{~N}, \mathrm{R} 3 \mathrm{~W}$ at 0200 hours.-.

Right bank Sun River, on power pole 8-56-R7 south of Great Northern Rallway about 15 miles cast of Simms in sec $8, T 20 \mathrm{~N}, \mathrm{R} 2 \mathrm{~W}$.

Left bank Sun River, $200 \mathrm{ft}$ north of cointy bridge 122 on road from Fort Shaw to Asheulot about 05 mile north of Fort Shaw, on gate post on west side of road in sec $2, \mathrm{~T} 20 \mathrm{~N}, \mathrm{R} 2 \mathrm{~W}$.

Right bank Sun River, approximately 05 mile southwest of Sun River on northwest corner of grain elevator in sec $34, \mathrm{~T} 21 \mathrm{~N}, \mathrm{R} 1 \mathrm{~W}$.

651

3,86814

581

3,75578

529

444

3,71644

3,56169

423

3,53418

381

3,47375

320

3,41656

Left bank Sun River, $600 \mathrm{ft}$ northeast of State Highway 20 bridge crossing at Sun River, on Montana Highway Commission sign in sec $34, \mathrm{~T} 21 \mathrm{~N}, \mathrm{R} 1 \mathrm{~W}$

Right bank Sun River, inside of Farmers Union oil station at Sun River in sec 34, T $21 \mathrm{~N}, \mathrm{R} 1 \mathrm{~W} . . . .$.
315

3,41085

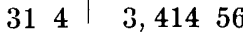


TABLE 12 -Flood-crest stagcs, Sun Ruer basin, floods of June 1964-Continued [Data mostly furnushed by U S Army Corps of Engineers]

\begin{tabular}{l|c|c}
\hline Stream, location, and time & $\begin{array}{c}\text { Miles above } \\
\text { mouth of } \\
\text { Sun Rivel }\end{array}$ & $\begin{array}{c}\text { Elevation } \\
\text { (feet) }\end{array}$ \\
\hline
\end{tabular}

June 9-Continued

Right bank Sun River, light pole at northwest corner of Union 76 service station at southwest end of State Highway 20 bridge over Sun River in sec 34, T 21 $\mathrm{N}, \mathrm{R} 1 \mathrm{~W}$.

Left bank Sun River, 49 miles southwest of Texaco service station at Vaughn, $50 \mathrm{ft}$ south of U S Highway 89, State Highway 20 in NE1/4 sec 29, T $21 \mathrm{~N}$, $\mathrm{R} 1 \mathrm{E}$

Left bank Sun River, 18 mile northeast of coin-operated laundry and 29 miles southwest of Vaughn on power pole in sec $28, \mathrm{~T} 21 \mathrm{~N}, \mathrm{R} 1 \mathrm{E}$

Left bank Sun River, $300 \mathrm{ft}$ east of Texaco service station at Vaughn in $\sec 34, \mathrm{~T} 21 \mathrm{~N}, \mathrm{R} 1 \mathrm{E}$

Left bank Sun River, $25 \mathrm{ft}$ east of road on corner of corral fence at Eidel Ranch in sec $23, \mathrm{~T} 21 \mathrm{~N}, \mathrm{R}$ $2 \mathrm{E}, 1800$ hours.

Left bank Sun River, in southwest corner of barn on Sam Lenz farm in sec 35, T $21 \mathrm{~N}, \mathrm{R} 2 \mathrm{E}$

Right bank Sun River, above main door of barn on Ochsner farm in sec $2, \mathrm{~T} 20 \mathrm{~N}, \mathrm{R} 2 \mathrm{E}$

Left bank Sun River, on corral post just east of livestock shed at Waldenberg residence, about 025 mile south of KFBB television station at Great Falls in sec 5, $\mathrm{T} 20 \mathrm{~N}, \mathrm{R} 3 \mathrm{E}$

Left bank Sun River, northeast corner of small building at Great Falls Trap and Skeet Club.

Left bank Sun River, $200 \mathrm{ft}$ east of Central Ave brıdgc west of Great Falls, on upstream side of road.

Left bank Sun River, corner of Central Ave West and $34 \mathrm{th}$ St, NW, Great Falls, on north side of large building

Lef t bank Sun River, $150 \mathrm{ft}$ cast of residence at 2719 Central Ave West, Great Falls.

Left bank Sun River, top of window frame at $12125 \mathrm{th}$ St , SW , Great Falls

Left bank Sun River, $11 / 2$ blocks west of $24 \mathrm{th}$ St , SW ${ }^{-}$ and Sunset Rd intersection, Great Falls

Left bank Sun River, $1 / 2$ block west of $24 \mathrm{th}$ St , $\mathrm{S} \bar{W}^{-}$, and Sunset Rd intersection, Great Falls

Left bank Sun River, power pole at 2217 Sunset Rd, Great Falls

Left bank Sun River, power pole at 2129 Sunset Rd, Great Falls

Left bank Sun River, power pole at 2105 Sunset Rd, Great Falls .

Left bank Sun River, power pole at 2013 Sunset Rd, Great Falls

Left bank Sun River, power pole at 2010 Sunset Rd, Great Falls

22

3,37374

204

3,35518

181

3,34919

108

3, 33879

92

$3,335 \quad 35$

91

3,33413

52

3, 33071

50

3,33064

48

3,32924

42

3, 32909

32

3, 32873

31

3,32783

28

3,32812

26

3,32810

22

3, 32782

22

3,32780

22

3,32741

21

3,32796

\begin{tabular}{ll|ll}
2 & 1 & 3,327 & 61
\end{tabular} 
TABLE 12 -Flood-crest slages, Sun River basin, floods of June 1964-Continued [Data mostly furnıshed by U S Army Corps of Engineers]

\begin{tabular}{c|c|c}
\hline Stream, location, and time & $\begin{array}{c}\text { Miles above } \\
\text { mouth of } \\
\text { Sun River }\end{array}$ & $\begin{array}{c}\text { Elevation } \\
\text { (feet) }\end{array}$ \\
\hline
\end{tabular}

June 9-10

Left bank Sun River, greenhouse at corner of 5 th Ave and 14th St, SW, Great Falls

Left bank Sun River, north side of residence at 721 14th St, SW, Great Falls

Left bank Sun River, power pole at 82514 th St, $\mathrm{s} \bar{W}^{-}$, Great Falls

Left bank Sun River, residence at $917 \overline{14 t h} \overline{\mathrm{St}}, \overline{\mathrm{SW}} \overline{\mathrm{W}}$, Great Falls

\begin{tabular}{ll|ll}
1 & 8 & 3,327 & 27 \\
1 & 7 & 3,326 & 71 \\
1 & 6 & 3,326 & 85 \\
1 & 6 & 3,325 & 80
\end{tabular}

\section{June 10}

Left bank Sun River, in garage at 1337 10th Ave, SW ,

Great Falls
Left bank Sun River, telephone pole at 1118 10th Ave, SW, Great Falls, at 0100 hours . . . . . . . . Left bank Sun River, power pole at 101910 th Ave, SW, Great Falls

Right bank Sun River, $200 \mathrm{ft}$ east of Great Northern Rallway and $200 \mathrm{ft}$ south of river in Great Falls...... Left bank Sun River, storage shed at 1010 10th Ave, SW, Great Falls.

Left bank Sun River, large cottonwood tree at entrance to $9281 / 2$ 10th Ave, SW, Great Falls

Left bank, Sun River, large cottonwood tree south of 208 10th Ave, SW, Great Falls.

TaBLE 13 -Flood-crest stages, Teton River, floods of June 1964

[Data mostly furnıshed by U S Army Corps of Engineers]

\begin{tabular}{c|c|c} 
Location and tıme & $\begin{array}{c}\text { Miles above } \\
\text { mouth }\end{array}$ & $\begin{array}{c}\text { Elevation } \\
\text { (feet) }\end{array}$ \\
\hline
\end{tabular}

June 8

Right bank, post of fuel-tank stand on Crawford Ranch in sec $33, T 25 \mathrm{~N}, \mathrm{R} 6 \mathrm{~W}$

Left bank, $20 \mathrm{ft}$ southwest of camp fireplace about 48 miles north of Choteau on U S Highway 89 in sec 4 , T $24 \mathrm{~N}, \mathrm{R} 5 \mathrm{~W}$

Left bank, foundation of Gus Depner residence about 29 miles north of Choteau in SW1/4 sec $11, \mathrm{~T} 24 \mathrm{~N}$, $\mathrm{R} 5 \mathrm{~W}$

Left bank, telephone pole on west side of U S Highway 89,15 miles north of Choteau in sec $14, \mathrm{~T} 24 \mathrm{~N}$, R $5 \mathrm{~W}$

1694

4,22961

1628

3,97295

1604

3,91096

159 
T IBLE 13 -Flood-crest stages, Teton Rver, floods of June 1964-Contmued [Data mostly furnished by U S Army Corps of Engineers]

\begin{tabular}{l|l|l}
\hline Location and time & $\begin{array}{c}\text { Miles above } \\
\text { mouth }\end{array}$ & $\begin{array}{c}\text { Elevation } \\
\text { (feet) }\end{array}$ \\
\hline
\end{tabular}

\section{June 9-Contınued}

Left bank, $1 / 2$ block west of corneı of $3 \mathrm{~d}$ Ave $\mathrm{NW}$, and Weaver St in Choteau in sec 24, T $24 \mathrm{~N}, \mathrm{R} 5 \mathrm{~W}$

Left bank, northwest corner of barn at intersection of 7 th Ave NW and Main St in Choteau in sec 24, $\mathrm{T} 24 \mathrm{~N}, \mathrm{R} 5 \mathrm{~W}$.

Left bank, foundation of residence approximately $1 / 4$ milc west of Choteau school in sce $25, \mathrm{~T} 24 \mathrm{~N}, \mathrm{R} 5 \mathrm{~W}$

Left bank, northwest corner of Teton County shop bullding in Choteau in sec 25, T $24 \mathrm{~N}, \mathrm{R} 5 \mathrm{~W}$

Left bank, northwest corner of housc foundation on southeast corner of $2 \mathrm{~d} \mathrm{St} \mathrm{SW,} \mathrm{and} 9$ th Ave $\mathrm{SW}$, in

Choteau
Left bank, large cottonwood tree at $\mathrm{T}$ H Hammond home about 10 mile south of Choteau in sec 30 , $\mathrm{T} 24 \mathrm{~N}, \mathrm{R} 4 \mathrm{~W}$

Right bank, door of Quonset building at Ferris farmstead in scc 24, T $24 \mathrm{~N}, \mathrm{R} 4 \mathrm{~W}$, at 2000 hours....-

Right bank, $200 \mathrm{ft}$ north of dwelling on power pole in sec $22, \mathrm{~T} 25 \mathrm{~N}, \mathrm{R} 2 \mathrm{~W}$

1587

1587

1576

1573

1572

1562

1473

1237
3,83294

3,83285

3,81948

3,81224

3,81189

3,79522

3,67581

3,44525

\section{June 8-9}

Right bank, west side of road crossing in $\mathrm{SE} 1 / 4$ sec 12 , $\mathrm{T} 25 \mathrm{~N}, \mathrm{R} 1 \mathrm{~W}$

\section{June 9}

Right bank, south foundation of Bill Maurer home $\mathrm{m}$ sec $22, \mathrm{~T} 25 \mathrm{~N}, \mathrm{R} 3 \mathrm{E}$, at 1200 hours ......... Left bank, $400 \mathrm{ft}$ northeast of Dent Bridge in sec 35 , $\mathrm{T} 25 \mathrm{~N}, \mathrm{R} 4 \mathrm{E}$

Right bank, steel pier of bridge about 5 miles north of Carter in NE $1 / 4$ sec $9, T 24 \mathrm{~N}$, R. 6 E, at 1800 hours..

June 9-10

Right bank, 02 mile west of red grain elevatol on brace pole in center of sec $13, \mathrm{~T} 24 \mathrm{~N}, \mathrm{R} 7 \mathrm{E}$.

Left bank, guard rall on northwest corner of $\mathrm{F}$ A S 223 road bridge in $\mathrm{S} 1 \frac{1}{2} \sec 9$, $\mathrm{T} 24 \mathrm{~N}, \mathrm{R} 8 \mathrm{E} \ldots \ldots$

\section{June 10}

Right bank, $200 \mathrm{ft}$ south of bridge on west side of road near center of sec $1, T 24 \mathrm{~N}, \mathrm{R} 8 \mathrm{E}$

Right bank, power pole leading to farmstead in N W1/4 sec $5, \mathrm{~T} 24 \mathrm{~N}, \mathrm{R} 9 \mathrm{E}$. 
T ।вLe 14 -Flood-crest slages, Flathead Rver, floods of June 1964

[Based on data furnished by U S Army Corps of Engineers]

Location and tıme $\quad \begin{gathered}\text { Miles above } \\ \text { Flathead Lake }\end{gathered} \mid \begin{gathered}\text { Elevation } \\ \text { (feet) }\end{gathered}$

June 9

Right bank, stieamward face of rock outcrop $9 \mathrm{ft}$ upstream from axis of proposed Glaciel I lew Dam, 16 miles downstream from Camas Creek, and $12 \frac{1}{2}$ miles northwest of West Glacier

Right bank, streamward side of $24-1 n$ fil tree, $15 \mathrm{ft}$ above ground, 09 mile upstream fiom Big Creek, in SE $1 / 4 \mathrm{SE}^{1 / 4}$ sec $15, \mathrm{~T} 33 \mathrm{~N}, \mathrm{R} 20 \mathrm{~W}$, and $11 \frac{1}{2}$ miles northwest of West Glacier

Right bank, Flathead River and left bank Big Creek, on streamwal face, downstream edge concrete bridge pier, $13 \mathrm{ft}$ above ground, bridge at mouth of Big Creek, in SW1/4 SW $1 / 4$ sec 22 , T $33 \mathrm{~N}, \mathrm{R} 20 \mathrm{~W}$, and 11 miles northwest of West Glacier ...

Right bank, 1/1/2-in iron pipe, 02 foot above ground, $30 \mathrm{ft}$ upstream from intersection of new and old North Fork roads, 03 mile downstieam from Deep Creek, in SE $1 / 4$ sec $34, \mathrm{~T} 33 \mathrm{~N}, \mathrm{R} 20 \mathrm{~W}$, and $9 \frac{1}{2}$ miles northwest of West Glacier.

Right bank, shoreward side of twin 8-in cottonwood tree, $15 \mathrm{ft}$ downstream from load culvert, 43 miles downstream from Big Creek, in W1/2W $1 / 2$ sec 2 , T 32 $\mathrm{N}, \mathrm{R} 20 \mathrm{~W}$, and 8 miles northwest of West Glacier.

Right bank, chiseled "X" on steep rock face, streamward from 24 in corrugated metal pipe on North Fork road, 38 miles upstream from Canyon Creek, in SE $1 / 4 \mathrm{SW} 1 / 4$ scc $11, \mathrm{~T} 32 \mathrm{~N}, \mathrm{R} 20 \mathrm{~W}$, and $7 \frac{1}{2}$ miles northwest of West Glacier.

Right bank, shoreward side $15-1 \mathrm{n}$ fir tree, $3 \mathrm{ft}$ above ground, in vicinity of Foolhen Hill, in N1/2 sec 14, T $32 \mathrm{~N}, \mathrm{R} 20 \mathrm{~W}$, and 7 miles northwest of West Glacier

Right bank, shoreward side of 12-1n twin top fir tree, upstream from rapids, 16 miles upstream from Canyon Creek, in $\mathrm{SE}^{1 / 4} \mathrm{NW}^{1 / 4}$ sec $23, \mathrm{~T} 32 \mathrm{~N}, \mathrm{R} 20 \mathrm{~W}$, and 7 miles west of West Glacier.

Right bank, root on downstream side of 14-in fir tree, 01 mile upstream from Canyon Creek, in SW1/4 NE $1 / 4$ sec $27, \mathrm{~T} 32 \mathrm{~N}, \mathrm{R} 20 \mathrm{~W}$, and 7 miles west of West Glacier

Gaging station on right bank, $1 \frac{1}{2}$ miles downstream from Canyon Creek, near center of $\mathrm{W}^{1 / 2}$ sec $35, \mathrm{~T} 32, \mathrm{~N}$, $\mathrm{R} 20 \mathrm{~W}$, and 9 miles northeast of Columbia Falls, at $0900 \mathrm{hr}$

Right bank, shoreward side of $18-\mathrm{in}$ pine tree, $55 \mathrm{ft}$ above ground, at point opposite high rock cliffs on the left bank, 17 miles downstream from Canyon Creek, in $\mathrm{NE}^{1 / 4} \mathrm{SW}^{1 / 4} / 4$ sec $35, \mathrm{~T} 32 \mathrm{~N}, \mathrm{R} 20 \mathrm{~W}$, and $61 / 2$

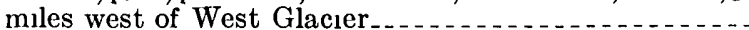

Right bank, at former gaging station site, upstream shoreward corner of wooden gage house, 30 in above ground, 11 miles upstream from Middle Fork, in $\mathrm{NE}^{1 / 4} \mathrm{NE} 1 / 4$ sec $12, \mathrm{~T} 31 \mathrm{~N}, \mathrm{R} 20 \mathrm{~W}$, and 8 miles northeast of Columbia Falls

Left bank, shoreward side $18-1 \mathrm{n}$ cottonwood tree, $45 \mathrm{ft}$ above ground, at first curve in road from Blankenship bridge, 01 mile downstream from Middle Fork in E1/2 sec $7, T 31 \mathrm{~N}, \mathrm{R} 19 \mathrm{~W}$, and $3 \frac{1}{2}$ miles north of Corum 
T' ıLe 14-Flood-crest slages, Flathead Rvver, floods of June 1964-Contınued

[Based on data furnished by U S Army Corps of Engineers]

\begin{tabular}{r|c|c} 
Location and time & $\begin{array}{c}\text { Miles above } \\
\text { Flathead Lake }\end{array}$ & $\begin{array}{c}\text { Elevation } \\
\text { (feet) }\end{array}$ \\
\hline
\end{tabular}

June 9

Lef $\mathrm{t}$ bank, downstream side of 30-in stump, 30 in above ground, at end of trall from bullings to river, 22 miles downstream from Middle Fork, in SE1/4 sec 17 T $31 \mathrm{~N}, \mathrm{R} 19 \mathrm{~W}$, and 2 miles north of Corum....

Left bank, upstream shoreward corner of log cabin, 30 III above ground, at end of access road from U S Highway 2 , in $\mathrm{NE}^{1 / 4}$ sec $19, \mathrm{~T} 31 \mathrm{~N}, \mathrm{R} 19 \mathrm{~W}$, and $1 \frac{1}{2}$ miles northwest of Corum

Left bank, $8 \mathrm{ft}$ above ground on streamward side of steel leg of middle pier, second pier from left bank of Great Northern Rallway bridge, in $\mathrm{NE}^{1 / 4}$ sec $32, \mathrm{~T} 31 \mathrm{~N}$, R $19 \mathrm{~W}$, and $1 / 2$ mile southwest of Corum

Left bank, center aluminum tag, south corner timber of wooden structure east of pump house, 05 mile downstream from Abbott Creek, near center $\mathrm{S} 1 / 2$ sec $5, \mathrm{~T}$ $30 \mathrm{~N}, \mathrm{R} 19 \mathrm{~W}$, and at Martin City

Left bank, shoreward side, 8-in fir tree, $20 \mathrm{ft}$ streamward from edge US Highway 2, 06 mile downstream from South Fork, in S $1 / 2$ sec 1, T $30 \mathrm{~N}, \mathrm{R} 20 \mathrm{~W}$, and 3 miles west of Martin City

Left bank, downstream side of $20-\mathrm{m}$ larch tree, $3 \mathrm{ft}$ above ground, 13 miles downstream from South Fork, in NE $1 / 4 \mathrm{NE}_{1 / 4}$ sec $11, \mathrm{~T} 30 \mathrm{~N}, \mathrm{R} 20 \mathrm{~W}$, and 3 miles east of Columbia Falls

Right bank, downstream side of 15 -in cottonwood tree, $3 \mathrm{ft}$ above ground, 36 miles downstream from South Fork neal line between secs 4 and $9, \mathrm{~T} 30 \mathrm{~N}, \mathrm{R} 20$ $\mathrm{W}$, and 1 mile northeast of Columbia Falls .......

Left bank, northwest wingwall of wooden box culvert under State Highway 40, 1/4 mile from intersection with US Highway 2, neal center of west edge sec $15, \mathrm{~T}$ $30 \mathrm{~N}, \mathrm{R} 20 \mathrm{~W}$, and $1 \frac{1}{2}$ miles southeast of Columbia Falls

Right bank, concrete bridge abutment, $02 \mathrm{ft}$ below concrete joint, $10 \mathrm{ft}$ upstream from downstream edge northwest corner, at new steel bridge on State Highway 40, in NW $1 / 4$ sec $16, \mathrm{~T} 30 \mathrm{~N}, \mathrm{R} 20 \mathrm{~W}$, and 1 mile southeast of Columbia Falls

Gaging station on right bank, $200 \mathrm{ft}$ downstream from county bridge, 58 miles downstream from South Fork in $\mathrm{NW}^{1 / 4} \mathrm{SE}^{1 / 4}$ sec $17, \mathrm{~T} 30 \mathrm{~N}, \mathrm{R} 20 \mathrm{~W}$, and $1 / 2$ mile south of Columbia Falls, at $0500 \mathrm{hrs}$

Right bank, east side of 36-in cottonwood tree, $55 \mathrm{ft}$ above ground, about 03 mile south of Great Northern Rallway underpass, in SE $1 / 4$ sec $24, \mathrm{~T} 30 \mathrm{~N}, \mathrm{R} 21$ $\mathrm{W}$, and $2 \frac{1}{2}$ miles southwest of Columbia Falls .....

Left bank, center 8-in $45^{\circ}$ elbow between hose and valve, $1 \mathrm{ft}$ below valve center, on irrigation pump intake line, pump near residence on left bank, in NE $1 / 4$ sec 31 , $\mathrm{T} 30 \mathrm{~N}, \mathrm{R} 20 \mathrm{~W}$, and 4 miles southwest of Columbia Falls . . . . . .

Left bank, shoreward side multiple birch tree, $1 \mathrm{ft}$ above ground, $10 \mathrm{ft}$ downstream from fence line, in $E^{1 / 2}$ sec 6 , T $29 \mathrm{~N}, \mathrm{R} 20 \mathrm{~W}$, and 5 miles southwest of Columbia Falls. 
T IBLE 14-Flood-ciest stages, Flathead River, floods of June 1964-Contmued [Based on data furnıshed by U S Army Corps of Engineers]

Location and time $\quad \begin{gathered}\text { Miles above } \\ \text { Flathead Lake }\end{gathered} \mid \begin{gathered}\text { Elevation } \\ \text { (feet) }\end{gathered}$

June 9

Right bank, shoreward side of 20 -in pine tree, $30 \mathrm{~m}$ above ground, $50 \mathrm{ft}$ streamward from fence on top left bank of old highwater channel, 4 miles upstream from McWenneger Slough drain, on line SE $1 / 4$ sec 14 and $\mathrm{NE}^{1 / 4}$ sec $23, \mathrm{~T} 29 \mathrm{~N}, \mathrm{R} 21 \mathrm{~W}$, and 7 miles northeast of Kalispell

Right bank, power pole, $4 \mathrm{ft}$ above ground, $50 \mathrm{ft}$ southeast of bridge over slough, 14 miles upstream from McWenneger Slough drain, in NW1/4 sec 35, T $29 \mathrm{~N}$, $\mathrm{R} 21 \mathrm{~W}$, and 5,2 miles northeast of Kalispell

Right bank, flood plain, cast face of power polc, northeast corner intersection LaSalle $\mathrm{Rd}$ and Spring Creek $\mathrm{Dr}$, near center sec $33, \mathrm{~T} 29 \mathrm{~N}, \mathrm{R} 21 \mathrm{~W}$, and $3 \frac{1}{2}$ miles northeast of Kalispel

Right bank, flood plain, on concretc curb, cast cdge of road across from Evergreen School, $200 \mathrm{ft}$ south of intersection, near ccnter of north edge sec $4, \mathrm{~T} 28 \mathrm{~N}$, $\mathrm{R} 21 \mathrm{~W}$, and 3 miles northeast of Kalispell
ight bank, on left upstream abutment of bridge over second slough 02 miles west of Flathead River bridge on U S Highway 2 , in NE $1 / 4 \sec 3, \mathrm{~T} 28 \mathrm{~N}, \mathrm{R} 21 \mathrm{~W}$, and $4 \frac{1}{2}$ miles northeast of Kalispell

Right bank, $083 \mathrm{ft}$ above point of survey stake on power pole on downstream side of U S Highway 2 between first and second sloughs, west of Flathead River bridge in $\mathrm{NE}^{1 / 4} \mathrm{sec} 3, \mathrm{~T} 28 \mathrm{~N}, \mathrm{R} 21 \mathrm{~W}$, and $4 \frac{1}{1} 2$ miles northcast of Kalispell

Right bank, upstream corner of bridge abutment, U S Highway 2 , in NW $1 / 4$ sec 2 , T $28 \mathrm{~N}, \mathrm{R} 21 \mathrm{~W}$, and $41 / 2$ miles northeast of Kalispell.................

Right bank, downstream side of steel case bridge pier, steel bridge on old U S Highway 2 , in NE $1 / 4 \mathrm{NW}^{1} / 4$ sec $10, \mathrm{~T} 28 \mathrm{~N}, \mathrm{R} 21 \mathrm{~W}$, and 3 miles northcast of Kalispell

Left bank, streamward side, downstream pole of "H" frame of cableway, in $\mathrm{NE}^{\mathrm{I}} / 4 \mathrm{sec} 15, \mathrm{~T} 28 \mathrm{~N}, \mathrm{R} 21 \mathrm{~W}$, and $2 \frac{1}{2}$ miles cast of Kalispell

Left bank, streamward side of 36-in cottonwood tree, $29 \mathrm{ft}$ above ground, $01 \mathrm{ft}$ below ralload spike, along road from dam across Bradley Channel, in NW1/4 sec $15, \mathrm{~T} 28 \mathrm{~N}, \mathrm{R} 21 \mathrm{E}$, and 2 miles cast of Kalispell

Right bank, base of streamward side of power pole, 30 ft upstream and opposite driveway to farm house, 08 mile downstream from Stillwater River, in vicinity of formel gage at Demersville, in NE $1 / 4 \mathrm{sec} 28, \mathrm{~T} 28 \mathrm{~N}$, R $21 \mathrm{~W}$, and $2 \frac{1}{2}$ miles southeast of Kalispell .......

ight bank, streamward side of power pole, $48 \mathrm{ft}$ above ground, $20 \mathrm{ft}$ south of gravel road centel linc, 20 miles upstream from Ashley Creek, in vicinity of former gage at Jetty, in SW $1 / 4 \sec 34, T 28 \mathrm{~N}, \mathrm{R} 21$ $\mathrm{W}$, and $3 \frac{1}{2}$ miles southeast of Kalispell 
TIBLE 14-Flood-crest stages, Flathead River, floods of June 1964-Contmued

[Based on data furnished by U S Army Corps of Engıneers]

\begin{tabular}{l|l|c}
\hline Location and time & $\begin{array}{c}\text { Miles above } \\
\text { Flathead Lake }\end{array}$ & $\begin{array}{c}\text { Elevation } \\
\text { (feet) }\end{array}$ \\
\hline
\end{tabular}

June 9-10

Right bank, at for mer gaging station at Damon's Ranch, glound level at 19 th fence post upstream from northeast corner of cultivated field just west of farmstead, 31 miles downstream from Ashley Cieek, in NW1/4 sec $32, \mathrm{~T} 28 \mathrm{~N}, \mathrm{R} 20 \mathrm{~W}$, and $6 \frac{1}{2}$ miles southeast of Kalispell.

Right bank, at for mel gaging station at Therriault Ferry, 14 in above ground level shoreward side of largest twin cottonwood tree, $25 \mathrm{ft}$ upstream from old ferry landing in W1/2 sec $4, \mathrm{~T} 27 \mathrm{~N}, \mathrm{R} 20 \mathrm{~W}$, and $81 / 2$ miles southeast of Kalispell

Left bank, at former gaging station at Keller's Ranch neal IIolt, upstream side of power pole, $200 \mathrm{ft}$ north of road, $500 \mathrm{ft}$ east of concrete bridge, in NW1/4 sec 23, $\mathrm{T} 27 \mathrm{~N}, \mathrm{R} 20 \mathrm{~W}$, and $21 / 2$ miles northwest of Bigfork.

Left bank, shoreward side upstream pole support of over head beam, $18 \mathrm{ft}$ above ground, on wood bridge at Holt, in SW $1 / 4$ sec $23, \mathrm{~T} 27 \mathrm{~N}, \mathrm{R} 20 \mathrm{~W}$, and 2 miles northwest of Bigfork.

137

$2,899.53$

\begin{tabular}{|c|c|}
\hline $7 j$ & $2,897 \quad 36$ \\
\hline 38 & $2,894 \quad 14$ \\
\hline 30 & $2,894 \quad 24$ \\
\hline
\end{tabular}

T IBLE 15-Flood-ciest stages, Middle Fork Flathead Rive) basin, floods of June 1964 [Based on data furmshed by U S Army Corps of Engıneers]

\begin{tabular}{c|c|c}
\hline Stream, location, and time & $\begin{array}{c}\text { Mules above } \\
\text { mouth }\end{array}$ & $\begin{array}{c}\text { Elevation } \\
\text { (feet) }\end{array}$ \\
\hline
\end{tabular}

June 8

Middle Fork Flathead River

Right bank, 4-in fil trec, $1 \frac{1}{\mathrm{ft}} \mathrm{ft}$ above ground, at mouth of Bear Creck, in W $1 / 2$ sec $31, T 29 \mathrm{~N}, \mathrm{R}$ $15 \mathrm{~W}$, and 4 miles southeast of Essex .......

Gaging station on right bank 4 miles downstream from Beal Creek, in NE1/4 SW1/4 sec 14, T $29 \mathrm{~N}$, R $16 \mathrm{~W}$, and 07 mile southeast of Essex, at $1830 \mathrm{ht}$

Left bank, root on sticamward side of 10 -in fil tiec at toe of slope $30 \mathrm{ft}$ north of dirt access road to US Highway 2, 01 mile downstream from Park Creek, in sec $2, \mathrm{~T} 29 \mathrm{~N}, \mathrm{R} 16 \mathrm{~W}$, and $2 \frac{1}{2}$ miles north of Essex.

Left bank, shoreward side of 6-in larch tiec on edge of foot trall, 08 mile downstream from Paola Creek, in sec 21, T $30 \mathrm{~N}, \mathrm{R} 16 \mathrm{~W}$, and i mles northwest of Essex.

Left bank, 8-in rotten stump, $3 \mathrm{ft}$ high, on top of bank, 02 mile downstream from Tunnel Creek, in sec $7, T 30 \mathrm{~N}, \mathrm{R} 16 \mathrm{~W}$, and $7 \frac{1}{2}$ miles northwest of Essex

445

3,88236

399

3,7488

362

j, 67718

32 1;

$3, .598 \quad 35$

279 
T 1вLE 1ว -Flood-crest slages, Middle Fork Flathead Rvver basin, floods of June 1964 -Continued

[Based on data furnıshed by U S Army Corps of Engineers]

\begin{tabular}{|c|c|c|}
\hline Stream, location, and time & $\begin{array}{l}\text { Miles above } \\
\text { mouth }\end{array}$ & $\begin{array}{c}\text { Elevation } \\
\text { (feet) }\end{array}$ \\
\hline \multicolumn{3}{|l|}{ June } \\
\hline 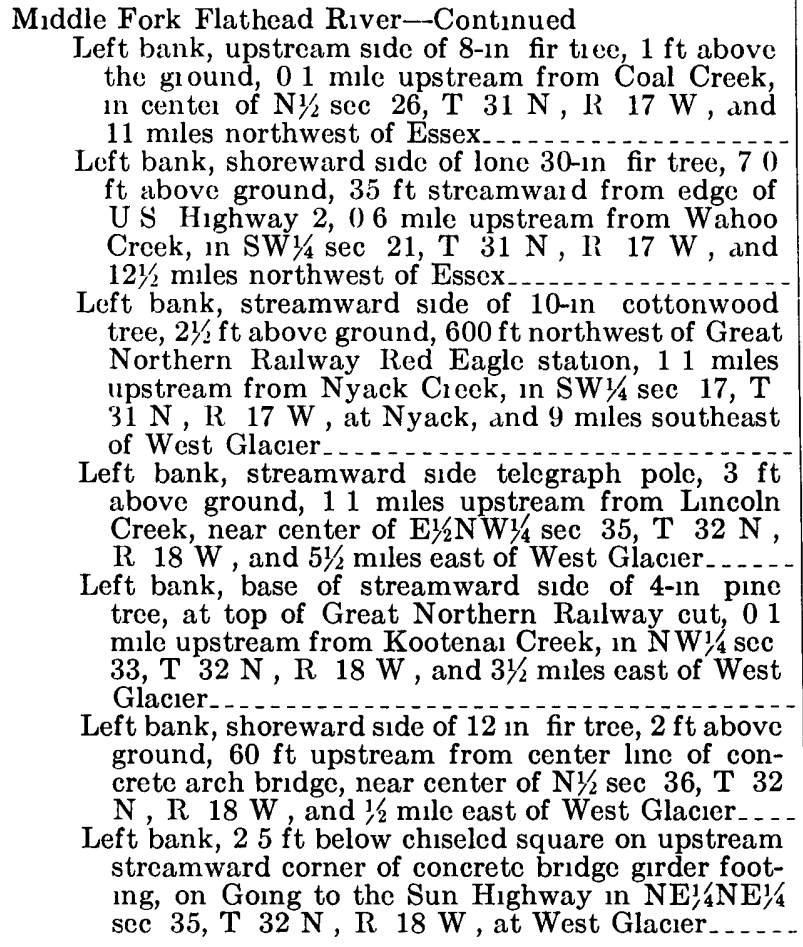 & 127 & 3,286 \\
\hline
\end{tabular}

June 9

Right bank, upstream side of 9-1n pıne tree, $04 \mathrm{ft}$ above ground, 01 mile downstream from Mc-

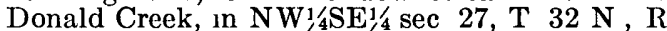
$19 \mathrm{~W}$, and 1 mile west of West Glacier, at $0300 \mathrm{hr}$ -

Left bank, shoreward side of 6-in pine tree, $2 \mathrm{ft}$ above ground, in NW 14 sec $8, T 31 \mathrm{~N}, \mathrm{R} 19 \mathrm{~W}$, and $4 \frac{1}{2}$ miles southwest of West Glacier. . . . . .

McDonald Creek

Left bank, streamward side of 28-in cottonwood tree, between cabins 6 and 7 of Village Motor Inn at outlet of Lake McDonald, in NW $1 / 4 \mathrm{NW}^{1 / 4} \mathrm{sec}$ $23, \mathrm{~T} 32 \mathrm{~N}, \mathrm{R} 18 \mathrm{~W}$, and 2 miles north of West Glacier 
TABLE 16-Flood-crest stages, Stillwater Rwer Basin, floods of June 1964

[Based mostly on data furnished by U S Army Corps of Engıneers]

\begin{tabular}{|c|c|c|}
\hline Streams and location & $\begin{array}{l}\text { Miles above } \\
\text { mouth }\end{array}$ & $\begin{array}{c}\text { Elevation } \\
\text { (feet) }\end{array}$ \\
\hline 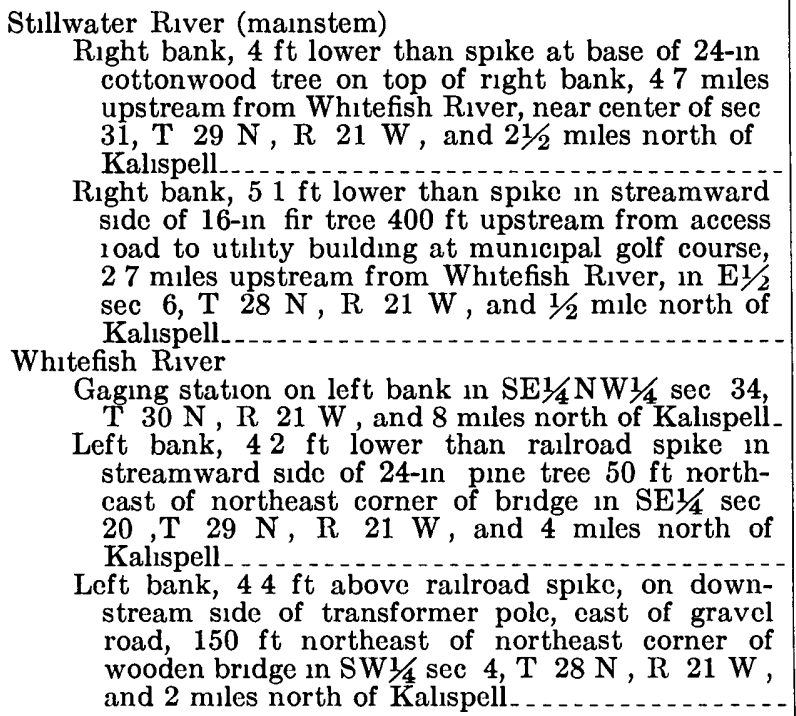 & 126 & 2,97320 \\
\hline
\end{tabular}

The records of flood stages may be a usetul guide to the limitations on the occupancy of lands along these rivers They also furnish basic data on the velocity of flood crests and on valley or chamnel storage The profile sites are described in enough detall so that they can be relocated for comparison with crests of other floods Other information at each site in the tables includes the date (and the hou, when known) that the crest occurred; the distance above the mouth, m river miles; and the elevation, in feet above sea level

The lower reach of the Flathead River between the discontinued gaging station nea Kalispell (mıle 26.3) and Flathead Lake has been subjected to high flood-crest elevations in 1928, 1933, 1948, and 1964 Table 18 is a summary of these elevations at discontinued gaging station sites converted to sea level datum of 1929, supplemental adjustment of 1947 Elevations of Flathead Lake referred to elsewhere in this report are to Somers datum 
TABLE 17 -Flood-crest stages, Swan Rver, floods of June 1964

[Based mostly on data furnıshed by U S Army Corps of Engıneers]

\begin{tabular}{l|l|l}
\hline Location and time & $\begin{array}{c}\text { Miles above } \\
\text { mouth }\end{array}$ & $\begin{array}{c}\text { Elevation } \\
\text { (feet) }\end{array}$ \\
\hline
\end{tabular}

June 9-10

Right bank, on center pilıng of 3 pilıng, on upstream side of bridge abutment, 1 mile upstream from Porcupine Creek, in SW $1 / 4$ sec $35, \mathrm{~T} 25 \mathrm{~N}, \mathrm{R} 18 \mathrm{~W}$, and $31 / 2$ miles south of Swan Lake

Right bank, shoreward side of 56 -in cottonwood tree, $1 \frac{1}{2} \mathrm{ft}$ above ground, $165 \mathrm{ft}$ north of boat launching area at Swan Lake Camp Ground, near north cdge sec 14 , T $26 \mathrm{~N}, \mathrm{R} 19 \mathrm{~W}$, and $1 / 2$ mile northwest of Swan Lake.

\section{June 10}

Gaging station on left bank, at outlet of Swan Lake, 1000 $\mathrm{ft}$ downstream from Johnson Creek, in $\mathrm{SE}_{1 / 4}^{1 / 2 \mathrm{SW}^{1} / 4} \mathrm{sec}$ $11, \mathrm{~T} 26 \mathrm{~N}, \mathrm{R} 19 \mathrm{~W}$, and 5 miles southeast of Bigfork, at 1200 hou rs . . . . . . . . . . . . . . . . .

Right bank, downstream end of concrete abutment, $425 \mathrm{ft}$ below alu minum tag, bridge 1 mile upstream from Bigfork Dam, in SE $1 / 4$ sec $32, T 27 \mathrm{~N}, \mathrm{R} 19 \mathrm{~W}$, and 2 miles east of Bigfork

Left bank, shoreward side of 6-in birch tree, $10 \mathrm{ft}$ above ground, on stream ward side of drive in Big Fork State Park, in NE $1 / 4$ sec $36, \mathrm{~T} 27 \mathrm{~N}, \mathrm{R} 20 \mathrm{~W}, 1 / 2$ mile south-

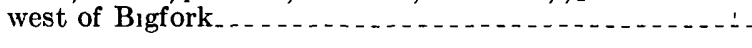

TABLE 18 -Flood-crest elevatıons, in feet, on the Flathead Rver between Kalıspell and Flathead Lake

[Elevations referenced to datum of 1929, supplemental adjustment of 1947]

\begin{tabular}{|c|c|c|c|c|c|}
\hline \multirow{2}{*}{ Name of gaging station } & \multirow{2}{*}{$\begin{array}{l}\text { Mules } \\
\text { above } \\
\text { mouth }\end{array}$} & \multicolumn{4}{|c|}{ Year of flood } \\
\hline & & 1928 & 1933 & 1948 & 1964 \\
\hline $\begin{array}{l}\text { Flathead River } \\
\text { Near Kalispell. } \\
\text { At Demersville. } \\
\text { At Damon Ranch.- } \\
\text { At Therriault Ferry } \\
\text { At Keller Ranch.- } \\
\text { Flathead Lake at Somers }\end{array}$ & $\begin{array}{rl}26 & 3 \\
21 & 7 \\
13 & 7 \\
7 & 5 \\
3 & 8 \\
0 & \end{array}$ & $\begin{array}{ll}2,912 & 96 \\
2,903 & 3 \\
2,898 & 5 \\
& \\
2,896 & 4 \\
2,894 & 92\end{array}$ & $\begin{array}{ll}2,912 & 28 \\
2,903 & 82 \\
2,899 & 85 \\
2,897 & 37 \\
2,896 & 0 \\
2,895 & 26\end{array}$ & \begin{tabular}{ll}
2,913 & 0 \\
2,903 & 1 \\
\hdashline 2,896 & 7 \\
2,895 & 8 \\
2,895 & 01
\end{tabular} & 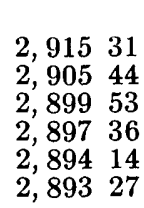 \\
\hline
\end{tabular}

${ }^{1}$ At site 30 miles above mouth 
Profiles of flood-crest stages in the Missour River basin along the Sun and Teton Rivers are shown in figures 39 and 40 The profile of the Sun River extends from State Highway 287, north of Augusta, downstream to the mouth. The Teton River profile extends from a point about 11 miles upstream from Choteau to the mouth.

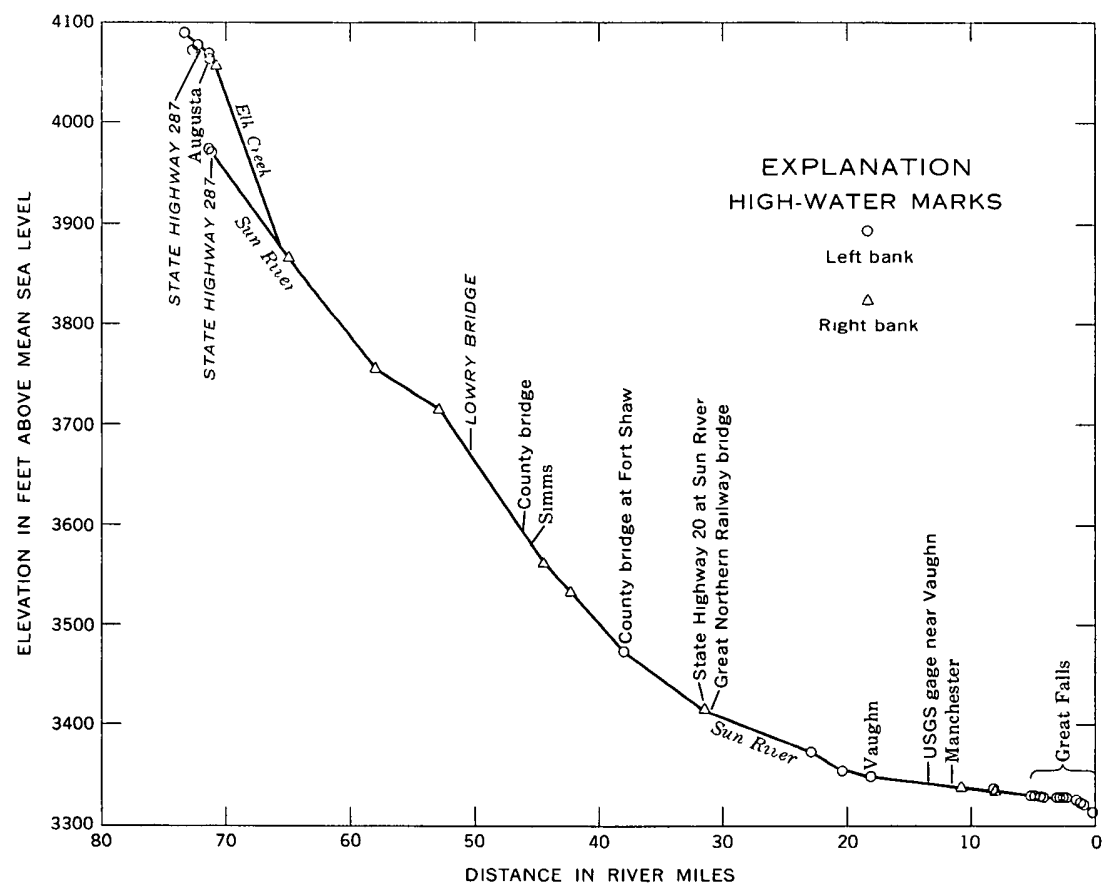

Figure 39-Profile of flood-crest elevations on the Sun River and Elk Creek upstream from the mouth of the Sun River 


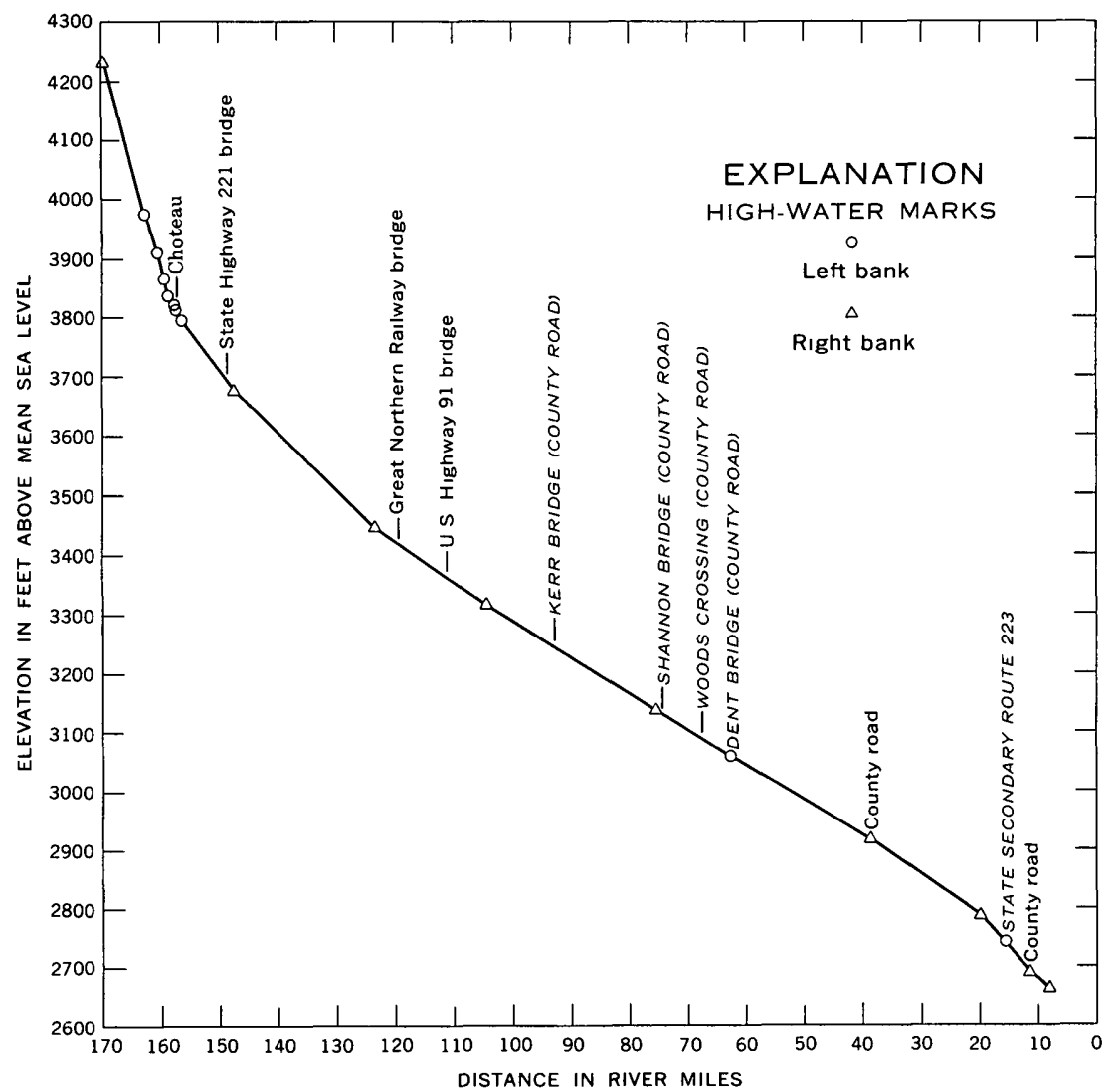

Figure 40 -Piofile of flood-crest elerations on the Teton Rivel upstieam from the month

Flood-crest profiles in the upper Columbia River basin are shown in figures 41 to 44 for the Flathead Rivel upstream from Flathead Lake, the Middle Fork Flathead Rırer, the Stillwateı River and one of its major tributaries, and the Swan River Figure 45 is an enlargement cf a part of the profile in figure 41, showing the reach of the Flathead River from Columbia Falls to within 3 miles of its mouth at Flathead Lake Also shown are the flood-stage elevations for 1948 and 1933.

The profiles shown were based primanly on data furnished by the Corps of Engmeers 
NORTHWESTERN MONTANA, JUNE 1964

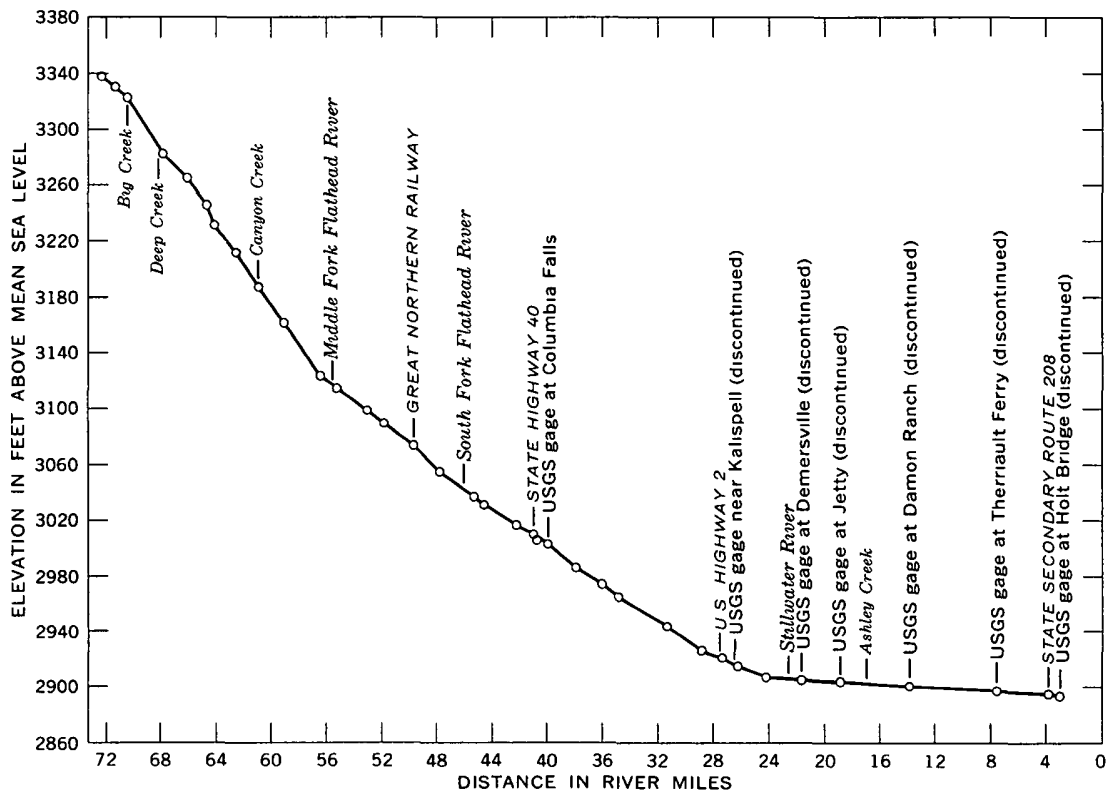

Figure 41 -Profile of flood-crest elevations on the Flathead River upstream from Flathead Lake

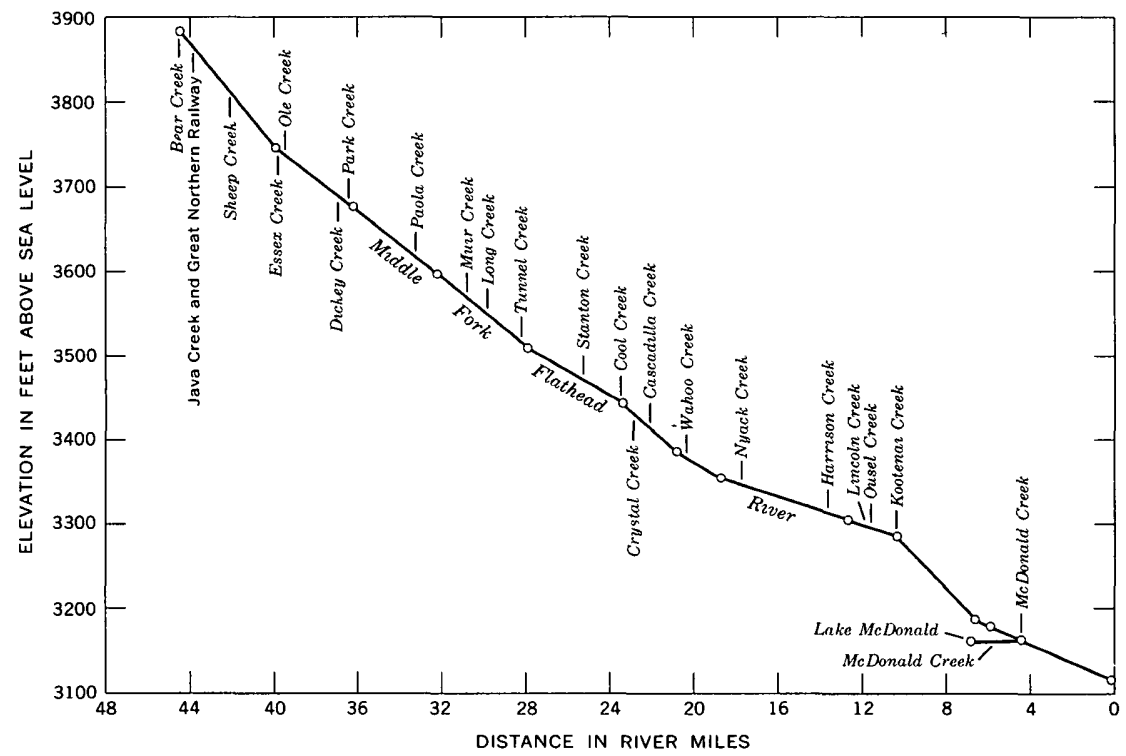

Figure 42 -Profile of flood-crest elevations on the Middle Fork Flathead River and McDonald Creek upstream from the mouth of the Middle Fork Flathead River 


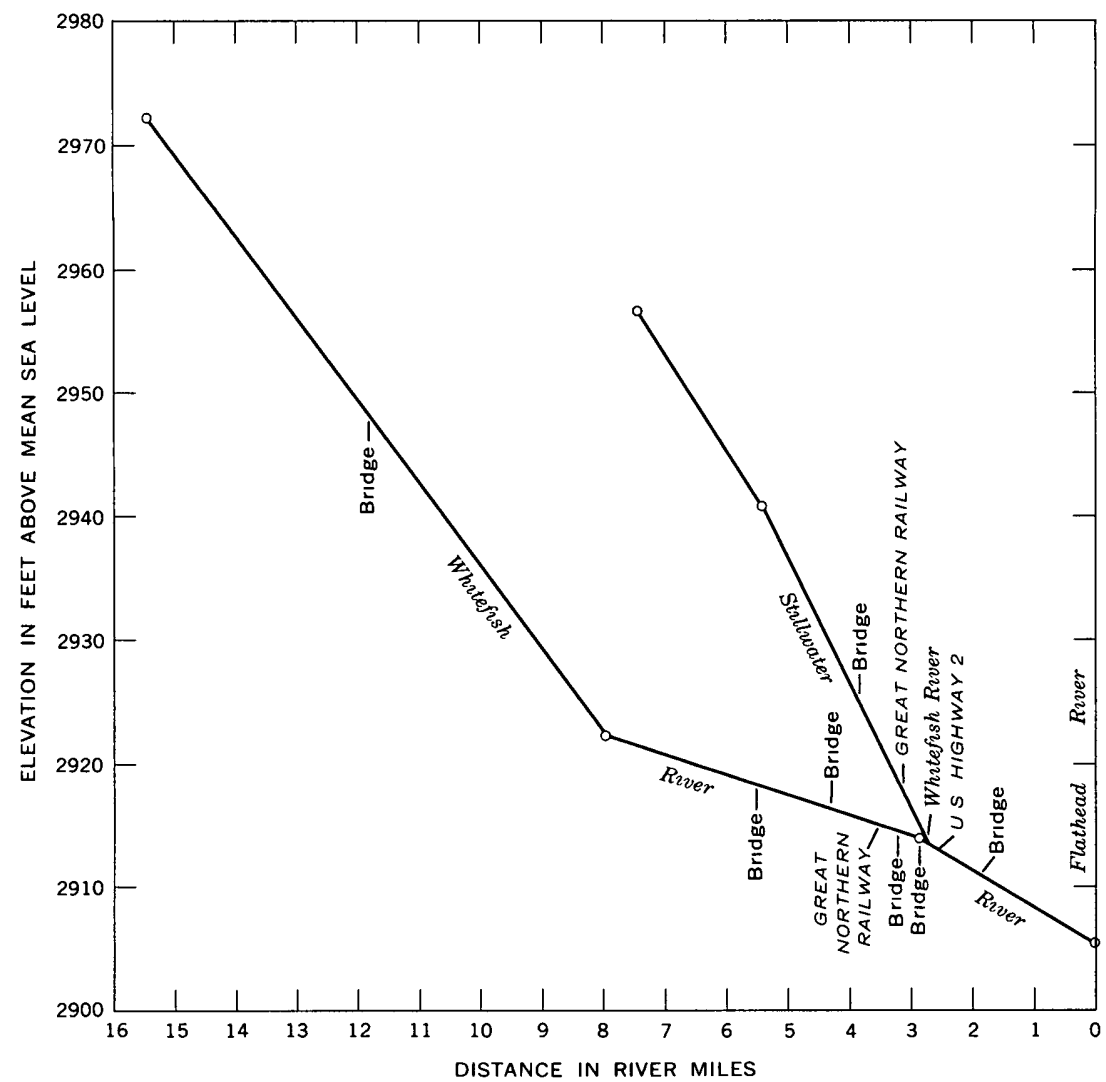

Figure 43-Profile of flood-ciest elerations on the Stillwater and Whitefish Rivers upstream from the mouth of the Strllwater River 


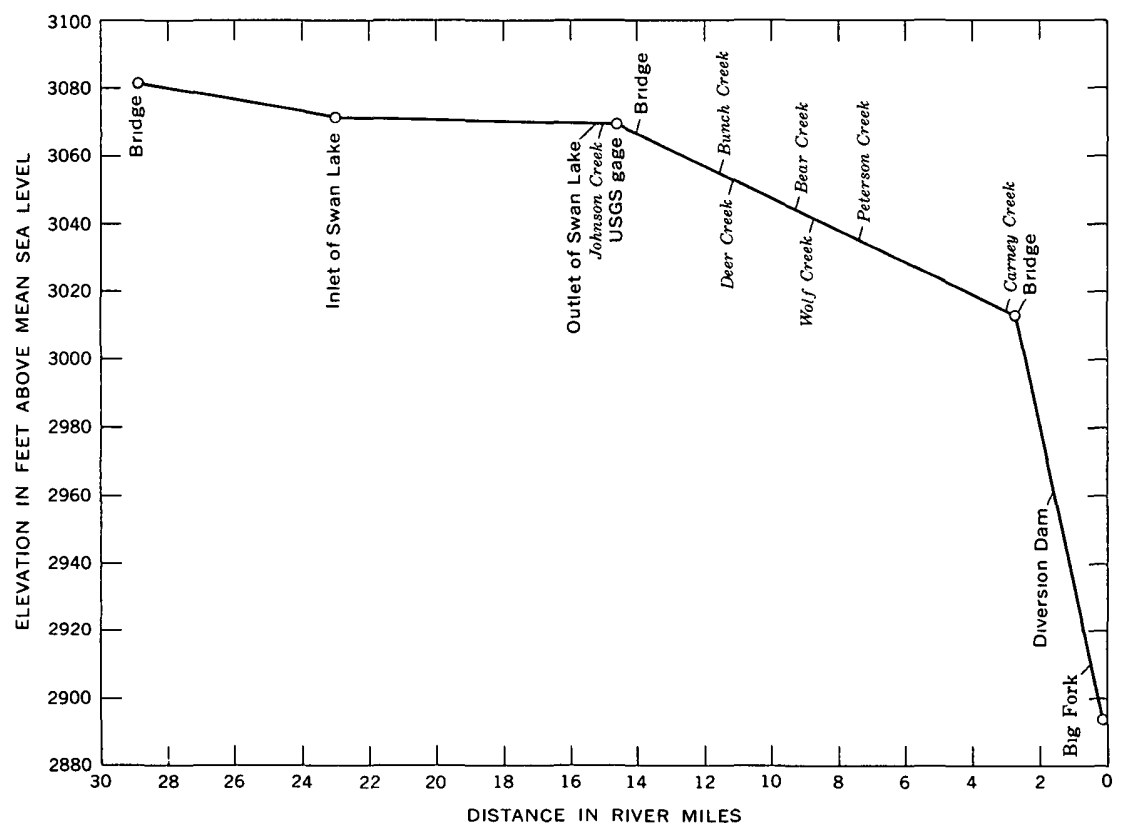

Figure 44 -Profle of flood-crest elerations on the Swan Rirei upstream from the mouth 


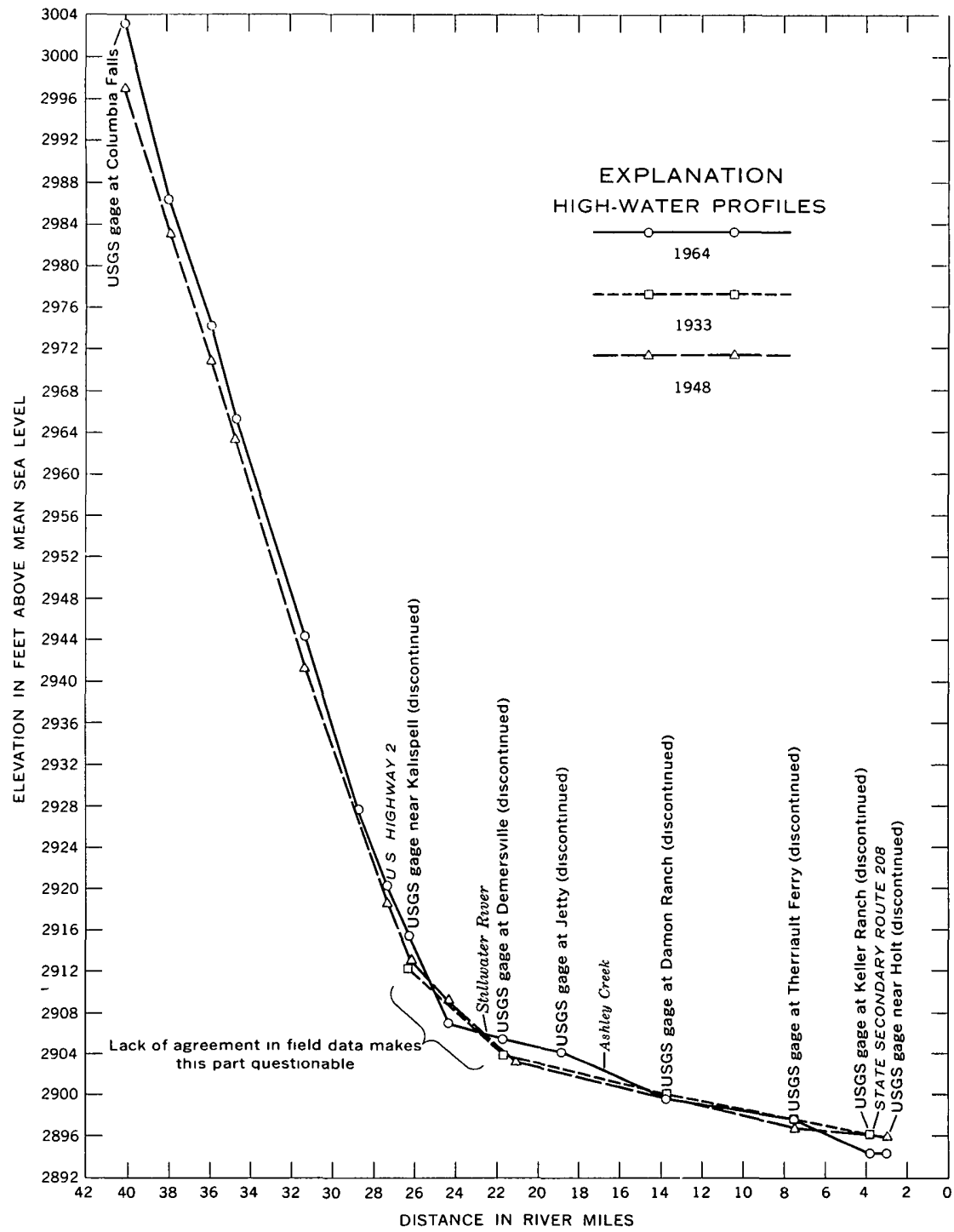

Figure 45-Profile of flood-crest elevations on the Flathedd River from 4005 to 30 miles upstieam from the mouth at Flathead Lake

\section{STORAGE REGULATION}

Lake Sherburne stored all inflow during the critical flood period; thus it reduced the peak on Swiftcurrent Creek by about 10,000 cfs and resulted in some beneficial effects on the flow of the St. Mary River About 25,000 acre-ft of floodwater were stored during the period June 7-10. 
Canyon Ferry Reservon on the Missoun Rives, near Helena, reduced the peak flow of the Missour R River to om about 24,000 cfs to ibout 5,000 cfs at that point for a period of nearly 3 days This reduction had a favorable effect at Great Falls where the combined record flow of the Sun River and high stage on the Missour River caused great damage The Colps of Engineers estimated this reduction prevented about $\$ 60,000$ damage Hauses, Holtes, Black Eagle, Rambow, Cochrane, Ryan, and Morony Dams on the Missourı River above and below Great Falls had little effect on discharge regulation

The Bureau of Reclamation estımated that Gibson Dam on the Sun Ruver reduced the peak flow of the Sun River near Great Falls and the Missour' River downstream from the Sun River by about 4,000 cfs 'The net reduction of the Missouı 1 River flow below the Sun River by Gibson Dam and Canyon Ferı y Dam was estmmated to have been about $23,000 \mathrm{cfs}$

The fallure of Swift Dam on Buch Creek, at about 1000 hours on . June 8, released about 30,000 acre-feet of stored water an a short time and greatly increased the natural peak flow of that stream. The discharge dimmished as it moved downstream. Fallure of Lower Two Medicine Lake Dam although less abi upt than that of Swift Dam resulted in unnaturally high flow tor a considerable distance downstream from the dam However, the maximum discharge of Two Modicine Rivel at the gagmg station southeast of Browning occurred prion to the ariual of water released by the dam fallure Storage by the dam, proo to fallure, was probably favorable to peak-flow reduction along much of Two Medicine River

Tiber Resel voll on the Mar ias River neal Chestel, with a dramage area of 4,923 square miles that moludes Buch Creek and Two Medicine Rwer where dams falled, had a peak inflow of about 200,000 cfs Dally outflow from the 1 eser voll was mcreased from 1,150 cfs on June 8 to about 10,000 cts on .June 11 Nearly 285,000 acre-tt of water was stored during the :3-day period of June 9-11 The regulation and storage by Tiber Dam and Reservorr aret ted flooding of a number of lanches and the town of Loma and prevented an estmated $\$ 600,000$ damage along the low er Mar ias River and the Missour i River upstream trom For t Peck Reser voll

Fiesno Reservoli on the Milk R11 el, 1:3 miles west of Haw e, stor ed about 15,000 acre-teet durmg the flood pen wod whle downstream releases tor nungation contmued Is the rutural peak flow was not unusually high, the regulat ion benefit was probably minor

Fort Peck Reservon on the Missouri Rivel, upstream fiom the Milk River, is one reservoll of a system of large r eser vours on the main stem 
of the Missourı River operated by the Corps of Engineers Damage prevented by these main-stem reservoirs and local Federal flood-control projects were estımated to be nearly $\$ 63$ million Bureau of Reclamation reservoirs were credited, by the Corps of Engmeers, with an additional downstream benefit estimated at about $\$ 11$ million

Hungry Horse Dam on the South Fork Flathead River reduced outflow from about 3,000 cfs at the beginning of the flood to $500 \mathrm{cfs}$ Peak inflow to the reservolr was computed at about 78,000 cfs. A stage reduction on the Flathead River of 4 feet at both Columbia Falls and Kalispell was attributed to reservoir storage (estimate by the Corps of Engineers) The corr esponding prevention of damage was estimated at $\$ 10$ million

\section{RECORDS OF PREVIOUS FLOODS}

Information on floods prior to the turn of the century is very scarce for the area east of the Continental Divide The Waterton, Belly, and St Mary Rivers of the Hudson Bay drainage basin had high flows in 1902, 1908, and 1953 The 1953 flood is discussed in detal by the Department of Northern Affairs and National Resources (1953), Ottawa, Canada. Noteworthy floods in the Missourı River basin, upstream from Fort Peck Reservorr, occurred in 1908, 1916, 1927, 1948 , and $1953 \quad \Lambda$ report of the 1953 flood and a general review of some previous floods have been published by the U.S Geological Survey (1957)

Information obtained trom residents and weather records indicate that the Jume 1908 and June 1953 floods in the Waterton, Belly and St Mary River basins were caused by exceptionally intense ianfall The maximum stages in 1908 on the Belly Rivel nea Mountain View, Alberta, and Waterton River near Waterton Park, Alberta, were slightly higher than in 1964.

The peak discharges of 1964 in the St. Mary River dramage basm upstream from Babb may have exceeded those of 1908 The peak discharge of the St. Mary River at the international boundary w as 21,000 cfs $1 n 1964$ and about 40,000 cfs in 1908

The floods in June 1908 in the Missour River basm above Fort Peck Reservolr were considered record floods in the memory of residents, and still stand as the record floods $m$ much of the area The longest continuous record of streamflow in the basin started in 1891 on the Missourı River at Fort Benton The June 1908 peak of about 140,000 cfs is nearly double the next highest peak of 78,700 cfs in June 1953 The 1964 peak of $77,400 \mathrm{cfs}$ ranks third, and the fourth highest known peak occurred in June 1892 Storage in Canyon Ferry Reservolr reduced both the 1953 and 1964 peaks 
The June 1916 peak on the Sun River at the diversion dam northwest of Augusta was 32,300 cfs compared with the June 1908 peak of $20,000 \mathrm{cfs}$ and the June 1964 peak of $59,700 \mathrm{cfs}$ Storage in Gibson Reservoll reduced the 1964 peak by about 4,000 cfs On Elk Creek at Augusta, the June 1908 peak was the highest recorded during the years 1904-24, when streamflow recor ds were being collected. Although records were not obtained during the June 1953 flood, local residents undicate the 1953 flood was higher than the 1908 flood and the 1964 peak exceeded the 1953 peak The June 1964 peak stage at the Sun River near Vaughn gaging station exceeded the June 1908 peak by about 3 feet

The peak discharge of $241,000 \mathrm{cfs}$ on the Manlas River near Shelby greatly exceeds any discharge since 1902, when intermittent record began. The peak discharge of 1908 may have been slightly higher than the $40,000 \mathrm{cfs}$ recorded for 1948. Records at the discontinued station on the Marias River near Brinkman list the 1908 peak discharge at about $70,000 \mathrm{cfs}$ and the 1948 peak at $50,000 \mathrm{cfs}$ Intermed Iate inflow between these sites was believed to have been much less in 1948 than in 1908 The 1948 flood in the Marias River basm has been discussed by Dightman (1950).

The peak stage of the Missourı River at Virgelle was about 2 feet higher in 1908 than in 1953 The 1953 peak discharge was 122,000 cfs as compared with 105,000 cfs in 1964.

The Milk River basin underwent flooding in 1899, 1906, 1908, 1948, 1952 , and 1953, serious flooding occurred in the central and lower parts of the basin. There was no serious flooding in this reach in June 1964 Very little is known of floods in the upper Milk River basm prior to 1905 , except that the Milk River at Havre had a peak in 1899 of about 20,000 cfs, the highest known prior to completion of Fresno Dam in 1939 The peak of the Milk River in 1964 evidently exceeded the peak of 1908 and subsequent years in the Del Bonta area

West of the Continental Divide severe general floods are known to have occurred in 1894, 1899, and 1948. Lesser or more localized floods occurred in 1913, 1916, 1928, and 1954. The floods of MayJune 1948 and May 1954 are discussed by the U S Geological Survey (1949, 1959)

The Clark Fork upstream from Missoula had its highest peak flow in 1908, according to information of local residents The Clark Fork peak discharge of about 48,000 cfs in 1908 at the Milltown Dam, just downstream from the mouth of the Blackfoot River, was the highest known The peak discharge of 1894 is not known but was probably the second highest, followed in diminishing order by the 1899, 1964, and 1948 peaks 
The Blackfoot River nea Bonner was probably higher in 1894 and 1908 than in 1964 The 1964 peak is the highest recorded discharge during the periods 1899-1904 and 1940-64 However, the upper Blackfoot River near Lincoln was higher in 1899, 1908, and 1953 than in 1964, according to information of local lesidents

The 1948 peak discharge for the Clark Fork below Missoula was $52,800 \mathrm{cfs}$ and is the hughest since record began in 1929 The 1964 peak is the second highest Higher flows are assumed to have occurred in 1894, 1899, and 1908 The summation of the peak discharges for Clark Fork at Missoula and Bitterroot River near Missoula for June 20, 1899, indicates a peak discharge for Clark Fork below Missoula of at least $70,000 \mathrm{cfs}$

At St Regis the Clark Fork peak discharge in 1948 is the highest since gaging station records began in 1911 This peak is followed in order of dimmishing magnitude by the peaks of 1913,1956 , and 1964 As is generally assumed withm this basm, peak discharges in 1894, 1899, and 1908 probably exceeded the 1948 peak

In the Flathead River basm, quantitative infor mation is meager for floods priol to 1910 The 1894 flood of $142,000 \mathrm{cfs}$ on the Flathead River at Columbia Falls was the highest known until the discharge of 176,000 cfs in 1964 The 1964 peak discharge would have been about 245,000 cfs if the South Fork Flathead River had not been regulated by Hungry Horse Dam The maximum known elevation of Flathead Lake (about 2,900 ft, Somers datum) occurred in 1894 The maxımum elevation of 2,894 27 feet in 1964 was exceeded six times between 1909 and 1964 The Corps of Engmeers estmmate that the storage $\mathrm{m}$ Hungry Hoise Reservorr reduced the potential maximum elevation of Flathead Lake in 1964 by 25 feet

\section{FLOOD FREQUENCY}

The evaluation of the flood potential of a stream is of primary mterest to persons concerned with location and design of structures subject to possible flooding The probable return frequency (1 ecurrence interval) can be determined by analysis of flood records for gaging stations Regional flood characteristics are developed from statistical study of flood experience on a number of streams The reliability of calculated return fiequencies may be expected to vary with the areal coverage and number of years of flood records on which they are based $\Lambda$ fair degree of confidence is indicated for recur rence intervals as great as 50 years, extension of curves beyond that perior is not recommended $\Lambda$ flood having a x ecurrence interval of 50 years will be equaled or exceeded once in 50 years, on an average, in other words, it has a 2-percent chance of occurring in any year 
Comparison of the peak discharge at a gaging station for a given flood with the probable 50-year flood as determined by flood-frequency relations provides an approximate measure of the severity of the flood The floods of June 1964 were outstanding, particularly on streams that drained the mountain slopes on both sides of the Continental Divide

In the Hudson Bay drannage basin, most streams had peak discharges that were more than twice the discharge of the probable 50year flood The peak of Street Creek at international boundary was 103 times the probable 50-year flood This may have been exceeded on some streams where peak discharges were not determmed

Peak discharges in the Missourı River basin were also outstanding in the upper drainage areas of the Sun, Teton, Marias, and Milk Rivers The ratios of the peak discharge to the probable 50-yea flood ranged from aboult 3 in the upper Sun River area to more than $10 \mathrm{~m}$ the Teton River drainage Peak discharges of 5 to 10 times the probable 50-year flood were common on Two Medicme Creek (called Two Medicine River downstream from lower Two Medicine Lake), North and South Fork Birch Creek, Badger Creek, Dupuyer Creek, and South Fork Milk River The highest determined ratio was 115 for Teton River near Farmington

West of the Continental Divide, ratios of the June 1964 peak discharge to the probable 50-year flood were generally less than $2 \mathrm{~m}$ the Clark Fork drainage except in the upper Blackfoot River area. In the upper Flathead River basin, the peak discharges determined ranged from 2 to 4 times the probable 50-year flood except in the Middle Fork Flathead Riveı basm where the ratios approached 9

Table 19 lists the calculated flood-recurrence intervals or ratios to the probable 50-year flood for gaged sites susceptrble to analysis through reports of the US Geological Survey on the magnitude and fiequency of floods The reports for the upper Columbia Rive basm and for the Missouri River basm have been prepared by the US Geological Survey $(1964,1966)$ The report for the Hudson Bay basin will be published after completion of studies

The variation of flood characteristics east of the Continental Divide led to the regional areal separations shown in figure 46 The peak discharges for the June 1964 flood have been plotted agamst dramage area in each appropriate region and area as shown in figures 47 to 55 Recurience-mterval lines for the 10-year flood and the 50-yea flood are shown to ald compauson Extension of the recur rence-mterval lines in these figur es is not advised

In general, flood-frequency relations are based upon natural streamflow conditions However, the Missourı River peak flows have been affected by a relatively constant degree of regulation during most of 


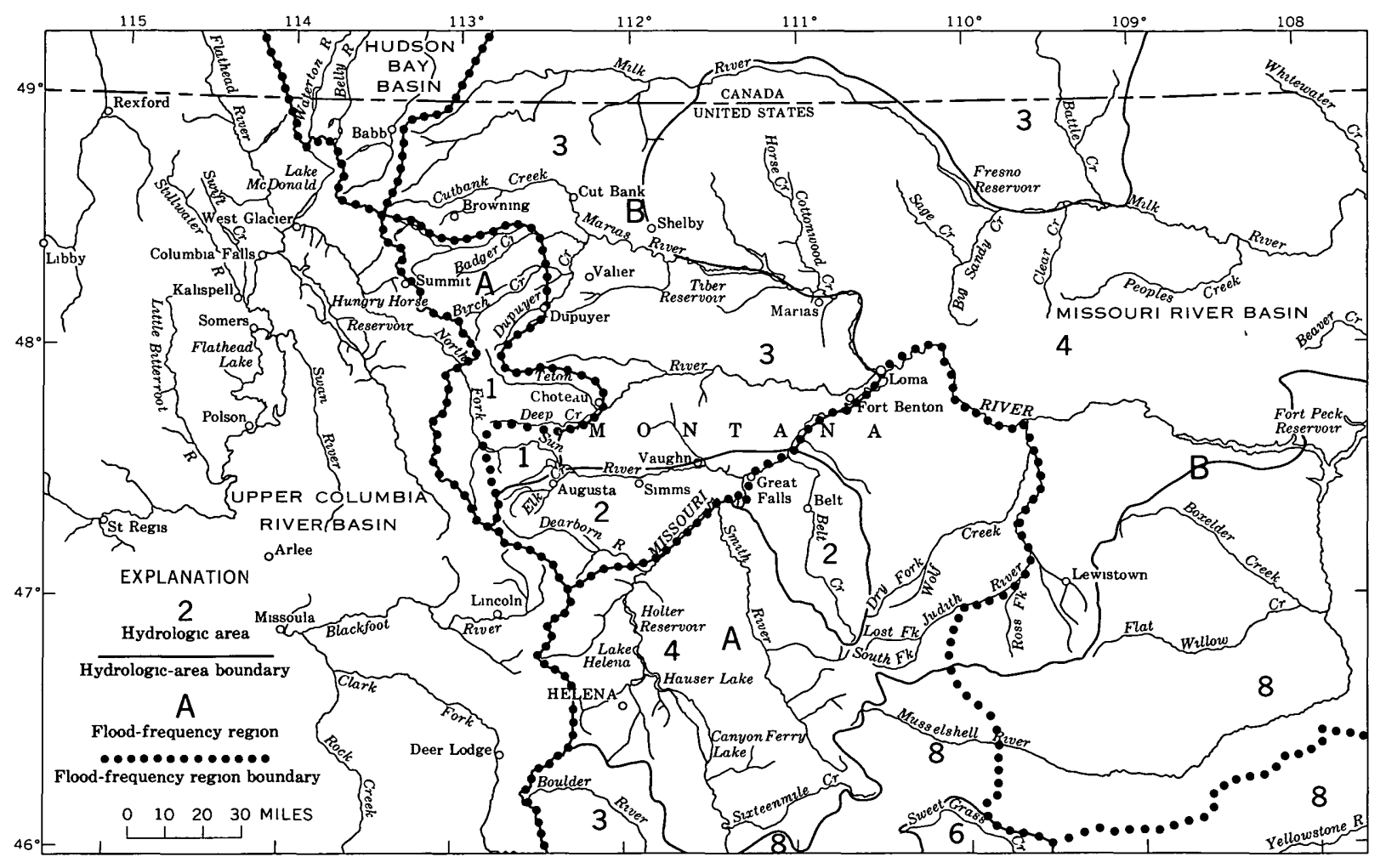


NORTHWESTERN MONTANA, JUNE 1964

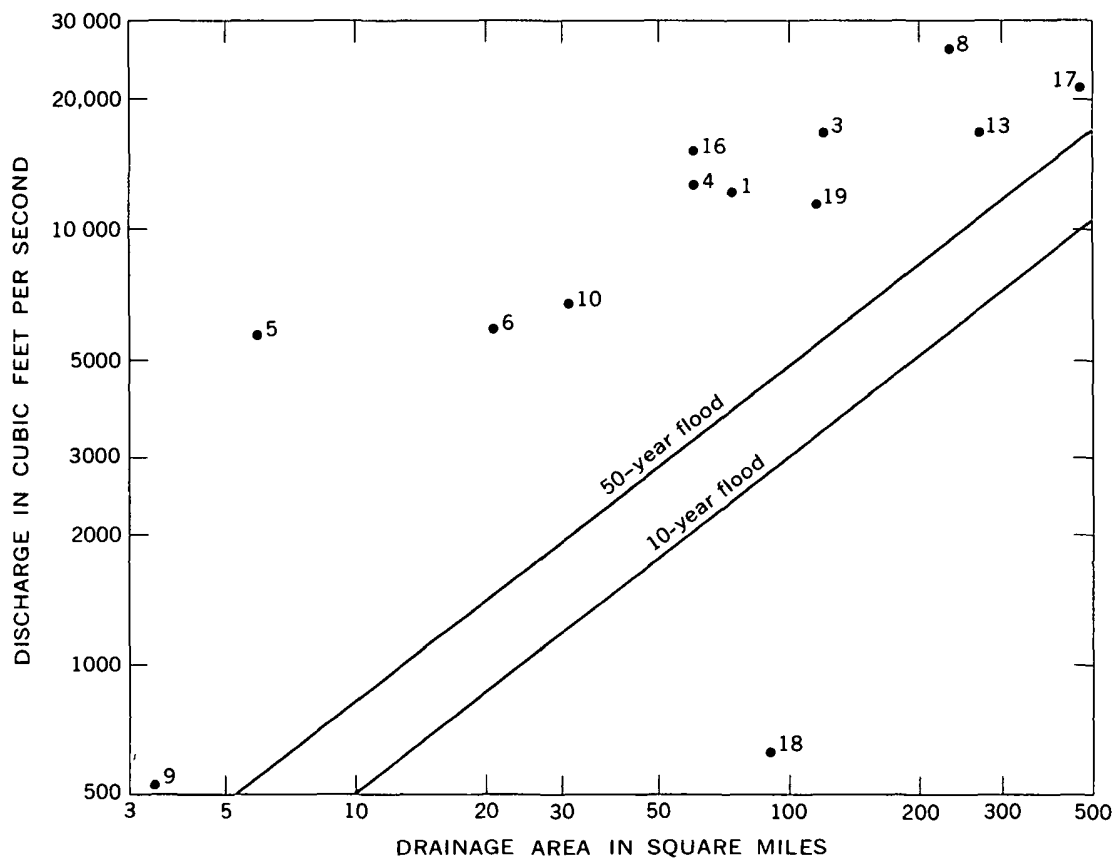

Figure 47.-Relation of 1964 peak discharge to 10- and 50-year floods in Hudson Bay basin Numbers conform with those in table 19 and on figure 2 
B104 FLOODS OF 1964 IN THE UNITED STATES

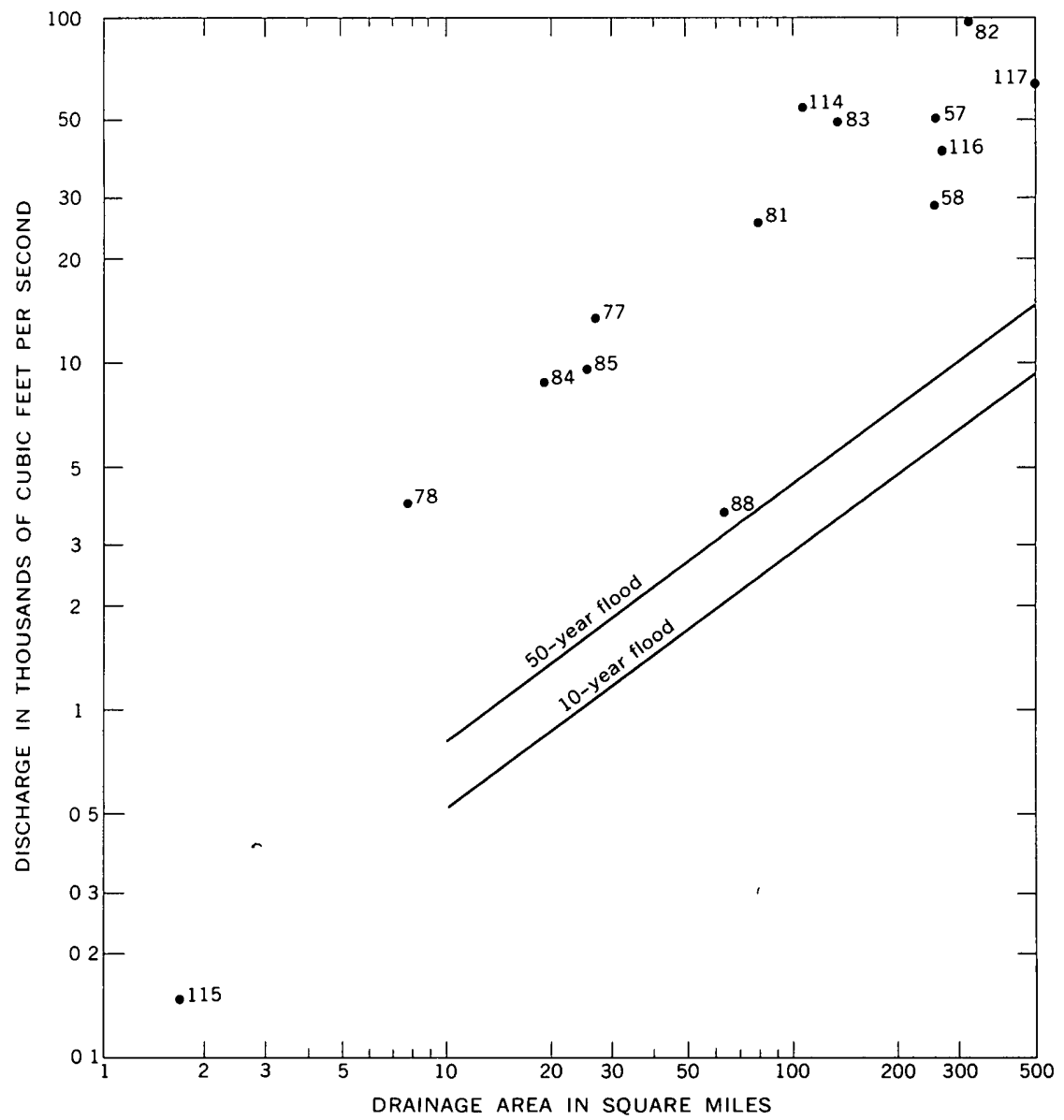

Figure 48 - Relation of 1964 peak discharge to 10 - and 50-yedi floods in region $A$, alea 1 Numbers conform with those in table 19 and on figure 2 


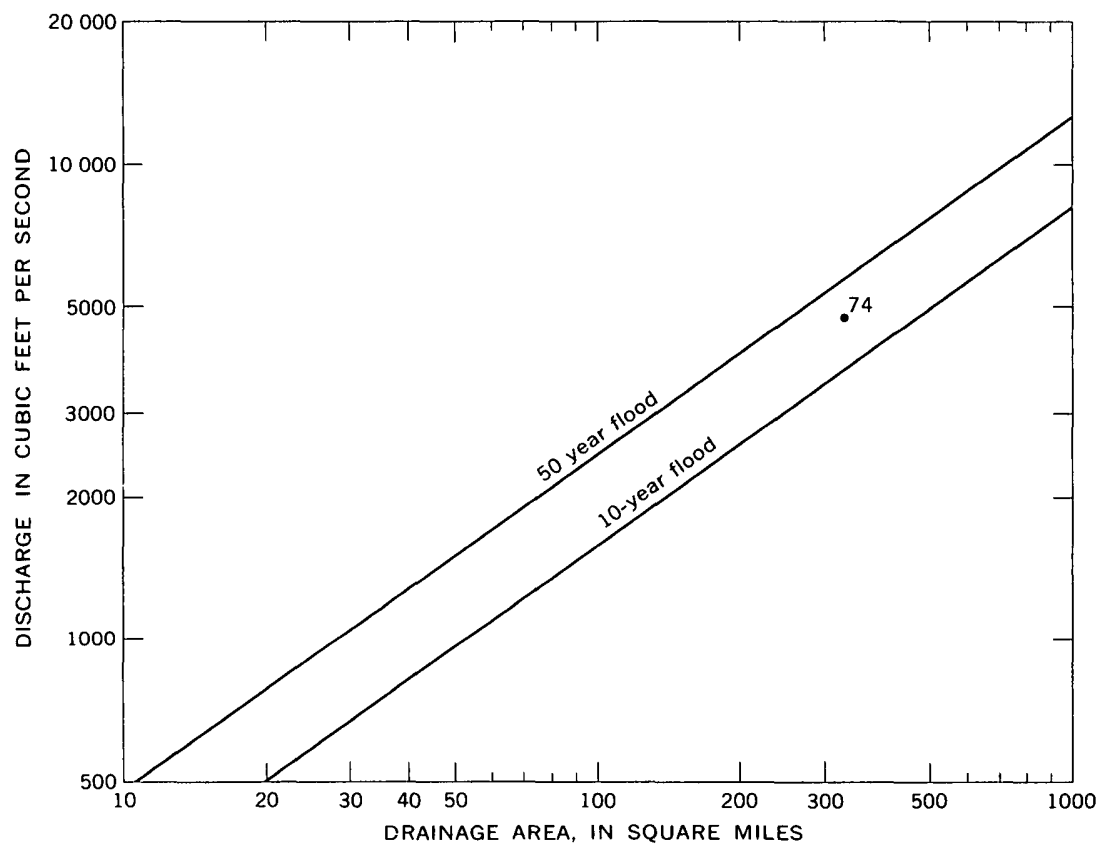

Figure 49 -Relation of 1964 peak discharge to 10 - and 50-year floods in region $A$, area 2 Number conforms with that in table 19 and on figure 2

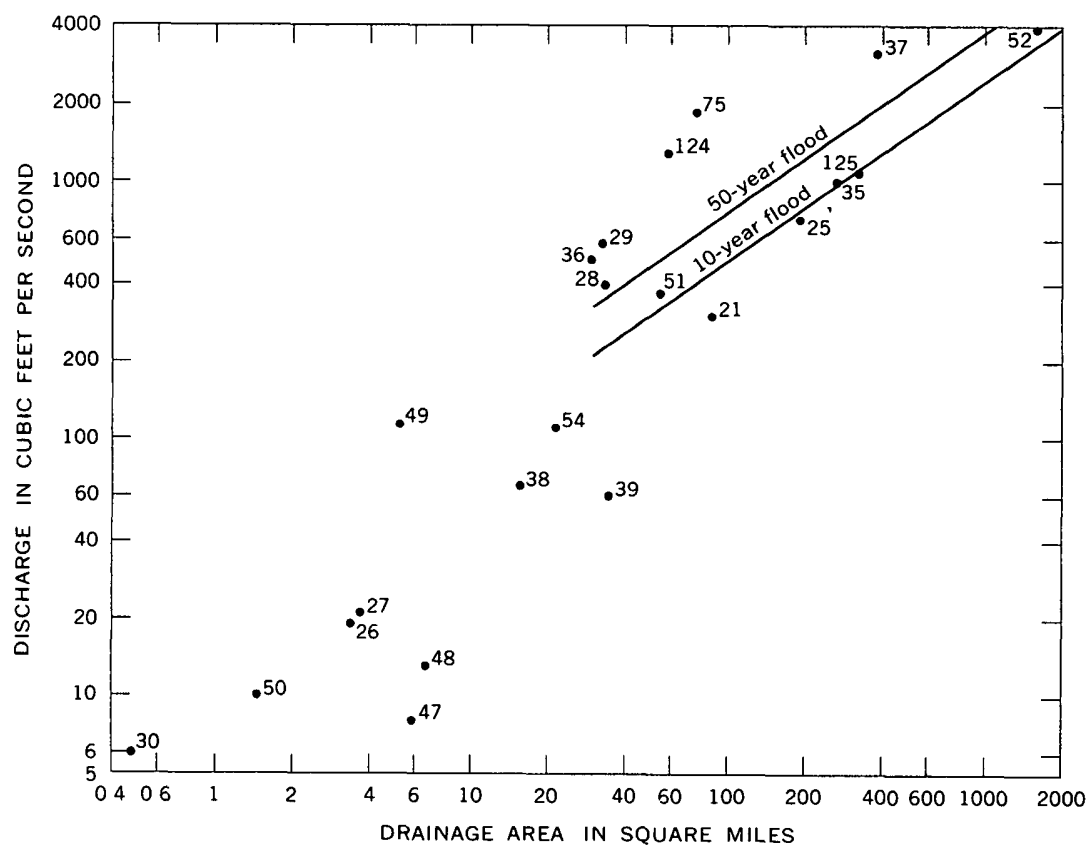

FIGURE 50 -Relation of 1964 peak discharge to 10 - and 50-year floods in region

A, area 4 Numbers conform with those in table 19 and on figure 2 


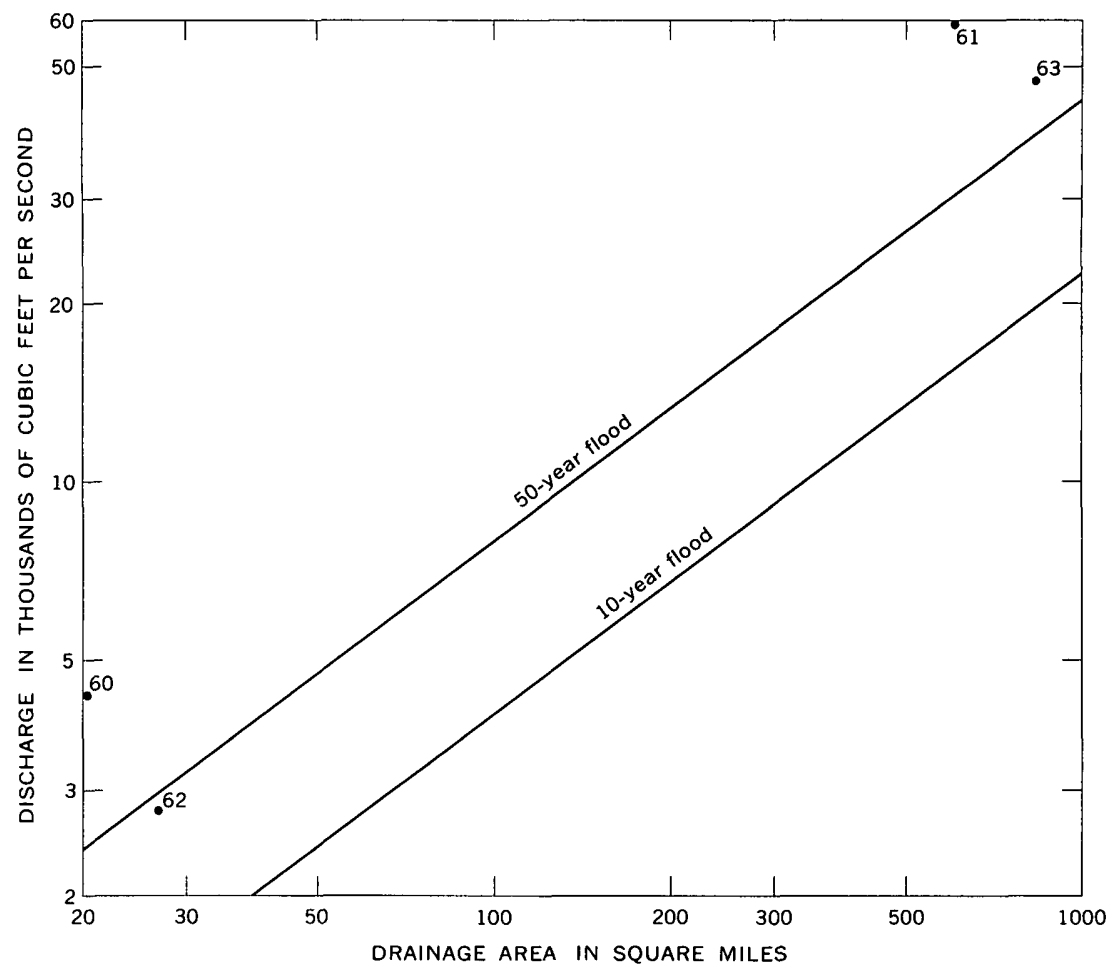

Figure 51 -Relation of 1964 peak discharge to 10 - and 50-year floods in region $B$, area 1 Numbers conform with those in table 19 and on figure 2 


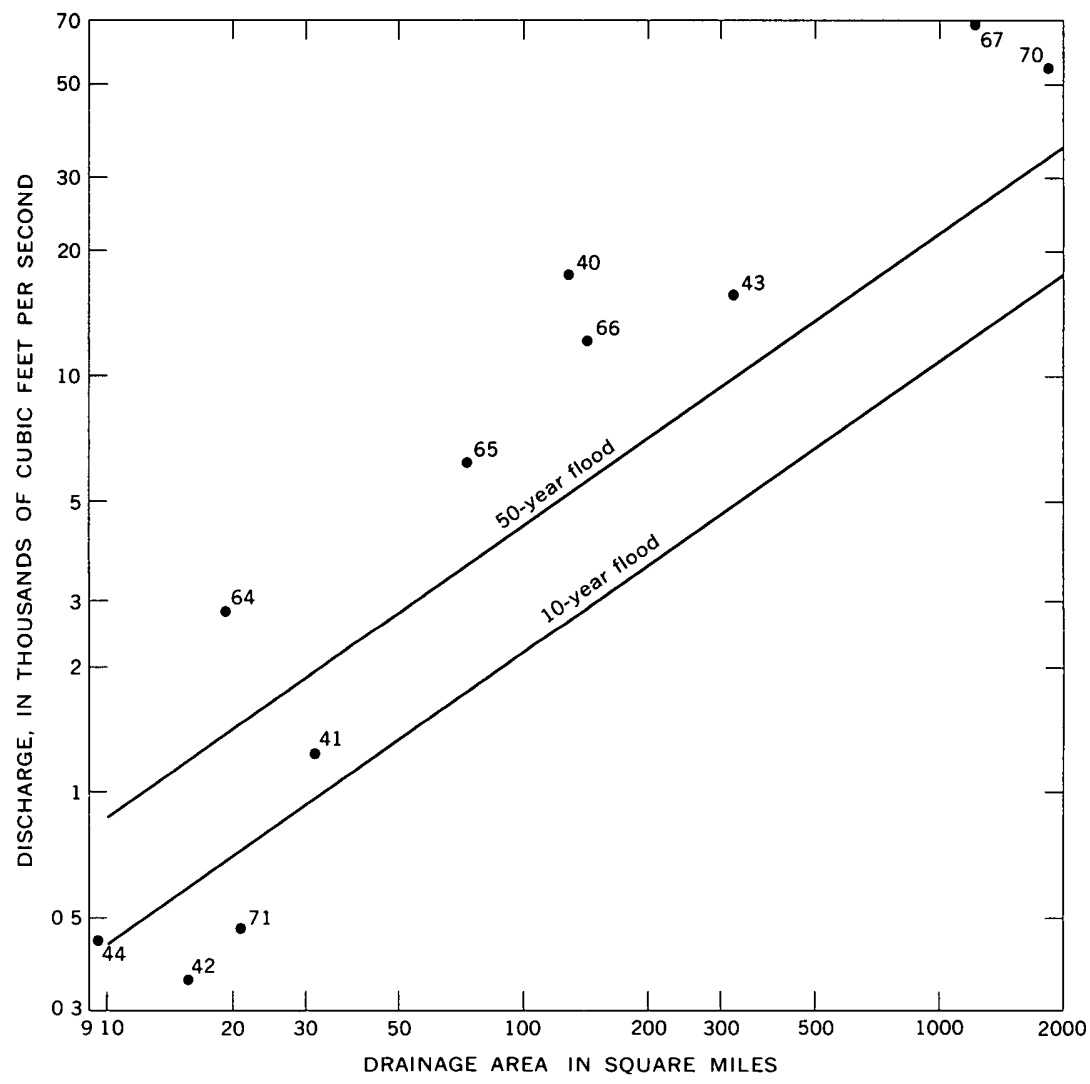

Figure 52-Relation of 1964 peak discharge to 10 - and 50-year floods in region $\mathrm{B}$, area 2 Numbers conform with those in table 19 and on figure 2 


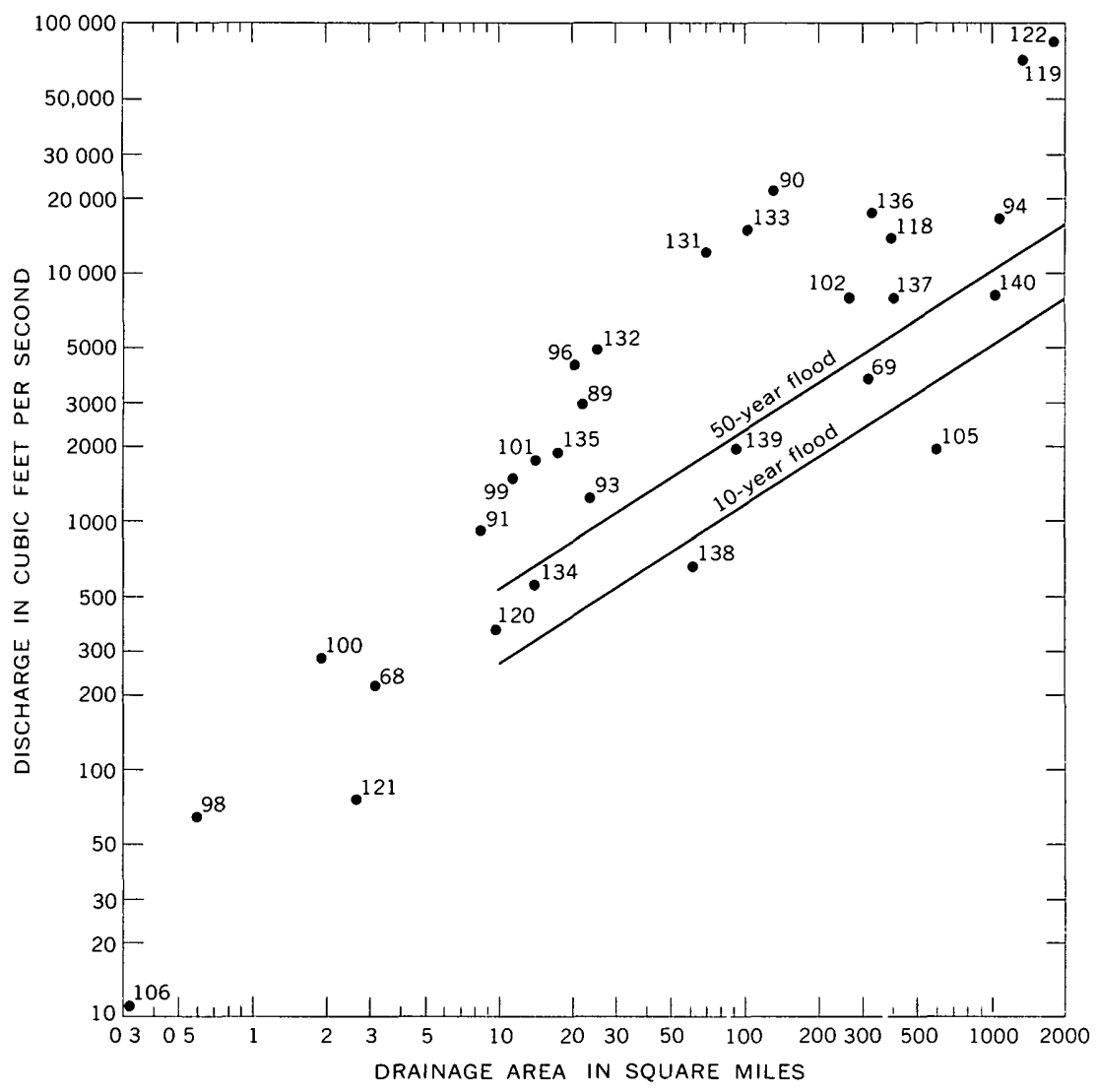

FigURE 53-Relation of 1964 peak discharge to 10 - and 50-year floods in region $B$, area 3 Numbers conform with those in table 19 and on figure 2 


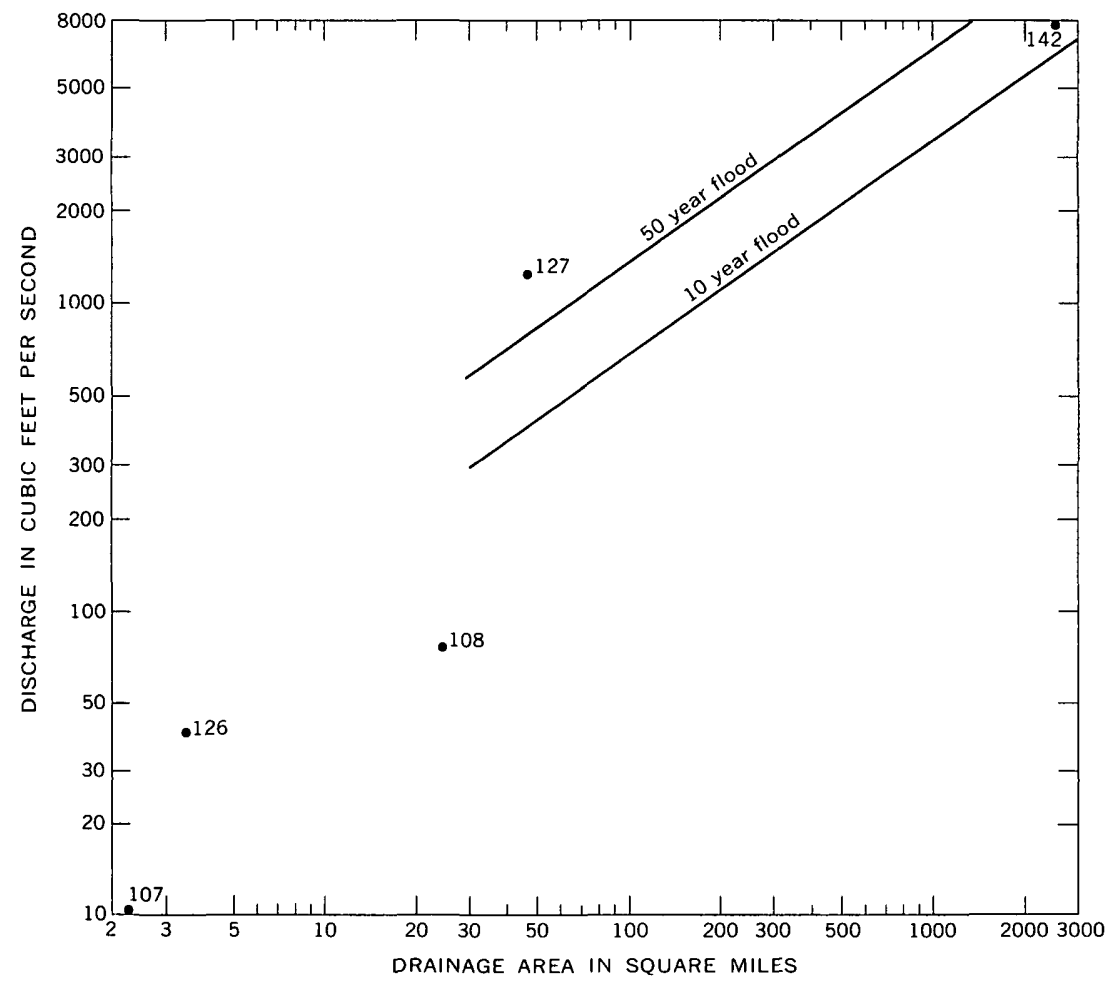

Figure $54-$ Relation of 1964 peak discharge to 10 - and 50-year floods in region $B$, area 4 Numbers conform with those in table 19 and on figure 2

the period tor which records have been collected Figure 56 shows the peak discharges of June 1964 and the 10-year and 50-year flood lines for gaging stations on the Missour' River mam stem between the Gallatm River and Fort Peck Reservorr

The flood-frequency formulas tor the area west of the Contmental Dir ide (US Geological Survey, 1964) were developed from the parameter's of dramage area, arerage ammual runoff, areas of lakes and ponds, and a numerical geographic factor Examples of derived recurrence inter vals for discharges at selected ganing-station sites are given in figure 57

The relations of peak discharge to dramage area provide casy comparison of the unit discharge of the 1964 flood peaks (figs 58 and 59) The same information for four points along the Teton Rivel is giv en in figure 60 to illustrate the downstream reduction in unit discharge and to provide a means of estimating the unit discharge at any intermediate point. 


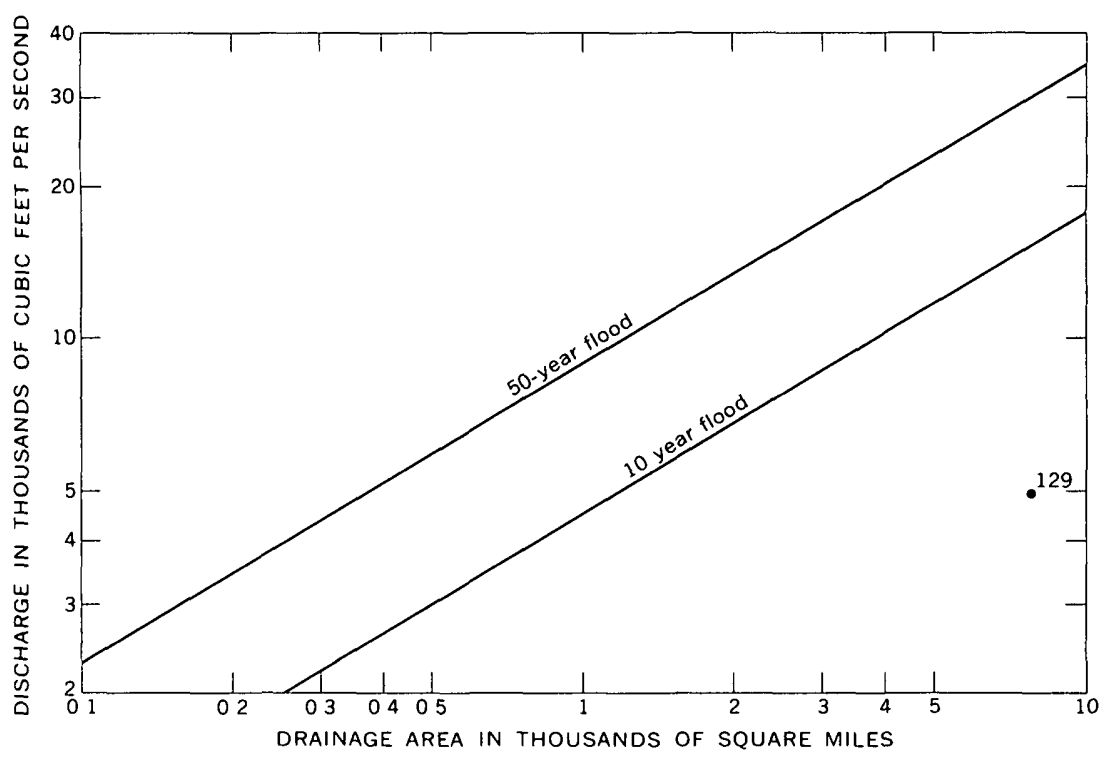

Figure 55-Relation of 1964 peak discharge to 10 - and 50-year floods in region $B$, area 8 Number conforms with that in table 19 and on figure 2

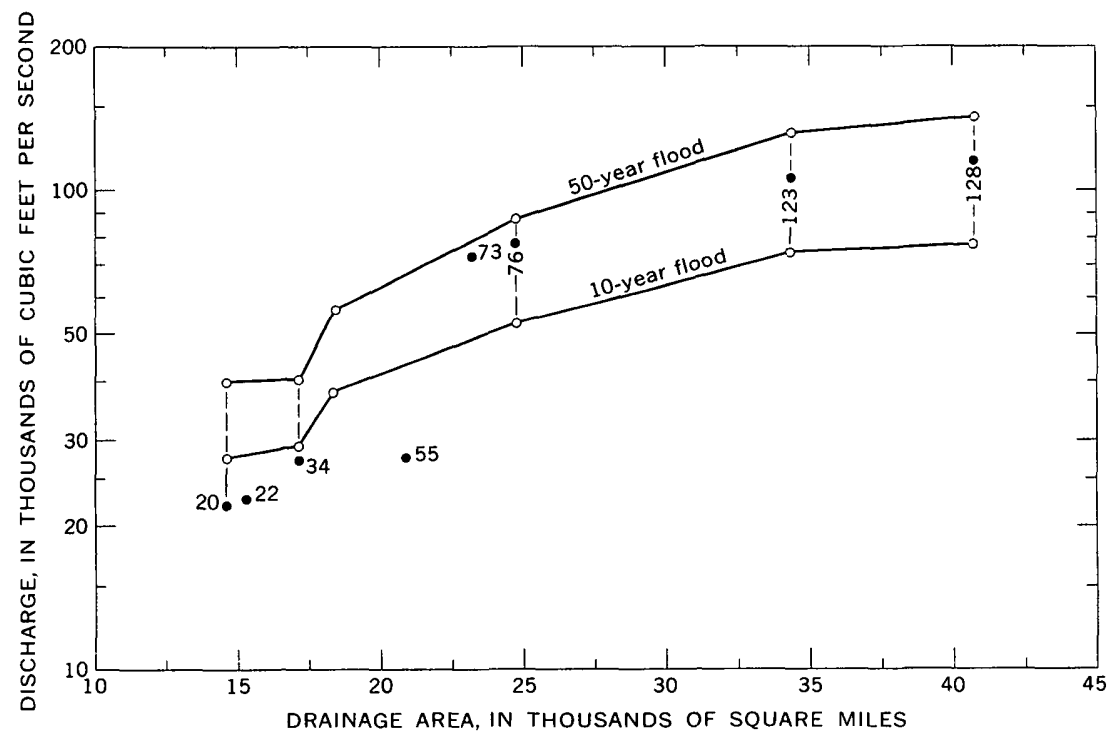

Frgure 56 - Relation of 1964 peak discharge to 10- and 50-year floods on Missour1 River main stem Numbers conform with those in table 19 and on figure 2 


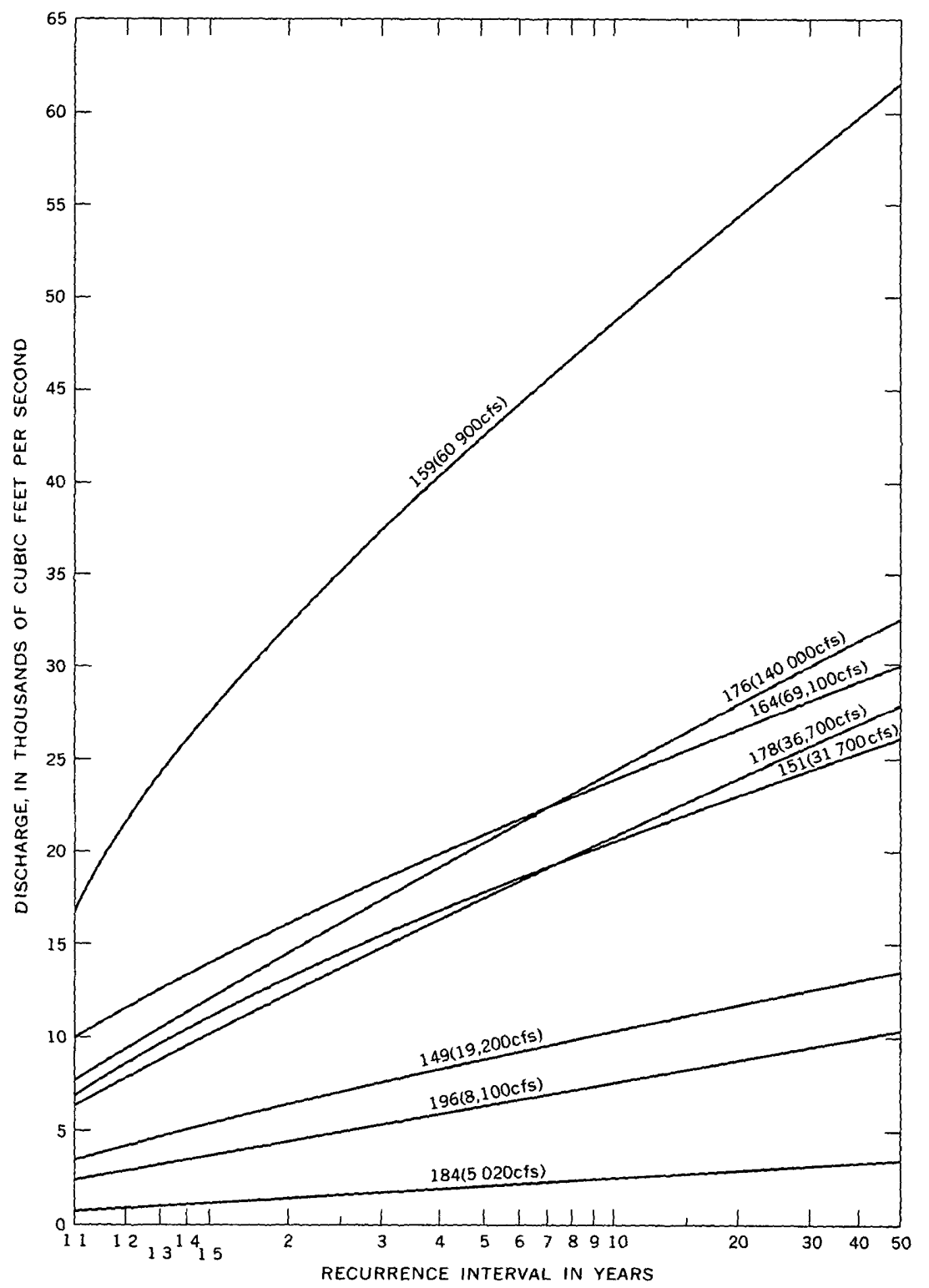

Figure 57 -Flood-frequency curves fol selected stations in upper Columbia Rive1 basin Numbers conform with those $m$ table 19 and on figure 2 Numbers 1 parentheses are June 1964 peak discharges 


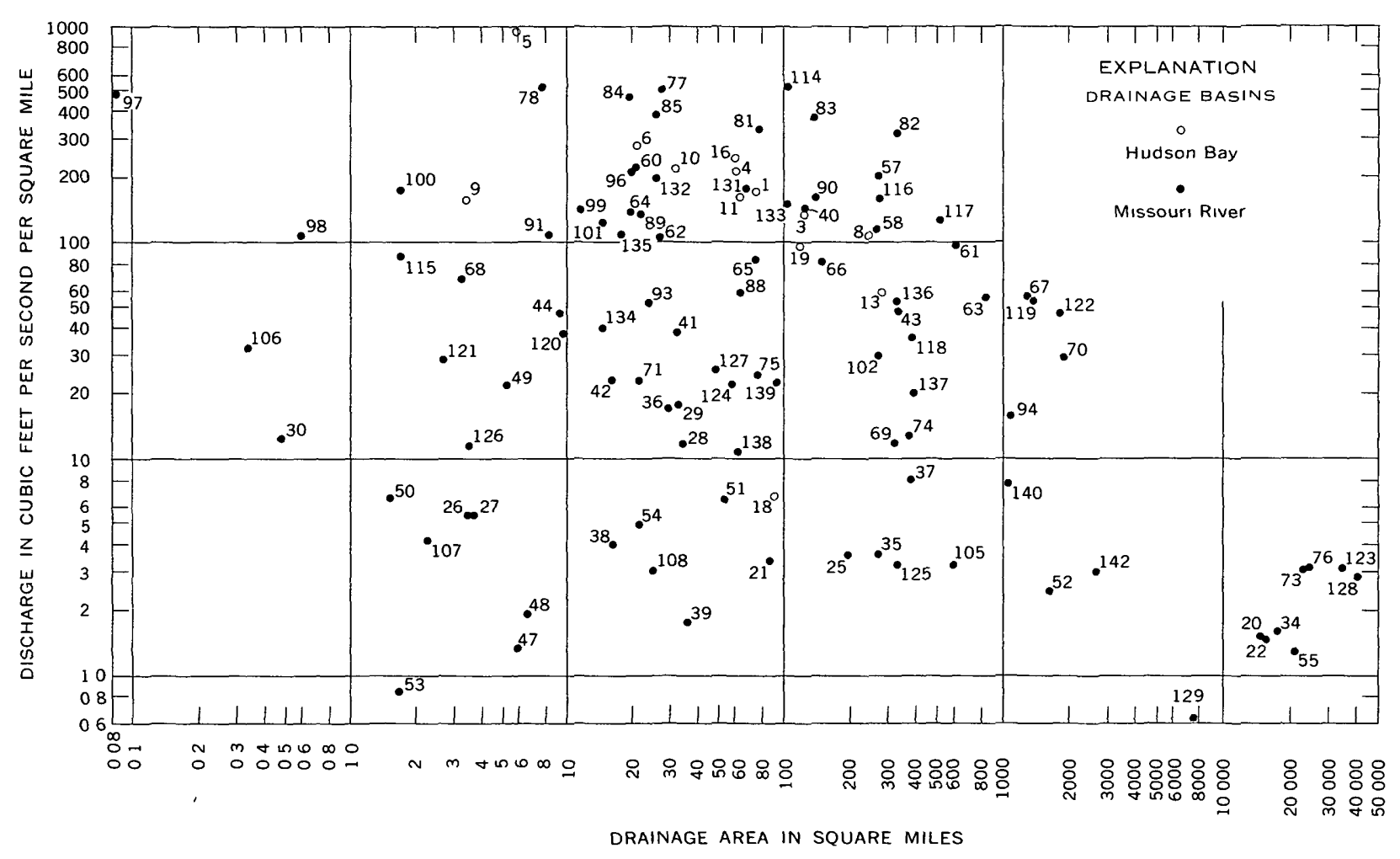

Figure 58-Relation of unit discharge to drainage area in Hudson Bay and Missouri River basins Numbers conform with those in table 19 and on figure 2 


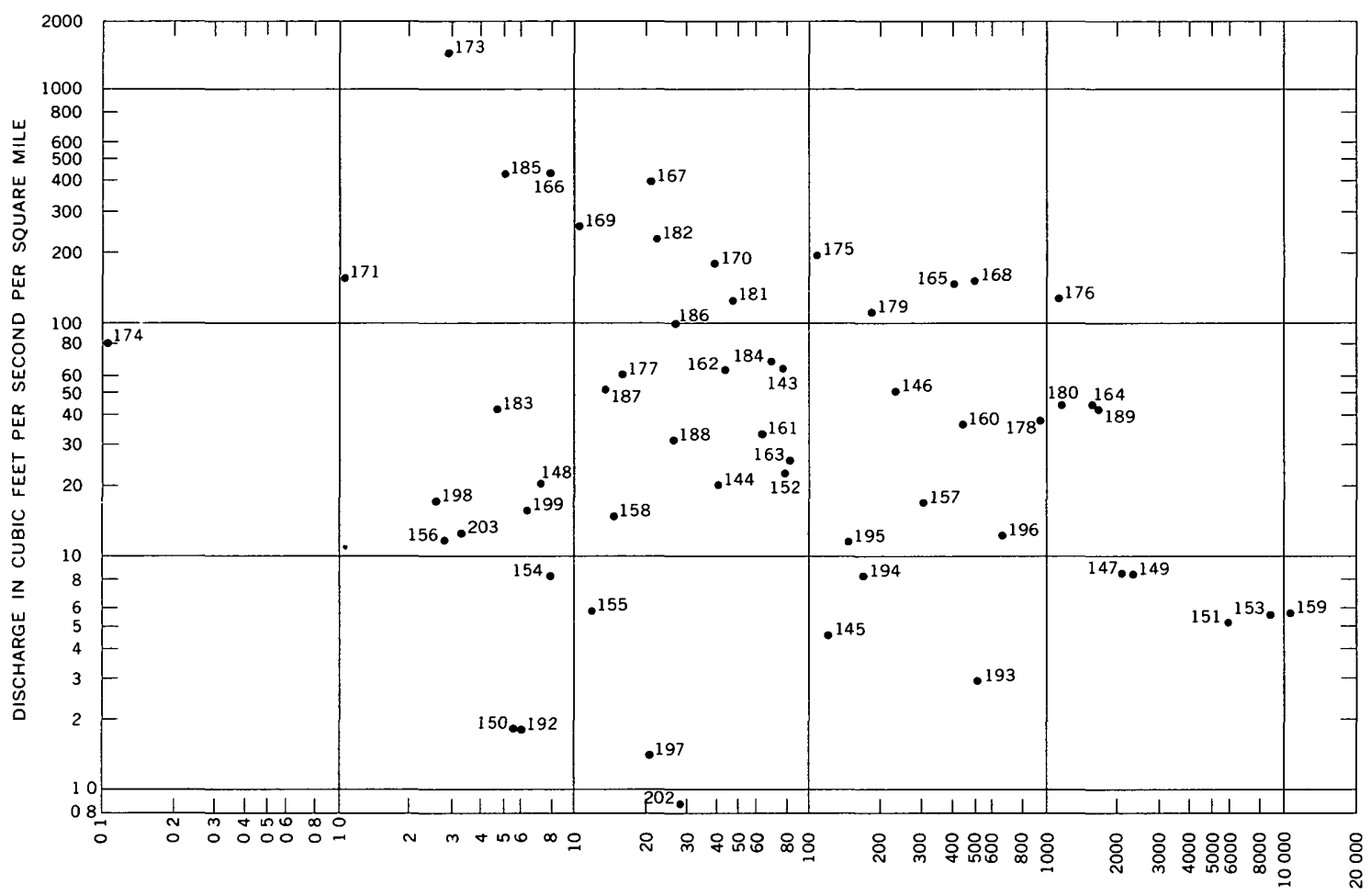

DRAINAGE AREA IN SQUARE MILES

Figure 59-Relation of unit discharge to dramage area in upper Columbia River basin Numbers conform with those in table 19 and on figure 2 


\section{$\mathrm{B} 114$}

FLOODS OF 1964 IN THE UNITED STATES

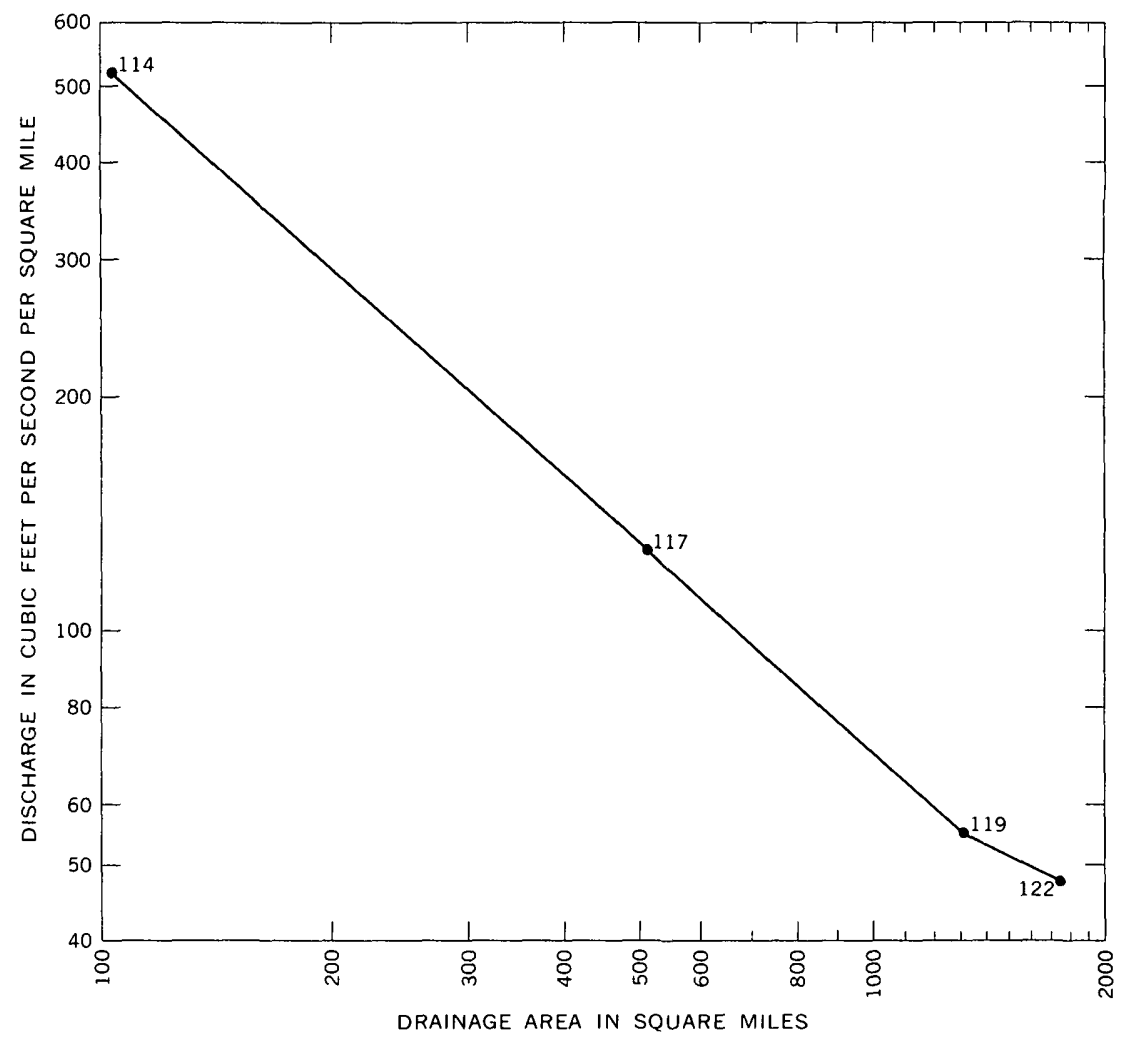

Figure 60 -Relation of unit discharge to drainage area, Teton River Numbers conform with those in table 19 and on figure 2 


\title{
EROSION AND DEPOSITION CAUSED BY FLOODS OF JUNE 1964 IN NORTHWESTERN MONTANA
}

\author{
By Richard F Hadlex
}

\section{INTRODUCTION}

This section of the report is concerned with the physical changes produced by the flood on stream channels and on landforms such as mountain slopes. Many of the changes in the landscape after such catastrophic floods as those of June 1964 in northwestern Montana are apparent to observers, but most changes cannot be verified quantitatively. Opportunities for comparison of natural features before and after the flood, by surveys or photographs, are limited Therefore, the data presented here are a combination of quantitative measurements and qualitative observations of geomorphic changes produced by an outstanding flood

The author wishes to express his thanks to Frank Stermitz, District Engmeer, Helena, Mont , and personnel of the Surface Water Branch, U S. Geological Survey, for assistance in the collection of field data and photographs

\section{FIELDWORK}

A reconnaissance of the area was made during the period September 1-10, 1964 Durıng this brief trip, field observations and surveys were made in several large river valleys and in valleys of smaller tributaries in the area affected by the flood Channel cross sections were surveyed at U.S Geological Survey gaging stations where channel dimensions were known for the period before the flood. At other sites, where exact preflood measurements were not avalable, an estımate of channel dimensions was made from photographs and topographic maps

\section{GENERAL FEATURES OF THE FLOOD AREA LOCATION}

The greatest damage caused by the flood was concentrated in an area bounded by the Dearborn River on the south, Interstate Highway 15 on the east between Helena and Great Falls, Middle Fork Flathead River on the north, and Flathead River on the west This roughly rectangular-shaped area includes about 12,000 square mıles, and the Continental Divide trends north west through it

\section{TOPOGRAPHY}

The topography is diverse Altitudes reach 8,500-9,000 feet in the rugged peaks along the Continental Divide, in the Flathead Range, and in the mountains of Glacier National Park west of the Divide. 
On the east side of the Divide, the northern Great Plains and foothills abut the mountams, and the general altitude of the area ranges from 3,300 feet at Great Falls to almost 5,000 feet in the foothills and to more than 8,500 feet in the mountans 10 miles a way

\section{GEOLOGY}

The Rocky Mountanns which bisect the flood area and form the Contınental Divide are composed of sedimentary, metamorphic, and igneous rocks ranging from Precambrian to Quaternary in age These rocks are folded and faulted into complex structural patterns. The sedimentary rocks are chefly limestone, sandstone, and shale. The metamorphic rocks are predommantly quarzite, and the igneous locks ar e diorite and gabbi o On the Great Plams east of the Rockies, the rocks are chefly Tertiary and Cretaceous sandstone and shale Some areas are mantled with Pleistocene glacial drift and moramal deposits

\section{PHYSIOGRAPHY}

The mountan valleys are generally narrow and steep, then shapes being contiolled to a large degi ee by geologic structure The valley side slopes are heavily forested, and the surficial mantle is thin and rocky The stream channels are mcised in the bottom of V-shaped troughs and most hate very narsow flood plans One reason for the heary damage to roads and rarlroads is the lack of 1 oom on the mountam valley floors for rights-of-way. Most roadbeds are high fills which tend to impinge on the riverbanks Immediately east of the mountans most irer valleys and the flood plans widen makedly, and the slope of the rivers and upland areas is much flatter There 1s, therefore, a significant difference $m$ the kind of flood damage $m$ the two physiographic types

\section{EROSIONAL EFFECTS OF THE FLOOD}

\section{UPLAND AREAS}

The steep upland slopes in the mountamous areas have a thin sol] mantle which was probably saturated or near saturation because of the above-arerage snowpack Therefore, when ramfall of such quantities and intensities as occuried on . June $7-8$ fell on the steep, relatively unstable slopes, the erosion on mountan slopes was extraordmary Gullying in small mountam rills and movement of debris on steep valley slopes were pronounced in the dranage area of Middle Fork Flathead River between Summit and West Glacier, Mont

For example, in sec 36, T $32 \mathrm{~N}, \mathrm{R} 18 \mathrm{~W}$, on Moccasin Creek, a tributary of the Middle Fork Flathesd River where the slope of the 
valley floor is 20 percent and the valley side slopes exceed 50 percent, an estimated 3.8- to 4-foot thickness of rock and alluvium was removed from the central part of the valley in a trench 32 feet wide. Boulders with maximum diameters of $33 / 4$ feet were scattered along the channel banks. On the upland slopes covered with ponderosa pine, trees up to 1 foot in diameter had been uprooted and moved down the slopes (figs. 61, 62). Less than 100 yards below the section shown in figure 62 , U.S. Highway 2 was closed by a debris cone that was transported from the Moccasin Creek drainage basin of about 2 square miles. In the area between Summit and Hungry Horse Dam, Mont., the flood discharge was extremely high, and erosion was severe from all headwater stream and mountain slopes.

On the east side of the Continental Divide, upland erosion was also severe and comparisons of aerial photographs taken before and after the flood reveal that upland slopes near the junction of the West Fork and South Fork Sun River were intricately gullied. The antecedent moisture in the soil mantle was probably responsible, in large part, for the high rate of discharge and upland erosion in the mountain-

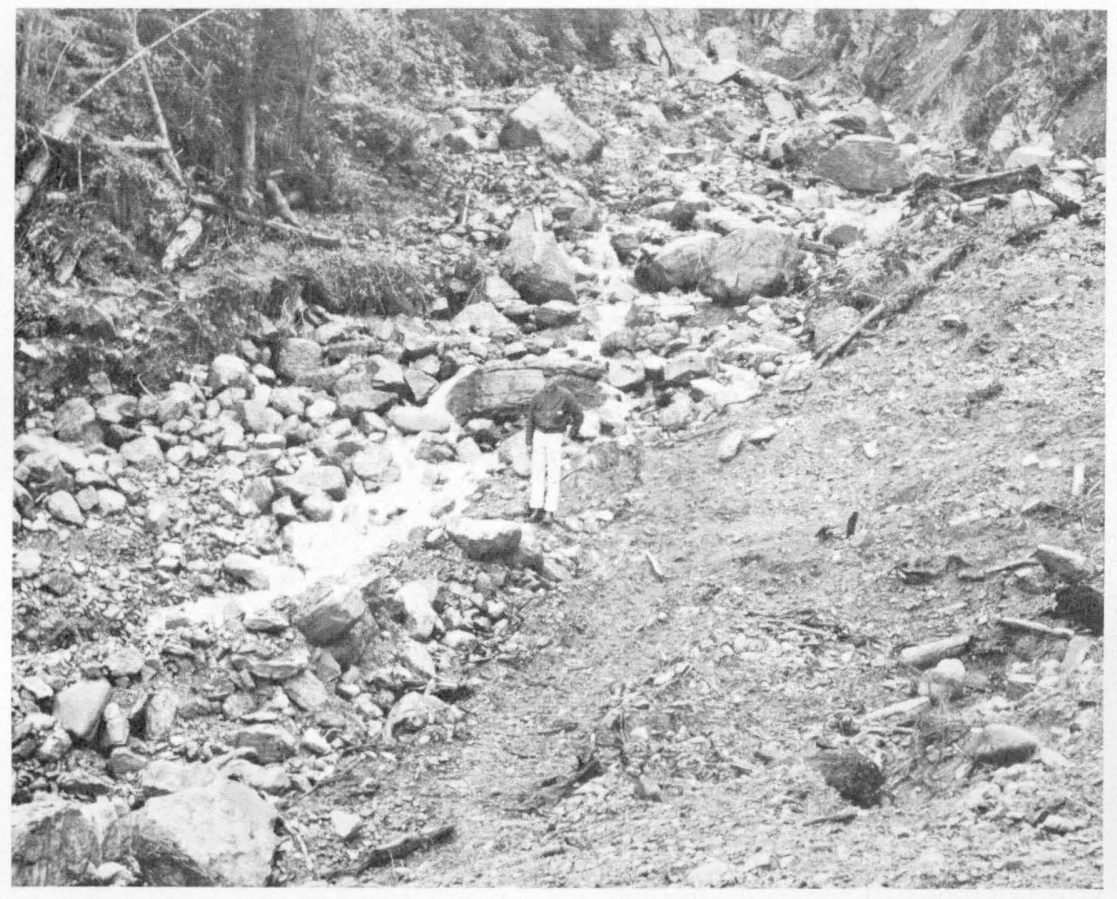

Figure 61.-Moccasin Creek near West Glacier, Mont. showing debris moved down steep mountain slopes by flood. 


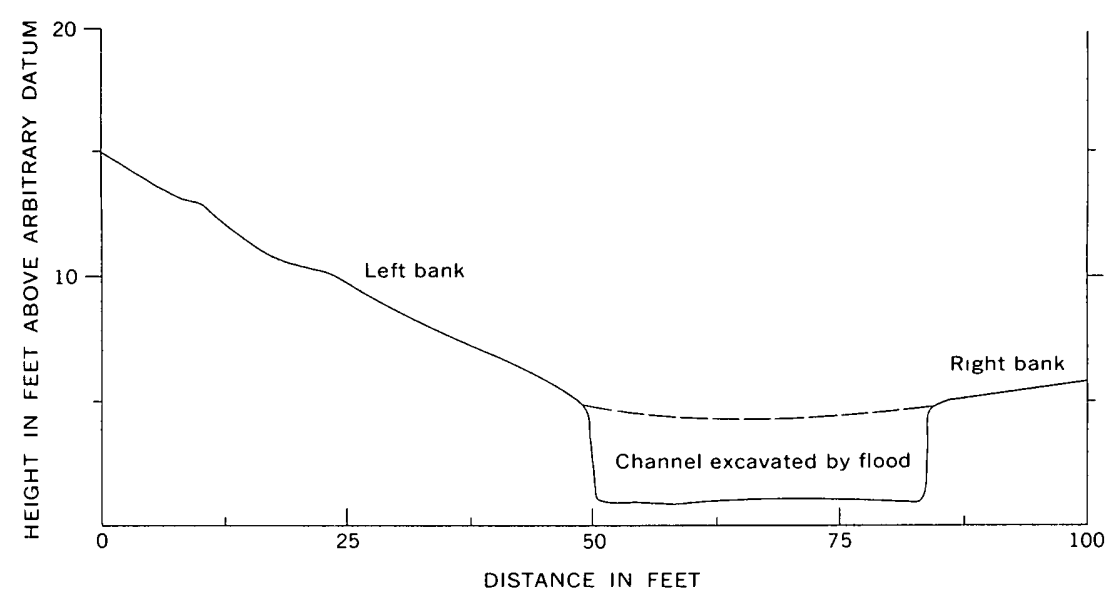

Figure 62 - Channel cross section on Moccasın Creek near West Glacier, Mont

ous areas On the High Plams east of the mountans, there was little gullymg on the grassed upland slopes and most erosion was confined to the channels and valley floors

\section{CHANNEL EROSION}

Data for determining channel erosion were obtained primarily at U S. Geological Survey gaging stations Figures 62, 63, 68, and 72 show six channel cross sections before and after the flood Although only a small sampling of ivers affected by the flood is included, it is representative of both mountam and plains streams The range in dramage area is from 8 to 1,380 square miles Surveys of these cross ections and obseivations at other locations indicate that most channels were considerably deepened and widened by the flood although the changes may be temporaly

\section{DETAILED DESCRIPTION OF CHANNEL CHANGES}

SKYLAND CREEK NEAR ESSEX, MONT.

The dramage basm of Skyland Creek is very representative of the small, forested headwater basins west of the Contmental Divide that recelved the brunt of the flood The dramage area at the Skyland Creek gaging station is 8.09 square miles, and the maximum known peak discharge prior to the 1964 flood was $284 \mathrm{cfs}$ The flood of 1964 produced a peak discharge of $3,580 \mathrm{cfs}$, and velocities must have been extremely high judging by the amount and size of debris that was 
moved into the valley. The channel was completely filled by uprooted trees up to 8 inches in diameter and by boulders as much as 2 feet in longest dimension. The stream now occupies a channel to the left of the gage house and slightly higher than the old channel (figs. $63,64)$.

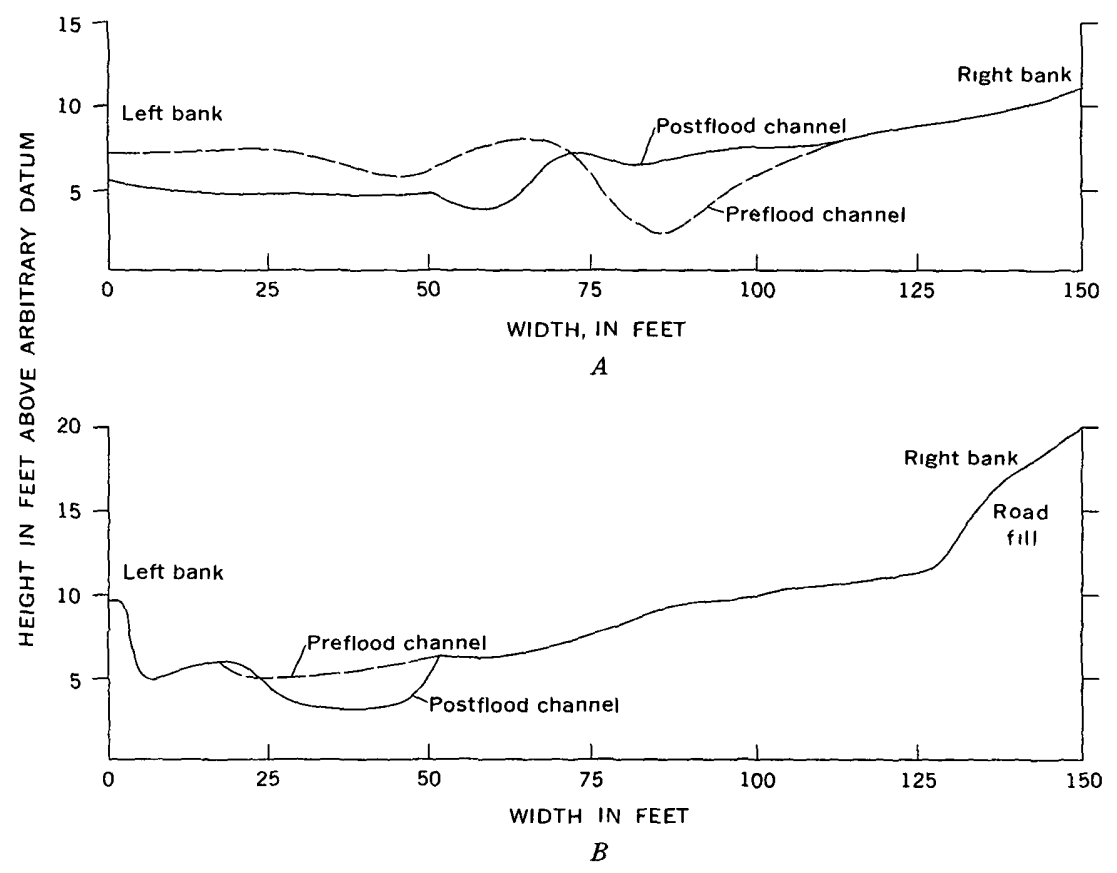

Figure 63 -Channel cross sections on Skyland Creek near Essex, Mont, $(A)$ and on Bear Creek near Essex $(B)$ 


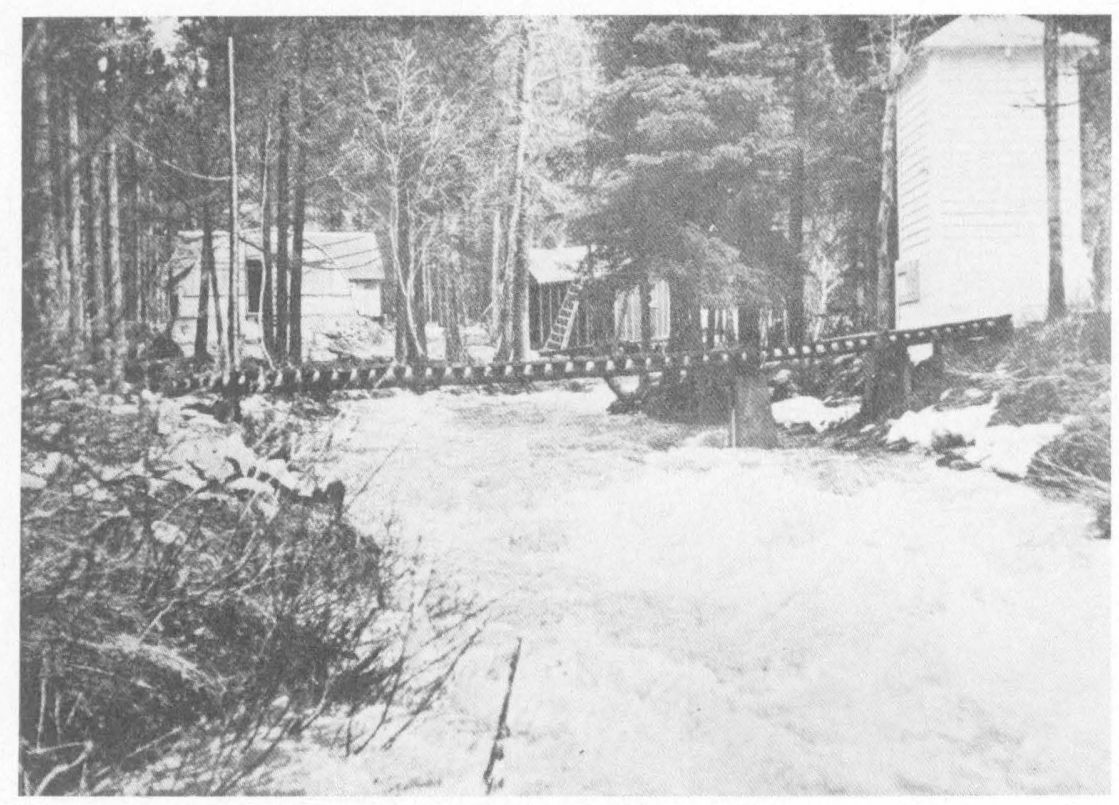

A, View looking upstream, May 22, 1948.

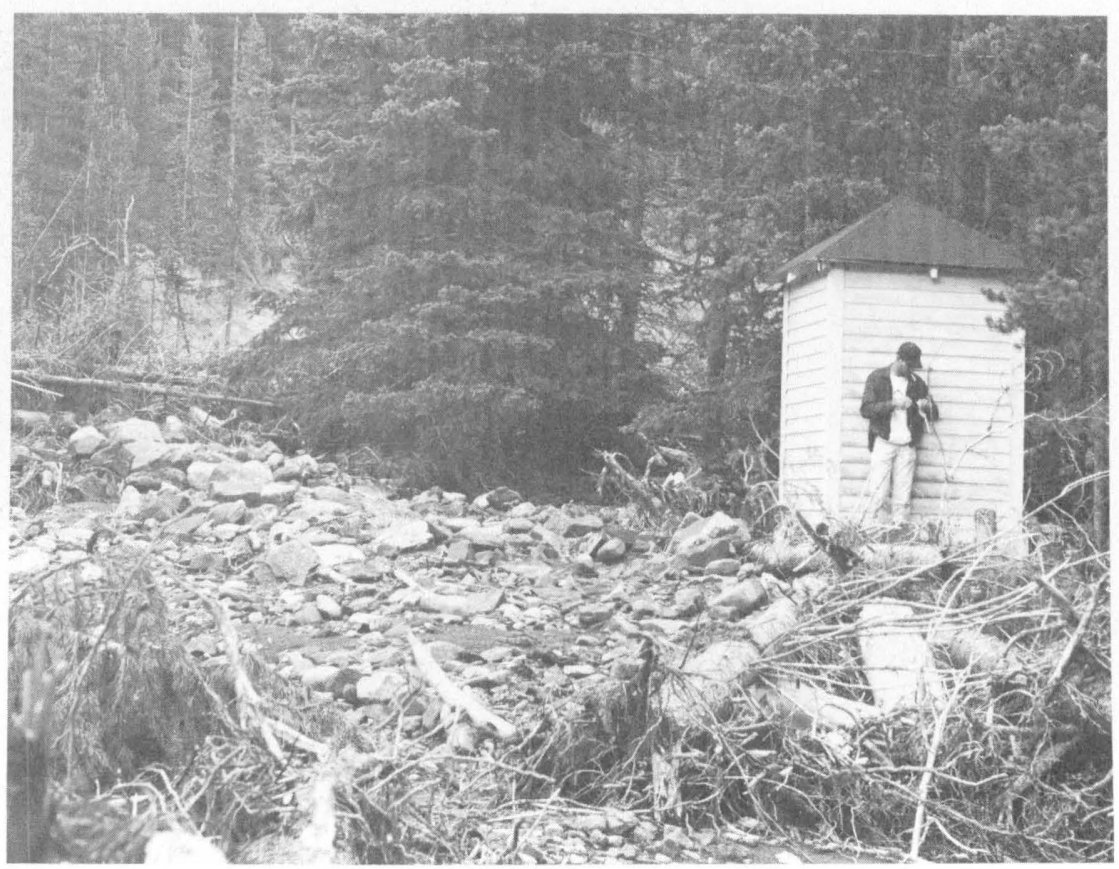

$B$, View on September 5,1964 , showing debris that has completely obliterated the channel. Gage house was not moved by the flood.

Figure 64.-GAGING STATION ON SKYLAND CREEK NEAR ESSEX, MONT. 
BEAR CREEK NEAR ESSEX, MONT

The Bear Creek cross section is downstream from the Skyland Creek gaging station The dramage ar ea is 207 square miles The gaging station is in a narrow valley bounded by a steep bedrock valley wall on the left bank and an ear th-fill 1oad embankment on the 11ght bank The previously known maxımum discharge was $696 \mathrm{cfs}$, and the peak discharge on the 1964 flood was $8,380 \mathrm{cfs}$ The channel does not appear to have been severely eroded by the high peak discharge Heavy growth of trees and shrubs on the flood plam was relatively undamaged, and there is little evidence of deposition on the low terrace along the right bank; however, approxmmately 3 feet of channel scour was accompanied by minor widening (fıgs $63,64,65,66$ ) 


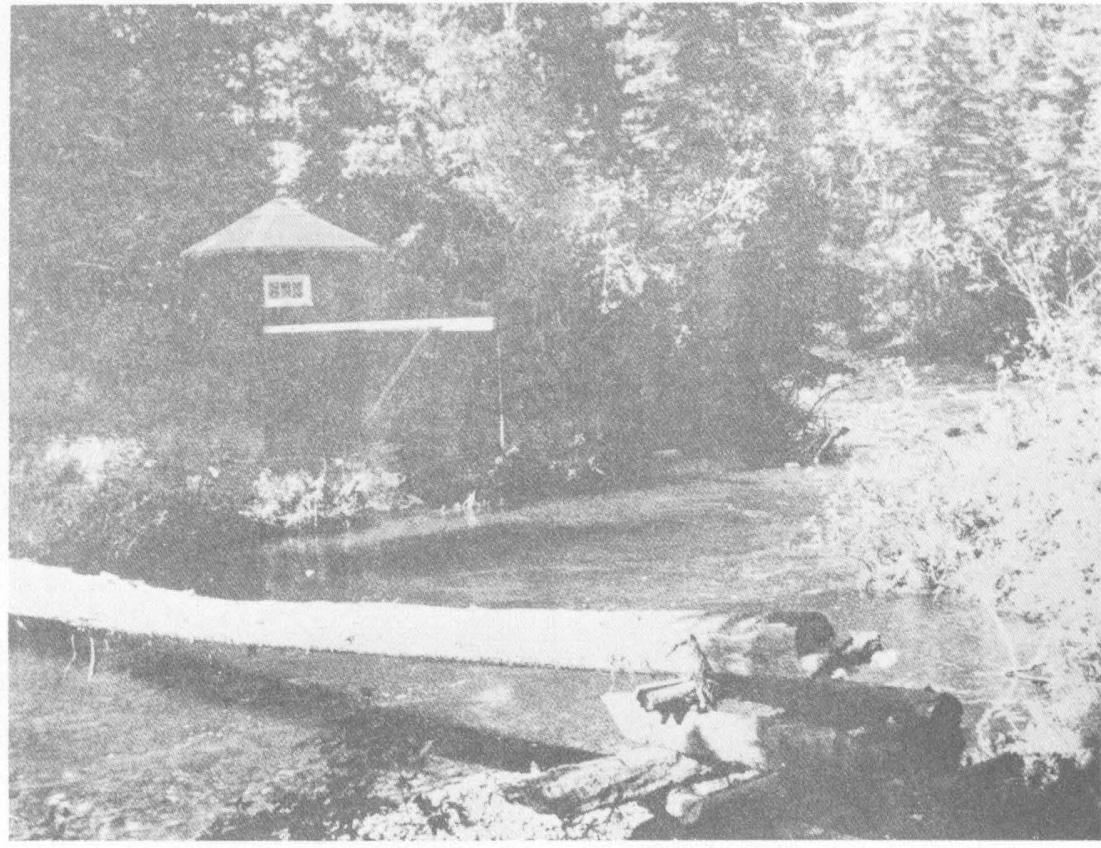

Figure 65.-Gaging station on Bear Creek near Essex, Mont., looking upstream, June 26, 1948.

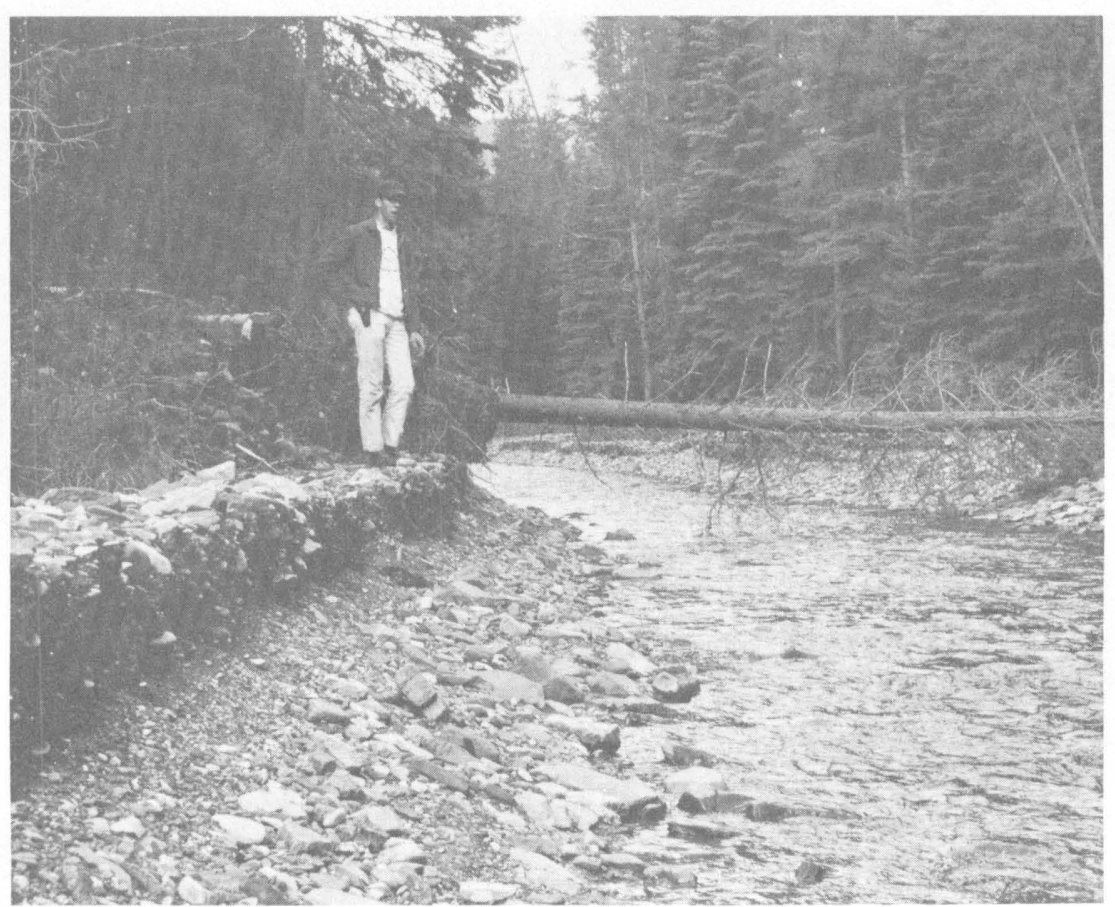

Figure 66.-View of Bear Creek near the gaging-station site on September 5 1964, showing erosion along channel sides. 
MIDDLE FORK FLATHEAD RIVER AT ESSEX, MONT.

On the Middle Fork Flathead River at Essex, below the mouth at Bear Creek, the gaging station and a highway bridge were destroyed by the flood. Datum that could have been used to survey the eroded channel was not recovered, but qualitative observations of channel erosion and deposition were made near the gaging station site. The drainage area at this site is 510 square miles, and the maximum discharge during the flood was 75,300 cfs. For about a quarter of a mile upstream from the bridge site and U.S. Highway 2 crossing, the channel had been widened about 135 feet and a house was left hanging over the edge of an 8-foot high raw cutbank. On the right bank and downstream from the highway crossing, fine sand and silt had been deposited in a Forest Service campground to a depth of 5 to 6 feet (fig. 67). Estimates of the depth of deposition were aided by the near burial by sediment of fireplaces in the campground. The fine sediment may have been derived from erosion of the left bank immediately upstream.

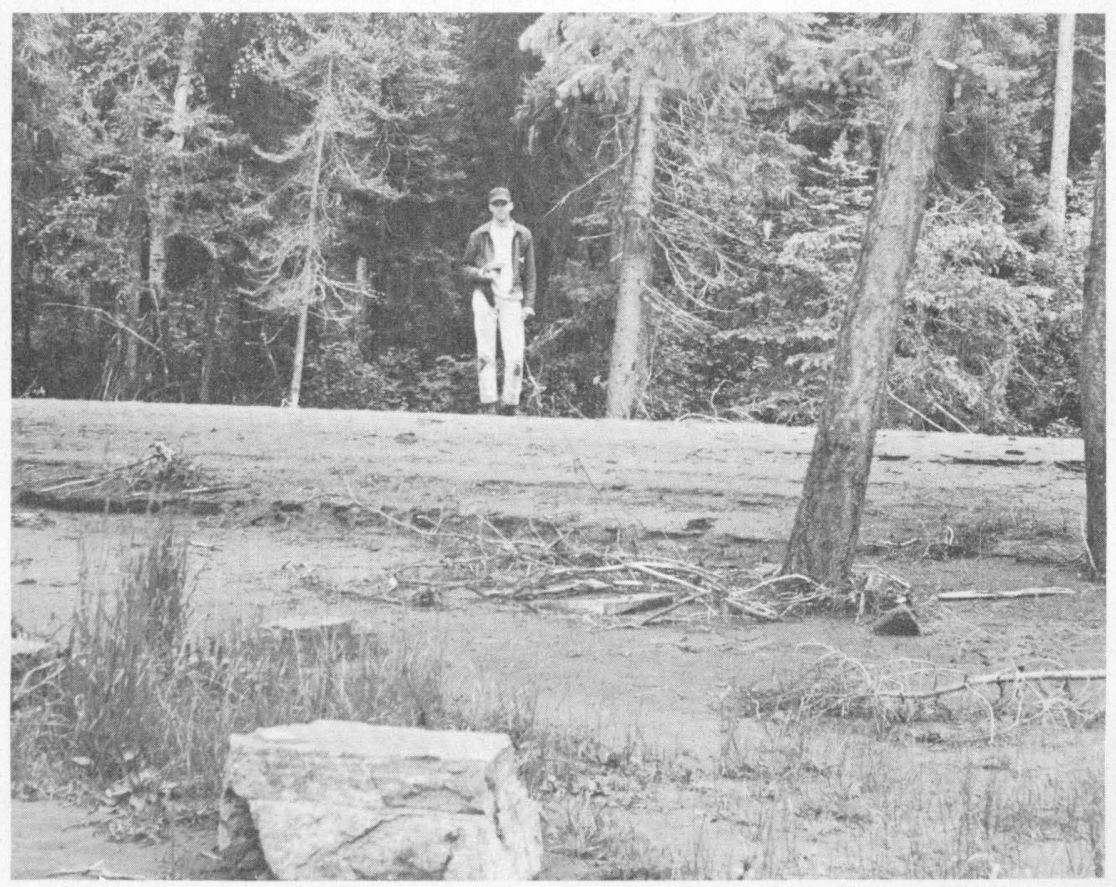

Figure 67:-View of flood plain of Middle Fork Flathead River at Essex, Mont., showing deposition of fine-grained material in Forest Service campground. 
TWO MEDICINE RIVER NEAR EAST GLACIER, MONT

On the east side of the Continental Divide, the channel erosion was equally as severe as on the west side and in some places was more spectacular because of the fallure of dams The gaging station site on Two Medicine River near East Glacier is a quarter of a mile downstream from Lower Two Medicme Lake Dam and reservoir on a drainage area of 511 square miles Comparison of channel erosion with rainfall amounts and intensities or runoff is not meaningful because the greater pait of the erosion and deposition in the valley is due to the fallure of the dam and the subsequent extremely high peak discharge Nevertheless, the channel changes are noteworthy as an example of the erosional forces of the flood The peak discharge at the gaging station was 63,500 cfs Prior to the 1964 flood the maximum known discharge was $1,390 \mathrm{cfs}$ in 1918 The channel at the gaging site was not deepened much by the flood presumably because of the rock control. However, the width of the channel was mcreased nearly fourfold (fig 68) Much of the vegetation along the banks was removed by the flood ('fig 69) and cobbles up to 12 inches in longest dimension were deposited on the flood plain (fig 70)

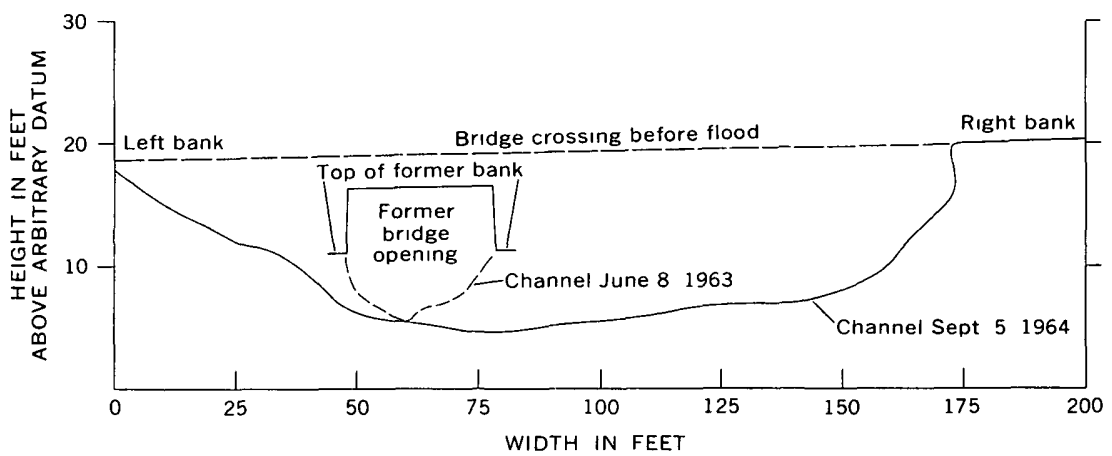

Figure $68-$ Channel cross section on Two Medicine River near East Glacier, Mont 


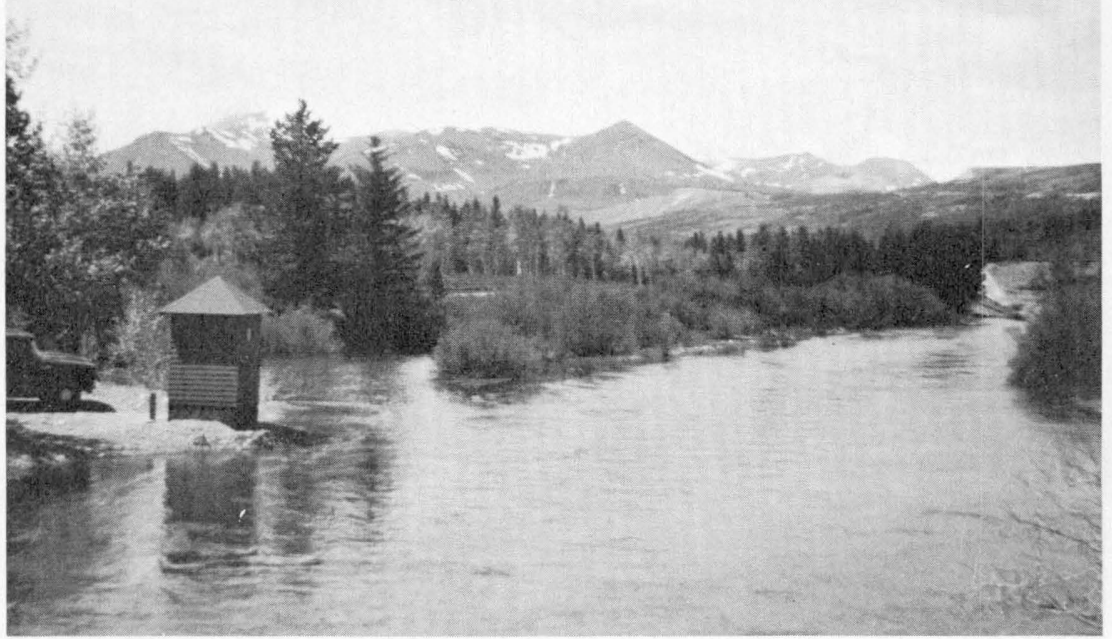

A, View on June 8, 1963.

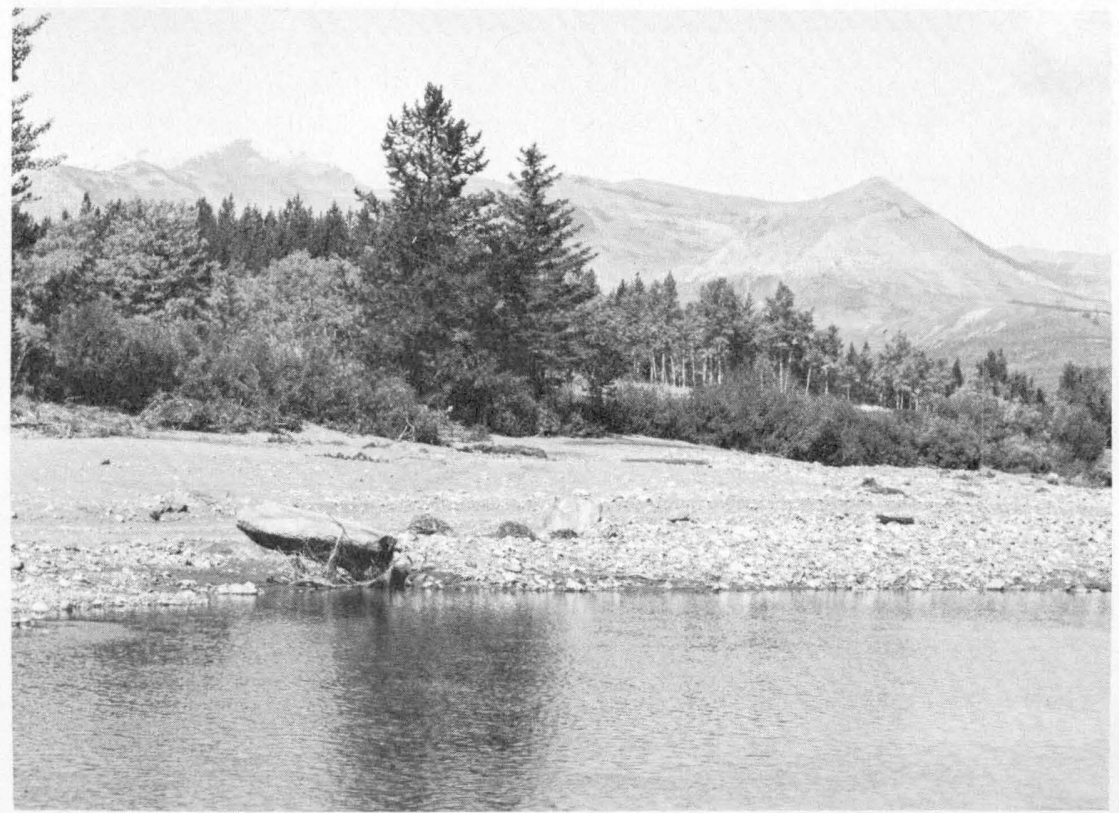

$B$, View on September 5, 1964. Two tall conifers in middle background appear on $A$ to the right gage house. Coarse debris was deposited by the flood of June 1964 .

Figure 69.-GAGING STATION ON TWO MEDICINE RIVER NEAR EAST GLACIER, MON'T. 


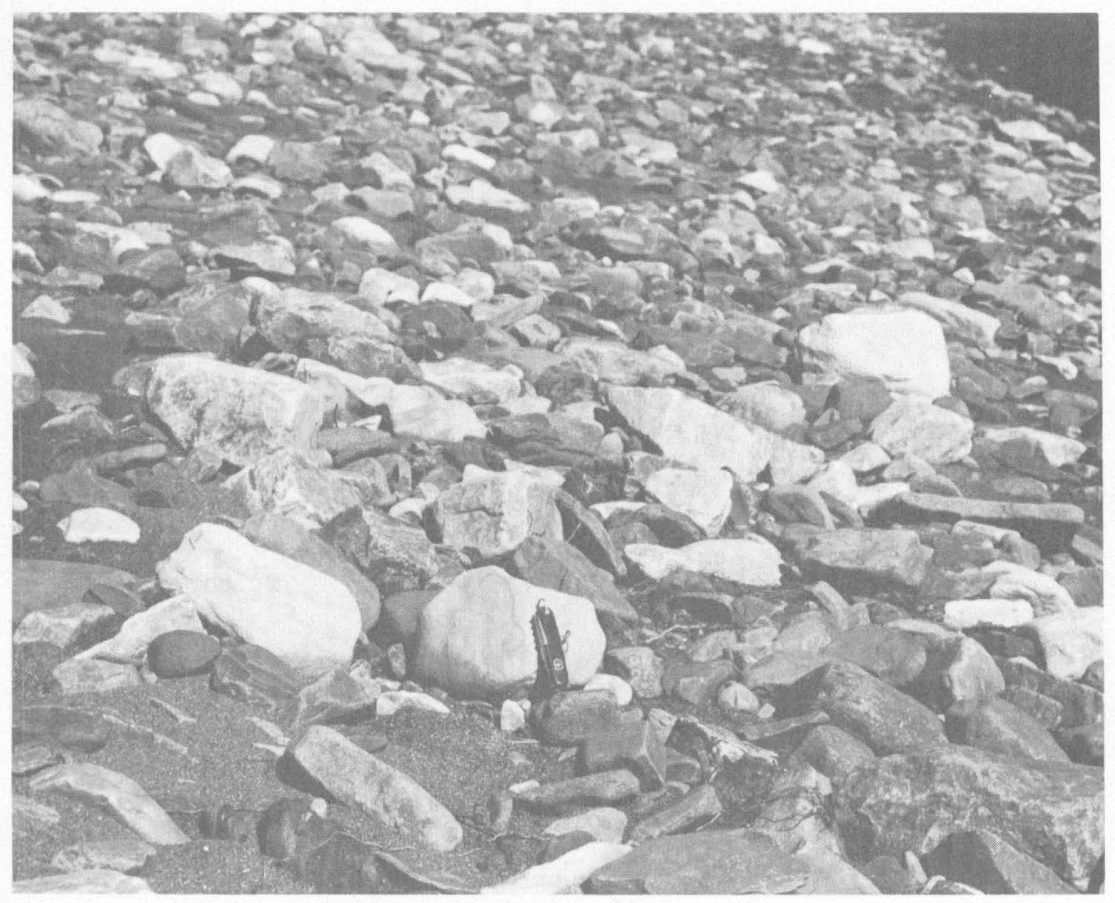

Figure 70.-Cobbles that were transported onto flood plain of Two Medicine River near East Glacier, Mont., by the flood. 


\section{NORTH FORK SUN RIVER NEAR AUGUSTA, MONT.}

The North Fork Sun River heads on the Continental Divide at an altitude of about 8,500 feet and drains an area of 258 square miles of heavily forested, rugged mountain country The gaging station is in a narrow, steep-sided valley. The channel floor is covered by coarse gravel and boulders. The maximum discharge during the flood was 51,100 cfs As shown in figure 71 the channel was widened and deepened several feet at the gagmg station cableway The maximum channel deepening was 55 feet, and the channel was widened about 25 feet. Although the flood stage rose higher than the bank on the left side, there is no indication of scour or fill on the low terrace

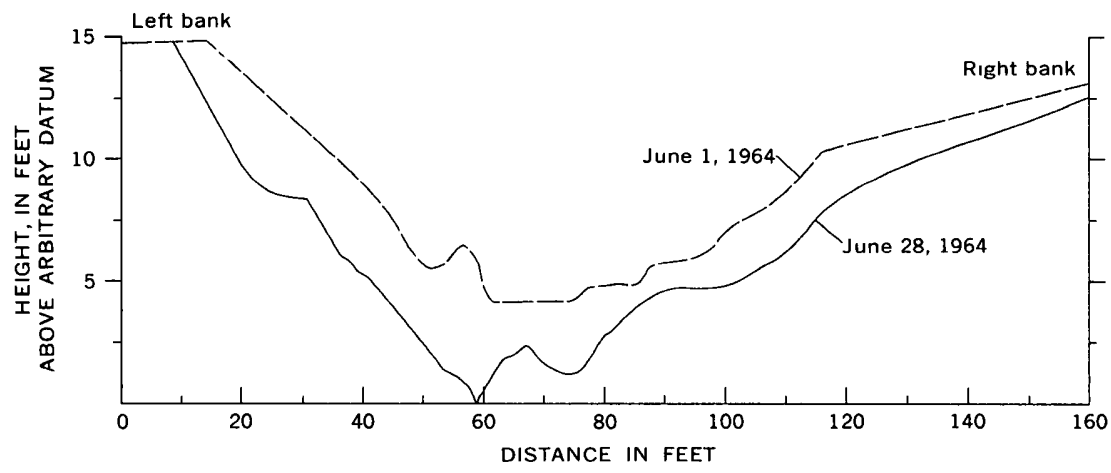

Figure 71 - Channel cross section on North Fork Sun River near Augusta, Mont 


\section{TETON RIVER NEAR DUTTON, MONT.}

On the plains east of the Rocky Mountams, the Teton River is representative of the rivers affected by the flood At the gaging station nea Dutton, Mont, the 1964 peak discharge was 71,300 cfs as compared with the previously known maximum discharge of 1,310 cfs The dramage area at the sur reyed cross section is 1,308 square miles The valley is wide and flat with few obstructions to flow In spite of the large flood there was very little scour in the chamel, and the widening was undoubtedly due to scour around the bridge abutments before the bridge was washed out (fig 72) In a study of erosion caused by floods of 1955 in Connecticut, Wolman and Eller (1958) found that where channel width was small compared to valley width, scour was generally slight This condition seems to be true for the Teton River near Dutton where the channel is less than 15 percent of the valley width The flood plam showed no evidence of scour, eren though it was completely mundated in the reach exammed

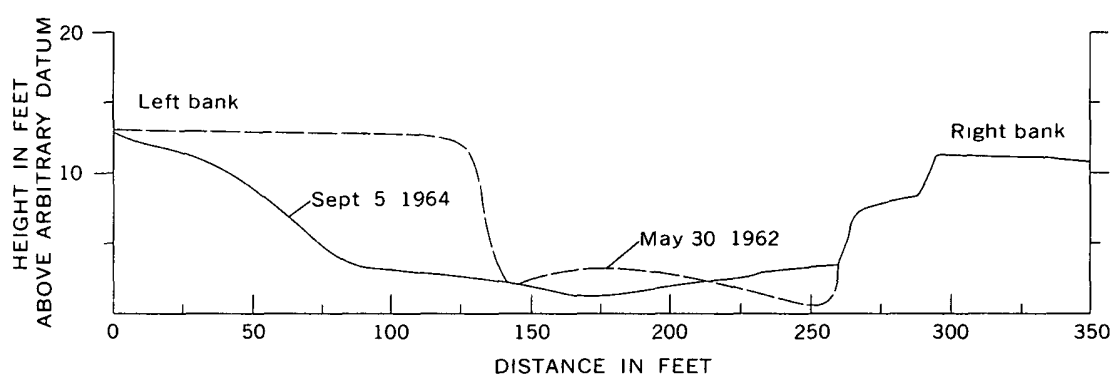

Figt, RE 72 - Channel cioss section on the Teton Riv er near Dutton. Mont

\section{DEPOSITION CAUSED BY FAILURE OF SWIFT DAM ON BIRCH CREEK}

The floods in the valley of Buch Creek were extremely severe because of the talure of Swift Dam and the dischange of the contents of Switt Reservon into the valley The maximum capacity of the 1eservolı was approximately 30,000 acre-ft, and evidence suggests that the dam falled suddenly The peak discharge of 881,000 cfs from an ar ea of 105 square miles was determmed by indırect measurements near Dupuyes, Mont, which is 17 miles downstream The force of 
the flood was remarkably demonstrated on the valley floor of Birch Creek in the half-mile reach directly below the dam. Several large blocks of rockfill material from the dam were moved a quarter to half a mile along the valley floor without being broken up. The stratification in the fill material was still visible in these large blocks in September 1964 (fig. 73). The largest block observed contained approximately 475 cubic yards of material and several others exceeded 100 cubic yards. The angular rock fragments in the fill material from the dam contrast sharply with the rounded cobbles and gravel of the flood plain on which they came to rest. Farther downstream on Birch Creek north of Valier, the channel was widened approximately 70 feet near the bridge crossing, and scour of the channel bed into bedrock probably exceeded 5 feet.

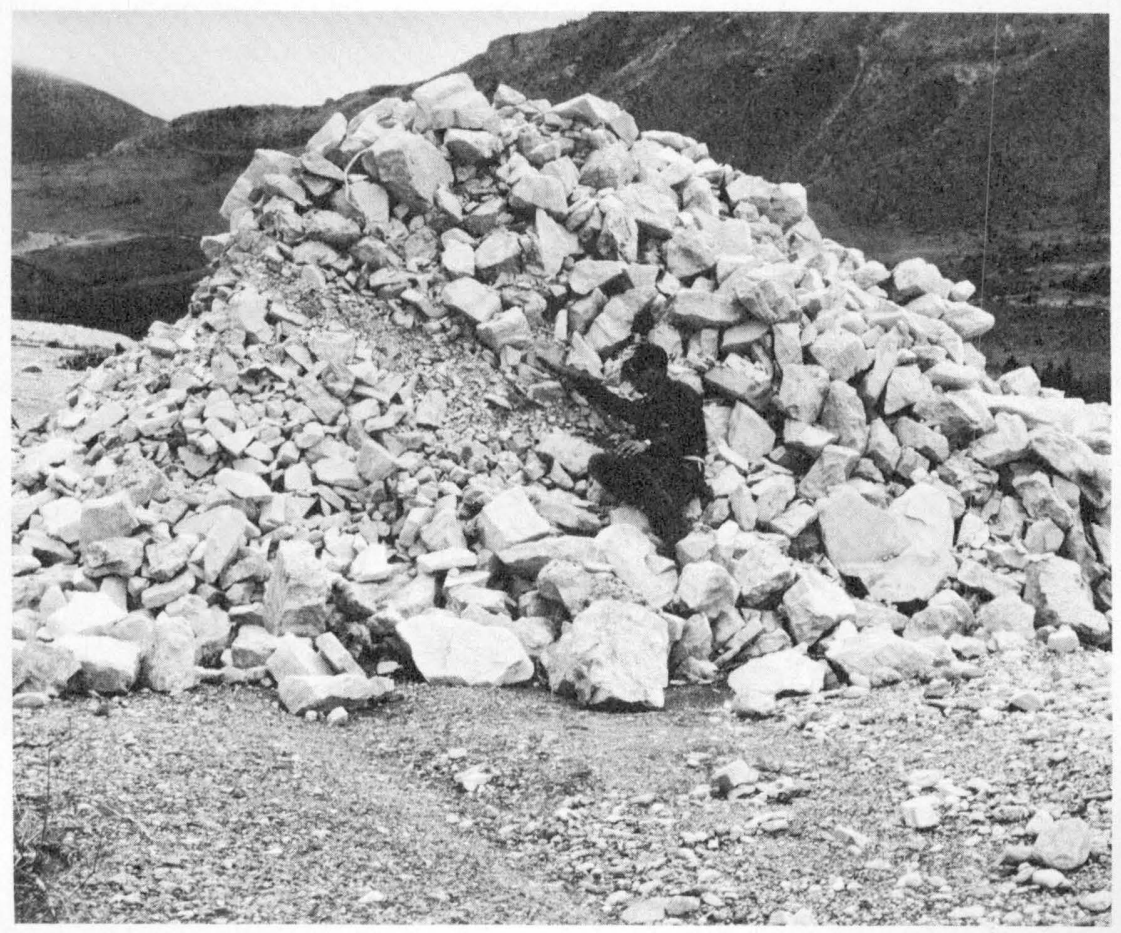

Figure 73.-Block of earthfill material from Swift Dam on Birch Creek that was carried intact from the damsite downstream about one-half mile by the flood. Stratification of earth fill is still discernible. Note the contrast in the blocky material from the dam and the rounded cobbles on the flood plain. 


\section{DETERMINATION OF FLOOD DISCHARGES}

The operation of a stream gaging station consists principally of the measurement of stage and discharge and the definition of the stagedischarge 1elation from which discharge can be calculated for a given stage The development of a stage-discharge relation is based upon current-meter measurements throughout the range of stage experienced, or through a sufficient part of the range so that the discharge corresponding to the maximum stage can be obtained by a reasonable extension of the stage-discharge relation, or rating curve Short extensions of a rating curve are usually made by logarıthmic plotting, from velocity-area studies, or by the use of other hydraulic or hydrologic principles.

Because of the record-breaking magnitude of the June 1964 floods, it was impossible to obtain current-meter measurements at or near peak stage at many of the gaging stations In some places, measuring facilities were destroyed, in others, access roads and bridges were flooded or washed out; and in some of the small streams, the durations of the flood peaks were too short to permit measurement.

For many of the gaging stations at which no high-water currentmeter measurements were made and for ungaged sites where peak discharge data were desired, peak discharges were obtained by slope-area measurements, contracted-opening measurements, or other types of indirect discharge measurements These indirect measurements are based on channel geometry and high-water profiles obtained by field survey and are computed by established hydraulic principles They aro indirect only in the sense that the data are collected subsequent to the passage of the peak discharge A general description of the mdirect measurement methods used by the Geological Survey is given by Johnson (1936), Dalrymple and others (1937), and Corbett and others (1943) More detalled information concerning the latest techniques is avallable in recent reports by Kindsvater and others (1953), Bodhaine (1963), and Tracy (1957)

\section{SUMMARY OF FLOOD STAGES AND DISCHARGES}

Maximum stages and discharges at 204 gaging statıons, crest-stage stations, miscellaneous sites, and reservolr statıons are summarized in table 19 The reference numbers 11 the table correspond to those on the location map (fig. 2) and aid in locating the sites at which peak discharges were determined

The derivation of the maxima data is explained in the station descriptions for each site The peak discharges in table 19 are those ac- 
tually determined; that is, no adjustments for storage, regulation, or diversion have been made For reservoir stations the maximum stage and contents are given, and for some, the computed peak inflow is given

Explanation of data in the 13 columns in table 19 follows

Number.-The number by which each station is identified at references in this report. The numerical order follows the Geological Survey's standard downstream order of listing stations

Permanent station number - The number used in the Geological Survey's water-supply papers of surface-water supply in the United States and the annual reports of surface watel records of Montana Blank spaces in the column indicate that a station is at a miscellaneous site or is a station operated by Canada, and no number has been assigned to it. The number for each station includes the part (Geological Survey's geographical division of principal river basins) numbei Station 1-19 are in Part 5 (Hudson Bay basin), stations 20-142 are in Part 6-A (Missourı River basm above Sioux City, Iowa), and stations 143-204 are in Part 12 (Pacific slope basins in Washington and upper Columbia River basin).

Stream and place of determination.-The permanent name adopted for the site to which the listed data apply, each name is unique

Drainage area - The gross drainage area, in square miles, above the station site as determined by the topography

The last nine columns of the table give data for all known floods at the site

Perrod.-The period of known floods prior to June 1964 This period does not necessarily correspond to that in which continuous records of discharge were obtamed, but for many records it extends back to an earlier date

Year-The calendar year, in the per od of known floods before June 1964, of the maximum stage or discharge

Date.-The date of the maximum stage or discharge during the floods of June 1964

Gage height and discharge-Data in each pan of columns arc associated with the year or date in the preceding column The 1964 peak dischaıges, in cubıc feet per second per square mile, have been given for sites not significantly affected by regulations or diversions

Recurrence interval - The average interval of time in which the peak discharge of June 1964 can be expected to be equaled or exceeded once Where the recurrence interval is greater than 50 years, the ratio of the peak discharge to the discharge of the 50-year flood is shown 


\section{EXPLANATION OF STATION DATA}

The main purpose of a flood report is presentation of stage and discharge data on streams These data are presented in the following section in sufficient detall so that the hydrographs of the flood peaks may be accurately constructed The hydrologist who needs more detaled data may find them in the Helena district office of the Geological Survey

The data consist of a description of the station or site, a table showing the dally discharge at gaging stations for May-June 1964, and tables of stages and discharges at indicated times for many of the gaging stations

The station description gives information relative to the location of the gage, size of the dranage basm above the gage, nature of the gage-height record obtamed durmg the per lod covered by this report, datum of gage, definition of the stage-discharge selation, maximum stage and discharge durmg the June 1964 floods and previous maximum during the period of record, maxima data for floods outside the period of record, effect of regulation and divession, and other per timent general information

The table of darly mean dischar ge gives data for the 2-month period, May-June 1964, to covel not only the per od of major flooding but a sufficient length of time to show discharges during antecedent and recession periods. The monthly figures of the table show the monthly mean discharge, in cubic fect per second, the rolume of monthly runoff, in acre-feet, and the volume of monthly 1 unoff, 11 mches, at selected stations. Monthly figures for a few stations downstream from a reservolr have been adjusted for change m contents of the reser roll

The table of stages and dischar ges at indicated tumes gives sufficient data so that hydrographs of stage and dischange can be drawn. The period of time covered is fiom prior to the start of the major rise to an arbitraly y rutoff point on the recession and is not the same for all stations.

The stiges and associated dischanges gilen should not be used in preparation of a stage-dischan ge relation (r atmg curve) for use outside the flood period For many stations the relation used to compute the discharge was shifted from the basic ratme tor ranous reasons, such as backwater from debris blockage or other changes in control conditions. 
Table 19 --Summary of flood stages and discharges

\begin{tabular}{|c|c|c|c|c|c|c|c|c|c|c|c|c|}
\hline \multirow{3}{*}{ No } & \multirow{3}{*}{$\begin{array}{l}\text { Permanent } \\
\text { station } \\
\text { number }\end{array}$} & \multirow{3}{*}{ Stream and place of determination } & \multirow{3}{*}{$\begin{array}{l}\text { Drainage } \\
\text { area } \\
(\mathrm{sq} \mathrm{mi})\end{array}$} & \multicolumn{4}{|c|}{ Maximum previously known } & \multicolumn{5}{|c|}{ Maximum June 1964} \\
\hline & & & & \multirow[b]{2}{*}{ Period } & \multirow[b]{2}{*}{ Year } & \multirow{2}{*}{$\begin{array}{l}\text { Gage } \\
\text { he1ght } \\
(\text { feet })\end{array}$} & \multirow[b]{2}{*}{$\begin{array}{l}\text { Discharge } \\
\text { (cfs) }\end{array}$} & \multirow[b]{2}{*}{ Day } & \multirow[b]{2}{*}{$\begin{array}{c}\text { Gage } \\
\text { helght } \\
(\text { feet) }\end{array}$} & \multicolumn{3}{|c|}{ Discharge } \\
\hline & & & & & & & & & & $\mathrm{Crs}$ & $\begin{array}{l}\text { Cfs per } \\
\text { sq mi }\end{array}$ & {$\left[\begin{array}{l}\text { Recur- } \\
\text { rence } \\
\text { lnterval } \\
\text { (years) }\end{array}\right.$} \\
\hline \multicolumn{13}{|c|}{ Saskatchewan R1ver basin } \\
\hline$\frac{1}{2}$ & $\begin{array}{l}5-100 \\
5-107\end{array}$ & $\begin{array}{l}\text { Belly River at International boundary } \\
\text { Mountain View Irrigation District Canal, } \\
\text { near Mountain View, Alberta }\end{array}$ & $\begin{array}{l}748 \\
-\end{array}$ & $\begin{array}{l}1947-64 \\
1935-64\end{array}$ & $\begin{array}{l}1953 \\
1961\end{array}$ & -666 & $\begin{array}{l}2,450 \\
\text { b } 155\end{array}$ & $\begin{array}{l}8 \\
8\end{array}$ & 1016 & $\begin{array}{r}12,000 \\
\text { b } 162\end{array}$ & 160 & a 310 \\
\hline 3 & $5-110$ & Belly River near Mountain View, Alberta & 121 & $\begin{array}{c}1908 \\
1911-64 \\
1947-64\end{array}$ & $\begin{array}{l}1908 \\
1953 \\
1954\end{array}$ & $\begin{array}{rr}12 & \\
6 & 64 \\
6 & 51\end{array}$ & $\begin{array}{l}\text { (c) } \\
4,500 \\
2,710\end{array}$ & $\dot{8}$ & i1 40 & $1 \overline{6}, 400$ & $\overline{136}$ & a $2{ }^{-} 93$ \\
\hline 4 & $5-115$ & $\begin{array}{l}\text { Waterton Rlver near international } \\
\text { boundary }\end{array}$ & 610 & $1947-64$ & 1954 & 651 & 2,710 & 8 & & & & \\
\hline $\begin{array}{l}5 \\
6\end{array}$ & $\begin{array}{l}5-120 \\
5-125\end{array}$ & $\begin{array}{l}\text { Street Creek at international boundary } \\
\text { Boundary Creek at international boundary }\end{array}$ & $\begin{array}{rl}6 & 0 \\
21 & 0\end{array}$ & $\begin{array}{l}1947-55 \\
2947-64\end{array}$ & $\begin{array}{l}1953 \\
1950 \\
1953\end{array}$ & $\begin{array}{rr}4 & 5 \\
-5 & 34 \\
- & \end{array} \mid$ & $-\begin{array}{l}437 \\
904\end{array}$ & $\begin{array}{l}8 \\
8 \\
-\end{array}$ & $\begin{array}{l}136 \\
-\end{array}$ & $\begin{array}{l}5,740 \\
5,930 \\
-\end{array}$ & $\begin{array}{l}957 \\
282 \\
-\end{array}$ & 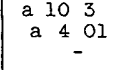 \\
\hline $\begin{array}{l}7 \\
8\end{array}$ & $5-\overline{130}$ & $\begin{array}{l}\text { Waterton Lake at Waterton Park, Alberta } \mathrm{d} / \\
\text { Waterton River near Waterton Park, } \\
\text { Alberta }\end{array}$ & $\begin{array}{l}146 \\
238\end{array}$ & $\begin{array}{l}1950-64 \\
1908-64\end{array}$ & $\begin{array}{l}1953 \\
1908\end{array}$ & $\begin{array}{r}4,1995 \\
\text { e9 } 5\end{array}$ & 24,000 & $\stackrel{\rho}{9}$ & $\begin{array}{r}4,20676 \\
922\end{array}$ & $2 \overline{5}, 700$ & 108 & a $2^{-} 72$ \\
\hline $\begin{array}{r}9 \\
10\end{array}$ & $\begin{array}{l}5-140 \\
5-145\end{array}$ & $\begin{array}{l}\text { Grinnell Creek near Many Glacier } \\
\text { Swiftcurrent Creek at Many Glacier }\end{array}$ & $\begin{array}{rl}3 & 47 \\
31 & 4\end{array}$ & $1949-64$ & $\begin{array}{l}1950 \\
1937\end{array}$ & $\begin{array}{r}345 \\
\mathrm{f} 689\end{array}$ & $\begin{array}{r}242 \\
2,250\end{array}$ & $\begin{array}{r}8 \\
8 \\
8\end{array}$ & $\begin{array}{r}488 \\
\mathrm{f} 1000\end{array}$ & $\begin{array}{r}536 \\
6,700 \\
\end{array}$ & $\begin{array}{l}154 \\
213\end{array}$ & 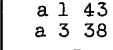 \\
\hline 11 & $5-155$ & Lake Sherburne at Sherburne & 637 & $1915-64$ & 1961 & 4,7881 & g 66,370 & 11 & $\begin{array}{c}4,78088 \\
-\end{array}$ & $\begin{array}{l}\text { g } 54,320 \\
\text { h } 10,000\end{array}$ & $\overline{157}$ & a $2-95$ \\
\hline $\begin{array}{l}12 \\
13\end{array}$ & $\begin{array}{l}5-160 \\
5-175\end{array}$ & $\begin{array}{l}\text { Swiftcurrent Creek at Sherburne } \\
\text { St Mary River near Babb }\end{array}$ & $\begin{array}{r}643 \\
278\end{array}$ & $\begin{array}{l}1912-64 \\
1902 \\
1911-25\end{array}$ & $\begin{array}{l}1916 \\
1902\end{array}$ & $\begin{array}{lll}\text { e } & 7 & 85 \\
\text { e } & 6 & 50\end{array}$ & $\begin{aligned} & 2,280 \\
& 9,300\end{aligned}$ & 11 & $\begin{array}{rr}8 & 37 \\
12 & 96\end{array}$ & $\begin{array}{r}12,360 \\
116,500\end{array}$ & 594 & a 156 \\
\hline 14 & $5-185$ & $\begin{array}{l}\text { St Mary Canal at st Mary Crossing, } \\
\text { near Babb }\end{array}$ & - & $1918-64$ & 1936 & - & b 767 & 7 & - & b 706 & - & - \\
\hline 15 & $5-190$ & $\begin{array}{l}\text { St Mary Canal at Hudson Bay Divide, near } \\
\text { Browning }\end{array}$ & - & $1917-64$ & 1937 & - & b 758 & 8 & - & b 816 & - & \\
\hline $\begin{array}{l}16 \\
17 \\
18\end{array}$ & $\begin{array}{l}5-200 \\
5-205 \\
-\end{array}$ & $\begin{array}{l}\text { Kennedy Creek near Babb } \\
\text { St Mary River at 1nternational boundary } \\
\text { Rolph Creek near Kimball, Alberta } d \text { f }\end{array}$ & $\begin{array}{r}606 \\
469 \\
906\end{array}$ & $\begin{array}{l}\text { jk 1905 } \\
1902-64 \\
1911-16\end{array}$ & $\begin{array}{l}\overline{-} \\
1908 \\
1953\end{array}$ & e $\begin{array}{r}-7275 \\
721\end{array}$ & $\begin{array}{r}- \\
40,000 \\
1,290\end{array}$ & $\begin{array}{l}8 \\
8 \\
8\end{array}$ & $\begin{array}{rr}12 & 06 \\
4 & 80\end{array}$ & $\begin{array}{r}15,000 \\
121,000 \\
630\end{array}$ & $\begin{array}{l}248 \\
-695\end{array}$ & $\begin{array}{c}\text { a } 456 \\
{ }_{1}^{-}\end{array}$ \\
\hline 19 & - & Lee Creek at Cardston, Alberta $\underline{d}$ / & 117 & $\begin{array}{l}1909-14 \\
1920-64\end{array}$ & 1951 & 1049 & 7,820 & 8 & 1259 & 11,400 & 974 & a 210 \\
\hline \multicolumn{13}{|c|}{ Missouri River main stem } \\
\hline 20 & $6-545$ & Missouri River at Toston & 14,669 & $\begin{array}{l}1890 \\
1910-16 \\
1941-64\end{array}$ & 1948 & 1177 & 32,000 & 12 & 1000 & 22,000 & 150 & 5 \\
\hline \multicolumn{13}{|c|}{ Deep Creek basin } \\
\hline 21 & $6-566$ & $\begin{array}{l}\text { Deep Creek below North Fork Deep Creek, } \\
\text { near Townsend }\end{array}$ & 877 & $1959-64$ & 1964 & 233 & 329 & 8 & 221 & 296 & 338 & 4 \\
\hline
\end{tabular}


Missour1 River main stem

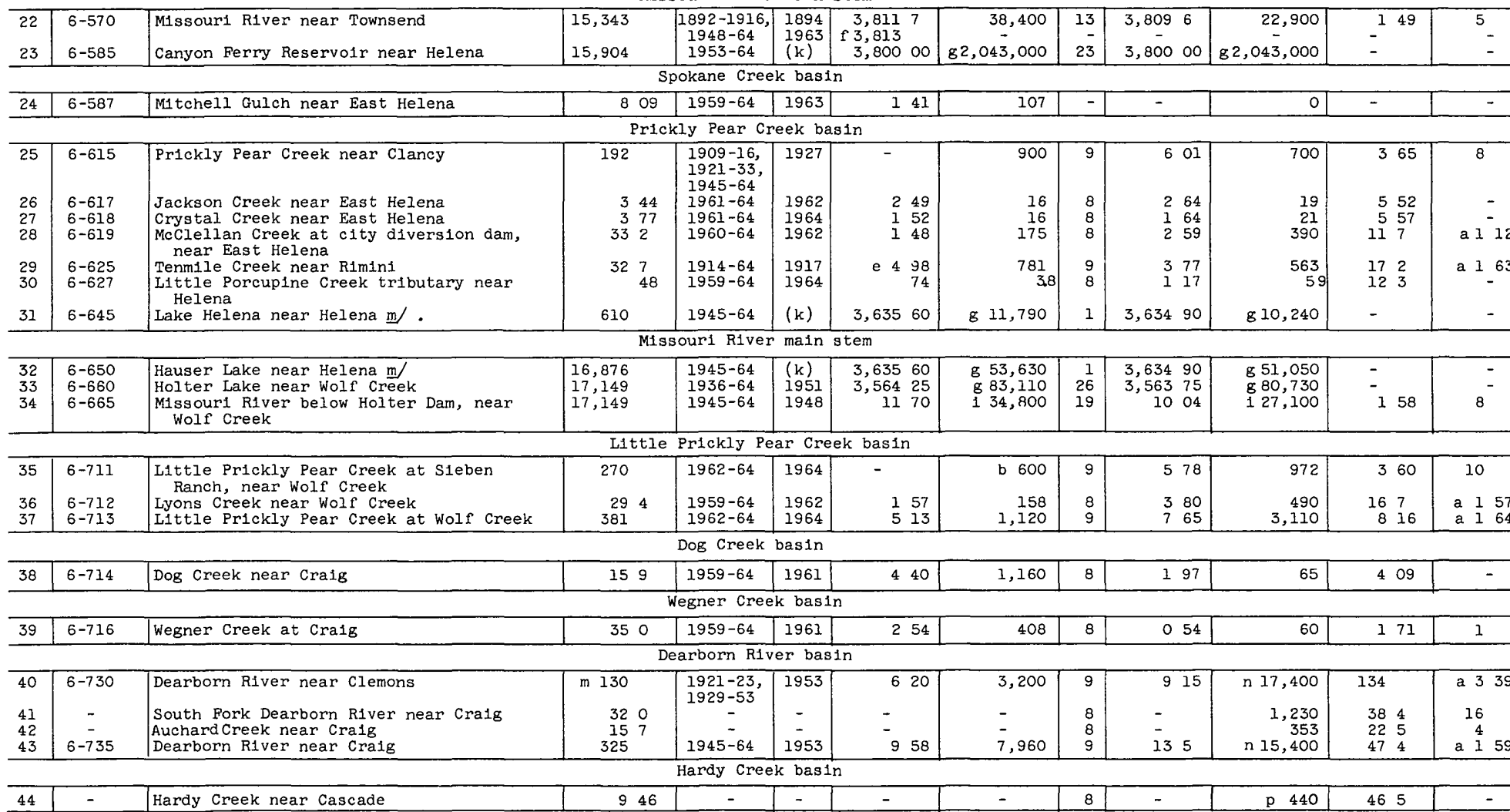

See footnotes at end of table 
Table 19 --Summary of flood stages and discharges--Continued

No

\begin{tabular}{|c|c|c|c|c|c|c|c|c|c|c|c|c|c|}
\hline \multicolumn{14}{|c|}{ Missouri River main stem } \\
\hline 45 & $6-740$ & Missouri River at Cascade & 18,493 & & $\begin{array}{l}1902-15 \\
1950-64\end{array}$ & 1908 & e 3,3542 & 54,250 & 26 & $m 3,34861$ & - & - & - \\
\hline \multicolumn{14}{|c|}{ Smith River basin } \\
\hline 46 & $6-750$ & $\begin{array}{l}\text { Sm1th River Reservoir near Wh1te Sulphur } \\
\text { Springs }\end{array}$ & 72 & & $\begin{array}{l}1938-50 \\
1959-64\end{array}$ & 1950 & 5,4886 & g 11,600 & $(\mathrm{k})$ & $5,488 \quad 45$ & 811,450 & - & - \\
\hline 47 & $6-756$ & $\begin{array}{l}\text { Five Mile Creek near White Sulphur } \\
\text { Springs }\end{array}$ & 6 & 00 & $1960-64$ & 1963 & 206 & 20 & 8 & 116 & 8 & 133 & - \\
\hline 48 & $6-760$ & Newland Creek near White Sulphur Springs & 6 & 74 & $\begin{array}{l}1946-53 \\
1960-64\end{array}$ & 1953 & 350 & 56 & 8 & 259 & 13 & 193 & - \\
\hline $\begin{array}{l}49 \\
50\end{array}$ & $\begin{array}{l}6-767 \\
6-768\end{array}$ & $\begin{array}{l}\text { Sheep Creek near Neihart } \\
\text { Nugget Creek near Neihart }\end{array}$ & & $\begin{array}{l}30 \\
48\end{array}$ & $\begin{array}{l}1960-64 \\
1959-64\end{array}$ & $\begin{array}{l}1964 \\
1964\end{array}$ & $\begin{array}{ll}1 & 67 \\
1 & 07\end{array}$ & $\begin{array}{l}78 \\
15\end{array}$ & $\begin{array}{l}8 \\
8\end{array}$ & $2 \frac{12}{77}$ & $\begin{array}{r}113 \\
10\end{array}$ & $\begin{array}{rl}21 & 3 \\
6 & 76\end{array}$ & - \\
\hline 51 & $6-770$ & Sheep Creek near White Sulphur Springs & & & $1941-64$ & 1953 & e 580 & 460 & 9 & 493 & 362 & $\begin{array}{ll}0 & 10 \\
6 & 65\end{array}$ & $15^{-}$ \\
\hline 52 & $6-775$ & Smith River near Eden & 1,594 & & $1951-64$ & $\begin{array}{l}1953 \\
1963\end{array}$ & $\begin{array}{rl}1046 \\
\mathrm{f} & 1250\end{array}$ & 12,300 & 10 & $\begin{array}{r}548 \\
-\end{array}$ & $-3,860$ & $\begin{array}{r}242 \\
-\end{array}$ & 17 \\
\hline $\begin{array}{l}53 \\
54\end{array}$ & $\begin{array}{l}6-777 \\
6-778\end{array}$ & $\begin{array}{l}\text { Smith River tributary near Eden } \\
\text { Goodman Coulee near Eden }\end{array}$ & 21 & $\begin{array}{l}63 \\
8\end{array}$ & $\begin{array}{l}1960-64 \\
1959-64\end{array}$ & $\begin{array}{l}1962 \\
1964\end{array}$ & $\begin{array}{r}72 \\
4 \quad 02\end{array}$ & $\begin{array}{r}45 \\
150\end{array}$ & $\begin{array}{l}8 \\
8\end{array}$ & $\begin{aligned} 24 \\
358\end{aligned}$ & $\begin{array}{r}1.4 \\
110\end{array}$ & $\begin{array}{l}86 \\
505\end{array}$ & - \\
\hline \multicolumn{14}{|c|}{ M1ssour1 River main stem } \\
\hline 55 & $6-782$ & Missour1 R1ver near Ulm & 20,941 & & $\begin{array}{c}1953 \\
1957-64\end{array}$ & $\begin{array}{l}1953 \\
1959 \\
1959\end{array}$ & $\begin{array}{r}17 \\
1126 \\
\mathrm{f} 1220\end{array}$ & $\begin{array}{l}35,000 \\
19,100 \\
-\end{array}$ & $\begin{array}{r}22 \\
-\end{array}$ & $\begin{array}{l}1444 \\
- \\
-\end{array}$ & $\begin{array}{l}127,500 \\
- \\
-\end{array}$ & $\begin{array}{ll}131 \\
- & \\
- & \end{array}$ & 3 \\
\hline 56 & - & $\begin{array}{l}\text { Missouri River above Sun River, at Great } \\
\text { Falls }\end{array}$ & 21,175 & & $1930-64$ & 1953 & 3,31784 & - & 10 & 3,3182 & - & - & - \\
\hline \multicolumn{14}{|c|}{ Sun River basin } \\
\hline 57 & $6-785$ & North Fork Sun River near Augusta & 258 & & $1911-12$, & 1948 & 703 & 4,840 & 8 & 1582 & 51,100 & 198 & a 557 \\
\hline $\begin{array}{l}58 \\
59\end{array}$ & $\begin{array}{l}6-790 \\
6-795\end{array}$ & $\begin{array}{l}\text { South Fork Sun River near Augusta } \\
\text { G1bson Reservolr near Augusta }\end{array}$ & $\begin{array}{l}252 \\
575\end{array}$ & & $\begin{array}{l}1911-12 \\
1930-64\end{array}$ & $\begin{array}{l}1911 \\
1940\end{array}$ & $\begin{array}{rr}4 & 6 \\
4,725 & 5\end{array}$ & $\begin{array}{r}2,740 \\
\text { g } 107,100\end{array}$ & $\begin{array}{l}8 \\
8 \\
8\end{array}$ & $4, \overline{732} 23$ & $\begin{array}{r}28,800 \\
\text { g } 116,400\end{array}$ & 114 & a 319 \\
\hline $\begin{array}{l}60 \\
61\end{array}$ & $\begin{array}{l}6-796 \\
6-800\end{array}$ & $\begin{array}{l}\text { Beaver Creek at Gibson Dam, near Augusta } \\
\text { Sun River near Augusta }\end{array}$ & $\begin{array}{r}20 \\
609\end{array}$ & & $\begin{array}{l}1959-64 \\
1889-90 \\
1904-64\end{array}$ & $\begin{array}{l}1962 \\
1916\end{array}$ & $\begin{array}{rl}2 & 45 \\
11 & 4\end{array}$ & $\begin{array}{r}496 \\
32,300\end{array}$ & $\begin{array}{l}8 \\
9\end{array}$ & ${ }^{-} 157$ & $\begin{array}{r}4,360 \\
159,700\end{array}$ & $\begin{array}{r}215 \\
98\end{array}$ & $\begin{array}{lll}\text { a } & 1 & 77 \\
\text { a } & 1 & 96\end{array}$ \\
\hline $\begin{array}{l}62 \\
63\end{array}$ & - & $\begin{array}{l}\text { South Fork willow Creek near Augusta } \\
\text { Sun River at State H1ghway } 287 \text {, near } \\
\text { Augusta. }\end{array}$ & $\begin{array}{r}26 \\
827\end{array}$ & & $\begin{array}{c}100 \\
-\end{array}$ & - & - & - & $\begin{array}{l}8 \\
9\end{array}$ & - & $\begin{array}{r}2,790 \\
146,700\end{array}$ & $\begin{array}{r}104 \\
565\end{array}$ & $\begin{array}{l}41 \\
2123\end{array}$ \\
\hline 64 & $6-835$ & Ford Creek near Augusta & 19 & 4 & $1906-12$ & 1909 & 55 & 1,230 & 8 & - & 2,700 & 139 & a 199 \\
\hline
\end{tabular}




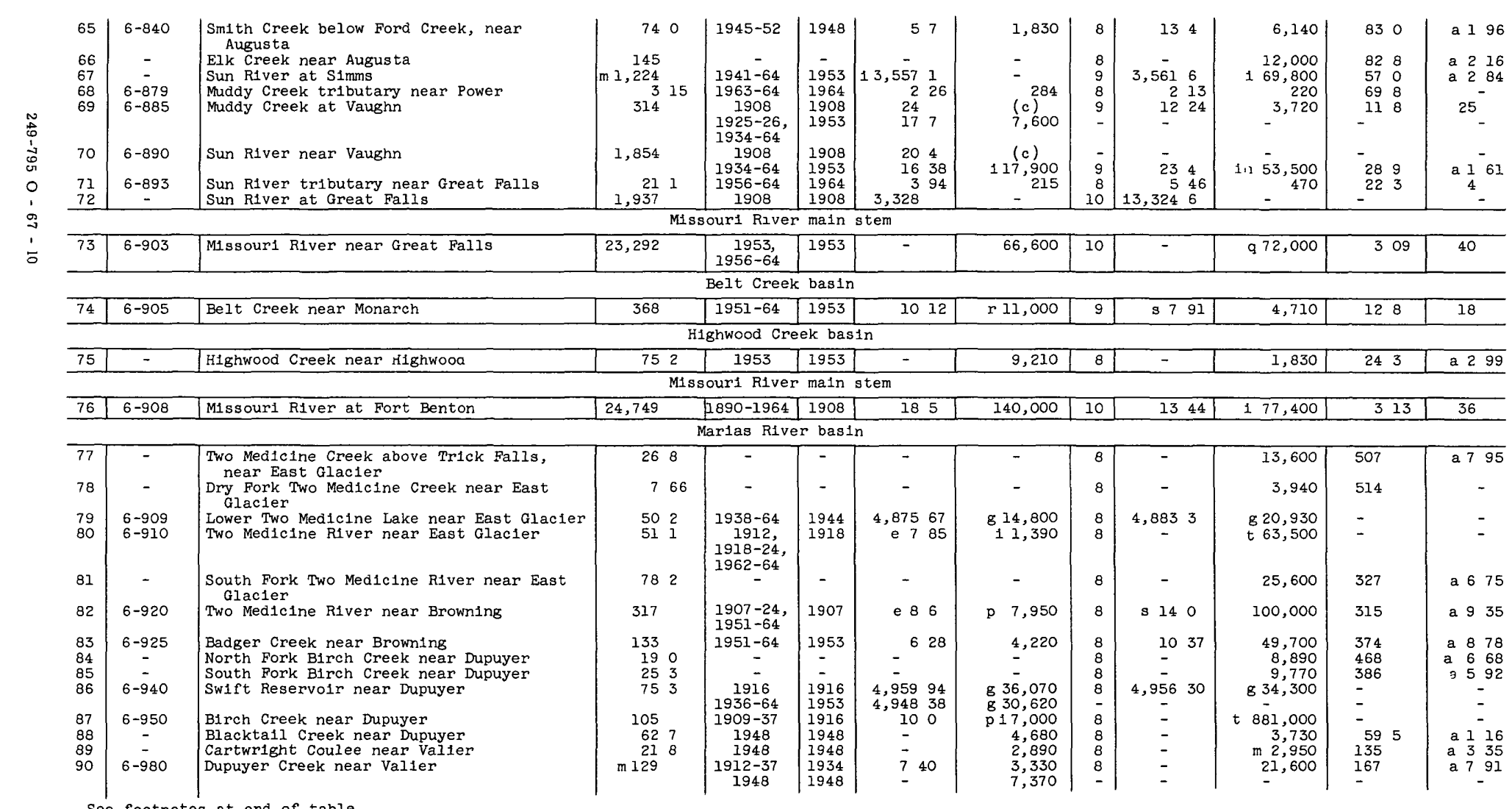


Table 19 --Summary of flood stages and discharges--Continued

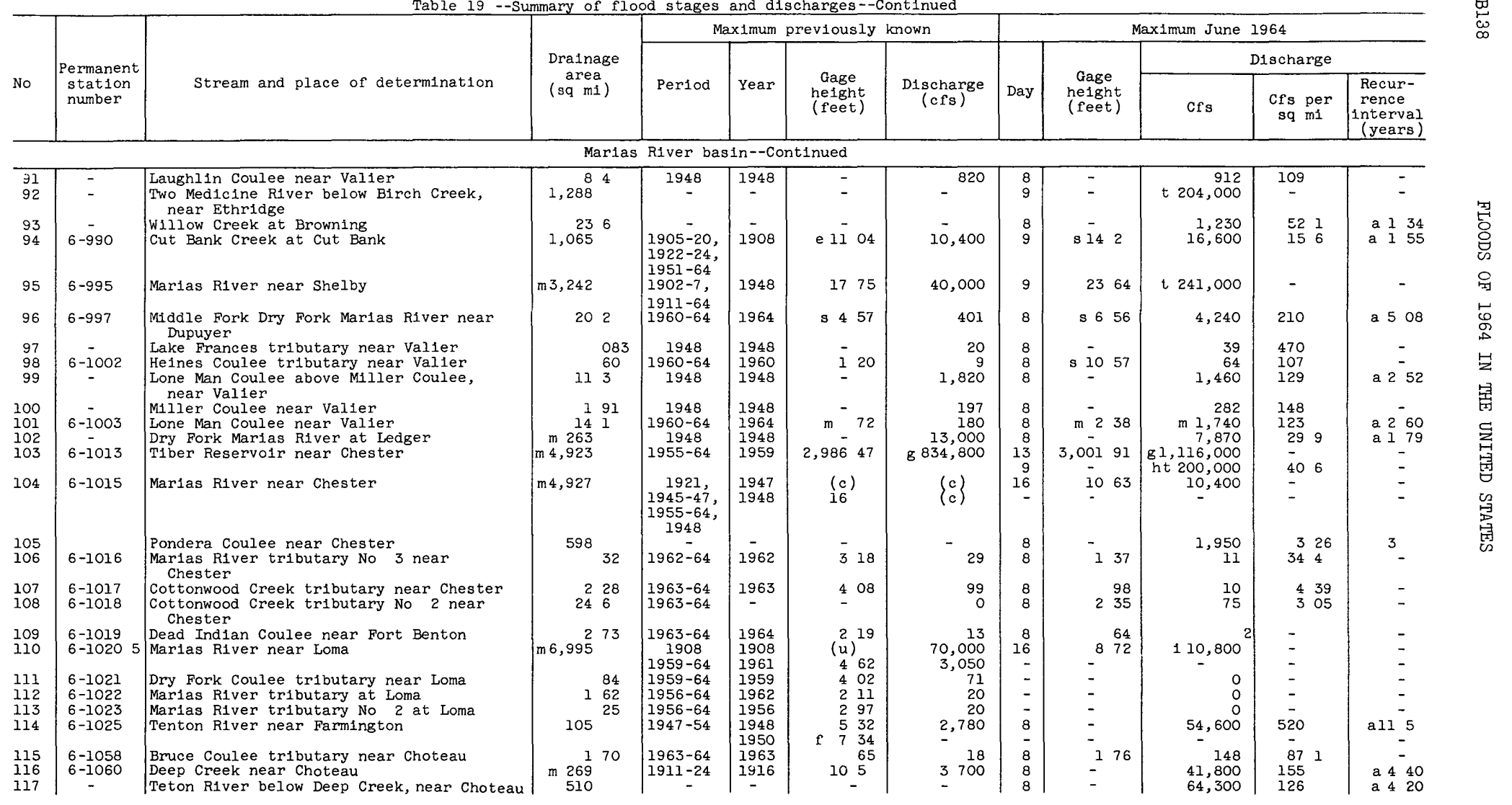




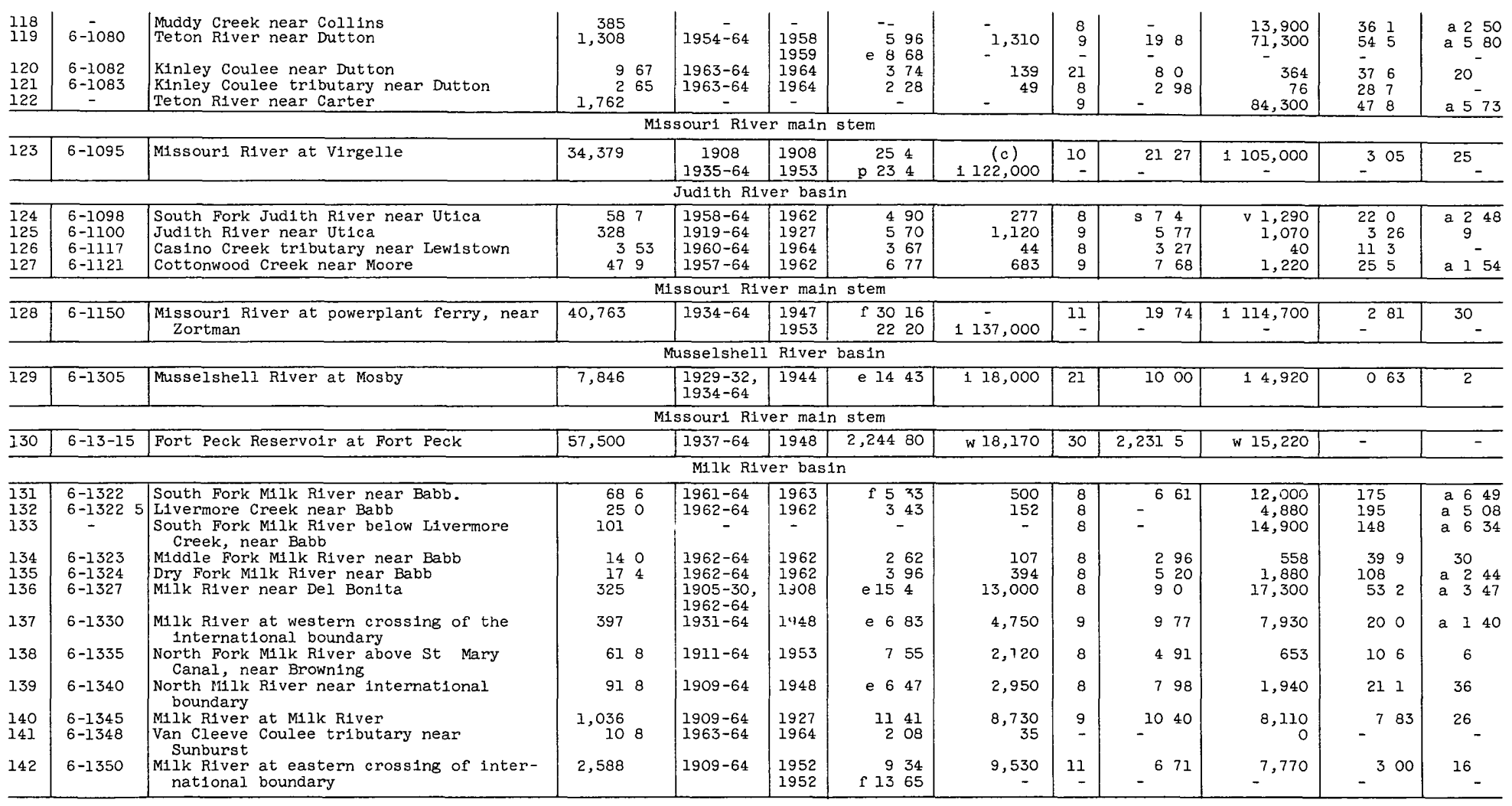

See footnotes at end of table 
Table 19 --Summary of flood stages and discharges--Continued

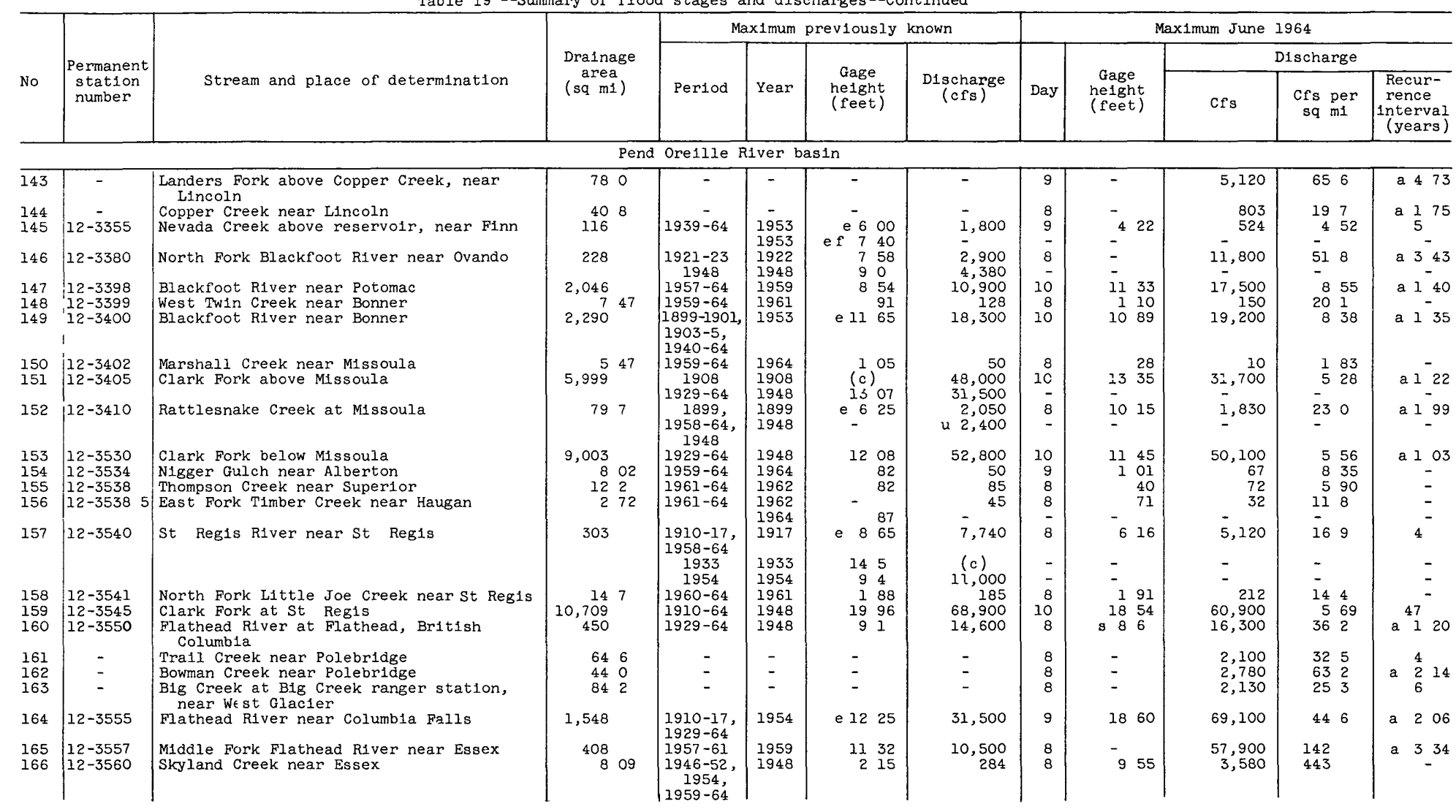




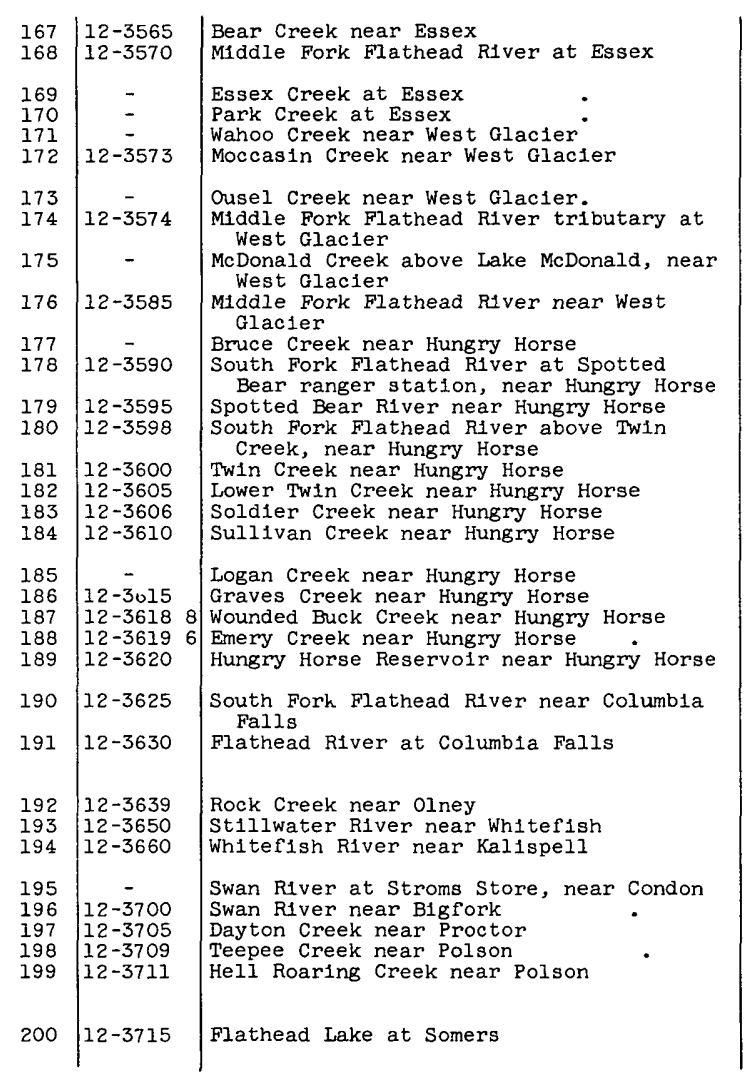

\begin{tabular}{|c|c|c|c|}
\hline $\begin{array}{r}207 \\
510^{7}\end{array}$ & $\begin{array}{l}1946-52 \\
1939-54,\end{array}$ & $\begin{array}{l}1948 \\
1954\end{array}$ & $\begin{array}{r}301 \\
127\end{array}$ \\
\hline $\begin{array}{rl}10 & 5 \\
39 & 4 \\
1 & 05 \\
1 & 97\end{array}$ & $\begin{array}{c}1950-64 \\
= \\
= \\
1959-64\end{array}$ & $\begin{array}{c}\bar{z} \\
\bar{z} \\
1960 \\
1961\end{array}$ & $\begin{array}{l}5 \\
z_{1}\end{array}$ \\
\hline $\begin{array}{l}292 \\
10\end{array}$ & $1960-64$ & $\begin{array}{l}-\overline{1} \\
1960\end{array}$ & $\begin{array}{r}140 \\
-\quad 27\end{array}$ \\
\hline 109 & - & - & - \\
\hline 1,128 & $1939-64$ & 1954 & 1301 \\
\hline $\begin{array}{r}160 \\
958\end{array}$ & $1948-57$, & $\overline{1948}$ & $-_{1400}$ \\
\hline $\begin{array}{r}184 \\
1,160\end{array}$ & $1948-56$ & 1954 & -740 \\
\hline $\begin{array}{rl}47 & 6 \\
22 & 2 \\
4 & 77\end{array}$ & $\begin{array}{c}1948-56 \\
1948-56 \\
-\end{array}$ & $\begin{array}{c}1954 \\
1948\end{array}$ & $\begin{array}{r}833 \\
-525 \\
-\quad\end{array}$ \\
\hline 713 & $\begin{array}{l}1948-56, \\
1959-64\end{array}$ & 1954 & 529 \\
\hline $\begin{array}{r}518 \\
270 \\
136 \\
264 \\
1,654\end{array}$ & $\begin{array}{c}1948-56 \\
- \\
- \\
1951-64\end{array}$ & $\begin{array}{c}\overline{1} \\
1950 \\
\overline{-} \\
1955\end{array}$ & $\begin{array}{c}\bar{e} 570 \\
\bar{z} \\
3,56140\end{array}$ \\
\hline 1,663 & 1910-16, & 1916 & e 166 \\
\hline 4,464 & $\begin{array}{c}1894 \\
1922-23, \\
1928-64\end{array}$ & $\begin{array}{l}1894 \\
1948\end{array}$ & $\begin{array}{ll}22 & 7 \\
19 & 08\end{array}$ \\
\hline $\begin{array}{l}618 \\
524 \\
170\end{array}$ & $\begin{array}{l}1968-64 \\
1930-64 \\
1930-50 \\
1928-50\end{array}$ & $\begin{array}{l}1964 \\
1948 \\
1948 \\
1950\end{array}$ & $\begin{array}{r}129 \\
2090 \\
-\quad 4 \quad 45\end{array}$ \\
\hline $\begin{array}{rl}146 & \\
671 & \\
20 & 9 \\
2 & 55 \\
6 & 41\end{array}$ & $\begin{array}{c}1948 \\
1922-64 \\
1959-64 \\
1960-64 \\
1917-32, \\
1948, \\
1960-64\end{array}$ & $\begin{array}{l}1940 \\
1948 \\
1961 \\
1961 \\
1917\end{array}$ & $\begin{array}{r}440 \\
712 \\
3400 \\
90 \\
e 24\end{array}$ \\
\hline 7,086 & $\begin{array}{c}960-64 \\
1894 \\
1909-64\end{array}$ & $\begin{array}{l}1894 \\
1933\end{array}$ & $\begin{array}{l}2,900 \\
2,896 \quad 26\end{array}$ \\
\hline
\end{tabular}

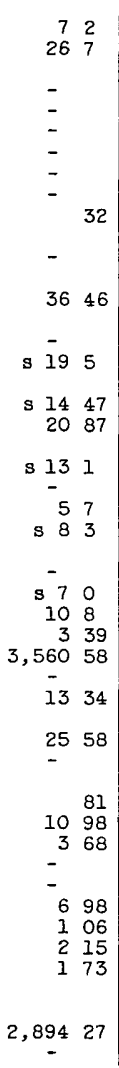

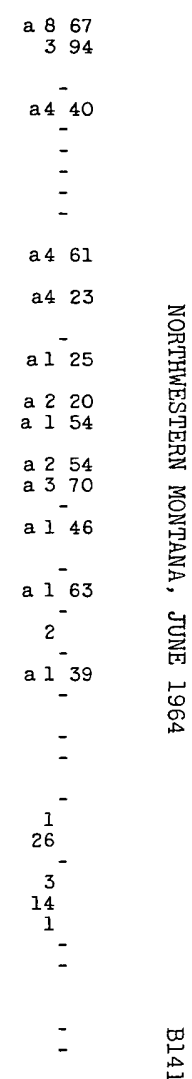


Table 19 --Summary of flood stages and discharges--Continued

\begin{tabular}{|c|c|c|c|c|c|c|c|c|c|c|c|c|}
\hline \multirow[b]{3}{*}{ No } & \multirow{3}{*}{$\begin{array}{l}\text { Permanent } \\
\text { station } \\
\text { number }\end{array}$} & \multirow[b]{3}{*}{ Stream and place of determination } & \multirow{3}{*}{$\begin{array}{l}\text { Drainage } \\
\text { area } \\
\text { (sq } \mathrm{mi} \text { ) }\end{array}$} & \multicolumn{4}{|c|}{ Maximum previously known } & \multicolumn{5}{|c|}{ Maximum June 1964} \\
\hline & & & & \multirow[b]{2}{*}{ Period } & \multirow[b]{2}{*}{ Year } & \multirow{2}{*}{$\begin{array}{c}\text { Gage } \\
\text { ne1ght } \\
\text { (feet) }\end{array}$} & \multirow[b]{2}{*}{$\begin{array}{c}\text { Discharge } \\
(\mathrm{cfs})\end{array}$} & \multirow[b]{2}{*}{ Day } & \multirow[b]{2}{*}{$\begin{array}{c}\text { Gage } \\
\text { helght } \\
\text { (feet) }\end{array}$} & \multicolumn{3}{|c|}{ Discharge } \\
\hline & & & & & & & & & & Crs & $\begin{array}{l}\text { Crs per } \\
\text { sq m1 }\end{array}$ & \begin{tabular}{|c|} 
Recur- \\
rence \\
Interval \\
(years)
\end{tabular} \\
\hline \multicolumn{13}{|c|}{ Pend Orellle River basin--Continued } \\
\hline $\begin{array}{l}202 \\
203 \\
204 \\
\end{array}$ & $\begin{array}{l}12-3720 \\
12-3743 \\
12-3757 \\
12-3890\end{array}$ & $\begin{array}{l}\text { Flathead River near Polson } \\
\text { Mill Creek near Niarada } \\
\text { South Fork Garden Creek near Hot Springs } \\
\text { Clark Fork near Plains }\end{array}$ & \begin{tabular}{|r|r|}
7,096 & \\
28 & 0 \\
3 & 29 \\
19,958 & \\
\end{tabular} & \begin{tabular}{|c|}
1894 \\
$1907-64$ \\
$1959-64$ \\
$1959-64$ \\
$1910-64$ \\
\end{tabular} & $\begin{array}{l}1894 \\
1928 \\
1961 \\
1964 \\
1948 \\
\end{array}$ & $\begin{array}{rl}21 & \\
\mathrm{e} & 2 \\
1 & 42 \\
1 & 02 \\
19 & 17 \\
\end{array}$ & $\begin{array}{r}110,000 \\
82,800 \\
140 \\
45 \\
134,000 \\
\end{array}$ & $\begin{array}{r}12 \\
8 \\
8 \\
11 \\
\end{array}$ & $\begin{array}{lr}17 & 99 \\
- & 62 \\
& 93 \\
17 & 48 \\
\end{array}$ & $\begin{array}{rr}166,800 \\
- \\
24 \\
40 \\
1128,000 \\
\end{array}$ & $\begin{array}{l}- \\
- \\
12 \\
-\end{array}$ & ${ }^{-}$ \\
\hline & \multicolumn{12}{|c|}{ 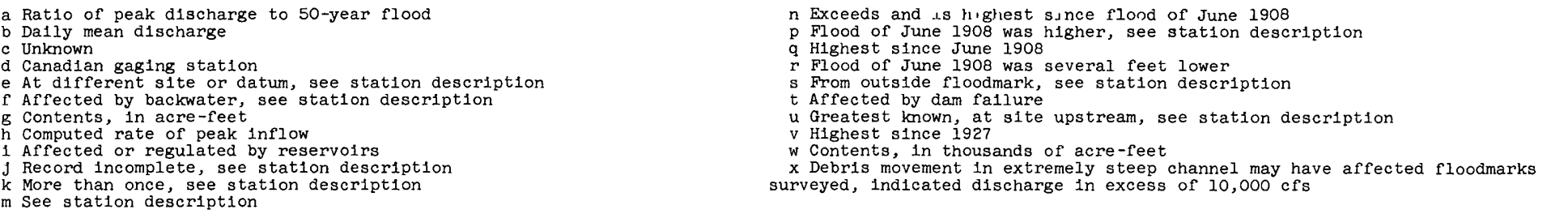 } \\
\hline
\end{tabular}


STATION DATA

\section{SASKATCHEWAN RIVER BASIN}

(1) 5-100 Belly River at international boundary

\section{(International gaging station)}

Location -Lat $48^{\circ} 59^{\prime} 50^{\prime \prime}$, long $113^{\circ} 40^{\prime} 50^{\prime \prime}$, in NW $\frac{1}{4} \sec 2, T 37 \mathrm{~N}, \mathrm{R} 16 \mathrm{~W}$ (unsurveyed), on right bank $200 \mathrm{ft}$ upstream from international boundary, 11 ml les southeast of Waterton Park, Alberta, and 15 miles northwest of Babb, Mont

Drainage area $--74 \quad 8 \mathrm{sq} \mathrm{mi}$ $\frac{\text { Gage-height record }}{\text { topographic map) }}$-Water-stage recorder graph Altitude of gage is 4,500 ft (from

Discharge record --Stage-discharge relation defined by current-meter measurements below $1,000 \mathrm{c}$ 's and extended above by logarithmic plotting, and on basis of records for station near Mountain View, Alberta

Maxima --June 1964 Discharge, about 12,000 cfs 1900 hours June 8 (gage height, $1016 \mathrm{ft}$ )

1947 to May 1964 Discharge $2,450 \mathrm{cfs}$ June 4, 1953 (gage height, $666 \mathrm{ft}$ )

Mean discharge, in cublc feet per second, 1964

\begin{tabular}{|c|c|c|c|c|c|c|c|c|}
\hline Day & May & June & Day & May & June & Day & May & June \\
\hline $\begin{array}{r}1 \\
2 \\
3 \\
4 \\
5 \\
6 \\
7 \\
8 \\
9 \\
10\end{array}$ & $\begin{array}{l}\overline{-} \\
= \\
\overline{-} \\
- \\
- \\
- \\
- \\
- \\
-\end{array}$ & $\begin{array}{r}685 \\
758 \\
934 \\
1,200 \\
1,350 \\
1,410 \\
1,570 \\
8,200 \\
7,830 \\
3,520\end{array}$ & $\begin{array}{l}11 \\
12 \\
13 \\
14 \\
15 \\
16 \\
17 \\
18 \\
19 \\
20\end{array}$ & $\begin{array}{r}- \\
400 \\
466 \\
483 \\
466 \\
457 \\
527 \\
691 \\
830 \\
1,050\end{array}$ & $\begin{array}{r}2,080 \\
1,810 \\
1,740 \\
1,690 \\
1,500 \\
1,310 \\
1,180 \\
1,100 \\
1,010 \\
946\end{array}$ & $\begin{array}{l}21 \\
22 \\
23 \\
24 \\
25 \\
26 \\
27 \\
28 \\
29 \\
30 \\
31\end{array}$ & $\begin{array}{r}1,210 \\
1,040 \\
771 \\
612 \\
510 \\
461 \\
457 \\
510 \\
604 \\
645 \\
655 \\
\end{array}$ & $\begin{array}{r}888 \\
856 \\
868 \\
1,000 \\
1,110 \\
1,080 \\
1,020 \\
998 \\
84.2 \\
715 \\
-\quad-\quad- \\
\end{array}$ \\
\hline \multicolumn{7}{|c|}{$\begin{array}{l}\text { Monthly mean dis } \\
\text { Runoff, in inche } \\
\text { Runoff, in acre- }\end{array}$} & $\begin{array}{l}- \\
- \\
-\end{array}$ & $\begin{array}{r}1,707 \\
2546 \\
101,600 \\
\end{array}$ \\
\hline
\end{tabular}

Gage helght, In feet, and discharge, in cublc feet per second, at indicated time, 1964

\begin{tabular}{|c|c|c|c|c|c|c|c|c|c|c|c|}
\hline Date & Hour & $\begin{array}{c}\text { Gage } \\
\text { helght }\end{array}$ & $\begin{array}{c}\text { D1s- } \\
\text { charge }\end{array}$ & Date & Hour & $\begin{array}{c}\text { Gage } \\
\text { height }\end{array}$ & $\begin{array}{l}\text { D1s- } \\
\text { charge }\end{array}$ & Date & Hour & $\begin{array}{c}\text { Gage } \\
\text { neight }\end{array}$ & $\begin{array}{c}\text { Dis- } \\
\text { charge }\end{array}$ \\
\hline June 7 & $\begin{array}{l}0000 \\
0600 \\
0900 \\
1500 \\
1800 \\
2400\end{array}$ & $\begin{array}{ll}4 & 81 \\
4 & 80 \\
4 & 83 \\
5 & 03 \\
5 & 18 \\
5 & 63\end{array}$ & $\begin{array}{l}1,380 \\
1,370 \\
1,390 \\
1,570 \\
1,700 \\
2,140\end{array}$ & June 8 & $\begin{array}{l}1200 \\
1500 \\
1800 \\
1900 \\
2000 \\
2200 \\
2400\end{array}$ & $\begin{array}{rl}9 & 31 \\
9 & 92 \\
10 & 12 \\
10 & 16 \\
10 & 15 \\
10 & 10 \\
9 & 97\end{array}$ & $\begin{array}{r}9,410 \\
11,200 \\
11,900 \\
12,000 \\
12,000 \\
11,800 \\
11,400\end{array}$ & June 9 & $\begin{array}{l}1200 \\
1600 \\
2000 \\
2400 \\
1200 \\
1800\end{array}$ & $\begin{array}{ll}8 & 66 \\
8 & 26 \\
7 & 86 \\
7 & 51 \\
& \\
6 & 60 \\
6 & 23\end{array}$ & $\begin{array}{l}7,590 \\
6,590 \\
5,660 \\
4,920 \\
3,360 \\
2,860\end{array}$ \\
\hline 8 & $\begin{array}{l}0200 \\
0400 \\
0600\end{array}$ & $\begin{array}{ll}6 & 00 \\
6 & 62 \\
7 & 29 \\
\end{array}$ & $\begin{array}{l}2,570 \\
3,390 \\
4,490\end{array}$ & 9 & $\begin{array}{l}0400 \\
0800\end{array}$ & $\begin{array}{ll}9 & 57 \\
9 & 10\end{array}$ & $\begin{array}{r}10,200 \\
8,790 \\
\end{array}$ & & 2400 & 595 & 2,510 \\
\hline
\end{tabular}

(2) 5-107 Mountain View Irrigation District Canal near Mountain View, Alberta (International gaging station)

Location --Lat $49^{\circ} 06^{\prime} 00^{\prime \prime}$, long $113^{\circ} 41^{\prime} 30^{\prime \prime}$, in $\mathrm{NW} \frac{1}{4} \sec 4$, T $2, \mathrm{R} 28 \mathrm{~W}$, fourth meridian, In Alberta, on left bank $1 \frac{1}{2}$ miles downstream from headgate, 5 miles southwest of Mountain View, and 7 miles north of international boundary

Gage-helght record --Water-stage recorder graph Datum of gage is 4,377 $26 \mathrm{ft}$ above mean sea level (Irrigation Surveys datum)

Discharge record --Stage-discharge relation defined by current-meter measurements

Maxıma --June 1964 Daily discharge, 162 cfs June 8

1935 to May 1964 Daily discharge 155 of's June 9, 1961 
Mean discharge, in cubic feet per second, 1964, of Mountain View Irrigation District Canal near Mountain View, Alberta

\begin{tabular}{|c|c|c|c|c|c|c|c|c|}
\hline Day & May & June & Day & May & June & Day & May & June \\
\hline $\begin{array}{r}1 \\
2 \\
3 \\
4 \\
5 \\
6 \\
7 \\
8 \\
9 \\
10\end{array}$ & $\begin{array}{rl}2 & 3 \\
14 & 7 \\
33 & 2 \\
19 & 2 \\
12 & 4 \\
7 & 4 \\
8 & 8 \\
7 & 7 \\
7 & 7 \\
7 & 7\end{array}$ & $\begin{array}{rr}4 & 0 \\
3 & 5 \\
3 & 5 \\
32 & 8 \\
65 & 9 \\
64 & 8 \\
71 & 4 \\
162 & \\
63 & 4 \\
25 & 2\end{array}$ & $\begin{array}{l}11 \\
12 \\
13 \\
14 \\
15 \\
16 \\
17 \\
18 \\
19 \\
20\end{array}$ & $\begin{array}{ll}8 & 4 \\
7 & 0 \\
6 & 7 \\
6 & 4 \\
5 & 3 \\
5 & 3 \\
5 & 3 \\
4 & 8 \\
5 & 3 \\
5 & 3\end{array}$ & $\begin{array}{rl}20 & 9 \\
19 & 8 \\
17 & 5 \\
15 & 1 \\
13 & 8 \\
13 & 8 \\
12 & 4 \\
10 & 4 \\
10 & 8 \\
6 & 4\end{array}$ & $\begin{array}{l}21 \\
22 \\
23 \\
24 \\
25 \\
26 \\
27 \\
28 \\
29 \\
30 \\
31\end{array}$ & $\begin{array}{ll}5 & 3 \\
5 & 3 \\
5 & 0 \\
5 & 0 \\
4 & 8 \\
4 & 8 \\
4 & 8 \\
5 & 3 \\
5 & 0 \\
4 & 5 \\
4 & 5 \\
\end{array}$ & 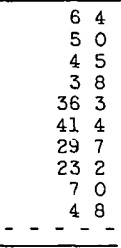 \\
\hline \multicolumn{7}{|c|}{$\begin{array}{l}\text { Monthly mean discharge, in cubic feet per second } \\
\text { Runoff, in acre-feet }\end{array}$} & $\begin{array}{r}759 \\
467 \\
\end{array}$ & $\begin{array}{r}266 \\
1,590 \\
\end{array}$ \\
\hline
\end{tabular}

(3) 5-110 Belly River near Mountain View, Alberta

\section{(International gaging station)}

Location --Lat $49^{\circ} 06^{\prime}$, long $113^{\circ} 42^{\prime}$, in $\mathrm{NE}_{\frac{1}{4}} \sec 5, \mathrm{~T} 2, \mathrm{R} 28 \mathrm{~W}$, fourth meridian, in Alberta, on right bank 2 miles downstream from intake of Mountain View Irrigation District Canal, 5 miles southwest of Mountain View, and 7 miles north of international boundary

Drainage area --121 sq mi

Gage-height record --Water-stage recorder graph except 1400 hours June 8 to 0600

hours June 9, when graph was reconstructed on basis of high-water mark Datum of gage is 4,344 $90 \mathrm{ft}$ above mean sea level (Irrigation Surveys datum)

Discharge record --Stage-discharge relation defined by current-meter measurements

Maxıma --June 1964 Discharge, $16,400 \mathrm{cfs}$ about 1900 hours June 8 (gage helght,

II $40 \mathrm{ft}$ from floodmark)

1911 to May 1964 Discharge, 4,500 cfs June 4, 1953 (gage height, $664 \mathrm{ft}$ ),

from slope-area measurement

Flood in June 1908 reached a stage of about $12 \mathrm{ft}$

Remarks - Natural flow affected by diversion in Mountain View Irrigation District Canal since 1935

Mean discharge, in cublc feet per second, 1964

\begin{tabular}{|c|c|c|c|c|c|c|c|c|}
\hline Day & May & June & Day & May & June & Day & May & June \\
\hline $\begin{array}{r}1 \\
2 \\
3 \\
4 \\
5 \\
6 \\
7 \\
8 \\
9 \\
10\end{array}$ & $\begin{array}{l}225 \\
368 \\
693 \\
653 \\
550 \\
465 \\
429 \\
423 \\
452 \\
550\end{array}$ & $\begin{array}{r}1,030 \\
1,140 \\
1,340 \\
1,550 \\
1,560 \\
1,730 \\
1,970 \\
10,700 \\
9,520 \\
4,440\end{array}$ & $\begin{array}{l}11 \\
12 \\
13 \\
14 \\
15 \\
16 \\
17 \\
18 \\
19 \\
20\end{array}$ & $\begin{array}{r}563 \\
585 \\
677 \\
709 \\
653 \\
638 \\
793 \\
1,040 \\
1,210 \\
1,470\end{array}$ & $\begin{array}{l}2,910 \\
2,590 \\
2,380 \\
2,330 \\
2,110 \\
1,860 \\
1,710 \\
1,610 \\
1,490 \\
1,390\end{array}$ & $\begin{array}{l}21 \\
22 \\
23 \\
24 \\
25 \\
26 \\
27 \\
28 \\
29 \\
30 \\
31\end{array}$ & $\begin{array}{r}1,610 \\
1,400 \\
1,110 \\
886 \\
725 \\
645 \\
661 \\
759 \\
912 \\
972 \\
989\end{array}$ & $\begin{array}{r}1,310 \\
1,230 \\
1,270 \\
1,480 \\
1,530 \\
1,460 \\
1,400 \\
1,360 \\
1,170 \\
1,030 \\
--1--\end{array}$ \\
\hline \multicolumn{7}{|c|}{$\begin{array}{l}\text { Monthly mean discharge, in cubic feet per second } \\
\text { Runoff, in acre-feet }\end{array}$} & $\begin{array}{r}768 \\
47,240 \\
\end{array}$ & $\begin{array}{r}2,290 \\
136,300 \\
\end{array}$ \\
\hline
\end{tabular}

Gage height, in reet, and discharge, in cublc feet per second, at indicated time, 1964

\begin{tabular}{|c|c|c|c|c|c|c|c|c|c|c|c|}
\hline Date & Hour & $\begin{array}{c}\text { Gage } \\
\text { he1ght }\end{array}$ & $\begin{array}{l}\text { D1s- } \\
\text { charge }\end{array}$ & Date & Hour & $\begin{array}{c}\text { Gage } \\
\text { helght }\end{array}$ & $\begin{array}{l}\text { D1s- } \\
\text { charge }\end{array}$ & Date & Hour & $\begin{array}{c}\text { Gage } \\
\text { helght }\end{array}$ & $\begin{array}{l}\text { Dis- } \\
\text { charge }\end{array}$ \\
\hline June 7 & $\begin{array}{l}0000 \\
0800 \\
1200 \\
1800 \\
2400 \\
\\
0400 \\
0700 \\
0900 \\
1000 \\
1100\end{array}$ & $\begin{array}{ll}4 & 05 \\
4 & 05 \\
4 & 12 \\
4 & 42 \\
4 & 89 \\
& \\
5 & 44 \\
6 & 71 \\
7 & 89 \\
8 & 49 \\
9 & 38 \\
\end{array}$ & $\begin{array}{r}1,680 \\
1,680 \\
1,760 \\
2,160 \\
2,900 \\
3,800 \\
6,000 \\
8,190 \\
9,490 \\
11,500 \\
\end{array}$ & June 8 & $\begin{array}{l}1200 \\
1400 \\
1700 \\
1900 \\
2200 \\
2400 \\
\\
0300 \\
0600 \\
0900 \\
1200\end{array}$ & $\begin{array}{ll}10 & 12 \\
10 & 60 \\
11 & 10 \\
11 & 40 \\
10 & 89 \\
10 & 51 \\
9 & 91 \\
9 & 40 \\
8 & 88 \\
7 & 85\end{array}$ & $\begin{array}{r}13,300 \\
14,400 \\
15,700 \\
16,400 \\
15,200 \\
14,300 \\
13,000 \\
11,900 \\
10,900 \\
8,850\end{array}$ & June 9 & $\begin{array}{l}1500 \\
1800 \\
2100 \\
2400 \\
0600 \\
1200 \\
1800 \\
2400\end{array}$ & $\begin{array}{ll}7 & 32 \\
6 & 82 \\
6 & 47 \\
6 & 15 \\
5 & 54 \\
5 & 16 \\
4 & 82 \\
4 & 49\end{array}$ & $\begin{array}{l}7,890 \\
7,010 \\
6,430 \\
5,900 \\
4,930 \\
4,350 \\
3,840 \\
3,340\end{array}$ \\
\hline
\end{tabular}


(4) 5-115 Waterton River near international boundary

(International gaging station)

Location --Lat $48^{\circ} 57^{\prime} 20^{\prime \prime}$, long $113^{\circ} 54^{\prime} 00^{\prime \prime}$, in $\mathrm{NW} \frac{1}{4} \sec 23, \mathrm{~T} 37 \mathrm{~N}, \mathrm{R} 18 \mathrm{~W}$ (unsurveyed), on right bank $100 \mathrm{ft}$ downstream from oison Creek, 3 miles south of international boundary, and 7 miles south of Waterton Park, Alberta

Drainage area $--610 \mathrm{sq} \mathrm{mi}$

Gage-height record --Water-stage recorder graph Altitude of gage is 4,200 $\mathrm{ft}$ (from topographic map

Discharge record --Stage-discharge relation defined by current-meter measurements below 1,900 cfs and by slope-area measurement at 12,400 cfs

Maxima --June 1964 Discharge, $12,400 \mathrm{cfs} 1700$ hours June 8 (gage helght, $1155 \mathrm{ft}$ ) 1947 to May 1964 Discharge, 2,710 cfs May 20, 1954 (gage height, $651 \mathrm{ft}$ )

Mean discharge, in cublc feet per second, 1964

\begin{tabular}{|c|c|c|c|c|c|c|c|c|}
\hline Day & May & June & Day & May & June & Day & May & June \\
\hline $\begin{array}{r}1 \\
2 \\
3 \\
4 \\
5 \\
6 \\
7 \\
8 \\
9 \\
10\end{array}$ & $\begin{array}{l}- \\
\overline{-} \\
\overline{-} \\
\overline{-} \\
\overline{-} \\
\overline{-}\end{array}$ & $\begin{array}{l}1,020 \\
1,080 \\
1,290 \\
1,550 \\
1,400 \\
1,480 \\
1,470 \\
7,280 \\
5,850 \\
2,500\end{array}$ & $\begin{array}{l}11 \\
12 \\
13 \\
14 \\
15 \\
16 \\
17 \\
18 \\
19 \\
20\end{array}$ & $\begin{array}{r}- \\
- \\
480 \\
556 \\
535 \\
530 \\
663 \\
869 \\
979 \\
1,280\end{array}$ & $\begin{array}{l}1,660 \\
1,760 \\
1,680 \\
1,670 \\
1,590 \\
1,460 \\
1,370 \\
1,200 \\
1,100 \\
1,090\end{array}$ & $\begin{array}{l}21 \\
22 \\
23 \\
24 \\
25 \\
26 \\
27 \\
28 \\
29 \\
30 \\
31\end{array}$ & $\begin{array}{r}1,410 \\
1,010 \\
691 \\
514 \\
427 \\
386 \\
436 \\
646 \\
773 \\
827 \\
905\end{array}$ & $\begin{array}{r}1,010 \\
1,010 \\
1,290 \\
1,750 \\
1,720 \\
1,470 \\
1,380 \\
1,130 \\
887 \\
863 \\
-\quad--\end{array}$ \\
\hline $\begin{array}{l}\text { Monthly } \\
\text { Runoff, } \\
\text { Runoff, }\end{array}$ & $\begin{array}{l}\text { mean diso } \\
\text { in Inches } \\
\text { in acre- }\end{array}$ & , In cul & feet & cond & & & $\overline{-}$ & $\begin{array}{r}1,734 \\
31,71 \\
103,200\end{array}$ \\
\hline
\end{tabular}

Gage height, in feet, and discharge, in cubic feet per second, at indicated time, 1964

\begin{tabular}{|c|c|c|c|c|c|c|c|c|c|c|c|}
\hline Date & Hour & $\begin{array}{c}\text { Gage } \\
\text { helght }\end{array}$ & $\begin{array}{c}\text { Dis- } \\
\text { charge }\end{array}$ & Date & Hour & $\begin{array}{c}\text { Gage } \\
\text { helght }\end{array}$ & $\begin{array}{l}\text { Dis- } \\
\text { charge }\end{array}$ & Date & Hour & $\begin{array}{c}\text { Gage } \\
\text { he1ght }\end{array}$ & $\begin{array}{l}\text { Dis- } \\
\text { charge }\end{array}$ \\
\hline June 7 & $\begin{array}{l}0000 \\
1000 \\
1600 \\
2000 \\
2400 \\
\\
0400 \\
0800 \\
1200\end{array}$ & $\begin{array}{rr}5 & 13 \\
5 & 18 \\
5 & 19 \\
5 & 34 \\
5 & 67 \\
& \\
6 & 46 \\
8 & 69 \\
10 & 57\end{array}$ & $\begin{array}{l}1,380 \\
1,420 \\
1,430 \\
1,550 \\
1,820 \\
2,590 \\
5,510 \\
9,350\end{array}$ & June 8 & $\begin{array}{l}1400 \\
1600 \\
1700 \\
1900 \\
2100 \\
2400 \\
0200 \\
0500\end{array}$ & $\begin{array}{ll}11 & 09 \\
11 & 34 \\
11 & 55 \\
11 & 05 \\
10 & 63 \\
10 & 31 \\
10 & 49 \\
10 & 57\end{array}$ & $\begin{array}{r}10,800 \\
11,700 \\
12,400 \\
10,100 \\
8,540 \\
7,600 \\
8,100 \\
8,340\end{array}$ & June 9 & $\begin{array}{l}0800 \\
1200 \\
1800 \\
2400 \\
0600 \\
1200 \\
1800 \\
2400\end{array}$ & $\begin{array}{rr}10 & 24 \\
9 & 48 \\
8 & 52 \\
8 & 07 \\
& \\
7 & 70 \\
7 & 36 \\
7 & 07 \\
6 & 89\end{array}$ & $\begin{array}{l}7,350 \\
5,580 \\
3,980 \\
3,370 \\
2,880 \\
2,430 \\
2,070 \\
1,870\end{array}$ \\
\hline
\end{tabular}

(5) 5-120 Street Creek at international boundary

(International gaging station, discontinued 1955)

Location --Lat $48^{\circ} 59^{\prime} 20^{\prime \prime}$, long $113^{\circ} 52^{\prime} 40^{\prime \prime}$, in $N E_{\frac{1}{4}} \sec 11, T 37 \mathrm{~N}, \mathrm{R} 18 \mathrm{~W}$ (unsurveyed), on left bank half a mile upstream from'mouth, three-quarters of a mile south of international boundary, and 5 miles south of Waterton Park, Alberta Gage destroyed by flood

Drainage area - $-60 \mathrm{sq} \mathrm{mi}$, approximately $\frac{\text { Gage-helght record }}{\text { topographic map) }}$-Floodmarks at gage site Altitude of gage was $4,400 \mathrm{ft}$ (from

Discharge record --Peak discharge by slope-area measurement

$\frac{\text { Maxima }}{\text { profile) }} 1964$ Discharge, $5,740 \mathrm{cfs}$ June 8 (gage height $136 \mathrm{ft}$, from flood 1947-55 Discharge, $437 \mathrm{cfs}$ June 3, 1953 (gage height $45 \mathrm{ft}$, from floodmarks) 
(6) 5-125 Boundary Creek at international boundary

(International gaging station, discontinued June 1964)

Location --Lat $48^{\circ} 59^{\prime} 50^{\prime \prime}$, long $113^{\circ} 54^{\prime} 20^{\prime \prime}$, in $\mathrm{NE} \frac{1}{4} \sec 3$, T $37 \mathrm{~N}, \mathrm{R} 18 \mathrm{~W}$ (unsurveyed), on right bank a quarter of a mlle upstream from mouth, a quarter of a mlle south of international boundary, and 4 miles south of Waterton Park, Alberta

Drainage area $--21 \quad 0 \mathrm{sq} \mathrm{mi}$

Gage-height record - Water-stage recorder graph to 1300 hours June 5 Station destroyed by flood on June 8 Altitude of gage is 4,300 ft (from topographic map)

Discharge record --Stage-discharge relation defined by current-meter measurements below $450 \mathrm{cf}$ 's and by slope-area measurement at 5,930 cfs Discharge for June 6,7 estimated on basis of records for nearby stations

Maxima --June 1964 Discharge, 5,930 cfs June 8

1947 to May 1964 Discharge $904 \mathrm{cfs}$ June 4, 1953 (gage helght, $524 \mathrm{ft}$ ), gage height, $534 \mathrm{ft}$ June 21 or 22 , 1950, from floodmarks

Mean discharge, in cubic feet per second, 1964

\begin{tabular}{|c|c|c|c|c|c|c|c|c|}
\hline Day & May & June & Day & May & June & Day & May & June \\
\hline $\begin{array}{r}1 \\
2 \\
3 \\
4 \\
5 \\
6 \\
7 \\
8 \\
9 \\
10\end{array}$ & $\begin{array}{l}- \\
- \\
- \\
- \\
- \\
- \\
- \\
- \\
-\end{array}$ & $\begin{array}{l}293 \\
333 \\
411 \\
450 \\
434 \\
475 \\
525 \\
- \\
- \\
-\end{array}$ & $\begin{array}{l}11 \\
12 \\
13 \\
14 \\
15 \\
16 \\
17 \\
18 \\
19 \\
20\end{array}$ & $\begin{array}{l}- \\
- \\
164 \\
162 \\
140 \\
140 \\
191 \\
237 \\
284 \\
349\end{array}$ & $\begin{array}{l}- \\
- \\
- \\
- \\
\bar{z} \\
- \\
-\end{array}$ & $\begin{array}{l}21 \\
22 \\
23 \\
24 \\
25 \\
26 \\
27 \\
28 \\
29 \\
30 \\
31\end{array}$ & $\begin{array}{l}363 \\
232 \\
178 \\
149 \\
132 \\
129 \\
155 \\
188 \\
209 \\
224 \\
254\end{array}$ & $\begin{array}{r}- \\
- \\
- \\
- \\
- \\
- \\
- \\
- \\
- \\
- \\
-\end{array}$ \\
\hline
\end{tabular}

(7) Waterton Lake at Waterton Park, Alberta

(Canadian gaging station)

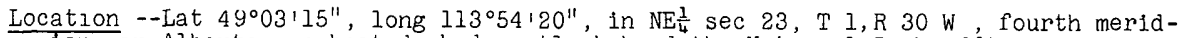
lan, in Alberta, on boat dock directly behind the National Park offices in the town of Waterton Park

Drainage area --146 sq $\mathrm{ml}$ (to Bosporus Narrows)

Gage-height record --Once-daily staff-gage readings at 0800 hours, except May 2, 3, $7-10,16-18,23,24,30,31$, June $6-16,18-21,27,28$, when lake stages were estimated on basis of outflow record at downstream gaging station

Maxıma --June 1964 Elevation, 4,206 $76 \mathrm{ft}$, from floodmark, 0200 hours June 9 1950 to May 1964 Elevation 4,199 5 ft June 3,1953

Remarks - No regulation Records furnished by Department of Northern Affairs and National Resources, Canada

Elevation, in feet, 1964

\begin{tabular}{|c|c|c|c|c|c|c|c|c|}
\hline Day & May & June & Day & May & June & Day & May & June \\
\hline $\begin{array}{r}1 \\
2 \\
3 \\
4 \\
5 \\
6 \\
7 \\
8 \\
9 \\
10\end{array}$ & 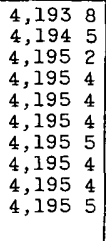 & 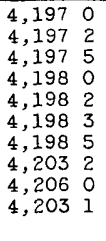 & $\begin{array}{l}11 \\
12 \\
13 \\
14 \\
15 \\
16 \\
17 \\
18 \\
19 \\
20\end{array}$ & 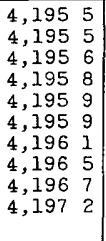 & 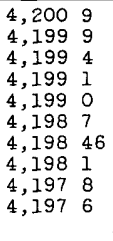 & $\begin{array}{l}21 \\
22 \\
23 \\
24 \\
25 \\
26 \\
27 \\
28 \\
29 \\
30 \\
31\end{array}$ & 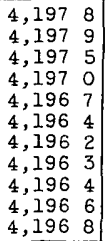 & $\begin{array}{rl}4,197 & 4 \\
4,197 & 67 \\
4,197 & 67 \\
4,197 & 95 \\
4,198 & 23 \\
4,198 & 28 \\
4,197 & 8 \\
4,197 & 7 \\
4,197 & 65 \\
4,197 & 45 \\
-4- & -\end{array}$ \\
\hline
\end{tabular}


(8) 5-130 Waterton River near Waterton Park, Alberta

(International gaging station)

Location --Lat $49^{\circ} 07^{\prime}$, long $113^{\circ} 50^{\prime}$, in $\mathrm{NE} \frac{1}{4} \sec 8$, T $2, \mathrm{R} 29 \mathrm{~W}$, fourth meridian, in Alberta, on right bank $300 \mathrm{ft}$ downstream from highway bridge, a quarter of a mile upstream from Crooked Creek and 5 miles northeast of Waterton Park

Drainage area $--238 \mathrm{sq} \mathrm{mi}$

Gage-height record --Water-stage recorder graph Datum of gage is $4,15419 \mathrm{ft}$ above mean sea level (Irrigation Surveys datum)

Discharge record --Stage-discharge relation defined by current-meter measurements

Maxima --June 1964 Discharge, 25,700 cfs 0400 hours June 9 (gage helght, $922 \mathrm{ft}$ ) 1908 to May 1964 Discharge, $24,000 \mathrm{cfs}$ June 6, 1908 (gage height, $9 \mathrm{ft}$, at site within $200 \mathrm{ft}$ of present site and at datum then in use, from graph based on gage readings), from rating curve extended above $7,000 \mathrm{cfs}$ by logarithmic plotting

Mean discharge, in cub1c feet per second, 1964

\begin{tabular}{|c|c|c|c|c|c|c|c|c|}
\hline Day & May & June & Day & May & June & Day & May & June \\
\hline $\begin{array}{r}1 \\
2 \\
3 \\
4 \\
5 \\
6 \\
7 \\
8 \\
9 \\
10\end{array}$ & $\begin{array}{r}331 \\
495 \\
965 \\
1,140 \\
1,130 \\
1,130 \\
1,080 \\
1,040 \\
1,030 \\
1,080\end{array}$ & $\begin{array}{r}2,340 \\
2,620 \\
2,940 \\
3,370 \\
3,690 \\
3,870 \\
4,130 \\
13,700 \\
22,700 \\
13,400\end{array}$ & $\begin{array}{l}11 \\
12 \\
13 \\
14 \\
15 \\
16 \\
17 \\
18 \\
19 \\
20\end{array}$ & $\begin{array}{l}1,140 \\
1,170 \\
1,280 \\
1,390 \\
1,420 \\
1,420 \\
1,570 \\
1,850 \\
2,160 \\
2,680\end{array}$ & $\begin{array}{l}8,220 \\
6,230 \\
5,450 \\
5,030 \\
4,710 \\
4,320 \\
3,940 \\
3,540 \\
3,210 \\
2,970\end{array}$ & $\begin{array}{l}21 \\
22 \\
23 \\
24 \\
25 \\
26 \\
27 \\
28 \\
29 \\
30 \\
31\end{array}$ & $\begin{array}{l}3,240 \\
3,170 \\
2,830 \\
2,340 \\
1,980 \\
1,710 \\
1,600 \\
1,640 \\
1,820 \\
1,980 \\
2,140\end{array}$ & $\begin{array}{r}2,790 \\
2,660 \\
2,660 \\
2,940 \\
3,240 \\
3,280 \\
3,210 \\
3,080 \\
2,680 \\
2,430 \\
-----\end{array}$ \\
\hline $\begin{array}{l}\text { Monthly } \\
\text { Runoff, } \\
\text { Runoff, }\end{array}$ & $\begin{array}{l}\text { mean discha } \\
\text { in inches } \\
\text { in acre-fee }\end{array}$ & , In cut & feet & cond & & & $\begin{array}{r}1,610 \\
781 \\
99,080\end{array}$ & $\begin{array}{r}4,980 \\
23 \quad 34 \\
296,200\end{array}$ \\
\hline
\end{tabular}

Gage height, In feet, and discharge, in cublc feet per second, at indicated time, 1964

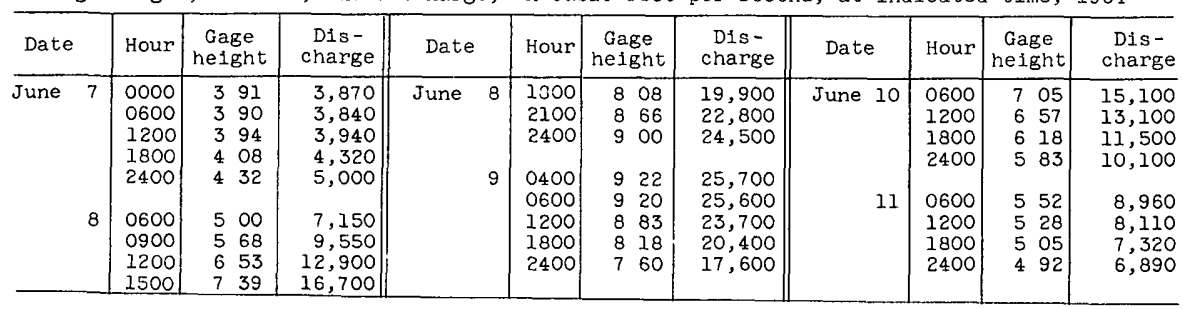

\section{(9) 5-140 Grinnell Creek near Many Glacier, Mont}

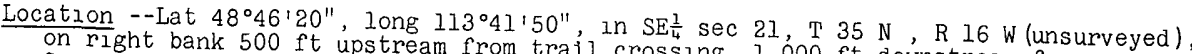
on right bank $500 \mathrm{ft}$ upstream from trail crossing, $1,000 \mathrm{ft}$ downstream from

Glacier, and $13 \frac{1}{2}$ miles southwest of Babb

Drainage area $--347 \mathrm{sq} \mathrm{ml}$

$\frac{\text { Gage-height record }}{\text { topographic map) }}$--Water-stage recorder graph Altitude of gage is 5,000 ft (from

Discharge record --Stage-discharge relation defined by current-meter measurements

below $115 \mathrm{crs}$ and by slope-area measurement at $536 \mathrm{cfs}$

Maxima --June 1964 Discharge, $536 \mathrm{cfs} 1300$ hours June 8 (gage helght, $488 \mathrm{ft}$ )

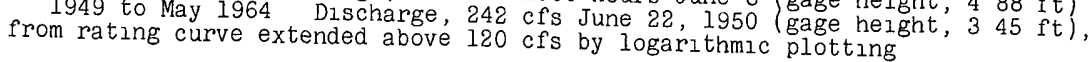


Mean discharge, in cub1c feet per second, 1964, of Grinnel1 Creek near Many Glacier, Mont

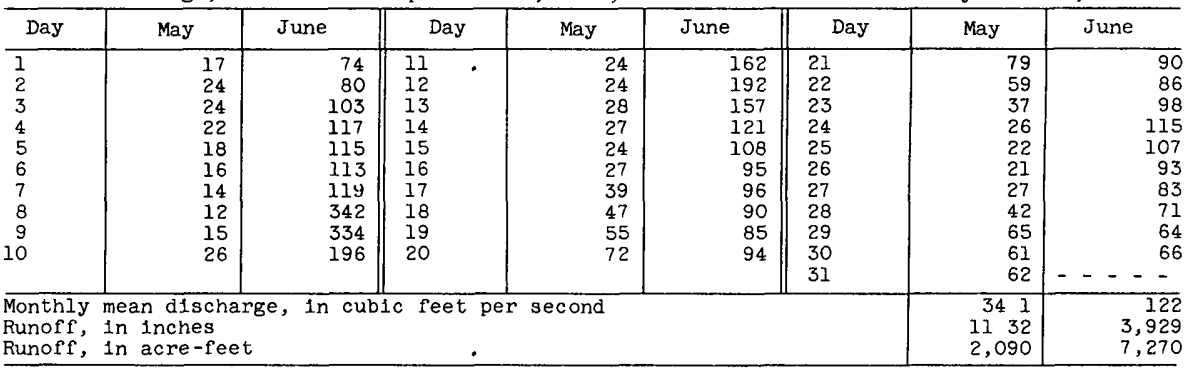

Gage he1ght, in feet, and discharge, in cub1c feet per second, at indicated time, 1964

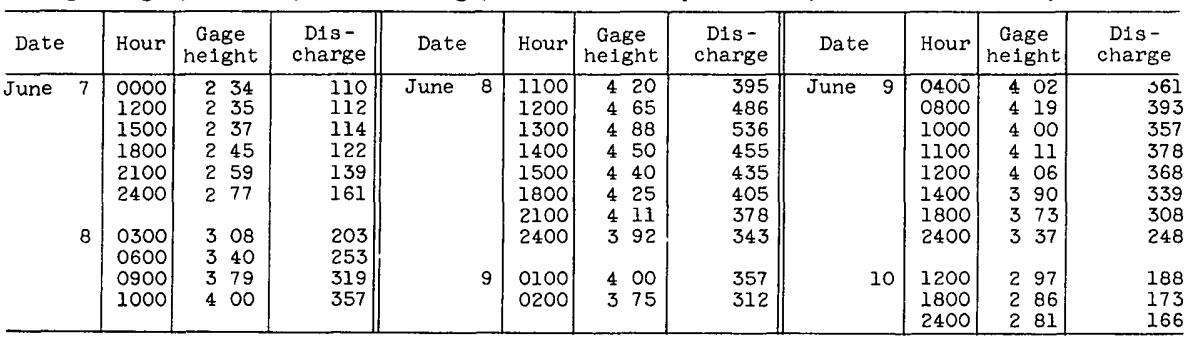

\section{(10) 5-145 Swiftcurrent Creek at Many Glacier, Mont}

(International gaging station)

Location --Lat $48^{\circ} 48^{\prime} 10^{\prime \prime}$, long $113^{\circ} 39^{1} 20^{\prime \prime}$, in $S E_{\frac{1}{4}} \sec 11, \mathrm{~T} 35 \mathrm{~N}, \mathrm{R} 16 \mathrm{~W}$ (unsurveyed), on right bank $100 \mathrm{ft}$ upstream from outlet of Swiftcurrent Lake at Many Glacier,

Glacier National Park, and 11 miles southwest of Babb

Drainage area $--314 \mathrm{sq} \mathrm{mi}$

Gage-height record --Water-stage recorder graph, except 1200 hours to 2200 hours June 8 , when graph based on high-water mark in gage house was used Altitude of gage is 4,860 ft (from topographic map)

Discharge record --Stage-discharge relation defined by current-meter measurements below 1,000 cfs and by flow-over-dam measurement at 6,700 cfs

Maxima --June 1964 Discharge, 6,700 cfs 1600 hours June 8 (gage height, $1000 \mathrm{ft}$, from high-water mark in well, backwater from bridge)

1912 to May 1964 Discharge, 2,250 cfs June 13, 1937 (gage height, $689 \mathrm{ft}$, backwater from bridge)

Mean discharge, In cubic reet per second, 1964

\begin{tabular}{|c|c|c|c|c|c|c|c|c|}
\hline Day & May & June & Day & May & June & Day & May & June \\
\hline $\begin{array}{r}1 \\
2 \\
3 \\
4 \\
5 \\
6 \\
7 \\
8 \\
9 \\
10\end{array}$ & $\begin{array}{l}126 \\
173 \\
181 \\
166 \\
150 \\
131 \\
114 \\
112 \\
140 \\
221\end{array}$ & $\begin{array}{r}514 \\
571 \\
686 \\
808 \\
779 \\
783 \\
820 \\
4,130 \\
2,480 \\
970\end{array}$ & $\begin{array}{l}11 \\
12 \\
13 \\
14 \\
15 \\
16 \\
17 \\
18 \\
19 \\
20\end{array}$ & $\begin{array}{l}230 \\
218 \\
280 \\
290 \\
252 \\
252 \\
349 \\
495 \\
548 \\
678\end{array}$ & $\begin{array}{l}682 \\
720 \\
766 \\
728 \\
633 \\
567 \\
525 \\
484 \\
447 \\
444\end{array}$ & $\begin{array}{l}21 \\
22 \\
23 \\
24 \\
25 \\
26 \\
27 \\
28 \\
29 \\
30 \\
31\end{array}$ & $\begin{array}{l}753 \\
548 \\
377 \\
270 \\
221 \\
206 \\
233 \\
336 \\
514 \\
499 \\
476\end{array}$ & $\begin{array}{r}440 \\
426 \\
458 \\
567 \\
586 \\
517 \\
458 \\
412 \\
356 \\
326 \\
----\end{array}$ \\
\hline \multicolumn{7}{|c|}{$\begin{array}{l}\text { Monthly } \\
\text { Runoff, } \\
\text { Runoff, } 1\end{array}$} & $\begin{array}{r}308 \\
1130 \\
18,920\end{array}$ & $\begin{array}{r}769 \\
27 \quad 34 \\
45,780\end{array}$ \\
\hline
\end{tabular}


Gage height, in feet, and discharge, in cublc feet per second, at 1nd1cated t1me 1964, of

\begin{tabular}{|c|c|c|c|c|c|c|c|c|c|c|c|}
\hline Date & Hour & $\begin{array}{c}\text { Gage } \\
\text { he1ght }\end{array}$ & $\begin{array}{l}\text { Dis- } \\
\text { charge }\end{array}$ & Date & Hour & $\begin{array}{c}\text { Gage } \\
\text { height }\end{array}$ & $\begin{array}{l}\text { D1s- } \\
\text { charge }\end{array}$ & Date & Hour & $\begin{array}{c}\text { Gage } \\
\text { height }\end{array}$ & $\begin{array}{l}\text { D1s- } \\
\text { charge }\end{array}$ \\
\hline June 7 & $\begin{array}{l}0000 \\
0800 \\
1200 \\
1600 \\
2000 \\
2200 \\
2400 \\
0200\end{array}$ & $\begin{array}{ll}4 & 02 \\
4 & 02 \\
4 & 08 \\
4 & 16 \\
4 & 39 \\
4 & 57 \\
4 & 83 \\
& \\
5 & 21\end{array}$ & $\begin{array}{r}753 \\
753 \\
779 \\
812 \\
909 \\
985 \\
1,100 \\
1,270\end{array}$ & June 8 & $\begin{array}{l}0400 \\
0600 \\
0800 \\
1200 \\
1400 \\
1600 \\
1800 \\
2400\end{array}$ & $\begin{array}{rr}5 & 80 \\
6 & 60 \\
7 & 52 \\
9 & 09 \\
9 & 74 \\
10 & 00 \\
9 & 84 \\
8 & 78\end{array}$ & $\begin{array}{l}1,550 \\
1,960 \\
2,880 \\
4,990 \\
6,200 \\
6,700 \\
6,390 \\
4,480\end{array}$ & June 9 & $\begin{array}{l}0600 \\
1200 \\
1800 \\
2400 \\
\\
0600 \\
1200 \\
1800 \\
2400\end{array}$ & $\begin{array}{ll}7 & 75 \\
6 & 90 \\
6 & 06 \\
5 & 42 \\
5 & 09 \\
4 & 82 \\
4 & 54 \\
4 & 33\end{array}$ & $\begin{array}{r}3,120 \\
2,260 \\
1,680 \\
1,210 \\
1,070 \\
964 \\
854 \\
774\end{array}$ \\
\hline
\end{tabular}

(11) 5-155 Lake Sherburne at Sherburne, Mont

(International gaging station)

Location --Lat $48^{\circ} 49^{\prime} 50^{\prime \prime}$, long $113^{\circ} 31^{\prime} 10^{\prime \prime}$, in SE $\frac{1}{4} \sec 35, \mathrm{~T} 36 \mathrm{~N}, \mathrm{R} 15 \mathrm{~W}$, in gatehouse at Lake Sherburne on Swiftcurrent Creek, $4 \frac{1}{2}$ miles southwest of Babb

Drainage area $--63 \quad \mathrm{sq} \mathrm{mi}$

Gage-height record --Water-stage recorder graph except May 1-20, 1700 hours June 11 to 0900 hours June 18 and 0900 hours June 19 to 2400 June 30 when graph was reconstructed on basis of outside gage readings Datum of gage is at mean sea level (levels by Bureau of Reclamation)

Discharge record --Inflow computed from change in contents adjusted for outflow

Maxima --June 1964 Contents, 54,320 acre-ft 0630 hours June 11 (elevation, $4,78088 \mathrm{ft})$ Rate of infiow, $10,000 \mathrm{cfs} 1500$ hours June 8

1915 to May 1964 Contents, 66,370 acre-ft June 30, 1961 (elevation, 4,788 I ft)

Remarks --Reservoir is formed on natural lake by earthfill dam completed in 1921 Prior to 1919, flashboards on a temporary dam provided limited storage storage behind main dam began in 1919 Capacity, 66,200 acre-ft between elevations $4,726 \mathrm{ft}$ ( $6 \mathrm{ft}$ above lowest outlet gate sill) and 4,788 ft (spillway crest) Streambed above gages prevents withdrawal of storage to sili elevation Dead storage is negligible Water is used for irrigation on Milk River projects of the Bureau of Reclamation Figures given herein represent usable contents

Elevation, in feet, and contents, in acre-feet, at 2400 hours and daily computed inflow, in cub1c feet per second, on Indicated day 1964

\begin{tabular}{|c|c|c|c|c|c|c|}
\hline \multirow{2}{*}{ Day } & \multicolumn{3}{|c|}{ May } & \multicolumn{3}{|c|}{ June } \\
\hline & Elevation & Contents & Inflow & Elevation & Contents & Inflow \\
\hline $\begin{array}{l}1 \\
2 \\
3 \\
4 \\
5\end{array}$ & $\begin{array}{ll}4,731 & 77 \\
4,732 & 14 \\
4,732 & 74 \\
4,733 & 84 \\
4,735 & 13\end{array}$ & $\begin{array}{l}2,680 \\
2,910 \\
3,280 \\
3,990 \\
4,850\end{array}$ & $\begin{array}{l}260 \\
350 \\
520 \\
560 \\
440\end{array}$ & 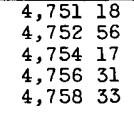 & $\begin{array}{l}17,880 \\
19,200 \\
20,770 \\
22,940 \\
25,130\end{array}$ & $\begin{array}{r}720 \\
840 \\
990 \\
1,180 \\
1,110\end{array}$ \\
\hline $\begin{array}{r}6 \\
7 \\
8 \\
9 \\
10\end{array}$ & $\begin{array}{ll}4,735 & 88 \\
4,735 & 76 \\
4,735 & 02 \\
4,734 & 37 \\
4,734 & 00\end{array}$ & $\begin{array}{l}5,360 \\
5,280 \\
4,770 \\
4,340 \\
4,090\end{array}$ & $\begin{array}{l}260 \\
210 \\
220 \\
270 \\
340\end{array}$ & 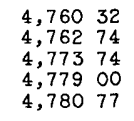 & $\begin{array}{l}27,250 \\
29,990 \\
43,640 \\
51,400 \\
54,160\end{array}$ & $\begin{array}{l}1,070 \\
1,380 \\
6,890 \\
3,920 \\
1,830\end{array}$ \\
\hline $\begin{array}{l}11 \\
12 \\
13 \\
14 \\
15\end{array}$ & 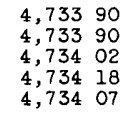 & $\begin{array}{l}4,020 \\
4,020 \\
4,100 \\
4,210 \\
4,140\end{array}$ & $\begin{array}{l}420 \\
430 \\
470 \\
490 \\
410\end{array}$ & 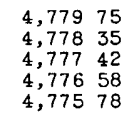 & $\begin{array}{l}52,600 \\
50,420 \\
49,030 \\
47,770 \\
46,590\end{array}$ & $\begin{array}{l}1,040 \\
1,240 \\
1,640 \\
1,340 \\
1,070\end{array}$ \\
\hline $\begin{array}{l}16 \\
17 \\
18 \\
19 \\
20\end{array}$ & $\begin{array}{ll}4,733 & 80 \\
4,734 & 31 \\
4,735 & 10 \\
4,736 & 28 \\
4,738 & 09\end{array}$ & $\begin{array}{l}3,960 \\
4,300 \\
4,830 \\
5,640 \\
6,930\end{array}$ & $\begin{array}{r}370 \\
640 \\
760 \\
940 \\
1,150\end{array}$ & 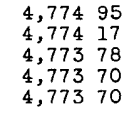 & $\begin{array}{l}45,420 \\
44,260 \\
43,640 \\
43,580 \\
43,580\end{array}$ & $\begin{array}{l}950 \\
790 \\
780 \\
640 \\
760\end{array}$ \\
\hline $\begin{array}{l}21 \\
22 \\
23 \\
24 \\
25\end{array}$ & 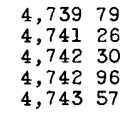 & $\begin{array}{r}8,180 \\
9,300 \\
10,130 \\
10,670 \\
11,160\end{array}$ & $\begin{array}{r}1,080 \\
860 \\
600 \\
400 \\
350\end{array}$ & 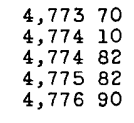 & $\begin{array}{l}43,580 \\
44,150 \\
45,230 \\
46,650 \\
48,250\end{array}$ & $\begin{array}{l}710 \\
640 \\
720 \\
730 \\
820\end{array}$ \\
\hline $\begin{array}{l}26 \\
27 \\
28 \\
29 \\
30 \\
31\end{array}$ & 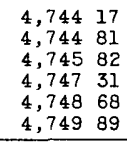 & $\begin{array}{l}11,640 \\
12,150 \\
13,040 \\
14,280 \\
15,510 \\
16,690 \\
\end{array}$ & $\begin{array}{l}340 \\
360 \\
560 \\
740 \\
740 \\
710 \\
\end{array}$ & 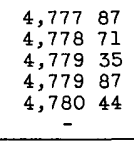 & $\begin{array}{l}47,700 \\
50,960 \\
51,960 \\
52,790 \\
53,660 \\
-\end{array}$ & $\begin{array}{l}750 \\
650 \\
520 \\
440 \\
450 \\
- \\
\end{array}$ \\
\hline Change in contents & - & $+14,200$ & - & - & $+36,970$ & - \\
\hline
\end{tabular}


Computed inflow, in cubic feet per second, at indicated time, 1964, of Lake Sherburne at Sherburne, Mont

\begin{tabular}{|c|c|c|c|c|c|c|c|c|}
\hline Date & Hour & Inflow & Date & Hour & Inflow & Date & Hour & Inflow \\
\hline June 7 & $\begin{array}{l}0000 \\
1200 \\
1800 \\
2400 \\
\\
0300 \\
0600 \\
0900 \\
1200\end{array}$ & $\begin{array}{l}1,080 \\
1,180 \\
1,470 \\
2,410 \\
3,480 \\
4,900 \\
6,600 \\
8,600\end{array}$ & June \& & $\begin{array}{l}1500 \\
1800 \\
2100 \\
2400 \\
0300 \\
0600 \\
0900 \\
1200\end{array}$ & $\begin{array}{r}10,000 \\
9,000 \\
7,900 \\
6,810 \\
5,800 \\
4,900 \\
4,100 \\
3,580\end{array}$ & 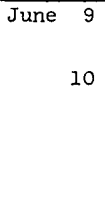 & $\begin{array}{l}1800 \\
2400 \\
\\
0600 \\
1200 \\
1800 \\
2400\end{array}$ & $\begin{array}{l}2,760 \\
2,290 \\
2,010 \\
1,790 \\
1,630 \\
1,500\end{array}$ \\
\hline
\end{tabular}

(12) 5-160 Swiftcurrent Creek at Sherburne, Mont

(International gaging station)

Location --Lat $48^{\circ} 50^{\prime} 0^{\prime \prime}$, long $113^{\circ} 30^{\prime} 50^{\prime \prime}$, in SW $\frac{1}{4} \sec 36$, T $36 \mathrm{~N}, \mathrm{R} 15 \mathrm{~W}$, on left bank $1,000 \mathrm{ft}$ downstream from outlet of Lake Sherburne Dam at Sherburne and $4 \frac{1}{2}$ mlles southwest of Babb

Drainage area $--64 \quad 3 \mathrm{sq} \mathrm{mi}$

Gage-height record --Water-stage recorder graph Datum of gage is 4,720 81 ft above mean sea level (Bureau of Reclamation bench mark)

Discharge record --Stage-discharge relation defined by current-meter measurements

Maxıma --June 1964 Discharge, 2,360 cfs 1630 hours June 11 (gage height, $837 \mathrm{ft}$ ) 1912 to May 1964 Discharge, $2,280 \mathrm{cfs}$ June 17, 1916 (gage he1ght, $785 \mathrm{ft}$, at site within $1,000 \mathrm{ft}$ of present site and at datum then in use)

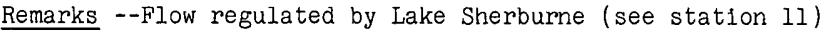

Mean discharge, in cubic feet per second, 1964

\begin{tabular}{|c|c|c|c|c|c|c|c|c|}
\hline Day & May & June & Day & May & June & Day & May & June \\
\hline \multicolumn{7}{|c|}{$\begin{array}{l}\text { Monthly mean discharge, in cublc feet per second } \\
\text { Runoff, in acre-feet }\end{array}$} & $\begin{array}{r}293 \\
18,040 \\
\end{array}$ & $\begin{array}{r}602 \\
35,840 \\
\end{array}$ \\
\hline
\end{tabular}

(13) 5-175 St Mary River near Babb, Mont

Location --Lat $48^{\circ} 50^{\prime} 00^{\prime \prime}$, long $113^{\circ} 25^{10} 00^{\prime \prime}$, in $\operatorname{SE} \frac{1}{4} \sec 34, \mathrm{~T} 36 \mathrm{~N}, \mathrm{R} 14 \mathrm{~W}$, on right bank half a mile upstream from outlet of Lower st Mary Lake and 2 miles southeast of Babb

Drainage area $--278 \mathrm{sq} \mathrm{mi}$

Gage-height record --Water-stage recorder graph, except 1800 hours June 8 to 1200 hours June 14 Peak stage from high-water mark in well Datum of gage is $4,46813 \mathrm{ft}$ above mean sea level, datum of 1929

Discharge record --Stage-discharge relation defined by current-meter measurements below 6,000 cfs and by slope-area measurement at 16,500 cfs $\frac{\text { Maxima }}{12} 96 \mathrm{ft}$, from high-water mark in well) 1964 Discharge, 16,500 cfs about 1400 hours June 8 (gage height

1902,1911-25, 1951 to May 1964 Discharge observed, 9,300 cfs July 4, 1902 (gage height, 6'50 ft, at site $3 \frac{3}{4}$ miles downstream and at datum then in use)

Remarks --Entire flow of Swiftcurrent Creek below Lake Sherburne is diverted into Lower St Mary Lake above station Flow of Swiftcurrent Creek is regulated by
Lake Sherburne (see station ll) 
Mean discharge, in cubic feet per second, 1964, of St Mary River near Babb, Mont

\begin{tabular}{|c|c|c|c|c|c|c|c|c|}
\hline Day & May & June & Day & May & June & Day & May & June \\
\hline \multicolumn{7}{|c|}{$\begin{array}{l}\text { Monthly mean discharge, in cubic feet per second } \\
\text { Runoff, in acre-feet }\end{array}$} & $\begin{array}{r}1,310 \\
80,470\end{array}$ & $\begin{array}{r}4,480 \\
266,700\end{array}$ \\
\hline
\end{tabular}

(14) 5-185 St Mary Canal at St Mary crossing, near Babb, Mont

(International gaging station)

Location --Lat $48^{\circ} 56^{\prime} 50^{\prime \prime}$, long $113^{\circ} 22^{\prime} 30^{\prime \prime}$, in $\mathrm{SW}_{\frac{1}{4}} \sec 19, \mathrm{~T} 37 \mathrm{~N}, \mathrm{R} 13 \mathrm{~W}$, on left bank $50 \mathrm{ft}$ upstream from inlet of St Mary siphon, 7 miles northeast of Babb, and 9 miles downstream from intake

Gage-height record --Water-stage recorder graph Altitude of gage is 4,440 ft (from topographic map)

Discharge record --Stage-discharge relation defined by current-meter measurements

Maxima --June 1964 Dally discharge, 706 cfs June 7

1918 to May 1964 Daily dischárge, 767 cfs June 19, 28, 1936

Remarks --Canal diverts water from left bank of St Mary River near Babb and discharges into North Fork Milk River

Mean discharge, in cubic feet per second, 1964

\begin{tabular}{|c|c|c|c|c|c|c|c|c|}
\hline Day & May & June & Day & May & June & Day & May & June \\
\hline $\begin{array}{r}1 \\
2 \\
3 \\
4 \\
5 \\
6 \\
7 \\
8 \\
9 \\
10\end{array}$ & $\begin{array}{l}133 \\
181 \\
290 \\
346 \\
503 \\
499 \\
523 \\
598 \\
610 \\
616\end{array}$ & $\begin{array}{r}683 \\
685 \\
690 \\
696 \\
700 \\
700 \\
706 \\
624 \\
103 \\
47\end{array}$ & $\begin{array}{l}11 \\
12 \\
13 \\
14 \\
15 \\
16 \\
17 \\
18 \\
19 \\
20\end{array}$ & $\begin{array}{l}616 \\
616 \\
618 \\
618 \\
618 \\
620 \\
624 \\
624 \\
629 \\
635\end{array}$ & $\begin{array}{rr}34 & 1 \\
19 & 2 \\
15 & 4 \\
12 & 3 \\
10 & 2 \\
3 & 2 \\
1 & 4 \\
1 & 4 \\
95 & 5 \\
499 & \end{array}$ & $\begin{array}{l}21 \\
22 \\
23 \\
24 \\
25 \\
26 \\
27 \\
28 \\
29 \\
30 \\
31\end{array}$ & $\begin{array}{l}643 \\
654 \\
668 \\
668 \\
662 \\
662 \\
675 \\
675 \\
679 \\
679 \\
681\end{array}$ & $\begin{array}{r}481 \\
451 \\
461 \\
517 \\
519 \\
471 \\
432 \\
392 \\
343 \\
316 \\
---\end{array}$ \\
\hline \multicolumn{7}{|c|}{$\begin{array}{l}\text { Monthly mean discharge, in cublc feet per second } \\
\text { Runoff, in acre-feet }\end{array}$} & $\begin{array}{r}576 \\
35,430\end{array}$ & $\begin{array}{r}357 \\
21,240\end{array}$ \\
\hline
\end{tabular}

(15) 5-190 St Mary Canal at Hudson Bay Divide, near Browning, Mont

(International gaging station)

Location --Lat $48^{\circ} 59^{\prime}$, long $113^{\circ} 04^{\prime}$, in sec $5, \mathrm{~T} 37 \mathrm{~N}, \mathrm{R} 11 \mathrm{~W}$, on right bank 3 miles upstream from canal outlet and 30 mlles north of Browning on Blackfeet. Indian Reservation

Gage-height record --Water-stage recorder graph Altitude of gage is 4,380 $\mathrm{ft}$ (from topographic map)

Discharge record --Stage-discharge relation defined by current-meter measurements

Maxima --June 1964 Dally discharge, 816 cfs June 8

1917 to May 1964 Dally discharge, $758 \mathrm{cfs}$ June 13, 1937

Remarks --Canal diverts water from left bank of St Mary River near Babb and discharges into North Fork Milk River 
Mean discharge, in cublc feet per second, 1964, of St Mary Canal at Hudson Bay D1vide,

\begin{tabular}{|c|c|c|c|c|c|c|c|c|}
\hline Day & May & June & Day & May & June & Day & May & June \\
\hline $\begin{array}{l}1 \\
2 \\
3 \\
4 \\
5 \\
6 \\
7 \\
8 \\
9 \\
10\end{array}$ & $\begin{array}{l}133 \\
150 \\
260 \\
311 \\
418 \\
486 \\
484 \\
542 \\
588 \\
595\end{array}$ & $\begin{array}{l}674 \\
682 \\
684 \\
687 \\
696 \\
693 \\
703 \\
816 \\
380 \\
70 \quad 8\end{array}$ & $\begin{array}{l}11 \\
12 \\
13 \\
14 \\
15 \\
16 \\
17 \\
18 \\
19 \\
20\end{array}$ & $\begin{array}{l}607 \\
607 \\
607 \\
602 \\
610 \\
605 \\
622 \\
605 \\
612 \\
619\end{array}$ & $\begin{array}{rr}25 & 9 \\
10 & 6 \\
5 & 5 \\
1 & 8 \\
1 & 8 \\
3 & 8 \\
2 & 6 \\
& 7 \\
& 2 \\
208 & \end{array}$ & $\begin{array}{l}21 \\
22 \\
23 \\
24 \\
25 \\
26 \\
27 \\
28 \\
29 \\
30 \\
31\end{array}$ & $\begin{array}{l}629 \\
637 \\
654 \\
659 \\
652 \\
647 \\
667 \\
672 \\
672 \\
672 \\
674\end{array}$ & $\begin{array}{r}450 \\
434 \\
418 \\
450 \\
484 \\
460 \\
424 \\
386 \\
343 \\
323 \\
----\end{array}$ \\
\hline $\begin{array}{l}\text { Month } \\
\text { Runof }\end{array}$ & $\begin{array}{l}\text { disch } \\
\text { re-fe }\end{array}$ & , in $c$ & $\mathrm{fe}$ & & & & $\begin{array}{r}558 \\
34,310 \\
\end{array}$ & $\begin{array}{r}351 \\
20,860 \\
\end{array}$ \\
\hline
\end{tabular}

(16) 5-200 Kennedy Creek near Babb, Mont

(Gaging station, discontinued 1912)

Location --Lat $48^{\circ} 55^{\prime} 00^{\prime \prime}$, long $113^{\circ} 26^{\prime} 10^{\prime \prime}$, in SW $\frac{1}{4} \sec 34$, T $37 \mathrm{~N}, \mathrm{R} 14 \mathrm{~W}$, $1 \frac{3}{4}$ miles upstream from mouth and 4 miles north of $\mathrm{Babb}$

Drainage area $--606 \mathrm{sq} \mathrm{ml}$

Maxima --June 1964 Discharge, about 15,000 cfs June 8, from slope-conveyance measurement

Remarks --Discharge measurements only in 1901,1903-4, 1906-7, 1911-12 Daily record in 1905, maximum not determined

\section{(17) 5-205 St Mary River at international boundary}

(International gaging station)

Location --Lat $49^{\circ} 00^{\prime} 10^{\prime \prime}$, long $113^{\circ} 18^{\prime} 50^{\prime \prime}$, in $\operatorname{SW} \frac{1}{4} \sec 5, \mathrm{~T} 1, \mathrm{R} 25 \mathrm{~W}$, fourth meridian, in Alberta, on right bank a quarter of a mlle north of international boundary, $2 \frac{1}{2}$ miles downstream from Boundary Creek, 7 miles southwest of Kimball, Alberta, and 11 miles northeast of Babb, Mont

Drainage area $--469 \mathrm{sq} \mathrm{mi}$

Gage-height record --Water-stage recorder graph Altitude of gage is 4,120 ft (from topographic map)

Discharge record --Stage-discharge relation defined by current-meter measurements

Maxima --June 1964 Discharge, $21,000 \mathrm{cfs} 1630$ hours June 8 (gage helght, $1206 \mathrm{ft}$ ) 1902 to May 1964 Discharge, about 40,000 cfs June 5, 1908 (gage he1ght, $1275 \mathrm{ft}$, from floodmarks, at site within a quarter mile of present site and at datum then in use), from rating curve extended above 6,000 ofs by logarithmic plotting

Remarks --Diversions by St Mary Canal at St Mary crossing, near Babb (see station 14) Flow partly regulated by Lake Sherburne (see station 11)

Mean discharge, in cubic feet per second, 1964

\begin{tabular}{|c|c|c|c|c|c|c|c|c|}
\hline Day & May & June & Day & May & June & Day & May & June \\
\hline \multicolumn{7}{|c|}{$\begin{array}{l}\text { Monthiy mean discharge, in cublc feet per second } \\
\text { Runoff, in acre-feet }\end{array}$} & $\begin{array}{r}1,185 \\
72,880\end{array}$ & $\begin{array}{r}5,423 \\
322,700\end{array}$ \\
\hline
\end{tabular}


Gage height, in feet, and discharge, in cubic feet per second, at indicated time, 1964, of

\begin{tabular}{|c|c|c|c|c|c|c|c|c|c|c|c|}
\hline Date & Hour & $\begin{array}{c}\text { Gage } \\
\text { height }\end{array}$ & $\begin{array}{l}\text { Dis- } \\
\text { charge }\end{array}$ & Date & Hour & $\begin{array}{c}\text { Gage } \\
\text { he1ght }\end{array}$ & $\begin{array}{l}\text { Dis- } \\
\text { charge }\end{array}$ & Date & Hour & $\begin{array}{c}\text { Gage } \\
\text { height }\end{array}$ & $\begin{array}{l}\text { Dis- } \\
\text { charge }\end{array}$ \\
\hline June 7 & $\begin{array}{l}0000 \\
0600 \\
1200 \\
1800 \\
2400 \\
0200 \\
0400 \\
0600 \\
\end{array}$ & $\begin{array}{ll}6 & 31 \\
6 & 32 \\
6 & 38 \\
6 & 56 \\
6 & 87 \\
7 & 10 \\
7 & 52 \\
8 & 16 \\
\end{array}$ & $\begin{array}{l}2,980 \\
3,000 \\
3,140 \\
3,540 \\
4,260 \\
4,810 \\
5,920 \\
7,590 \\
\end{array}$ & June 8 & $\begin{array}{l}0800 \\
1200 \\
1400 \\
1600 \\
1630 \\
1800 \\
2000 \\
2400\end{array}$ & $\begin{array}{rl}8 & 99 \\
10 & 24 \\
10 & 73 \\
11 & 86 \\
12 & 06 \\
11 & 48 \\
11 & 08 \\
10 & 64\end{array}$ & $\begin{array}{r}9,950 \\
13,800 \\
15,600 \\
20,100 \\
21,000 \\
18,400 \\
17,000 \\
15,600\end{array}$ & June 9 & $\begin{array}{l}0600 \\
1200 \\
1800 \\
2400 \\
\\
0600 \\
1200 \\
1800 \\
2400 \\
\end{array}$ & $\begin{array}{rr}11 & 09 \\
11 & 16 \\
11 & 31 \\
10 & 96 \\
10 & 51 \\
10 & 22 \\
9 & 89 \\
9 & 64 \\
\end{array}$ & $\begin{array}{l}17,000 \\
17,300 \\
17,800 \\
16,600 \\
15,200 \\
14,300 \\
13,300 \\
12,500\end{array}$ \\
\hline
\end{tabular}

(18) Rolph Creek near Kimball, Alberta

(Canadian gaging station)

Location --Lat $49^{\circ} 07^{\prime} 30^{\prime \prime}$, long $113^{\circ} 08^{\prime} 30^{\prime \prime}$, in NW $\frac{1}{4} \sec 15$, T $2, \mathrm{R} 24 \mathrm{~W}$, fourth meridian in Alberta, about 3 miles above mouth and $4 \frac{1}{2}$ miles northeast of K1mball

Drainage area $--906 \mathrm{sq} \mathrm{mi}$

Gage-height record - Twice-daily staff-gage readings, graph based on floodmark and observed readings June 8-10 Altitude of gage is $3,860 \mathrm{ft}$ (from topographic map)

Discharge record --Stage-discharge relation defined by current-meter measurements below $95 \mathrm{cf}$ 's and extended above by logarithmic plotting

Maxima --June 1964 Discharge, $630 \mathrm{cfs} 1800$ hours June 8 (gage height, $480 \mathrm{ft}$, from graph based on gage readings)

1911-16, 1935 to May 1964 Discharge, 1,290 cfs about 1800 hours June 3, 1953 (gage helght, $721 \mathrm{ft}$, from high-water mark)

Remarks --Records furnished by Department of Northern Affairs and National Resources, Canada

Mean discharge, in cublc feet per second, 1964

\begin{tabular}{|c|c|c|c|c|c|c|c|c|}
\hline Day & May & June & Day & May & June & Day & May & June \\
\hline $\begin{array}{r}1 \\
2 \\
3 \\
4 \\
5 \\
6 \\
7 \\
8 \\
9 \\
10\end{array}$ & $\begin{array}{rr}17 & 8 \\
31 & 2 \\
185 & \\
230 & \\
262 & \\
167 & \\
162 & \\
113 & \\
85 & 6 \\
61 & 3\end{array}$ & $\begin{array}{rr}7 & 1 \\
5 & 9 \\
5 & 0 \\
4 & 2 \\
3 & 7 \\
2 & 8 \\
3 & 5 \\
265 & \\
183 & \\
136 & \end{array}$ & $\begin{array}{l}11 \\
12 \\
13 \\
14 \\
15 \\
16 \\
17 \\
18 \\
19 \\
20\end{array}$ & $\begin{array}{rr}44 & 0 \\
33 & 8 \\
24 & 3 \\
18 & 5 \\
23 & 8 \\
19 & 0 \\
12 & 8 \\
9 & 5 \\
9 & 5 \\
8 & 1\end{array}$ & $\begin{array}{rl}143 & \\
132 & \\
97 & 1 \\
77 & 2 \\
74 & 9 \\
66 & 4 \\
120 & \\
76 & 0 \\
57 & 4 \\
65 & 3\end{array}$ & $\begin{array}{l}21 \\
22 \\
23 \\
24 \\
25 \\
26 \\
27 \\
28 \\
29 \\
30 \\
31\end{array}$ & $\begin{array}{ll}7 & 1 \\
5 & 9 \\
5 & 0 \\
5 & 0 \\
5 & 0 \\
5 & 0 \\
5 & 3 \\
5 & 6 \\
6 & 2 \\
5 & 3 \\
7 & 5\end{array}$ & 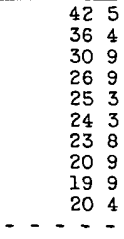 \\
\hline $\begin{array}{l}\text { Monthly } \\
\text { Runoff, } \\
\text { Runoff, }\end{array}$ & $\begin{array}{l}\text { mean discha } \\
\text { In inches } \\
\text { in acre-fee }\end{array}$ & , In cub & c feet & cond & & & $\begin{array}{r}510 \\
065 \\
3,140\end{array}$ & $\begin{array}{r}599 \\
074 \\
3,560\end{array}$ \\
\hline
\end{tabular}

(19) Lee Creẹ at Cardston, Alberta

(Canadian gaging station)

Location --Lat $49^{\circ} 12^{\prime} 00^{\prime \prime}$, long $113^{\circ} 17^{\prime} 45^{\prime \prime}$, in $\mathrm{NW} \frac{1}{4} \sec 10$, T $3, \mathrm{R} 25 \mathrm{~W}$, fourth meridlan, in Alberta, upstream from St Mary River Reservoir, 2 miles above mouth, and about $600 \mathrm{ft}$ downstream from bridge on Highway 2 at Cardston

Drainage area --117 sq́ $\mathrm{mi}$

Gage-helght record --Water-stage recorder graph, except 1500 hours to 2000 hours June 8, when graph was reconstructed from high-water mark Altitude of gage is $3,710 \mathrm{ft}$ (from topographic map)

D1scharge record --Stage-discharge relation defined by current-meter measurements below $8,700 \mathrm{c}$ 's

Maxima --June 1964 Discharge, $11,400 \mathrm{cfs}$ about 1700 hours June 8 (gage height, $1259 \mathrm{ft}$, from high-water mark)

1909-14, 1920 to May 1964 Discharge, 7,820 cfs June 24, 1951 (gage height, $1049 \mathrm{ft}$, from high-water mark)

Remar's --Records frunished by Department of Northern Affairs and National Resources, Canada 
Mean discharge, in cub1c feet per second, 1964, of Lee Creek at Cardston, Alberta

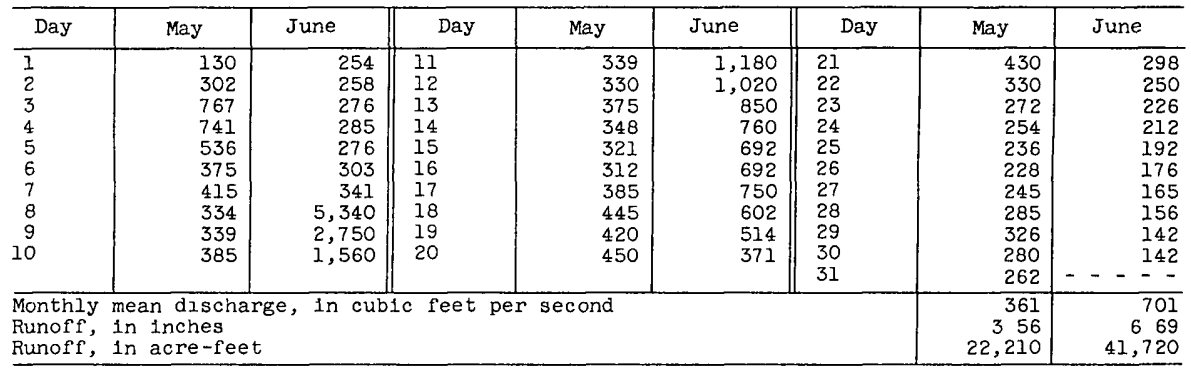

Gage height, in feet, and discharge, in cubic feet per second, at indicated time, 1964

\begin{tabular}{|c|c|c|c|c|c|c|c|c|c|c|c|}
\hline Date & Hour & $\begin{array}{c}\text { Gage } \\
\text { helght }\end{array}$ & $\begin{array}{c}\text { Dis- } \\
\text { charge }\end{array}$ & Date & Hour & $\begin{array}{c}\text { Gage } \\
\text { height }\end{array}$ & $\begin{array}{c}\text { Dis- } \\
\text { charge }\end{array}$ & Date & Hour & $\begin{array}{c}\text { Gage } \\
\text { helght }\end{array}$ & $\begin{array}{l}\text { Dis- } \\
\text { charge }\end{array}$ \\
\hline June 7 & $\begin{array}{l}0000 \\
0800 \\
1200 \\
1600 \\
1800 \\
2200 \\
2400\end{array}$ & $\begin{array}{ll}4 & 53 \\
4 & 57 \\
4 & 56 \\
4 & 62 \\
4 & 72 \\
5 & 05 \\
5 & 16 \\
\end{array}$ & $\begin{array}{l}280 \\
298 \\
294 \\
321 \\
366 \\
492 \\
554\end{array}$ & June 8 & $\begin{array}{l}0200 \\
0600 \\
0900 \\
1200 \\
1700 \\
2000 \\
2200\end{array}$ & $\begin{array}{rr}5 & 34 \\
6 & 20 \\
7 & 48 \\
9 & 00 \\
12 & 59 \\
11 & 25 \\
9 & 96\end{array}$ & $\begin{array}{r}663 \\
1,530 \\
3,370 \\
5,650 \\
11,400 \\
9,160 \\
7,100 \\
\end{array}$ & June & $\begin{array}{l}2400 \\
0300 \\
0600 \\
1200 \\
1800 \\
2400 \\
\end{array}$ & $\begin{array}{ll}8 & 58 \\
7 & 64 \\
7 & 27 \\
6 & 97 \\
6 & 61 \\
6 & 44 \\
\end{array}$ & $\begin{array}{l}5,020 \\
3,610 \\
3,060 \\
2,610 \\
2,100 \\
1,870\end{array}$ \\
\hline
\end{tabular}

\section{MISSOURI RIVER MAIN STEM}

(20) 6-545 Missour1 River at Toston, Mont

Location --Lat $46^{\circ} 08^{\prime} 45^{\prime \prime}$, long $111^{\circ} 25^{\prime} 15^{\prime \prime}$, in NWt $\sec 36, \mathrm{~T} 5 \mathrm{~N}, \mathrm{R} 2 \mathrm{E}$, on left bank 2 miles southeast of Toston, $4 \frac{1}{2}$ miles upstream from Crow Creek, and $7 \mathrm{miles}$ downstream from Sixteenmile Creek

Drainage area $--14,669 \mathrm{sq} \mathrm{mI}$

Gage-helght record --Water-stage recorder graph Altitude of gage is 3,920 ft (from topographic map)

Discharge record --Stage-discharge relation defined by current-meter measurements

Maxima --June 1964 Discharge, $22,000 \mathrm{cfs} 2200$ hours June 12 (gage height, $1000 \mathrm{ft}$ ) $1890,1910-16,1941$ to May 1964 Discharge, 32,000 cfs June 6, 1948 (gage height, $1177 \mathrm{ft}$ )

Remarks --Flow partly regulated by six reservoirs on tributaries (combined capacity, 567,200 acre-ft) Diversions for irrigation of about 535,000 acres

Mean discharge, In cub1c feet per second, 1964

\begin{tabular}{|c|c|c|c|c|c|c|c|c|}
\hline Day & May & June & Day & May & June & Day & May & June \\
\hline $\begin{array}{r}1 \\
2 \\
3 \\
4 \\
5 \\
6 \\
7 \\
8 \\
9 \\
10\end{array}$ & $\begin{array}{l}4,850 \\
5,850 \\
6,740 \\
6,530 \\
6,220 \\
5,800 \\
5,440 \\
5,180 \\
5,010 \\
4,950\end{array}$ & $\begin{array}{l}11,800 \\
11,000 \\
10,500 \\
10,600 \\
11,200 \\
12,000 \\
13,800 \\
17,500 \\
19,300 \\
19,800\end{array}$ & $\begin{array}{l}11 \\
12 \\
13 \\
14 \\
15 \\
16 \\
17 \\
18 \\
19 \\
20\end{array}$ & $\begin{array}{l}5,200 \\
5,400 \\
5,290 \\
5,510 \\
5,850 \\
6,240 \\
7,060 \\
7,960 \\
8,700 \\
9,340\end{array}$ & $\begin{array}{l}20,600 \\
21,600 \\
21,100 \\
19,000 \\
17,900 \\
18,400 \\
19,100 \\
19,700 \\
20,500 \\
20,600\end{array}$ & $\begin{array}{l}21 \\
22 \\
23 \\
24 \\
25 \\
26 \\
27 \\
28 \\
29 \\
30 \\
31\end{array}$ & $\begin{array}{r}8,640 \\
11,800 \\
12,100 \\
11,400 \\
10,200 \\
9,120 \\
8,760 \\
8,550 \\
10,100 \\
11,400 \\
11,800\end{array}$ & $\begin{array}{r}20,500 \\
20,600 \\
19,900 \\
20,500 \\
20,300 \\
19,700 \\
19,700 \\
19,800 \\
20,000 \\
19,000 \\
-\quad----\end{array}$ \\
\hline $\begin{array}{l}\text { Monthl } \\
\text { Runoff }\end{array}$ & $\begin{array}{l}\text { dische } \\
\text { are-fee }\end{array}$ & in $\mathrm{c}$ & feet & cond & & & $\begin{array}{r}7,645 \\
470,100 \\
\end{array}$ & $\begin{array}{r}17,870 \\
1,063,000 \\
\end{array}$ \\
\hline
\end{tabular}




\section{DEEP CREEK BASIN}

(21) 6-566 Deep Creek below North Fork Deep Creek, near Townsend, Mont

$$
\text { (Crest-stage station) }
$$

Location --Lat $46^{\circ} 20^{\prime}$, long $111^{\circ} 17^{\prime}$, in $\mathrm{SE} \frac{\mathrm{l}}{4} \sec 25, \mathrm{~T} 7 \mathrm{~N}, \mathrm{R} 3 \mathrm{E}$, at bridge on county road, 11 miles east of Townsend

Drainage area $--87 \quad \mathrm{sq} \mathrm{mi}$

Gage-height record --Crest stages only Altitude of gage is 4,440 ft (from topographic map)

Discharge record --Stage-discharge relation defined by current-meter measurements

Maxima --June 1964 Discharge, $296 \mathrm{cfs}$ June 8 (gage height, $221 \mathrm{ft}$ )

1959 to May 1964 Discharge, $329 \mathrm{cfs}$ May 18, 1964 (gage height, $233 \mathrm{ft}$ )

\section{MISSOURI RIVER MAIN STEM}

(22) 6-570 Missour River near Townsend, Mont

(Gaglng station, discontinued 1904, U S Weather Bureau stage station 1902-16 and since 1957)

Location --Lat $46^{\circ} 20^{\prime} 10^{\prime \prime}$, long $111^{\circ} 31^{\prime} 55^{\prime \prime}$, in $\mathrm{SW}_{\frac{1}{4}} \mathrm{NW} \frac{1}{4} \sec 30, \mathrm{~T} 7 \mathrm{~N}, \mathrm{R} 2 \mathrm{E}$, at highway bridge, 1 mile northwest of mownsend

Drainage area $--15,343 \mathrm{sq} \mathrm{mI}$

Gage-height record --Wire-weight gage read at 0730 hours Maximum from graph of gage readings, based on shape of graph at the Toston gage Datum of gage is at mean sea level, adjustment of 1929

D1scharge record --Stage-discharge relation defined by current-meter measurements

Maxima --June 1964 Discharge $22,900 \mathrm{cfs} 0100$ hours June 13 (elevation, 3,809 $6 \mathrm{ft}$, from graph of gage readings)

1892-1916, 1948 to May 1964 Discharge observed, 38,400 cfs June 3-5, 1894 (elevation, 3,811 $7 \mathrm{ft}$ ), elevation, 3,813 $0 \mathrm{ft}$ about Feb 6, 1963, result of ice jam, but may have been higher in November 1959

Remarks --Dally stage record furnıshed by the U S Weather Bureau Flow partly regulated by six reservoirs on tributary streams (combined capacity, 567,200 acre-ft)

Elevation, in feet, at 0730 hours, of indicated day, 1964

\begin{tabular}{|c|c|c|c|c|c|c|c|c|}
\hline Day & May & June & Day & May & June & Day & May & June \\
\hline $\begin{array}{r}1 \\
2 \\
3 \\
4 \\
5 \\
6 \\
7 \\
8 \\
9 \\
10\end{array}$ & $\begin{array}{ll}3,805 & 84 \\
3,806 & 10 \\
3,806 & 50 \\
3,806 & 52 \\
3,806 & 42 \\
3,806 & 30 \\
3,806 & 19 \\
3,806 & 12 \\
3,806 & 02 \\
3,805 & 98\end{array}$ & $\begin{array}{ll}3,807 & 62 \\
3,807 & 58 \\
3,807 & 35 \\
3,807 & 35 \\
3,807 & 42 \\
3,807 & 57 \\
3,807 & 81 \\
3,8013 & 45 \\
3,809 & 10 \\
3,809 & 25\end{array}$ & $\begin{array}{l}11 \\
12 \\
13 \\
14 \\
15 \\
16 \\
17 \\
18 \\
19 \\
20\end{array}$ & $\begin{array}{ll}3,806 & 02 \\
3,806 & 14 \\
3,806 & 11 \\
3,806 & 12 \\
3,806 & 27 \\
3,806 & 35 \\
3,806 & 52 \\
3,806 & 14 \\
3,806 & 94 \\
3,807 & 09\end{array}$ & $\begin{array}{ll}3,809 & 25 \\
3,809 & 45 \\
3,809 & 48 \\
3,809 & 23 \\
3,808 & 94 \\
3,808 & 85 \\
3,809 & 10 \\
3,809 & 01 \\
3,809 & 32 \\
3,809 & 42\end{array}$ & $\begin{array}{l}21 \\
22 \\
23 \\
24 \\
25 \\
26 \\
27 \\
28 \\
29 \\
30 \\
31\end{array}$ & $\begin{array}{ll}3,807 & 26 \\
3,807 & 46 \\
3,807 & 73 \\
3,807 & 64 \\
3,807 & 40 \\
3,807 & 10 \\
3,806 & 97 \\
3,806 & 92 \\
3,807 & 00 \\
3,807 & 46 \\
3,807 & 57\end{array}$ & 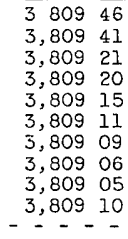 \\
\hline
\end{tabular}


(23) 6-585 Canyon Ferry Reservoir near Helena, Mont

Location --Lat $46^{\circ} 39^{\prime} 00^{\prime \prime}$, long $111^{\circ} 43^{\prime} 40^{\prime \prime}$, in $\mathrm{SE}_{\frac{1}{4}} \mathrm{SE}_{\frac{1}{4}} \sec 4, \mathrm{~T} 10 \mathrm{~N}, \mathrm{R} 1 \mathrm{~W}$, in block 17 of Canyon Ferry Dam, 15 miles east of Helena

Drainage area $=-15,904 \mathrm{sq} \mathrm{mi}$

Gage-helght record --Water-stage recorder Datum of gage is at mean sea level (levels by Bureau of Reclamation)

Maxima --June 1964 Dally contents, 2,043,000 acre-ft June 23 (elevation, $3,80000 \mathrm{ft})$

1953 to May 1964 Da1ly contents, 2,043,000 acre-ft at times in July 1955, 1956, 1962 and June 23, 1964 (elevation, 3,800 $00 \mathrm{ft}$ )

Remarks --Reservoir is iormed by concrete dam, construction began in 1949, completed in 1953 Storage began in March 1953 Usable capacity, 2,043,000 acre-ft at controlled spiliway elevation $(3,800 \mathrm{ft})$ Dead storage, 8,000 acre-ft below elevation 3,650 ft Minimum operating level, 3,728 ft for on-site power generation (usable contents, 428,000 acre-ft) Water is used for power production, flood control, irrigation, recreation, and supplemental water supply for city of Helena Elevations and capacity table furnished by Bureau of Reclamation Figures given herein represent usable contents

Elevation, in feet, and contents, in acre-feet, at 2400 hours of indicated day, 1964

\begin{tabular}{|c|c|c|c|c|c|c|c|c|c|}
\hline Day & \multicolumn{2}{|c|}{ May } & \multicolumn{2}{|c|}{ June } & Day & \multicolumn{2}{|c|}{ May } & \multicolumn{2}{|c|}{ June } \\
\hline $\begin{array}{l}1 \\
2 \\
3 \\
4 \\
5\end{array}$ & $\begin{array}{ll}3,791 & 02 \\
3,791 & 15 \\
3,791 & 59 \\
3,791 & 95 \\
3,792 & 21\end{array}$ & {$\left[\begin{array}{l}1,740,000 \\
1,744,000 \\
1,759,000 \\
1,771,000 \\
1,780,000\end{array}\right.$} & 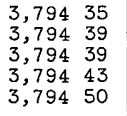 & $\begin{array}{l}1,852,000 \\
1,854,000 \\
1,854,000 \\
1,855,000 \\
1,857,000\end{array}$ & $\begin{array}{l}16 \\
17 \\
18 \\
19 \\
20\end{array}$ & $\begin{array}{ll}3,792 & 64 \\
3,792 & 69 \\
3,792 & 74 \\
3,792 & 74 \\
3,792 & 75\end{array}$ & $\begin{array}{l}1,795,000 \\
1,796,000 \\
1,798,000 \\
1,798,000 \\
1,798,000\end{array}$ & 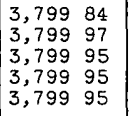 & $\begin{array}{l}2,038,000 \\
2,042,000 \\
2,041,000 \\
2,041,000 \\
2,041,000\end{array}$ \\
\hline $\begin{array}{l}11 \\
12 \\
13 \\
14 \\
15\end{array}$ & $\begin{array}{ll}3,792 & 44 \\
3,792 & 45 \\
3,792 & 45 \\
3,792 & 50 \\
3,792 & 57\end{array}$ & $\begin{array}{l}1,788,000 \\
1,788,000 \\
1,788,000 \\
1,790,000 \\
1,792,000\end{array}$ & $\begin{array}{ll}3,798 & 14 \\
3,798 & 69 \\
3,799 & 06 \\
3,799 & 36 \\
3,799 & 67\end{array}$ & $\begin{array}{l}1,980,000 \\
1,999,000 \\
2,011,000 \\
2,021,000 \\
2,032,000\end{array}$ & $\begin{array}{l}26 \\
27 \\
28 \\
29 \\
30 \\
31\end{array}$ & 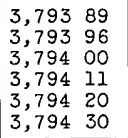 & $\begin{array}{l}1,837,000 \\
1,839,000 \\
1,841,000 \\
1,844,000 \\
1,847,000 \\
1,851,000\end{array}$ & 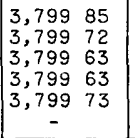 & $\begin{array}{c}2,038,000 \\
2,033,000 \\
2,030,000 \\
2,030,000 \\
2,034,000 \\
-\end{array}$ \\
\hline
\end{tabular}

\section{SPOKANE CREEK BASIN}

(24) 6-587 Mitchell Gulch near East Helena, Mont

(Crest-stage station)

Location --Lat $46^{\circ} 34^{\prime}$, long $111^{\circ} 49^{\prime}$, in $N W^{\frac{1}{4}} \sec 2, \mathrm{~T} 9 \mathrm{~N}, \mathrm{R} 2 \mathrm{~W}$, at culvert on US Highway 12,47 miles east of East Helena

Drainage area $--809 \mathrm{sq} \mathrm{ml}$

Gage-helght record --Crest stage only Altitude of gage is 4,060 ft (from topographic map)

Discharge record --Stage-discharge relation defined by current-meter measurements

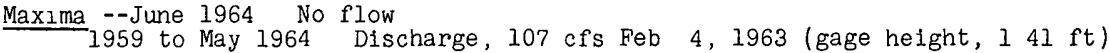




\section{PRICKLY PEAR CREEK BASIN}

(25) 6-615 Prickly Pear Creek near Clancy, Mont

Location --Lat $46^{\circ} 31^{\prime} 05^{\prime \prime}$, long $111^{\circ} 56^{\prime} 45^{\prime \prime}$, in $N E \frac{1}{4} S W \frac{1}{4} \sec 23, \mathrm{~T} 9 \mathrm{~N}, \mathrm{R} 3 \mathrm{~W}$, on right bank $100 \mathrm{ft}$ upstream from bridge' on U S Highway $91,3 \frac{1}{2}$ miles downstream from Lump Gulch Creek, 4 miles northeast of Clancy, and 7 miles southeast of Helena

Drainage area $--192 \mathrm{sq} \mathrm{mi}$

Gage-helght record --Water-stage recorder graph Datum of gage is 4,067 $1 \mathrm{ft}$ above mean sea level, datum of 1929

Discharge record --Stage-discharge relation defined by current-meter measurements

Maxima --June 1964 Discharge, $700 \mathrm{cfs} 1100$ hours June 9 (gage height, $601 \mathrm{ft}$ ) 1909-16, 1921-33, 1945 to May 1964 Discharge, about $900 \mathrm{cfs}$ about June 9 , 1927 (estimated on basis of hydrographic comparison)

Mean discharge, in cubic feet per second, 1964

\begin{tabular}{|c|c|c|c|c|c|c|c|c|}
\hline Day & May & June & Day & May & June & Day & May & June \\
\hline $\begin{array}{r}1 \\
2 \\
3 \\
4 \\
5 \\
6 \\
7 \\
8 \\
9 \\
10\end{array}$ & $\begin{array}{r}89 \\
104 \\
79 \\
70 \\
80 \\
81 \\
76 \\
73 \\
74 \\
82\end{array}$ & $\begin{array}{l}173 \\
171 \\
177 \\
178 \\
175 \\
180 \\
239 \\
373 \\
540 \\
376\end{array}$ & $\begin{array}{l}11 \\
12 \\
13 \\
14 \\
15 \\
16 \\
17 \\
18 \\
19 \\
20\end{array}$ & $\begin{array}{r}87 \\
86 \\
97 \\
108 \\
112 \\
127 \\
153 \\
172 \\
178 \\
196\end{array}$ & $\begin{array}{l}310 \\
271 \\
247 \\
243 \\
260 \\
267 \\
316 \\
247 \\
288 \\
288\end{array}$ & $\begin{array}{l}21 \\
22 \\
23 \\
24 \\
25 \\
26 \\
27 \\
28 \\
29 \\
30 \\
31\end{array}$ & $\begin{array}{l}213 \\
201 \\
169 \\
156 \\
158 \\
144 \\
138 \\
157 \\
250 \\
217 \\
186 \\
\end{array}$ & $\begin{array}{r}249 \\
260 \\
225 \\
213 \\
205 \\
207 \\
209 \\
187 \\
172 \\
166 \\
--2- \\
\end{array}$ \\
\hline $\begin{array}{l}\text { Monthly } \\
\text { Runoff, } \\
\text { Runoff, }\end{array}$ & $\begin{array}{l}\text { mean discha } \\
\text { in inches } \\
\text { in acre-fee }\end{array}$ & , In cub & c feet & cond & & & $\begin{array}{r}133 \\
080 \\
8,160\end{array}$ & $\begin{array}{r}247 \\
144 \\
14,700\end{array}$ \\
\hline
\end{tabular}

Gage helght, in feet, and discharge, in cubic feet per second, at indicated time, 1964

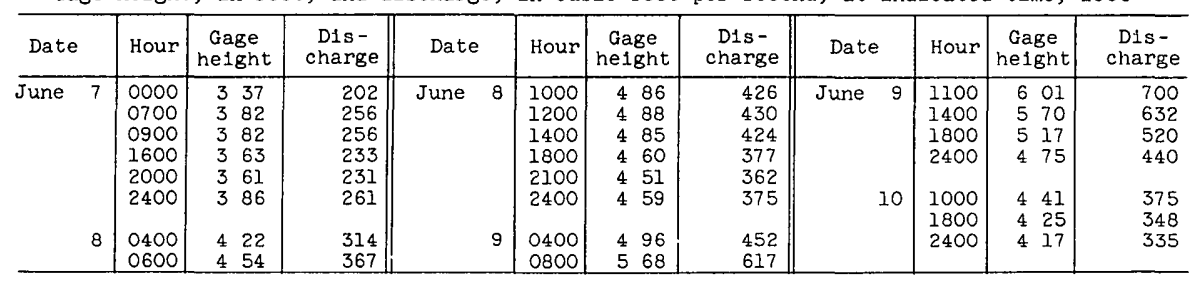

(26) 6-617 Jackson Creek near East Helena, Mont

(Crest-stage station)

Location --Lat $46^{\circ} 28^{\prime} 20^{\prime \prime}$, long $111^{\circ} 51^{\prime} 10^{\prime \prime}$, in SE $\frac{1}{4} \sec 4$, T $8 \mathrm{~N}, \mathrm{R} 2 \mathrm{~W}, 300 \mathrm{ft}$ upstream from mouth, $8 \frac{1}{2}$ miles southeast of East Helena

Drainage area $--3 \quad 44 \mathrm{sq} \mathrm{mi}$

Gage-height record --Crest stages only Altitude of gage is 4,990 ft (from topographic mapl

D1scharge record --Stage-discharge relation defined by current-meter measurements

Maxima --June 1964 Discharge, $19 \mathrm{cfs}$ June 8 (gage height, $264 \mathrm{ft}$ )

1961 to May 1964 Discharge, $16 \mathrm{cfs}$ June 2, 1962 (gage helght, $249 \mathrm{ft}$ ) 
(27) 6-618 Crystal Creek near East Helena, Mont

(Crest-stage station)

Location --Lat $46^{\circ} 29^{\prime} 00^{\prime \prime}$, long $111^{\circ} 51^{\prime} 40^{\prime \prime}$, In $N W^{\frac{1}{4}} \sec 4, \mathrm{~T} 8 \mathrm{~N}, \mathrm{R} 2 \mathrm{~W}$, a quarter of a mile upstream from mouth, 8 miles southeast of East Helena

Drainage area $--377 \mathrm{sq} \mathrm{mi}$

$\frac{\text { Gage-height record }}{\text { graphic map) }}$-Crest stages only Altitude of gage is 4,860 ft (from topo-

Discharge record --Stage-discharge relation defined by current-meter measurements

Maxima --June 1964 Discharge, 21 cfs June 8 (gage height, $164 \mathrm{ft}$ )

1961 to May 1964 Discharge, $16 \mathrm{cfs}$ May 28, 1964 (gage height, $152 \mathrm{ft}$ )

(28) 6-619 McClellan Creek at c1ty diversion dam, near East Helena, Mont

(Crest-stage station)

Location --Lat $46^{\circ} 32^{\prime} 00^{\prime \prime}$, long $111^{\circ} 52^{\prime} 40^{\prime \prime}$, in SE $\frac{1}{4} \sec 17, \mathrm{~T} 9 \mathrm{~N}, \mathrm{R} 2 \mathrm{~W}, 300 \mathrm{ft}$ upstream from diversion'dam, $4 \frac{3}{2}$ miles southeast of East Helena

Drainage area $--332 \mathrm{sq} \mathrm{mi}$

$\frac{\text { Gage-height record }}{\text { graphic map) }}$-Crest stages only Altitude of gage is 4,200 ft (from topo-

Discharge record --Stage-discharge relation defined by current-meter measurements

below $100 \mathrm{cfs}$ and by flow-over-dam measurement at $390 \mathrm{cfs}$

Maxima --June 1964 Discharge, $390 \mathrm{cfs}$ June 8 (gage height, $259 \mathrm{ft}$ )

1960 to May 1964 Discharge, $175 \mathrm{cfs}$ June 2, 1962 (gage helght, $148 \mathrm{ft}$ )

(29) 6-625 Tenmile Creek near Rimini, Mont

Location --Lat $46^{\circ} 31^{\prime} 30^{\prime \prime}$, long $112^{\circ} 15^{\prime} 20^{\prime \prime}$, in $\operatorname{SW} \frac{1}{4} \mathrm{NE} \frac{1}{4} \sec 20$, T $9 \mathrm{~N}, \mathrm{R} 5 \mathrm{~W}$, on left bank at Moose Creek ranger station, $500 \mathrm{ft}$ upstream from Moose Creek and' 3 miles north of Rimini

Drainage area $--327 \mathrm{sq} \mathrm{mi}$ $\frac{\text { Gage-height record }}{\text { topographic map) }}$-Water-stage recorder graph Altitude of gage is 4,850 ft (from

Discharge record --Stage-discharge relation defined by current-meter measurements below $450 \mathrm{cfs}$ and by contracted-opening measurement at $556 \mathrm{cfs}$

Maxima --June 1964 Discharge, $563 \mathrm{cfs} 0300$ hours June 9 (gage height, $377 \mathrm{ft}$ ) 1914 to May 1964 Discharge $781 \mathrm{cfs}$ May 27, 1917 (gage height, $498 \mathrm{ft}$, at site $40 \mathrm{ft}$ downstream and at datum then in use?

Remarks -Flow partly regulated by two reservoirs on tributary streams (combined capacity, 2,340 acre-ft)

Mean discharge, in cub1c feet per second, 1964

\begin{tabular}{|c|c|c|c|c|c|c|c|c|}
\hline Day & May & June & Day & May & June & Day & May & June \\
\hline $\begin{array}{r}1 \\
2 \\
3 \\
4 \\
5 \\
6 \\
7 \\
8 \\
9 \\
10\end{array}$ & $\begin{array}{l}21 \\
21 \\
18 \\
17 \\
15 \\
15 \\
15 \\
17 \\
23 \\
34\end{array}$ & $\begin{array}{l}141 \\
145 \\
153 \\
149 \\
138 \\
134 \\
152 \\
310 \\
412 \\
263\end{array}$ & $\begin{array}{l}11 \\
12 \\
13 \\
14 \\
15 \\
16 \\
17 \\
18 \\
19 \\
20\end{array}$ & $\begin{array}{r}35 \\
41 \\
53 \\
68 \\
86 \\
123 \\
168 \\
164 \\
157 \\
202\end{array}$ & $\begin{array}{l}203 \\
173 \\
154 \\
150 \\
144 \\
142 \\
140 \\
121 \\
162 \\
162\end{array}$ & $\begin{array}{l}21 \\
22 \\
23 \\
24 \\
25 \\
26 \\
27 \\
28 \\
29 \\
30 \\
31\end{array}$ & $\begin{array}{l}202 \\
172 \\
149 \\
130 \\
123 \\
114 \\
117 \\
145 \\
206 \\
157 \\
145\end{array}$ & $\begin{array}{r}160 \\
160 \\
137 \\
123 \\
110 \\
106 \\
95 \\
86 \\
75 \\
67 \\
----\end{array}$ \\
\hline $\begin{array}{l}\text { Month] } \\
\text { Runoff }\end{array}$ & $\begin{array}{l}\text { disch } \\
\text { cre-fee }\end{array}$ & , in cu & feet & cond & & & $\begin{array}{r}953 \\
5,860\end{array}$ & $\begin{array}{r}156 \\
9,260\end{array}$ \\
\hline
\end{tabular}


Gage height, in feet, and discharge, in cubic feet per second, at indicated time, 1964, of

\begin{tabular}{|c|c|c|c|c|c|c|c|c|c|c|c|}
\hline Date & Hour & $\begin{array}{c}\text { Gage } \\
\text { helght }\end{array}$ & $\begin{array}{c}\text { Dis- } \\
\text { charge }\end{array}$ & Date & Hour & $\begin{array}{c}\text { Gage } \\
\text { height }\end{array}$ & $\begin{array}{c}\text { D1s- } \\
\text { charge }\end{array}$ & Date & Hour & $\begin{array}{c}\text { Gage } \\
\text { helght }\end{array}$ & $\begin{array}{c}\text { Dis- } \\
\text { charge }\end{array}$ \\
\hline June 7 & $\begin{array}{l}0000 \\
0600 \\
1400 \\
2000 \\
2300 \\
2400 \\
\\
0300 \\
0330 \\
0600\end{array}$ & $\begin{array}{ll}2 & 44 \\
2 & 44 \\
2 & 39 \\
2 & 49 \\
2 & 60 \\
2 & 75 \\
2 & 99 \\
3 & 14 \\
3 & 02\end{array}$ & $\begin{array}{l}145 \\
145 \\
127 \\
164 \\
210 \\
278 \\
\\
395 \\
319 \\
264\end{array}$ & June 8 & $\begin{array}{l}0700 \\
0900 \\
1300 \\
1600 \\
1700 \\
2000 \\
2100 \\
2200 \\
2300 \\
2400\end{array}$ & $\begin{array}{ll}2 & 82 \\
2 & 74 \\
2 & 73 \\
2 & 68 \\
2 & 69 \\
2 & 85 \\
3 & 05 \\
3 & 50 \\
3 & 68 \\
3 & 65\end{array}$ & $\begin{array}{l}310 \\
273 \\
268 \\
246 \\
250 \\
278 \\
324 \\
515 \\
533 \\
515\end{array}$ & June 9 & $\begin{array}{l}0100 \\
0300 \\
0600 \\
1000 \\
1030 \\
1100 \\
1900 \\
2000 \\
2400\end{array}$ & $\begin{array}{ll}3 & 73 \\
3 & 77 \\
3 & 59 \\
3 & 43 \\
3 & 32 \\
3 & 37 \\
3 & 18 \\
3 & 20 \\
3 & 15\end{array}$ & $\begin{array}{l}546 \\
563 \\
486 \\
418 \\
375 \\
394 \\
322 \\
329 \\
310\end{array}$ \\
\hline
\end{tabular}

(30) 6-627 Little Porcupine Creek tributary near Helena, Mont

(Crest-stage station)

Location --Lat $46^{\circ} 35^{\prime}$, long $112^{\circ} 16^{\prime}$, in $\operatorname{SW} \frac{1}{4} \sec 29, \mathrm{~T} 10 \mathrm{~N}, \mathrm{R} 5 \mathrm{~W}$, at culvert on US Highway 12,11 miles west of Helena

Drainage area $--0 \quad 48 \mathrm{sq} \mathrm{ml}$

Gage-height record --Crest stages only Altitude of gage is 5,360 ft (from topographic map)

Discharge record --Stage-discharge relation defined by current-meter measurements below $35 \mathrm{cfs}$ and by flow-through-culvert measurement at $59 \mathrm{cfs}$

Maxima --June 1964 Discharge, $59 \mathrm{cfs}$ June 8 (gage height, $117 \mathrm{ft}$ ) 1959 to May 1964 Discharge, 38 cfs May 17, 1964 (gage helght, $074 \mathrm{ft}$ )

(31) 6-645 Lake Helena near Helena, Mont

Location --Lat $46^{\circ} 46^{\prime} 00^{\prime \prime}$, long $111^{\circ} 54^{\prime} 10^{\prime \prime}$, in SE $\frac{1}{4} \sec 29, \mathrm{~T} 12 \mathrm{~N}, \mathrm{R} 2 \mathrm{~W}$, at Hauser Dam on Missouri River, $1 \frac{3}{4}$ miles downstream from Prickiy Pear Creek, and 13 miles northeast of Helena

Drainage area --610 sq $\mathrm{ml}$, above dam and control works on Prickly Pear Creek

Gage-height record --Water-stage indicator at Hauser Dam read daily at 2400 hours Datum of gage Is at mean sea level (levels by The Montana Power Co )

Maxima --June 1964 Contents observed, 10,240 acre-ft 2400 hours June 1 (elevation, $3,63490 \mathrm{ft}$ )

1945 to May 1964 Contents observed, 11,790 acre-ft Aug 2, 1960, Dec 10, 1962, July 19, 20, Sept 4, 1963 (elevation, 3,635 $60 \mathrm{ft}$ )

Remarks --Gage heights collected at Hauser Dam are effective on Lake Helena at control dam Prior to April 1945, contents of Lake Helena included with records of Hauser Lake Since that date, a dam and control works has separated the two lakes to allow independent regulation of Lake Helena if needed Usable capacity, 10,450 acre-ft at elevation, $3,63500 \mathrm{ft}$ No dead storage Water is used for recreation, wildlife, and power production through Hauser Dam Records furnished by The Montana Power Co Figures given herein represent usable contents 
Elevation, in feet, and contents, in acre-feet, at 2400 hours on Indicated day, 1964 , of

\begin{tabular}{|c|c|c|c|c|c|c|c|c|c|}
\hline Day & Elevation & Contents & Elevation & Contents & Day & Elevation & Contents & Elevation & Contents \\
\hline $\begin{array}{l}1 \\
2 \\
3 \\
4 \\
5\end{array}$ & $\begin{array}{ll}3,634 & 90 \\
3,635 & 20 \\
3,634 & 80 \\
3,634 & 50 \\
3,634 & 70\end{array}$ & $\begin{array}{r}10,240 \\
10,890 \\
10,030 \\
9,420 \\
9,820\end{array}$ & $\begin{array}{ll}3,634 & 90 \\
3,634 & 20 \\
3,633 & 70 \\
3,634 & 20 \\
3,634 & 30\end{array}$ & $\begin{array}{r}10,240 \\
8,830 \\
7,900 \\
8,830 \\
9,020\end{array}$ & $\begin{array}{l}16 \\
17 \\
18 \\
19 \\
20\end{array}$ & $\begin{array}{ll}3,635 & 40 \\
3,635 & 40 \\
3,634 & 90 \\
3,634 & 60 \\
3,634 & 00\end{array}$ & $\begin{array}{r}11,340 \\
11,340 \\
10,240 \\
9,620 \\
8,450\end{array}$ & $\begin{array}{ll}3,634 & 00 \\
3,633 & 90 \\
3,634 & 20 \\
3,633 & 60 \\
3,633 & 20\end{array}$ & $\begin{array}{l}8,450 \\
8,270 \\
8,830 \\
7,720 \\
7,030\end{array}$ \\
\hline $\begin{array}{l}11 \\
12 \\
13 \\
14 \\
15\end{array}$ & $\begin{array}{ll}3,635 & 00 \\
3,634 & 80 \\
3,634 & 50 \\
3,634 & 60 \\
3,635 & 20\end{array}$ & $\begin{array}{r}10,450 \\
10,030 \\
9,420 \\
9,620 \\
10,890\end{array}$ & $\begin{array}{ll}3,633 & 30 \\
3,634 & 10 \\
3,634 & 10 \\
3,634 & 00 \\
3,634 & 00\end{array}$ & $\begin{array}{l}7,200 \\
8,640 \\
8,640 \\
8,450 \\
8,450\end{array}$ & $\begin{array}{l}26 \\
27 \\
28 \\
29 \\
30 \\
31\end{array}$ & $\begin{array}{ll}3,634 & 30 \\
3,634 & 50 \\
3,634 & 00 \\
3,633 & 90 \\
3,635 & 30 \\
3,635 & 40\end{array}$ & $\begin{array}{r}9,020 \\
9,420 \\
8,450 \\
8,270 \\
11,110 \\
11,340\end{array}$ & $\begin{array}{cc}3,634 & 00 \\
3,634 & 00 \\
3,634 & 10 \\
3,633 & 30 \\
3,633 & 40 \\
- & \end{array}$ & $\begin{array}{l}8,450 \\
8,450 \\
8,640 \\
7,200 \\
7,370 \\
-\end{array}$ \\
\hline \multicolumn{6}{|c|}{ Change in contents } & - & +450 & - & $-3,970$ \\
\hline
\end{tabular}

\section{MISSOURI RIVER MAIN STEM}

(32) 6-650 Hauser Lake near Helena, Mont

Location --Lat $46^{\circ} 46^{\prime} 00^{\prime \prime}$, long $111^{\circ} 54^{\prime} 10^{\prime \prime}$, in $\mathrm{SE}_{\frac{1}{4}} \sec 29$, T $12 \mathrm{~N}, \mathrm{R} 2 \mathrm{~W}$, at dam on Missouri River, $1 \frac{3}{4}$ miles downstream from Prickly Pear Creek, and 13 miles northeast of Helena

Drainage area $--16,876 \mathrm{sq} \mathrm{mI}$

Gage-height record --Water-stage indicator read daily at 2400 hours Datum of gage is at mean sea level (levels by The Montana Power Co)

Maxima --June 1964 Contents observed, 51,050 cfs 2400 hours June 1 (elevation, $\left.3,63490 \mathrm{ft}^{\prime}\right)$

1945 to May 1964 Contents observed, 53,630 acre-ft Aug 2, 1960, Dec 10, 1962, July 19, 20, Sept 4, 1963 (elevation, 3,635 $60 \mathrm{ft}$ )

Remarks - -Reservoir is formed by concrete dam completed in 1907, separated from Lake Helena in April 1945 Usable capacity, 51,420 acre-ft (52,090 acre-ft prior to Nov 28,1949 ) at elevation $3,63500 \mathrm{ft}$ (not including capacity of Lake Helena) Dead storage, 46,810 acre-ft below elevation $3,6170 \mathrm{ft}$ Not normally drawn below 3,621 $00 \mathrm{ft}(8,870$ acre-ft) Water is used for power and recreation Records furnished by The Montana Power Co Figures given herein represent usable contents

Elevation, in feet, and contents, in acre-feet, at 2400 hours on indicated day, 1964

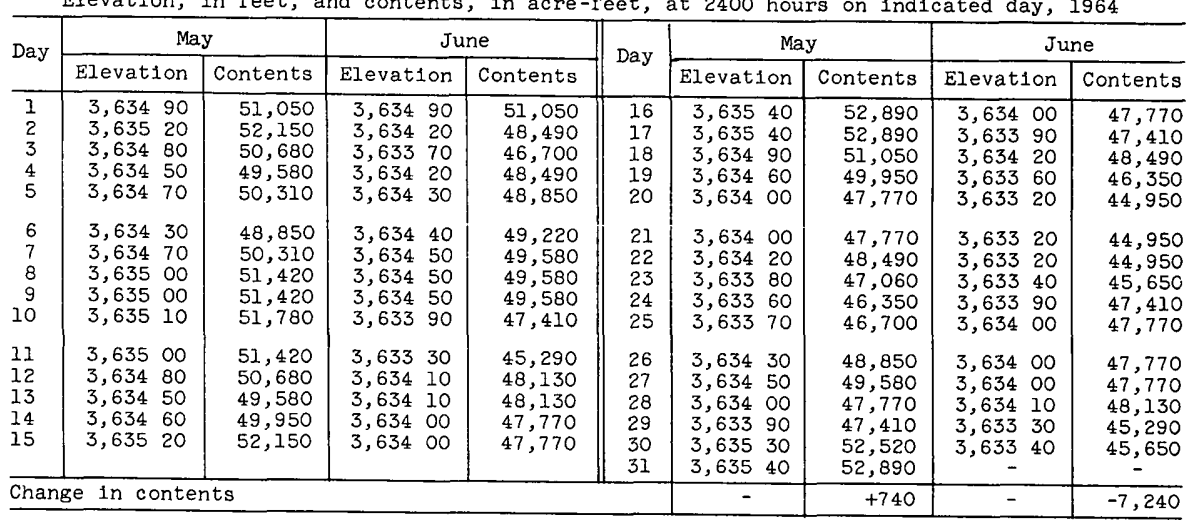


(33) 6-660 Holter Lake near Wolf Creek, Mont

Location --Lat $46^{\circ} 59^{\prime} 30^{\prime \prime}$, long $112^{\circ} 00^{\prime} 30^{\prime \prime}$, on line between SE $\frac{1}{4} \sec 5$ and NE $\frac{1}{4}$ sec 8 , $T 14 \mathrm{~N}, \mathrm{R} 3 \mathrm{~W}$, at Holter Dam on Missouri River, $3 \frac{1}{2}$ miles southeast of Wolf Creek

Drainage area $--17,149 \mathrm{sq} \mathrm{mi}$

Gage-helght record --Water-stage indicator read at 0800 hours daily Datum of gage is at mean sea level (levels by The Montana Power Co )

Maxima --June 1964 Contents observed, 80,730 acre-ft 0800 hours June 26 (elevation, $3,56375 \mathrm{ft}$ )

1936 to May 1964 Contents observed, 83,110 acre-ft Aug 31, 1951 (elevation, $3,56425 \mathrm{ft}$ )

Remarks --Reservolr is formed by concrete dam completed in 1918 Usable capacity, 81,920 acre-ft at elevation $3,5640 \mathrm{ft}$ Dead storage, 158,500 acre-ft below elevation $3,5430 \mathrm{ft}$ Not normally drawn below $3,548 \mathrm{oft}(16,660$ acre-ft) Water is used for power and recreation Records furnished by The Montana Power Co Figures given herein represent usable contents

Elevation, in feet, and contents, in acre-feet, at 0800 hours of Indicated day, 1964

\begin{tabular}{|c|c|c|c|c|c|c|c|c|c|}
\hline Day & \multicolumn{2}{|c|}{ May } & \multicolumn{2}{|c|}{ June } & Day & \multicolumn{2}{|c|}{ May } & \multicolumn{2}{|c|}{ June } \\
\hline $\begin{array}{l}1 \\
2 \\
3 \\
4 \\
5\end{array}$ & $\begin{array}{ll}3,562 & 10 \\
3,562 & 50 \\
3,562 & 70 \\
3,563 & 30 \\
3,563 & 50\end{array}$ & $\begin{array}{l}73,050 \\
74,890 \\
75,810 \\
78,610 \\
79,550\end{array}$ & $\begin{array}{ll}3,563 & 35 \\
3,563 & 35 \\
3,563 & 10 \\
3,562 & 70 \\
3,562 & 00\end{array}$ & $\begin{array}{l}78,840 \\
78,840 \\
77,670 \\
75,810 \\
72,600\end{array}$ & $\begin{array}{l}16 \\
17 \\
18 \\
19 \\
20\end{array}$ & $\begin{array}{ll}3,562 & 30 \\
3,562 & 70 \\
3,563 & 00 \\
3,563 & 45 \\
3,563 & 10\end{array}$ & $\begin{array}{l}73,970 \\
75,810 \\
77,210 \\
79,320 \\
77,670\end{array}$ & $\begin{array}{ll}3,562 & 80 \\
3,563 & 00 \\
3,563 & 30 \\
3,563 & 00 \\
3,563 & 00\end{array}$ & $\begin{array}{l}76,280 \\
77,210 \\
78,610 \\
77,210 \\
77,210\end{array}$ \\
\hline $\begin{array}{l}11 \\
12 \\
13 \\
14 \\
15\end{array}$ & $\begin{array}{ll}3,563 & 35 \\
3,563 & 20 \\
3,563 & 10 \\
3,562 & 40 \\
3,562 & 30\end{array}$ & $\begin{array}{l}78,840 \\
78,140 \\
77,670 \\
74,430 \\
73,970\end{array}$ & $\begin{array}{ll}3,563 & 10 \\
3,563 & 00 \\
3,562 & 90 \\
3,562 & 80 \\
3,562 & 70\end{array}$ & $\begin{array}{l}77,670 \\
77,210 \\
76,740 \\
76,280 \\
75,810\end{array}$ & $\begin{array}{l}26 \\
27 \\
28 \\
29 \\
30 \\
31\end{array}$ & $\begin{array}{ll}3,563 & 70 \\
3,563 & 60 \\
3,563 & 45 \\
3,563 & 30 \\
3,563 & 30 \\
3,563 & 20\end{array}$ & $\begin{array}{l}80,490 \\
80,020 \\
79,320 \\
78,610 \\
78,610 \\
78,140\end{array}$ & $\begin{array}{cc}3,563 & 75 \\
3,563 & 60 \\
3,563 & 50 \\
3,563 & 40 \\
3,563 & 00 \\
- & \end{array}$ & $\begin{array}{l}80,730 \\
80,020 \\
79,550 \\
79,080 \\
77,210 \\
=\end{array}$ \\
\hline
\end{tabular}

(34) 6-665 Missouri River below Holter Dam, near Wolf Creek, Mont

Location --Lat $46^{\circ} 59^{\prime} 40^{\prime \prime}$, long $112^{\circ} 00^{\prime} 50^{\prime \prime}$, in $\mathrm{S} \frac{1}{2} \sec 5, \mathrm{~T} 14 \mathrm{~N}, \mathrm{R} 3 \mathrm{~W}$, on left bank a quarter of a mile downstream from Holter Dam and 3 miles southeast of Wolf Creek

Drainage area $--17,149 \mathrm{sq} \mathrm{ml}$

Gage-height record --Digital-recorder tape punched at 15-minute intervals Datum of gage is $3,464 \mathrm{Il} \mathrm{ft}$ above mean sea level, datum of 1929

Discharge record --Stage-discharge relation defined by current-meter measurements Mean dally discharges computed from 96 punch-tape recordings per day

Maxima --June 1964 Discharge, 27,100 cfs 2115 hours June 19 (gage he1ght, $1004 \mathrm{ft}$ )

1945 to May 1964 Discharge, $34,800 \mathrm{cfs} J u n e$ 8, 1948 (gage helght, $1170 \mathrm{ft}$ )

Remarks --Flow regulated by rine smaller irrigation reservoirs and powerplants having a combined capacity of 710,970 acre-ft and by Canyon Ferry Reservolr (see station 23) 
Mean discharge, in cub1c feet per second, 1964, of Missouri River below Holter Dam, near

\begin{tabular}{|c|c|c|c|c|c|c|c|c|}
\hline Day & May & June & Day & May & June & Day & May & June \\
\hline $\begin{array}{r}1 \\
2 \\
3 \\
4 \\
5 \\
6 \\
7 \\
8 \\
9 \\
10\end{array}$ & $\begin{array}{l}3,060 \\
3,410 \\
2,390 \\
1,910 \\
2,640 \\
2,910 \\
4,100 \\
6,820 \\
7,350 \\
6,510\end{array}$ & $\begin{array}{r}12,500 \\
13,800 \\
13,100 \\
11,400 \\
10,900 \\
10,600 \\
11,300 \\
10,400 \\
5,580 \\
5,540\end{array}$ & $\begin{array}{l}11 \\
12 \\
13 \\
14 \\
15 \\
16 \\
17 \\
18 \\
19 \\
20\end{array}$ & $\begin{array}{l}7,530 \\
7,420 \\
7,700 \\
5,890 \\
4,740 \\
4,680 \\
6,100 \\
8,230 \\
12,000 \\
11,700\end{array}$ & $\begin{array}{l}6,890 \\
13,700 \\
16,800 \\
16,400 \\
15,800 \\
15,000 \\
19,000 \\
22,500 \\
25,200 \\
25,600\end{array}$ & $\begin{array}{l}21 \\
22 \\
23 \\
24 \\
25 \\
26 \\
27 \\
28 \\
29 \\
30 \\
31\end{array}$ & $\begin{array}{r}11,400 \\
10,300 \\
6,600 \\
7,170 \\
7,170 \\
7,120 \\
8,030 \\
9,440 \\
9,620 \\
8,900 \\
10,400\end{array}$ & $\begin{array}{r}21,100 \\
21,200 \\
20,600 \\
21,200 \\
23,300 \\
24,200 \\
22,600 \\
22,500 \\
22,300 \\
20,900 \\
-\quad-\quad-\quad- \\
\end{array}$ \\
\hline \multicolumn{7}{|c|}{$\begin{array}{l}\text { Monthly mean discharge, in cublc feet per second } \\
\text { Runoff, in acre-feet }\end{array}$} & $\begin{array}{r}6,879 \\
423,000 \\
\end{array}$ & $\begin{array}{r}16,730 \\
995,500 \\
\end{array}$ \\
\hline
\end{tabular}

Gage height, in feet, and discharge, in cublc feet per second, at indicated time, 1964

\begin{tabular}{|c|c|c|c|c|c|c|c|c|c|c|c|}
\hline Date & Hour & $\begin{array}{c}\text { Gage } \\
\text { helght }\end{array}$ & $\begin{array}{c}\text { Dis- } \\
\text { charge }\end{array}$ & Date & Hour & $\begin{array}{c}\text { Gage } \\
\text { helght }\end{array}$ & $\begin{array}{c}\text { Dis- } \\
\text { charge }\end{array}$ & Date & Hour & $\begin{array}{c}\text { Gage } \\
\text { helght }\end{array}$ & $\begin{array}{l}\text { Dis- } \\
\text { charge }\end{array}$ \\
\hline June 8 & $\begin{array}{l}0000 \\
1000 \\
1200 \\
1600 \\
1800 \\
2000 \\
2400 \\
\\
1200 \\
2400\end{array}$ & $\begin{array}{ll}5 & 58 \\
5 & 60 \\
5 & 82 \\
5 & 90 \\
3 & 89 \\
3 & 30 \\
3 & 29 \\
& \\
3 & 23 \\
3 & 23\end{array}$ & $\begin{array}{r}11,900 \\
11,900 \\
12,600 \\
12,900 \\
7,080 \\
5,670 \\
5,650 \\
5,510 \\
5,510\end{array}$ & June 10 & $\begin{array}{l}1200 \\
2400 \\
0200 \\
0400 \\
0600 \\
0800 \\
1000 \\
1200 \\
1400\end{array}$ & $\begin{array}{ll}3 & 27 \\
3 & 27 \\
& \\
3 & 21 \\
3 & 08 \\
1 & 87 \\
2 & 87 \\
3 & 19 \\
3 & 18 \\
3 & 21\end{array}$ & $\begin{array}{l}5,600 \\
5,600 \\
5,350 \\
5,070 \\
2,770 \\
4,620 \\
5,310 \\
5,290 \\
5,350\end{array}$ & June 11 & $\begin{array}{l}1600 \\
1800 \\
2400 \\
\\
0600 \\
1200 \\
1400 \\
1600 \\
1800 \\
2000 \\
2400\end{array}$ & $\begin{array}{ll}4 & 49 \\
5 & 36 \\
5 & 35 \\
5 & 34 \\
5 & 37 \\
5 & 41 \\
7 & 24 \\
7 & 75 \\
7 & 69 \\
7 & 64\end{array}$ & $\begin{array}{r}8,540 \\
11,000 \\
11,000 \\
10,800 \\
10,900 \\
11,000 \\
17,100 \\
19,000 \\
18,700 \\
18,600\end{array}$ \\
\hline
\end{tabular}

\section{LITTLE PRICKLY PEAR CREEK BASIN}

(35) 6-711 Little Prickly Pear Creek at Sieben Ranch, near Wolf Creek, Mont Location --Lat $46^{\circ} 53^{\prime} 50^{\prime \prime}$, long $112^{\circ} 07^{\prime} 40^{\prime \prime}$, near east line of $\operatorname{SE} \frac{1}{4} \sec 8$, T $13 \mathrm{~N}$, R $4 \mathrm{~W}$, on left bank $30 \mathrm{ft}$ downstream from farm bridge, a quarter of a mile upstream from Clark Creek, and 8 miles south of Wolf Creek

Drainage area $--270 \mathrm{sq} \mathrm{ml}$

Gage-height record --Water-stage recorder graph Altitude of gage is 3,880 ft (from topographic map)

Discharge record --Stage-discharge relation defined by current-meter measurements

Maxıma --June 1964 Discharge, $972 \mathrm{cfs} 2230$ hours June 9 (gage height, $578 \mathrm{ft}$ ) 1962 to May 1964 Daily discharge, 600 cfs May 30, 1964

Mean discharge, in cub1c feet per second, 1964

\begin{tabular}{|c|c|c|c|c|c|c|c|c|}
\hline Day & May & June & Day & May & June & Day & May & June \\
\hline $\begin{array}{r}1 \\
2 \\
3 \\
4 \\
5 \\
6 \\
7 \\
8 \\
9 \\
10\end{array}$ & $\begin{array}{r}70 \\
117 \\
139 \\
175 \\
180 \\
171 \\
164 \\
157 \\
169 \\
208\end{array}$ & $\begin{array}{l}350 \\
278 \\
232 \\
220 \\
220 \\
212 \\
216 \\
338 \\
663 \\
857\end{array}$ & $\begin{array}{l}11 \\
12 \\
13 \\
14 \\
15 \\
16 \\
17 \\
18 \\
19 \\
20\end{array}$ & $\begin{array}{l}244 \\
269 \\
244 \\
258 \\
271 \\
271 \\
284 \\
358 \\
400 \\
410\end{array}$ & $\begin{array}{l}699 \\
554 \\
446 \\
359 \\
318 \\
318 \\
422 \\
323 \\
292 \\
283\end{array}$ & $\begin{array}{l}21 \\
22 \\
23 \\
24 \\
25 \\
26 \\
27 \\
28 \\
29 \\
30 \\
31\end{array}$ & $\begin{array}{l}380 \\
340 \\
300 \\
250 \\
200 \\
190 \\
180 \\
210 \\
300 \\
600 \\
480\end{array}$ & $\begin{array}{r}253 \\
245 \\
220 \\
196 \\
162 \\
129 \\
115 \\
110 \\
110 \\
-\quad-\quad-\quad-\end{array}$ \\
\hline $\begin{array}{l}\text { Monthly } \\
\text { Runoff, } \\
\text { Runoff, }\end{array}$ & $\begin{array}{l}\text { mean discha } \\
\text { in Inches } \\
\text { in acre-fee }\end{array}$ & in cu & feet & & & & $\begin{array}{r}258 \\
110 \\
15,850 \\
\end{array}$ & $\begin{array}{r}308 \\
127 \\
18,320\end{array}$ \\
\hline
\end{tabular}

Gage he1ght, in feet, and discharge, in cublc feet per second, at indicated time, 2964

\begin{tabular}{|c|c|c|c|c|c|c|c|c|c|c|c|}
\hline Date & Hour & $\begin{array}{c}\text { Gage } \\
\text { helght }\end{array}$ & $\begin{array}{l}\text { D1s- } \\
\text { charge }\end{array}$ & Date & Hour & $\begin{array}{c}\text { Gage } \\
\text { helght }\end{array}$ & $\begin{array}{c}\text { Dis- } \\
\text { charge }\end{array}$ & Date & Hour & $\begin{array}{c}\text { Gage } \\
\text { helght }\end{array}$ & $\begin{array}{l}\text { Dis- } \\
\text { charge }\end{array}$ \\
\hline June 8 & $\begin{array}{l}0000 \\
1200 \\
2400 \\
\\
0800\end{array}$ & $\begin{array}{ll}4 & 36 \\
4 & 54 \\
4 & 82 \\
& \\
4 & 95\end{array}$ & $\begin{array}{l}266 \\
318 \\
450 \\
495\end{array}$ & June 9 & $\begin{array}{l}1200 \\
1300 \\
1600 \\
2300 \\
2400\end{array}$ & $\begin{array}{ll}5 & 21 \\
5 & 40 \\
5 & 42 \\
5 & 78 \\
5 & 75\end{array}$ & $\begin{array}{l}631 \\
735 \\
747 \\
972 \\
952\end{array}$ & June 10 & $\begin{array}{l}1200 \\
2400\end{array}$ & $\begin{array}{ll}5 & 57 \\
5 & 51\end{array}$ & $\begin{array}{l}837 \\
801\end{array}$ \\
\hline
\end{tabular}


(36) 6-712 Lyons Creek near Wolf Creek, Mont

\section{(Crest-stage station)}

Location --Lat $46^{\circ} 56^{\prime}$, long $112^{\circ} 08^{\prime}$, in $\mathrm{NE} \frac{1}{4} \sec 29$, T $14 \mathrm{~N}, \mathrm{R} 4 \mathrm{~W}, 135 \mathrm{ft}$ upstream from mouth, $5 \frac{1}{2}$ miles southwest of Wolf Creek

Drainage area $--294 \mathrm{sq} \mathrm{mi}$

Gage-height record --Crest stages only Altitude of gage is 3,730 ft (from topographic map)

Discharge record --Stage-discharge relation defined by current-meter measurements

Maxima --June 1964 Discharge, $490 \mathrm{cfs}$ June 8 (gage height, $380 \mathrm{ft}$ )

1959 to May 1964 Discharge, $158 \mathrm{cfs}$ May 22, 1962 (gage height, $157 \mathrm{ft}$ )

(37) 6-713 Little Prickly Pear Creek at Wolf Creek, Mont

Location --Lat $47^{\circ} 00^{\prime} 20^{\prime \prime}$, long $112^{\circ} 04^{\prime} 00^{\prime \prime}$, in SW $\frac{1}{4} \operatorname{SE} \frac{1}{4} \sec 35, \mathrm{~T} 15 \mathrm{~N}, \mathrm{R} 4 \mathrm{~W}$, on left bank $25 \mathrm{ft}$ downstream from county bridge, $150 \mathrm{ft}$ south of Wolf Creek post office, and half a mile downstream from Wolf Creek

Drainage area $--381 \mathrm{sq} \mathrm{mi}$

Gage-helght record --Water-stage recorder graph Datum of gage is $3,57782 \mathrm{ft}$ above mean sea level, datum of 1929, supplementary adjustment of 1962

Discharge record --Stage-discharge relation defined by current-meter measurements

Maxıma --June 1964 Discharge, 3,110 cfs 1200 hours June 9 (gage height, $765 \mathrm{ft}$ ) 1962 to May 1964 Discharge, 1,120 cfs May 30, 1964 (gage height, 5 13 ft)

Mean discharge, In cub1c feet per second, 1964

\begin{tabular}{|c|c|c|c|c|c|c|c|c|}
\hline Day & May & June & Day & May & June & Day & May & June \\
\hline $\begin{array}{l}\text { Monthiy } \\
\text { Runoff, } \\
\text { Runoff, }\end{array}$ & $\begin{array}{l}\text { mean dischar } \\
\text { In inches } \\
\text { In acre-feet }\end{array}$ & , In cub & $c$ feet & cond & & & $\begin{array}{r}563 \\
170 \\
34,630 \\
\end{array}$ & $\begin{array}{r}601 \\
176 \\
35,760 \\
\end{array}$ \\
\hline
\end{tabular}

Gage height, in feet, and discharge, in cubic feet per second, at indicated time, 1964

\begin{tabular}{|c|c|c|c|c|c|c|c|c|c|c|c|}
\hline Date & Hour & $\begin{array}{c}\text { Gage } \\
\text { helght }\end{array}$ & $\begin{array}{l}\text { Dis- } \\
\text { charge }\end{array}$ & Date & Hour & $\begin{array}{c}\text { Gage } \\
\text { helght }\end{array}$ & $\begin{array}{c}\text { Dis- } \\
\text { charge }\end{array}$ & Date & Hour & $\begin{array}{c}\text { Gage } \\
\text { he1ght }\end{array}$ & $\begin{array}{l}\text { Dis- } \\
\text { charge }\end{array}$ \\
\hline June 8 & $\begin{array}{l}0000 \\
0500 \\
1200 \\
1500 \\
1800 \\
2000 \\
2200 \\
2400\end{array}$ & $\begin{array}{ll}3 & 91 \\
4 & 40 \\
4 & 43 \\
4 & 50 \\
4 & 80 \\
5 & 25 \\
5 & 88 \\
6 & 40\end{array}$ & $\begin{array}{r}501 \\
668 \\
681 \\
690 \\
780 \\
975 \\
1,440 \\
1,890\end{array}$ & June & $\begin{array}{l}0400 \\
0600 \\
0900 \\
1000 \\
1200 \\
1500 \\
1800 \\
2400\end{array}$ & $\begin{array}{ll}7 & 00 \\
7 & 08 \\
7 & 00 \\
7 & 45 \\
7 & 65 \\
7 & 00 \\
6 & 80 \\
6 & 65\end{array}$ & $\begin{array}{l}2,460 \\
2,540 \\
2,460 \\
2,910 \\
3,110 \\
2,460 \\
2,260 \\
2,120\end{array}$ & June 10 & $\begin{array}{l}1200 \\
1800 \\
2400 \\
1200 \\
2400 \\
2400\end{array}$ & $\begin{array}{ll}6 & 10 \\
5 & 90 \\
5 & 70 \\
& \\
5 & 38 \\
5 & 05 \\
4 & 72\end{array}$ & $\begin{array}{r}1,710 \\
1,540 \\
1,420 \\
1,190 \\
975 \\
802\end{array}$ \\
\hline 9 & 0200 & 677 & 2,230 & 10 & 0600 & 640 & 1,940 & & & & \\
\hline
\end{tabular}




\section{DOG CREEK BASIN}

(38) 6-714 Dog Creek near Craig, Mont

(Crest-stage station)

Location --Lat $47^{\circ} 05^{\prime}$, long $112^{\circ} 00^{\prime}$, in $N \frac{1}{4}^{\frac{1}{4}} \sec 4, \mathrm{~T} 15 \mathrm{~N}, \mathrm{R} 3 \mathrm{~W}$, at bridge on county road, 2 miles west of Craig

Drainage area $--159 \mathrm{sq} \mathrm{mi}$

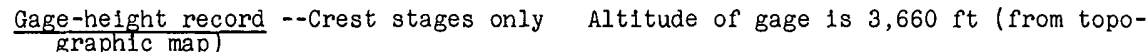

Discharge record --Stage-discharge relation defined by current-meter measurements

Maxima --June 1964 Discharge, $65 \mathrm{cfs}$ June 8 (gage height, $197 \mathrm{ft}$ )

1959 to May 1964 Discharge, $1,160 \mathrm{cfs}$ May 30, 1961' (gage he1ght, $440 \mathrm{ft}$ ), from slope-area measurement

\section{WEGNER CREEK BASIN}

(39) 6-716 Wegner Creek at Craig, Mont

(Crest-stage station)

Location - - Lat $47^{\circ} 05^{\prime}$, long $111^{\circ} 57^{\prime}$, in $N W^{\frac{1}{4}} \sec 11, \mathrm{~T} 15 \mathrm{~N}, \mathrm{R} 3 \mathrm{~W}$, at bridge on Interstate Highway' 15 and U S Highway 91,09 mile east of Cralg

Drainage area $--350 \mathrm{sq} \mathrm{ml}$

$\frac{\text { Gage-helght record }}{\text { graphlc map) }}$-Crest stages only Altitude of gage is $3,450 \mathrm{ft}$ (from topo-

Discharge record --Stage-discharge relation defined by current-meter measurements

Maxima --June 1964 Discharge, $60 \mathrm{cfs}$ June 8 (gage he1ght, $054 \mathrm{ft}$ )

1959 to May 1964 Discharge, $408 \mathrm{cfs}$ July 6, 1961 (gage height, $254 \mathrm{ft}$ )

\section{DEARBORN RIVER BASIN}

(40) 6-730 Dearborn River near Clemons, Mont

(Gaging station, discontinued 1953)

Location --Lat $47^{\circ} 17^{\prime} 30^{\prime \prime}$, long $112^{\circ} 27^{\prime} 00^{\prime \prime}$, in $\operatorname{SE} \frac{1}{4} S E \frac{1}{4} \sec 23$, T $18 \mathrm{~N}, \mathrm{R} 7 \mathrm{~W}$, on right bank $300 \mathrm{ft}$ upstream from highway bridge, half a mile southeast of former post office at Clemons, 2 miles downstream from Falls Creek, and 14 mlles south of Augusta

Drainage area $--123 \mathrm{sq} \mathrm{mi}$ (130 sq $\mathrm{mi}$ at slope-area site)

Gage-height record --High-water marks at gage site Altıtude of gage is 4,560 $\mathrm{ft}$ (by barometer)

Discharge record --Peak discharge by slope-area measurement at site 3 miles downstream

Maxima --June 1964 Discharge, 17,400 cfs about 0300 hours June 9 (gage height, 9 I5 ft, from high-water marks on gage house)

1921-23, 1929-53 Discharge, 3,200 cfs June 4, 1953 (gage heignt, $620 \mathrm{ft}$ )

Flood of June 1964 exceeds that of June 1908 and is the highest since 1908, from information by local residents 
(41) South Fork Dearborn River near Craig, Mont

(M1scellaneous site)

Location --Lat $47^{\circ} 09^{1} 40^{\prime \prime}$, long $112^{\circ} 13^{1} 00^{\prime \prime}$, in $\sec 10$, T $16 \mathrm{~N}, \mathrm{R} 5 \mathrm{~W}$, on state H1ghway 434 and $13 \frac{1}{2}$ miles northwest of 'Craig

Drainage area $--320 \mathrm{sq} \mathrm{mi}$

Maxima --June 1964 Discharge, 1,230 cfs about 2400 hours June 8 , from flowthrough-culvert measurement

(42) Auchard Creek near Craig, Mont

(M1scellaneous site)

Location --Lat $4^{\circ} 15^{\prime} 30^{\prime \prime}$, long $112^{\circ} 13^{1} 00^{\prime \prime}$, in $\sec 3$, T $17 \mathrm{~N}, \mathrm{R} 5 \mathrm{~W}$, on State Highway 20, 3 miles southwest of Bowman's corner and $17 \frac{1}{2}$ miles northwest of Craig

Drainage area $--157 \mathrm{sq} \mathrm{mi}$

Maximum --June 1964 Discharge, $353 \mathrm{cfs}$ about 2200 hours June 8 , from flowthrough-culvert measurement

\section{(43) 6-735 Dearborn River near Craig, Mont}

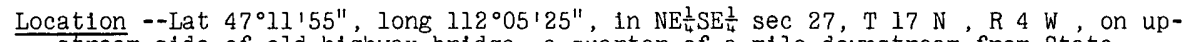
stream side of old highway bridge, a quarter of a mile downstream from state Highway 287, 5 miles downstream from South Fork, and 10 miles northwest of $\mathrm{Cra} 1 \mathrm{~g}$ Water-stage recorder installation on right bank destroyed by flood on June 9 Type-A wire-welght gage on upstream side of bridge

\section{Drainage area $--325 \mathrm{sq} \mathrm{mi}$}

Gage-height record --Water-stage recorder graph May 1-31, graph reconstructed from high-water marks and outslde gage readings June 1-13, observer's wire-welght gage readings June 14-30 Altitude of gage is $3,790 \mathrm{ft}$ (from topographic map)

Discharge record --Stage-discharge relation defined by current-meter measurements below 11,500 cf's and by slope-area measurement at 15,400 cfs

Maxima --June 1964 Discharge, 15,400 cfs about 0800 hours June 9 (gage height,

$135 \mathrm{ft}$, from high-water profile)

1945 to May 1964 Discharge, 7,960 cfs June 4, 1953 (gage height, $958 \mathrm{ft}$ )

Flood of June 1964 exceeded that of 1908 and is the highest since 1908, from information by local residents

Mean discharge, in cub1c feet per second, 1964

\begin{tabular}{|c|c|c|c|c|c|c|c|c|}
\hline Day & May & June & Day & May & June & Day & May & June \\
\hline $\begin{array}{rrr}1 & & \\
2 & & \\
3 & & \\
4 & & \\
5 & & \\
6 & & \\
7 & & \\
8 & & \\
9 & & \\
10 & & \end{array}$ & $\begin{array}{r}349 \\
625 \\
1,020 \\
1,090 \\
799 \\
707 \\
625 \\
619 \\
662 \\
740\end{array}$ & $\begin{array}{r}2,130 \\
1,640 \\
1,510 \\
1,510 \\
1,440 \\
1,400 \\
1,560 \\
6,990 \\
12,500 \\
7,330\end{array}$ & $\begin{array}{l}11 \\
12 \\
13 \\
14 \\
15 \\
16 . . \\
17 \\
18 \\
19 \\
20\end{array}$ & $\begin{array}{r}799 \\
759 \\
806 \\
938 \\
938 \\
962 \\
1,190 \\
1,340 \\
1,300 \\
1,480\end{array}$ & $\begin{array}{r}3,670 \\
2,560 \\
2,080 \\
1,780 \\
1,530 \\
1,440 \\
1,400 \\
1,190 \\
980 \\
980\end{array}$ & $\begin{array}{l}21 \\
22 \\
23 \\
24 \\
25 \\
26 \ldots \\
27 \\
28 \\
29 \\
30 \\
31\end{array}$ & $\begin{array}{r}1,620 \\
1,390 \\
1,100 \\
954 \\
892 \\
726 \\
714 \\
1,120 \\
3,470 \\
3,400 \\
2,310\end{array}$ & $\begin{array}{r}922 \\
837 \\
772 \\
752 \\
822 \\
752 \\
733 \\
701 \\
622 \\
\quad-\quad 586 \\
-\end{array}$ \\
\hline $\begin{array}{l}\text { Monthly } \\
\text { Runoff, } \\
\text { Runoff, }\end{array}$ & $\begin{array}{l}\text { mean discha } \\
\text { in Inches } \\
\text { in acre-fee }\end{array}$ & , in cu & c feet & cond & & & $\begin{array}{r}1,143 \\
406 \\
70,300\end{array}$ & $\begin{array}{r}2,104 \\
722 \\
125,200\end{array}$ \\
\hline
\end{tabular}


Gage helght, in feet, and discharge, in cublc feet per second, at indicated time, 1964, of Dearborn River near Craig, Mont

\begin{tabular}{|c|c|c|c|c|c|c|c|c|c|c|c|}
\hline Date & Hour & $\begin{array}{c}\text { Gage } \\
\text { height }\end{array}$ & $\begin{array}{l}\text { D1s- } \\
\text { charge }\end{array}$ & Date & Hour & $\begin{array}{c}\text { Gage } \\
\text { helght }\end{array}$ & $\begin{array}{l}\text { Dis- } \\
\text { charge }\end{array}$ & Date & Hour & $\begin{array}{c}\text { Gage } \\
\text { he1ght }\end{array}$ & $\begin{array}{c}\text { Dis- } \\
\text { charge }\end{array}$ \\
\hline June 7 & $\begin{array}{l}0000 \\
0400 \\
0800 \\
1200 \\
1500 \\
1800 \\
2100 \\
2400\end{array}$ & $\begin{array}{ll}5 & 12 \\
5 & 22 \\
5 & 08 \\
4 & 93 \\
4 & 91 \\
4 & 95 \\
5 & 35 \\
6 & 15\end{array}$ & $\begin{array}{l}1,550 \\
1,640 \\
1,510 \\
1,380 \\
1,360 \\
1,400 \\
1,670 \\
2,400\end{array}$ & June 8 & $\begin{array}{l}0500 \\
0700 \\
1100 \\
1800 \\
2400 \\
0400 \\
0700\end{array}$ & $\begin{array}{rl}9 & 25 \\
9 & 48 \\
9 & 30 \\
8 & 94 \\
10 & 20 \\
11 & 5 \\
13 & 3\end{array}$ & $\begin{array}{r}7,370 \\
7,780 \\
7,460 \\
6,810 \\
9,080 \\
11,500 \\
15,000\end{array}$ & June 9 & $\begin{array}{l}0800 \\
1200 \\
1500 \\
1800 \\
1900 \\
2400\end{array}$ & $\begin{array}{rl}13 & 5 \\
11 & 4 \\
9 & 0 \\
7 & 9 \\
7 & 35 \\
7 & 05\end{array}$ & $\begin{array}{l}15,400 \\
14,000 \\
13,000 \\
12,000 \\
11,800 \\
10,500\end{array}$ \\
\hline
\end{tabular}

\section{HARDY CREEK BASIN}

(44) Hardy Creek near Cascade, Mont

(Miscellaneous site)

Location --Lat $47^{\circ} 11^{\prime} 00^{\prime \prime}$, long $111^{\circ} 48^{\prime} 40^{\prime}$, in $S W^{\frac{1}{4}} \sec 25$, T $17 \mathrm{~N}, R 2 W$, a quarter of a mile upstream from U S Highway $9 i$ and 8 miles southwest of Cascade

Drainage area $--946 \mathrm{sq} \mathrm{mi}$

Maximum --June 1964 Discharge, $440 \mathrm{cfs}$ about 2200 hours June 8, from slope-area measurement

Flood of June 1908 was much larger (from information by local residents)

\section{MISSOURI RIVER MAIN STEM}

(45) 6-740 Missouri River at Cascade, Mont

(Gaging station, discontinued 1915, U S Weather Bureau gage since 1950)

Location --Lat $47^{\circ} 16^{\prime} 10^{\prime \prime}$, long $111^{\circ} 41^{\prime} 45^{\prime \prime}$, in $N \frac{1}{4}_{4} \mathrm{SE} \frac{1}{4} \sec 35, \mathrm{~T} 18 \mathrm{~N}, \mathrm{R} 1 \mathrm{~W}$, on downstream side of highway bridge at Cascade, 26 miles upstream from mouth of Smith River

Drainage area $--18,493 \mathrm{sq} \mathrm{mi}$

Gage-height record --Wire-weight gage read once dally at 0800 hours, except Saturdays and Sundays, and twice dally June $19,22-26$ Datum of gage is at mean sea level, datum of 1929

Maxıma --June 1964 Elevation observed, 3,348 $61 \mathrm{ft} 1600$ hours June 26, but may have been higher on June 9 when elevation observed was $3,34845 \mathrm{ft}$ $1902-1915$, 1950 to May 1964 Discharge observed, 54,250 cfs June 5, 1908 (elevation $3,3542 \mathrm{ft}$, revised), site then in use

Remarks --Flow regulated by 9 smaller irrigation reservolrs and powerplants having a combined capacity of 711,000 acre-ft and by Canyon Ferry Reservoir (see station 23 )

Elevation, in feet, at 0800 hours on indicated day, 1964

\begin{tabular}{|c|c|c|c|c|c|c|c|c|}
\hline Day & May & June & Day & May & June & Day & May & June \\
\hline $\begin{array}{l}1 \\
2 \\
3 \\
4 \\
5 \\
6 \\
7 \\
8 \\
9 \\
10\end{array}$ & $\begin{array}{cc}3,341 & 81 \\
- & \\
- & \\
3,342 & 26 \\
3,343 & 16 \\
3,342 & 56 \\
3,342 & 69 \\
3,342 & 76 \\
- & \\
- & \end{array}$ & $\begin{array}{cc}3,344 & 76 \\
3,345 & 46 \\
3,345 & 46 \\
3,345 & 04 \\
3,344 & 72 \\
- & \\
- & \\
3,345 & 23 \\
3,348 & 45 \\
3,346 & 41\end{array}$ & $\begin{array}{l}11 \\
12 \\
13 \\
14 \\
15 \\
16 \\
17 \\
18 \\
19 \\
20\end{array}$ & $\begin{array}{cc}3,343 & 25 \\
3,343 & 38 \\
3,343 & 22 \\
3,343 & 80 \\
3,342 & 54 \\
- & \\
- & \\
3,343 & 35 \\
3,344 & 85 \\
3,344 & 92\end{array}$ & 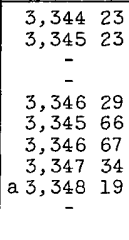 & $\begin{array}{l}21 \\
22 \\
23 \\
24 \\
25 \\
26 \\
27 \\
28 \\
29 \\
30 \\
31\end{array}$ & $\begin{array}{cc}3,344 & 96 \\
3,345 & 01 \\
- & \\
- & \\
3,343 & 10 \\
3,343 & 12 \\
3,343 & 26 \\
3,343 & 70 \\
3,344 & 00 \\
- & \\
- & \end{array}$ & $\begin{array}{rr}\text { b } 3,348 & 34 \\
\text { a } 3,347 & 36 \\
\text { a } 3,347 & 42 \\
\text { a } 3,347 & 26 \\
\text { a } 3,347 & 60 \\
\text { a 3,348 } & 37 \\
- & \\
3,347 & 76 \\
3,347 & 61 \\
3,347 & 61 \\
\text { - }- \text { - _ - }\end{array}$ \\
\hline
\end{tabular}

a Average of readings made at 0800 and 1600 nours

b Reading made at 1800 hours 


\section{SMITH RIVER BASIN}

(46) 6-750 Smith River Reservolr near White Sulphur Springs, Mont

Location --Lat $46^{\circ} 37^{\prime}$, long $110^{\circ} 45^{\prime}$, near center of south line of sec $17, \mathrm{~T} 10 \mathrm{~N}$, $\mathrm{R} 8 \mathrm{E}$, at dam on Smith River, 9 miles northeast of White Sulphur Springs

Drainage area $--723 \mathrm{sq} \mathrm{m}$

Gage-height record --Elevations determined by measuring from a reference mark about once a month Datum of gage is at mean sea level (levels by Montana Water Conservation Board)

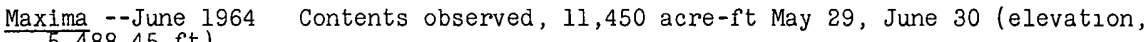
$5,48845 \mathrm{ft}$ )

1938-50, 1959 to May 1964 Contents observed, 11,600 acre-ft Apr 30, 1950

(elevation, 5,488 $6 \mathrm{ft}$ )

Remarks --Reservoir is formed by earthfill dam with concrete spillway completed in 1936 Total capacity, 10,700 acre-ft at elevation 5,486 $0 \mathrm{ft}$ Dead storage, 52 acre-ft below elevation $5,4150 \mathrm{ft}$ Water is used for irrigation Elevations and capacity table furnished by Montana Water Conservation Board Figures given herein represent usable contents

Elevation, in feet, and contents, in acre-feet, 1964

$\begin{array}{lrrrrr} & & \text { Elevation } & \text { Contents } \\ \text { May } & 1 & 5,480 & 45 & 9,030 \\ \text { May } & 29 & 5,488 & 45 & 11,450 \\ \text { July } & 1 & 5,488 & 45 & 11,450\end{array}$

(47) 6-756 Five Mile Creek near White Sulphur Springs, Mont

(Crest-stage station)

Location --Lat $46^{\circ} 37^{\prime}$, long $110^{\circ} 45^{\prime}$, in $\operatorname{SW} \frac{1}{4} \sec 20, T 10 \mathrm{~N}, \mathrm{R} 8 \mathrm{E}$, at culvert on US Highway 12,8 miles northeast of White Sulphur Springs

Drainage area $-600 \mathrm{sq} \mathrm{mI}$

Gage-height record --Crest stages only Altitude of gage is 5,380 ft (from topographic map)

Discharge record --Stage-discharge relation defined by current-meter measurements below 5 cr's

Maxima --June 1964 Discharge, $8 \mathrm{cfs}$ June 8 (gage height, $116 \mathrm{ft}$ )

1960 to May 1964 Discharge, about $20 \mathrm{cfs}$ Feb 4, 1963 (gage height, $206 \mathrm{ft}$ )

(48) 6-760 Newland Creek near White Sulphur Springs, Mont

(Gaging station, discontinued 1953, crest-stage station since 1960)

Location --Lat $46^{\circ} 44^{\prime}$, long $110^{\circ} 50^{\prime}$, near line between secs 9 and $10, \mathrm{~T} 11 \mathrm{~N}$,

$\mathrm{R} 7 \mathrm{E}, 13$ miles north of White Sulphur Springs and 15 miles upstream from mouth

Drainage area $--6 \quad 74 \mathrm{sq} \mathrm{ml}$

Gage-height record - -Water-stage recorder graph used for crest stages only Altitude of gage is $5,590 \mathrm{ft}$ (by barometer)

Discharge record --Stage-discharge relation defined by current-meter measurements

Maxima --June 1964 Discharge, $13 \mathrm{cfs} 2000$ hours June 8 (gage height, $259 \mathrm{ft}$ ) 1946-53, 1960 to May 1964 Discharge, 56 cfs June 4, 1953 (gage height, 
(49) 6-767 Sheep Creek near Neihart, Mont

(Crest-stage station)

Location --Lat $46^{\circ} 48^{\prime}$, long $110^{\circ} 42^{\prime}$, in $\mathrm{SE} \frac{1}{4} \sec 15, \mathrm{~T} 12 \mathrm{~N}, \mathrm{R} 8 \mathrm{E}$, at culvert on US Highway 89,10 miles south of Nelhart

Drainage area $--530 \mathrm{sq} \mathrm{ml}$

Gage-height record --Crest stages only Altitude of gage is 6,600 ft (from topographic map)

Discharge record --Stage-discharge relation defined by current-meter measurements

Maxima --June 1964 Discharge, $113 \mathrm{cfs}$ June 8 (gage height, $212 \mathrm{ft}$ )

1960 to May 1964 Discharge, $78 \mathrm{cfs}$ May 21, 1964 (gage height, $167 \mathrm{ft}$ )

(50) 6-768 Nugget Creek near Neihart, Mont

(Crest-stage station)

Location --Lat $46^{\circ} 27^{\prime}$, long $110^{\circ} 42^{\prime}$, in $\mathrm{NE} \frac{1}{4} \sec 27, \mathrm{~T} 12 \mathrm{~N}, \mathrm{R} 8 \mathrm{E}$, at culvert on US Highway 89,11 miles south of Neihart

Drainage area $--148 \mathrm{sq} \mathrm{ml}$

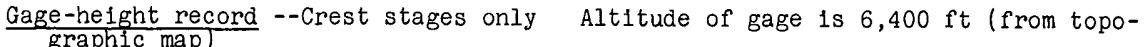

Discharge record --Stage-discharge relation defined by current-meter measurements below $8 \mathrm{cf}$ 's and from flow-through-culvert measurement at $14 \mathrm{cfs}$

Maxima --June 1964 Discharge, $10 \mathrm{cfs}$ June 8 (gage helght, $077 \mathrm{ft}$ )

1959 to May 1964 D1scharge, $15 \mathrm{cfs}$ May 21, 1964 (gáge helght, $107 \mathrm{ft}$ )

(51) 6-770 Sheep Creek near White Sulphur Springs, Mont

Location --Lat $46^{\circ} 46^{\prime}$, long $110^{\circ} 49^{\prime}$, in $\mathrm{SW}_{4} \frac{1}{4} \mathrm{SE} \frac{1}{4} \sec 26, \mathrm{~T} 12 \mathrm{~N}, \mathrm{R} 7 \mathrm{E}$, on right bank 7 miles upstream from Moose' Creek and 16 miles north of White Sulphur Springs

Drainage area $--54 \quad 4 \mathrm{sq} \mathrm{mi}$

$\frac{\text { Gage-helght record }}{\text { barometer) }}$-Water-stage recorder graph Altitude of gage is $5,820 \mathrm{ft}$ (by

Discharge record --Stage-discharge relation defined by current-meter measurements

Maxima --June 1964 Discharge, $362 \mathrm{cfs} 0300$ hours June 9 (gage height, $493 \mathrm{ft}$ )

1941 to May 1964 Discharge, $460 \mathrm{cfs}$ June 4 , 1953 (gage height, $580 \mathrm{ft}$, from graph based on gage readings, at site $700 \mathrm{ft}$ upstream and at datum $533 \mathrm{ft}$ higher)

Mean discharge, in cublc feet per second, 1964

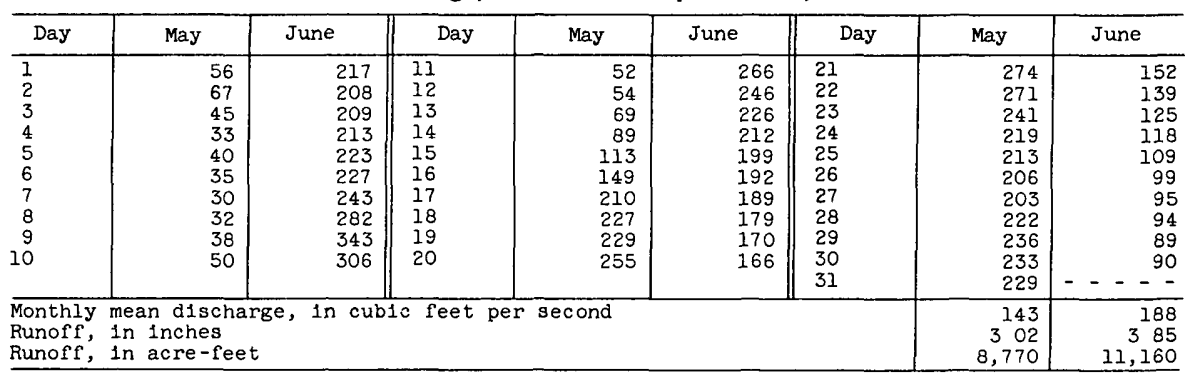


Gage height, in feet, and discharge, In cubic feet per second, at indicated time, 1964, of Sheep Creek near White Sulphur Springs, Mont

\begin{tabular}{|c|c|c|c|c|c|c|c|c|c|c|c|}
\hline Date & Hour & $\begin{array}{c}\text { Gage } \\
\text { helght }\end{array}$ & $\begin{array}{c}\text { D1s- } \\
\text { charge }\end{array}$ & Date & Hour & $\begin{array}{c}\text { Gage } \\
\text { he1ght }\end{array}$ & $\begin{array}{l}\text { D1s- } \\
\text { charge }\end{array}$ & Date & Hour & $\begin{array}{c}\text { Gage } \\
\text { he1ght }\end{array}$ & $\begin{array}{c}\text { Dis - } \\
\text { charge }\end{array}$ \\
\hline June 8 & $\begin{array}{l}0000 \\
1200 \\
2400\end{array}$ & $\begin{array}{ll}4 & 40 \\
4 & 38 \\
4 & 89\end{array}$ & $\begin{array}{l}260 \\
257 \\
354\end{array}$ & June 9 & $\begin{array}{l}0300 \\
1200 \\
2400\end{array}$ & $\begin{array}{ll}4 & 93 \\
4 & 84 \\
4 & 77\end{array}$ & $\begin{array}{l}362 \\
344 \\
330\end{array}$ & June 10 & $\begin{array}{l}1200 \\
2400\end{array}$ & $\begin{array}{ll}4 & 65 \\
4 & 53\end{array}$ & $\begin{array}{l}306 \\
282\end{array}$ \\
\hline
\end{tabular}

(52) 6-775 Smith River near Eden, Mont

Location --Lat $47^{\circ} 12^{\prime}$, long $111^{\circ} 23^{\prime}$, in SW $\frac{1}{4} S W \frac{1}{4} \sec 29, \mathrm{~T} 17 \mathrm{~N}, \mathrm{R} 3 \mathrm{E}$, on left bank a quarter of a mile upstream from Mullens Creek, 2 miles upstream from Hound Creek, and 7 miles southwest of Eden

Drainage area $--1,594 \mathrm{sq} \mathrm{mi}$

Gage-height record --Water-stage recorder graph Graph reconstructed on basis of partial recorder graph and observed gage helght from 1800 hours June 8 to 0900 hours June 10 Altitude of gage is $3,500 \mathrm{ft}$ (by barometer)

Discharge record --Stage-discharge relation defined by current-meter measurements

Maxima --June 1964 Discharge, $3,860 \mathrm{cfs} 1000$ hours June 10 (gage he1ght, $548 \mathrm{ft}$ ) 1951 to May 1964 Discharge, 12,300 cfs June 4, 1953 (gage helght, $1046 \mathrm{ft}$ ), from rating curve extended above $3,800 \mathrm{cfs}$ on basis of slope-area measurement of

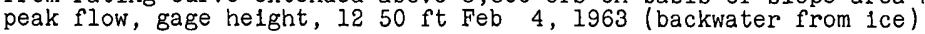

Mean discharge, in cubic feet per second, 1964

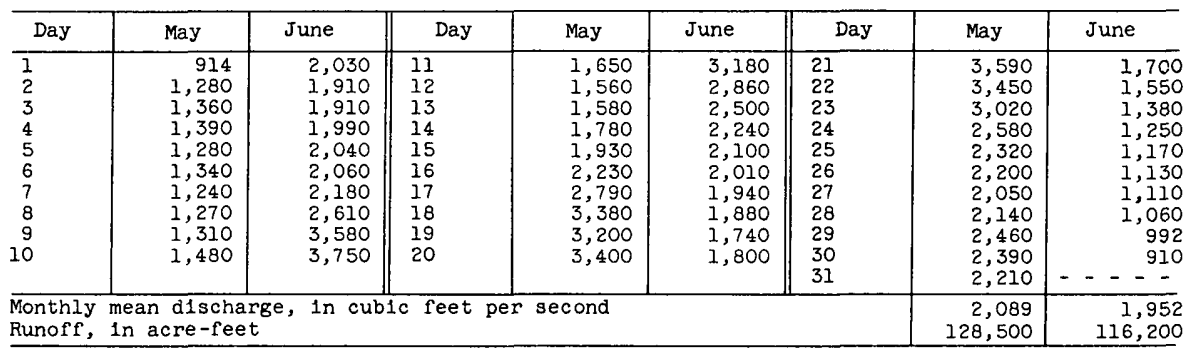

Gage height, In feet, and discharge, in cub1c feet per second, at ind1cated t1me, 1964

\begin{tabular}{|c|c|c|c|c|c|c|c|c|c|c|c|}
\hline Date & Hour & $\begin{array}{c}\text { Gage } \\
\text { he1ght }\end{array}$ & $\begin{array}{l}\text { D1s - } \\
\text { charge }\end{array}$ & Date & Hour & $\begin{array}{c}\text { Gage } \\
\text { helght }\end{array}$ & $\begin{array}{l}\text { D1s- } \\
\text { charge }\end{array}$ & Date & Hour & $\begin{array}{c}\text { Gage } \\
\text { helght }\end{array}$ & $\begin{array}{c}\text { D1s- } \\
\text { charge }\end{array}$ \\
\hline June 7 & $\begin{array}{l}0000 \\
0600 \\
1200 \\
1600 \\
2100 \\
2400 \\
0600 \\
\end{array}$ & $\begin{array}{ll}3 & 98 \\
4 & 05 \\
4 & 13 \\
4 & 15 \\
4 & 13 \\
4 & 14 \\
& \\
4 & 28 \\
\end{array}$ & $\begin{array}{l}2,060 \\
2,140 \\
2,220 \\
2,240 \\
2,220 \\
2,230 \\
2,390\end{array}$ & June 8 & $\begin{array}{l}1200 \\
1800 \\
2400 \\
\\
0600 \\
1200 \\
1800 \\
2400 \\
\end{array}$ & $\begin{array}{ll}4 & 47 \\
4 & 64 \\
4 & 85 \\
& \\
5 & 13 \\
5 & 34 \\
5 & 41 \\
5 & 45 \\
\end{array}$ & $\begin{array}{l}2,600 \\
2,810 \\
3,060 \\
3,410 \\
3,680 \\
3,770 \\
3,820\end{array}$ & June 10 & $\begin{array}{l}0600 \\
1000 \\
1200 \\
1800 \\
2400 \\
\\
1200 \\
2400\end{array}$ & $\begin{array}{ll}5 & 46 \\
5 & 48 \\
5 & 45 \\
5 & 34 \\
5 & 20 \\
& \\
4 & 93 \\
4 & 73\end{array}$ & $\begin{array}{l}3,840 \\
3,860 \\
3,820 \\
3,680 \\
3,500 \\
3,160 \\
2,920\end{array}$ \\
\hline
\end{tabular}

(53) 6-777 Smith River tributary near Eden, Mont

(Crest-stage station)

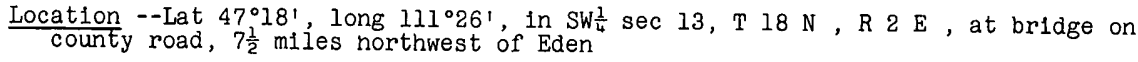

Drainage area $--163 \mathrm{sq} \mathrm{mi}$

$\frac{\text { Gage-height record }}{\text { graphic map) }}$-Crest stages only Altitude of gage is $3,420 \mathrm{ft}$ (from topo-

Discharge record --Stage-discharge relation defined by current-meter measurements

Maxima --June 1964 Discharge, $14 \mathrm{cfs}$ June 8 (gage he1ght, $024 \mathrm{ft}$ )

1960 to May 1964 Discharge, $45 \mathrm{cfs}$ June 15, 1962 (gage he1ght, $072 \mathrm{ft}$ )

$249-705$ O - $67-12$ 
(54) 6-778 Goodman Coulee near Eden, Mont

(Crest-stage station)

Location --Lat $47^{\circ} 20^{\prime}$, long $111^{\circ} 25^{\prime}$, in center sec 12 , T $18 \mathrm{~N}, \mathrm{R} 2 \mathrm{E}$, at culvert on county road, 8 miles northwest of Eden

Drainage area --21 $8 \mathrm{sq} \mathrm{mj}$

Gage-height record --Crest stages only Altitude of gage is 3,370 ft (from topographic map)

Discharge record --Stage-discharge relation defined by current-meter measurements below $80 \mathrm{cfs}$ and by flow-through-culvert-measurement at $120 \mathrm{cfs}$ $\frac{\text { Maxıma }}{\text { gage) }}$-June 1964 Discharge, $110 \mathrm{cfs}$ June 8 (gage he1ght, $358 \mathrm{ft}$, downstream

1959 to May 1964 Discharge, about $150 \mathrm{cfs}$ May 3, 1964 (gage helght, $402 \mathrm{ft}$, downstream gage, $573 \mathrm{ft}$, upstream gage

\section{MISSOURI RIVER MAIN STEM}

(55) 6-782 Missour River near Ulm, Mont

Location --Lat $47^{\circ} 26^{\prime} 10^{\prime \prime}$, long $111^{\circ} 23^{\prime} 10^{\prime \prime}$, in $\mathrm{NW} \frac{\mathrm{l}}{4} \mathrm{NW} \frac{1}{4} \sec 5, \mathrm{~T} 19 \mathrm{~N}, \mathrm{R} 3 \mathrm{E}$, on left bank 6 miles east of Ulm and 9 miles downstream from Smith River

Drainage area $--20,941 \mathrm{sq} \mathrm{mi}$

Gage-helght record --Digital-recorder tape punched at 15-minute intervals Alt1tude of gage is $3,310 \mathrm{ft}$ (from topographic map)

Discharge record --Stage-discharge relation defined by current-meter measurements Wean daily discharges computed from 96 punch-tape recordings per day and may not agree precisely with that derived from discharge at indicated times

Maxima --June 1964 Discharge, 27,500 cfs 0200 hours June 22 (gage he1ght, $1444 \mathrm{ft}$ ) 1957 to May 1964 D1scharge, 19,100 cfs June 19, 1959 (gage he1ght,

$1126 \mathrm{ft}$ ), maximum gage height, $1220 \mathrm{ft}$ Nov 17,1959 (ice jam)

Flood in June 1953 reached a stage of about $17 \mathrm{ft}$ (discharge, 35,000 cfs) flood in June 1948 reached a stage of about $16 \mathrm{ft}$ (discharge, 32,000 cfs), from information by local residents

Remarks --Flow regulated by 10 smaller irrigation reservoirs and powerplants having a combined capacity of 721,620 acre-ft and by Canyon Ferry Reservoir (see station 23)

Mean discharge, in cubic feet per second, 1964

\begin{tabular}{|c|c|c|c|c|c|c|c|c|}
\hline Day & May & June & Day & May & June & Day & May & June \\
\hline $\begin{array}{r}1 \\
2 \\
3 \\
4 \\
5 \\
6 \\
7 \\
8 \\
9 \\
10\end{array}$ & $\begin{array}{r}5,420 \\
6,120 \\
7,890 \\
9,350 \\
9,450 \\
9,220 \\
9,250 \\
9,690 \\
11,600 \\
12,800\end{array}$ & $\begin{array}{l}16,700 \\
17,000 \\
18,000 \\
17,800 \\
16,400 \\
15,400 \\
14,900 \\
16,400 \\
21,700 \\
26,100\end{array}$ & $\begin{array}{l}11 \\
12 \\
13 \\
14 \\
15 \\
16 \\
17 \\
18 \\
19 \\
20\end{array}$ & $\begin{array}{l}12,600 \\
13,000 \\
12,800 \\
12,800 \\
11,900 \\
10,400 \\
10,700 \\
12,600 \\
14,600 \\
17,500\end{array}$ & $\begin{array}{l}23,000 \\
18,300 \\
19,700 \\
22,200 \\
22,000 \\
21,500 \\
20,600 \\
22,300 \\
24,100 \\
25,900\end{array}$ & $\begin{array}{l}21 \\
22 \\
23 \\
24 \\
25 \\
26 \\
27 \\
28 \\
29 \\
30 \\
31\end{array}$ & $\begin{array}{l}18,300 \\
18,300 \\
17,100 \\
13,200 \\
12,000 \\
11,500 \\
11,200 \\
11,800 \\
13,500 \\
16,600 \\
17,300\end{array}$ & $\begin{array}{r}27,200 \\
27,200 \\
25,700 \\
24,700 \\
24,200 \\
24,600 \\
25,800 \\
25,800 \\
25,300 \\
24,900 \\
-\quad----\end{array}$ \\
\hline $\begin{array}{l}\text { Monthl } \\
\text { Runoff }\end{array}$ & $\begin{array}{l}\text { discha } \\
\text { acre-fee }\end{array}$ & In cu & & & & & $\begin{array}{r}12,270 \\
754,700\end{array}$ & $\begin{array}{r}21,850 \\
1,300,000\end{array}$ \\
\hline
\end{tabular}

Gage he1ght, in feet, and discharge, in cublc feet per second, at indicated time, 1964

\begin{tabular}{|c|c|c|c|c|c|c|c|c|c|c|c|c|}
\hline June & 8 & $\begin{array}{l}0000 \\
0400 \\
0800 \\
1200 \\
1600 \\
2000 \\
2400 \\
\\
0400 \\
0800 \\
1200 \\
1600\end{array}$ & $\begin{array}{rr}9 & 55 \\
9 & 72 \\
9 & 83 \\
9 & 97 \\
10 & 17 \\
10 & 49 \\
10 & 88 \\
11 & 40 \\
11 & 92 \\
12 & 39 \\
12 & 87 \\
\end{array}$ & $\begin{array}{l}15,300 \\
15,700 \\
15,900 \\
16,200 \\
16,700 \\
17,400 \\
18,200 \\
19,400 \\
20,600 \\
21,800 \\
23,100\end{array}$ & June 9 & $\begin{array}{l}2000 \\
2400 \\
\\
0400 \\
0800 \\
1200 \\
1500 \\
2000 \\
2400\end{array}$ & $\begin{array}{ll}13 & 25 \\
13 & 55 \\
13 & 79 \\
13 & 95 \\
14 & 04 \\
14 & 07 \\
14 & 00 \\
13 & 86 \\
13 & 62 \\
13 & 2 y\end{array}$ & $\begin{array}{l}24,200 \\
25,000 \\
25,700 \\
26,200 \\
26,400 \\
26,500 \\
26,300 \\
25,900 \\
25,200 \\
21,300\end{array}$ & June 11 & $\begin{array}{l}1200 \\
1600 \\
2000 \\
2400 \\
\\
0400 \\
0800 \\
1200 \\
1600 \\
2000 \\
2400\end{array}$ & $\begin{array}{ll}12 & 91 \\
12 & 48 \\
11 & 98 \\
11 & 48 \\
11 & 03 \\
10 & 77 \\
10 & 71 \\
10 & 77 \\
10 & 87 \\
11 & 01\end{array}$ & $\begin{array}{l}23,200 \\
22,000 \\
20,800 \\
19,600 \\
18,600 \\
18,000 \\
17,900 \\
18,000 \\
18,200 \\
18,500\end{array}$ \\
\hline
\end{tabular}


(56) Missouri River above Sun River, at Great Falls, Mont

\section{(C1ty of Great Falls gage)}

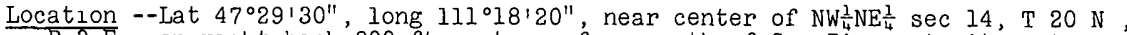
R $3 \bar{E}$, on right bank 800 ft upstream from mouth of Sun River at city watersupply pumping plant

Drainage area $--21,175 \mathrm{sq} \mathrm{mi}$ (revised)

Gage-helght record --Float-gage readings in forebay of pumping plant Graph based on hourly readings June 8-16 Datum of gage is at mean sea level (levels by city of Great Falls)

Maxima --June 1964 Elevation, 3,318 $2 \mathrm{ft} 0400$ hours to 1200 hours June 10 1930 to May 1964 Elevation, 3,317 $84 \mathrm{ft}$ June 5, 1953 (from floodmarks)

Remarks --Records furnished by city of Great Falls

Elevation, in feet, at 2400 hours, on indicated day, 1964

\begin{tabular}{|c|c|c|c|c|c|c|c|c|}
\hline Day & May & June & Day & May & June & Day & May & June \\
\hline $\begin{array}{r}1 \\
2 \\
3 \\
4 \\
5 \\
6 \\
7 \\
8 \\
9 \\
10\end{array}$ & $\begin{array}{ll}3,311 & 2 \\
3,311 & 6 \\
3,312 & 5 \\
3,312 & 5 \\
3,312 & 3 \\
3,312 & 1 \\
3,312 & 0 \\
3,312 & 1 \\
3,312 & 4 \\
3,312 & 4\end{array}$ & $\begin{array}{ll}3,313 & 9 \\
3,313 & 9 \\
3,313 & 6 \\
3,314 & 0 \\
3,313 & 8 \\
3,313 & 6 \\
3,313 & 5 \\
3,313 & 7 \\
3,317 & 2 \\
3,317 & 4\end{array}$ & $\begin{array}{l}11 \\
12 \\
13 \\
14 \\
15 \\
16 \\
17 \\
18 \\
19 \\
20\end{array}$ & 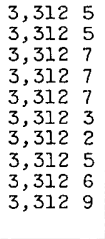 & $\begin{array}{ll}3,315 & 8 \\
3,314 & 7 \\
3,314 & 5 \\
3,314 & 5 \\
3,314 & 3 \\
3,314 & 15 \\
3,313 & 95 \\
3,314 & 1 \\
3,314 & 25 \\
3,314 & 35\end{array}$ & $\begin{array}{l}21 \\
22 \\
23 \\
24 \\
25 \\
26 \\
27 \\
28 \\
29 \\
30 \\
31\end{array}$ & $\begin{array}{ll}3,313 & 3 \\
3,313 & 6 \\
3,313 & 1 \\
3,312 & 1 \\
3,312 & 1 \\
3,312 & 0 \\
3,312 & 5 \\
3,312 & 7 \\
3,313 & 0 \\
3,314 & 0 \\
3,313 & 5\end{array}$ & $\begin{array}{cl}3,314 & 5 \\
3,314 & 25 \\
3,313 & 85 \\
3,313 & 45 \\
3,313 & 5 \\
3,314 & 0 \\
3,314 & 1 \\
3,314 & 0 \\
3,313 & 6 \\
3,313 & 3 \\
-- & -\end{array}$ \\
\hline
\end{tabular}

\begin{tabular}{|c|c|c|c|c|c|c|c|c|}
\hline Date & Hour & Elevation & Date & Hour & Elevat1on & Date & Hour & Elevation \\
\hline June 8 & $\begin{array}{l}0000 \\
1500 \\
1800 \\
2100 \\
2400 \\
\\
0300 \\
0600 \\
0900 \\
1200 \\
1500 \\
1800\end{array}$ & $\begin{array}{ll}3,313 & 5 \\
3,313 & 25 \\
3,313 & 4 \\
3,313 & 6 \\
3,313 & 7 \\
& \\
3,313 & 85 \\
3,314 & 05 \\
3,314 & 4 \\
3,314 & 5 \\
3,314 & 8 \\
3,315 & 2\end{array}$ & June 9 & $\begin{array}{l}2100 \\
2400 \\
\\
0100 \\
0200 \\
0300 \\
0400 \\
1200 \\
1300 \\
1500 \\
1820 \\
2100\end{array}$ & $\begin{array}{ll}3,316 & 0 \\
3,317 & 2 \\
& \\
3,317 & 45 \\
3,317 & 7 \\
3,317 & 85 \\
3,318 & 2 \\
3,318 & 2 \\
3,317 & 95 \\
3,317 & 85 \\
3,317 & 9 \\
3,317 & 65\end{array}$ & $\begin{array}{r}\text { June } 10 \\
11\end{array}$ & $\begin{array}{l}2400 \\
\\
0600 \\
1200 \\
1800 \\
2400 \\
\\
0600 \\
1200 \\
1800 \\
2400\end{array}$ & 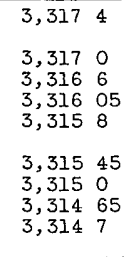 \\
\hline
\end{tabular}

\section{SUN RIVER BASIN}

(57) 6-785 North Fork Sun River near Augusta, Mont

Location --Lat $47^{\circ} 38^{\prime} 30^{\prime \prime}$, long $112^{\circ} 51^{\prime} 30^{\prime \prime}$, in SW $\frac{1}{4} S W^{\frac{1}{4}} \sec 23, \mathrm{~T} 22 \mathrm{~N}, \mathrm{R} 10 \mathrm{~W}$, on left bank $400 \mathrm{ft}$ upstream from Arsenic Creek, 1 mile upstream from confluence with South Fork, and 25 miles northwest of Augusta

Drainage area $--258 \mathrm{sq} \mathrm{mi}$

Gage-height record --Floodmarks at gage site staff-gage readings at site threequarters of a mile downstream at different datum used June 20-30 Datum of gage is 4,785 $72 \mathrm{ft}$ above mean sea level (levels by Bureau of Reclamation)

Discharge record --Stage-discharge relation defined by current-meter measurements below 4,000 cfs and by slope-area measurement at 51,100 cfs

Maxima --June 1964 Discharge, 51,100 cfs June 8 (gage height, $1582 \mathrm{ft}$, from floodmarks )

1911-12, 1945 to May 1964 Discharge, 4,840 cf's June 3, 1948 (gage height, 
Mean discharge, in cub1c feet per second, 1964, of North Fork Sun River near Augusta, Mont

\begin{tabular}{|c|c|c|c|c|c|c|c|c|}
\hline Day & May & June & Day & May & June & Day & May & June \\
\hline $\begin{array}{r}1 \\
2 \\
3 \\
4 \\
5 \\
6 \\
7 \\
8 \\
9 \\
10\end{array}$ & $\begin{array}{l}303 \\
316 \\
288 \\
278 \\
272 \\
266 \\
254 \\
275 \\
306 \\
363\end{array}$ & $\begin{array}{r}1,900 \\
1,800 \\
1,700 \\
1,600 \\
1,600 \\
2,500 \\
4,000 \\
20,000 \\
14,000 \\
7,000\end{array}$ & $\begin{array}{l}11 \\
12 \\
13 \\
14 \\
15 \\
16 \\
17 \\
18 \\
19 \\
20\end{array}$ & $\begin{array}{r}386 \\
428 \\
542 \\
596 \\
655 \\
836 \\
1,180 \\
1,430 \\
1,590 \\
1,940\end{array}$ & $\begin{array}{l}5,000 \\
3,500 \\
3,000 \\
2,800 \\
2,500 \\
2,300 \\
2,000 \\
1,800 \\
1,700 \\
1,560\end{array}$ & $\begin{array}{l}21 \\
22 \\
23 \\
24 \\
25 \\
26 \\
27 \\
28 \\
29 \\
30 \\
31\end{array}$ & $\begin{array}{l}2,200 \\
2,300 \\
1,800 \\
1,500 \\
1,300 \\
1,100 \\
1,000 \\
1,400 \\
3,100 \\
3,000 \\
2,200\end{array}$ & $\begin{array}{r}1,410 \\
1,320 \\
1,400 \\
1,620 \\
1,740 \\
1,570 \\
1,560 \\
1,390 \\
1,200 \\
1,090 \\
-\end{array}$ \\
\hline \multicolumn{7}{|c|}{$\begin{array}{l}\text { Monthly mean disch } \\
\text { Runoff, in Inches } \\
\text { Runoff, in acre-fe }\end{array}$} & $\begin{array}{r}1,078 \\
482 \\
66,260\end{array}$ & $\begin{array}{r}3,219 \\
1392 \\
191,500\end{array}$ \\
\hline
\end{tabular}

(58) 6-790 South Fork Sun River near Augusta, Mont

(Gaging station, discontinued 1912, formerly published as South Fork of North Fork Sun River)

Location --Lat $47^{\circ} 38^{\prime}$, long $112^{\circ} 52^{\prime \prime}$, in $\mathrm{SE} \frac{1}{4} \sec 27, \mathrm{~T} 22 \mathrm{~N}, \mathrm{R} 10 \mathrm{~W}$, I mile upstream from confluence with North Fork and 24 miles northwest of Augusta Alt1tude of gage was $4,730 \mathrm{ft}$ (from topograph1c map)

Drainage area $--252 \mathrm{sq} \mathrm{ml}$

Maxima --June 1964 Discharge, 28,800 cfs June 8, from slope-area measurement 1911-12 Discharge, 2,740 cfs June 3, 1911 (gage height, $46 \mathrm{ft}$ )

(59) 6-795 Gibson Reservoir near Augusta, Mont

Location --Lat $47^{\circ} 36^{\prime} 10^{\prime \prime}$, long $112^{\circ} 45^{\prime} 40^{\prime \prime}$, in $\mathrm{NE} \frac{1}{4} \mathrm{NW} \frac{1}{4} \mathrm{SE} \frac{1}{4} \sec 4, \mathrm{~T} 21 \mathrm{~N}, \mathrm{R} 9 \mathrm{~W}$, at Gibson Dam on Sun River, 19 miles northwest of Augusta

Drainage area $--575 \mathrm{sq} \mathrm{ml}$

Gage-helght recorder --Tape gage read once dally and more often during period June 7-13 Datum of gage is at mean sea level (levels by Bureau of Reclamation)

Discharge record --Inflow computed from gage readings at time intervals shown and from change in contents

Maxima --June 1964 Contents, 116,400 acre-ft 1930 hours June 8 (elevation, 4,732 $23 \mathrm{ft}$, from floodmark) Rate of inflow, $60,000 \mathrm{cfs} 1400$ to 1600 hours June 8

1930 to May 1964 Contents observed, 107,100 acre-ft May 30, 1940 (elevation, $4,7255 \mathrm{ft}$ )

Remarks --Reservoir is formed by concrete dam with glory-hole type spillway completed in 1929 Usable capacity is 105,000 acre-ft $\{88,560$ acre-ft prior to 1939) at elevation 4,724 $00 \mathrm{ft}$ No dead storage below elevation 4,560 $0 \mathrm{ft}$ Water is used for irrigation and recreation Records furnished by Bureau of Reclamation Figures given herein represent usable contents

Elevation, in feet, and contents, in acre-feet, at 0800 hours of 1ndicated day, 1964

\begin{tabular}{|c|c|c|c|c|c|c|c|c|c|}
\hline \multirow{2}{*}{ Day } & \multicolumn{2}{|c|}{ May } & \multicolumn{2}{|c|}{ June } & \multirow{2}{*}{ Day } & \multicolumn{2}{|c|}{ May } & \multicolumn{2}{|c|}{ June } \\
\hline & Elevation & Contents & Elevation & Contents & & Elevation & Contents & Elevation & Contents \\
\hline $\begin{array}{l}1 \\
2 \\
3 \\
4 \\
5\end{array}$ & $\begin{array}{ll}4,640 & 0 \\
4,641 & 0 \\
4,641 & 5 \\
4,641 & 5 \\
4,641 & 5\end{array}$ & $\begin{array}{l}22,090 \\
22,720 \\
23,040 \\
23040 \\
23,040\end{array}$ & 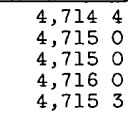 & $\begin{array}{l}92,310 \\
93,080 \\
93,080 \\
94,380 \\
93,470\end{array}$ & $\begin{array}{l}16 \\
17 \\
18 \\
19 \\
20\end{array}$ & $\begin{array}{ll}4,652 & 6 \\
4,656 & 3 \\
4,660 & 0 \\
4,671 & 5 \\
4,681 & 0\end{array}$ & $\begin{array}{l}30,220 \\
32,800 \\
35,390 \\
44,770 \\
53,640\end{array}$ & 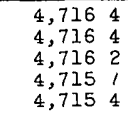 & $\begin{array}{l}94,890 \\
94,890 \\
94,630 \\
93,990 \\
93,600\end{array}$ \\
\hline $\begin{array}{r}6 \\
7 \\
8 \\
9 \\
10\end{array}$ & $\begin{array}{l}4,640 \\
4,640 \\
4,639 \\
4,639 \\
4,6395\end{array}$ & $\begin{array}{l}22,400 \\
22,400 \\
21,800 \\
21,800 \\
21,800\end{array}$ & $\begin{array}{l}4,715 \\
4,715 \\
4,720 \\
4,729 \\
4,722\end{array}$ & $\begin{array}{r}93,730 \\
93,730 \\
99,600 \\
112,800 \\
102,600\end{array}$ & $\begin{array}{l}21 \\
22 \\
23 \\
24 \\
25\end{array}$ & 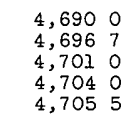 & $\begin{array}{l}62,930 \\
70,580 \\
75,570 \\
79,270 \\
81,100\end{array}$ & 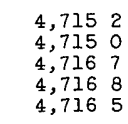 & $\begin{array}{l}93,340 \\
93,080 \\
95,280 \\
95,410 \\
95,020\end{array}$ \\
\hline $\begin{array}{l}11 \\
12 \\
13 \\
14 \\
15\end{array}$ & $\begin{array}{l}4,639 \\
4,639 \\
4,640 \\
4,644 \\
4,649 \\
0\end{array}$ & $\begin{array}{l}21,800 \\
21,800 \\
22,400 \\
25,120 \\
27,770\end{array}$ & 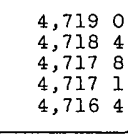 & $\begin{array}{l}98,250 \\
97,470 \\
96,800 \\
95,800 \\
94,890\end{array}$ & $\begin{array}{l}26 \\
27 \\
28 \\
29 \\
30 \\
31\end{array}$ & 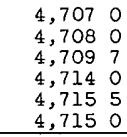 & $\begin{array}{l}82,940 \\
84,170 \\
86,260 \\
91,790 \\
93,730 \\
93,080 \\
\end{array}$ & 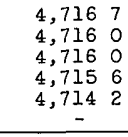 & $\begin{array}{c}95,280 \\
94,380 \\
94,380 \\
93,860 \\
92,050 \\
- \\
\end{array}$ \\
\hline h & e in con & & & & & - & $+70,990$ & - & $-1,030$ \\
\hline
\end{tabular}


Est1mated average da1ly flows, in cublc feet per second, 1964, of G1bson Reservolr near Augusta, Mont

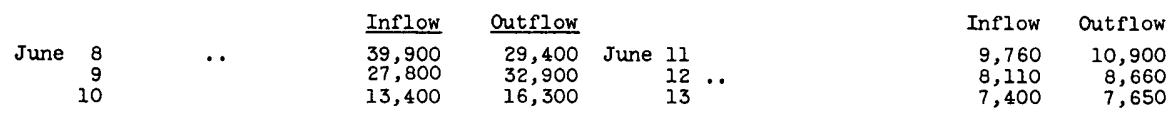

Elevation, in feet, and computed inflow, in cublc feet per second, at indicated time, 1964

\begin{tabular}{|c|c|c|c|c|c|c|c|c|}
\hline & Date & Hour & Elevation & Infliow & Date & Hour & Elevation & Inflow \\
\hline \multirow[t]{4}{*}{ June } & 7 & 2400 & 4,71641 & 6,300 & \multirow[t]{4}{*}{ June } & 2400 & 4,73171 & 48,400 \\
\hline & 8 & $\begin{array}{l}0100 \\
0200 \\
0300 \\
0400 \\
0500 \\
0600 \\
0700 \\
0800 \\
0900 \\
1000 \\
1100 \\
1200 \\
1300 \\
1400\end{array}$ & 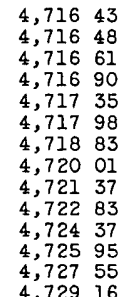 & $\begin{array}{l}6,700 \\
7,100 \\
9,800 \\
12,500 \\
16,000 \\
20,000 \\
25,500 \\
34,000 \\
38,300 \\
42,700 \\
47,000 \\
51,300 \\
55,700 \\
60,000\end{array}$ & & $\begin{array}{l}0100 \\
0200 \\
0300 \\
0400 \\
0500 \\
0600 \\
0700 \\
0800 \\
0900 \\
1000 \\
1200 \\
1800 \\
2400\end{array}$ & 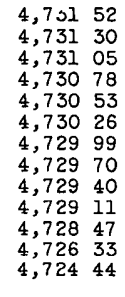 & $\begin{array}{l}46,100 \\
43,500 \\
40,000 \\
38,000 \\
35,800 \\
33,900 \\
32,200 \\
30,600 \\
29,100 \\
27,800 \\
25,300 \\
20,000 \\
16,900\end{array}$ \\
\hline & & $\begin{array}{l}1500 \\
1600 \\
1700 \\
1800 \\
1900\end{array}$ & $\begin{array}{ll}4,730 & 53 \\
4,731 & 41 \\
4,731 & 90 \\
4,732 & 12\end{array}$ & $\begin{array}{l}60,000 \\
60,000 \\
58,900 \\
57,700 \\
56,600\end{array}$ & & $\begin{array}{l}0600 \\
1200 \\
1800 \\
2400\end{array}$ & 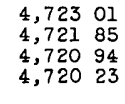 & $\begin{array}{l}14,700 \\
13,000 \\
12,000 \\
11,000\end{array}$ \\
\hline & & $\begin{array}{l}1930 \\
2000 \\
2100 \\
2200 \\
2300\end{array}$ & $\begin{array}{ll}4,732 & 23 \\
4,732 & 20 \\
4,732 & 09 \\
4,732 & 00 \\
4,731 & 86\end{array}$ & $\begin{array}{l}56,000 \\
55,300 \\
53,800 \\
52,200 \\
50,400\end{array}$ & & $\begin{array}{l}0600 \\
1200 \\
1800 \\
2400\end{array}$ & 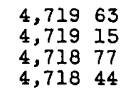 & $\begin{array}{r}10,300 \\
9,700 \\
9,200 \\
8,700\end{array}$ \\
\hline
\end{tabular}

(60) 6-796 Beaver Creek at Gibson Dam, near Augusta, Mont (Crest-stage station)

Location --Lat $47^{\circ} 36^{\prime}$, long $112^{\circ} 45^{\prime}$, in $\operatorname{SE} \frac{1}{4} \sec 4, \mathrm{~T} 21 \mathrm{~N}, \mathrm{R} 9 \mathrm{~W}$, at bridge on Bureau of Reclamation road, a quarter of a mile downstream from Gibson Dam, and 19 miles northwest of Augusta

Drainage area $--203 \mathrm{sq} \mathrm{ml}$

Gage-helght record --Crest stages only Altitude of gage is 4,560 ft (from topographic map)

Discharge record --Stage-discharge relation defined by current-meter measurements below 70 cf's and by slope-area measurements at $496 \mathrm{cfs}$ and $4,360 \mathrm{cfs}$

Maxima --June 1964 D1scharge, 4,360 cfs June 8, from slope-area measurement 1959 to May 1964 Discharge, $496 \mathrm{cfs}$ May 26, 1962 (gage height, $245 \mathrm{ft}$ ), from slope-area measurement

(61) 6-800 Sun River near Augusta, Mont

(Gaging station, discontinued 1940, formerly called North Fork Sun River)

Locat1on --Lat $47^{\circ} 37^{\prime}$, long $112^{\circ} 42^{\prime}$, in $\mathrm{NW} \frac{1}{4} \sec 36, \mathrm{~T} 22 \mathrm{~N}, \mathrm{R} 9 \mathrm{~W}$, about $150 \mathrm{ft}$ upstream from diversion dam and 18 miles northwest of Augusta

Drainage area $--609 \mathrm{sq} \mathrm{mi}$

Gage-helght record --Staff-gage readings Peak stage determined from floodmark Datum of gage Is 4,474 $\mathrm{ft}$ above mean sea level (levels by Bureau of Reclamation)

Discharge record --Peak discharge by flow-over-dam measurement observed da1ly flow, adjusted flow based on change in contents of Gibson Reservoir, furnished by
Bureau of Reclamation

Maxima - -June 1964 Discharge, 59,700 cfs 0500 hours June 9 (gage he1ght, $157 \mathrm{ft}$, from high-water mark on gage house)

$1889-90,1904$ to May 1964 Discharge, 32,300 cfs June 21, 1916 (gage height, $114 \mathrm{ft}$ )

Remarks --Flow regulated since 1930 by Gibson Reservoir (see station 59) Records 1916-36 furnished by Bureau of Reclamation 
Computed flow over diversion dam, Sun River near Augusta, Mont, on indicated day 1964

\begin{tabular}{|c|c|c|c|c|c|c|}
\hline Date & $\begin{array}{c}\text { Contents in } \\
\text { Gibson } \\
\text { Reservolr } \\
\text { (acre-feet) }\end{array}$ & $\begin{array}{c}\text { Change in } \\
\text { contents } \\
\text { in Gibson } \\
\text { Reservolr } \\
\text { (equivalent } \\
\text { cfs-days) }\end{array}$ & $\begin{array}{l}\text { Flow in } \\
\text { Plshkun } \\
\text { Canal } \\
\text { (cfs) }\end{array}$ & $\begin{array}{l}\text { Flow In } \\
\text { W1llow Creek } \\
\text { feeder canal } \\
\text { (cfs) }\end{array}$ & $\begin{array}{l}\text { Observed } \\
\text { flow over } \\
\text { diversion } \\
\text { dam } \\
\text { (cfs) }\end{array}$ & $\begin{array}{l}\text { Adjusted } \\
\text { flow over } \\
\text { diversion } \\
\text { dam } \\
\text { (cfs) }\end{array}$ \\
\hline $\begin{array}{l}\text { May } \\
2 \\
3 \\
4 \\
5\end{array}$ & $\begin{array}{l}22,090 \\
22,720 \\
23,040 \\
23,040 \\
23,040\end{array}$ & $\begin{array}{r}0 \\
+320 \\
+160 \\
0 \\
0\end{array}$ & $\begin{array}{l}430 \\
560 \\
620 \\
620 \\
620\end{array}$ & $\begin{array}{l}0 \\
0 \\
0 \\
0 \\
0\end{array}$ & $\begin{array}{l}110 \\
110 \\
140 \\
150 \\
140\end{array}$ & $\begin{array}{l}540 \\
990 \\
920 \\
770 \\
760\end{array}$ \\
\hline $\begin{array}{r}6 \\
7 \\
8 \\
9 \\
10\end{array}$ & $\begin{array}{l}22,400 \\
22,400 \\
21,800 \\
21,800 \\
21,800\end{array}$ & $\begin{array}{r}-320 \\
0 \\
-300 \\
0 \\
0\end{array}$ & $\begin{array}{l}620 \\
620 \\
620 \\
620 \\
620\end{array}$ & $\begin{array}{l}0 \\
0 \\
0 \\
0 \\
0\end{array}$ & $\begin{array}{l}130 \\
120 \\
120 \\
120 \\
120\end{array}$ & $\begin{array}{l}430 \\
740 \\
440 \\
740 \\
740\end{array}$ \\
\hline $\begin{array}{l}11 \\
12 \\
13 \\
14 \\
15\end{array}$ & $\begin{array}{l}21,800 \\
21,800 \\
22,400 \\
25,120 \\
27,770\end{array}$ & $\begin{array}{r}0 \\
0 \\
+300 \\
+1,370 \\
+1,340\end{array}$ & $\begin{array}{r}470 \\
380 \\
160 \\
20 \\
20\end{array}$ & $\begin{array}{r}0 \\
50 \\
90 \\
90 \\
0\end{array}$ & $\begin{array}{l}120 \\
120 \\
130 \\
250 \\
250\end{array}$ & $\begin{array}{r}590 \\
550 \\
680 \\
1,730 \\
1,610\end{array}$ \\
\hline $\begin{array}{l}16 \\
17 \\
18 \\
19 \\
20\end{array}$ & $\begin{array}{l}30,220 \\
32,800 \\
35,390 \\
44,770 \\
53,640\end{array}$ & $\begin{array}{l}+1,230 \\
+1,300 \\
+1,300 \\
+4,730 \\
+4,470\end{array}$ & $\begin{array}{r}20 \\
20 \\
20 \\
20 \\
140\end{array}$ & $\begin{array}{l}0 \\
0 \\
0 \\
0 \\
0\end{array}$ & $\begin{array}{l}250 \\
250 \\
260 \\
280 \\
290\end{array}$ & $\begin{array}{l}1,500 \\
1,570 \\
1,580 \\
5,030 \\
4,900\end{array}$ \\
\hline $\begin{array}{l}21 \\
22 \\
23 \\
24 \\
25\end{array}$ & $\begin{array}{l}62,930 \\
70,580 \\
75,570 \\
79,270 \\
81,100\end{array}$ & $\begin{array}{r}+4,680 \\
+3,860 \\
+2,520 \\
+1,860 \\
+930\end{array}$ & $\begin{array}{l}340 \\
680 \\
800 \\
800 \\
930\end{array}$ & $\begin{array}{l}50 \\
90 \\
90 \\
90 \\
90\end{array}$ & $\begin{array}{l}290 \\
290 \\
290 \\
290 \\
290\end{array}$ & $\begin{array}{l}5,360 \\
4,920 \\
3,700 \\
3,040 \\
2,240\end{array}$ \\
\hline $\begin{array}{l}26 \\
27 \\
28 \\
29 \\
30 \\
31\end{array}$ & $\begin{array}{l}82,940 \\
84,170 \\
86,260 \\
91,790 \\
93,730 \\
93,080\end{array}$ & $\begin{array}{r}+930 \\
+620 \\
+1,050 \\
+2,790 \\
+980 \\
-330\end{array}$ & $\begin{array}{r}1,100 \\
1,290 \\
1,340 \\
1,160 \\
1,000 \\
960\end{array}$ & $\begin{array}{l}100 \\
100 \\
100 \\
100 \\
100 \\
100\end{array}$ & $\begin{array}{r}290 \\
290 \\
430 \\
2,100 \\
3,990 \\
3,510\end{array}$ & $\begin{array}{l}2,420 \\
2,300 \\
2,920 \\
6,150 \\
6,070 \\
4,240\end{array}$ \\
\hline $\begin{array}{l}\text { Total cfs-days } \\
\text { Mean }\end{array}$ & - & $+35,790$ & $\begin{array}{r}17,620 \\
568\end{array}$ & $\begin{array}{r}1,240 \\
400\end{array}$ & $\begin{array}{r}15,520 \\
501\end{array}$ & $\begin{array}{r}70,170 \\
2,264\end{array}$ \\
\hline $\begin{array}{r}1 \\
\text { June } \\
3 \\
4 \\
5\end{array}$ & $\begin{array}{l}92,310 \\
93,080 \\
93,080 \\
94,380 \\
93,470\end{array}$ & $\begin{array}{r}-390 \\
+390 \\
0 \\
+650 \\
-460\end{array}$ & $\begin{array}{r}960 \\
960 \\
1,110 \\
1,110 \\
1,340\end{array}$ & $\begin{array}{l}100 \\
100 \\
100 \\
100 \\
100\end{array}$ & $\begin{array}{l}3,130 \\
3,280 \\
3,510 \\
4,560 \\
2,230\end{array}$ & $\begin{array}{l}3,800 \\
4,730 \\
4,720 \\
6,420 \\
3,210\end{array}$ \\
\hline $\begin{array}{r}6 \\
7 \\
8 \\
9 \\
10\end{array}$ & $\begin{array}{r}93,730 \\
93,730 \\
99,600 \\
112,800 \\
102,600\end{array}$ & $\begin{array}{r}+130 \\
0 \\
+2,960 \\
+6,660 \\
-5,140\end{array}$ & $\begin{array}{r}1,340 \\
1,340 \\
1,340 \\
690 \\
100\end{array}$ & $\begin{array}{r}100 \\
100 \\
100 \\
0 \\
0\end{array}$ & $\begin{array}{r}4,080 \\
4,210 \\
27,960 \\
32,210 \\
16,200\end{array}$ & $\begin{array}{r}5,650 \\
5,650 \\
32,360 \\
39,560 \\
11,160\end{array}$ \\
\hline $\begin{array}{l}11 \\
12 \\
13 \\
14 \\
15\end{array}$ & $\begin{array}{l}98,250 \\
97,470 \\
96,800 \\
95,800 \\
94,890\end{array}$ & $\begin{array}{r}-2,190 \\
-390 \\
-340 \\
-510 \\
-490\end{array}$ & $\begin{array}{l}100 \\
100 \\
100 \\
100 \\
100\end{array}$ & $\begin{array}{l}0 \\
0 \\
0 \\
0 \\
0\end{array}$ & $\begin{array}{r}10,800 \\
8,560 \\
7,550 \\
6,800 \\
6,500\end{array}$ & $\begin{array}{l}8,710 \\
8,270 \\
7,310 \\
6,390 \\
6,140\end{array}$ \\
\hline $\begin{array}{l}16 \\
17 \\
18 \\
19 \\
20\end{array}$ & $\begin{array}{l}94,890 \\
94,890 \\
94,630 \\
93,990 \\
93,600\end{array}$ & $\begin{array}{r}0 \\
0 \\
-130 \\
-320 \\
-200\end{array}$ & $\begin{array}{l}100 \\
100 \\
100 \\
200 \\
200\end{array}$ & $\begin{array}{l}0 \\
0 \\
0 \\
0 \\
0\end{array}$ & $\begin{array}{l}6,650 \\
6,900 \\
6,160 \\
5,300 \\
3,990\end{array}$ & $\begin{array}{l}6,750 \\
7,000 \\
6,130 \\
5,180 \\
3,990\end{array}$ \\
\hline $\begin{array}{l}21 \\
22 \\
23 \\
24 \\
25\end{array}$ & $\begin{array}{l}93,340 \\
93,080 \\
95,280 \\
95,410 \\
95,020\end{array}$ & $\begin{array}{r}-130 \\
-130 \\
+1,110 \\
+70 \\
-200\end{array}$ & $\begin{array}{l}200 \\
200 \\
400 \\
640 \\
640\end{array}$ & $\begin{array}{l}0 \\
0 \\
0 \\
0 \\
0\end{array}$ & $\begin{array}{l}3,280 \\
3,550 \\
3,050 \\
3,390 \\
3,390\end{array}$ & $\begin{array}{l}3,350 \\
3,620 \\
4,560 \\
4,100 \\
3,830\end{array}$ \\
\hline $\begin{array}{l}26 \\
27 \\
28 \\
29 \\
30\end{array}$ & $\begin{array}{l}95,280 \\
94,380 \\
94,380 \\
93,860 \\
92,050\end{array}$ & $\begin{array}{r}+130 \\
-460 \\
0 \\
-260 \\
-910\end{array}$ & $\begin{array}{r}830 \\
830 \\
1,010 \\
1,010 \\
1,280\end{array}$ & $\begin{array}{l}0 \\
0 \\
0 \\
0 \\
0\end{array}$ & $\begin{array}{l}4,510 \\
3,510 \\
3,130 \\
3,130 \\
1,970\end{array}$ & $\begin{array}{l}5,470 \\
3,880 \\
4,140 \\
3,880 \\
2,340\end{array}$ \\
\hline $\begin{array}{l}\text { Total cfs-days } \\
\text { Mean }\end{array}$ & $\overline{-}$ & $\begin{array}{l}-520 \\
-\end{array}$ & $\begin{array}{r}18,530 \\
618\end{array}$ & $\begin{array}{r}800 \\
267\end{array}$ & $\begin{array}{r}203,490 \\
6,783\end{array}$ & $\begin{array}{r}222,300 \\
7,410\end{array}$ \\
\hline
\end{tabular}


(62) South Fork Willow Creek near Augusta, Mont

(Miscellaneous site)

Location --Lat $47^{\circ} 31^{\prime} 00^{\prime \prime}$, long $112^{\circ} 31^{\prime} 00^{\prime \prime}$, in center of $\sec 5, T 20 \mathrm{~N}, \mathrm{R} 7 \mathrm{~W}$, a quarter of a mile upstream from bridge on county road and 7 miles northwest of Augusta

Drainage area $--269 \mathrm{sq} \mathrm{ml}$

Maximum --June 1964 Discharge, 2,790 cf's about 1800 hours June 8, from slope-area measurement

(63) Sun River at State Highway 287, near Augusta, Mont

(Miscellaneous site)

Location --Lat $47^{\circ} 32^{\prime} 40^{\prime \prime}$, long $112^{\circ} 21^{\prime} 50^{\prime \prime}$, in $\mathrm{NW} \frac{1}{4} \sec 27, \mathrm{~T} 21 \mathrm{~N}, \mathrm{R} 6 \mathrm{~W}$, at bridge on State Highway 287,4 miles northeast of Augusta

Drainage area $--827 \mathrm{sq} \mathrm{ml}$

Maximum --June 1964 Discharge, 46,700 cfs June 9, from contracted-opening measurement

Remarks --Peak flow partly regulated by storage in Gibson Reservoir (see station 59)

(64) 6-835 Ford Creek near Augusta, Mont

(Gaging station, discontinued 1912)

Location --Lat $47^{\circ} 26^{\prime}$, long $112^{\circ} 40^{\prime}$, near center of south line sec 31 , T $20 \mathrm{~N}$ R $8 \mathrm{~W}$, at Ford Ranch, 14 miles west of Augusta Alt1tude of gage is $4,760 \mathrm{f}^{\prime} \mathrm{t}$ (from topographic map)

Drainage area $--194 \mathrm{sq} \mathrm{mi}$

Discharge record --Peak discharge by slope-area measurement at site about $1 \mathrm{mlle}$ upstream

Maxıma --June 1964 Discharge, 2,700 cfs 1300 hours June 8

1906-12 Discharge, 1,230 cfs June 19, 1909 (gage helght, 5 ft, from graph based on gage readings), from rating curve extended above $140 \mathrm{cfs}$

(65) 6-840 Smith Creek below Ford Creek, near Augusta, Mont

(Gaging station, discontinued 1952)

Location --Lat $47^{\circ} 26^{\prime}$, long $112^{\circ} 31^{\prime}$, in $S \frac{1}{2} \sec 32, T 20 \mathrm{~N}, \mathrm{R} 7 \mathrm{~W}$, on right bank 2 miles downstream from Ford Creek, 4 miles upstream from mouth, and 7 miles southwest of Augusta

Drainage area $-74 \quad 0 \mathrm{sq} \mathrm{mi}$

Gage-height record --High-water marks on the right bank at gage site Altitude of gage is 4,300 ft (from topographic map)

Discharge record --Peak discharge by slope-area measurement

Maxima --June 1964 Discharge, 6,140 cfs about 2100 hours June 8 (gage height, $134 \mathrm{ft}$, from floodmarks )

1945-52 Discharge, 1,830 cf's June 5, 1948 (gage helght, $57 \mathrm{ft}$ ), from rating curve extended above $940 \mathrm{cfs}$ 
(66) Elk Creek near Augusta, Mont

(Miscellaneous site)

Location - Lat $47^{\circ} 27^{\prime} 00^{\prime \prime}$, long $112^{\circ} 26^{\prime} 00^{\prime \prime}$, in $\mathrm{NE} \frac{1}{4} \sec 36$, T $20 \mathrm{~N}$, $\mathrm{R} 7 \mathrm{~W}$, half a mile downstream from Smith Creek, and $3 \frac{1}{2}$ miles southwest of Augusta

Drainage area $--145 \mathrm{sq} \mathrm{mi}$

Maximum--June 1964 Discharge, about $12,000 \mathrm{cfs} 2200$ hours June 8, from slopearea measurement

(67) Sun River at Simms, Mont

(U S Weather Bureau gage)

Location --Lat $47^{\circ} 30^{\prime} 25^{\prime \prime}$, long $111^{\circ} 55^{\prime} 50^{\prime \prime}$, in SW $\frac{1}{4} \mathrm{NE} \frac{1}{4} \sec 12, \mathrm{~T} 20 \mathrm{~N}, \mathrm{R} 3 \mathrm{~W}$, on right bank at downstream side of county bridge 1 mile north of Simms and i mile downstream from Simms Creek

Drainage area $-1,320 \mathrm{sq} \mathrm{mi}(1,224 \mathrm{sq} \mathrm{mi}$ at slope-area site 4 miles upstream)

Gage-helght record--Once-dally staff-gage readings, except some additional observations during peak flows The maximum stage is based on floodmarks at the gage Datum of gage is at mean sea level, on basis of Great Northern Railway datum

Maxima --June 1964 Discharge, 69,800 cfs 0600-1000 hours June 9 (elevation, $3,5616 \mathrm{ft}$, from floodmarks), from slope-area measurement of peak flow at site 4 miles upstream

1941 to May 1964 Elevation observed, 3,557 I ft June 4, 1953

Remarks --Peak flow partly regulated by storage in Gibson Reservoir (see station 59)

Elevation, in feet, at about 0800 hours, on Indicated day, 1964

\begin{tabular}{|c|c|c|c|c|c|c|c|c|}
\hline Day & May & June & Day & May & June & Day & May & June \\
\hline $\begin{array}{r}1 \\
2 \\
3 \\
4 \\
5 \\
6 \\
7 \\
8 \\
9 \\
10\end{array}$ & $\begin{array}{cc}- & \\
3, & \\
3,551 & 0 \\
3,550 & 5 \\
3,550 & 3 \\
3,549 & 8 \\
3,549 & 8 \\
3,549 & 8 \\
3,549 & 8 \\
3,549 & 8\end{array}$ & $\begin{array}{ll}3,553 & 0 \\
3,552 & 9 \\
3,552 & 9 \\
3,553 & 2 \\
3,553 & 5 \\
3,553 & 3 \\
3,553 & 3 \\
3,554 & 3 \\
3,561 & 6 \\
3,558 & 3\end{array}$ & $\begin{array}{l}11 \\
12 \\
13 \\
14 \\
15 \\
16 \\
17 \\
18 \\
19 \\
20\end{array}$ & 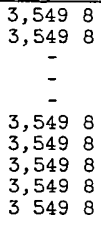 & $\begin{array}{ll}3,556 & 0 \\
3,554 & 8 \\
3,554 & 3 \\
3,553 & 9 \\
3,553 & 7 \\
3,553 & 7 \\
3,553 & 9 \\
3,553 & 7 \\
3,553 & 3 \\
3,552 & 8\end{array}$ & $\begin{array}{l}21 \\
22 \\
23 \\
24 \\
25 \\
26 \\
27 \\
28 \\
29 \\
30 \\
31\end{array}$ & $\begin{array}{cc}3,549 & 8 \\
3,549 & 8 \\
3,549 & 8 \\
3,549 & 8 \\
3,549 & 8 \\
- & \\
3,549 & 8 \\
3,549 & 8 \\
3,550 & 0 \\
3,553 & 4 \\
3,553 & 4\end{array}$ & $\begin{array}{r}3,5527 \\
3,552 \\
3,5518 \\
3,551 \\
3,5518 \\
3,552 \\
3,552 \\
3,552 \\
3,5518 \\
3,5515 \\
-\quad-\quad-\quad-\end{array}$ \\
\hline
\end{tabular}

Elevation, in feet, at indicated time, 1964

\begin{tabular}{c|l|c||c|c|c||c|c|c|c}
\hline Date & Hour & Elevation & Date & Hour & Elevation & Date & Hour & Elevat1on \\
\hline June 8 & 0800 & 3,5543 & June 9 & 1945 & 3,5566 & June 9 & 0600 & 3,5616 \\
& 1030 & 3,5553 & & 2100 & 3,5566 & & & 1000 & 3,5616 \\
& 1500 & 3,5557 & & 2300 & 3,5586 & & & & \\
& 1700 & 3,5561 & & 2400 & 3,5591 & & & \\
\hline
\end{tabular}

(68) 6-879 Muddy Creek tributary near Power, Mont

(Crest-stage station)

Location --Lat $47^{\circ} 45^{\prime}$, long $111^{\circ} 43^{\prime}$, on south line of SW $\frac{1}{4}$ sec $10 \mathrm{~T} 23 \mathrm{~N}, \mathrm{R} 1 \mathrm{~W}$, at culvert on county road, 3 miles west of US Highway $91,3 \frac{1}{2}$ miles northwest of Power, and 6 miles south of Dutton

Drainage area $--315 \mathrm{sq} \mathrm{ms}$

Gage-he1ght record --Crest stages only Altitude of gage is $3,710 \mathrm{ft}$ (from topographic map

Discharge record --Stage-discharge relation defined by current-meter measurements below $100 \mathrm{cf}$ 's and by a combined flow-over-road and flow-through-culvert measurement at $284 \mathrm{cfs}$

Maxima --June 1964 Discharge, $220 \mathrm{cfs}$ June 8 (gage height, $213 \mathrm{ft}$, downstream gage, $351 \mathrm{ft}$, upstream gage)

1963 to May 1964 Discharge, 284 cfs May 3, 1964 (gage height, $226 \mathrm{ft}$, downstream gage, $475 \mathrm{ft}$, upstream gage) 
(69) Muddy Creek at Vaughn, Mont

Location --Lat $47^{\circ} 33^{\prime} 40^{\prime \prime}$, long $111^{\circ} 32^{\prime} 30^{\prime \prime}$, near center of $S \frac{1}{2} \mathrm{NE} \frac{1}{4}$ sec $24, T 21 \mathrm{~N}$, R IE , near center of span on upstream side of old highway bridge at Vaughn, $1 \frac{1}{2}$ miles upstream from mouth

Gage-height record --Once-daily readings by observer and crest stages Graph based on gage readings and crest-stage gage June 7-15 Altitude of gage is $3,350 \mathrm{ft}$ (from topographic map)

Discharge record --Stage-discharge relation defined by current-meter measurements

Maxima --June 1964, Discharge, 3,720 cfs 0200 hours June 9 (gage height, $1224 \mathrm{ft}$ ) 1925-26, 1934 to May 1964 Discharge, 7,600 cfs June 4, 1953 (gage helght, $177 \mathrm{ft}$, from floodmarks), from rating curve extended above $3,000 \mathrm{cfs}$ on basis of slope-area measurement of peak flow

Flood in June 1908 reached a stage of about $24 \mathrm{ft}$ (discharge not determined), flood in June 1932 reached a stage of about $19 \mathrm{ft}$, present datum (discharge not determined)

Mean discharge, in cubic feet per second, 1964

\begin{tabular}{l} 
Day \\
\hline 1
\end{tabular}

Gage height, in feet, and discharge, in cublc feet per second, at indicated time, 1964

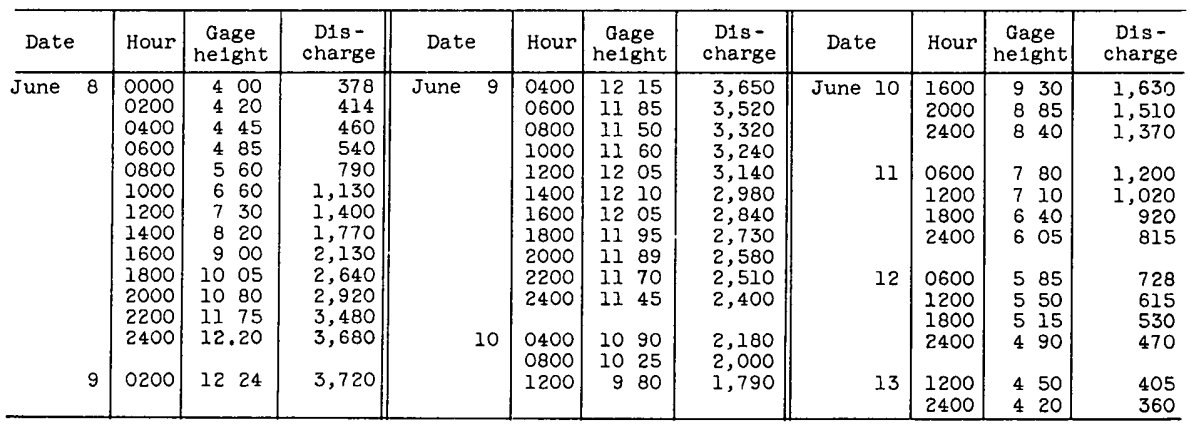


(70) 6-890 Sun River near Vaughn, Mont

Location --Lat $47^{\circ} 31^{\prime} 35^{\prime \prime}$, long $111^{\circ} 29^{\prime} 05^{\prime \prime}$, in $\mathrm{SE} \frac{1}{4} \mathrm{SW} \frac{1}{4} \sec 33, \mathrm{~T} 21 \mathrm{~N}, \mathrm{R} 2 \mathrm{E}$, on right bank 4 miles downstream from Muddy Creek, 4 miles southeast of Vaughn, and 13 miles upstream from mouth

Drainage area $--1,854 \mathrm{sq} \mathrm{m}$

Gage-hezght record --Water-stage recorder graph for main channel Graph re-

constructed from engineer's readings and floodmarks for 1000 hours June 9 to

1700 hours June 12 Datum of gage is $3,31712 \mathrm{ft}$ above mean sea level, datum of

1929, supplementary adjustment of 1962

Discharge record --Stage-discharge relation defined by current-meter measurements for main channel flow Bypass flow from slope-area measurement at peak stage Bypass flow 1400 hours June 9 to 1800 hours June 10 included in discharge data

Maxima --June 1964 Discharge, $53,500 \mathrm{cfs} 1800$ hours June 9 (gage helght, $234 \mathrm{ft}$, from floodmarks), includes il, 300 cfs bypass flow

1934 to May 1964 Discharge, $17,900 \mathrm{cfs}$ June 4, 1953 (gage height, $1638 \mathrm{ft}$, from high-water mark on gage house)

Flood of June 1964 exceeded the stage of the June $1908 \mathrm{flood}$ by about $3 \mathrm{ft}$ and 1 s the highest since 1908 , from information by local residents

Remarks -Flow partly regulated by storage in Gibson Reservoir (see station 59)

Mean discharge, in cub1c feet per second, 1964

\begin{tabular}{|c|c|c|c|c|c|c|c|c|}
\hline Day & May & June & Day & May & June & Day & May & June \\
\hline $\begin{array}{r}1 \\
2 \\
3 \\
4 \\
5 \\
6 \\
7 \\
8 \\
9 \\
10\end{array}$ & $\begin{array}{r}315 \\
532 \\
1,700 \\
2,990 \\
1,340 \\
864 \\
585 \\
506 \\
431 \\
391\end{array}$ & $\begin{array}{r}3,910 \\
3,420 \\
3,460 \\
3,900 \\
4,490 \\
4,250 \\
4,260 \\
6,700 \\
29,500 \\
37,000\end{array}$ & $\begin{array}{l}11 \\
12 \\
13 \\
14 \\
15 \\
16 \\
17 \\
18 \\
19 \\
20\end{array}$ & $\begin{array}{l}360 \\
345 \\
300 \\
300 \\
308 \\
322 \\
330 \\
360 \\
368 \\
375\end{array}$ & $\begin{array}{r}21,400 \\
14,300 \\
10,400 \\
8,750 \\
7,950 \\
7,690 \\
7,860 \\
7,610 \\
6,680 \\
5,670\end{array}$ & $\begin{array}{l}21 \\
22 \\
23 \\
24 \\
25 \\
26 \\
27 \\
28 \\
29 \\
30 \\
31\end{array}$ & $\begin{array}{r}360 \\
391 \\
439 \\
399 \\
360 \\
368 \\
368 \\
415 \\
675 \\
2,760 \\
4,460\end{array}$ & $\begin{array}{r}5,180 \\
4,500 \\
4,080 \\
3,880 \\
4,210 \\
4,430 \\
4,220 \\
3,880 \\
3,550 \\
3,280 \\
-----\end{array}$ \\
\hline $\begin{array}{l}\text { Monthly } \\
\text { Runoff, }\end{array}$ & \multicolumn{6}{|c|}{$\begin{array}{l}\text { mean discharge, in cubic feet per second } \\
\text { in acre-feet }\end{array}$} & $\begin{array}{r}775 \\
47,640 \\
\end{array}$ & $\begin{array}{r}8,014 \\
476,800 \\
\end{array}$ \\
\hline
\end{tabular}

Gage height, in feet, and discharge, in cublc feet per second, at indicated time, 1964

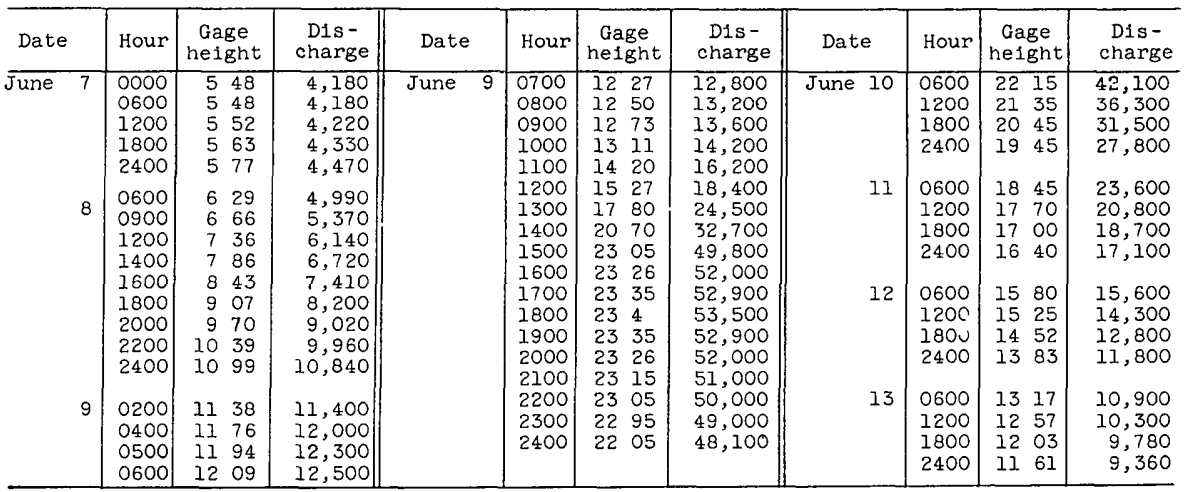


(71) 6-893 Sun River tributary near Great Falls, Mont

(Crest-stage gage)

Location --Lat $47^{\circ} 32^{\prime}$, long $111^{\circ} 24^{\prime}$, in SW $\frac{1}{4} \sec 31$, T $21 \mathrm{~N}$, R $3 \mathrm{E}$, at culvert on old U S Highway 89 and 91,4 miles northwest of Great Faíls

Drainage area $--211 \mathrm{sq} \mathrm{mi}$

Gage-helght record --Crest stages only Altitude of gage is 3,330 ft (from topographic map)

Discharge record --Stage-discharge relation defined by current-meter measurements below $110 \mathrm{cfs}$ and by flow-through-culvert measurement at $470 \mathrm{cfs}$

Maxıma --June 1964 Discharge, $470 \mathrm{cfs}$ June 8 (gage helght, $546 \mathrm{ft}$ )

1956 to May 1964 Discharge, $215 \mathrm{cfs}$ May 5, 1964 (gage helght, $394 \mathrm{ft}$ )

(72) Sun River at Great Falls, Mont

(Corps of Engineers gage)

Location --Lat $47^{\circ} 29^{\prime} 40^{\prime \prime}$, long $120^{\circ} 20^{\prime} 00^{\prime \prime}$, in $\mathrm{NE} \frac{1}{4} \sec 15$, T $20 \mathrm{~N}, \mathrm{R} 3 \mathrm{E}$, at l4th Street Bridge, I mile upstream from mouth

Drainage area $--1,937 \mathrm{sq} \mathrm{ml}$

Gage-height record --Stage observations made from one to thirty times daily by measuring down to water surface from reference point on handrail of bridge Datum of gage is at mean sea level (levels by Corps of Englneers)

Maxıma --June 1964 Elevation observed, 3,324 $6 \mathrm{ft} 0045$ hours June 10

Peak of 1908 reached a stage of about 3,328 ft, Corps of Engineers estimate

Renarks --Stage observations furnished by Corps of Engineers Peak stages partly affected by storage in Gibson Reservoir (see station 59)

Elevation in feet, at indicated time, 1964

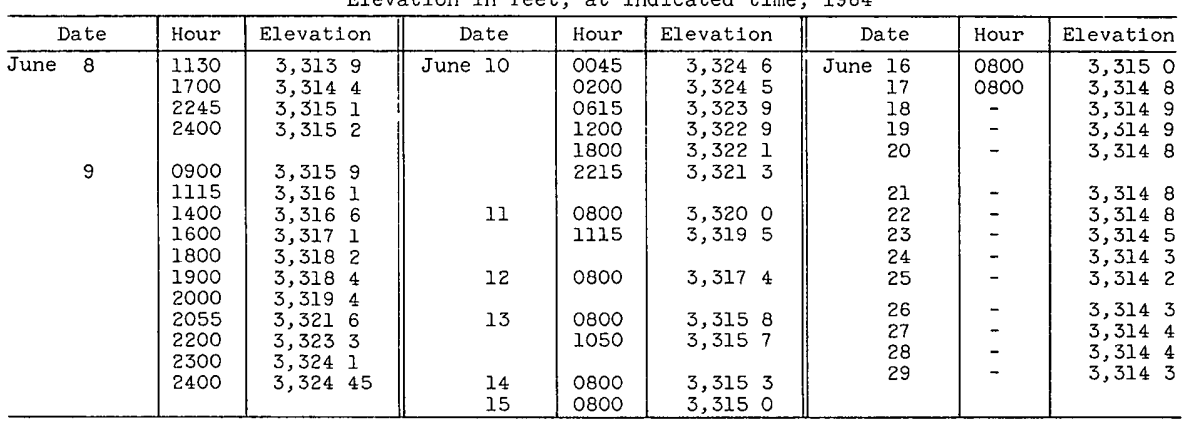




\section{MISSOURI RIVER MAIN STEM}

\section{(73) 6-903 Missouri River near Great Falls, Mont}

Location --Lat $47^{\circ} 34^{\prime} 55^{\prime \prime}$, long $111^{\circ} 03^{\prime} 35^{\prime \prime}$, in $N E \frac{1}{4} \operatorname{SW} \frac{1}{4} \sec 14, T 21 \mathrm{~N}, \mathrm{R} 5 \mathrm{E}$, at Morony Dam, 10 miles northeast of Great Falls

Drainage area $--23,292 \mathrm{sq} \mathrm{mi}$

Gage-he1ght record --Water-stage recorder on reservoir determines head on taintor gates Dally and hourly records of outflow furnished by The Montana Power Co adjusted on basis of discharge measurements, except 1800 hours June 9 to 1700 hours June 11, for which a graph was based on a discharge measurement, hourly outflow figures, and comparison with adjacent stations Datum of gage is at mean sea level (levels by The Montana Power Co)

Discharge record --Dally records of outflow and hourly records June 8-13 supplied by The Montana Power Co

Maxima --June 1964 Discharge, 72,000 cfs 1000 hours June 10 (from graph based on outflow figures)

1953, 1956 to May 1964 Discharge, 66,600 cfs June 4, 1953

Flood of June 10, 1964, is the highest since 1908

Remarks --Records collected by The Montana Power Co

Mean discharge, in cublc feet per second, 1964

\begin{tabular}{|c|c|c|c|c|c|c|c|c|}
\hline Day & May & June & Day & May & June & Day & May & June \\
\hline $\begin{array}{r}1 \\
2 \\
3 \\
4 \\
5 \\
6 \\
7 \\
8 \\
9 \\
10\end{array}$ & $\begin{array}{r}6,750 \\
5,980 \\
9,520 \\
14,200 \\
11,500 \\
10,800 \\
10,900 \\
10,600 \\
11,600 \\
13,700\end{array}$ & $\begin{array}{l}21,200 \\
20,300 \\
21,400 \\
21,800 \\
21,400 \\
20,200 \\
19,200 \\
22,700 \\
32,300 \\
63,400\end{array}$ & $\begin{array}{l}11 \\
12 \\
13 \\
14 \\
15 \\
16 \\
17 \\
18 \\
19 \\
20\end{array}$ & $\begin{array}{l}14,100 \\
13,300 \\
13,800 \\
13,800 \\
13,400 \\
11,400 \\
11,400 \\
12,900 \\
14,200 \\
17,700\end{array}$ & $\begin{array}{l}54,300 \\
38,300 \\
31,400 \\
30,800 \\
31,600 \\
29,800 \\
29,000 \\
29,300 \\
30,400 \\
31,700\end{array}$ & $\begin{array}{l}21 \\
22 \\
23 \\
24 \\
25 \\
26 \\
27 \\
28 \\
29 \\
30 \\
31\end{array}$ & $\begin{array}{l}18,600 \\
19,200 \\
18,200 \\
15,300 \\
13,000 \\
12,800 \\
11,500 \\
11,900 \\
14,200 \\
17,700 \\
21,700\end{array}$ & $\begin{array}{r}32,600 \\
33,100 \\
31,700 \\
29,600 \\
29,200 \\
29,300 \\
29,900 \\
30,300 \\
29,700 \\
28,900 \\
-\quad-\quad-\quad\end{array}$ \\
\hline $\begin{array}{l}\text { Monthl } \\
\text { Runoff }\end{array}$ & $\begin{array}{l}\text { discha } \\
\text { acre-fee }\end{array}$ & , in cu & feet & cond & & & $\begin{array}{r}13,410 \\
824,400\end{array}$ & $\begin{array}{r}30,160 \\
1,795,000\end{array}$ \\
\hline
\end{tabular}

Gage height, In feet, and discharge, in cublc feet per second, at indicated time, 1964

\begin{tabular}{|c|c|c|c|c|c|c|c|c|c|c|c|}
\hline Date & Hour & $\begin{array}{c}\text { Gage } \\
\text { height }\end{array}$ & $\begin{array}{l}\text { Lis- } \\
\text { charge }\end{array}$ & Date & Hour & $\begin{array}{c}\text { Gage } \\
\text { helght }\end{array}$ & $\begin{array}{l}\text { Dis- } \\
\text { charge }\end{array}$ & Date & Hour & $\begin{array}{c}\text { Gage } \\
\text { helght }\end{array}$ & $\begin{array}{c}\text { D1s- } \\
\text { charge }\end{array}$ \\
\hline June 8 & $\begin{array}{l}0000 \\
0600 \\
1200 \\
1500 \\
1800 \\
2100 \\
2400 \\
0200 \\
\end{array}$ & $\begin{array}{l}- \\
- \\
- \\
- \\
- \\
- \\
-\end{array}$ & $\begin{array}{l}19,800 \\
22,000 \\
22,400 \\
22,300 \\
23,900 \\
25,300 \\
28,400 \\
30,300\end{array}$ & June 9 & $\begin{array}{l}0600 \\
1000 \\
1200 \\
1800 \\
2400 \\
\\
0400 \\
0800 \\
1000 \\
\end{array}$ & $\begin{array}{l}- \\
- \\
- \\
- \\
- \\
-\end{array}$ & $\begin{array}{l}26,800 \\
33,200 \\
31,500 \\
35,000 \\
40,000 \\
52,000 \\
70,000 \\
72,000\end{array}$ & June 10 & $\begin{array}{l}1200 \\
1800 \\
2400 \\
\\
0600 \\
1200 \\
1800 \\
2000 \\
2400\end{array}$ & $\begin{array}{l}- \\
- \\
- \\
- \\
- \\
-\end{array}$ & $\begin{array}{l}71,400 \\
67,700 \\
63,700 \\
60,000 \\
55,000 \\
47,800 \\
45,500 \\
45,500\end{array}$ \\
\hline
\end{tabular}

\section{BELT CREEK BASIN}

(74) 6-905 Belt Creek near Monarch, Mont

Location --Lat $47^{\circ} 12^{\prime}$, long $110^{\circ} 56^{\prime}$, in $\mathrm{SE} \frac{1}{4} \mathrm{NW} \frac{1}{4} \sec 26, \mathrm{~T} 17 \mathrm{~N}, \mathrm{R} 6 \mathrm{E}$, on left

bank half a mile south of Ricevilie and 9 miles northwest of Monarch

Drainage area $--368 \mathrm{sq} \mathrm{mi}$

Gage-height record --Water-stage recorder graph High-water marks at peak stage Discharge record --Stage-discharge relation defined by current-meter measurements

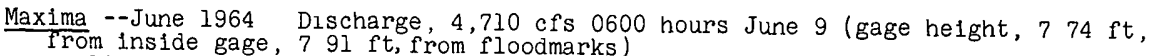

1951 to May 1964 Discharge, $11,000 \mathrm{cfs}$ June 4, 1953 (gage height, $1012 \mathrm{ft}$ ) from rating curve extended above $2,500 \mathrm{cfs}$ on basis of slope-area measurement of
peak flow

Flood in June 1908 was several feet lower than that in 1953 , from information by local resident 
Mean discharge, in cub1c feet per second, 1964, of Belt Creek near Monarch, Mont

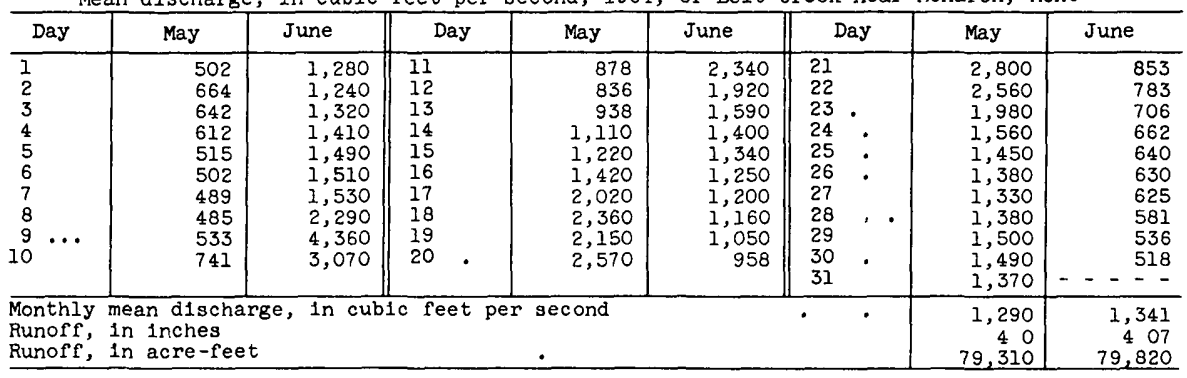

Gage height, in feet, and discharge, in cubic feet per second, at indicated time, 1964

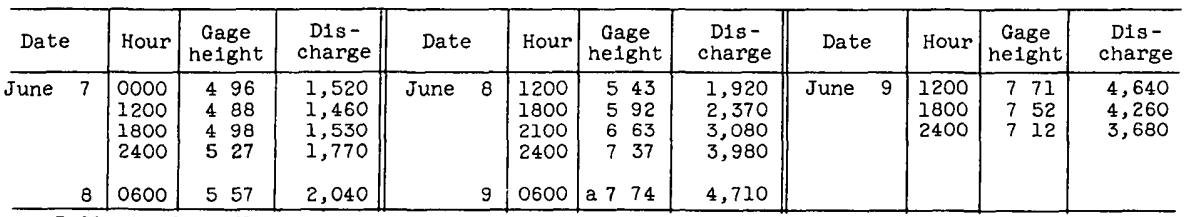

a 791 t, from floodmark

\section{HIGHWOOD CREEK BASIN}

(75) H1ghwood Creek near Highwood, Mont

\section{(Miscellaneous site)}

Location --Lat $47^{\circ} 33^{\prime} 40^{\prime \prime}$, long $110^{\circ} 46^{\prime} 40^{\prime \prime}$, near center of $\sec 24, T 21 \mathrm{~N}, \mathrm{R} 7 \mathrm{E}$, $1 \frac{7}{4}$ mIles southeast of Highwood

\section{Drainage area $--752 \mathrm{sq} \mathrm{mi}$}

Maxima --June 1964 Discharge, 1,830 cfs June 8, from slope-area measurement Flood of June 4, 1953, reached a discharge of $9,210 \mathrm{cf}$, from slope-area measurement

\section{MISSOURI RIVER MAIN STEM}

(76) 6-908 Missours River at Fort Benton, Mont

Location --Lat $47^{\circ} 49^{\prime} 03^{\prime \prime}$, long $110^{\circ} 39^{\prime} 59^{\prime \prime}$, in $\mathrm{SE}_{\frac{1}{4}} \mathrm{SE} \frac{1}{4} \sec 23, \mathrm{~T} 24 \mathrm{~N}, \mathrm{R} 8 \mathrm{~g}$, on lef't bank at downstream side of former'highway bridge at Fort Benton, 4 miles upstream from Shonkin Creek

Dra1nage area $--24,749 \mathrm{sq} \mathrm{mi}$

Gage-helght record --Digital-recorder tape punched at 15-minute intervals except 0100 hours June 10 to 0900 hours June 11, when water-stage recorder graph was used Datum of gage is $2,61405 \mathrm{ft}$ above mean sea level, datum of 1929

Discharge record --Stage-discharge relation defined by current-meter measurements Mean dally discharges computed from 96 punch-tape recordings per day June 8,9 , 12 may not agree precisely with that derived from discharge at indicated times

Maxıma --June 1964 Discharge, 77,400 cfs 1000 hours June 10 (gage helght, $1344 \mathrm{ft}$ ) 1890 to May 1964 Discharge observed, about $140,000 \mathrm{cfs}$ June 6,1908 (gage height, $185 \mathrm{ftl}$, from rating curve extended above $63,000 \mathrm{cfs}$

Remarks - Flow regulated by 18 small reservolrs and powerplants and Canyon Ferry Reservoir (see station 23) 
Mean discharge, in cubic feet per second, 1964, of Missour1 R1ver at Fort Benton, Mont

\begin{tabular}{|c|c|c|c|c|c|c|c|c|}
\hline Day & May & June & Day & May & June & Day & May & June \\
\hline $\begin{array}{r}1 \\
2 \\
3 \\
4 \\
5 \\
6 \\
7 \\
8 \\
9 \\
10\end{array}$ & $\begin{array}{r}6,760 \\
6,760 \\
10,700 \\
18,200 \\
14,600 \\
12,000 \\
11,500 \\
11,600 \\
12,100 \\
14,400\end{array}$ & $\begin{array}{l}22,800 \\
21,900 \\
22,600 \\
23,300 \\
23,200 \\
22,300 \\
21,100 \\
24,600 \\
35,400 \\
68,900\end{array}$ & $\begin{array}{l}11 \\
12 \\
13 \\
14 \\
15 \\
16 \\
17 \\
18 \\
19 \\
20\end{array}$ & $\begin{array}{l}15,000 \\
14,600 \\
14,800 \\
15,000 \\
15,100 \\
13,100 \\
13,000 \\
14,800 \\
16,900 \\
19,300\end{array}$ & $\begin{array}{l}59,100 \\
42,100 \\
33,900 \\
31,600 \\
31,500 \\
31,000 \\
30,100 \\
29,800 \\
30,600 \\
31,400\end{array}$ & $\begin{array}{l}21 \\
22 \\
23 \\
24 \\
25 \\
26 \\
27 \\
28 \\
29 \\
30 \\
31\end{array}$ & $\begin{array}{l}21,200 \\
21,700 \\
21,400 \\
18,400 \\
15,400 \\
14,100 \\
13,800 \\
13,700 \\
15,500 \\
18,300 \\
23,800\end{array}$ & $\begin{array}{r}32,100 \\
32,800 \\
31,900 \\
30,100 \\
29,500 \\
28,900 \\
29,500 \\
30,100 \\
29,900 \\
29,200 \\
--\quad-\quad-\end{array}$ \\
\hline $\begin{array}{l}\text { Monthly } \\
\text { Runoff, }\end{array}$ & $\begin{array}{l}\text { mean discha } \\
\text { in acre-fee }\end{array}$ & e, in cub & feet & econd & & & $\begin{array}{r}15,080 \\
927,300\end{array}$ & $\begin{array}{r}31,370 \\
1,867,000 \\
\end{array}$ \\
\hline
\end{tabular}

Gage he1ght, in feet, and discharge, in cub1c feet per second, at indicated time, 1964

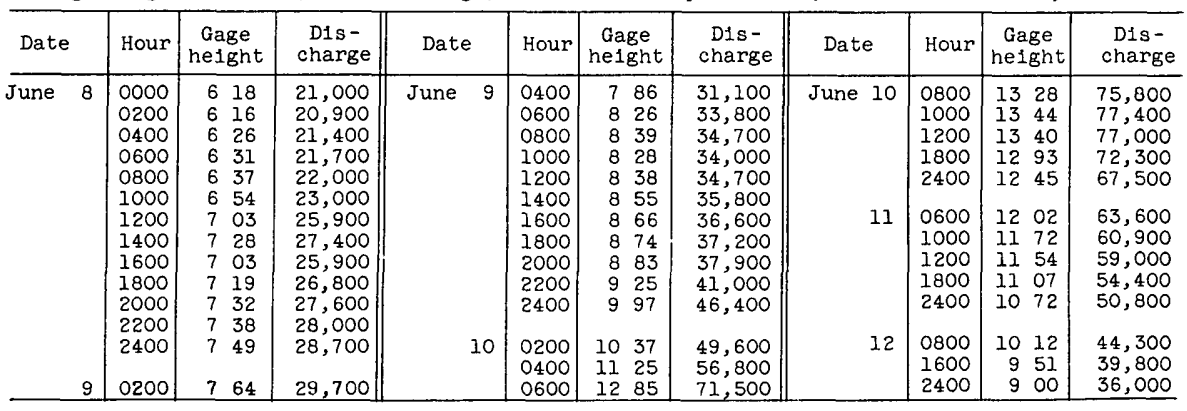

\section{MARIAS RIVER BASIN}

(77) Two Medicine Creek above Trick Falls, near East Glacier, Mont

(Miscellaneous site)

Location --Lat $48^{\circ} 30^{\prime}$, long $113^{\circ} 22^{\prime}$, half a mile upstream from Trick Falls, threequarters of a mile downstream from Two Medicine Lake, and $7 \frac{1}{2}$ miles northwest of East Glacier

Drainage area $--26 \quad 8 \mathrm{sq} \mathrm{mi}$

Maximum --June 1964 Discharge, 13,600 cfs June 8, from slope-area measurement

(78) Dry Fork Two Medicine Creek near East Glacier, Mont

(Miscellaneous site)

Location --Lat $48^{\circ} 30^{\prime} 45^{\prime \prime}$, long $113^{\circ} 23^{\prime} 30^{\prime \prime}$, in an unsurveyed area about $2 \frac{1}{2}$ miles upstream from mouth and ' 10 miles northwest of East Glacier

Drainage area $-766 \mathrm{sq} \mathrm{mi}$

Maxlmum --June 1964 Discharge, 3,940 cfs June 8, from slope-area measurement 
(79) 6-909 Lower Two Medicine Lake near East Glacier, Mont

(Discontinued June 8 , 1964, due to dam failure)

Location - -Lat $48^{\circ} 30^{\prime}$, long $113^{\circ} 16^{\prime}$, in $\mathrm{NE} \frac{2}{4} \sec 34, \mathrm{~T} 32 \mathrm{~N}, \mathrm{R} 13 \mathrm{~W}$, at dam on Two Medicine Creek, 4 miles northwest of East Glacler

Drainage area $--502 \mathrm{sq} \mathrm{mi}$

Gage-helght record --Wire-welght gage read about once a month Datum of gage is at mean sea level (levels by Bureau of Indian Affairs)

Maxima --June 1964 Contents, 20,930 acre-ft 1530 hours June 8 (elevation, 4,883 3 f't, from floodmark in gage box)

1938 to May 1964 Contents observed, 14,800 acre-ft May 31, 1944 (elevation, $4,87567 \mathrm{ft})$

Remarks --Reservour was formed by earthfill dam completed in 1913 Usable capacity, 16,620 acre-ft at elevation $4,8780 \mathrm{ft}$ Dead storage unknown below $4,8480 \mathrm{ft}$ (elevation of natural outlet) Water is used for irrigation and recreation Figures given herein represent usable contents Records furnished by Bureau of Indian Affairs

Elevation, in feet, and contents, in acre-feet, 1964

\begin{tabular}{rrr} 
Elevation & Contents \\
\hline 4,8758 & 14,900 \\
4,8759 & 14,980 \\
4,8833 & 20,930
\end{tabular}

(80) 6-910 Two Medicine River near East Glacier, Mont

(Gaging station, discontinued May 31, 1964)

Location --Lat $48^{\circ} 29^{\prime} 30^{\prime \prime}$, long $113^{\circ} 15^{\prime} 40^{\prime \prime}$, in $N W^{\frac{1}{4}} \sec 35$, T $32 \mathrm{~N}, \mathrm{R} 13 \mathrm{~W}$, on right bank $85 \mathrm{ft}$ upstream from timber bridge, $125 \mathrm{ft}$ upstream from Fortymle Creek, a quarter of a mile downstream from Lower Two Medicine Dam, and $3 \frac{1}{2}$ miles northwest of East Glacler

Drainage area --51 I sq $\mathrm{mi}$

Gage-helght record - -Water-stage recorder graph Altitude of gage is 4,870 ft (from topographic map) Gage destroyed by flood on June 8 and datum not recovered

Discharge record --Stage-discharge relation defined by current-meter measurements below 640 cf's Peak discharge by slope-area measurement

Maxima --June 1964 Discharge, $63,500 \mathrm{cfs}$ about 1600 hours June 8 (partly due to failure of Lower Two Medicine Dam)

1912 , 1918-24, 1962 to May 1964 Discharge, 1,390 cf's June 11, 1918 (gage helght, $785 \mathrm{ft}$, at site three-quarters of a mile downstream and at datum then in use

Remarks --Flow regulated by storage in Lower Two Medicine Lake (see station 79)

Mean discharge, in cubic feet per second, 1964

\begin{tabular}{|c|c|c|c|c|c|c|c|c|}
\hline Day & May & June & Day & May & June & Day & May & June \\
\hline $\begin{array}{r}1 \\
2 \\
3 \\
4 \\
5 \\
6 \\
7 \\
8 \\
9 \\
10\end{array}$ & $\begin{array}{r}59 \\
81 \\
96 \\
103 \\
111 \\
103 \\
101 \\
103 \\
96 \\
105\end{array}$ & $\begin{array}{c}- \\
- \\
- \\
- \\
- \\
- \\
- \\
\text { a } 63,500 \\
- \\
-\end{array}$ & $\begin{array}{l}11 \\
12 \\
13 \\
14 \\
15 \\
16 \\
17 \\
18 \\
19 \\
20\end{array}$ & $\begin{array}{l}107 \\
111 \\
111 \\
106 \\
107 \\
115 \\
116 \\
121 \\
130 \\
144\end{array}$ & $\begin{array}{l}- \\
- \\
- \\
- \\
- \\
- \\
- \\
\text { b } 710 \\
- \\
-\end{array}$ & $\begin{array}{l}21 \\
22 \\
23 \\
24 \\
25 \\
26 \\
27 \\
28 \\
29 \\
30 \\
31\end{array}$ & $\begin{array}{l}133 \\
120 \\
111 \\
170 \\
256 \\
336 \\
340 \\
368 \\
524 \\
638 \\
641\end{array}$ & $\begin{array}{r}- \\
- \\
- \\
- \\
- \\
- \\
- \\
- \\
- \\
- \\
-\end{array}$ \\
\hline \multicolumn{7}{|c|}{$\begin{array}{l}\text { Monchly mean discharge, in cublc feet per second } \\
\text { Runoff, in acre-feet }\end{array}$} & $\begin{array}{r}186 \\
11,430\end{array}$ & - \\
\hline
\end{tabular}

a From indirect measurement of peak flow

b From current-meter measurement 
(81) South Fork Two Medicine River near East Glacier, Mont

(Miscellaneous site)

Location --Lat $48^{\circ} 24^{\prime}$, long $113^{\circ} 10^{\prime}$, near east edge of sec $33, T 31 \mathrm{~N}, \mathrm{R} 12 \mathrm{~W}$, half a mile upstream from bridge on East Glacier-Heart Butte road, 4 miles southeast of East Glacier

Drainage area $--782 \mathrm{sq} \mathrm{mi}$

Maximum -June 1964 D1scharge, 25,600 cfs June 8, from slope-area measurement

(82) 6-920 Two Medicine River near Browning, Mont

Location --Lat $48^{\circ} 28^{\prime} 30^{\prime \prime}$, long $112^{\circ} 48^{\prime} 10^{\prime \prime}$, in $\mathrm{SE} \frac{1}{4} \sec 5, \mathrm{~T} 31 \mathrm{~N}$, $\mathrm{R} 9 \mathrm{~W}$, on right bank $800 \mathrm{ft}$ upstream from new bridge on U S Highway 89 , 11 miles southeast of Browning, and 15 miles upstream from Badger Creek

Drainage area $--317 \mathrm{sq} \mathrm{mi}$

Gage-height record --Water-stage recorder graph, except 1200 hours June 8 to 1100 hours June II Reconstructed graph based on floodmark used 1200 hours to 2400 hours June 8 Alt1tude of gage is $3,930 \mathrm{ft}$ (from topographic map)

Discharge record --Stage-discharge relation defined by current-meter measurements below $3,600 \mathrm{c} f \mathrm{~s}$ and by slope-area measurement at $100,000 \mathrm{cfs}$

Maxima --June 1964 Discharge, 100,000 cfs 1200 hours June 8 (gage height $135 \mathrm{ft}$, from floodmark in gage well, $140 \mathrm{ft}$, from flood profile)

1907-24, 1951 to May 1964 Discharge, 7,950 cfs June 23, 1907 (gage helght, $86 \mathrm{ft}$, from graph based on gage readings, site and datum then in use) Flood in June 1908, which destroyed gage, was larger

$\frac{\text { Remarks }}{\text { Dam }}$-The 1964 maximum was not affected by fallure of Lower Two Medicine Lake

Mean discharge, in cubic feet per second, 1964

\begin{tabular}{|c|c|c|c|c|c|c|c|c|}
\hline Day & May & June & Day & May & June & Day & May & June \\
\hline $\begin{array}{r}1 \\
2 \\
3 \\
4 \\
5 \\
6 \\
7 \\
8 \\
9 \\
10\end{array}$ & $\begin{array}{r}915 \\
1,130 \\
1,260 \\
1,090 \\
915 \\
769 \\
649 \\
649 \\
853 \\
1,030\end{array}$ & $\begin{array}{r}1,830 \\
1,760 \\
1,940 \\
2,180 \\
2,290 \\
2,380 \\
2,480 \\
30,000 \\
14,200 \\
4,450\end{array}$ & $\begin{array}{l}11 \\
12 \\
13 \\
14 \\
15 \\
16 \\
17 \\
18 \\
19 \\
20\end{array}$ & $\begin{array}{r}1,060 \\
1,090 \\
1,250 \\
1,150 \\
987 \\
1,030 \\
1,450 \\
1,740 \\
1,690 \\
2,180\end{array}$ & $\begin{array}{l}3,490 \\
2,830 \\
2,310 \\
2,030 \\
1,980 \\
1,960 \\
1,950 \\
1,750 \\
1,620 \\
1,500\end{array}$ & $\begin{array}{l}21 \\
22 \\
23 \\
24 \\
25 \\
26 \\
27 \\
28 \\
29 \\
30 \\
31\end{array}$ & $\begin{array}{l}2,280 \\
1,660 \\
1,180 \\
1,150 \\
1,230 \\
1,330 \\
1,390 \\
1,690 \\
3,240 \\
2,410 \\
2,100\end{array}$ & $\begin{array}{r}1,380 \\
1,260 \\
1,240 \\
1,250 \\
1,290 \\
1,210 \\
1,120 \\
1,020 \\
900 \\
802 \\
-\quad-\quad-\end{array}$ \\
\hline \multicolumn{7}{|c|}{$\begin{array}{l}\text { Monthly mean discharge, in cubic feet per second } \\
\text { Runoff, in acre-feet }\end{array}$} & $\begin{array}{r}1,372 \\
84,390\end{array}$ & $\begin{array}{r}3,213 \\
191,200\end{array}$ \\
\hline
\end{tabular}

Gage height, in feet, and discharge, in cublc feet per second, at indicated time, 1964

\begin{tabular}{|c|c|c|c|c|c|c|c|c|c|c|c|}
\hline Date & Hour & $\begin{array}{c}\text { Gage } \\
\text { he1ght }\end{array}$ & $\begin{array}{c}\text { DIs- } \\
\text { charge }\end{array}$ & Date & Hour & $\begin{array}{c}\text { Gage } \\
\text { helght }\end{array}$ & $\begin{array}{l}\text { D1s - } \\
\text { charge }\end{array}$ & Date & Hour & $\begin{array}{c}\text { Gage } \\
\text { he1ght }\end{array}$ & $\begin{array}{l}\text { Dis- } \\
\text { charge }\end{array}$ \\
\hline June 7 & $\begin{array}{l}0000 \\
0500 \\
1100 \\
1800 \\
2400\end{array}$ & $\begin{array}{ll}3 & 67 \\
3 & 71 \\
3 & 51 \\
3 & 93 \\
4 & 50\end{array}$ & $\begin{array}{l}2,150 \\
2,270 \\
2,070 \\
2,680 \\
3,610\end{array}$ & June 8 & $\begin{array}{l}0300 \\
0600 \\
0700 \\
0800 \\
0900\end{array}$ & \begin{tabular}{ll|}
5 & 08 \\
6 & 78 \\
6 & 30 \\
6 & 88 \\
7 & 25
\end{tabular} & $\begin{array}{r}5,370 \\
8,020 \\
11,200 \\
15,300 \\
17,700\end{array}$ & June 8 & $\begin{array}{l}1000 \\
1100 \\
1200\end{array}$ & $\begin{array}{rl}7 & 80 \\
11 & 50 \\
\mathrm{a} 13 & 5\end{array}$ & $\begin{array}{r}22,700 \\
65,500 \\
100,000\end{array}$ \\
\hline
\end{tabular}

a $140 \mathrm{ft}$, from floodmark 
(83) 6-925 Badger Creek near Browning, Mont

Location --Lat $48^{\circ} 2 \mathrm{I}^{\prime} 00^{\prime \prime}$, long $112^{\circ} 50^{\prime} 20^{\prime \prime}$, in $\mathrm{NE} \frac{1}{4} \sec 24$, T $30 \mathrm{~N}, \mathrm{R} 10 \mathrm{~W}$, on right bank just upstream from polnt of diversion to Four Horns Canal, 15 miles upstream from mouth, and 17 miles southeast of Browning

Drainage area $--133 \mathrm{sq} \mathrm{ml}$

Gage-he1ght record --Water-stage recorder graph Datum of gage is 4,179 $26 \mathrm{ft}$ above mean sea level (Bureau of Reclamation bench mark)

Discharge record --Stage-discharge relation defined by current-meter measurements below $1,900 \mathrm{cfs}$, by logarithmic extension from $2,000 \mathrm{cfs}$ to $10,000 \mathrm{cfs}$, and by slope-area measurement at $49,700 \mathrm{cfs}$

Maxima --June 1964 Discharge, 49,700 cfs at 1600 hours June 8 (gage height, $1037 \mathrm{ft}$ )

1951 to May 1964 Discharge, 4,220 cfs June 4, 1953 (gage height, $628 \mathrm{ft}$ ), from rating curve extended above $2,000 \mathrm{cfs}$

Remarks --Figures of discharge given herein are sum of flow over diversion dam and that diverted by Four Horns Canal (canal headgates inundated June 8)

Mean discharge, in cublc feet per second, 1964

\begin{tabular}{|c|c|c|c|c|c|c|c|c|}
\hline Day & May & June & Day & May & June & Day & May & June \\
\hline $\begin{array}{r}1 \\
2 \\
3 \\
4 \\
5 \\
6 \\
7 \\
8 \\
9 \\
10\end{array}$ & $\begin{array}{l}255 \\
333 \\
304 \\
277 \\
261 \\
245 \\
224 \\
218 \\
234 \\
277\end{array}$ & $\begin{array}{r}1,170 \\
1,150 \\
1,220 \\
1,260 \\
1,250 \\
1,230 \\
1,270 \\
16,300 \\
4,140 \\
2,140\end{array}$ & $\begin{array}{l}11 \\
12 \\
13 \\
14 \\
15 \\
16 \\
17 \\
18 \\
19 \\
20\end{array}$ & $\begin{array}{r}304 \\
316 \\
392 \\
410 \\
404 \\
434 \\
596 \\
834 \\
982 \\
1,1360\end{array}$ & $\begin{array}{r}1,720 \\
1,480 \\
1,360 \\
1,330 \\
1,310 \\
1,290 \\
1,180 \\
1,100 \\
1,040 \\
954\end{array}$ & $\begin{array}{l}21 \\
22 \\
23 \\
24 \\
25 \\
26 \\
27 \\
28 \\
29 \\
30 \\
31\end{array}$ & $\begin{array}{r}1,330 \\
992 \\
795 \\
735 \\
711 \\
714 \\
813 \\
1,210 \\
1,640 \\
1,340 \\
1,190\end{array}$ & $\begin{array}{r}900 \\
855 \\
891 \\
972 \\
954 \\
855 \\
784 \\
734 \\
653 \\
617 \\
-\quad--\end{array}$ \\
\hline \multicolumn{7}{|l|}{$\begin{array}{l}\text { Monthly } \\
\text { Runoff, } \\
\text { Runoff, }\end{array}$} & $\begin{array}{r}665 \\
577 \\
40,920 \\
\end{array}$ & $\begin{array}{r}1,737 \\
1457 \\
103,400 \\
\end{array}$ \\
\hline
\end{tabular}

Gage height, in feet, and discharge, in cublc feet per second, at indicated time, 1964

\begin{tabular}{|c|c|c|c|c|c|c|c|c|c|c|c|}
\hline Date & Hour & $\begin{array}{c}\text { Gage } \\
\text { height }\end{array}$ & $\begin{array}{l}\text { D1s- } \\
\text { charge }\end{array}$ & Date & Hour & $\begin{array}{c}\text { Gage } \\
\text { height }\end{array}$ & $\begin{array}{l}\text { D1s- } \\
\text { charge }\end{array}$ & Date & Hour & $\begin{array}{c}\text { Gage } \\
\text { nelght }\end{array}$ & $\begin{array}{l}\text { Dis- } \\
\text { charge }\end{array}$ \\
\hline June 8 & $\begin{array}{l}0000 \\
0200 \\
0400 \\
0600 \\
0800 \\
1000 \\
1200 \\
1400 \\
1600\end{array}$ & $\begin{array}{rr}4 & 67 \\
4 & 79 \\
5 & 39 \\
6 & 10 \\
7 & 12 \\
8 & 15 \\
9 & 50 \\
10 & 15 \\
10 & 37\end{array}$ & $\begin{array}{r}1,540 \\
1,720 \\
2,650 \\
4,040 \\
6,670 \\
10,200 \\
27,400 \\
43,400 \\
49,700\end{array}$ & June & $\begin{array}{l}1700 \\
2000 \\
2200 \\
2400 \\
0200 \\
0400 \\
0600 \\
0800\end{array}$ & $\begin{array}{ll}9 & 62 \\
8 & 78 \\
8 & 22 \\
7 & 68 \\
& \\
7 & 22 \\
6 & 75 \\
6 & 39 \\
6 & 25\end{array}$ & $\begin{array}{r}29,900 \\
15,800 \\
10,500 \\
8,330 \\
6,820 \\
5,440 \\
4,480 \\
4,150\end{array}$ & June 9 & $\begin{array}{l}1200 \\
1800 \\
2400 \\
\\
0600 \\
1200 \\
1800 \\
2400\end{array}$ & $\begin{array}{ll}6 & 05 \\
5 & 76 \\
5 & 58 \\
5 & 37 \\
5 & 21 \\
5 & 09 \\
5 & 04\end{array}$ & $\begin{array}{l}3,710 \\
3,080 \\
2,720 \\
2,350 \\
2,080 \\
1,880 \\
1,800\end{array}$ \\
\hline
\end{tabular}

(84) North Fork Birch Creek near Dupuyer, Mont

(Miscellaneous site)

Location - Lat $48^{\circ} 10^{\prime} 00^{\prime \prime}$, long $112^{\circ} 55^{\prime} 40^{\prime \prime}$, in $\sec 29, \mathrm{~T} 28 \mathrm{~N}, \mathrm{R} 10 \mathrm{~W}$ (unsurveyed), 2 miles upstream from'Swift Reservoir and 20 miles west of Dupuyer

Drainage area $--190 \mathrm{sq} \mathrm{mi}$

Maximum --June 1964 Discharge, 8,890 cfs June 8, from slope-area measurement

(85) South Fork Birch Creek near Dupuyer, Mont

(Miscellaneous site)

Location --Lat $48^{\circ} 07^{\prime}$, long $112^{\circ} 54^{\prime}$, in $\sec 9, \mathrm{~T} 27 \mathrm{~N}, \mathrm{R} 10 \mathrm{~W}$ (unsurveyed), half a mlle upstream from Middle Fork Birch Creek, and 19 miles southwest of Dupuyer

Drainage area $--25 \quad 3 \mathrm{sq} \mathrm{mi}$

Maximum --June 1964 Discharge, 9,770 cfs June 8, from slope-area measurement 
(86) 6-940 Swift Reservolr near Dupuyer, Mont

(Discontinued June 8,1964 , due to dam fallure)

Location --Lat $48^{\circ} 10^{\prime}$, long $112^{\circ} 52^{\prime}$, in $\mathrm{NE} \frac{1}{4} \sec 27, \mathrm{~T} 28 \mathrm{~N}, \mathrm{R} 10 \mathrm{~W}$, at Swift Dam on Birch Creek, 17 miles west of Dupuyer

Drainage area --753 sq $\mathrm{ml}$

Gage-helght record --Elevations determined by measuring from reference mark about once a month and high-water marks at the damsite for June 8, 1964 Datum of gage is at mean sea level (levels by Pondera County Canal and Reservoir Co ) To obtain U S Coast and Geodetic Survey datum, subtract $6367 \mathrm{ft}$

Maxima - June 1964 Contents, 34,300 acre-ft 1000 hours June 8 (elevation, $4,95630 \mathrm{ft}$, from floodmarks)

1936 to May 1964 Contents observed, 30,620 acre-f't June 4, 1953 (elevation, $4,94838 \mathrm{ft}$ )

During flood of June 29, 1916, the reservoir reached an elevation of 4,959 94 ft (contents, 36,070 acre-ft) This high elevation was caused by an inadequate splilway capacity that was enlarged in 1917

Remarks --Reservoir was formed by a rockfill dam with a concrete face completed in 1915 Usable capacity, 30,000 acre-ft at elevation 4,947 $0 \mathrm{ft}$ Dead storage is negligible Water is used for irrigation Records furnished by Pondera County Canal and Reservoir Co Figures given herein represent usable contents

Elevation, in feet, and contents, in acre-feet, 1964

Elevation Contents

$\begin{array}{lr}\text { Apr } & 30 \\ \text { June } & 1\end{array}$

June 8

$\begin{array}{lll}4,9057 & 14,100 \\ 4,9265 & 21,560 \\ 4,9563 & 34,300\end{array}$

(87) 6-950 B1rch Creek near Dupuyer, Mont

- (Gaging station, discontinued 1937)

Location --Lat $48^{\circ} 15^{\prime}$, long $112^{\circ} 39^{\prime}$, near center of $\sec 28$, T $29 \mathrm{~N}, \mathrm{R} 8 \mathrm{~W}$, half a mile upstream from 13 canal headgates and 8 miles northwest of Dupuyer 'Alt1tude of gage is 4,180 ft (from topographic map) Gage site completely destroyed by flood caused by fallure of Swift Dam

Drainage area --105 sq $\mathrm{mi}$

Maxima --June 1964 Discharge, 881,000 cfs about 1200 hours June 8, from slopearea measurement (result of dam failure)

1909-37 Discharge, 7,000 cfs June 21, 1916 (gage height $100 \mathrm{ft}$, from floodmarks), from rating curve extended above 1,200 cfs by logarithmic plotting

Flood of June 6, 1908 (discharge not determined) was larger

$\underline{\text { Remarks }}$-Flow regulated since 1913 by Swift Reservolr (see station 86)

(88) Blacktail Creek near Dupuyer, Mont

(Miscellaneous site)

Location --Lat $48^{\circ} 21^{\prime}$, lont $112^{\circ} 35^{\prime}$, in $\mathrm{NE} \frac{1}{4} \sec 24$, T $30 \mathrm{~N}, \mathrm{R} 8 \mathrm{~W}, 1$ mile upstream from $S$ Highway 89 and 12 miles northwest of Dupuyer

Drainage area $--627 \mathrm{sq} \mathrm{mi}$

Maxima --June 1964 Discharge, 3,730 cfs about 1200 hours June 8, from slope-area measurement

1948 Discharge, 4,680 cfs about June 17, 1948, from slope-area measurement 
(89) Cartwright Coulee near Valier, Mont

(M1scellaneous site)

Location --Lat $48^{\circ} 18^{\prime} 30^{\prime \prime}$, long $112^{\circ} 25^{\prime} 10^{\prime \prime}$, in NW $\frac{1}{4} \sec 5$, T $29 \mathrm{~N}, \mathrm{R} 6 \mathrm{~W}, 1 \mathrm{mile}$ upstream from mouth and 5 miles south of valier

Drainage area $--218 \mathrm{sq} \mathrm{mi}$

Maxima --June 1964 Discharge, 2,950 efs 1300 hours June 8, from contracted-opening measurement

1948 Discharge, 2,890 cfs about June 17, 1948, from contracted-opening measurement

Remarks - -The 1964 maximum may include some water from Birch Creek drainage via the B canal which was breached

(90) 6-980 Dupuyer Creek near Valier, Mont

(Gaging station, discontinued 1937)

Location - Lat $48^{\circ} 14^{\prime} 10^{\prime \prime}$, long $112^{\circ} 23^{\prime} 50^{\prime \prime}$, in $N W \frac{1}{4} \sec 33, \mathrm{~T} 29 \mathrm{~N}, \mathrm{R} 6 \mathrm{~W}, 6 \mathrm{miles}$ downstream from Sheep Creek and 8 miles southwest of valler Altitude of gage

is 3,920 ft (from topographic map) The 1964 measurement was made at site

3 miles upstream

Drainage area - -137 sq $\mathrm{mi}$ (129 sq $\mathrm{mi}$ at 1964 measurement site)

Maxima --June 1964 Discharge, 21,600 cfs 1200 hours June 8, from slope-area measurement

1912-37 Discharge, 3,330 cfs June 7, 1934 (gage height, 740 ft, from graph based on gage readings)

Flood of about June 17, 1948, reached a discharge of $7,370 \mathrm{cfs}$, from slopearea measurement

(91) Laughlin Coulee near Val1er, Mont

(M1scellaneous site)

Location --Lat $48^{\circ} 17^{\prime} 50^{\prime \prime}$, long $112^{\circ} 21^{\prime} 30^{\prime \prime}$, in $\mathrm{SW}_{\frac{1}{4}} \sec 2, \mathrm{~T} 29^{\mathrm{N}}, \mathrm{R} 6 \mathrm{~W}$ at culverts on county road 5 miles west of Valier

Drainage area $--8 \quad 4 \mathrm{sq} \mathrm{mi}$

Maxima --June 1964 Discharge, 912 cf's 1600 hours June 8, from combined culvert and flow-over-road measurements

1948 Discharge, $820 \mathrm{cf}$ s about June 17, 1948, from slope-area measurement

(92) Two Medicine River below Birch Creek, near Ethridge, Mont

\section{(Miscellaneous site)}

Location --Lat $48^{\circ} 28^{\prime} 50^{\prime \prime}$, long $112^{\circ} 13^{\prime} 40^{\prime \prime}$, In $\mathrm{NE} \frac{1}{4} \sec 3, \mathrm{~T} 31 \mathrm{~N}, \mathrm{R} 5 \mathrm{~W}$, about $2 \mathrm{mile}$ upstream from Cut Bank Creek and 7 miles southwest of Ethridge

Drainage area $--1,288 \mathrm{sq} \mathrm{mi}$

Maximum --June 1964 Discharge, 204,000 cfs June 9, from slope-area measurement (affected by failure of Swift Dam) 
(93) Willow Creek at Browning, Mont

\section{(Miscellaneous site)}

Location --Lat $48^{\circ} 33^{\prime} 40^{\prime \prime}$, long $113^{\circ} 02^{\prime} 00^{\prime \prime}$, on east line of sec 4, T $32 \mathrm{~N}, \mathrm{R} 11 \mathrm{~W}$, at bridge on old county road, about 1 mile northwest of Browning

Drainage area $--236 \mathrm{sq} \mathrm{mi}$

Maximum --June 1964 Discharge, 1,230 cfs June 8, from contracted-opening measurement

(94) 6-990 Cut Bank Creek at Cut Bank, Mont

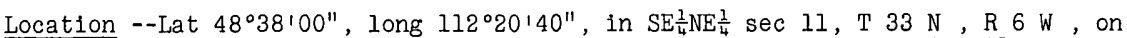
right bank at highway'bridge, half a mile west of Cut Bank and 17 miles upstream from confluence with Two Medicine Creek

\section{Drainage area $--1,065 \mathrm{sq} \mathrm{mi}$}

Gage-height record --Water-stage recorder graph and high water-marks near the gage Altitude of gage is $3,550 \mathrm{ft}$ (from topographic map)

Discharge record --Stage-discharge relation defined by current-meter measurements below $12,000 \mathrm{cfs}$ and by slope-area measurement at 16,600 cfs

Maxima --June 1964 Discharge, $16,600 \mathrm{cfs} 0530$ hours June 9 (gage he1ght, $1393 \mathrm{ft}$, $142 \mathrm{ft}$, from floodmarks)

$1905-20,1922-24,1951$ to May 1964 Discharge, 10,400 cf's June 5, 1908 (gage helght $1104 \mathrm{ft}$, from graph based on gage readings, at site half a mile upstream and at datum then in use), from rating curve extended above $1,200 \mathrm{cfs}$

Mean discharge, in cubic feet per second, 1964

\begin{tabular}{|c|c|c|c|c|c|c|c|c|}
\hline Day & May & June & Day & May & June & Day & May & June \\
\hline $\begin{array}{r}1 \\
2 \\
3 \\
4 \\
5 \\
6 \\
7 \\
8 \\
9 \\
10\end{array}$ & $\begin{array}{r}158 \\
452 \\
1,950 \\
1,640 \\
1,010 \\
532 \\
308 \\
258 \\
229 \\
220\end{array}$ & $\begin{array}{r}535 \\
520 \\
591 \\
674 \\
798 \\
786 \\
846 \\
1,790 \\
11,200 \\
5,080\end{array}$ & $\begin{array}{l}11 \\
12 \\
13 \\
14 \\
15 \\
16 \\
17 \\
18 \\
19 \\
20\end{array}$ & $\begin{array}{l}252 \\
252 \\
235 \\
242 \\
255 \\
245 \\
248 \\
304 \\
450 \\
500\end{array}$ & $\begin{array}{r}2,490 \\
1,610 \\
1,330 \\
1,160 \\
1,110 \\
1,110 \\
1,100 \\
993 \\
890 \\
774\end{array}$ & $\begin{array}{l}21 \\
22 \\
23 \\
24 \\
25 \\
26 \\
27 \\
28 \\
29 \\
30 \\
31\end{array}$ & $\begin{array}{l}596 \\
696 \\
586 \\
416 \\
324 \\
279 \\
255 \\
276 \\
416 \\
690 \\
657\end{array}$ & $\begin{array}{r}708 \\
662 \\
586 \\
602 \\
608 \\
635 \\
613 \\
510 \\
455 \\
408 \\
----\end{array}$ \\
\hline $\begin{array}{l}\text { Monthly } \\
\text { Runoff, } \\
\text { Runoff, }\end{array}$ & $\begin{array}{l}\text { mean discha } \\
\text { In Inches } \\
\text { in acre-fee }\end{array}$ & , In cub & feet & cond & & & $\begin{array}{r}482 \\
0 \quad 52 \\
29,620\end{array}$ & $\begin{array}{r}1,372 \\
144 \\
81,670\end{array}$ \\
\hline
\end{tabular}

Gage height, in feet, and discharge, in cublc feet per second, at indicated time, 1964

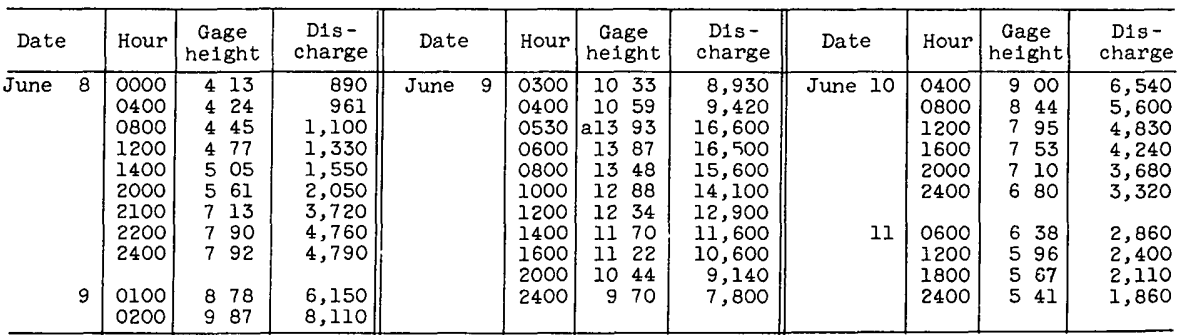

a $142 \mathrm{ft}$, from floodmark 
(95) 6-995 Marias River near Shelby, Mont

Location --Lat $48^{\circ} 26^{\prime}$, long $111^{\circ} 53^{\prime}$, in $\mathrm{SE}_{4}^{1} \mathrm{sec} 20, \mathrm{~T} 31 \mathrm{~N}, \mathrm{R} 2 \mathrm{~W}$, on left bank $200 \mathrm{ft}$ downstream from bridge on U S Highway 91, 6 miles south of Shelby, and 24 miles downstream from Cut Bank Creek

Drainage area $--3,242 \mathrm{sq} \mathrm{ml}$, of which $518 \mathrm{sq} \mathrm{ml}$ is probably noncontributing

Gage-he1ght record --Water-stage recorder graph, except June 10 when graph was reconstructed on basis of engineer's wire-weight gage readings and June 11,12 , when there was no gage-height record The maximum gage height was determined from high-water mark in the well Datum of gage is 3,087 $72 \mathrm{ft}$ above mean sea level, datum of 1929

Discharge record --Stage-discharge relation defined by current-meter measurements below $34,000 \mathrm{cfs}$ and by slope-area measurement at $241,000 \mathrm{cfs}$

Maxima --June 1964 discharge, $241,000 \mathrm{cfs} 0100$ hours June 9 (gage he1ght, $2364 \mathrm{ft}$, from floodmark in well), largely the result of fallure of Swift Dam 1902-7, 1911 to May 1964 Discharge, 40,000 cfs June 18, 1948 (gage he1ght, $1775 \mathrm{ft}$, from floodmark)

Flood of June 1908 may have exceeded that of June 1948

Remarks --Floodflows only slightly affected by storage in four reservoirs on tributary streams

Mean discharge, in cub1c feet per second, 1964

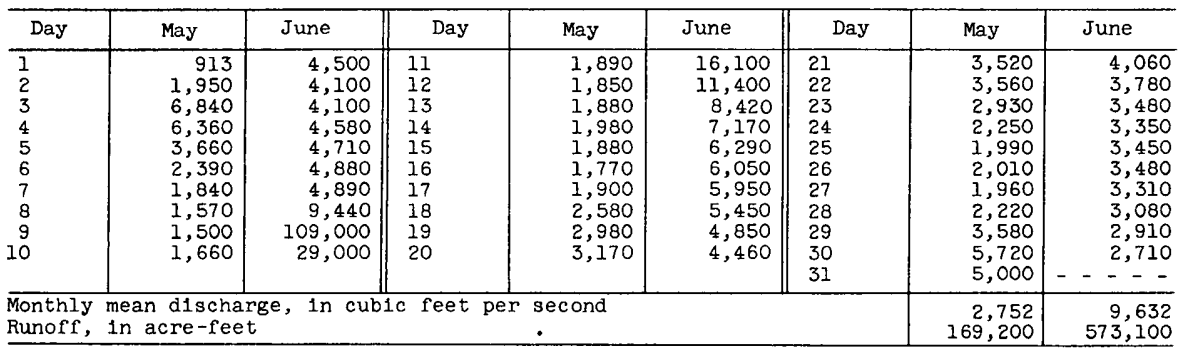

Gage he1ght, in feet, and discharge, in cublc feet per second, at indicated time, 1964

\begin{tabular}{|c|c|c|c|c|c|c|c|c|c|c|c|}
\hline Date & Hour & $\begin{array}{c}\text { Gage } \\
\text { he1ght }\end{array}$ & $\begin{array}{l}\text { Dis - } \\
\text { charge }\end{array}$ & Date & Hour & $\begin{array}{c}\text { Gage } \\
\text { height }\end{array}$ & $\begin{array}{l}\text { Dis - } \\
\text { charge }\end{array}$ & Date & Hour & $\begin{array}{c}\text { Gage } \\
\text { helght }\end{array}$ & $\begin{array}{c}\text { Dis- } \\
\text { charge }\end{array}$ \\
\hline June 7 & $\begin{array}{l}0000 \\
1400 \\
2200 \\
2400\end{array}$ & $\begin{array}{ll}5 & 58 \\
5 & 39 \\
5 & 61 \\
5 & 64\end{array}$ & $\begin{array}{l}5,010 \\
4,710 \\
5,060 \\
5,110\end{array}$ & June & $\begin{array}{l}2230 \\
2300 \\
2330 \\
2400\end{array}$ & $\begin{array}{ll}10 & 05 \\
11 & 50 \\
16 & 80 \\
22 & 00\end{array}$ & $\begin{array}{r}13,200 \\
18,100 \\
42,100 \\
160,000\end{array}$ & June 9 & $\begin{array}{l}1800 \\
2000 \\
2200 \\
2400\end{array}$ & $\begin{array}{ll}18 & 17 \\
17 & 58 \\
17 & 08 \\
16 & 78\end{array}$ & $\begin{array}{l}54,600 \\
47,100 \\
43,700 \\
42,000\end{array}$ \\
\hline 8 & $\begin{array}{l}0300 \\
0600 \\
0900 \\
1200 \\
1400 \\
1500 \\
1600 \\
1800 \\
2000 \\
2200\end{array}$ & $\begin{array}{ll}5 & 65 \\
5 & 76 \\
5 & 91 \\
6 & 17 \\
6 & 53 \\
6 & 96 \\
7 & 07 \\
7 & 67 \\
8 & 35 \\
9 & 30\end{array}$ & $\begin{array}{r}5,120 \\
5,300 \\
5,560 \\
6,010 \\
6,710 \\
7,220 \\
7,460 \\
8,420 \\
9,650 \\
11,700\end{array}$ & 9 & $\begin{array}{l}0100 \\
0200 \\
0300 \\
0400 \\
0600 \\
0800 \\
0930 \\
1200 \\
1400 \\
1600\end{array}$ & $\begin{array}{ll}23 & 64 \\
23 & 30 \\
22 & 85 \\
22 & 40 \\
21 & 50 \\
20 & 88 \\
21 & 17 \\
20 & 45 \\
19 & 60 \\
18 & 83\end{array}$ & $\begin{array}{r}241,000 \\
220,000 \\
196,000 \\
176,000 \\
141,000 \\
120,000 \\
130,000 \\
107,000 \\
83,000 \\
66,600\end{array}$ & 10 & $\begin{array}{l}0300 \\
0600 \\
0900 \\
1200 \\
1500 \\
1800 \\
2100 \\
2400\end{array}$ & $\begin{array}{ll}\text { al6 } & 00 \\
\text { al5 } & 28 \\
\text { al4 } & 58 \\
\text { al3 } & 95 \\
\text { al3 } & 40 \\
\text { al2 } & 88 \\
\text { al2 } & 38 \\
\text { al2 } & 00\end{array}$ & $\begin{array}{l}37,700 \\
34,100 \\
30,800 \\
28,000 \\
25,800 \\
23,500 \\
21,500 \\
20,000\end{array}$ \\
\hline
\end{tabular}

a From graph based on wire-welght-gage readings 
(96) 6-997 Middle Fork Dry Fork Marias River near Dupuyer, Mont

(Crest-stage gage, formerly published as North Fork Dry Fork)

Location --Lat $48^{\circ} 09^{\prime}$, long $112^{\circ} 28^{\prime}$, in $N E \frac{1}{4} \sec 35, T 28 \mathrm{~N}, \mathrm{R} 7 \mathrm{~W}$, at culvert on county road, 4 miles southeast of Dupuyer

Drainage area $--202 \mathrm{sq} \mathrm{mi}$

Gage-helght record --Crest stages and high-water marks only Elevation of gage is 4,120 f't (from topographic map)

Discharge record --Stage-discharge relation defined by current-meter measurements below $75 \mathrm{cf}$ 's and by combined culvert and flow-over-road measurements at 401 and $4,240 \mathrm{cfs}$

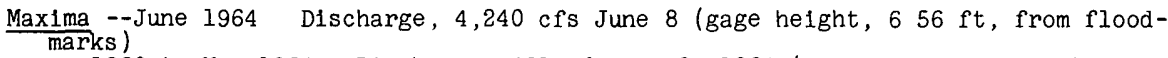

1960 to May 1964 Discharge, 401 cfs May 3, 1964 (gage height, $479 \mathrm{ft}$, $457 \mathrm{ft}$, from floodmarks)

\section{(97) Lake Frances tributary near Valier, Mont}

\section{(Miscellaneous site)}

Location --Lat $48^{\circ} 15^{\prime}$, long $112^{\circ} 17^{\prime}$, in $\mathrm{NW} \frac{1}{4} \sec 29, \mathrm{~T} 29 \mathrm{~N}, \mathrm{R} 5 \mathrm{~W}$, at culvert on county road, 4 miles south of valier

Drainage area $--0083 \mathrm{sq} \mathrm{mi}$

Maxima --June 1964 Discharge, $39 \mathrm{cfs}$ June 8, from flow-through-culvert measurements 1948 Discharge, $20 \mathrm{cfs}$ about June 17, 1948, from flow-through-culvert measurement

(98) 6-1002 Helnes Coulee tributary near Valier, Mont

\section{(Crest-stage gage)}

Location --Lat $48^{\circ} 15^{\prime}$, long $112^{\circ} 14^{\prime}$, in $N E \frac{1}{4} \sec 27, \mathrm{~T} 29 \mathrm{~N}, \mathrm{R} 5 \mathrm{~W}$, at culvert on county road, 4 miles south of Valier

Dra1nage area --0 $60 \mathrm{sq} \mathrm{ml}$

Gage-height record --Crest stages and high-water marks only Altitude of gage is 3,860 f't (from topographic map)

Discharge record --Stage-discharge relation defined by flow-through-culvert measurements

Max1ma --June 1964 D1scharge, $64 \mathrm{cfs}$ June 8 (upstream gage he1ght, $1057 \mathrm{ft}$, from f'loodmarks, downstream gage height, $101 \mathrm{ft}$ )

1960 to May 1964 Discharge, 9 cf's May 1, 1960 (upstream gage height, $120 \mathrm{ft}$, downstream gage height, $092 \mathrm{ft}$ )

(99) Lone Man Coulee above Miller Coulee, near Valier, Mont

\section{(Miscellaneous site)}

Location --Lat $48^{\circ} 14^{\prime} 00^{\prime \prime}$, long $112^{\circ} 14^{\prime} 20^{\prime \prime}$, near center of $N \frac{1}{2} \sec 34, T 29 \mathrm{~N}, \mathrm{R} 5 \mathrm{~W}$, half a mile upstream from Miller Coulee and 5 miles south of valier

Drainage area $--113 \mathrm{sq} \mathrm{ml}$

Maxima --June 1964 Discharge, 1,460 cfs about 1500 hours June 8, from slope-area measurement, furnished by Montana State College

1948 Díscharge, 1,820 cfs about June 17, from slope-area measurement 
(100) Miller Coulee near Valier, Mont

(Miscellaneous site)

Location --Lat $48^{\circ} 14^{\prime} 20^{\prime \prime}$, long $112^{\circ} 14^{\prime} 00^{\prime \prime}$, in $\mathrm{SE} \frac{1}{4} \sec 27$, T $29 \mathrm{~N}$, R $5 \mathrm{~W}$, near mouth and 5 miles south of Valier

Drainage area $-191 \mathrm{sq} \mathrm{mi}$

Maxima --June 1964 D1scharge, $282 \mathrm{cfs}$ about 1500 hours June 8 , from slope-area measurement furnished by Montana State College

1948 Discharge, $197 \mathrm{cfs}$ about June 17, from slope-area measurement

(101) 6-1003 Lone Man Coulee near Valier, Mont

(Crest-stage gage)

Location --Lat $48^{\circ} 14^{\prime}$, long $112^{\circ} 14^{\prime}$, in $\mathrm{SE}_{\frac{1}{4}} \sec 27, \mathrm{~T} 29 \mathrm{~N}, \mathrm{R} 5 \mathrm{~W}$, at culvert on county road, 5 miles south of Valier Culvert washed out by flood on June 8

Drainage area $--141 \mathrm{sq} \mathrm{m}$

Gage-height record --Crest stages and high-water marks Water-stage recorder graph obtained at supplementary site $300 \mathrm{ft}$ downstream by Montana State College, used to determine time of peak Elevation of gage is about 3,780 ft (from topographic map) Datum at the recorder site is $223 \mathrm{ft}$ higher

Discharge record --Stage-discharge relation defined by current-meter measurements below 25 cf's, by flow through culvert measurement at $180 \mathrm{cfs}$, and by sloce-area measurement at site half a mile upstream, 1,460 cfs, added to slope-area measurement of Miller Coulee, $282 \mathrm{cfs}$, to obtain a natural peak of 1,740 cf's Artificial peak caused by failure of road grade was determined to be 2,680 cfs from slope-area measurement at the recorder site)

Maxima --June 1964 Natural discharge, 1,740 cfs 1530 hours June 8 (gage height observed, $238 \mathrm{ft}$, from downstream crest-stage gage, $420 \mathrm{ft}$, at recorder site), due to failure of road grade, discharge, 2,680 cfs 1700 hours June 8 (gage height, $498 \mathrm{ft}$ at recorder site)

1960 to May 1964 Discharge, $180 \mathrm{cfs}$ May 3, 1964 (gage height, $072 \mathrm{ft}$, $281 \mathrm{ft}$ at recorder sitel

(102) Dry Fork Marias River at Ledger, Mont

(Miscellaneous site)

Location --Lat $48^{\circ} 15^{\prime} 30^{\prime \prime}$, long $111^{\circ} 49^{\prime} 10^{\prime \prime}$, in $\mathrm{NE} \frac{1}{4} \mathrm{NE} \frac{1}{4} \sec 23$, T $29 \mathrm{~N}, \mathrm{R} 2 \mathrm{~W}$, at bridge on county road at Ledger

Drainage area $--263 \mathrm{sq} \mathrm{mi}$

Maxima --June 1964 Discharge, 7,870 cfs June 8, by contracted-opening measurement Flood of June 1948, reached a discharge of $13,000 \mathrm{cfs}$ at site about 9 miles upstream, drainage area, $241 \mathrm{sq} \mathrm{mi}$, from contracted-opening measurement 
(103) 6-1013 Tiber Reservolr near Chester, Mont

Location --Lat $48^{\circ} 19^{\prime}$, long $111^{\circ} 06^{\prime}$, in NW $\frac{1}{4} \sec 33$, T $30 \mathrm{~N}, \mathrm{R} 5 \mathrm{E}$, in control house of river outiet tunnel of Tiber Dam on Marias River, 15 miles southwest of Chester

Drainage area --4,923 sq $\mathrm{ml}$, of which $518 \mathrm{sq} \mathrm{ml}$ is probably noncontributing

Gage-he1ght record - Tape and staff gages read once daily or more frequently June 8-16 Graph based on observed readings used Apr 30 to June 30 to obtain midnight elevations Datum of gage is at mean sea level (levels by Bureau of Reclamation)

Discharge record --Inflow computed from change in contents adjusted for outflow

Maxima --June 1964 Contents observed, 1,116,000 acre-ft 0525 hours June 13 (elevation, 3,001 $91 \mathrm{ft}$ ) Rate of inflow, $200,000 \mathrm{cfs} 0800$ hours June 9

1955 to May 1964 Contents observed, 834,800 acre-ft June 27, $1959(815,900$ acre-ft, capacity table used prior to oct 1 , 1963) at elevation $2,98647 \mathrm{ft}$

Remarks --Reservoir formed by rolled earthfill dam with concrete spillway chute, construction began September 1952, completed March 1956 Storage began Oct '28, 1955 Usable capacity, $1,347,000$ acre-ft $(1,313,000$ acre-ft prior to Oct 1 , 1963) at controlled spillway elevation $(3,0125 \mathrm{ft})$ Dead storage, 21,580 acre-ft (24,000 acre-ft prior to oct 1 , 1963) Reservoir is presently used for recreation and flood control Records furnished by Bureau of Reclamation Figures given herein represent usable contents

Elevation, in feet, and contents, in acre-feet, at 2400 hours and daily computed inflow, in

\begin{tabular}{|c|c|c|c|c|c|c|}
\hline \multirow{2}{*}{ Day } & \multicolumn{3}{|c|}{ May } & \multicolumn{3}{|c|}{ June } \\
\hline & Elevationt & Contents & Inflow & Elevationt & Contents & Inflow \\
\hline $\begin{array}{l}1 \\
2 \\
3 \\
4 \\
5\end{array}$ & 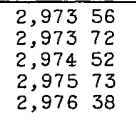 & $\begin{array}{l}644,800 \\
646,900 \\
657,600 \\
674,100 \\
683,000\end{array}$ & $\begin{array}{l}1,200 \\
1,990 \\
6,320 \\
9,220 \\
5,460\end{array}$ & $\begin{array}{ll}2,982 & 44 \\
2,982 & 83 \\
2,983 & 17 \\
2,983 & 58 \\
2,984 & 02\end{array}$ & $\begin{array}{l}771,300 \\
777,200 \\
782,500 \\
788,800 \\
795,700\end{array}$ & $\begin{array}{l}3,980 \\
3,970 \\
3,610 \\
4,180 \\
4,420\end{array}$ \\
\hline $\begin{array}{r}6 \\
7 \\
8 \\
9 \\
10\end{array}$ & 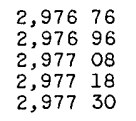 & $\begin{array}{l}688,300 \\
691,100 \\
692,800 \\
694,200 \\
695,900\end{array}$ & $\begin{array}{l}3,600 \\
2,340 \\
1,790 \\
1,660 \\
1,800\end{array}$ & $\begin{array}{ll}2,984 & 45 \\
2,984 & 88 \\
2,985 & 86 \\
2,996 & 53 \\
3,000 & 40\end{array}$ & $\begin{array}{r}802,500 \\
809,300 \\
824,900 \\
1,011,000 \\
1,086,000\end{array}$ & $\begin{array}{r}4,400 \\
4,400 \\
9,050 \\
95,400 \\
44,500\end{array}$ \\
\hline $\begin{array}{l}11 \\
12 \\
13 \\
14 \\
15\end{array}$ & 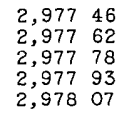 & $\begin{array}{l}698,100 \\
700,400 \\
702,700 \\
704,800 \\
706,800\end{array}$ & $\begin{array}{l}2,080 \\
2,080 \\
2,080 \\
2,010 \\
1,950\end{array}$ & $\begin{array}{ll}3,001 & 65 \\
3,001 & 88 \\
3,001 & 82 \\
3,001 & 62 \\
3,001 & 37\end{array}$ & $\begin{array}{l}1,111,000 \\
1,116,000 \\
1,114,000 \\
1,110,000 \\
1,105,000\end{array}$ & $\begin{array}{r}22,600 \\
12,400 \\
9,490 \\
8,060 \\
7,450\end{array}$ \\
\hline $\begin{array}{l}16 \\
17 \\
18 \\
19 \\
20\end{array}$ & $\begin{array}{ll}2,978 & 20 \\
2,978 & 33 \\
2,978 & 51 \\
2,978 & 78 \\
2,979 & 08\end{array}$ & $\begin{array}{l}708,600 \\
710,500 \\
713,100 \\
717,000 \\
721,300\end{array}$ & $\begin{array}{l}1,890 \\
1,890 \\
2,250 \\
2,910 \\
3,130\end{array}$ & $\begin{array}{ll}3,001 & 10 \\
3,000 & 92 \\
3,000 & 77 \\
3,000 & 56 \\
3,000 & 28\end{array}$ & $\begin{array}{l}1,100,000 \\
1,096,000 \\
1,093,000 \\
1,089,000 \\
1,083,000\end{array}$ & $\begin{array}{l}7,190 \\
6,940 \\
6,400 \\
5,770 \\
5,000\end{array}$ \\
\hline $\begin{array}{l}21 \\
22 \\
23 \\
24 \\
25\end{array}$ & $\begin{array}{ll}2,979 & 40 \\
2,979 & 71 \\
2,979 & 99 \\
2,980 & 21 \\
2,980 & 38\end{array}$ & $\begin{array}{l}725,900 \\
730,500 \\
734,500 \\
737,800 \\
740,300\end{array}$ & $\begin{array}{l}3,300 \\
3,240 \\
3,020 \\
2,600 \\
2,230\end{array}$ & 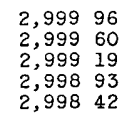 & $\begin{array}{l}1,077,000 \\
1,070,000 \\
1,062,000 \\
1,057,000 \\
1,047,000\end{array}$ & $\begin{array}{l}4,550 \\
4,140 \\
3,940 \\
3,650 \\
3,420\end{array}$ \\
\hline $\begin{array}{l}26 \\
27 \\
28 \\
29 \\
30 \\
31\end{array}$ & $\begin{array}{ll}2,980 & 50 \\
2,380 & 63 \\
2,980 & 83 \\
2,981 & 17 \\
2,981 & 56 \\
2,982 & 05 \\
\end{array}$ & $\begin{array}{l}742,100 \\
744,000 \\
747,000 \\
752,000 \\
757,900 \\
765,300 \\
\end{array}$ & $\begin{array}{l}1,860 \\
1,940 \\
2,450 \\
3,520 \\
3,930 \\
4,690 \\
\end{array}$ & 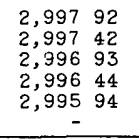 & $\begin{array}{c}1,037,000 \\
1,028,000 \\
1,018,000 \\
1,009,000 \\
999,600 \\
-\end{array}$ & $\begin{array}{l}3,420 \\
3,400 \\
3,420 \\
3,360 \\
3,230 \\
- \\
\end{array}$ \\
\hline Change in contents & - & $+121,000$ & - & - & $+234,300$ & - \\
\hline
\end{tabular}

+ Elevations at midnight from graph drawn through observed gage readings 
Elevation, in feet, and average computed inflow in cubic feet per second, for time period shown, 1964, of T1ber Reservolr near Chester, Mont

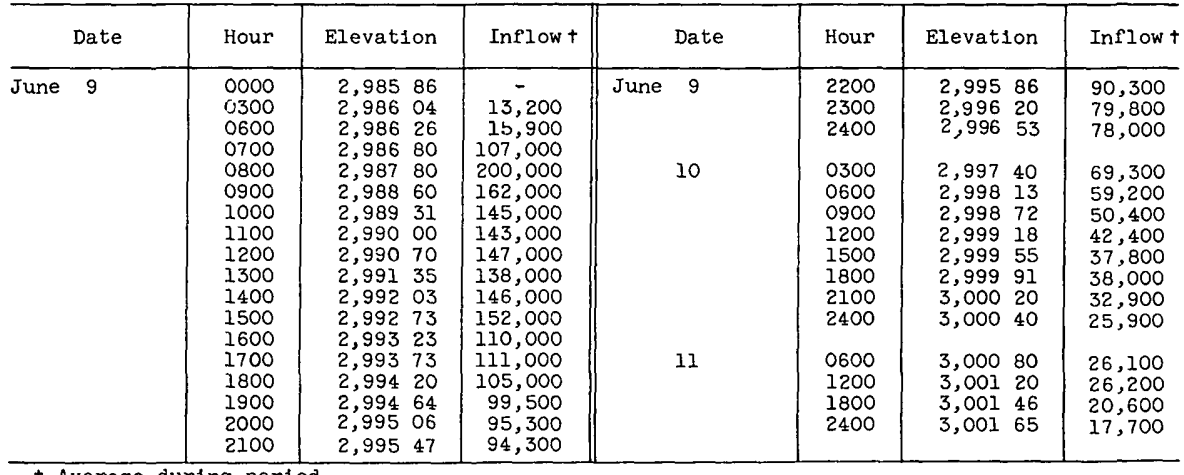

(104) 6-1015 Marias River near Chester, Mont

Location --Lat $48^{\circ} 18^{\prime}$, long $111^{\circ} 05^{\prime}$, in $\mathrm{SW} \frac{1}{4} \mathrm{SW} \frac{1}{4} \sec 34, \mathrm{~T} 30 \mathrm{~N}, \mathrm{R} 5 \mathrm{E}$, on left bank 1 mile downstream from Tiber Dam, 4 miles upstream from Pondera Coulee, and 15 miles southwest of Chester

Drainage area $--4,927 \mathrm{sq} \mathrm{mi}$, of which $516 \mathrm{sq} \mathrm{mi}$ is probably noncontributing

Gage-height record --Water-stage recorder graph Datum of gage is 2,814 $03 \mathrm{ft}$ above mean sea level (Bureau of Reclamation bench mark)

Discharge record --Stage-discharge relation defined by current-meter measurements

Maxima --June 1964 Discharge, $10,400 \mathrm{cfs} 2000$ hours June 16 (gage height, $1063 \mathrm{ft}$ ) 1921, 1945-47, 1955 to May 1964 Discharge not determined, occurred about Mar 20, 1947

Flood in June 1948 reached a stage of $16 \mathrm{ft}$

Remarks --Flow completely regulated by Tiber Reservolr since Oct 28, 1955 (see station 103) and four other reservolrs having a combined capacity of 177,900 acre-ft

Mean discharge, in cub1c feet per second, 1964

\begin{tabular}{|c|c|c|c|c|c|c|c|c|}
\hline Day & May & June & Day & May & June & Day & May & June \\
\hline $\begin{array}{l}1 \\
2 \\
3 \\
4 \\
5 \\
6 \\
7 \\
8 \\
9 \\
10\end{array}$ & $\begin{array}{l}930 \\
930 \\
930 \\
938 \\
938 \\
938 \\
938 \\
938 \\
945 \\
945\end{array}$ & $\begin{array}{r}968 \\
968 \\
968 \\
968 \\
975 \\
975 \\
982 \\
1,150 \\
1,700 \\
6,640\end{array}$ & $\begin{array}{l}11 \\
12 \\
13 \\
14 \\
15 \\
16 \\
17 \\
18 \\
19 \\
20\end{array}$ & $\begin{array}{l}945 \\
945 \\
945 \\
945 \\
945 \\
952 \\
952 \\
952 \\
952 \\
952\end{array}$ & $\begin{array}{r}9,960 \\
10,100 \\
10,100 \\
10,100 \\
10,000 \\
9,940 \\
8,760 \\
7,910 \\
7,880 \\
7,810\end{array}$ & $\begin{array}{l}21 \\
22 \\
23 \\
24 \\
25 \\
26 \\
27 \\
28 \\
29 \\
30 \\
31\end{array}$ & $\begin{array}{l}952 \\
960 \\
960 \\
960 \\
960 \\
960 \\
968 \\
960 \\
960 \\
968 \\
968\end{array}$ & $\begin{array}{r}7,760 \\
7,710 \\
8,000 \\
6,220 \\
8,410 \\
8,300 \\
8,220 \\
8,140 \\
8,020 \\
7,980 \\
- \\
-\end{array}$ \\
\hline $\begin{array}{l}\text { Month } \\
\text { Runof }\end{array}$ & $\begin{array}{l}\text { d1sch } \\
\text { re-fe }\end{array}$ & , in cul & feet & ond & & & $\begin{array}{r}949 \\
58,380 \\
\end{array}$ & $\begin{array}{r}6,254 \\
372,100 \\
\end{array}$ \\
\hline
\end{tabular}

Gage he1ght, in feet, and discharge, in cub1c feet per second, at 1ndicated t1me, 1964

\begin{tabular}{|c|c|c|c|c|c|c|c|c|c|c|c|}
\hline Date & Hour & $\begin{array}{c}\text { Gage } \\
\text { he1ght }\end{array}$ & $\begin{array}{c}\text { Dis- } \\
\text { charge }\end{array}$ & Date & Hour & $\begin{array}{c}\text { Gage } \\
\text { helght }\end{array}$ & $\begin{array}{l}\text { D1s- } \\
\text { charge }\end{array}$ & Date & Hour & $\begin{array}{c}\text { Gage } \\
\text { helght }\end{array}$ & $\begin{array}{l}\text { Dis- } \\
\text { charge }\end{array}$ \\
\hline June 8 & $\begin{array}{l}0000 \\
1000 \\
1300 \\
1400 \\
1600 \\
1700 \\
1800 \\
2000 \\
2400 \\
1000\end{array}$ & $\begin{array}{ll}4 & 05 \\
4 & 07 \\
4 & 06 \\
4 & 26 \\
4 & 37 \\
4 & 30 \\
4 & 64 \\
4 & 66 \\
4 & 66 \\
4 & 68\end{array}$ & $\begin{array}{r}982 \\
998 \\
990 \\
1,130 \\
1,220 \\
1,170 \\
1,440 \\
1,450 \\
1,450 \\
1,470\end{array}$ & June 9 & $\begin{array}{l}1200 \\
1700 \\
1800 \\
2100 \\
2200 \\
2300 \\
2400 \\
\\
0600 \\
0700 \\
0800\end{array}$ & $\begin{array}{ll}4 & 86 \\
4 & 89 \\
5 & 12 \\
5 & 15 \\
5 & 68 \\
5 & 77 \\
5 & 78 \\
& \\
5 & 85 \\
6 & 85 \\
7 & 31\end{array}$ & $\begin{array}{l}1,630 \\
1,660 \\
1,890 \\
1,920 \\
2,500 \\
2,600 \\
2,620 \\
2,700 \\
4,040 \\
4,720\end{array}$ & June 10 & $\begin{array}{l}0900 \\
1200 \\
1300 \\
1400 \\
1500 \\
1600 \\
2000 \\
2400\end{array}$ & $\begin{array}{rr}7 & .41 \\
9 & 00 \\
9 & 50 \\
9 & 65 \\
10 & 00 \\
10 & 15 \\
10 & 25 \\
10 & 32\end{array}$ & $\begin{array}{l}4,880 \\
7,540 \\
8,390 \\
8,640 \\
9,240 \\
9,510 \\
9,690 \\
9,820\end{array}$ \\
\hline
\end{tabular}


(105) Pondera Coulee near Chester, Mont

\section{(Miscellaneous site)}

Location - -Lat $48^{\circ} 16^{\prime} 10^{\prime \prime}$, long $111^{\circ} 08^{\prime} 30^{\prime \prime}$, in center west line sec 18, T $29 \mathrm{~N}$, R $5 \mathrm{E}$, at bridge 19 miles southwest of Chester

Drainage area $-598 \mathrm{sq} \mathrm{m}$

Maximum --June 1964 Discharge, 1,950 cfs June 8 from contracted-opening measurement

(106) 6-1016 Marlas River tributary No 3 near Chester, Mont

(Crest-stage station)

Location --Lat $48^{\circ} 14^{\prime}$, long $110^{\circ} 53^{\prime}$, In $\mathrm{NE} \frac{1}{4} \mathrm{sec} 36, \mathrm{~T} 29 \mathrm{~N}, \mathrm{R} 6 \mathrm{E}$, at culvert on State Highway 223, 2 miles south of Marias River bridge, and 20 miles southeast of Chester

Drainage area $--032 \mathrm{sq} \mathrm{ml}$

Gage-height record --Crest-stages only Altitude of gage is 2,900 ft (from topographic mapl

Discharge record --Stage-discharge relation defined by flow-through-culvert measurements at $9 \mathrm{cf}$ s and $29 \mathrm{cfs}$

Maxima --June 1964 Discharge, $11 \mathrm{cfs}$ June 8 (gage height, $137 \mathrm{ft}$ )

1962 to May 1964 Discharge, 29 cfs May 21, 1962 (gage height, $318 \mathrm{ft}$ )

(107) 6-1017 Cottonwood Creek tributary near Chester, Mont

(Crest-stage station)

Location --Lat $48^{\circ} 27^{\prime}$, long $111^{\circ} 05^{\prime}$, near center of east line of sec $9, \mathrm{~T} 31 \mathrm{~N}$, R5E, at culvert on county road, $3 \frac{1}{2}$ miles south of Tiber Siding on Great Northern Railway and U S Highway 2 , and $6 \frac{1}{2}$ miles southwest of Chester

Drainage area $--2 \quad 28 \mathrm{sq} \mathrm{mi}$ $\frac{\text { Gage-height record }}{\text { raphic map) }}$-Crest stages only Altitude of gage is 3,100 ft (from topog-

Discharge record --Stage-discharge relation defined by flow-through-culvert measurements at $66 \mathrm{cfs}, 80 \mathrm{cfs}$ and $99 \mathrm{cfs}$

Maxima --June 1964 Discharge, about $10 \mathrm{cfs}$ June 8 (gage helght, $098 \mathrm{ft}$ ) 1963 to May 1964 Discharge, $99 \mathrm{cfs}$ June 28,1963 (gage height, $408 \mathrm{ft}$ ) 
(108) 6-1018 Cottonwood Creek tributary No 2 near Chester, Mont

$$
\text { (Crest-stage station) }
$$

Location --Lat $48^{\circ} 20^{\prime}$, long, $110^{\circ} 57^{\prime}$, in $\mathrm{NW} \frac{1}{4} \sec 27, \mathrm{~T} 30 \mathrm{~N}, \mathrm{R} 6 \mathrm{E}$, at bridge on State Highway $223,5 \frac{1}{2}$ road miles north of Marias River bridge, and $12 \frac{1}{2}$ miles south of Chester

Drainage area $--246 \mathrm{sq} \mathrm{mi}$

Gage-height record --Crest stages only Altitude of gage is 2,950 ft (from topographic map)

Discharge record --Stage-discharge relation defined by current-meter measurements

Maxima --June 1964 Discharge, $75 \mathrm{cfs}$ June 8 (gage helght, $235 \mathrm{ft}$ )

1963 to May 1964 No flow

(109) 6-1019 Dead Indian Coulee near Fort Benton, Mont

(Crest-stage station)

Location --Lat $48^{\circ} 05^{\prime}$, long $110^{\circ} 50^{\prime}$, in center of $\sec 21, T 27 \mathrm{~N}, \mathrm{R} 7 \mathrm{E}$, at culvert on State Highway 223,20 miles northwest of Fort Benton

Drainage area $--273 \mathrm{sq} \mathrm{ml}$

Gage-height record --Crest stages only Alt1tude of gage is 3,250 ft (from topographic map)

Discharge record --Stage-discharge relation defined by flow-through-culvert measurement at $13 \mathrm{cf}^{2} \mathrm{~s}$

Maxima --June 1964 Discharge, $02 \mathrm{cfs}$ June 8 (gage he1ght, $064 \mathrm{ft}$ upstream gage, $050 \mathrm{ft}$ downstream gage)

1963 to May 1964 Discharge, $13 \mathrm{cfs}$ May 3, 1964 (gage he1ght, $219 \mathrm{ft}$ upstream gage, $095 \mathrm{ft}$ downstream gage)

(110) 6-1020 5 Marias River near Loma, Mont.

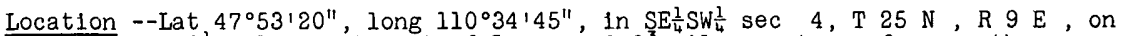
left bank $3 \frac{1}{2}$ miles northwest of Loma, and $6 \frac{3}{4}$ miles upstream from mouth

Drainage area $--6,995 \mathrm{sq} \mathrm{mi}$, of which $518 \mathrm{sq} \mathrm{mi}$ is probably noncontributing

Gage-height record --Water-stage recorder graph Altitude of gage is 2,570 ft (from topographic map)

Discharge record --Stage-discharge relation defined by current-meter measurements

Maxima --June 1964 Discharge, $10,800 \mathrm{cfs} 0400$ hours June 16 (gage height, $872 \mathrm{ft}$ )

1959 to May 1964 Discharge, 3,050 cfs June 8, 1961 (gage helght, 462 ft)

Flood of June 1908, the greatest known, reached a discharge of about $70,000 \mathrm{cfs}$ at a site 34 miles upstream with a drainage area of $6,425 \mathrm{sq} \mathrm{m1}$ (6-1020 Marias River near Brinkman)

Remarks --Flow regulated by Tiber Reservoir (see station 103) and four other reservolrs having a combined capacity of 177,900 acre-ft 
Mean discharge, in cublc feet per second, 1964 of Marlas River near Loma, Mont

\begin{tabular}{|c|c|c|c|c|c|c|c|c|}
\hline Day & May & June & Day & May & June & Day & May & June \\
\hline $\begin{array}{r}1 \\
2 \\
3 \\
4 \\
5 \\
6 \\
7 \\
8 \\
9 \\
10\end{array}$ & $\begin{array}{r}912 \\
956 \\
1,060 \\
1,320 \\
1,070 \\
1,450 \\
1,430 \\
1,210 \\
1,070 \\
1,000\end{array}$ & $\begin{array}{r}912 \\
904 \\
904 \\
904 \\
912 \\
929 \\
956 \\
1,060 \\
1,150 \\
1,750\end{array}$ & $\begin{array}{l}11 \\
12 \\
13 \\
14 \\
15 \\
16 \\
17 \\
18 \\
19 \\
20\end{array}$ & $\begin{array}{l}983 \\
974 \\
956 \\
938 \\
938 \\
938 \\
929 \\
929 \\
920 \\
920\end{array}$ & $\begin{array}{r}8,640 \\
9,850 \\
9,740 \\
9,650 \\
9,760 \\
10,300 \\
10,200 \\
8,100 \\
7,900 \\
7,840\end{array}$ & $\begin{array}{l}21 \\
22 \\
23 \\
24 \\
25 \\
26 \\
27 \\
28 \\
29 \\
30 \\
31\end{array}$ & $\begin{array}{l}912 \\
904 \\
912 \\
920 \\
920 \\
920 \\
920 \\
920 \\
938 \\
920 \\
912\end{array}$ & $\begin{array}{r}7,790 \\
7,790 \\
7,750 \\
6,520 \\
7,080 \\
8,420 \\
8,400 \\
8,260 \\
8,120 \\
8,040 \\
--.--\end{array}$ \\
\hline $\begin{array}{l}\text { Month } \\
\text { Runof }\end{array}$ & $\begin{array}{l}\text { disch } \\
\text { cre-fe }\end{array}$ & , In cu & feet & ond & & & $\begin{array}{r}1,000 \\
61,490\end{array}$ & $\begin{array}{r}6,018 \\
358,100\end{array}$ \\
\hline
\end{tabular}

Gage he1ght, in feet, and discharge, in cubic feet per second, at indicated time, 1964

\begin{tabular}{|c|c|c|c|c|c|c|c|c|c|c|c|}
\hline Date & Hour & $\begin{array}{c}\text { Gage } \\
\text { height }\end{array}$ & $\begin{array}{c}\text { Dis- } \\
\text { charge }\end{array}$ & Date & Hour & $\begin{array}{c}\text { Gage } \\
\text { helght }\end{array}$ & $\begin{array}{l}\text { Dis - } \\
\text { charge }\end{array}$ & Date & Hour & $\begin{array}{c}\text { Gage } \\
\text { height }\end{array}$ & $\begin{array}{l}\text { Dis- } \\
\text { charge }\end{array}$ \\
\hline June 7 & $\begin{array}{l}0000 \\
1200 \\
2400 \\
1200 \\
2000 \\
2400\end{array}$ & $\begin{array}{ll}3 & 03 \\
3 & 03 \\
3 & 07 \\
& \\
3 & 13 \\
3 & 25 \\
3 & 23\end{array}$ & $\begin{array}{r}947 \\
947 \\
983 \\
\\
1,040 \\
1,150 \\
1,130\end{array}$ & June 9 & $\begin{array}{l}1200 \\
2400 \\
1200 \\
1500 \\
1800 \\
1900\end{array}$ & $\begin{array}{ll}3 & 16 \\
3 & 48 \\
& \\
3 & 63 \\
3 & 72 \\
4 & 07 \\
4 & 23\end{array}$ & $\begin{array}{l}1,060 \\
1,360 \\
1,510 \\
1,6100 \\
1,984 \\
2,176\end{array}$ & June 10 & $\begin{array}{l}2000 \\
2100 \\
2200 \\
2300 \\
2400\end{array}$ & $\begin{array}{ll}4 & 34 \\
4 & 43 \\
4 & 53 \\
4 & 68 \\
5 & 00\end{array}$ & $\begin{array}{l}2,312 \\
2,429 \\
2,559 \\
2,754 \\
3,180\end{array}$ \\
\hline
\end{tabular}

(111) 6-1021 Dry Fork Coulee tributary near Loma, Mont (Crest-stage station)

Location --Lat $47^{\circ} 57^{\prime}$, long $110^{\circ} 33^{\prime}$, in $\operatorname{SW} \frac{1}{4} \sec 2, T 25 \mathrm{~N}, \mathrm{R} 9 \mathrm{E}$, at culvert on county road, 2 miles west of Loma

Drainage area $-084 \mathrm{sq} \mathrm{mi}$

Gage-height record --Crest stages only Altitude of gage is 2,580 ft (from topographic map)

Discharge record --Stage-discharge relation defined by flow-through-culvert measurements at $16 \mathrm{cfs}$ and $71 \mathrm{cfs}$

Maxima --June 1964 No flow

1959 to May 1964 Discharge, $71 \mathrm{cfs}$ Mar 1, 1959 (gage height, $402 \mathrm{ft}$ )

\section{(112) 6-1022 Marias River tributary at Loma, Mont \\ (Crest-stage station)}

Location - Lat $47^{\circ} 57^{\prime}$, long $110^{\circ} 31^{\prime}$, in SW $\frac{1}{4} S E \frac{1}{4} \sec 1$, T $25 \mathrm{~N}, \mathrm{R} 9 \mathrm{E}$, at bridge on county road, five eighths of a mile west of Loma

Drainage area $--162 \mathrm{sq} \mathrm{mi}$ $\frac{\text { Gage-height record }}{\text { graphic map) }}$-Crest stages only Altitude of gage is 2,590 ft (from topo-

Discharge record --Stage-discharge relation defined by current-meter measurement at

$4 \mathrm{cfs}$ and slope-area measurement at $6 \mathrm{cfs}$

Maxima --June 1964 No flow

1956 to May 1964 Discharge about $20 \mathrm{cfs}$ May 21, 1962 (gage height, $211 \mathrm{ft}$ ) 
(113) 6-1023 Marias River tributary No 2 at Loma, Mont

(Crest-stage station)

Location --Lat $47^{\circ} 57^{\prime}$, long $110^{\circ} 30^{\prime}$, in $\mathrm{NE} \frac{1}{4} \mathrm{NE} \frac{1}{4} \sec 12, \mathrm{~T} 25 \mathrm{~N}, \mathrm{R} 9 \mathrm{E}$, at culvert on approach to U S'Highway 87, a quarter of a mile north of Loma

Drainage area $--025 \mathrm{sq} \mathrm{ml}$

Gage-helght record --Crest stages only Alt1tude of gage is 2,590 ft (from topographic map)

Discharge record --Stage-discharge relation defined by flow-through-culvert measurement at $15 \mathrm{cf} s$

Maxima --June 1964 No flow

1956 to May 1964 Discharge, about $20 \mathrm{cfs}$ May 27, 1956 (gage he1ght, $297 \mathrm{ft}$ )

\section{(114) 6-1025 Teton River near Farmington, Mont}

(Gaging station, discontinued 1954)

Location --Lat $47^{\circ} 53^{\prime} 00^{\prime \prime}$, long $112^{\circ} 36^{\prime} 35^{\prime \prime}$, in $\mathrm{NE} \frac{1}{4} \mathrm{NE} \frac{1}{4} \sec 34$, T $25 \mathrm{~N}, \mathrm{R} 8 \mathrm{~W}, 300 \mathrm{ft}$ downstream from highway bridge, 1 1/8 miles downstream from South Fork, and

20 miles west of Farmington Gage site destroyed by flood Altitude of gage was $4,770 \mathrm{ft}$ (from topographic map)

Drainage area $--105 \mathrm{sq} \mathrm{mi}$

Maxima --June 1964 Discharge, 54,600 cfs June 8, from slope-area measurement 1947-54 Discharge, 2,780 cfs June 3, 1948 (gage helght, $532 \mathrm{ft}$ ), from rating curve extended above $1,100 \mathrm{cfs}$, gage height observed, $734 \mathrm{ft}$ Jan 6,1950 (ice jam)

(115) 6-1058 Bruce Coulee tributary near Choteau, Mont (Crest-stage gage)

Location --Lat $47^{\circ} 44^{\prime}$, long $112^{\circ} 15^{\prime}$, near center sec 21 , T $23 \mathrm{~N}, \mathrm{R} 5 \mathrm{~W}$, at bridge on county road, 12 miles west of State Highway 287,6 miles southwest of Choteau

Drainage area $--170 \mathrm{sq} \mathrm{mi}$

Gage-height record --Crest stages only Altitude of gage is 3,940 ft (from topographic map) $\frac{\text { Maxima }}{\text { area measurement }}$-June 1964 Discharge, $148 \mathrm{cfs}$ June 8 (gage height, $176 \mathrm{ft}$ ), from slope-

1963 to May 1964 Discharge, about 18 cfs June 28, 1963 (gage height, $065 \mathrm{ft})$

(116) 6-1060 Deep Creek near Choteau, Mont

(Gaging station, discontinued 1924)

Location --Lat $47^{\circ} 45^{\prime}$, long $112^{\circ} 14^{\prime}$, in SW $\frac{1}{4} N W \frac{1}{4} \sec 15$, T $23 \mathrm{~N}, \mathrm{R} 5 \mathrm{~W}, 2$ miles downstream from Willow Creek and 5 miles southwest of Choteau

Drainage area --223 sq $\mathrm{mi}$ (269 sq mi at 1964 measurement site)

$\frac{\text { Gage-height record }}{\text { barometer) }}$-Gage datum not recovered Altitude of gage was $3,860 \mathrm{ft}$ (oy

Maxima --June 1964 Discharge, 41,800 cfs 1900 hours June 8, from slope-area measurement at site $2 \frac{1}{2}$ miles downstream

1911-24 Discharge observed, 3,700 cfs June 21, 1916 (gage height, $105 \mathrm{ft}$ ),

from rating curve extended above 1,300 cfs by logarithmic plotting 
(117) Teton River below Deep Creek, near Choteau, Mont

(Miscellaneous site)

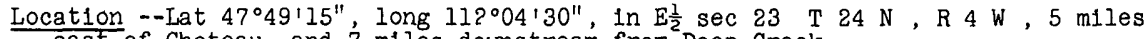
east of Choteau and 7 miles downstream from Deep Creek

Dra1nage area $--510 \mathrm{sq} \mathrm{mi}$

Maximum --June 1964 D1scharge, 64,300 cfs 2000 hours June 8, from slope-area measurements on main and overflow channels

(118) Muddy Creek near Collins, Mont

(Miscellaneous site)

Location --Lat $47^{\circ} 57^{\prime} 40^{\prime \prime}, 111^{\circ} 51^{\prime} 45^{\prime \prime}$, near center of $\mathrm{S} \frac{1}{2} \sec 33, \mathrm{~T} 26 \mathrm{~N}, \mathrm{R} 2 \mathrm{~W}$, 3 mIles northwest of Collins

Drainage area $--385 \mathrm{sq} \mathrm{mi}$

Maximum --June 1964 Discharge, 13,900 cfs June 8, from slope-area measurement

(119) 6-1080 Teton River near Dutton, Mont

Location --Lat $47^{\circ} 55^{\prime} 55^{\prime \prime}$, long $111^{\circ} 33^{\prime} 05^{\prime \prime}$, in SE $\frac{1}{4} S W^{\frac{1}{4}} \sec 12, \mathrm{~T} 25 \mathrm{~N}, \mathrm{R} 1 \mathrm{E}$, on lef't bank $300 \mathrm{ft}$ downstream from Kerr Bridge, 1 mile downstream from Hunt Coulee, and 10 miles northeast of Dutton

Drainage area $--1,308 \mathrm{sq} \mathrm{ml}$

Gage-he1ght record --Water-stage recorder graph, except 0700 hours June 9 to 1900 hours June 19 Mean dally gage heights based on inside gage readings June 14, 18 Altitude of gage is $3,235 \mathrm{ft}$ (from topographic map)

D1scharge record --Stage-discharge relation defined by current-meter measurements below 2,700 cf's and by slope-area measurement at $71,300 \mathrm{cfs}$

Maxima --June 1964 Discharge, $71,300 \mathrm{cfs} 0800$ hours June 9 (gage he1ght, $198 \mathrm{ft}$ from floodmarks)

1954 to May 1964 Discharge, 1, $310 \mathrm{cfs} J u n e$ 21, 1958 (gage height, $596 \mathrm{ft}$ ), gage helght, $868 \mathrm{ft}$ Mar 9, 1959 (1ce jam)

Remarks --Floodflows may be affected by diversions for storage in Bynum Reservoir (usable capacity, 75,000 acre-ft)

Mean discharge, in cubic feet per second, 1964

\begin{tabular}{|c|c|c|c|c|c|c|c|c|}
\hline Day & May & June & Day & May & June & Day & May & June \\
\hline $\begin{array}{r}1 \\
2 \\
3 \\
4 \\
5 \\
6 \\
7 \\
8 \\
9 \\
10\end{array}$ & $\begin{array}{r}158 \\
302 \\
1,540 \\
3,140 \\
2,870 \\
1,610 \\
910 \\
668 \\
538 \\
452\end{array}$ & $\begin{array}{r}704 \\
518 \\
444 \\
401 \\
362 \\
349 \\
339 \\
660 \\
20,000 \\
15,000\end{array}$ & $\begin{array}{l}11 . \\
12 \\
13 \\
14 \\
15 \\
16 \\
17 \\
18 \\
19 \\
20\end{array}$ & $\begin{array}{l}416 \\
362 \\
318 \\
284 \\
257 \\
232 \\
211 \\
196 \\
196 \\
198\end{array}$ & $\begin{array}{l}8,000 \\
5,000 \\
3,500 \\
2,680 \\
2,200 \\
2,000 \\
1,900 \\
2,560 \\
2,030 \\
1,720\end{array}$ & $\begin{array}{l}21 \\
22 \\
23 \\
24 \\
25 \\
26 \\
27 \\
28 \\
29 \\
30 \\
31\end{array}$ & $\begin{array}{l}180 \\
178 \\
178 \\
158 \\
136 \\
120 \\
115 \\
120 \\
134 \\
344 \\
840\end{array}$ & $\begin{array}{r}1,550 \\
1,440 \\
1,310 \\
1,210 \\
1,150 \\
1,090 \\
981 \\
953 \\
904 \\
848 \\
-\quad-\quad--\end{array}$ \\
\hline \multicolumn{7}{|c|}{$\begin{array}{l}\text { Monthly mean discharge, in cublc feet per second } \\
\text { Runoff, in acre-feet }\end{array}$} & $\begin{array}{r}560 \\
34,440 \\
\end{array}$ & $\begin{array}{r}2,727 \\
162,300 \\
\end{array}$ \\
\hline
\end{tabular}

Gage he1ght, in feet, and discharge, in cublc feet per second, at indicated time, 1964

\begin{tabular}{|c|c|c|c|c|c|c|c|c|c|c|c|}
\hline Date & Hour & $\begin{array}{c}\text { Gage } \\
\text { he1ght }\end{array}$ & $\begin{array}{c}\text { D1s- } \\
\text { charge }\end{array}$ & Date & Hour & $\begin{array}{c}\text { Gage } \\
\text { helght }\end{array}$ & $\begin{array}{l}\text { D1s- } \\
\text { charge }\end{array}$ & Date & Hour & $\begin{array}{c}\text { Gage } \\
\text { he1ght }\end{array}$ & $\begin{array}{l}\text { Dis- } \\
\text { charge }\end{array}$ \\
\hline June 8 & $\begin{array}{l}0000 \\
0700 \\
0800 \\
0900 \\
1200 \\
1400\end{array}$ & $\begin{array}{ll}3 & 62 \\
3 & 77 \\
3 & 99 \\
4 & 06 \\
4 & 17 \\
4 & 32 \\
\end{array}$ & $\begin{array}{l}342 \\
394 \\
463 \\
490 \\
530 \\
582\end{array}$ & June 8 & $\begin{array}{l}1600 \\
1800 \\
2000 \\
2200 \\
2400\end{array}$ & $\begin{array}{ll}4 & 56 \\
4 & 95 \\
5 & 40 \\
5 & 85 \\
6 & 13\end{array}$ & $\begin{array}{r}682 \\
845 \\
1,030 \\
1,280 \\
1,470\end{array}$ & June 9 & $\begin{array}{l}0200 \\
0400 \\
0600 \\
0800\end{array}$ & $\begin{array}{rl}6 & 47 \\
7 & 07 \\
7 & 54 \\
19 & 8\end{array}$ & $\begin{array}{r}1,750 \\
2,320 \\
2,800 \\
71,300\end{array}$ \\
\hline
\end{tabular}


Location --Lat $47^{\circ} 51^{\prime}$, long $111^{\circ} 36^{\prime}$, in center of north line of sec 15, T $24 \mathrm{~N}$, RIE, at culverts on county road, 51 miles east of Dutton on Diamond Valley Road

Drainage area $--967 \mathrm{sq} \mathrm{ml}$

Gage-helght record --Crest stages only Altitude of gage is 3,560 ft (from topographic map)

Discharge record --Stage-discharge relation defined by current-meter measurements below $20 \mathrm{cfs}$ and by flow-through-culvert measurements at $139 \mathrm{cfs}$ and $364 \mathrm{cfs}$

Maxima --June 1964 Discharge, $364 \mathrm{cfs} J u n e ~ 21$ (gage height, $80 \mathrm{ft}$ ) 1963 to May 1964 Discharge, $139 \mathrm{cf}$ s May 3, 1964 (gage height, $374 \mathrm{ft}$ )

(121) 6-1083 Kinley Coulee tributary near Dutton, Mont

(Crest-stage station)

Location --Lat $47^{\circ} 51^{\prime}$, long $111^{\circ} 33^{\prime}$, on north line of $N \frac{1}{4}^{\frac{1}{4}} \sec 13, \mathrm{~T} 24 \mathrm{~N}, \mathrm{R} 1 \mathrm{E}$, at culverts on county road, 65 miles east of Dutton on Diamond Valley Road

Drainage area $--265 \mathrm{sq} \mathrm{mi}$

Gage-height record --Crest stages only Alt1tude of gage is $3,610 \mathrm{ft}$ (from topographic map)

Discharge record --Stage-discharge relation defined by current-meter measurements below $25 \mathrm{cf}$ 's and by flow-through-culvert measurements at $49 \mathrm{cfs}$ and $76 \mathrm{cfs}$

Maxima --June 1964 Discharge, $76 \mathrm{cfs}$ June 8 (gage height, $298 \mathrm{ft}$ ) 1963 to May 1964 Discharge, $49 \mathrm{cfs}$ May 3, 1964 (gage he1ght, $228 \mathrm{ft}$ )

(122) Teton River near Carter, Mont

(Miscellaneous site)

Location --Lat $47^{\circ} 51^{\prime} 15^{\prime \prime}$, long $110^{\circ} 58^{1} 20^{\prime \prime}$, in $N E \frac{1}{4} \sec 9, \mathrm{~T} 24 \mathrm{~N}, \mathrm{R} 6 \mathrm{E}$, just upstream from bridge on county highway, 5 miles north of Carter'

Drainage area $--1,762 \mathrm{sq} \mathrm{mi}$

Maximum --June 1964 Discharge, 84,300 cfs June 9, from slope-area measurement

\section{MISSOURI RIVER MAIN STEM}

(123) 6-1095 Missouri River at Virgelle, Mont

Location --Lat $48^{\circ} 00^{\prime} 14^{\prime \prime}$, long $110^{\circ} 15^{\prime} 19^{\prime \prime}$, in SW $\frac{1}{4} S E \frac{1}{4} \sec 13, \mathrm{~T} 26 \mathrm{~N}, \mathrm{R} 11 \mathrm{E}$, on left bank a quarter of a mile upstream from Virgelle Ferry, half a mile southwest of Virgelle, and 3 miles downstream from Spring Coulee

Drainage area $--34,379 \mathrm{sq} \mathrm{ml}$

Gage-height record--Digital-recorder tape punched at 15-minute intervals Datum of gage is 2,50750 ft above mean sea level, datum of 1929

Discharge record --Stage-discharge relation defined by current-meter measurements Mean daily discharges computed from 96 punch-tape recordings per day June $8,9,13$, may not agree precisely with that derived from discharge at indicated times

Maxima --June 1964 Discharge, 105,000 cfs 2330 hours June 10 (gage helght, $2127 \mathrm{ft}$ )

1935 to May 1964 Discharge, $122,000 \mathrm{cfs}$ June 5, 1953 (gage height, $234 \mathrm{ft}$, from floodmark), from rating curve for former site at Loma extended above $66,000 \mathrm{cfs}$, adjusted to present site

Flood in June 1908 reached a stage about $2 \mathrm{ft}$ higher than that of June 5, 1953, from information by local residents

Remarks --Flow regulated by 23 smaller irrigation reservolrs and powerplants, Canyon Ferry Reservolr (see station 23), and Tiber Reservoir (see station 103) 
Mean discharge, in cublc feet per second, 1964, of Missouri River at Virgelle, Mont

\begin{tabular}{|c|c|c|c|c|c|c|c|c|}
\hline Day & May & June & Day & May & June & Day & May & June \\
\hline $\begin{array}{r}1 \\
2 \\
3 \\
4 \\
5 \\
6 \\
7 \\
8 \\
9 \\
10\end{array}$ & $\begin{array}{r}6,460 \\
8,390 \\
10,500 \\
18,400 \\
23,500 \\
18,500 \\
16,500 \\
14,800 \\
14,800 \\
16,100\end{array}$ & $\begin{array}{l}25,100 \\
23,900 \\
24,100 \\
24,800 \\
25,100 \\
24,200 \\
23,100 \\
25,000 \\
34,600 \\
77,000\end{array}$ & $\begin{array}{l}11 \\
12 \\
13 \\
14 \\
15 \\
16 \\
17 \\
18 \\
19 \\
20\end{array}$ & $\begin{array}{l}17,500 \\
17,100 \\
17,200 \\
17,000 \\
17,000 \\
16,000 \\
14,500 \\
15,500 \\
17,700 \\
20,000\end{array}$ & $\begin{array}{l}96,600 \\
70,700 \\
51,300 \\
50,500 \\
49,900 \\
49,300 \\
48,700 \\
47,000 \\
42,800 \\
42,600\end{array}$ & $\begin{array}{l}21 \\
22 \\
23 \\
24 \\
25 \\
26 \\
27 \\
28 \\
29 \\
30 \\
31\end{array}$ & $\begin{array}{l}22,900 \\
23,500 \\
23,900 \\
21,800 \\
17,200 \\
15,800 \\
15,100 \\
15,200 \\
15,800 \\
18,200 \\
24,100\end{array}$ & $\begin{array}{r}42,900 \\
43,400 \\
41,900 \\
39,000 \\
37,300 \\
38,700 \\
39,400 \\
39,900 \\
39,300 \\
38,500 \\
--.- \\
\end{array}$ \\
\hline \multicolumn{7}{|c|}{$\begin{array}{l}\text { Monthly mean discharge, in cublc feet per second } \\
\text { Runoff, in acre-feet }\end{array}$} & $\begin{array}{r}17,130 \\
1,053,000\end{array}$ & $\begin{array}{r}41,910 \\
2,494,000\end{array}$ \\
\hline
\end{tabular}

Gage he1ght, in feet, and discharge, in cubic feet per second, at indicated time, 1964

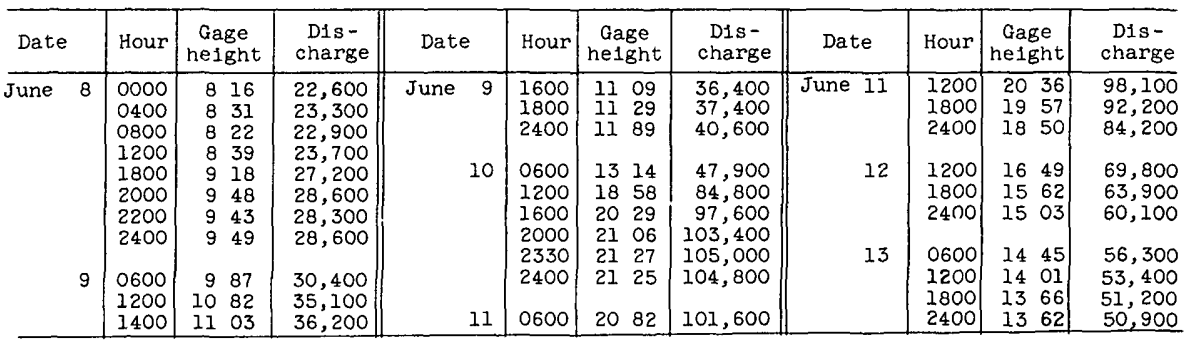

\section{JUDITH RIVER BASIN}

(124) 6-1098 South Fork Judith River near Utica, Mont

Location --Lat $46^{\circ} 45^{\prime}$, long $110^{\circ} 19^{\prime}$, in $S \frac{1}{2} \sec 34, \mathrm{~T} 12 \mathrm{~N}, \mathrm{R} 11 \mathrm{E}$, on right bank Just downstream from Trask Gulch', 8 miles upstream from confluence with Middle

Fork and 18 miles southwest of Utica

Dra1nage area $--587 \mathrm{sq} \mathrm{mi}$

Gage-height record --Water-stage recorder graph Altitude of gage is 5,300 ft (from topographic map)

D1scharge record --Stage-discharge relation defined by current-meter measurements below $180 \mathrm{cfs}$ and by slope-area measurement at $1,290 \mathrm{cfs}$

Maxima --June 1964 Discharge, $1,290 \mathrm{cfs} 2230$ hours June 8 (gage helght, $680 \mathrm{ft}$, in gage well, $74 \mathrm{ft}$, from outside floodmarks)

1958 to May 1964 Discharge, $277 \mathrm{cfs}$ May 25, 1962 (gage height, $490 \mathrm{ft}$ )

Flood of June 8,1964 , is the highest since 1927, from information by local resident

Mean d1scharge, in cub1c feet per second, 1964

\begin{tabular}{|c|c|c|c|c|c|c|c|c|}
\hline Day & May & June & Day & May & June & Day & May & June \\
\hline $\begin{array}{r}1 \\
2 \\
3 \\
4 \\
5 \\
6 \\
7 \\
8 \\
9 \\
10\end{array}$ & $\begin{array}{l}39 \\
51 \\
54 \\
43 \\
40 \\
45 \\
44 \\
47 \\
56 \\
82\end{array}$ & $\begin{array}{r}96 \\
87 \\
87 \\
83 \\
74 \\
73 \\
105 \\
421 \\
615 \\
336\end{array}$ & $\begin{array}{l}11 \\
12 \\
13 \\
14 \\
15 \\
16 \\
17 \\
18 \\
19 \\
20\end{array}$ & $\begin{array}{r}90 \\
85 \\
125 \\
149 \\
167 \\
196 \\
225 \\
206 \\
186 \\
179\end{array}$ & $\begin{array}{l}257 \\
217 \\
186 \\
164 \\
153 \\
143 \\
139 \\
129 \\
119 \\
122\end{array}$ & $\begin{array}{l}21 \\
22 \\
23 \\
24 \\
25 \\
26 \\
27 \\
28 \\
29 \\
30 \\
31\end{array}$ & $\begin{array}{r}162 \\
146 \\
127 \\
107 \\
97 \\
82 \\
76 \\
123 \\
132 \\
111 \\
103\end{array}$ & $\begin{array}{r}103 \\
93 \\
81 \\
73 \\
67 \\
64 \\
59 \\
55 \\
51 \\
50\end{array}$ \\
\hline $\begin{array}{l}\text { Monthly } \\
\text { Runoff, } \\
\text { Runoff, }\end{array}$ & $\begin{array}{l}\text { mean discha } \\
\text { In Inches } \\
\text { In acre-fee }\end{array}$ & $e$, in cub & feet & second & & & $\begin{array}{r}109 \\
2 \quad 14 \\
6,690 \\
\end{array}$ & $\begin{array}{r}143 \\
273 \\
8,530 \\
\end{array}$ \\
\hline
\end{tabular}


Gage he1ght, in feet, and discharge, in cublc feet per second, at 1nd1cated t1me, 1964, of South Fork Judith River near Utica, Mont

\begin{tabular}{|c|c|c|c|c|c|c|c|c|c|c|c|}
\hline Date & Hour & $\begin{array}{c}\text { Gage } \\
\text { he1ght }\end{array}$ & $\begin{array}{c}\text { Dis- } \\
\text { charge }\end{array}$ & Date & Hour & $\begin{array}{c}\text { Gage } \\
\text { helght }\end{array}$ & $\begin{array}{l}\text { D1s- } \\
\text { charge }\end{array}$ & Date & Hour & $\begin{array}{c}\text { Gage } \\
\text { he1ght }\end{array}$ & $\begin{array}{l}\text { Dis- } \\
\text { charge }\end{array}$ \\
\hline June 7 & $\begin{array}{l}0000 \\
0300 \\
1000 \\
1400 \\
1800 \\
2400 \\
0100 \\
0200 \\
0600 \\
\end{array}$ & $\begin{array}{ll}3 & 51 \\
3 & 54 \\
3 & 52 \\
3 & 60 \\
3 & 89 \\
4 & 38 \\
& \\
4 & 43 \\
4 & 42 \\
4 & 22 \\
\end{array}$ & $\begin{array}{r}76 \\
80 \\
77 \\
87 \\
127 \\
197 \\
\\
204 \\
203 \\
173 \\
\end{array}$ & June & $\begin{array}{l}1100 \\
1300 \\
1500 \\
1800 \\
2100 \\
2230 \\
2400 \\
\\
0200 \\
0400\end{array}$ & $\begin{array}{rr}4 & 10 \\
4 & 18 \\
4 & 55 \\
5 & 64 \\
6 & 53 \\
\text { a } 6 & 80 \\
6 & 66 \\
& \\
6 & 31 \\
6 & 01 \\
\end{array}$ & $\begin{array}{r}156 \\
167 \\
225 \\
590 \\
1,100 \\
1,290 \\
1,190 \\
\\
966 \\
791\end{array}$ & June 9 & $\begin{array}{l}0800 \\
1200 \\
1800 \\
2400 \\
\\
0800 \\
1600 \\
1900 \\
2400\end{array}$ & $\begin{array}{ll}5 & 77 \\
5 & 56 \\
5 & 35 \\
5 & 17 \\
& \\
5 & 04 \\
4 & 86 \\
4 & 86 \\
4 & 74\end{array}$ & $\begin{array}{l}658 \\
550 \\
455 \\
384 \\
\\
357 \\
312 \\
312 \\
285\end{array}$ \\
\hline
\end{tabular}

(125) 6-1100 Judith River near Utica, Mont

Location --Lat $46^{\circ} 54^{\prime}$, long $110^{\circ} 14^{\prime}$, in $\mathrm{NW} \frac{1}{4} \sec 17, \mathrm{~T} 13 \mathrm{~N}, \mathrm{R} 12 \mathrm{E}$, on left bank at Noel Ranch, $3 \frac{1}{2}$ miles downstream from confluence of South and Middle Forks and 9 miles southwest of Utica

Drainage area $--328 \mathrm{sq} \mathrm{ml}$

Gage-height record --Water-stage recorder graph Altitude of gage is 4,790 ft (by barometer

Discharge record --Stage-discharge relation defined by current-meter measurements Maxima --June 1964 Discharge, $1,070 \mathrm{cfs} 1100$ hours June 9 (gage he1ght, $577 \mathrm{ft}$ ) 1919 to May 1964 Discharge observed, 1,120 cfs June 11, 12, 1927 (gage

height, $570 \mathrm{ft}$ ), from rating curve extended above $580 \mathrm{cfs}$

Mean discharge, in cubic feet per second, 1964

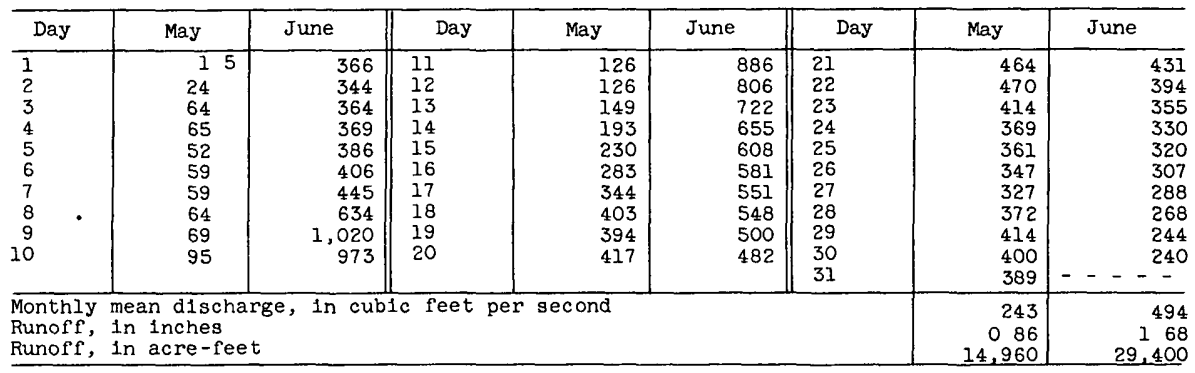

Gage he1ght, in feet, and discharge, in cub1c feet per second, at indicated time, 1964

\begin{tabular}{|c|c|c|c|c|c|c|c|c|c|c|c|}
\hline Date & Hour & $\begin{array}{c}\text { Gage } \\
\text { he1ght }\end{array}$ & $\begin{array}{c}\text { Dis- } \\
\text { charge }\end{array}$ & Date & Hour & $\begin{array}{c}\text { Gage } \\
\text { he1ght }\end{array}$ & $\begin{array}{l}\text { Dis- } \\
\text { charge }\end{array}$ & Date & Hour & $\begin{array}{c}\text { Gage } \\
\text { helght }\end{array}$ & $\begin{array}{l}\text { Dis- } \\
\text { charge }\end{array}$ \\
\hline June 7 & $\begin{array}{l}0000 \\
1200 \\
1800 \\
2100 \\
2400 \\
\\
0300 \\
0600 \\
0900 \\
1200 \\
1500\end{array}$ & $\begin{array}{ll}3 & 75 \\
3 & 80 \\
3 & 93 \\
4 & 01 \\
4 & 17 \\
& \\
4 & 17 \\
4 & 22 \\
4 & 30 \\
4 & 32 \\
4 & 62\end{array}$ & $\begin{array}{l}414 \\
428 \\
464 \\
488 \\
527 \\
\\
527 \\
536 \\
554 \\
560 \\
648\end{array}$ & June 8 & $\begin{array}{l}1800 \\
2100 \\
2400 \\
\\
0100 \\
0200 \\
0300 \\
0400 \\
0500 \\
0600 \\
0800\end{array}$ & $\begin{array}{ll}4 & 84 \\
5 & 07 \\
5 & 42 \\
5 & 12 \\
5 & 68 \\
5 & 64 \\
5 & 55 \\
5 & 75 \\
5 & 75 \\
5 & 73\end{array}$ & $\begin{array}{r}725 \\
798 \\
920 \\
\\
812 \\
1,020 \\
1,010 \\
972 \\
1,060 \\
1,060 \\
1,050\end{array}$ & June 9 & $\begin{array}{l}1000 \\
1100 \\
1500 \\
1800 \\
2100 \\
2400 \\
\\
0600 \\
1200 \\
1800 \\
2400\end{array}$ & $\begin{array}{ll}5 & 70 \\
5 & 77 \\
5 & 72 \\
5 & 67 \\
5 & 67 \\
5 & 65 \\
& \\
5 & 60 \\
5 & 55 \\
5 & 52 \\
5 & 44\end{array}$ & $\begin{array}{r}1,040 \\
1,070 \\
1,040 \\
1,020 \\
1,020 \\
1,010 \\
992 \\
972 \\
960 \\
928\end{array}$ \\
\hline
\end{tabular}

$249-7950-67-14$ 
(126) 6-1117 Casino Creek tributary near Lewistown, Mont

(Crest-stage station)

Location --Lat $47^{\circ} 00^{\prime}$, long $109^{\circ} 26^{\prime}$, in $\mathrm{NE} \frac{1}{4} \sec 9, \mathrm{~T} 14 \mathrm{~N}, \mathrm{R} 18 \mathrm{E}$, at culvert on county road, 5 miles south of Lewistown

Drainage area $--353 \mathrm{sq} \mathrm{mi}$

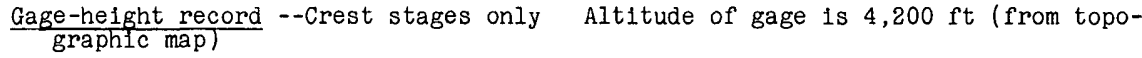

Discharge record --Stage-discharge relation defined by current-meter measurements below $16 \mathrm{cfs}$ and by flow-through-culvert measurements at 36 and $38 \mathrm{cfs}$

Maxima --June 1964 Discharge, $40 \mathrm{cfs}$ June 8 (gage height, $327 \mathrm{ft}$ )

1960 to May 1964 Discharge, $44 \mathrm{cfs}$ May 3, 1964 (gage height, $367 \mathrm{ft}$ )

(127) 6-1121 Cottonwood Creek near Moore, Mont

(Gaging station, crest-stage station beginning 1964)

Location --Lat $46^{\circ} 59^{\prime}$, long $109^{\circ} 29^{\prime}$, in $N W^{\frac{1}{4}} \sec 18, \mathrm{~T} 14 \mathrm{~N}, \mathrm{R} 18 \mathrm{E}$, on right bank $30 \mathrm{f}^{\prime} \mathrm{t}$ downstream from bridge, $9 \frac{1}{2}$ 'miles east of Moore, and 12 miles upstream from mouth

Drainage area $--479 \mathrm{sq} \mathrm{ml}$

Gage-height record --Water-stage recorder graph Altitude of gage is 4,300 ft (from topographic map)

Discharge record --Stage-discharge relation defined by current-meter measurements below $700 \mathrm{cfs}$ and by contracted-opening measurement at $1,220 \mathrm{cfs}$

Maxima --June 1964 Discharge, 1,220 cfs 0700 hours June 9 (gage he1ght, $768 \mathrm{ft}$ ) 1957 to May 1964 Discharge, $683 \mathrm{cfs}$ May 22 , 1962 (gage height, 6 $77 \mathrm{ft}$ )

\section{MISSOURI RIVER MAIN STEM}

(128) 6-1150 Missour1 River at powerplant ferry, near Zortman, Mont

Location --Lat $47^{\circ} 43^{\prime} 51^{\prime \prime}$, long $108^{\circ} 56^{\prime} 06^{\prime \prime}$, in $\mathrm{NE}_{\frac{1}{4}} \mathrm{NE} \frac{1}{4} \sec 30, \mathrm{~T} 23 \mathrm{~N}, \mathrm{R} 22 \mathrm{E}$, on left bank at powerplant ferry, $1 \frac{1}{2}$ miles downstream from woodhawk Creek and 22 miles southwest of Zortman

Drainage area $--40,763 \mathrm{sq} \mathrm{mi}$

Gage-height record --Digital-recorder tape punched at 15-minute intervals, except 2300 hours June 9 to 2300 hours June 10, 2100 hours June 13 to 0500 hours June 16, and 1500 hours June 23 to 1500 hours June 24, for which graphs were drawn based on staff-gage readings

Discharge record --Stage-discharge relation defined by current-meter measurements Mean daily discharges computed from 96 punch-tape recordings per day June 9,11 , 12 may not agree precisely with that derived from discharge at indicated times

Maxima --June 1964 Discharge, $114,700 \mathrm{cfs} 2000$ hours June 11 (gage height, $1974 \mathrm{ft}$

1934 to May 1964 Discharge, $137,000 \mathrm{cfs}$ June 6, 1953 (gage height, $2220 \mathrm{ft}$, from graph based on gage readings), maximum gage height, $3016 \mathrm{ft}$ Mar '19, 1947 (1ce jam)

Remarks -Flow regulated by 24 small irrigation reservolrs and powerplants, Canyon Reservolr (see station 23), and Tiber Reservoir (see station 103) 
Mean discharge, in cublc feet per second, 1964, of Missour1 River at powerplant ferry near Zortman, Mont

\begin{tabular}{|c|c|c|c|c|c|c|c|c|}
\hline Day & May & June & Day & May & June & Day & May & June \\
\hline $\begin{array}{r}1 \\
2 \\
3 \\
4 \\
5 \\
6 \\
7 \\
8 \\
9 \\
10\end{array}$ & $\begin{array}{r}7,980 \\
7,500 \\
11,500 \\
16,000 \\
27,300 \\
25,900 \\
22,000 \\
19,000 \\
17,100 \\
17,100\end{array}$ & $\begin{array}{l}26,600 \\
26,500 \\
25,600 \\
25,900 \\
26,500 \\
26,500 \\
25,700 \\
24,900 \\
34,300 \\
58,300\end{array}$ & $\begin{array}{l}11 \\
12 \\
13 \\
14 \\
15 \\
16 \\
17 \\
18 \\
19 \\
20\end{array}$ & $\begin{array}{l}18,700 \\
19,200 \\
18,600 \\
18,500 \\
18,400 \\
18,600 \\
16,900 \\
16,300 \\
17,800 \\
20,200\end{array}$ & $\begin{array}{r}105,000 \\
101,000 \\
71,900 \\
58,500 \\
54,600 \\
54,500 \\
53,000 \\
51,500 \\
48,900 \\
48,700\end{array}$ & $\begin{array}{l}21 \\
22 \\
23 \\
24 \\
25 \\
26 \\
27 \\
28 \\
29 \\
30 \\
31\end{array}$ & $\begin{array}{l}22,800 \\
25,000 \\
25,700 \\
25,200 \\
22,000 \\
18,200 \\
16,900 \\
16,500 \\
16,600 \\
17,700 \\
20,800\end{array}$ & $\begin{array}{r}48,700 \\
48,800 \\
49,000 \\
46,600 \\
41,500 \\
41,900 \\
43,100 \\
43,900 \\
43,400 \\
42,500 \\
--\quad---\end{array}$ \\
\hline \multicolumn{7}{|c|}{$\begin{array}{l}\text { Monthly mean discharge, in cublc feet per second } \\
\text { Runoff, in acre-feet }\end{array}$} & $\begin{array}{r}18,770 \\
1,154,000\end{array}$ & $\begin{array}{r}46,590 \\
2,772,000\end{array}$ \\
\hline
\end{tabular}

Gage he1ght, in feet, and discharge, in cublc feet per second, at indicated time, 1964

\begin{tabular}{|c|c|c|c|c|c|c|c|c|c|c|c|}
\hline Date & Hour & $\begin{array}{c}\text { Gage } \\
\text { helght }\end{array}$ & $\begin{array}{c}\text { D1s- } \\
\text { charge }\end{array}$ & Date & Hour & $\begin{array}{c}\text { Gage } \\
\text { he1ght }\end{array}$ & $\begin{array}{l}\text { D1s- } \\
\text { charge }\end{array}$ & Date & Hour & $\begin{array}{c}\text { Gage } \\
\text { helght }\end{array}$ & $\begin{array}{c}\text { D1s- } \\
\text { charge }\end{array}$ \\
\hline June 9 & $\begin{array}{l}0000 \\
0600 \\
1200 \\
1800 \\
2400\end{array}$ & $\begin{array}{rr}8 & 50 \\
8 & 97 \\
9 & 73 \\
10 & 48 \\
11 & 24 \\
11 & 95 \\
12 & 77 \\
13 & 73 \\
15 & 38 \\
17 & 75 \\
\end{array}$ & $\begin{array}{l}25,600 \\
28,600 \\
33,900 \\
39,500 \\
45,200 \\
50,500 \\
56,900 \\
64,500 \\
77,700 \\
96,800\end{array}$ & June 11 & $\begin{array}{l}1200 \\
1600 \\
2000 \\
2400 \\
\\
0600 \\
1200 \\
1800 \\
2400 \\
0200 \\
0400\end{array}$ & $\begin{array}{ll}19 & 22 \\
19 & 64 \\
19 & 74 \\
19 & 61 \\
19 & 12 \\
18 & 31 \\
17 & 31 \\
16 & 31 \\
15 & 96 \\
15 & 64\end{array}$ & $\begin{array}{r}110,000 \\
113,800 \\
114,700 \\
113,500 \\
109,100 \\
101,800 \\
93,100 \\
84,600 \\
81,700 \\
78,900\end{array}$ & June 13 & $\begin{array}{l}0600 \\
0800 \\
1000 \\
1200 \\
1400 \\
1600 \\
1800 \\
2000 \\
2200 \\
2400\end{array}$ & $\begin{array}{ll}15 & 33 \\
15 & 12 \\
14 & 93 \\
14 & 74 \\
14 & 59 \\
14 & 36 \\
14 & 22 \\
14 & 05 \\
13 & 79 \\
13 & 65\end{array}$ & $\begin{array}{l}76,300 \\
74,500 \\
72,900 \\
71,300 \\
70,000 \\
68,100 \\
66,900 \\
65,400 \\
63,300 \\
62,200\end{array}$ \\
\hline
\end{tabular}

\section{MUSSELSHELL RIVER BASIN}

(129) 6-1305 Musselshell River at Mosby, Mont

Location --Lat $47^{\circ} 00^{\prime}$, long $107^{\circ} 54^{\prime}$, near northwest corner of sec $11, T 14 \mathrm{~N}$, $\mathrm{R} 30 \mathrm{E}$, on left bank $800 \mathrm{ft}$ downstream from highway bridge, half a mile west of Mosby and 6 miles downstream from Flatwlllow Creek

Drainage area $--7,846 \mathrm{sq} \mathrm{mi}$

Gage-helght record --Water-stage recorder graph Altitude of gage is 2,500 ft (by barometer

Discharge record --Stage-discharge relation defined by current-meter measurements

Maxima --June 1964 Discharge, 4,920 cfs 2330 hours June 21 (gage he1ght, $1000 \mathrm{ft}$ ) 1929-32, 1934 to May 1964 Discharge, 18,000 cfs June 18, 1944 (gage he1ght,

$1443 \mathrm{ft}$, at site $800 \mathrm{ft}$ upstream and at datum $112 \mathrm{ft}$ higher), from rating curve extended above $10,000 \mathrm{cfs}$

Remarks --Some regulation by Durand, Martinsdale, and Deadmans Basin Reservolrs

(combined capacity, 102,340 acre-ft)

Mean discharge, in cublc feet per second, 1964

\begin{tabular}{|c|c|c|c|c|c|c|c|c|}
\hline Day & May & June & Day & May & June & Day & May & June \\
\hline $\begin{array}{r}1 \\
2 \\
3 \\
4 \\
5 \\
6 \\
7 \\
8 \\
9 \\
10\end{array}$ & $\begin{array}{r}51 \\
52 \\
370 \\
1,160 \\
1,410 \\
1,390 \\
1,240 \\
1,060 \\
850 \\
676\end{array}$ & $\begin{array}{l}199 \\
199 \\
308 \\
359 \\
320 \\
271 \\
242 \\
222 \\
233 \\
378\end{array}$ & $\begin{array}{l}11 \\
12 \\
13 \\
14 \\
15 \\
16 \\
17 \\
18 \\
19 \\
20\end{array}$ & $\begin{array}{l}565 \\
459 \\
408 \\
380 \\
370 \\
348 \\
334 \\
328 \\
314 \\
298\end{array}$ & $\begin{array}{l}1,540 \\
3,100 \\
3,010 \\
2,740 \\
2,660 \\
2,240 \\
1,880 \\
2,380 \\
3,870 \\
4,380\end{array}$ & $\begin{array}{l}21 \\
22 \\
23 \\
24 \\
25 \\
26 \\
27 \\
28 \\
29 \\
30 \\
31\end{array}$ & $\begin{array}{l}286 \\
268 \\
250 \\
268 \\
274 \\
310 \\
328 \\
292 \\
239 \\
212 \\
201\end{array}$ & $\begin{array}{r}4,590 \\
3,840 \\
3,060 \\
2,600 \\
2,310 \\
2,100 \\
2,000 \\
1,850 \\
1,690 \\
1,660 \\
-\quad-\quad-\quad\end{array}$ \\
\hline $\begin{array}{l}\text { Monthl } \\
\text { Runof }\end{array}$ & $\begin{array}{l}\text { discha } \\
\text { cre-fee }\end{array}$ & In cu & $t$ & & & & $\begin{array}{r}484 \\
29,730\end{array}$ & $\begin{array}{r}1,874 \\
111,500\end{array}$ \\
\hline
\end{tabular}


Gage helght, in feet, and discharge, in cublc feet per second, at ind1cated time, 1964, of Musselshell River at Mosby, Mont

\begin{tabular}{|c|c|c|c|c|c|c|c|c|c|c|c|}
\hline Date & Hour & $\begin{array}{c}\text { Gage } \\
\text { he1ght }\end{array}$ & $\begin{array}{l}\text { Dis- } \\
\text { charge }\end{array}$ & Date & Hour & $\begin{array}{c}\text { Gage } \\
\text { helght }\end{array}$ & $\begin{array}{l}\text { D1s- } \\
\text { charge }\end{array}$ & Date & Hour & $\begin{array}{c}\text { Gage } \\
\text { height }\end{array}$ & $\begin{array}{c}\text { Dis- } \\
\text { charge }\end{array}$ \\
\hline June 10 & $\begin{array}{l}0000 \\
0300 \\
0600 \\
0900 \\
1200 \\
1800 \\
2100 \\
2400\end{array}$ & $\begin{array}{ll}3 & 24 \\
3 & 27 \\
3 & 37 \\
3 & 47 \\
3 & 58 \\
3 & 90 \\
4 & 12 \\
4 & 40\end{array}$ & $\begin{array}{l}233 \\
242 \\
271 \\
301 \\
338 \\
455 \\
550 \\
700\end{array}$ & June 11 & $\begin{array}{l}0300 \\
0600 \\
1200 \\
1800 \\
2100 \\
2400 \\
0600\end{array}$ & $\begin{array}{ll}4 & 82 \\
5 & 24 \\
5 & 74 \\
6 & 17 \\
6 & 63 \\
6 & 67 \\
7 & 69\end{array}$ & $\begin{array}{r}952 \\
1,230 \\
1,580 \\
1,900 \\
2,240 \\
2,270 \\
3,070\end{array}$ & June 12 & $\begin{array}{l}1200 \\
1400 \\
1500 \\
1800 \\
2400\end{array}$ & $\begin{array}{ll}8 & 04 \\
8 & 07 \\
8 & 07 \\
7 & 32 \\
7 & 73\end{array}$ & $\begin{array}{l}3,350 \\
3,380 \\
3,380 \\
3,260 \\
3,100\end{array}$ \\
\hline
\end{tabular}

\section{MISSOURI RIVER MAIN STEM}

(130) 6-1315 Fort Peck Reservoir at Fort Peck, Mont

Location --Lat $48^{\circ} 00^{\prime} 26^{\prime \prime}$, long $106^{\circ} 23^{\prime} 49^{\prime \prime}$, in sec $14, \mathrm{~T} 26 \mathrm{~N}, \mathrm{R} 41 \mathrm{E}$, in No 4 emergency gate shaft of dam on Missourl River at Fort Peck, 2 miles downstream from Bear Creek, $9 \frac{1}{2}$ miles southwest of Nashua, and about $9 \frac{1}{2}$ miles upstream from Milk River

Drainage area $--57,500 \mathrm{sq} \mathrm{mi}$

Gage-helght record - Water-stage recorder graph Datum of gage is at mean sea level, datum of 1929

Maxima --June 1964 Contents, 15,220,000 acre-ft 2400 hours June 30 (elevation, $2,2315 \mathrm{ft}$ )

1937 to May 1964 Contents, 18,170,000 acre-ft July 15, 1948 (elevation, $2,24480 \mathrm{ft}$ )

Remarks --Reservoir is formed by earthfill dam completed in 1939, storage began in 1937 Total capacity, 19,410,000 acre-ft below elevation 2,250 ft (top of 25-foot gates) Normal operating level, 18,450,000 acre-ft (elevation, 2,246 ft) Elevation of crest of spillway, 2,225 ft Dead storage, 617,000 acre-ft below elevation 2,095 ft Minimum operating level, 2,160 ft for on-site power generation (usable contents, 4,535,000 acre-ft) Water is stored for navigation, recreation, flood control and power generation Elevations materially affected by wind Elevations and capacity table furnished by Corps of Engineers Figures given here represent total contents

Elevation, in feet, and contents, in thousands of acre-feet, at 2400 hours of indicated day, 1964

\begin{tabular}{|c|c|c|c|c|c|c|c|c|c|}
\hline \multirow{2}{*}{ Day } & \multicolumn{2}{|c|}{ May } & \multicolumn{2}{|c|}{ June } & \multirow{2}{*}{ Day } & \multicolumn{2}{|c|}{ May } & \multicolumn{2}{|c|}{ June } \\
\hline & Elevation & Contentst & Elevation & Contentst & & Elevation & Contentst & Elevation & Contentst \\
\hline $\begin{array}{l}1 \\
2 \\
3 \\
4 \\
5\end{array}$ & $\begin{array}{ll}2,214 & 4 \\
2,214 & 4 \\
2,214 & 9 \\
2,215 & 1 \\
2,215 & 2\end{array}$ & $\begin{array}{l}11,920 \\
11,920 \\
12,010 \\
12,040 \\
12,060\end{array}$ & $\begin{array}{ll}2,219 & 3 \\
2,219 & 5 \\
2,219 & 7 \\
2,219 & 9 \\
2,220 & 2\end{array}$ & $\begin{array}{l}12,810 \\
12,850 \\
12,890 \\
12,920 \\
12,980\end{array}$ & $\begin{array}{l}16 \\
17 \\
18 \\
19 \\
20\end{array}$ & $\begin{array}{ll}2,216 & 6 \\
2,216 & 7 \\
2,216 & 8 \\
2,216 & 9 \\
2,217 & 2\end{array}$ & $\begin{array}{l}12,310 \\
12,330 \\
12,350 \\
12,370 \\
12,420\end{array}$ & $\begin{array}{ll}2,225 & 4 \\
2,225 & 9 \\
2,226 & 8 \\
2,227 & 3 \\
2,227 & 8\end{array}$ & $\begin{array}{l}13,980 \\
14,080 \\
14,260 \\
14,360 \\
14,460\end{array}$ \\
\hline $\begin{array}{l}11 \\
12 \\
13 \\
14 \\
15\end{array}$ & $\begin{array}{ll}2,215 & 8 \\
2,216 & 0 \\
2,216 & 1 \\
2,216 & 3 \\
2,216 & 4\end{array}$ & $\begin{array}{l}12,170 \\
12,200 \\
12,220 \\
12,260 \\
12,280\end{array}$ & $\begin{array}{ll}2,222 & 0 \\
2,222 & 8 \\
2,223 & 6 \\
2,224 & 3 \\
2,224 & 8\end{array}$ & $\begin{array}{l}13,320 \\
13,480 \\
13,630 \\
13,770 \\
13,870\end{array}$ & $\begin{array}{l}26 \\
27 \\
28 \\
29 \\
30 \\
31\end{array}$ & $\begin{array}{ll}2,218 & 3 \\
2,218 & 4 \\
2,218 & 5 \\
2,218 & 8 \\
2,218 & 9 \\
2,219 & 1\end{array}$ & $\begin{array}{l}12,630 \\
12,650 \\
12,660 \\
12,720 \\
12,740 \\
12,780\end{array}$ & $\begin{array}{cc}2,230 & 1 \\
2,230 & 5 \\
2,230 & 9 \\
2,231 & 1 \\
2,231 & 5 \\
- & \end{array}$ & $\begin{array}{l}14,930 \\
15,020 \\
15,100 \\
15,140 \\
15,220 \\
=\end{array}$ \\
\hline
\end{tabular}

$t$ In thousands of acre-feet 


\section{MILK RIVER BASIN}

(131) 6-1322 South Fork Milk River near Babb, Mont

(International gaging station)

Location --Lat $48^{\circ} 45^{\prime} 20^{\prime \prime}$, long $113^{\circ} 10^{\prime} 00^{\prime \prime}$, in $N W^{\frac{1}{4}} \sec 34, T 35 N, R 12 \mathrm{~W}$, on right bank $300 \mathrm{ft}$ upstream from bridge on FAS 464 ("Duck Lake Road")', $14 \frac{1}{2}$ milés southeast of $\mathrm{Babb}$, and $15 \frac{1}{2}$ miles northwest of Browning

Drainage area $--686 \mathrm{sq} \mathrm{mi}$

Gage-height record --Water-stage recorder graph Datum of gage is $4,7316 \mathrm{ft}$ above mean sea level, datum of 1929

Discharge record --Stage-discharge relation defined by current-meter measurements below $250 \mathrm{cfs}$ and by slope-area measurement (made at site 3 miles downstream and corrected for intervening drainage) at $12,000 \mathrm{cfs}$

Maxima --June 1964 Discharge, $12,000 \mathrm{cfs} 1300$ hours June 8 (gage he1ght, $661 \mathrm{ft}$ ) 1961 to May 1964 Discharge, about $500 \mathrm{cfs}$ Feb 5, 1963 (gage height, $533 \mathrm{ft}$, from floodmark, backwater from ice)

Mean discharge, in cub1c feet per second, 1964

\begin{tabular}{|c|c|c|c|c|c|c|c|c|}
\hline Day & May & June & Day & May & June & Day & May & June \\
\hline $\begin{array}{rr}1 & \\
2 & \\
3 & \\
4 & \\
5 & \\
6 & \\
7 & \\
8 & \\
9 & \ldots \\
10 & \end{array}$ & $\begin{array}{r}82 \\
155 \\
148 \\
148 \\
143 \\
132 \\
132 \\
143 \\
159 \\
154\end{array}$ & $\begin{array}{r}86 \\
78 \\
76 \\
82 \\
82 \\
88 \\
130 \\
4,940 \\
734 \\
355\end{array}$ & $\begin{array}{l}11 \\
12 \\
13 \\
14 \\
15 \\
16 \\
17 \\
18 \\
19 \\
20\end{array}$ & $\begin{array}{r}145 \\
117 \\
114 \\
108 \\
90 \\
86 \\
97 \\
112 \\
101 \\
101\end{array}$ & $\begin{array}{l}288 \\
248 \\
230 \\
206 \\
218 \\
244 \\
244 \\
189 \\
167 \\
151\end{array}$ & $\begin{array}{l}21 \\
22 \\
23 \\
24 \\
25 \\
26 \\
27 \\
28 \cdot . \\
29 \\
30 \\
31\end{array}$ & $\begin{array}{r}97 \\
94 \\
82 \\
68 \\
65 \\
59 \\
59 \\
103 \\
168 \\
117 \\
94\end{array}$ & $\begin{array}{r}141 \\
132 \\
124 \\
115 \\
106 \\
101 \\
101 \\
93 \\
89 \\
87 \\
-+-\quad-\end{array}$ \\
\hline $\begin{array}{l}\text { Monthly } \\
\text { Runoff, } \\
\text { Runoff, }\end{array}$ & $\begin{array}{l}\text { mean discha } \\
\text { in Inches } \\
\text { in acre-fee }\end{array}$ & , In cul & feet & second & . & $\cdots$ & $\begin{array}{r}112 \\
1.88 \\
6,890 \\
\end{array}$ & $\begin{array}{r}331 \\
5.38 \\
19,690 \\
\end{array}$ \\
\hline
\end{tabular}

Gage height, In feet, and discharge, In cubic feet per second, at indicated t1me, 1964

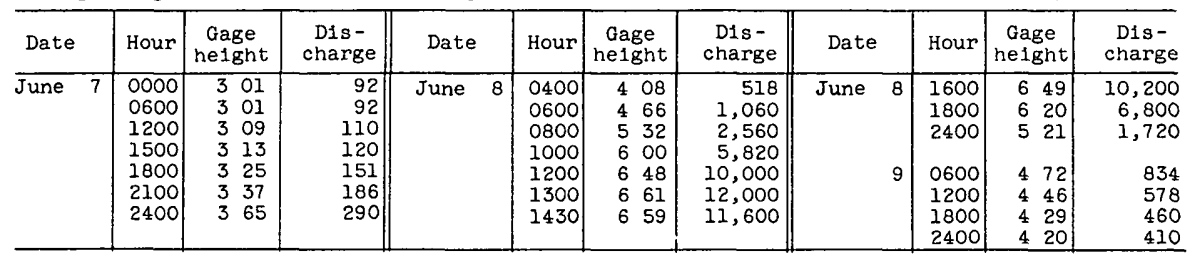

(132) 6-1322 5 Livermore Creek near Babb, Mont

(Crest-stage station)

Location --Lat $48^{\circ} 46^{\prime}$, long $113^{\circ} 11^{\prime}$, in $\mathrm{NE} \frac{1}{4} \sec 28, \mathrm{~T} 35 \mathrm{~N}, \mathrm{R} 12 \mathrm{~W}$, at bridge on State Highway 464 , $13 \frac{1}{2}$ miles southeast of Babb Gage destroyed by flood Datum of gage not recovered

Drainage area $--250 \mathrm{sq} \mathrm{mi}$

Gage-height record --Crest stages only Altitude of gage is 4,730 ft (from topographic map)

Maxima --June 1964 Discharge, 4,880 cfs 1600 hours June 8, from slope-area measurement

1962 to May 1964 Discharge, $152 \mathrm{cfs}$ Apr 13, 1962 (gage height, $343 \mathrm{ft}$ ), from flow-through-culvert measurement 
(133) South Fork Milk River below Livermore Creek, near Babb, Mont

\section{(M1scellaneous site)}

Location --Lat $48^{\circ} 45^{\prime} 00^{\prime \prime}$, long $113^{\circ} 07^{\prime} 30^{\prime \prime}$, in $\mathrm{SE}_{\frac{1}{4}} \sec 13$, T $35 \mathrm{~N}, \mathrm{R} 12 \mathrm{~W}$, at Jeff Harwood Ranch, 2 miles downstream from Livermore Creek, and 15 miles southeast of Babb

Drainage area $--101 \mathrm{sq} \mathrm{mi}$

Maximum --June 1964 Discharge, 14,900 cfs 1600 hours June 8, from slope-area measurement

\section{(134) 6-1323 Middle Fork Milk River near Babb, Mont}

\section{(Crest-stage station)}

Location --Lat $48^{\circ} 51^{\prime}$, long $113^{\circ} 13^{\prime}$, in $\mathrm{SE} \frac{1}{4} \sec 30, \mathrm{~T} 36 \mathrm{~N}, \mathrm{R} 12 \mathrm{~W}$, at culvert on State Highway 464,10 miles east of Babb

Drainage area $--14 \quad 0 \mathrm{sq} \mathrm{mi}$

Gage-he1ght record --Crest stages only Altitude of gage is 4,810 ft (from topograph1c map)

Discharge record --Stage-discharge relation defined by current-meter measurements below $25 \mathrm{cf}$ s and by flow-over-road plus flow-through-culvert measurements at 107 and 558 cfs

Maxima --June 1964 D1scharge, $558 \mathrm{cfs} 1430$ hours June 8 (gage he1ght, $296 \mathrm{ft}$ ) 1962 to May 1964 Discharge, $107 \mathrm{cfs}$ Apr 13, 1962 (gage he1ght, $262 \mathrm{ft}$ )

\section{(135) 6-1324 Dry Fork Milk River near Babb, Mont}

\section{(Crest-stage station)}

Location --Lat $48^{\circ} 50^{\prime}$, long $113^{\circ} 12^{\prime}$, In $\mathrm{SE} \frac{1}{4} \sec 32, \mathrm{~T} 36 \mathrm{~N}, \mathrm{R} 12 \mathrm{~W}$, at bridge on State Highway 464 ,' 11 miles east' of $\mathrm{Babb}$

Drainage area $--174 \mathrm{sq} \mathrm{mi}$

Gage-height record --Crest stages only Alt1tude of gage is 4,750 ft (from topographic map)

Discharge record --Stage-discharge relation defined by current-meter measurements below $65 \mathrm{cf}$ 's and by contracted-opening measurement at $1,880 \mathrm{cfs}$

Maxima --June 1964 Discharge, 1,880 cfs 1400 hours June 8 (gage he1ght, $520 \mathrm{ft}$ ) 1962 to May 1964 Dischárge, $394 \mathrm{cfs}$ Apr 13, 1962 (gage height, $396 \mathrm{ft}$ ), from flow-through-culvert measurement

\section{(136) 6-1327 Milk River near Del Bonita, Mont}

Location --Lat $48^{\circ} 57^{\prime}$, long $112^{\circ} 45^{\prime}$, in center of $N \frac{1}{2} \sec 23, T 37 \mathrm{~N}, \mathrm{R} 9 \mathrm{~W}$, at bridge on State Highway 483 , $3 \frac{1}{2}$ miles southeast of Del Bonita Port of Entry

Drainage area $--325 \mathrm{sq} \mathrm{mi}$

Gage-height record --Once-daily readings of staff gage, infrequent engineer's gage readings and crest stages Graph based on gage readings used May 2-6, June 7-24 Altitude of gage is $4,030 \mathrm{ft}$ (from topographic map)

D1scharge record --Stage-discharge relation defined by current-meter measurements below $3,800 \mathrm{cfs}$ and by sum of flow-over-road, contracted-opening, and four flowthrough-culvert measurements at $17,300 \mathrm{cfs}$

Maxima --June 1964 D1scharge, 17,300 cfs 2330 hours June 8 (gage height, $90 \mathrm{ft}$, from floodmarks)

1905-30, 1962 to May 1964 Discharge, about 13,000 cfs June 6, 1908 (gage he1ght, $154 \mathrm{ft}$, at site 5 miles upstream and at datum then in use), from rating curve extended above $600 \mathrm{cfs}$ on basis of velocity-area study 
Mean discharge, in cublc feet per second, 1964, of M1lk River near Del Bon1ta, Mont

\begin{tabular}{|c|c|c|c|c|c|c|c|c|}
\hline Day & May & June & Day & May & June & Day & May & June \\
\hline $\begin{array}{r}1 \\
2 \\
3 \\
4 \\
5 \\
6 \\
7 \\
8 \\
9 \\
10\end{array}$ & $\begin{array}{r}262 \\
550 \\
1,740 \\
1,350 \\
907 \\
496 \\
402 \\
345 \\
304 \\
317\end{array}$ & $\begin{array}{r}166 \\
104 \\
138 \\
141 \\
145 \\
127 \\
150 \\
3,380 \\
5,780 \\
1,880\end{array}$ & $\begin{array}{l}11 . \\
12 \\
13 \\
14 \\
15 \\
16 \\
17 \\
18 \\
19 \\
20\end{array}$ & $\begin{array}{l}331 \\
284 \\
262 \\
234 \\
231 \\
198 \\
204 \\
265 \\
231 \\
216\end{array}$ & $\begin{array}{r}1,030 \\
662 \\
507 \\
458 \\
414 \\
680 \\
924 \\
544 \\
343 \\
286\end{array}$ & $\begin{array}{l}21 \\
22 \\
23 \\
24 \\
25 \\
26 \\
27 \\
28 \\
29 \\
30 \\
31\end{array}$ & $\begin{array}{l}222 \\
198 \\
193 \\
166 \\
155 \\
127 \\
122 \\
141 \\
234 \\
284 \\
204 \\
\end{array}$ & $\begin{array}{r}209 \\
139 \\
221 \\
172 \\
161 \\
153 \\
128 \\
126 \\
125 \\
-125 \\
-\end{array}$ \\
\hline $\begin{array}{l}\text { Monthly } \\
\text { Runoff, } \\
\text { Runoff, }\end{array}$ & $\begin{array}{l}\text { mean discha } \\
\text { In inches } \\
\text { In acre-fee }\end{array}$ & $e$, in cub & feet & cond & & & $\begin{array}{r}360 \\
1 \quad 28 \\
22,770\end{array}$ & $\begin{array}{r}647 \\
2 \quad 22 \\
38,500 \\
\end{array}$ \\
\hline
\end{tabular}

Gage height, in feet, and discharge, in cub1c feet per second, at ind1cated time, 1964

\begin{tabular}{|c|c|c|c|c|c|c|c|c|c|c|c|}
\hline Date & Hour & $\begin{array}{c}\text { Gage } \\
\text { helght }\end{array}$ & $\begin{array}{l}\text { D1s- } \\
\text { charge }\end{array}$ & Date & Hour & $\begin{array}{c}\text { Gage } \\
\text { helght }\end{array}$ & $\begin{array}{l}\text { D1s- } \\
\text { charge }\end{array}$ & Date & Hour & $\begin{array}{c}\text { Gage } \\
\text { height }\end{array}$ & $\begin{array}{l}\text { Dis- } \\
\text { charge }\end{array}$ \\
\hline June 7 & $\begin{array}{l}0000 \\
1200 \\
1800 \\
2100 \\
2400\end{array}$ & $\begin{array}{ll}2 & 02 \\
2 & 03 \\
2 & 06 \\
2 & 23 \\
2 & 53\end{array}$ & $\begin{array}{l}132 \\
134 \\
141 \\
184 \\
275\end{array}$ & June 8 & $\begin{array}{l}1500 \\
1800 \\
2100 \\
2330 \\
2400\end{array}$ & $\begin{array}{ll}5 & 70 \\
5 & 85 \\
6 & 50 \\
9 & 00 \\
8 & 95\end{array}$ & $\begin{array}{r}3,800 \\
4,180 \\
6,000 \\
17,300 \\
17,000\end{array}$ & June 9 & $\begin{array}{l}1200 \\
1800 \\
2400\end{array}$ & $\begin{array}{ll}6 & 40 \\
6 & 15 \\
5 & 70\end{array}$ & $\begin{array}{l}4,600 \\
3,920 \\
2,910\end{array}$ \\
\hline 8 & $\begin{array}{l}0300 \\
0600 \\
1200\end{array}$ & $\begin{array}{ll}2 & 70 \\
2 & 80 \\
4 & 50 \\
\end{array}$ & $\begin{array}{r}331 \\
366 \\
1,650 \\
\end{array}$ & 9 & $\begin{array}{l}0200 \\
0400 \\
0600\end{array}$ & $\begin{array}{ll}8 & 10 \\
7 & 15 \\
6 & 80\end{array}$ & $\begin{array}{r}11,800 \\
7,300 \\
5,900\end{array}$ & & 2400 & $\begin{array}{ll}5 & 00 \\
4 & 50\end{array}$ & $\begin{array}{l}1,770 \\
1,180\end{array}$ \\
\hline
\end{tabular}

(137) 6-1330 Milk River at western crossing of international boundary

(International gaging station)

Location --Lat $49^{\circ} 00^{\prime} 30^{\prime \prime}$, long $112^{\circ} 32^{\prime} 40^{\prime \prime}$, in $\mathrm{NE} \frac{1}{4} \sec 1, \mathrm{~T} 1, \mathrm{R} 20 \mathrm{~W}$, fourth mer1dlan, on left bank half a mile north of international boundary, 22 miles upstream from North Milk River, and 23 miles southwest of Milk River, Alberta

Drainage area $-397 \mathrm{sq} \mathrm{ml}$

Gage-height record --Water-stage recorder graph Alt1tude of gage is $3,820 \mathrm{ft}$ (from topographic map)

Discharge record --Stage-discharge relation defined by current-meter measurements

Maxima --June 1964 Discharge, 7,930 cfs 0600 hours June 9 (gage height, $977 \mathrm{ft}$ ) 1931 to May 1964 Discharge, 4,750 cfs June 18, 1948 (gage helght, $683 \mathrm{ft}$, at site $04 \mathrm{mile}$ downstream and at datum then in use), from rating curve extended above $1,300 \mathrm{cfs}$

Mean discharge, in cubic feet per second, 1964

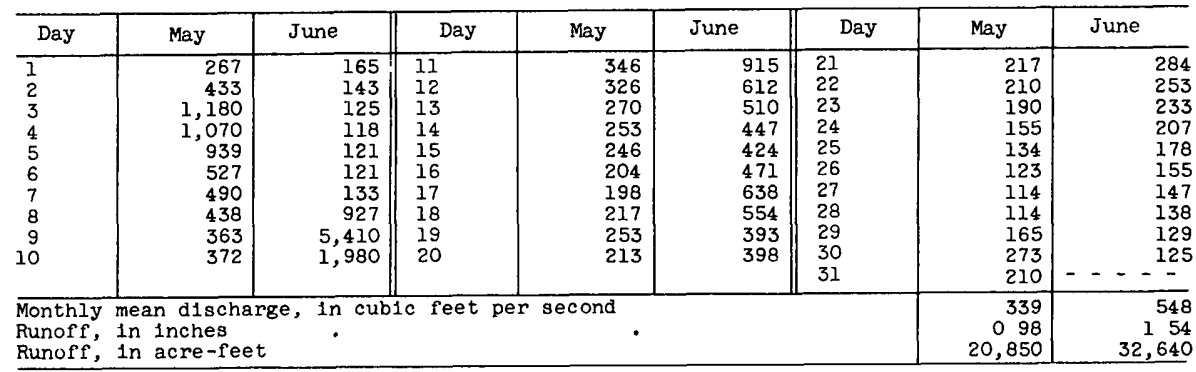


Gage he1ght, in feet, and discharge, in cub1c feet per second, at 1nd1cated time, 1964, of Milk River at western crossing of international boundary

\begin{tabular}{|c|c|c|c|c|c|c|c|c|c|c|c|}
\hline Date & Hour & $\begin{array}{c}\text { Gage } \\
\text { height }\end{array}$ & $\begin{array}{c}\text { Dis- } \\
\text { charge }\end{array}$ & Date & Hour & $\begin{array}{c}\text { Gage } \\
\text { he1ght }\end{array}$ & $\begin{array}{l}\text { D1s- } \\
\text { charge }\end{array}$ & Date & Hour & $\begin{array}{c}\text { Gage } \\
\text { height }\end{array}$ & $\begin{array}{l}\text { Dis- } \\
\text { charge }\end{array}$ \\
\hline June 7 & $\begin{array}{l}0000 \\
1200 \\
1800 \\
2400\end{array}$ & $\begin{array}{ll}3 & 39 \\
3 & 38 \\
3 & 45 \\
3 & 57 \\
& \\
3 & 70\end{array}$ & $\begin{array}{l}123 \\
121 \\
140 \\
178\end{array}$ & June 8 & $\begin{array}{l}1700 \\
1900 \\
2100 \\
2400\end{array}$ & $\begin{array}{ll}5 & 59 \\
5 & 57 \\
5 & 76 \\
6 & 30 \\
& \end{array}$ & $\begin{array}{l}1,400 \\
1,380 \\
1,550 \\
2,080\end{array}$ & June 10 & $\begin{array}{l}0600 \\
1000 \\
1400 \\
1800 \\
2400\end{array}$ & $\begin{array}{ll}6 & 54 \\
6 & 20 \\
6 & 02 \\
5 & 83 \\
5 & 49\end{array}$ & $\begin{array}{l}2,310 \\
1,940 \\
1,750 \\
1,560 \\
1,260\end{array}$ \\
\hline 8 & $\begin{array}{l}0200 \\
0600 \\
0700 \\
0900 \\
1100 \\
1200 \\
1400 \\
\end{array}$ & $\begin{array}{ll}3 & 70 \\
4 & 16 \\
4 & 12 \\
4 & 31 \\
4 & 80 \\
4 & 89 \\
5 & 30 \\
\end{array}$ & $\begin{array}{r}226 \\
443 \\
420 \\
519 \\
790 \\
848 \\
1,150 \\
\end{array}$ & 9 & $\begin{array}{l}0100 \\
0300 \\
0500 \\
0600 \\
1200 \\
1700 \\
2400\end{array}$ & $\begin{array}{ll}6 & 49 \\
7 & 72 \\
9 & 72 \\
9 & 77 \\
9 & 12 \\
8 & 40 \\
7 & 28 \\
\end{array}$ & $\begin{array}{l}2,290 \\
3,930 \\
7,850 \\
7,930 \\
6,550 \\
5,110 \\
3,240\end{array}$ & 11 & $\begin{array}{l}0600 \\
1200 \\
2400\end{array}$ & $\begin{array}{ll}5 & 15 \\
5 & 00 \\
4 & 74\end{array}$ & $\begin{array}{l}988 \\
881 \\
718\end{array}$ \\
\hline
\end{tabular}

(138) 6-1335 North Fork Milk River above St Mary Canal, near Browning, Mont

\section{(International gaging station)}

Location --Lat $48^{\circ} 59^{\prime}$, long $113^{\circ} 03^{\prime}$, in $\mathrm{NE} \frac{1}{4} \sec 16, \mathrm{~T} 37 \mathrm{~N}, \mathrm{R} 11 \mathrm{~W}$, on left bank $1 \frac{1}{4}$ mlles upstream from outlet of canal, 2 miles south of international boundary, and 29 miles north of Browning

Dra1nage area $--618 \mathrm{sq} \mathrm{ml}$

Gage-height record --Water-stage recorder graph Altitude of gage 1s $4,220 \mathrm{ft}$ (from topographic map)

Discharge record --Stage-discharge relation defined by current-meter measurements below $110 \mathrm{cfs}$ and extended above on basis of slope-area measurement, made in 1953 at $2,120 \mathrm{cfs}$

Maxima --June 1964 Discharge, $653 \mathrm{cfs} 1500$ hours June 8 (gage height, $491 \mathrm{ft}$ ) 1911 to May 1964 Discharge, $2,120 \mathrm{cfs}$ Apr 22,1953 (gage height, $755 \mathrm{ft}$, from floodmarks)

Mean discharge, in cubic feet per second, 1964

\begin{tabular}{|c|c|c|c|c|c|c|c|c|}
\hline Day & May & June & Day & May & June & Day & May & June \\
\hline $\begin{array}{r}1 \\
2 \\
3 \\
4 \\
5 \\
6 \\
7 \\
8 \\
9 \\
10\end{array}$ & $\begin{array}{rl}40 & 6 \\
103 & \\
176 & \\
141 & \\
92 & 9 \\
62 & 0 \\
74 & 0 \\
59 & 0 \\
50 & 7 \\
56 & 1\end{array}$ & $\begin{array}{rr}17 & 8 \\
17 & 3 \\
16 & 8 \\
16 & 3 \\
16 & 3 \\
16 & 3 \\
22 & 6 \\
391 & \\
148 & \\
59 & 0\end{array}$ & $\begin{array}{l}11 \\
12 \\
13 \\
14 \\
15 \\
16 \\
17 \\
18 \\
19 \\
20\end{array}$ & $\begin{array}{ll}46 & 2 \\
39 & 1 \\
36 & 2 \\
33 & 4 \\
29 & 2 \\
27 & 3 \\
27 & 3 \\
27 & 3 \\
24 & 8 \\
24 & 2\end{array}$ & $\begin{array}{ll}46 & 2 \\
41 & 4 \\
43 & 0 \\
36 & 9 \\
44 & 6 \\
54 & 3 \\
57 & 0 \\
37 & 6 \\
34 & 8 \\
33 & 4\end{array}$ & $\begin{array}{l}21 \\
22 \\
23 \\
24 \\
25 \\
26 \\
27 \\
28 \\
29 \\
30 \\
31\end{array}$ & $\begin{array}{ll}22 & 4 \\
21 & 9 \\
20 & 3 \\
18 & 8 \\
18 & 8 \\
18 & 3 \\
17 & 8 \\
21 & 3 \\
23 & 0 \\
20 & 3 \\
18 & 8\end{array}$ & $\begin{array}{r}334 \\
32 \\
306 \\
292 \\
286 \\
279 \\
279 \\
273 \\
273 \\
266 \\
----\end{array}$ \\
\hline \multicolumn{7}{|c|}{$\begin{array}{l}\text { Monthly mean dische } \\
\text { Runoff, in inches } \\
\text { Runoff, in acre-fe }\end{array}$} & $\begin{array}{r}449 \\
0 \quad 84 \\
2,760\end{array}$ & $\begin{array}{r}481 \\
0 \quad 87 \\
2,860\end{array}$ \\
\hline
\end{tabular}

Gage he1ght, in feet, and discharge, in cubic feet per second, at indicated time, 1964

\begin{tabular}{|c|c|c|c|c|c|c|c|c|c|c|c|}
\hline Date & Hour & $\begin{array}{c}\text { Gage } \\
\text { helght }\end{array}$ & $\begin{array}{c}\text { D1s- } \\
\text { charge }\end{array}$ & Date & Hour & $\begin{array}{c}\text { Gage } \\
\text { helght }\end{array}$ & $\begin{array}{l}\text { D1s- } \\
\text { charge }\end{array}$ & Date & Hour & $\begin{array}{c}\text { Gage } \\
\text { he1ght }\end{array}$ & $\begin{array}{l}\text { Dis- } \\
\text { charge }\end{array}$ \\
\hline June 7 & $\begin{array}{l}0000 \\
1400 \\
2000 \\
2400 \\
\\
0200 \\
0500 \\
0700\end{array}$ & $\begin{array}{ll}1 & 14 \\
1 & 16 \\
1 & 39 \\
1 & 66 \\
1 & 90 \\
2 & 51 \\
3 & 12\end{array}$ & $\begin{array}{rr}16 & 3 \\
17 & 3 \\
30 & 6 \\
51 & 6 \\
76 & 0 \\
149 & \\
242 & \end{array}$ & June 8 & $\begin{array}{l}0900 \\
1200 \\
1500 \\
1800 \\
2000 \\
2100 \\
2300 \\
2400\end{array}$ & $\begin{array}{ll}3 & 43 \\
4 & 23 \\
4 & 91 \\
4 & 78 \\
4 & 36 \\
4 & 38 \\
4 & 68 \\
4 & 47\end{array}$ & $\begin{array}{l}296 \\
468 \\
653 \\
614 \\
500 \\
505 \\
585 \\
528\end{array}$ & June 9 & $\begin{array}{l}0300 \\
0600 \\
1200 \\
1800 \\
2400\end{array}$ & $\begin{array}{ll}3 & 14 \\
2 & 54 \\
2 & 14 \\
1 & 93 \\
1 & 82\end{array}$ & $\begin{array}{rr}247 & \\
156 & \\
105 & \\
81 & 3 \\
70 & 0\end{array}$ \\
\hline
\end{tabular}


(139) 6-1340 North Milk River near international boundary

(International gaging station)

Location --Lat $40^{\circ} 011^{\prime} 20^{\prime \prime}$, long $112^{\circ} 58^{\prime} 20^{\prime \prime}$, in $\mathrm{SW}_{\frac{1}{4}} \mathrm{NE} \frac{1}{4} \sec 11, \mathrm{~T} 1, \mathrm{R} 23 \mathrm{~W}$, fourth merldian, on left bank $1,500 \mathrm{ft}$ upstream from highway bridge, $1 \frac{1}{2}$ mlles north of international boundary, 3 miles east of Whiskey Gap, Alberta, and 11 miles southeast of Kimball, Alberta

Drainage area $--918 \mathrm{sq} \mathrm{mi}$

Gage-height record - -Water-stage recorder graph Datum of gage is $4,11216 \mathrm{ft}$ above mean sea level (Geodetic Surveys of Canada datum)

Discharge record --Stage-discharge relation defined by current-meter measurements below $700 \mathrm{cfs}$ and by slope-area measurement at $1,940 \mathrm{cfs}$

Maxima --June 1964 Discharge, $1,940 \mathrm{cfs} 1600$ hours June 8 (gage helght, $798 \mathrm{ft}$ ) 1909 to May 1964 D1scharge, 2,950 cf's June 17, 1948 (gage he1ght, $647 \mathrm{ft}$, at site $1500 \mathrm{ft}$ downstream and at datum then in use), from rating curve extended
above $1,500 \mathrm{cfs}$ $\frac{\text { Remarks }}{\text { Canal }}$ - Since 1917, flow increased during irrigation season by water from st Mary

Mean discharge, in cublc feet per second, 1964

\begin{tabular}{|c|c|c|c|c|c|c|c|c|}
\hline Day & May & June & Day & May & June & Day & May & June \\
\hline $\begin{array}{r}1 \\
2 \\
3 \\
4 \\
5 \\
6 \\
7 \\
8 \\
9 \\
10\end{array}$ & $\begin{array}{l}186 \\
314 \\
521 \\
578 \\
557 \\
561 \\
573 \\
586 \\
623 \\
627\end{array}$ & $\begin{array}{r}680 \\
680 \\
687 \\
691 \\
691 \\
696 \\
724 \\
1,360 \\
697 \\
172\end{array}$ & $\begin{array}{l}11 \\
12 \\
13 \\
14 \\
15 \\
16 \\
17 \\
18 \\
19 \\
20\end{array}$ & $\begin{array}{l}639 \\
631 \\
631 \\
623 \\
618 \\
614 \\
631 \\
614 \\
623 \\
623\end{array}$ & $\begin{array}{rl}86 & 9 \\
60 & 0 \\
58 & 7 \\
51 & 7 \\
57 & 5 \\
70 & 1 \\
79 & 6 \\
50 & 6 \\
46 & 2 \\
118 & \end{array}$ & $\begin{array}{l}21 \\
22 \\
23 \\
24 \\
25 \\
26 \\
27 \\
28 \\
29 \\
30 \\
31\end{array}$ & $\begin{array}{l}635 \\
639 \\
651 \\
660 \\
655 \\
651 \\
664 \\
676 \\
680 \\
676 \\
680\end{array}$ & $\begin{array}{r}474 \\
470 \\
448 \\
470 \\
509 \\
497 \\
459 \\
423 \\
372 \\
353 \\
----\end{array}$ \\
\hline $\begin{array}{l}\text { Monthl } \\
\text { Runoff }\end{array}$ & $\begin{array}{l}\text { disch } \\
\text { cre-fee }\end{array}$ & , in cub & feet & cond & & & $\begin{array}{r}601 \\
36,970\end{array}$ & $\begin{array}{r}408 \\
24,260 \\
\end{array}$ \\
\hline
\end{tabular}

Gage height, in feet, and discharge, in cub1c feet per second, at indicated time, 1964

\begin{tabular}{|c|c|c|c|c|c|c|c|c|c|c|c|}
\hline Date & Hour & $\begin{array}{c}\text { Gage } \\
\text { height }\end{array}$ & $\begin{array}{c}\text { Dis- } \\
\text { charge }\end{array}$ & Date & Hour & $\begin{array}{c}\text { Gage } \\
\text { helght }\end{array}$ & $\begin{array}{c}\text { Dis - } \\
\text { charge }\end{array}$ & Date & Hour & $\begin{array}{c}\text { Gage } \\
\text { helght }\end{array}$ & $\begin{array}{c}\text { Dis- } \\
\text { charge }\end{array}$ \\
\hline June 7 & $\begin{array}{l}0000 \\
1200 \\
1800 \\
2400 \\
0600 \\
1200 \\
\end{array}$ & $\begin{array}{ll}5 & 94 \\
5 & 95 \\
6 & 06 \\
6 & 15 \\
6 & 50 \\
7 & 28 \\
\end{array}$ & $\begin{array}{r}696 \\
700 \\
751 \\
799 \\
\\
988 \\
1.460 \\
\end{array}$ & June 8 & $\begin{array}{l}1600 \\
2000 \\
2400 \\
0600 \\
1200 \\
1800 \\
\end{array}$ & $\begin{array}{ll}7 & 98 \\
7 & 51 \\
7 & 16 \\
& \\
6 & 37 \\
5 & 68 \\
5 & 18 \\
\end{array}$ & $\begin{array}{r}1,940 \\
1,620 \\
1,390 \\
934 \\
605 \\
412 \\
\end{array}$ & $\begin{array}{r} \\
\text { June } \\
10\end{array}$ & $\begin{array}{l}2400 \\
0600 \\
1200 \\
2400\end{array}$ & $\begin{array}{ll}4 & 78 \\
4 & 47 \\
4 & 23 \\
4 & 00\end{array}$ & $\begin{array}{l}287 \\
206 \\
153 \\
111\end{array}$ \\
\hline
\end{tabular}

(140) 6-1345 Milk River at Milk River, Alberta

(International gaging station)

Location - - Lat $49^{\circ} 09^{\prime}$, long $112^{\circ} 05^{\prime}$, in $S E_{\frac{1}{4}} \sec 28, \mathrm{~T} 2, \mathrm{R} 16 \mathrm{~W}$, fourth meridian, on left bank $700 \mathrm{ft}$ downstream from highway bridge at Milk River, Alberta, and 22 miles downstream from North Milk River

Drainage area $--1,036 \mathrm{sq} \mathrm{mi}$

Gage-helght record --Water-stage recorder graph Datum of gage is $3,40278 \mathrm{ft}$ above mean sea level (Geodetic Surveys of Canada datum)

Discharge record --Stage-discharge relation defined by current-meter measurements below $3,800 \mathrm{c}$ s and above on basis of logarithmic extension

Maxima - June 1964 Discharge, 8,110 cfs 2300 hours June 9 (gage height, $1040 \mathrm{ft}$ ) 1909 to May 1964 Discharge, 8,730 cfs May 22, 1927 (gage helght, $1141 \mathrm{ft}$ ) from rating curve extended above $4,000 \mathrm{cfs}$ on basis of area-velocity study of
peak discharge

$\frac{\text { Remarks }}{\text { Canal) }}$-Since 1917, flow increased during irrigation season by water from St Mary 
Mean discharge, in cub1c feet per second, 1964, of M1lk R1ver at M1lk R1ver, Alberta

\begin{tabular}{|c|c|c|c|c|c|c|c|c|}
\hline Day & May & June & Day & May & June & Day & May & June \\
\hline $\begin{array}{l}1 \\
2 \\
3 \\
4 \\
5 \\
6 \\
7 \\
8 \\
9 \\
10\end{array}$ & $\begin{array}{r}524 \\
607 \\
1,360 \\
2,190 \\
2,290 \\
1,620 \\
1,390 \\
1,240 \\
1,080 \\
1,040\end{array}$ & $\begin{array}{r}877 \\
846 \\
827 \\
809 \\
803 \\
815 \\
840 \\
1,200 \\
4,560 \\
4,310\end{array}$ & $\begin{array}{l}11 \\
12 \\
13 \\
14 \\
15 \\
16 \\
17 \\
18 \\
19 \\
20\end{array}$ & $\begin{array}{r}1,020 \\
1,020 \\
969 \\
929 \\
910 \\
890 \\
858 \\
871 \\
890 \\
896\end{array}$ & $\begin{array}{r}1,540 \\
929 \\
725 \\
628 \\
569 \\
564 \\
707 \\
760 \\
569 \\
518\end{array}$ & $\begin{array}{l}21 \\
22 \\
23 \\
24 \\
25 \\
26 \\
27 \\
28 \\
29 \\
30 \\
31\end{array}$ & $\begin{array}{l}865 \\
865 \\
865 \\
852 \\
833 \\
821 \\
809 \\
815 \\
846 \\
922 \\
948\end{array}$ & $\begin{array}{r}483 \\
754 \\
719 \\
673 \\
673 \\
696 \\
667 \\
622 \\
585 \\
538 \\
-----\end{array}$ \\
\hline $\begin{array}{l}\text { Month } \\
\text { Runof }\end{array}$ & $\begin{array}{l}\text { disch } \\
\text { cre-fee }\end{array}$ & e, in cub & feet & cond & & & $\begin{array}{r}1,030 \\
63,540\end{array}$ & $\begin{array}{r}994 \\
59,120\end{array}$ \\
\hline
\end{tabular}

Gage he1ght, in feet, and discharge, in cublc feet per second, at indicated time, 1964

\begin{tabular}{|c|c|c|c|c|c|c|c|c|c|c|c|c|c|}
\hline \multicolumn{2}{|l|}{ Date } & Hour & $\begin{array}{c}\text { Gage } \\
\text { height }\end{array}$ & $\begin{array}{c}\text { D1s- } \\
\text { charge }\end{array}$ & \multicolumn{2}{|l|}{ Date } & Hour & $\begin{array}{c}\text { Gage } \\
\text { he1ght }\end{array}$ & $\begin{array}{c}\text { D1s- } \\
\text { charge }\end{array}$ & Date & Hour & $\begin{array}{c}\text { Gage } \\
\text { he1ght }\end{array}$ & $\begin{array}{l}\text { D1s- } \\
\text { charge }\end{array}$ \\
\hline June & 8 & $\begin{array}{l}0000 \\
0200 \\
0400 \\
1000 \\
1400 \\
2000 \\
2400\end{array}$ & $\begin{array}{ll}3 & 37 \\
3 & 41 \\
3 & 43 \\
3 & 63 \\
3 & 75 \\
4 & 20 \\
5 & 03\end{array}$ & $\begin{array}{r}884 \\
910 \\
922 \\
1,060 \\
1,150 \\
1,440 \\
2,060\end{array}$ & June & 9 & $\begin{array}{l}1300 \\
1400 \\
1600 \\
1800 \\
1900 \\
2300 \\
2400\end{array}$ & $\begin{array}{rr}7 & 30 \\
7 & 89 \\
8 & 50 \\
9 & 10 \\
9 & 75 \\
10 & 40 \\
10 & 30\end{array}$ & $\begin{array}{l}4,210 \\
4,920 \\
5,650 \\
6,420 \\
7,260 \\
8,110 \\
7,980\end{array}$ & June 10 & $\begin{array}{l}0700 \\
0800 \\
1000 \\
1200 \\
1400 \\
2000 \\
2400\end{array}$ & $\begin{array}{ll}8 & 22 \\
7 & 78 \\
7 & 15 \\
6 & 68 \\
6 & 31 \\
5 & 52 \\
5 & 18\end{array}$ & $\begin{array}{l}5,310 \\
4,790 \\
4,040 \\
3,560 \\
3,200 \\
2,480 \\
2,180\end{array}$ \\
\hline & 9 & $\begin{array}{l}0700 \\
0800 \\
0900 \\
1100 \\
\end{array}$ & $\begin{array}{ll}5 & 83 \\
5 & 77 \\
5 & 99 \\
6 & 73 \\
\end{array}$ & $\begin{array}{l}2,760 \\
2,700 \\
2,900 \\
3,610 \\
\end{array}$ & & 10 & $\begin{array}{l}0200 \\
0400 \\
0500 \\
0600\end{array}$ & $\begin{array}{ll}9 & 95 \\
9 & 53 \\
9 & 25 \\
8 & 77\end{array}$ & $\begin{array}{l}7,520 \\
6,980 \\
6,620 \\
5,990\end{array}$ & 11 & $\begin{array}{l}0600 \\
1200 \\
1800 \\
2400\end{array}$ & $\begin{array}{ll}4 & 72 \\
4 & 30 \\
3 & 98 \\
3 & 80\end{array}$ & $\begin{array}{l}1,810 \\
1,480 \\
1,240 \\
1,100\end{array}$ \\
\hline
\end{tabular}

(141) 6-1348 Van Cleeve Coulee tributary near Sunburst, Mont

(Crest-stage station)

Location --Lat $48^{\circ} 53^{\prime}$, long $111^{\circ} 49^{\prime}$, on north line of $\mathrm{NE} \frac{1}{4} \sec 14$, T $36 \mathrm{~N}, \mathrm{R} 2 \mathrm{~W}$, at culverts on county road, 37 miles east of interchange on Interstate Highway 15 at Sunburst

Drainage area $--108 \mathrm{sq} \mathrm{m}$

$\frac{\text { Gage-height record }}{\text { graphic map) }}$-Crest stages only Altitude of gage is $3,350 \mathrm{ft}$ (from topo-

scharge record --Stage-discharge relation defined by current-meter measurements below $05 \mathrm{cfs}$ and by flow-through-culvert measurement at $35 \mathrm{cfs}$

Maxima --June 1964 No flow

1963 to May 1964 Discharge, 35 cfs May 3, 1964 (gage he1ght, upstream gage, $208 \mathrm{ft}$, downstream gage, $169 \mathrm{ft})$

(142) 6-1350 Milk River at eastern crossing of international boundary

(International gaging station)

Location - -Lat $48^{\circ} 59^{\prime} 50^{\prime \prime}$, long $110^{\circ} 35^{\prime} 30^{\prime \prime}$, in $\mathrm{NE} \frac{1}{4} \sec 6, \mathrm{~T} 37 \mathrm{~N}, \mathrm{R} 9 \mathrm{E}$, on right bank $500 \mathrm{ft}$ south of international boundary, $500 \mathrm{ft}$ downstream from Canada Coulee, 30 miles north of Rudyard, Mont, and 37 miles south of Many Berries, Alberta

Drainage area $--2,588 \mathrm{sq} \mathrm{mi}$

Gage-he1ght record --Water-stage recorder graph, except June 13-16 Graph reconstructed on basis of gage readings June 13, 14 Datum of gage is $2,6984 \mathrm{ft}$ above mean sea level (Intermational Boundary Survey datum)

Discharge record --Stage-discharge relation defined by current-meter measurements

Maxima --June 1964 Discharge, 7,770 cfs 0600 to 0800 hours June 11 (gage he1ght, $671 \mathrm{ft})$

1909 to May 1964 Discharge, 9,530 cfs Mar 31, 1952 (gage height, $934 \mathrm{ft}$ ), but may have been higher Mar 28, 1952 (gage height, $1365 \mathrm{ft}$, backwater from $1 œ$ )

Remarks --Since 1917 flow increased during irrigation season by water from St Mary Canal 
Mean discharge, In cublc feet per second, 1964, of Milk River at eastern crossing of International boundary

\begin{tabular}{|c|c|c|c|c|c|c|c|c|}
\hline Day & May & June & Day & May & June & Day & May & June \\
\hline $\begin{array}{r}1 \\
2 \\
3 \\
4 \\
5 \\
6 \\
7 \\
8 \\
9 \\
10\end{array}$ & $\begin{array}{r}506 \\
567 \\
666 \\
2,170 \\
3,460 \\
2,830 \\
2,100 \\
1,650 \\
1,560 \\
1,340\end{array}$ & $\begin{array}{r}903 \\
941 \\
861 \\
843 \\
837 \\
825 \\
831 \\
897 \\
1,120 \\
3,820\end{array}$ & $\begin{array}{l}11 \\
12 \\
13 \\
14 \\
15 \\
16 \\
17 \\
18 \\
19 \\
20\end{array}$ & $\begin{array}{r}1,260 \\
1,230 \\
1,140 \\
1,130 \\
1,030 \\
980 \\
958 \\
930 \\
895 \\
930\end{array}$ & $\begin{array}{r}5,790 \\
2,220 \\
1,300 \\
974 \\
864 \\
752 \\
630 \\
650 \\
720 \\
778\end{array}$ & $\begin{array}{l}21 \\
22 \\
23 \\
24 \\
25 \\
26 \\
27 \\
28 \\
29 \\
30 \\
31\end{array}$ & $\begin{array}{l}958 \\
965 \\
874 \\
867 \\
881 \\
839 \\
825 \\
846 \\
818 \\
837 \\
849\end{array}$ & $\begin{array}{r}645 \\
545 \\
531 \\
650 \\
710 \\
660 \\
645 \\
660 \\
640 \\
590 \\
----\end{array}$ \\
\hline $\begin{array}{l}\text { Monthl } \\
\text { Runoff }\end{array}$ & $\begin{array}{l}\text { dlscha } \\
\text { cre-fee }\end{array}$ & , in cub & feet & ond & & & $\begin{array}{r}1,190 \\
73,170\end{array}$ & $\begin{array}{r}1,090 \\
65,120\end{array}$ \\
\hline
\end{tabular}

Gage height, in feet, and discharge, in cublc feet per second, at indicated time, 1964

\begin{tabular}{|c|c|c|c|c|c|c|c|c|c|c|c|}
\hline Date & Hour & $\begin{array}{c}\text { Gage } \\
\text { helght }\end{array}$ & $\begin{array}{l}\text { Dis- } \\
\text { charge }\end{array}$ & Date & Hour & $\begin{array}{c}\text { Gage } \\
\text { height }\end{array}$ & $\begin{array}{l}\text { D1s- } \\
\text { charge }\end{array}$ & Date & Hour & $\begin{array}{c}\text { Gage } \\
\text { he1ght }\end{array}$ & $\begin{array}{c}\text { Dis- } \\
\text { charge }\end{array}$ \\
\hline June 10 & $\begin{array}{l}0000 \\
0400 \\
0600 \\
0900 \\
1200 \\
1800 \\
\end{array}$ & $\begin{array}{ll}2 & 23 \\
2 & 29 \\
2 & 74 \\
3 & 80 \\
4 & 56 \\
5 & 60 \\
\end{array}$ & $\begin{array}{l}1,220 \\
1,260 \\
1,700 \\
2,910 \\
3,990 \\
5,700\end{array}$ & $\begin{array}{r}\text { June } 10 \\
11\end{array}$ & $\begin{array}{l}2400 \\
0600 \\
0800 \\
1100 \\
1700 \\
\end{array}$ & $\begin{array}{ll}6 & 18 \\
6 & 71 \\
6 & 71 \\
6 & 39 \\
4 & 56 \\
\end{array}$ & $\begin{array}{l}6,760 \\
7,770 \\
7,770 \\
7,160 \\
3,990\end{array}$ & $\begin{array}{r}\text { June } 11 \\
12\end{array}$ & $\begin{array}{l}2400 \\
0600 \\
1200 \\
1800 \\
2400 \\
\end{array}$ & $\begin{array}{ll}3 & 87 \\
3 & 47 \\
3 & 23 \\
2 & 88 \\
2 & 66 \\
\end{array}$ & $\begin{array}{l}3,000 \\
2,500 \\
2,220 \\
1,840 \\
1,620 \\
\end{array}$ \\
\hline
\end{tabular}

\section{PEND OREILLE RIVER BASIN}

(143) Landers Fork above Copper Creek, near Lincoln, Mont

(Miscelianeous site)

Location --Lat $47^{\circ} 03^{\prime} 40^{\prime \prime}$, long $112^{\circ} 33^{\prime} 10^{\prime \prime}$, near north line of sec $13, \mathrm{~T} 15 \mathrm{~N}, \mathrm{R} 8 \mathrm{~W}$, 4 miles upstream from Copper Creek and $10 \frac{1}{2}$ miles northeast of Lincoln

Drainage area $--78 \quad 0 \mathrm{sq} \mathrm{mi}$

Maximum --June 1964 Discharge, 5,120 cfs June 9, from slope-area measurement

(144) Copper Creek near Lincoln, Mont

(Miscellaneous site)

Location --Lat $47^{\circ} 01^{1} 00^{\prime \prime}$, long $112^{\circ} 33^{\prime} 40^{\prime \prime}$, In $N W^{\frac{1}{4}} \sec 36$, T $15 \mathrm{~N}, \mathrm{R} 8 \mathrm{~W}$, half a mile above Landers Fork and 7 miles northeast of Lincoln

Drainage area $--408 \mathrm{sq} \mathrm{ml}$

Maximum --June 1964 Discharge, 803 cfs June 8, from contracted-opening measurement

(145) 12-3355 Nevada Creek above reservo1r, near Finn, Mont

Location --Lat $46^{\circ} 46^{\prime} 30^{\prime \prime}$, long $112^{\circ} 45^{\prime} 20^{\prime \prime}$, near south line of sec $20, \mathrm{~T} 12 \mathrm{~N}, \mathrm{R} 9 \mathrm{~W}$, on right bank a quarter of a mile downstream from Gallagher Creek, 2 miles upstream from Buffalo Creek, and 3 miles west of Finn

Drainage area $--116 \mathrm{sq} \mathrm{ml}$

Gage-helght record - Water-stage recorder graph Altitude of gage is 4,660 ft (from river-profile map)

D1scharge record --Stage-discharge relation defined by current-meter measurements

Maxima --June 1964 Discharge, 524 cfs 1500 hours June 9 (gage height, $422 \mathrm{ft}$ ) 1939 to May 1964 Discharge, 1,800 cf's June 2, 1953 (gage height, $600 \mathrm{ft}$, at site $1 \mathrm{mile}$ downstream at different datum), from rating curve extended above $400 \mathrm{cfs}$ on basis of inflow-outflow study of Nevada Creek Reservolr, gage height, $740 \mathrm{ft}$ May 29, 1953, at site 1 mile downstream at different datum (backwater from diversion dam) 
Mean discharge, In cubic feet per second, 1964, of Nevada Creek above reservo1r, near Finn, Mont

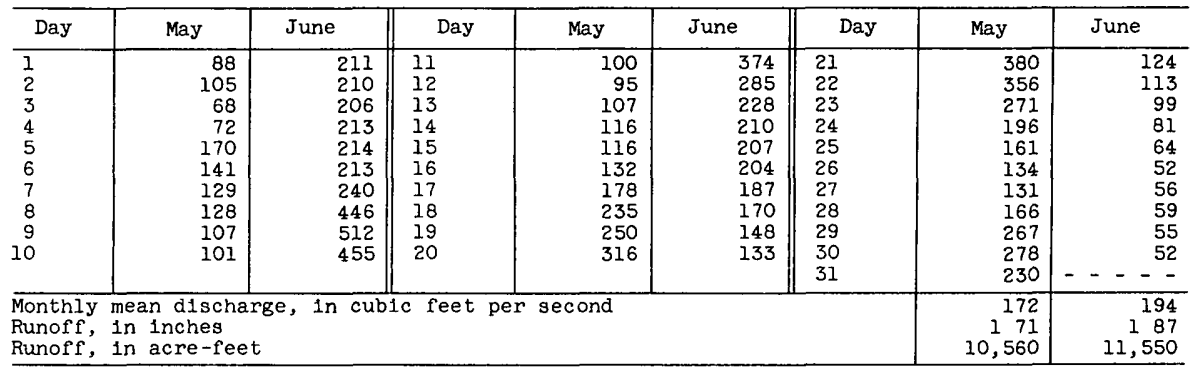

Gage he1ght, in feet, and discharge, in cub1c feet per second, at indicated time, 1964

\begin{tabular}{|c|c|c|c|c|c|c|c|c|c|c|c|}
\hline Date & Hour & $\begin{array}{c}\text { Gage } \\
\text { helght }\end{array}$ & $\begin{array}{l}\text { D1s- } \\
\text { charge }\end{array}$ & Date & Hour & $\begin{array}{c}\text { Gage } \\
\text { he1ght }\end{array}$ & $\begin{array}{l}\text { Dis- } \\
\text { charge }\end{array}$ & Date & Hour & $\begin{array}{c}\text { Gage } \\
\text { helght }\end{array}$ & $\begin{array}{l}\text { D1s- } \\
\text { charge }\end{array}$ \\
\hline June 7 & $\begin{array}{l}0000 \\
1200 \\
1800 \\
2400 \\
0300 \\
0600\end{array}$ & $\begin{array}{ll}3 & 42 \\
3 & 32 \\
3 & 43 \\
3 & 90 \\
& \\
4 & 17 \\
4 & 17\end{array}$ & $\begin{array}{l}235 \\
220 \\
237 \\
320 \\
473 \\
473\end{array}$ & June 8 & $\begin{array}{l}0900 \\
1200 \\
1500 \\
1800 \\
2100 \\
2400\end{array}$ & $\begin{array}{ll}4 & 14 \\
4 & 10 \\
4 & 07 \\
4 & 14 \\
4 & 21 \\
4 & 21\end{array}$ & $\begin{array}{l}446 \\
410 \\
392 \\
446 \\
512 \\
512\end{array}$ & June 9 & $\begin{array}{l}0400 \\
1500 \\
2400 \\
1200 \\
2400\end{array}$ & $\begin{array}{ll}4 & 21 \\
4 & 22 \\
4 & 19 \\
& \\
4 & 15 \\
4 & 11\end{array}$ & $\begin{array}{l}512 \\
524 \\
491 \\
\\
455 \\
419\end{array}$ \\
\hline
\end{tabular}

(146) 12-3380 North Fork Blackfoot River near Ovando, Mont

(Gaging station, discontinued 1923)

Location --Lat $47^{\circ} 03^{\prime} 00^{\prime \prime}$, long $112^{\circ} 59^{\prime} 00^{\prime \prime}$, in $\mathrm{NW} \frac{1}{4} \mathrm{NW} \frac{1}{4} \sec 22, \mathrm{~T} 15 \mathrm{~N}, \mathrm{R} 11 \mathrm{~W}$, on left bank at Pitkin's ranch, 11 miles northeast of Ovando Altitude of gage was $4,270 \mathrm{ft}$ (from topographic map) Gage and datum not recovered

Drainage area $--228 \mathrm{sq} \mathrm{mi}$

Discharge record --Peak discharge by slope-area measurement

Maxima --June 1964 Discharge, 11,800 cfs June 8

1921-23 Discharge observed, 2,900 cfs June 5, 1922 (gage he1ght, $758 \mathrm{ft}$ )

Flood of about May 22 , 1948, reached a stage of $90 \mathrm{ft}$, from floodmarks (discharge, 4,380 cfs, from slope-area measurement)

(147) 12-3398 Blackfoot River near Potomac, Mont

Location --Lat $46^{\circ} 57^{\prime} 10^{\prime \prime}$, long $113^{\circ} 34^{\prime} 00^{\prime \prime}$, in $N E \frac{1}{4} S W \frac{1}{4} \sec 24, T 14 \mathrm{~N}, \mathrm{R} 16 \mathrm{~W}$, on right bank an eighth of a mile upstream from Belmont Creek and 5 miles north of Potomac

Drainage area $--2,046 \mathrm{sq} \mathrm{mi}$

Gage-height record --Water-stage recorder graph Datum of gage is $3,53336 \mathrm{ft}$ above mean sea level, datum of 1929 (levels by Bureau of Reclamation)

Discharge record --Stage-discharge relation defined by current-meter measurements

Maxima --June 1964 Discharge, 17,500 cfs 1500 hours June 10 (gage height, $1133 \mathrm{ft}$ ) 1957 to May 1964 Discharge, $10,900 \mathrm{cfs}$ June 15, 1959 (gage height. $854 \mathrm{ft}$ ) 
Mean discharge, in cub1c feet per second, 1964, of Blackfoot River near Potomac, Mont

\begin{tabular}{|c|c|c|c|c|c|c|c|c|}
\hline Day & May & June & Day & May & June & Day & May & June \\
\hline $\begin{array}{r}1 \\
2 \\
3 \\
4 \\
5 \\
6 \\
7 \\
8 \\
9 \\
10\end{array}$ & $\begin{array}{l}1,710 \\
2,120 \\
2,350 \\
2,330 \\
2,330 \\
2,330 \\
2,330 \\
2,250 \\
2,200 \\
2,280\end{array}$ & $\begin{array}{r}6,660 \\
6,470 \\
6,590 \\
7,190 \\
7,380 \\
7,460 \\
7,650 \\
9,290 \\
13,700 \\
16,300\end{array}$ & $\begin{array}{l}11 \\
12 \\
13 \\
14 \\
15 \\
16 \\
17 \\
18 \\
19 \\
20\end{array}$ & $\begin{array}{l}2,440 \\
2,570 \\
2,810 \\
3,060 \\
3,370 \\
3,760 \\
4,480 \\
5,270 \\
5,880 \\
6,640\end{array}$ & $\begin{array}{r}14,800 \\
11,800 \\
9,940 \\
8,850 \\
8,320 \\
8,230 \\
8,280 \\
7,560 \\
6,760 \\
5,980\end{array}$ & $\begin{array}{l}21 \\
22 \\
23 \\
24 \\
25 \\
26 \\
27 \\
28 \\
29 \\
30 \\
31\end{array}$ & $\begin{array}{l}7,790 \\
8,110 \\
7,540 \\
6,950 \\
6,040 \\
5,480 \\
5,250 \\
5,700 \\
6,440 \\
6,550 \\
6,660\end{array}$ & $\begin{array}{r}5,360 \\
4,920 \\
4,540 \\
4,500 \\
4,690 \\
4,710 \\
4,550 \\
4,330 \\
4,070 \\
3,820 \\
-----\end{array}$ \\
\hline \multicolumn{7}{|c|}{$\begin{array}{l}\text { Monthly mean discharge, in cublc feet per second } \\
\text { Runoff, in inches } \\
\text { Runoff, in acre-feet }\end{array}$} & $\begin{array}{r}4,355 \\
245 \\
267,800\end{array}$ & $\begin{array}{r}7,490 \\
4,08 \\
445,700\end{array}$ \\
\hline
\end{tabular}

Gage he1ght, in feet, and discharge, in cublc feet per second, at indicated time, 1964

\begin{tabular}{|c|c|c|c|c|c|c|c|c|c|c|c|}
\hline Date & Hour & $\begin{array}{c}\text { Gage } \\
\text { helght }\end{array}$ & $\begin{array}{c}\text { Dis- } \\
\text { charge }\end{array}$ & Date & Hour & $\begin{array}{c}\text { Gage } \\
\text { helght }\end{array}$ & $\begin{array}{l}\text { D1s- } \\
\text { charge }\end{array}$ & Date & Hour & $\begin{array}{c}\text { Gage } \\
\text { he1ght }\end{array}$ & $\begin{array}{l}\text { D1s- } \\
\text { charge }\end{array}$ \\
\hline June 8 & $\begin{array}{l}0000 \\
0600 \\
1200 \\
1900 \\
2400 \\
0400 \\
0700 \\
1100 \\
1500\end{array}$ & $\begin{array}{rr}6 & 96 \\
7 & 12 \\
7 & 61 \\
8 & 51 \\
8 & 69 \\
9 & 15 \\
9 & 82 \\
9 & 90 \\
10 & 11\end{array}$ & $\begin{array}{r}7,770 \\
8,070 \\
8,980 \\
10,800 \\
11,200 \\
12,300 \\
13,800 \\
14,000 \\
14,500\end{array}$ & 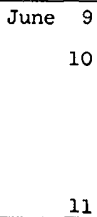 & $\begin{array}{l}2400 \\
0600 \\
0900 \\
1200 \\
1500 \\
1800 \\
2400 \\
0600\end{array}$ & $\begin{array}{ll}10 & 09 \\
10 & 33 \\
10 & 73 \\
11 & 18 \\
11 & 33 \\
11 & 30 \\
10 & 93 \\
10 & 62\end{array}$ & $\begin{array}{l}14,500 \\
15,100 \\
16,000 \\
17,100 \\
17,500 \\
17,400 \\
16,500 \\
15,700\end{array}$ & June 11 & $\begin{array}{l}1200 \\
1800 \\
2400 \\
1200 \\
2400 \\
1200 \\
2400\end{array}$ & $\begin{array}{rr}10 & 24 \\
9 & 83 \\
9 & 40 \\
8 & 92 \\
8 & 41 \\
8 & 14 \\
7 & 78\end{array}$ & $\begin{array}{r}14,800 \\
13,900 \\
12,900 \\
11,800 \\
10,600 \\
10,000 \\
9,160\end{array}$ \\
\hline
\end{tabular}

(148) 12-3399 West Twin Creek near Bonner, Mont

(Crest-stage station)

Location - - Lat $46^{\circ} 55^{\prime}$, long $113^{\circ} 43^{\prime}$, in $\mathrm{NW} \frac{1}{4} \sec 2, \mathrm{~T} 13 \mathrm{~N}, \mathrm{R} 17 \mathrm{~W}$, at bridge on State H1ghway 20,8 miles east of Bonner

Drainage area $--747 \mathrm{sq} \mathrm{mI}$

Gage-he1ght record --Crest stages only Altitude of gage is $3,410 \mathrm{ft}$ (from topographic map)

Discharge record --Stage-discharge relation defined by current-meter measurements below 80 cfs

Maxima --June 1964 Discharge, about $150 \mathrm{cfs}$ June 8 (gage height, $110 \mathrm{ft}$ )

1959 to May 1964 Discharge, 128 cfs May 27, 1961 (gage height, 0 $91 \mathrm{ft}$ )

\section{(149) 12-3400 Blackfoot River near Bonner, Mont}

Location --Lat $46^{\circ} 53^{\prime} 50^{\prime \prime}$, long $113^{\circ} 45^{\prime} 20^{\prime \prime}$, near center of $\sec 9, \mathrm{~T} 13 \mathrm{~N}, \mathrm{R} 17 \mathrm{~W}$, on right bank 5 miles northeast of Bonner, 5 miles downstream from Union Creek, and 7 miles upstream from mouth

Drainage area $--2,290 \mathrm{sq} \mathrm{mi}$

Gage-he1ght record --Water-stage recorder graph Datum of gage is $3,34476 \mathrm{ft}$ above mean sea level, datum of 1929 , supplementary adjustment of 1947

Discharge record --Stage-discharge relation defined by current-meter measurements

Maxima -- June 1964 Discharge, $19,200 \mathrm{cfs} 1400$ hours June 10 (gage he1ght, $1089 \mathrm{ft}$ ) 1899-1901, 1903-5, 1940 to May 1964 Discharge, 18,300 cfs June 4, 1953 (gage height, $1165 \mathrm{ft}$, from graph based on gage readings at site 13 miles downstream and at datum $2182 \mathrm{ft}$ lower) 
Mean discharge, in cublc feet per second, 1964, of Blackfoot River near Bonner, Mont

\begin{tabular}{|c|c|c|c|c|c|c|c|c|}
\hline Day & May & June & Day & May & June & Day & May & June \\
\hline $\begin{array}{r}1 \\
2 \\
3 \\
4 \\
5 \\
6 \\
7 \\
8 \\
9 \\
10\end{array}$ & $\begin{array}{l}2,200 \\
2,640 \\
2,860 \\
2,880 \\
2,820 \\
2,800 \\
2,770 \\
2,700 \\
2,680 \\
2,830\end{array}$ & $\begin{array}{r}7,600 \\
7,460 \\
7,750 \\
8,350 \\
8,430 \\
8,480 \\
8,720 \\
10,800 \\
16,400 \\
18,000\end{array}$ & $\begin{array}{l}11 \\
12 \\
13 \\
14 \\
15 \\
16 \\
17 \\
18 \\
19 \\
20\end{array}$ & $\begin{array}{l}3,060 \\
3,200 \\
3,510 \\
3,840 \\
4,180 \\
4,610 \\
5,420 \\
6,340 \\
7,010 \\
8,040\end{array}$ & $\begin{array}{r}15,200 \\
12,000 \\
10,200 \\
9,180 \\
8,690 \\
8,640 \\
8,820 \\
8,160 \\
7,340 \\
6,640\end{array}$ & $\begin{array}{l}21 \\
22 \\
23 \\
24 \\
25 \\
26 \\
27 \\
28 \\
29 \\
30 \\
31\end{array}$ & $\begin{array}{l}9,260 \\
9,290 \\
8,400 \\
7,650 \\
6,750 \\
6,120 \\
5,840 \\
6,300 \\
7,120 \\
7,410 \\
7,530\end{array}$ & $\begin{array}{r}6,100 \\
5,680 \\
5,290 \\
5,240 \\
5,420 \\
5,460 \\
5,350 \\
5,130 \\
4,680 \\
-\quad 4,260 \\
-\quad-\quad-\end{array}$ \\
\hline \multicolumn{9}{|c|}{$\begin{array}{l}\text { Monthly mean discharge, in cublc feet per second } \\
\text { Runoff, in inches } \\
\text { Runoff, in acre-feet }\end{array}$} \\
\hline
\end{tabular}

Gage he1ght, in feet, and discharge, in cublc feet per second, at indicated time, 1964

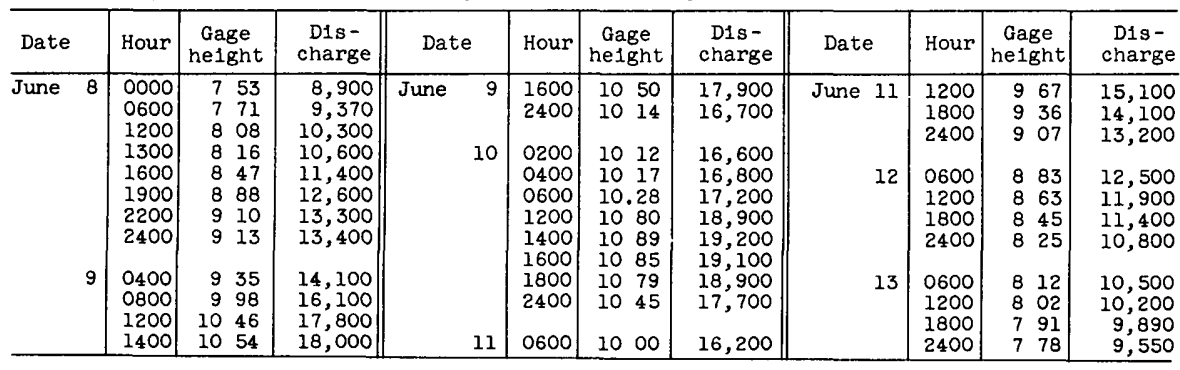

(150) 12-3402 Marshall Creek near Missoula, Mont

(Crest-stage station)

Location - - Lat $46^{\circ} 53^{\prime}$, long $113^{\circ} 55^{\prime}$, in $\mathrm{NW} \frac{1}{4} \sec 18, \mathrm{~T} 13 \mathrm{~N}$, $\mathrm{R} 18 \mathrm{~W}$, at culvert on Interstate H1ghway 90 and $U \mathrm{~S}$ Highways 10 and 12,3 miles east of M1ssoula

Drainage area $--547 \mathrm{sq} \mathrm{ml}$

$\frac{\text { Gage-height record }}{\text { graphic map) }}$-Crest stages only Alt1tude of gage $1 \mathrm{~s} 3,310 \mathrm{ft}$ (from topo$\frac{\text { Discharge record }}{\text { below } 25 \mathrm{cfs}}--$ Stage-discharge relation defined by current-meter measurements

Maxima --June 1964 Discharge, $10 \mathrm{cfs}$ June 8 (gage he1ght, $028 \mathrm{ft}$ )

1959 to May 1964 Discharge, about $50 \mathrm{cfs}$ May 21 , 1964 (gage height, $1 \mathrm{foft}$

(151) 12-3405 Clark Fork above M1ssoula, Mont

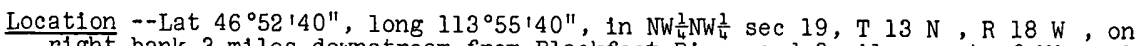

right bank 3 miles downstream from Blackfoot River and 3 miles east of Missoula

Drainage area $--5,999 \mathrm{sq} \mathrm{ml}$ $\frac{\text { Gage-he1ght record }}{\text { topograph1c map) }}$-Water-stage recorder graph Altitude of gage is $3,230 \mathrm{ft}$ (from

Discharge record --Stage-discharge relation defined by current-meter measurements

$\frac{\text { Maxima }}{13} 35 \mathrm{ft}$ ) 1964 Discharge, $31,700 \mathrm{cfs} 1800$ hours, June 10, (gage he1ght,

$35 \mathrm{ft}$ )

1929 to May 1964 Discharge, $31,500 \mathrm{cfs}$, May 23, 1948 (gage height, $1307 \mathrm{ft}$ )

Flood in June 1908 reached a discharge of about $48,000 \mathrm{cfs}$ (furnished by The
Montana Power Co)

Remarks --Flood stages not affected by regulation of powerplant at Bonner 
Mean discharge, in cub1c feet per second, 1964, of Clark Fork above Missoula, Mont

\begin{tabular}{|c|c|c|c|c|c|c|c|c|}
\hline Day & May & June & Day & May & June & Day & May & June \\
\hline $\begin{array}{r}1 \\
2 \\
3 \\
4 \\
5 \\
6 \\
7 \\
8 \\
9 \\
10\end{array}$ & $\begin{array}{l}5,040 \\
5,560 \\
5,800 \\
5,700 \\
5,480 \\
5,660 \\
5,760 \\
5,600 \\
5,520 \\
5,840\end{array}$ & $\begin{array}{l}13,200 \\
13,000 \\
13,400 \\
14,200 \\
14,400 \\
14,500 \\
15,100 \\
18,900 \\
27,400 \\
30,500\end{array}$ & $\begin{array}{l}11 \\
12 \\
13 \\
14 \\
15 \\
16 \\
17 \\
18 \\
19 \\
20\end{array}$ & $\begin{array}{r}6,250 \\
6,140 \\
6,420 \\
6,870 \\
7,390 \\
8,080 \\
9,400 \\
10,800 \\
11,400 \\
12,900\end{array}$ & $\begin{array}{l}27,500 \\
21,900 \\
18,500 \\
16,500 \\
15,700 \\
15,400 \\
16,000 \\
16,000 \\
14,500 \\
13,700\end{array}$ & $\begin{array}{l}21 \\
22 \\
23 \\
24 \\
25 \\
26 \\
27 \\
28 \\
29 \\
30 \\
31\end{array}$ & $\begin{array}{l}15,000 \\
15,300 \\
14,200 \\
12,600 \\
11,300 \\
10,300 \\
11,200 \\
10,700 \\
12,600 \\
13,500 \\
13,300\end{array}$ & $\begin{array}{r}12,800 \\
12,100 \\
11,300 \\
10,800 \\
10,800 \\
10,900 \\
10,900 \\
10,500 \\
9,750 \\
8,800 \\
-\quad-\quad-\quad\end{array}$ \\
\hline \multicolumn{7}{|c|}{$\begin{array}{l}\text { Monthly mean discharge, in cubic feet per second } \\
\text { Runoff, in acre-feet }\end{array}$} & $\begin{array}{r}9,084 \\
558,600\end{array}$ & $\begin{array}{r}15,300 \\
910,300\end{array}$ \\
\hline
\end{tabular}

Gage helght, in feet, and discharge, in cublc feet per second, at indicated time, 1964

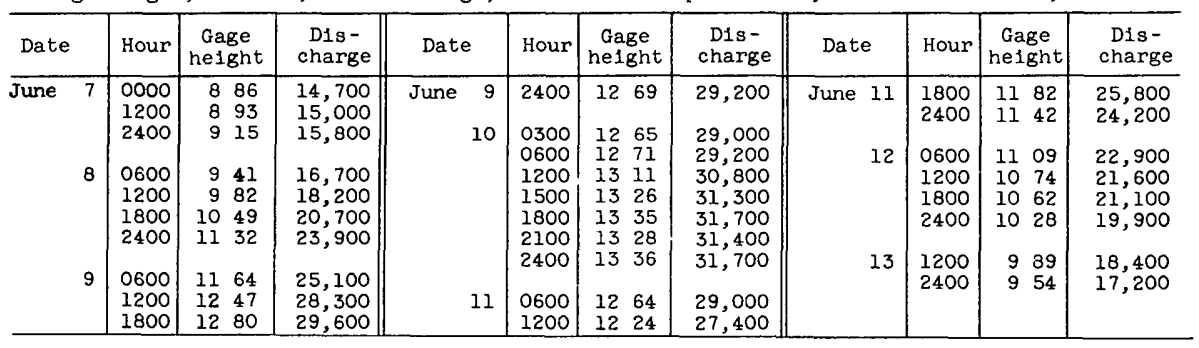

(152) 12-3410 Rattlesnake Creek at Missoula, Mont

Location --Lat $46^{\circ} 52^{\prime} 20^{\prime \prime}$, long $113^{\circ} 59^{\prime} 00^{\prime \prime}$, in $S W \frac{1}{4} \mathrm{NE} \frac{1}{4} \sec 22$, T $13 \mathrm{~N}$, R $19 \mathrm{~W}$, on upstream side of Vine Street Bridge in Missoula, half a mile upstream from mouth

Drainage area $-797 \mathrm{sq} \mathrm{mi}$

Gage-he1ght record --Once-da11y wire-welght gage readings Alt1tude of gage is $3,220 \mathrm{ft}$ (from topographic map)

Discharge record --Stage-discharge relation defined by current-meter measurements Maxima --June 1964 Discharge observed, 1,830 cfs 1820 hours June 8 (gage he1ght, $1015 \mathrm{ft})$

1899, 1958 to May 1964 Discharge observed, 2,050 cf's June 18, 1899 (gage helght, $625 \mathrm{ft}$, site and datum then in use)

Discharge known, 2,400 cfs June 6, 1948, from flow-over-dam measurement at site

4 miles upstream

Mean discharge, in cubic feet per second, 1964

\begin{tabular}{|c|c|c|c|c|c|c|c|c|}
\hline Day & May & June & Day & May & June & Day & May & June \\
\hline $\begin{array}{r}1 \\
2 \\
3 \\
4 \\
5 \\
6 \\
7 \\
8 \\
9 \\
10\end{array}$ & $\begin{array}{l}173 \\
200 \\
176 \\
161 \\
161 \\
123 \\
128 \\
135 \\
142 \\
170\end{array}$ & $\begin{array}{r}690 \\
770 \\
828 \\
855 \\
770 \\
770 \\
770 \\
1,590 \\
1,480 \\
900\end{array}$ & $\begin{array}{l}11 \\
12 \\
13 \\
14 \\
15 \\
16 \\
17 \\
18 \\
19 \\
20\end{array}$ & $\begin{array}{l}170 \\
185 \\
295 \\
290 \\
295 \\
340 \\
810 \\
855 \\
960 \\
980\end{array}$ & $\begin{array}{l}770 \\
690 \\
706 \\
706 \\
770 \\
770 \\
770 \\
730 \\
650 \\
706\end{array}$ & $\begin{array}{l}21 \\
22 \\
23 \\
24 \\
25 \\
26 \\
27 \\
28 \\
29 \\
30 \\
31\end{array}$ & $\begin{array}{r}1,200 \\
855 \\
510 \\
340 \\
315 \\
290 \\
375 \\
706 \\
690 \\
510 \\
492 \\
\end{array}$ & $\begin{array}{r}580 \\
580 \\
615 \\
666 \\
650 \\
636 \\
580 \\
510 \\
390 \\
290 \\
---\quad-\end{array}$ \\
\hline $\begin{array}{l}\text { Monthl } \\
\text { Runof } f \\
\text { Runoff }\end{array}$ & $\begin{array}{l}\text { n discha } \\
\text { inches } \\
\text { acre-fee }\end{array}$ & e, In cul & c feet & cond & & & $\begin{array}{r}420 \\
608 \\
25,850\end{array}$ & $\begin{array}{r}740 \\
10 \quad 35 \\
44,000\end{array}$ \\
\hline
\end{tabular}


(153) 12-3530 Clark Fork below Missoula, Mont

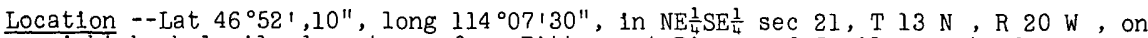
right bank 1 mile downstream from Bitterroot River and 5 miles west of Missoula

Drainage area $--9,003 \mathrm{sq} \mathrm{ml}$

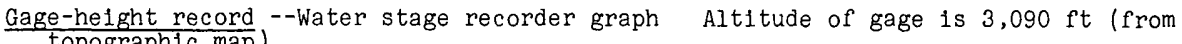
topographic map)

D1scharge record --Stage-discharge relation defined by current-meter measurements

Maxima --June 1964 Discharge, 50,100 cfs 2100 hours, June 10 (gage he1ght, $1145 \mathrm{ft}$ ) 1929 to May 1964 Discharge, $52,800 \mathrm{cfs}$ May 23, 1948 (gage helght, $1208 \mathrm{ft}$ )

Mean discharge, in cub1c feet per second, 1964

\begin{tabular}{|c|c|c|c|c|c|c|c|c|}
\hline Day & May & June & Day & May & June & Day & May & June \\
\hline $\begin{array}{r}1 \\
2 \\
3 \\
4 \\
5 \\
6 \\
7 \\
8 \\
9 \\
10\end{array}$ & $\begin{array}{l}7,190 \\
8,320 \\
8,660 \\
8,320 \\
7,840 \\
7,720 \\
7,600 \\
7,310 \\
7,340 \\
7,810\end{array}$ & $\begin{array}{l}25,200 \\
25,800 \\
27,400 \\
28,700 \\
28,100 \\
28,600 \\
30,500 \\
34,800 \\
45,000 \\
49,100\end{array}$ & $\begin{array}{l}11 \\
12 \\
13 \\
14 \\
15 \\
16 \\
17 \\
18 \\
19 \\
20\end{array}$ & $\begin{array}{r}8,860 \\
9,250 \\
9,830 \\
11,100 \\
11,900 \\
13,300 \\
16,100 \\
19,500 \\
21,100 \\
23,900\end{array}$ & $\begin{array}{l}45,600 \\
37,400 \\
32,200 \\
29,900 \\
29,500 \\
29,800 \\
30,900 \\
31,200 \\
28,700 \\
27,800\end{array}$ & $\begin{array}{l}21 \\
22 \\
23 \\
24 \\
25 \\
26 \\
27 \\
28 \\
29 \\
30 \\
31\end{array}$ & $\begin{array}{l}27,600 \\
28,700 \\
25,700 \\
22,000 \\
19,300 \\
17,600 \\
17,000 \\
19,200 \\
24,100 \\
26,900 \\
25,800\end{array}$ & $\begin{array}{r}25,900 \\
24,300 \\
22,600 \\
22,300 \\
23,400 \\
24,800 \\
25,100 \\
24,000 \\
21,700 \\
18,800 \\
-\quad-\quad--\end{array}$ \\
\hline \multicolumn{7}{|c|}{$\begin{array}{l}\text { Monthly mean discharge, in cublc feet per second } \\
\text { Runoff, in acre-feet }\end{array}$} & $\begin{array}{r}15,380 \\
945,800\end{array}$ & $\begin{array}{r}29,320 \\
1,744,000\end{array}$ \\
\hline
\end{tabular}

Gage height, in feet, and discharge, in cublc feet per second, at indicated time, 1964

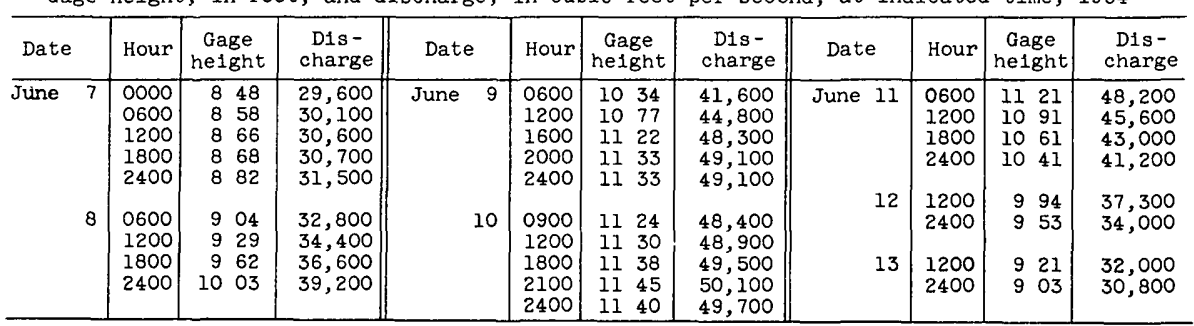

(154) 12-3534 Nigger Gulch near Alberton, Mont

(Crest-stage gage)

Location --Lat $47^{\circ} 01^{\prime}$, long $114^{\circ} 32^{\prime}$, in $N W^{\frac{1}{4}} \sec 33, \mathrm{~T} 15 \mathrm{~N}, \mathrm{R} 23 \mathrm{~W}$, at culvert on county road, 26 miles west of Alberton

Drainage area $--802 \mathrm{sq} \mathrm{mi}$

$\frac{\text { Gage-height record }}{\text { graphic map) }}$-Crest-stages only Altitude of gage is $3,000 \mathrm{ft}$ (from topo-

Discharge record --Stage-discharge relation defined by current-meter measurements

Maxima --June 1964 Discharge, $67 \mathrm{cfs}$ June 9 (gage helght, $101 \mathrm{ft}$ )

1959 to May 1964 D1scharge, 50 cfs May 21, 1964 (gage he1ght, $082 \mathrm{ft}$ ) 
(155) 12-3538 Thompson Creek near Superior, Mont

(Crest-stage station)

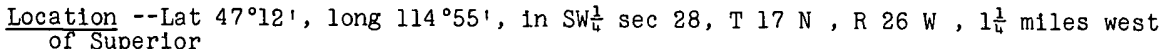
Drainage area $--122 \mathrm{sq} \mathrm{mi}$

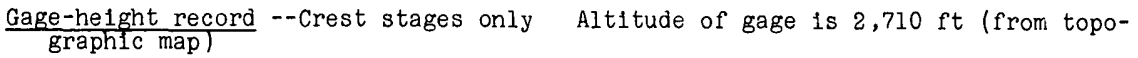

Discharge record --Stage-discharge relation defined by current-meter measurements

Maxima --June 1964 Discharge, $72 \mathrm{cfs}$ June 8 (gage helght, $040 \mathrm{ft}$ )

1961 to May 1964 Discharge, $85 \mathrm{cfs}$ Apr 24, 1962 (gage height, $082 \mathrm{ft}$ )

(156) 12-3538 5 East Fork T1mber Creek near Haugan, Mont

(Crest-stage station)

Location --Lat $47^{\circ} 25^{\prime}$, long $115^{\circ} 25^{\prime}$, in $\mathrm{NE} \frac{1}{4} \sec 16, \mathrm{~T} 19 \mathrm{~N}, \mathrm{R} 30 \mathrm{~W}$, at culvert on county road 2 miles north of Haugan

Drainage area $--272 \mathrm{sq} \mathrm{ms}$

$\frac{\text { Gage-helght record }}{\text { graphlc map) }}$-Crest stages only Altitude of gage is $3,350 \mathrm{ft}$ (from topo-

D1scharge record --Stage-discharge relation defined by current-meter measurements

Maxima --June 1964 Discharge, $32 \mathrm{cfs}$ June 8 (gage he1ght, $071 \mathrm{ft}$ )

1961 to May 1964 Discharge, $45 \mathrm{cfs}$ Apr 15, 1962 (gage he1ght, $082 \mathrm{ft}$ ), gage helght, $087 \mathrm{ft}$ May 21 , 1964

\section{(157) 12-3540 St Regis River near St Reg1s, Mont}

Location --Lat $47^{\circ} 17^{\prime} 50^{\prime \prime}$, long $115^{\circ} 07^{\prime} 20^{\prime \prime}$, in $\mathrm{NE} \frac{1}{4} \sec 26, \mathrm{~T} 18 \mathrm{~N}$, $\mathrm{R} 28 \mathrm{~W}$, on left bank at county road bridge, $500 \mathrm{ft}$ upstream from Little Joe Creek, $1 \frac{1}{4}$ miles west of St Regis, and $1 \frac{1}{2}$ miles upstream from mouth

Drainage area $--303 \mathrm{sq} \mathrm{m}$

Gage-he1ght record --Water-stage recorder graph Datum of gage is $2,64500 \mathrm{ft}$ above mean sea level, datum of 1929

Discharge record --Stage-discharge relation defined by current-meter measurements

Maxima --June 1964 Discharge, 5,120 cfs 2200 hours June 8 (gage he1ght, $616 \mathrm{ft}$ ) 1910-17, 1958 to May 1964 Discharge observed, 7,740 cfs May 28, 1917 (gage height, $865 \mathrm{ft}$ at site 2 miles upstream and at datum then in use)

Flood of about Dec 20,1933 , reached a stage of about $145 \mathrm{ft}$, from information by local residents (discharge unknown) Flood of May 19, 1954, reached a discharge of about $11,000 \mathrm{cfs}$ (gage height, $94 \mathrm{ft}$ ), from rating curve extended above $5,100 \mathrm{cfs}$

Mean discharge, in cublc feet per second, 1964

\begin{tabular}{|c|c|c|c|c|c|c|c|c|}
\hline Day & May & June & Day & May & June & Day & May & June \\
\hline $\begin{array}{r}1 \\
2 \\
3 \\
4 \\
5 \\
6 \\
7 \\
8 \\
9 \\
10\end{array}$ & $\begin{array}{r}940 \\
950 \\
880 \\
789 \\
729 \\
671 \\
663 \\
712 \\
900 \\
1,190\end{array}$ & $\begin{array}{l}3,660 \\
3,240 \\
3,160 \\
2,910 \\
2,600 \\
2,800 \\
2,820 \\
4,150 \\
4,420 \\
3,460\end{array}$ & $\begin{array}{l}11 \ldots \\
12 \\
13 \\
14 \\
15 \\
16 \\
17 \\
18 \\
19 \\
20\end{array}$ & $\begin{array}{l}1,290 \\
1,400 \\
1,620 \\
1,590 \\
1,590 \\
1,840 \\
2,560 \\
2,700 \\
3,000 \\
3,440\end{array}$ & $\begin{array}{l}2,130 \\
2,380 \\
2,220 \\
2,130 \\
2,010 \\
2,020 \\
1,820 \\
1,620 \\
1,430 \\
1,290\end{array}$ & $\begin{array}{l}21 \\
22 \\
23 \\
24 \\
25 \\
26 \\
27 \\
28 . \\
29 \\
30 \\
31\end{array}$ & $\begin{array}{l}3,750 \\
2,780 \\
2,040 \\
1,700 \\
1,520 \\
1,480 \\
1,470 \\
2,000 \\
2,860 \\
2,400 \\
2,980\end{array}$ & $\begin{array}{r}1,220 \\
1,160 \\
1,140 \\
1,200 \\
1,180 \\
1,100 \\
1,060 \\
950 \\
861 \\
816 \\
----\end{array}$ \\
\hline $\begin{array}{l}\text { Month } \\
\text { Runoff } \\
\text { Runoff }\end{array}$ & $\begin{array}{l}\text { mean discha } \\
\text { In Inches } \\
\text { in acre-fee }\end{array}$ & , In cu & feet & cond & & & $\begin{array}{r}1,740 \\
6.62 \\
107,000\end{array}$ & $\begin{array}{r}2,099 \\
773 \\
124,900\end{array}$ \\
\hline
\end{tabular}


Gage height, in feet, and discharge, in cub1c feet per second, at indicated t1me, 1964, of

\begin{tabular}{|c|c|c|c|c|c|c|c|c|c|c|c|c|}
\hline Date & Hour & $\begin{array}{c}\text { Gage } \\
\text { height }\end{array}$ & $\begin{array}{c}\text { D1s- } \\
\text { charge }\end{array}$ & Date & & Hour & $\begin{array}{c}\text { Gage } \\
\text { helght }\end{array}$ & $\begin{array}{c}\text { Dis- } \\
\text { charge }\end{array}$ & Date & Hour & $\begin{array}{c}\text { Gage } \\
\text { height }\end{array}$ & $\begin{array}{l}\text { Dis- } \\
\text { charge }\end{array}$ \\
\hline June 8 & $\begin{array}{l}0000 \\
0300 \\
0400 \\
0600 \\
0900 \\
1200 \\
1400 \\
1500 \\
1700\end{array}$ & $\begin{array}{ll}4 & 78 \\
4 & 82 \\
4 & 90 \\
5 & 10 \\
5 & 40 \\
5 & 83 \\
5 & 96 \\
6 & 05 \\
6 & 06\end{array}$ & $\begin{array}{l}2,790 \\
2,850 \\
2,970 \\
3,270 \\
3,770 \\
4,520 \\
4,760 \\
4,920 \\
4,940\end{array}$ & June & 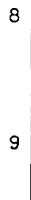 & $\begin{array}{l}1800 \\
2000 \\
2100 \\
2200 \\
2400 \\
0600 \\
1200 \\
1800\end{array}$ & $\begin{array}{ll}6 & 01 \\
6 & 08 \\
6 & 09 \\
6 & 16 \\
6 & 14 \\
& \\
5 & 97 \\
5 & 71 \\
5 & 56\end{array}$ & $\begin{array}{l}4,850 \\
4,970 \\
4,990 \\
5,120 \\
5,090 \\
4,780 \\
4,320 \\
4,060\end{array}$ & $\begin{array}{r}\text { June } 9 \\
10\end{array}$ & $\begin{array}{l}2400 \\
0600 \\
1200 \\
1400 \\
1800 \\
2100 \\
2400\end{array}$ & $\begin{array}{ll}5 & 50 \\
5 & 35 \\
5 & 15 \\
5 & 03 \\
4 & 98 \\
5 & 03 \\
5 & 02\end{array}$ & $\begin{array}{l}3,960 \\
3,720 \\
3,400 \\
3,220 \\
3,150 \\
3,220 \\
3,210\end{array}$ \\
\hline
\end{tabular}

(158) 12-3541 North Fork Little Joe Creek near St Regis, Mont

(Crest-stage station)

Location --Lat $47^{\circ} 16^{\prime}$, long $115^{\circ} 09^{\prime}$, in $\mathrm{SW} \frac{1}{4} \mathrm{SE} \frac{1}{4} \sec 34, \mathrm{~T} 18 \mathrm{~N}, \mathrm{R} 28 \mathrm{~W}$, at bridge on county road, 3 miles southwest of $S t$ Regis

Drainage area $--14 \quad 7 \mathrm{sq} \mathrm{mi}$

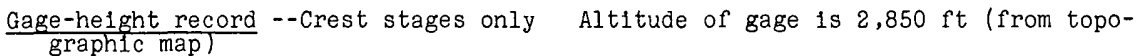

Discharge record --Stage-discharge relation defined by current-meter measurements

Maxima --June 1964 Discharge, $212 \mathrm{cfs}$ June 8 (gage he1ght, $191 \mathrm{ft}$ )

1960 to May 1964 Discharge, $185 \mathrm{cfs}$ May 26, 1961 (gage height, I $88 \mathrm{ft}$ )

(159) 12-3545 Clark Fork at St Reg1s, Mont

Location --Lat $47^{\circ} 18^{\prime} 05^{\prime \prime}$, long $115^{\circ} 05^{\prime} 15^{\prime \prime}$, in center of SW $\frac{1}{4} \sec 19, \mathrm{~T} 18 \mathrm{~N}, \mathrm{R} 27 \mathrm{~W}$, on left bank at St Regis, half a mile downstream from St Regis River

Drainage area $--10,709 \mathrm{sq} \mathrm{mi}$

Gage-he1ght record - Water-stage recorder graph Altitude of gage is 2,600 $\mathrm{ft}$ (river-profile map)

D1scharge record --Stage-discharge relation defined by current-meter measurements

Maxima --June 1964 Discharge, $60,900 \mathrm{cfs} 1200$ hours June 10'(gage he1ght, $1854 \mathrm{ft}$ ) 1910 to May 1964 Discharge, 68,900 cfs May 24, 1948 (gage height, $1996 \mathrm{ft}$,

from graph based on gage readings)

Remarks --Many diversions above station

Mean discharge, in cubic feet per second, 1964

\begin{tabular}{|c|c|c|c|c|c|c|c|c|}
\hline Day & May & June & Day & May & June & Day & May & June \\
\hline $\begin{array}{r}1 \\
2 \\
3 \\
4 \\
5 \\
6 \\
7 \\
8 \\
9 \\
10\end{array}$ & $\begin{array}{r}8,350 \\
9,980 \\
10,900 \\
10,700 \\
10,200 \\
9,710 \\
9,630 \\
9,500 \\
9,630 \\
10,400\end{array}$ & $\begin{array}{l}34,500 \\
35,400 \\
37,100 \\
38,500 \\
38,500 \\
38,400 \\
39,800 \\
45,300 \\
53,700 \\
60,000\end{array}$ & $\begin{array}{l}11 \\
12 \\
13 \\
14 \\
15 \\
16 \\
17 \\
18 \\
19 \\
20\end{array}$ & $\begin{array}{l}11,500 \\
12,700 \\
13,700 \\
14,800 \\
16,100 \\
17,700 \\
21,100 \\
25,500 \\
29,100 \\
32,100\end{array}$ & $\begin{array}{l}59,700 \\
52,200 \\
45,400 \\
40,900 \\
39,000 \\
38,900 \\
38,900 \\
39,500 \\
37,600 \\
34,700\end{array}$ & $\begin{array}{l}1 \\
22 \\
23 \\
24 \\
25 \\
26 \\
27 \\
28 \\
29 \\
30 \\
31\end{array}$ & $\begin{array}{l}36,300 \\
38,000 \\
35,200 \\
30,600 \\
26,600 \\
24,100 \\
22,500 \\
24,200 \\
28,800 \\
33,800 \\
35,000\end{array}$ & $\begin{array}{r}33,500 \\
31,200 \\
29,400 \\
28,400 \\
28,700 \\
29,700 \\
30,400 \\
29,800 \\
27,800 \\
-\quad 24,300 \\
-\end{array}$ \\
\hline lontr & & In & feet & & & . & $\begin{array}{r}20,270 \\
1,246,000\end{array}$ & $\begin{array}{r}38,040 \\
2,264,000\end{array}$ \\
\hline
\end{tabular}


Gage height, In feet, and discharge, in cublc feet per second, at 1ndicated time, 1964, of Clark Fork at St Regis, Mont

\begin{tabular}{|c|c|c|c|c|c|c|c|c|c|c|c|c|c|}
\hline Date & & Hour & $\begin{array}{c}\text { Gage } \\
\text { helght }\end{array}$ & $\begin{array}{c}\text { D1s- } \\
\text { charge }\end{array}$ & Date & Hour & $\begin{array}{c}\text { Gage } \\
\text { he1ght }\end{array}$ & $\begin{array}{c}\text { Dis- } \\
\text { charge }\end{array}$ & \multicolumn{2}{|l|}{ Date } & Hour & $\begin{array}{c}\text { Gage } \\
\text { helght }\end{array}$ & $\begin{array}{l}\text { D1s- } \\
\text { charge }\end{array}$ \\
\hline June & 7 & $\begin{array}{l}0000 \\
0600 \\
1200 \\
1800\end{array}$ & $\begin{array}{ll}15 & 04 \\
15 & 19 \\
15 & 23 \\
15 & 26\end{array}$ & $\begin{array}{l}38,700 \\
39,600 \\
39,900 \\
40,100\end{array}$ & June 9 & $\begin{array}{l}1200 \\
1800 \\
2400\end{array}$ & $\begin{array}{ll}17 & 55 \\
17 & 80 \\
18 & 05\end{array}$ & $\begin{array}{l}54,000 \\
55,700 \\
57,400\end{array}$ & June & 11 & $\begin{array}{l}1400 \\
1800 \\
2400\end{array}$ & $\begin{array}{ll}18 & 44 \\
18 & 34 \\
17 & 98\end{array}$ & $\begin{array}{l}60,200 \\
59,500 \\
57,000\end{array}$ \\
\hline & 8 & $\begin{array}{l}2400 \\
0600 \\
1200 \\
1800\end{array}$ & $\begin{array}{ll}15 & 35 \\
15 & 63 \\
16 & 21 \\
16 & 59\end{array}$ & $\begin{array}{l}40,600 \\
42,300 \\
45,800 \\
48,000\end{array}$ & 10 & $\begin{array}{l}0400 \\
0800 \\
1200 \\
1800 \\
2400\end{array}$ & $\begin{array}{ll}18 & 28 \\
18 & 45 \\
18 & 54 \\
18 & 48 \\
18 & 44\end{array}$ & $\begin{array}{l}59,100 \\
60,200 \\
60,900 \\
60,500 \\
60,200\end{array}$ & & 12 & $\begin{array}{l}0600 \\
1200 \\
1800 \\
2400\end{array}$ & $\begin{array}{ll}17 & 59 \\
17 & 23 \\
16 & 92 \\
16 & 61\end{array}$ & $\begin{array}{l}54,200 \\
51,900 \\
50,000 \\
48,200\end{array}$ \\
\hline & 9 & $\begin{array}{l}2400 \\
0600\end{array}$ & $\begin{array}{l}1688 \\
17 \quad 19\end{array}$ & $\begin{array}{l}49,800 \\
51,600\end{array}$ & 11 & $\begin{array}{l}0400 \\
0800\end{array}$ & $\begin{array}{ll}18 & 45 \\
18 & 50 \\
\end{array}$ & $\begin{array}{l}60,200 \\
60,600\end{array}$ & & 13 & $\begin{array}{l}0600 \\
1200 \\
2400\end{array}$ & $\begin{array}{ll}16 & 43 \\
16 & 11 \\
15 & 68\end{array}$ & $\begin{array}{l}47,100 \\
45,200 \\
42,600\end{array}$ \\
\hline
\end{tabular}

(160) 12-3550 Flathead River at Flathead, British Columbia (International gaging station)

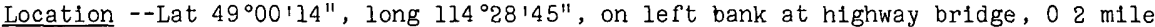
north of internationai boundary, 02 mile northwest of Flathead, British Columbia, and 7 miles northwest of Trail Creek, Mont

Drainage area $-450 \mathrm{sq} \mathrm{mi}$, approximately

Gage-helght record --Water-stage recorder graph Altitude of gage $1 \mathrm{~s} 3,980 \mathrm{ft}$ (from topographic map)

Discharge record --Stage-discharge relation defined by current-meter measurements below $8,000 \mathrm{c}$ 's and by slope-area measurement at $16,300 \mathrm{cfs}$

Maxima -- June 1964 Discharge, 16,300 cfs 2315 hours June 8 (gage he1ght, $80 \mathrm{ft}$, from recorder graph, 86 ft, from floodmarks)

1929 to May 1964 Discharge, 14,600 cfs May 23, 1948 (gage height, $91 \mathrm{ft}$, from floodmark

Mean discharge, in cubic feet per second, 1964

\begin{tabular}{|c|c|c|c|c|c|c|c|c|}
\hline Day & May & June & Day & May & June & Day & May & June \\
\hline $\begin{array}{r}1 \\
2 \\
3 \\
4 \\
5 \\
6 \\
7 \\
8 \\
9 \\
10\end{array}$ & $\begin{array}{l}1,100 \\
1,290 \\
2,270 \\
2,850 \\
2,560 \\
2,160 \\
1,930 \\
2,060 \\
2,470 \\
3,350\end{array}$ & $\begin{array}{r}6,080 \\
6,330 \\
6,410 \\
7,260 \\
6,540 \\
6,830 \\
6,440 \\
11,900 \\
13,500 \\
8,450\end{array}$ & $\begin{array}{l}11 \\
12 \\
13 \\
14 \\
15 \\
16 \\
17 \\
18 \\
19 \\
20\end{array}$ & $\begin{array}{l}3,330 \\
3,350 \\
3,910 \\
4,150 \\
3,730 \\
3,840 \\
4,630 \\
5,310 \\
6,050 \\
6,970\end{array}$ & $\begin{array}{l}6,710 \\
6,510 \\
5,780 \\
5,550 \\
5,010 \\
4,740 \\
4,640 \\
4,040 \\
3,710 \\
3,580\end{array}$ & $\begin{array}{l}21 \\
22 \\
23 \\
24 \\
25 \\
26 \\
27 \\
28 \\
29 \\
30 \\
31\end{array}$ & $\begin{array}{l}8,220 \\
5,650 \\
3,980 \\
3,370 \\
3,000 \\
3,080 \\
3,760 \\
4,770 \\
5,050 \\
5,480 \\
5,780\end{array}$ & $\begin{array}{r}3,290 \\
3,210 \\
3,320 \\
3,540 \\
3,400 \\
3,200 \\
3,060 \\
2,780 \\
2,440 \\
-2,320 \\
-\end{array}$ \\
\hline \multicolumn{7}{|c|}{$\begin{array}{l}\text { Monthly mean discharge, in cublc feet per second } \\
\text { Runoff, in inches } \\
\text { Runoff, in acre-feet }\end{array}$} & $\begin{array}{r}3,850 \\
9 \quad 87 \\
236,900\end{array}$ & $\begin{array}{r}5,350 \\
13 \quad 27 \\
318,500\end{array}$ \\
\hline
\end{tabular}

Gage height, in feet, and discharge, in cublc feet per second, at indicated time, 1964

\begin{tabular}{|c|c|c|c|c|c|c|c|c|c|c|c|}
\hline Date & Hour & $\begin{array}{c}\text { Gage } \\
\text { helght }\end{array}$ & $\begin{array}{c}\text { D1s - } \\
\text { charge }\end{array}$ & Date & Hour & $\begin{array}{c}\text { Gage } \\
\text { he1ght }\end{array}$ & $\begin{array}{c}\text { Dis - } \\
\text { charge }\end{array}$ & Date & Hour & $\begin{array}{c}\text { Gage } \\
\text { height }\end{array}$ & $\begin{array}{c}\text { Dis- } \\
\text { charge }\end{array}$ \\
\hline June 7 & $\begin{array}{l}0000 \\
0500 \\
1200 \\
1800 \\
2400 \\
\\
0300 \\
0600 \\
0900\end{array}$ & $\begin{array}{ll}4 & 76 \\
4 & 64 \\
4 & 78 \\
4 & 88 \\
5 & 12 \\
5 & 37 \\
5 & 60 \\
6 & 06\end{array}$ & $\begin{array}{l}6,310 \\
6,000 \\
6,360 \\
6,620 \\
7,260 \\
7,940 \\
8,590 \\
9,960\end{array}$ & June 8 & $\begin{array}{l}1200 \\
1500 \\
1700 \\
1800 \\
2000 \\
2200 \\
2315 \\
2400\end{array}$ & $\begin{array}{rr}6 & 75 \\
7 & 30 \\
7 & 50 \\
7 & 80 \\
7 & 88 \\
7 & 80 \\
\mathrm{a} 8 & 00 \\
7 & 88\end{array}$ & $\begin{array}{l}12,100 \\
14,000 \\
14,600 \\
15,600 \\
15,900 \\
15,600 \\
16,300 \\
15,900\end{array}$ & June 9 & $\begin{array}{l}0300 \\
0400 \\
0530 \\
0800 \\
1200 \\
1500 \\
1800 \\
2100 \\
2400\end{array}$ & $\begin{array}{ll}7 & 83 \\
7 & 58 \\
7 & 39 \\
7 & 70 \\
7 & 40 \\
7 & 02 \\
6 & 65 \\
6 & 38 \\
6 & 08\end{array}$ & $\begin{array}{l}15,700 \\
14,900 \\
14,300 \\
15,300 \\
14,300 \\
13,000 \\
11,800 \\
11,000 \\
10,000\end{array}$ \\
\hline
\end{tabular}

a Gage helght, $86 \mathrm{ft}$, from floodmark 
(161) Tra11 Creek near Polebridge, Mont

(Miscellaneous site)

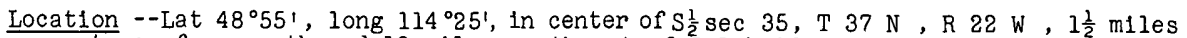

upstream from mouth and 12 miles northwest of Polebridge

Drainage area $--64 \quad 6 \mathrm{sq} \mathrm{mi}$

Maximum --June 1964 Discharge, 2,100 cfs June 8, from slope-area measurement

(162) Bowman Creek near Polebridge, Mont

(Miscellaneous site)

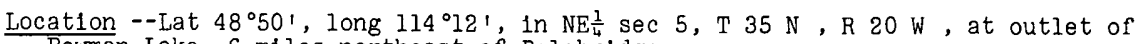

Bowman Lake, 6 miles northeast of Polebridge

Drainage area $--44 \quad 0 \mathrm{sq} \mathrm{ml}$

Maximum --June 1964 Discharge, 2,780 cfs June 8, from slope-area measurement

(163) Big Creek at Big Creek ranger station, near West Glacler, Mont

(Miscellaneous site)

Location --Lat $48^{\circ} 36^{\prime}$, long $114^{\circ} 10^{\prime}$, in sec 21 , T $33 \mathrm{~N}, \mathrm{R} 20 \mathrm{~W}$, at B1g Creek ranger station, $500 \mathrm{ft}$ upstream from road, a quarter of a mile upstream from mouth, $15 \frac{1}{2}$ miles northeast of Whitefish, and 11 miles northwest of West Glacler

Drainage area $--842 \mathrm{sq} \mathrm{ml}$

Maximum --June 1964 Discharge, 2,130 cfs June 8, from slope-area measurement

\section{(164) 12-3555 Flathead River near Columbla Falls, Mont}

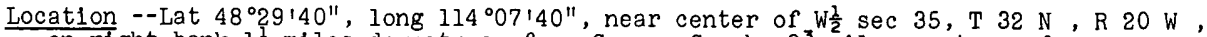
on right bank $1 \frac{1}{2}$ miles downstream from Canyon Creek, $3 \frac{3}{4}$ miles upstream from Middle Fork, and 9 miles northeast of Columbia Falls

Drainage area $--1,548 \mathrm{sq} \mathrm{mi}$

Gage-helght record --Water-stage recorder graph Datum of gage is $3,14559 \mathrm{ft}$ above mean sea level, datum of 1929 , supplementary adjustment of 1947

Discharge record --Stage-discharge relation defined by current-meter measurements below $37,000 \mathrm{cfs}$ and by slope-area measurement at 69,100 cfs

Niaxima --June 1964 Discharge, 69,100 cfs 0900 hours June 9 (gage he1ght, $1860 \mathrm{ft}$, from floodmarks)

1910-17, 1929 to May 1964 Discharge, 31,500 cfs May 21, 1954 (gage he1ght, $1225 \mathrm{ft}$, at site $2 \frac{1}{4}$ miles downstream and at datum then in use)

Mean d1scharge, In cublc feet per second, 1964

\begin{tabular}{|c|c|c|c|c|c|c|c|c|}
\hline Day & May & June & Day & May & June & Day & May & June \\
\hline $\begin{array}{l}\text { Monthly } \\
\text { Runoff, } \\
\text { Runoff, }\end{array}$ & \multicolumn{6}{|c|}{ mean discharge, in cubic feet per second } & $\begin{array}{r}10,400 \\
774 \\
639,300\end{array}$ & $\begin{array}{r}17,260 \\
1244 \\
1,027,000\end{array}$ \\
\hline
\end{tabular}


Gage height, in feet, and discharge, in cublc feet per second, at ind1cated time, 1964, of Flathead River near Columbia Falls, Mont

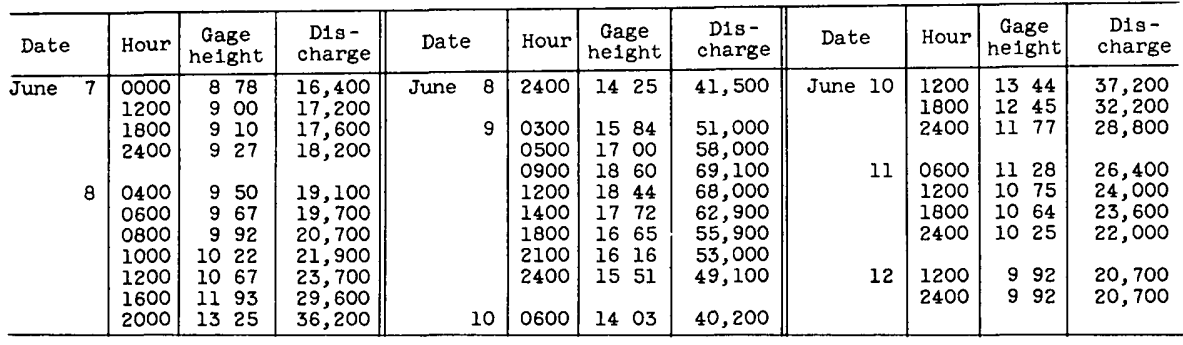

(165) 12-3557 Middle Fork Flathead River near Essex, Mont

(Gaging station, discontinued 1961)

Location - Lat $48^{\circ} 10^{\prime} 20^{\prime \prime}$, long $113^{\circ} 32^{\prime} 40^{\prime \prime}$, near center sec 19, T $28 \mathrm{~N}, \mathrm{R} 15 \mathrm{~W}$, on right bank a quarter of a mile downstream from Spruce Park Cabin (déstroyed in flood), 1 mile downstream from Charlie Creek, and $7 \frac{1}{2}$ miles southeast of Essex Alt1tude of gage was $3,130 \mathrm{ft}$ (from river-profile map)

Drainage area $--408 \mathrm{sq} \mathrm{mi}$

Maxima --June 1964 Discharge, $57,900 \mathrm{cf}$ 's June 8 , from slope-area measurement 1957-61 Discharge, 10,500 cfs June 6, 1959 (gage height, $1132 \mathrm{ft}$ )

\section{(166) 12-3560 Skyland Creek near Essex, Mont}

(Gaging station, partial-record station beginning 1959)

Location --Lat $48^{\circ} 17^{\prime} 30^{\prime \prime}$, long $113^{\circ} 23^{\prime} 10^{\prime \prime}$, in SE $\frac{1}{4} \mathrm{NW} \frac{1}{4} \sec 9$, T $29 \mathrm{~N}, \mathrm{R} 14 \mathrm{~W}$, on left bank $150 \mathrm{ft}$ upstream from mouth and 10 miles east of Essex

Drainage area $--809 \mathrm{sq} \mathrm{mi}$

Gage-height record --Water-stage recorder graph, except maximum stage obtained from high-water mark in gage house Datum of gage is 4,835 $83 \mathrm{ft}$ above mean sea level, datum of 1929 (Corps of Eng1neers bench mark)

D1scharge record --Stage-discharge relation defined by current-meter measurements below $240 \mathrm{cf}$ Discharge for 1964 determined by slope-area measurement

Maxima --June 1964 Discharge, 3,580 cfs 1500 hours June 8 (gage helght, $955 \mathrm{ft}$, from high-water mark in weli)

1946-52, 1954, 1959 to May 1964 Discharge, 284 cfs May 22, 1948 (gage height, 2 is $\mathrm{ft}$ )

\section{(167) 12-3565 Bear Creek near Essex, Mont}

(Gaging station, discontinued 1952 )

Location --Lat $48^{\circ} 16^{\prime} 50^{\prime \prime}$, long $113^{\circ} 25^{\prime} 30^{\prime \prime}$, in SE $\frac{1}{4} \mathrm{NW} \frac{1}{4} \sec 18$, T $29 \mathrm{~N}, \mathrm{R} 14 \mathrm{~W}$, on right bank 1 mile downstream from Autumn Creek and $8 \frac{1}{2}$ miles northeast of Essex

Drainage area $--207 \mathrm{sq} \mathrm{mI}$

Gage-height record --High-water marks at gage site Datum of gage is 4,484,14 $\mathrm{ft}$ above mean sea level (Corps of Englneers bench mark)

Discharge record --Peak discharge by slope-area measurement

Maxima --June 1964 Discharge, $8,380 \mathrm{cf}$ 's June 8 (gage height, about $72 \mathrm{ft}$, from floodmarks ) 1946-52 D1scharge, 696 cfs May 22, 1948 (gage height, $301 \mathrm{ft}$ ) 
(168) 12-3570 Middle Fork Flathead River at Essex, Mont

Location --Lat $48^{\circ} 16^{\prime} 30^{\prime \prime}$, long $113^{\circ} 36^{\prime} 10^{\prime \prime}$, in $\mathrm{NE} \frac{1}{4} \mathrm{SW}_{\frac{1}{4}} \mathrm{sec}-14$, T $29 \mathrm{~N}, \mathrm{R} 16 \mathrm{~W}$, on right bank 06 mile upstream from ole Creek, 07 mile southeast of Essex, and 4 miles downstream from Bear Creek

Drainage area $--510 \mathrm{sq} \mathrm{mi}$

Gage-helght record --Water-stage recorder graph, except May 14, to June 30 Datum of gage is $3,72193 \mathrm{ft}$ above mean sea level, datum of 1929 , supplementary adjustment of 1947

Discharge record --Stage-discharge relation defined by current-meter measurements below $12,000 \mathrm{cfs}$ and by slope-area measurements at 75,300 cfs Discharges May 14 to June 13 estimated on basis of four discharge measurements, weather records, and records for station near West Glacier

Maxima --June 1964 Discharge, $75,300 \mathrm{cfs}$ about 1830 hours June 8 (gage height, $267 \mathrm{ft}$, from floodmark)

1939-53, 1956 to May 1964 Discharge, 14,500 cfs May 22, 1948 (gage helght, $1095 \mathrm{ft}$, from partly estimated gage-helght record)

Flood in May 1954 reached a stage of $127 \mathrm{ft}$ (discharge, 18,000 cf's, from rating curve extended above $12,000 \mathrm{cfs})$

Mean discharge, in cublc feet per second, 1964

\begin{tabular}{|c|c|c|c|c|c|c|c|c|}
\hline Day & May & June & Day & May & June & Day & May & June \\
\hline $\begin{array}{r}1 \\
2 \\
3 \\
4 \\
5 \\
6 \\
7 \\
8 \\
9 \\
10\end{array}$ & $\begin{array}{l}2,010 \\
2,070 \\
1,860 \\
1,740 \\
1,660 \\
1,510 \\
1,380 \\
1,390 \\
1,620 \\
2,220\end{array}$ & $\begin{array}{r}6,900 \\
7,200 \\
7,600 \\
8,600 \\
7,900 \\
8,100 \\
7,900 \\
23,000 \\
37,000 \\
14,500\end{array}$ & $\begin{array}{l}11 \\
12 \\
13 \\
14 \\
15 \\
16 \\
17 \\
18 \\
19 \\
20\end{array}$ & $\begin{array}{l}2,560 \\
2,610 \\
3,080 \\
3,700 \\
3,600 \\
3,800 \\
5,000 \\
6,200 \\
6,600 \\
7,900\end{array}$ & $\begin{array}{l}9,200 \\
6,300 \\
5,900 \\
5,600 \\
5,400 \\
5,200 \\
5,100 \\
4,400 \\
3,900 \\
3,600\end{array}$ & $\begin{array}{l}21 \\
22 \\
23 \\
24 \\
25 \\
26 \\
27 \\
28 \\
29 \\
30 \\
31\end{array}$ & $\begin{array}{l}9,210 \\
6,660 \\
5,600 \\
4,500 \\
4,000 \\
3,800 \\
4,000 \\
5,700 \\
7,200 \\
7,100 \\
6,800\end{array}$ & $\begin{array}{r}3,300 \\
3,200 \\
3,300 \\
4,000 \\
4,300 \\
3,700 \\
3,500 \\
3,200 \\
2,600 \\
2,400 \\
--\quad--\end{array}$ \\
\hline $\begin{array}{l}\text { Monthiy } \\
\text { Runoff, } \\
\text { Runoff, }\end{array}$ & $\begin{array}{l}\text { mean discha } \\
\text { In inches } \\
\text { in acre-fee }\end{array}$ & , In cub & feet & cond & & & $\begin{array}{r}4,099 \\
9 \quad 27 \\
252,100\end{array}$ & $\begin{array}{r}7,227 \\
1581 \\
430,000\end{array}$ \\
\hline
\end{tabular}

(169) Essex Creek at Essex, Mont

(Miscellaneous site).

Location --Lat $48^{\circ} 16^{\prime}$, long $113^{\circ} 37^{\prime}$, in $\mathrm{W} \frac{1}{2} \sec 15, \mathrm{~T} 29 \mathrm{~N}, \mathrm{R} 16 \mathrm{~W}, 300 \mathrm{ft}$ upstream from Great Northern Railroad bridge, half a mile southwest of Essex, and 1 mile upstream from mouth

Drainage area $--105 \mathrm{sq} \mathrm{mi}$

Maximum --June 1964 Discharge, 2,760 cfs June 8, from slope-area measurement

(170) Park Creek near Essex, Mont

\section{(Miscellaneous site)}

Location --Lat $48^{\circ} 18^{1} 50^{\prime \prime}$, long $113^{\circ} 36^{\prime} 20^{\prime \prime}$, in $\operatorname{SW} \frac{1}{4} \sec 35$, T $30 \mathrm{~N}, \mathrm{R} 16 \mathrm{~W}$, half a mile upstream from mouth and $2 \frac{1}{2}$ miles north of Essex

Drainage area $--394 \mathrm{sq} \mathrm{m} 1$

Maximum --June 1964 Discharge, 7,180 cfs June 8, from slope-area measurement 
(171) Wahoo Creek near West Glacier, Mont

\section{(Miscellaneous site)}

Location --Lat $48^{\circ} 25^{\prime} 30^{\prime \prime}$, long $113^{\circ} 47^{\prime} 15^{\prime \prime}$, in $S E \frac{1}{4} \sec 20$, T $31 \mathrm{~N}, \mathrm{R} 17 \mathrm{~W}$, at culvert on old U S Highway 2,10 miles southeast of West Glacier and 13 miles northwest of Essex

Drainage area $--105 \mathrm{sq} \mathrm{mi}$

Maximum --June 1964 Discharge, 161 cfs June 8, from flow-through-culvert measurement

(172) 12-3573 Moccasin Creek near West Glacier, Mont

(Crest-stage station)

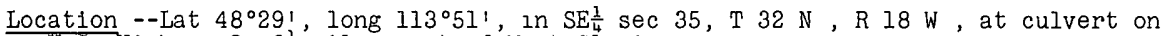
US Highway 2, $6 \frac{1}{2}$ 'miles east of 'West Glacier

Drainage area $--197 \mathrm{sq} \mathrm{mi}$

Gage-helght record --Crest stages only

Discharge record --Stage-discharge relation defined by current-meter measurements below 70 cf's

Maxima.--June 1964 Discharge unknown, but evidence indicates the flow to be more than $10,000 \mathrm{cfs}$

1959 to May 1964 Discharge, 120 cfs June 3, 1960 (gage height, 129 ft), gage height, $143 \mathrm{ft}$ May 27, 1961

\section{(173) Ousel Creek near West Glacler, Mont}

(Miscellaneous site)

Location --Lat $48^{\circ} 29^{\prime} 50^{\prime \prime}$, long $113^{\circ} 53^{\prime} 10^{\prime \prime}$, in $\mathrm{NW} \frac{1}{4} \mathrm{sec} 34$, T $32 \mathrm{~N}, \mathrm{R} 18 \mathrm{~W}$, about $1,000 \mathrm{ft}$ upstream from U S Highway 2, $4 \frac{1}{2}$ miles east of West Giacler

Drainage area $--292 \mathrm{sq} \mathrm{mi}$

Maximum --June 1964 Discharge, 4,160 cfs June 8, from slope-area measurement

(174) 12-3574 Middle Fork Flathead River tributary at West Glacier, Mont

(Crest-stage station)

Location --Lat $48^{\circ} 30^{\prime}$, long $113^{\circ} 58^{\prime}$, in $\mathrm{NE} \frac{1}{4} \sec 36, \mathrm{~T} 32 \mathrm{~N}, \mathrm{R} 19 \mathrm{~W}$, at culvert on US Highway 2, 09 mile east of west Glacier

Drainage area $--010 \mathrm{sq} \mathrm{mi}$

Gage-height record --Crest stages only

Discharge record --Stage-discharge relation defined by area-velocity estimate -

Maxima --June 1964 Discharge, about $8 \mathrm{cfs}$ June 8 (gage height, $032 \mathrm{ft}$ )

1960 to May 1964 Discharge, $3 \mathrm{cfs}$ Apr 3, 1960 (gage height, $027 \mathrm{ft}$ )

(175) McDonald Creek above Lake McDonald, near West Glacier, Mont

(Miscellaneous site)

Location --Lat $48^{\circ} 38^{\prime} 10^{\prime \prime}$, Iong $113^{\circ} 52^{1} 00^{\prime \prime}$, in $\mathrm{NE} \frac{1}{4} \mathrm{NE} \frac{1}{4} \mathrm{sec} 11$, T $33 \mathrm{~N}, \mathrm{R} 18 \mathrm{~W}$, at mouth of canyon, downstream from McDonald Falis, and 10 miles north of west Glacier -

Drainage area $--109 \mathrm{sq} \mathrm{mi}$

Maximum --June 1964 Discharge, 21,200 cfs June 8, from slope-area measurement 
(176) 12-3585 Middle Fork Flathead River near West Glacier, Mont

Location --Lat $48^{\circ} 29^{\prime} 50^{\prime \prime}$, long $114^{\circ} 00^{\prime} 30^{\prime \prime}$, in $\mathrm{SW}_{\frac{1}{4}} \mathrm{NE} \frac{1}{4} \sec 34, \mathrm{~T} 32 \mathrm{~N}, \mathrm{R} 19 \mathrm{~W}$, on left bank three-quarters of a mile downstream from McDonald Creek, $1 \frac{1}{4}$ miles west of West Glacier (formerly Belton), and $3 \frac{1}{2}$ miles upstream from mouth

Drainage area $--1,128 \mathrm{sq} \mathrm{m} 1$

Gage-he1ght record --Water-stage recorder graph except 1500 hours June 8 to 1900 hours June 12, for which graph was reconstructed on basis of floodmarks for peak and several observed stage readings Altitude of gage is $3,130 \mathrm{ft}$ (from riverprofile map)

Discharge record --Stage-discharge relation defined by current-meter measurements below $35,000 \mathrm{cfs}$ and extended above on basis of flood-volume hydrographic comparison $\frac{\text { Maxima }}{36} 46 \mathrm{ft}$, from floodmarks)

1939 to May 1964 Discharge, $34,500 \mathrm{cfs}$ May 20, 1954 (gage height, $1301 \mathrm{ft}$ )

Mean discharge, in cublc feet per second, 1964

\begin{tabular}{|c|c|c|c|c|c|c|c|c|}
\hline Day & May & June & Day & May & June & Day & May & June \\
\hline \multicolumn{7}{|c|}{$\begin{array}{l}\text { Monthly mean discharge, in cublc feet per second } \\
\text { Runoff, in inches } \\
\text { Runoff, in acre-feet }\end{array}$} & $\begin{array}{r}9,251 \\
946 \\
568,800 \\
\end{array}$ & $\begin{array}{r}19,870 \\
1965 \\
1,182,000 \\
\end{array}$ \\
\hline
\end{tabular}

Gage helght, in feet, and discharge, In cublc feet per second, at indicated time, 1964

\begin{tabular}{|c|c|c|c|c|c|c|c|c|c|c|c|}
\hline Date & Hour & $\begin{array}{c}\text { Gage } \\
\text { helght }\end{array}$ & $\begin{array}{c}\text { Dis- } \\
\text { charge }\end{array}$ & Date & Hour & $\begin{array}{c}\text { Gage } \\
\text { height }\end{array}$ & $\begin{array}{l}\text { D1s- } \\
\text { charge }\end{array}$ & Date & Hour & $\begin{array}{c}\text { Gage } \\
\text { helght }\end{array}$ & $\begin{array}{l}\text { D1s- } \\
\text { charge }\end{array}$ \\
\hline June 7 & $\begin{array}{l}0000 \\
0600 \\
1200 \\
1800 \\
2400 \\
0600 \\
1000 \\
1200 \\
1500 \\
1800\end{array}$ & $\begin{array}{rl}7 & 97 \\
7 & 96 \\
8 & 00 \\
8 & 00 \\
8 & 15 \\
8 & 94 \\
10 & 50 \\
12 & 54 \\
16 & 44 \\
22 & 7\end{array}$ & $\begin{array}{l}17,400 \\
17,400 \\
17,500 \\
17,500 \\
18,000 \\
20,900 \\
26,700 \\
32,400 \\
44,400 \\
74,100\end{array}$ & June 8 & $\begin{array}{l}2000 \\
2200 \\
2400 \\
\\
0030 \\
0200 \\
0600 \\
1200 \\
1800 \\
2400\end{array}$ & $\begin{array}{ll}27 & 1 \\
31 & 8 \\
36 & 1 \\
36 & 46 \\
35 & 5 \\
30 & 2 \\
25 & 3 \\
21 & 9 \\
19 & 4\end{array}$ & $\begin{array}{r}96,500 \\
119,000 \\
139,000 \\
114,000 \\
136,000 \\
112,000 \\
87,400 \\
70,000 \\
57,000\end{array}$ & June 10 & $\begin{array}{l}0600 \\
1200 \\
1800 \\
2400 \\
1200 \\
2400 \\
1200 \\
2400\end{array}$ & $\begin{array}{rl}17 & 2 \\
15 & 3 \\
13 & 5 \\
11 & 9 \\
10 & 3 \\
9 & 5 \\
9 & 0 \\
8 & 33\end{array}$ & $\begin{array}{l}47,200 \\
40,400 \\
34,800 \\
30,800 \\
26,000 \\
23,000 \\
21,200 \\
18,700\end{array}$ \\
\hline
\end{tabular}

(177) Bruce Creek near Hungry Horse, Mont

(Miscellaneous site)

Location --Lat $47^{\circ} 54^{\prime} 40^{\prime \prime}$, long $113^{\circ} 32^{\prime} 30^{\prime \prime}$, In NE $\frac{1}{4} S W \frac{1}{4} S E \frac{1}{4} \sec 19, T 25 \mathrm{~N}$, R $15 \mathrm{~W}$, $04 \mathrm{mile}$ downstream from Addition Creek, $1 \frac{1}{2}$ miles upstream from mouth, and 41 miles southeast of Hungry Horse

Dra1nage area $--160 \mathrm{sq} \mathrm{m}$

Maximum --June 1964 Discharge, 988 cfs June 8, from slope-area measurement 
(178) 12-3590 South Fork Flathead River at Spotted Bear ranger station, near Hungry Horse, Mont

Location --Lat $47^{\circ} 55^{\prime} 20^{\prime \prime}$, long $113^{\circ} 31^{\prime} 2^{\prime \prime}$, in $\operatorname{SE} \frac{1}{4} \operatorname{SW} \frac{1}{4} \sec 17, \mathrm{~T} 25 \mathrm{~N}, \mathrm{R} 15 \mathrm{~W}$, on left bank $600 \mathrm{ft}$ south of Spotted Bear ranger station, 1,000 ft upstream from Spotted Bear River, and 40 miles southeast of Hungry Horse

Drainage area $--958 \mathrm{sq} \mathrm{mi}$

Gage-helght record --Water-stage recorder graph Altitude of gage is 3,670 ft (from river-profile map)

D1scharge record --Stage-discharge relation defined by current-meter measurements below $18,000 \mathrm{cfs}$ and by slope-area measurement at $36,700 \mathrm{cfs}$

Maxima --June 1964 D1scharge, $36,700 \mathrm{cfs} 2200$ hours June 8 (gage he1ght, $1896 \mathrm{ft}$, In gage well, $195 \mathrm{ft}$, from outside floodmarks)

1948-57, 1959 to May 1964 Discharge, 21,200 cfs June 2, 1956 (gage helght.

$1252 \mathrm{ft}$ ), gage height, $1275 \mathrm{ft}$ May 20,1954

Flood of about May 22,1948 , reached a stage of $1400 \mathrm{ft}$, from outside floodmarks (discharge, 22,000 cfs, by slope-area measurement of peak flow)

Mean d1scharge, in cubic feet per second, 1964

\begin{tabular}{|c|c|c|c|c|c|c|c|c|c|}
\hline Day & May & June & Day & May & June & Day & & May & June \\
\hline $\begin{array}{r}1 \\
2 \\
3 \\
4 \\
5 \\
6 \\
7 \\
8 \\
9 \\
10\end{array}$ & $\begin{array}{l}2,960 \\
2,970 \\
2,690 \\
2,420 \\
2,270 \\
2,130 \\
1,980 \\
1,960 \\
2,080 \\
2,490\end{array}$ & $\begin{array}{r}9,000 \\
9,990 \\
11,500 \\
13,000 \\
11,400 \\
11,800 \\
11,800 \\
25,000 \\
29,500 \\
18,400\end{array}$ & $\begin{array}{l}11 \\
12 \\
13 \\
14 \\
15 \\
16 \\
17 \\
18 \\
19 \\
20\end{array}$ & $\begin{array}{r}2,860 \\
3,100 \\
3,860 \\
4,250 \\
4,460 \\
5,460 \\
8,030 \\
8,980 \\
9,930 \\
12,200\end{array}$ & $\begin{array}{r}12,700 \\
10,800 \\
10,800 \\
11,200 \\
11,500 \\
12,100 \\
12,300 \\
11,300 \\
9,860 \\
8,650\end{array}$ & $\begin{array}{l}21 \\
22 \\
23 \\
24 \\
25 \\
26 \\
27 \\
28 \\
29 \\
30 \\
31\end{array}$ & . & $\begin{array}{r}13,600 \\
10,100 \\
7,310 \\
6,090 \\
5,590 \\
5,540 \\
6,070 \\
8,560 \\
9,290 \\
8,690 \\
8,410 \\
\end{array}$ & $\begin{array}{r}7,660 \\
7,060 \\
7,640 \\
9,380 \\
10,500 \\
9,620 \\
8,870 \\
8,280 \\
6,660 \\
5,850 \\
--.- \\
\end{array}$ \\
\hline $\begin{array}{l}\text { Monthly } \\
\text { Runoff, } \\
\text { Runoff, }\end{array}$ & $\begin{array}{l}\text { mean dischar } \\
\text { in inches. } \\
\text { In acre-feet }\end{array}$ & $\begin{array}{l}e, \text { in cub } \\
\ldots\end{array}$ & feet & ec ond & $\begin{array}{l}\cdot \cdot \cdot \\
\cdot .\end{array}$ & & . & $\begin{array}{r}5,688 \\
685 \\
349,700\end{array}$ & $\begin{array}{r}11,470 \\
1336 \\
682,600\end{array}$ \\
\hline
\end{tabular}

Gage helght, In feet, and discharge, in cublc feet per second, at indicated time, 1964

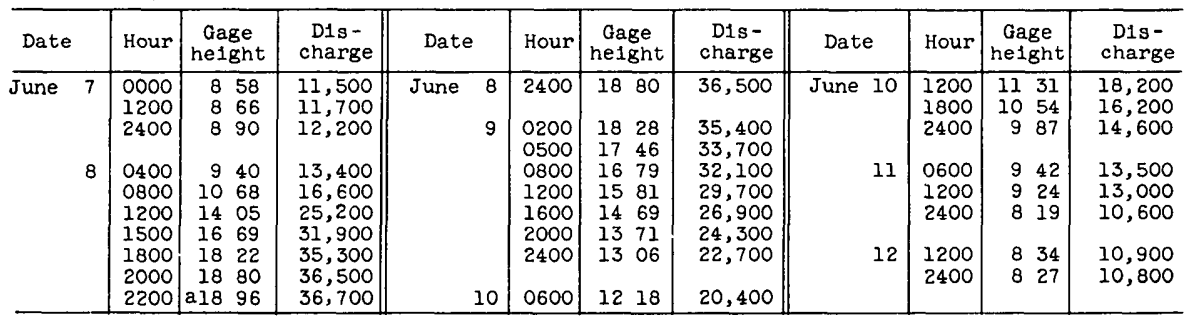

a $195 \mathrm{ft}$, from floodmark

(179) 12-3595 Spotted Bear River near Hungry Horse, Mont

(Gaging station, discontinued 1956)

Location --Lat $47^{\circ} 55^{\prime} 40^{\prime \prime}$, long $113^{\circ} 31110^{\prime \prime}$, near center of $\sec 17, \mathrm{~T} 25 \mathrm{~N}, \mathrm{R} 15 \mathrm{~W}$, on left bank a third of a mile upstream from mouth and 40 miles southeast of Hungry Horse

Dra1nage area $--184 \mathrm{sq} \mathrm{ml}$

Gage-helght record - -high-water marks at gage site Alt1tude of gage is 3,690 ft (from river-profile map)

D1scharge record --Peak discharge by slope-area measurement

Maxima --June 1964 Discharge, 20,200 cfs June 8 (gage he1ght, $1429 \mathrm{ft}$, from h1ghwater nark in well, $1447 \mathrm{ft}$, from high-water profile)

1948-56 Discharge, 5,480 cfs May 20, 1954 (gage helght, $740 \mathrm{ft}$ ) 
(180) 12-3598 South Fork Flathead River above Twin Creek, near Hungry Horse, Mont

(Miscellaneous site, gaging station since October 1964)

Location --Lat $47^{\circ} 58^{1} 45^{\prime \prime}$, long $113^{\circ} 33^{\prime} 50^{\prime \prime}$, in $\mathrm{SE}_{\frac{1}{4}} \mathrm{SW} \frac{1}{4} \mathrm{SE} \frac{1}{4} \sec 25$, T $26 \mathrm{~N}$, $\mathrm{R} 16 \mathrm{~W}$, on left bank 1,000 ft downstream from Tin Creek, a quarter of a mile upstream from

Twin Creek, and 36 miles southeast of Hungry Horse

Drainage area $--1,160 \mathrm{sq} \mathrm{mi}$

Gage-height record --High-water marks at gage site Altitude of gage is $3,580 \mathrm{ft}$ (from river-profile map)

Discharge record --Peak discharge by slope-area measurement

Maximum --June 1964 Discharge, 50,900 cfs June 8 (gage height, $2087 \mathrm{ft}$, from highwater profile, at gage established in October 1964)

(181) 12-3600 Twin Creek near Hungry Horse, Mont

(Gaging station, reestablished September 1964)

Location --Lat $47^{\circ} 59^{1} 10^{\prime \prime}$, long $113^{\circ} 33^{\prime} 30^{\prime \prime}$, in $E_{\frac{1}{2}} \sec 25, T 26 \mathrm{~N}, \mathrm{R} 16 \mathrm{~W}$, on left bank $300 \mathrm{ft}$ upstream from road bridge, 01 mile upstream from mouth, and 36 miles southeast of Hun'gry Horse

Drainage area $--476 \mathrm{sq} \mathrm{ml}$ (revised)

Gage-height record --High-water marks at gage site Altitude of gage is $3,610 \mathrm{ft}$ (from river-profile map)

Discharge record --Peak discharge by slope-area measurement

Maxima --June 1964 Discharge, 5,830 cfs June 8 (gage he1ght, $1234 \mathrm{ft}$, from highwater mark in well, $13 \mathrm{lt}$, from high-water proflle, at gage reactivated in September 1964)

1948-56 Discharge, 2,790 cfs May 19, 1954 (gage height, $833 \mathrm{ft}$ ), from rating curve extended above $1,000 \mathrm{cf}$ 's on basis of slope-area measurements at gage helght of $81 \mathrm{ft}$

(182) 12-3605 Lower Twin Creek near Hungry Horse, Mont

(Gaging station, discontinued 1956)

Location --Lat $47^{\circ} 59^{1} 40^{\prime \prime}$, long $113^{\circ} 33^{1} 20^{\prime \prime}$, in $\mathrm{SE}_{4}^{1} \sec 24, \mathrm{~T} 26 \mathrm{~N}, \mathrm{R} 16 \mathrm{~W}$, on left bank half a mile upstream from mouth and 35 miles southeast of Hungry Horse Gaging station destroyed by flood Altitude of gage was 3,630 ft from riverprofile map)

Drainage area - $-222 \mathrm{sq} \mathrm{ml}$ (revised)

Maxima --June 1964 Discharge, 5,110 cfs June 8, from slope-area measurement 1948-56 D1scharge, 1,200 cf's about May 22, 1948 (gage helght, 525 ft, from floodmark), from slope-area measurement

(183) 12-3606 Soldier Creek near Hungry Horse, Mont

(M1scellaneous site, gaging station since September 1964)

Location --Lat $47^{\circ} 59130^{\prime \prime}$, long $113^{\circ} 34155^{\prime \prime}$, in $\mathrm{NE} \frac{1}{4} \sec 26, \mathrm{~T} 26 \mathrm{~N}, \mathrm{R} 16 \mathrm{~W}$, on left bank $200 \mathrm{ft}$ upstream from culverts on west shore road and 35 miles southeast of Hungry Horse

Drainage area $--4 \quad 77 \mathrm{sq} \mathrm{mi}$

Gage-height record --High-water marks at gage site Altitude of gage is $3,640 \mathrm{ft}$ (from river-profile map)

Discharge record --Peak discharge by flow-through-culvert measurement

Maximum --June 1964 Discharge, $206 \mathrm{cfs}$ June 8 (gage height, 5 ? ft, from highwater profile at gage established in September 1964) 
(184) 12-3610 Sullivan Creek near Hungry Horse, Mont

Location --Lat $48^{\circ} 01^{\prime} 45^{\prime \prime}$, long $113^{\circ} 42^{\prime} 10^{\prime \prime}$, in $\mathrm{W} \frac{1}{2} \sec 12$, T $26 \mathrm{~N}, \mathrm{R} 17 \mathrm{~W}$, on left bank a quarter of a mile downstream from Quintonkon Creek, 1 mile upstream from Hungry Horse Reservolr flow line, and 30 miles southeast of Hungry Horse

Drainage area $--71 \quad 3 \mathrm{sq} \mathrm{ml}$

$\frac{\text { Gage-he1ght record }}{\text { topographic map) }}$-Water-stage recorder graph Altitude of gage is $3,740 \mathrm{ft}$ (from

Discharge record --Stage-discharge relation defined by current-meter measurements below $1,300 \mathrm{cfs}$ and by slope-area measurement at $5,020 \mathrm{cfs}$

Maxima - June 1964 Discharge, 5,020 cfs 1830 hours June 8 (gage height, $721 \mathrm{ft}$ in gage well, $83 \mathrm{ft}$ from outside floodmarks)

5 1948-56, 1959 to May 1964 Discharge, 2,750 cfs May 19, 1954 (gage height, $529 \mathrm{ft})$

Mean discharge, in cubic feet per second, 1964

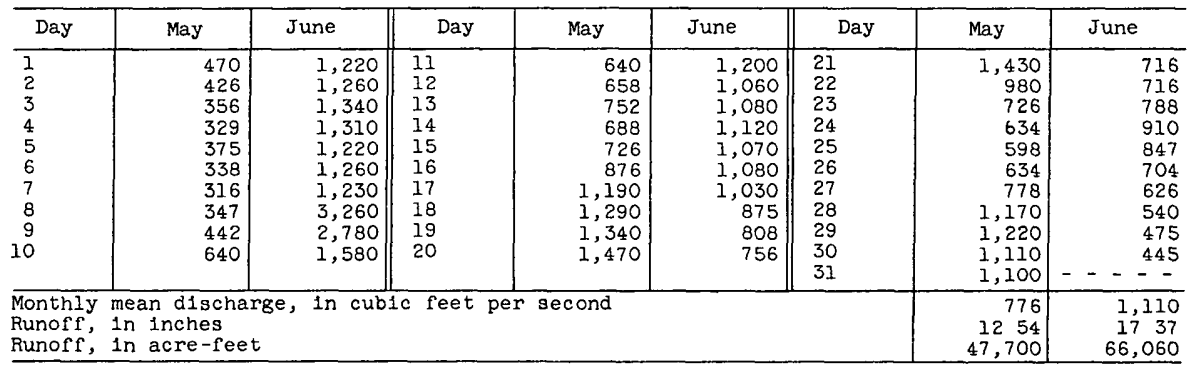

Gage height, in feet, and discharge, in cub1c feet per second, at indicated time, 1964

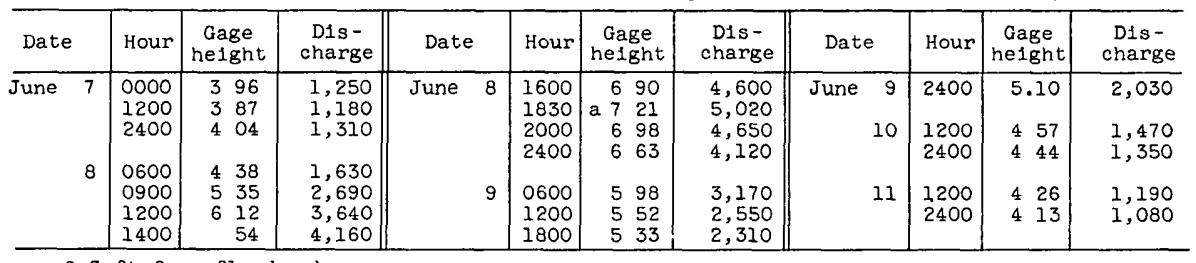

a $83 \mathrm{ft}$ from floodmark

(185) Logan Creek near Hungry Horse, Mont

(Miscellaneous site)

Location --Lat $48^{\circ} 08^{\prime} 35^{\prime \prime}$, long $113^{\circ} 42^{\prime} 35^{\prime \prime}$, in $\operatorname{SW} \frac{1}{4} \mathrm{NE} \frac{1}{4} \mathrm{SE} \frac{1}{4} \sec 35, \mathrm{~T} 28 \mathrm{~N}, \mathrm{R} 17 \mathrm{~W}$, downstream from culvert on east shore road, a third of a mile upstream from

Hungry Horse Reservoir flow line, and 23 miles southeast of Hungry Horse

Drainage area $--518 \mathrm{sq} \mathrm{mi}$

Maximum --June 1964 Discharge, 2,310 cfs June 8, from slope-area measurement 
(186) 12-3615 Graves Creek near Hungry Horse, Mont

(Gaging station, reestablished october 1964)

Location --Lat $48^{\circ} 07^{\prime} 30^{\prime \prime}$, long $113^{\circ} 49^{\prime} 10^{\prime \prime}$, in $\mathrm{SE}_{\frac{1}{4}} \sec 1$, T $27 \mathrm{~N}, \mathrm{R} 18 \mathrm{~W}$, on left bank $500 \mathrm{ft}$ upstream from Hungry Horse Reservolr flow line and 22 miles southeast of Hungry Horse

Drainage area $--270 \mathrm{sq} \mathrm{ml}$

Gage-he1ght record --High-water marks at gage site Alt1tude of gage is $3,600 \mathrm{ft}$ (from topographic map)

Discharge record --Peak discharge by slope-area measurement

Maxima --June 1964 D1scharge, 2,710 cfs June 8 (gage helght, $583 \mathrm{ft}$, from highwater mark in well, $70 \mathrm{ft}$, from high-water proflle, at gage reactivated

October 1964 )

1948-56 Discharge, 1,520 cfs June 22, 1950 (gage height, $570 \mathrm{ft}$, at site $2 \frac{1}{2}$ miles downstream and at datum then in use)

(187) 12-3618 8 Wounded Buck Creek near Hungry Horse, Mont

(Miscellaneous site, gaging station since October 1964)

Location --Lat $48^{\circ} 16^{1} 40^{\prime \prime}$, long $113^{\circ} 56^{\prime} 10^{\prime \prime}$, in $\mathrm{SW}_{\frac{1}{4}} \mathrm{SW} \frac{1}{4} \mathrm{NW} \frac{1}{4} \sec 17$, T $29 \mathrm{~N}, \mathrm{R} 18 \mathrm{~W}$, on right bank $50 \mathrm{ft}$ upstream from culvert on west shore road, $800 \mathrm{ft}$ upstream from Hungry Horse Reservoir flow line, and 9 miles southeast of Hungry Horse

Dra1nage area $--136 \mathrm{sq} \mathrm{m}$

Gage-helght record --High-water marks at gage site Altitude of gage is $3,580 \mathrm{ft}$ (from topographic map)

Discharge record -Peak discharge defined by flow-through-culvert measurement

Maximum --June 1964 Discharge, $706 \mathrm{cfs}$ June 8 (gage height, $108 \mathrm{ft}$, from highwater marks, at gage established in October 1964)

(188) 12-3619 6 Emery Creek near Hungry Horse, Mont

(M1scellaneous site, gaging station since September 1964)

Location --Lat $48^{\circ} 21^{\prime} 30^{\prime \prime}$, long $113^{\circ} 55^{\prime} 35^{\prime \prime}$, in $\mathrm{NE} \frac{1}{4} \mathrm{SE} \frac{1}{4} \mathrm{SW} \frac{1}{4} \mathrm{sec} 17, \mathrm{~T} 30 \mathrm{~N}, \mathrm{R} 18 \mathrm{~W}$, on left bank on east shore road, $500 \mathrm{ft}$ upstream from Hungry Horse Reservolr flow line and 6 miles southeast of Hungry Horse

Drainage area --26 $4 \mathrm{sq} \mathrm{mi}$

Gage-helght record --High-water marks at gage site Altitude of gage is 3,580 ft (from topographic map)

Discharge record --Stage-discharge relation defined by slope-area measurement

Maximum --June 1964 Discharge, $832 \mathrm{cf}$ s June 8 (gage height, $339 \mathrm{ft}$ from highwater profile, at gage established September 1964) 
(189) 12-3620 Hungry Horse Reservolr near Hungry Horse, Mont

Location --Lat $48^{\circ} 20^{\prime} 30^{\prime \prime}$, long $114^{\circ} 00^{\prime} 50^{\prime \prime}$, in $N E \frac{1}{4} N E \frac{1}{4} N W \frac{1}{4} \sec 27, T 30 \mathrm{~N}, \mathrm{R} 19 \mathrm{~W}$, in block 14 of Hungry Horse Dam, 3 miles southeast of Hungry Horse

Drainage area $--1,654 \mathrm{sq} \mathrm{m} 1$

Gage-helght record --Water-stage recorder graph Midnight readings only, except June 8-10, when hourly readings were furnished Datum of gage $1 \mathrm{~s}$ at mean sea level (levels by Bureau of Reclamation)

Discharge record --Inflow computed from change in contents corrected for outflow, for the times indicated

Maxima --June 1964 Contents observed, 3,429,000 acre-ft 2400 hours June 30 (elevation, 3,560 $03 \mathrm{ft})$ Rate of inflow, 78,000 cfs 2100 hours June 8

1951 to May 1964 Contents observed, 3,461,000 acre-ft July 3, 4, 1955 (elevation, $3,56140 \mathrm{ft}$ )

Remarks --Reservo1r formed by concrete dam, construction began in 1948, completed in 1952 Storage began Sept 21, 1951 Usable capac1ty, 3,428,000 acre-ft between elevations 3,560 (controlled spillway elevation) and $3,196 \mathrm{ft}$ Dead storage, 40,140 acre-ft below elevation 3,196 ft Minimum operating level, $3,336 \mathrm{ft}$ for on-site power generation (usable contents, 445,900 acre-ft) Water is stored for power production, flood control, irrigation, and recreation Figures given herein represent usable contents

Cooperation --Elevations furnlshed by Bureau of Reclamation

Elevation, in feet, and contents, in acre-feet, at 2400 hours and daily computed inflow, in cublc feet per second, on indicated day, 1964

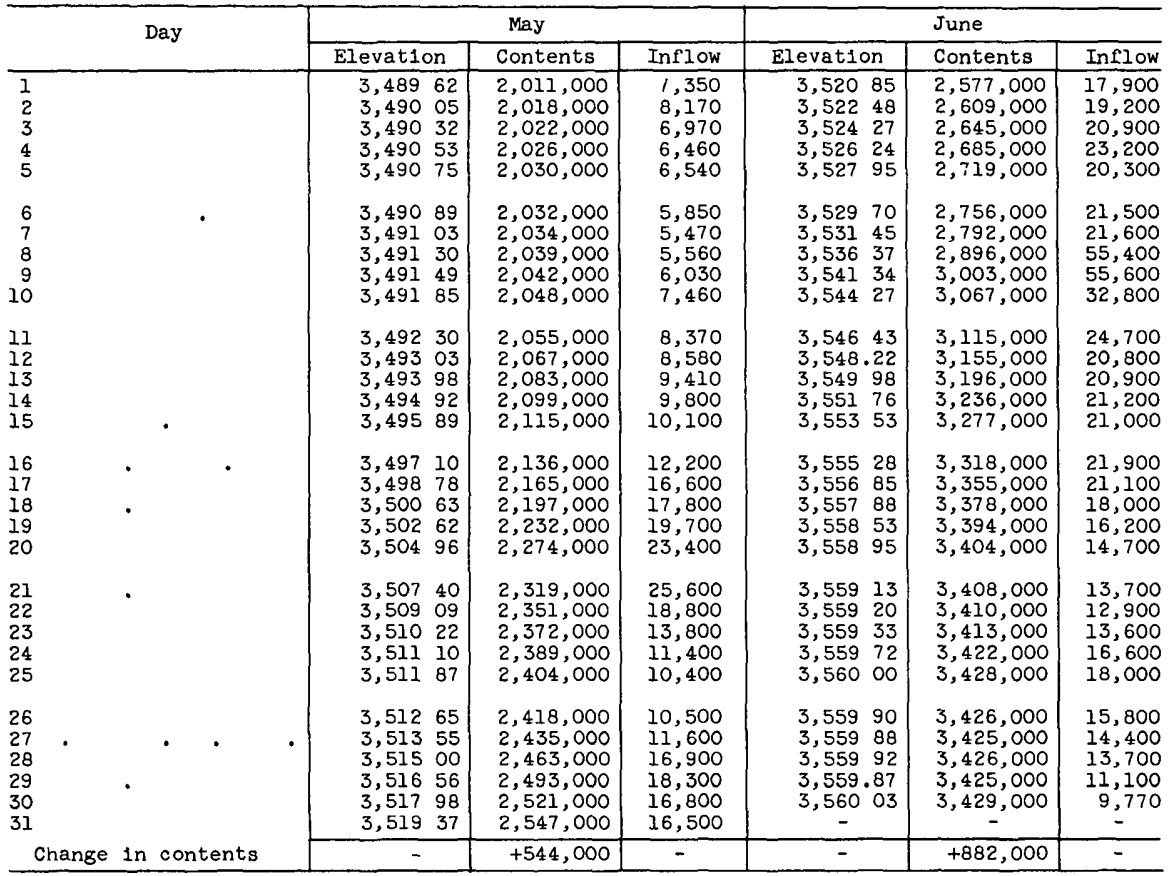


Elevation, in feet, and computed inflow, in cubic feet per second, at indicated time, 1964, of Hungry Horse Reservolr near Hungry Horse, Mont

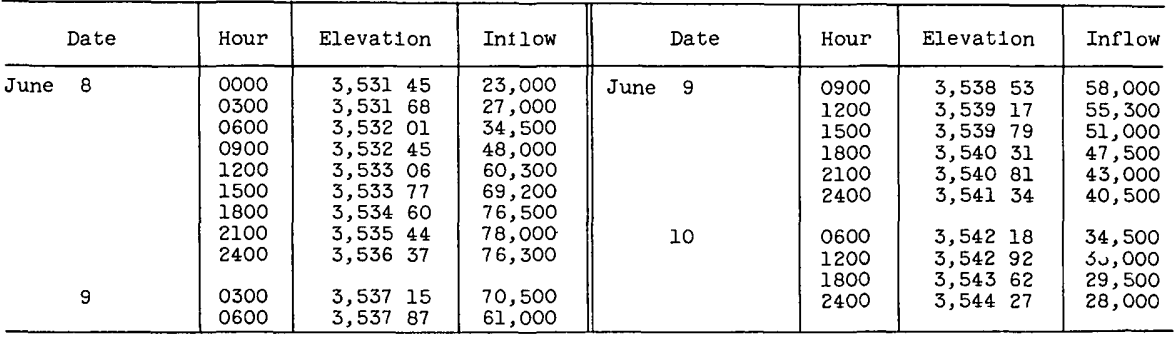

(190) 12-3625 South Fork Flathead River near Columbla, Falls, Mont

Location --Lat $48^{\circ} 21^{\prime} 30^{\prime \prime}$, long $114^{\circ} 02^{\prime} 15^{\prime \prime}$, in $\mathrm{SW}_{\frac{1}{4}} \mathrm{SE} \frac{1}{4} \mathrm{SW} \frac{1}{4} \sec 16, \mathrm{~T} 30 \mathrm{~N}, \mathrm{R} 19 \mathrm{~W}$, on right bank $1 \frac{1}{2}$ miles downstream from Hungry Horse Dam, $3 \frac{1}{2}$ miles upstream from mouth, and 7 miles east of Columbla Falls

Drainage area $--1,663 \mathrm{sq} \mathrm{mi}$

Gage-helght record --Digital-recorder tape punched at 15-minute intervals Datum of gage is 3,040 $0 \mathrm{ft}$ above mean sea level (levels by Bureau of Reclamation)

Discharge record --Stage-discharge relation defined by current-meter measurements

Maxima --June 1964 Discharge, 18,000 cfs 2345 hours June 25 and 0915 hours June 26 (gage height, $1334 \mathrm{ft}$ )

1910-16, 1923 to May 1964 Discharge observed, 46,200 cfs June 19, 1916 (gage helght, $166 \mathrm{ft}^{\prime}$, at site 3 miles downstream and at datum then in use), from rating curve extended above $20,000 \mathrm{cfs}$

Remarks --Flow regulated since Sept 21, 1951, by Hungry Horse Reservolr (see station 189)

Mean discharge, in cuble feet per second, 1964

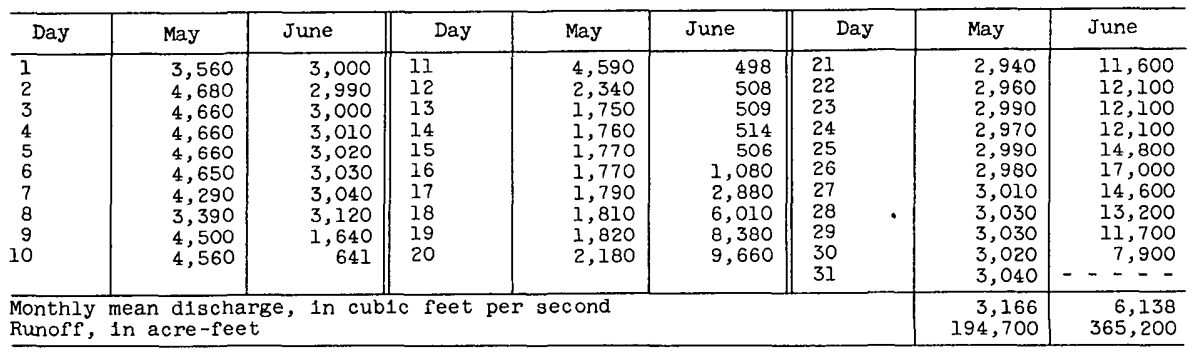

Gage he1ght, in feet, and discharge, in cub1c feet per second, at 1ndicated time, 1964

\begin{tabular}{|c|c|c|c|c|c|c|c|c|c|c|c|}
\hline Date & Hour & $\begin{array}{c}\text { Gage } \\
\text { helght }\end{array}$ & $\begin{array}{l}\text { D1s- } \\
\text { charge }\end{array}$ & Date & Hour & $\begin{array}{c}\text { Gage } \\
\text { he1ght }\end{array}$ & $\begin{array}{l}\text { Dis- } \\
\text { charge }\end{array}$ & Date & Hour & $\begin{array}{c}\text { Gage } \\
\text { he1ght }\end{array}$ & $\begin{array}{c}\text { Dis- } \\
\text { charge }\end{array}$ \\
\hline Tune 7 & $\begin{array}{l}0000 \\
1200 \\
2400 \\
1200\end{array}$ & $\begin{array}{ll}6 & 25 \\
6 & 28 \\
6 & 30 \\
6 & 36\end{array}$ & $\begin{array}{l}2,980 \\
3,020 \\
3,040 \\
3,120\end{array}$ & June 8 & $\begin{array}{l}2400 \\
1000 \\
1200 \\
2400\end{array}$ & $\begin{array}{ll}6 & 41 \\
6 & 32 \\
3 & 60 \\
3 & 57\end{array}$ & $\begin{array}{r}3,180 \\
3,070 \\
542 \\
529\end{array}$ & June 10 & $\begin{array}{l}1200 \\
2400 \\
1200 \\
2400\end{array}$ & $\begin{array}{ll}3 & 50 \\
3 & 48 \\
3 & 47 \\
3 & 52\end{array}$ & $\begin{array}{l}500 \\
492 \\
\\
488 \\
508\end{array}$ \\
\hline
\end{tabular}


(191) 12-3630 Flathead River at Columbia Falls, Mont

Location - -Lat $48^{\circ} 21^{\prime} 50^{\prime \prime}$, long $114^{\circ} 11^{\prime} 10^{\prime \prime}$, in $N W \frac{1}{4} S E \frac{1}{4} \sec 17$, T $30 \mathrm{~N}, \mathrm{R} 20 \mathrm{~W}$, on right bank $200 \mathrm{ft}$ downstream from county bridge at Columbia Falls and 5 miles downstream from South Fork

Drainage area $--4,464 \mathrm{sq} \mathrm{ml}$

Gage-height record --Digital-recorder tape punched at 15-minute intervals except 2320 hours June 8 to 2030 hours June 9 , for which partly estimated graph was drawn Datum of gage is 2,977 $67 \mathrm{ft}$ above mean sea level, datum of 1929, supplementary adjustment of 1947 (levels by Corps of Engineers)

Discharge record --Stage-discharge relation defined by current-meter measurements below $95,000 \mathrm{cfs}$ and by slope-area measurement at $176,000 \mathrm{cfs}$

Maxima --June 1964 Discharge, 176,000 cfs 0500 hours June 9 (gage height, $2558 \mathrm{ft}$, from floodmarks in gage house)

1922-23, 1928 to May 1964 Discharge, 102,000 cfs May 23, 1948 (gage height, $1908 \mathrm{ft}$ )

Flood of June 1894 reached a stage of $227 \mathrm{ft}$, from floodmarks (discharge, $142,000 \mathrm{cfs}$, revised, from rating curve extended above $95,000 \mathrm{cfs}$ on basis of slope-area measurement of peak flow in 1964)

Remarks --South Fork Flathead River, which contributes about one-third of flow, completely regulated by Hungry Horse Reservoir since Sept 21, 1951 (see station 189)

Mean discharge, in cub1c feet per second, 1964

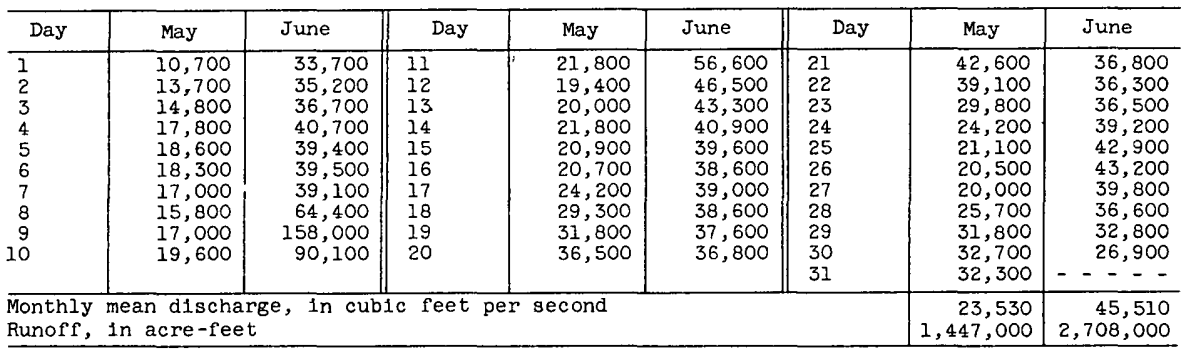

Gage he1ght, in feet, and discharge, in cublc feet per second, at inaicated time, 1964

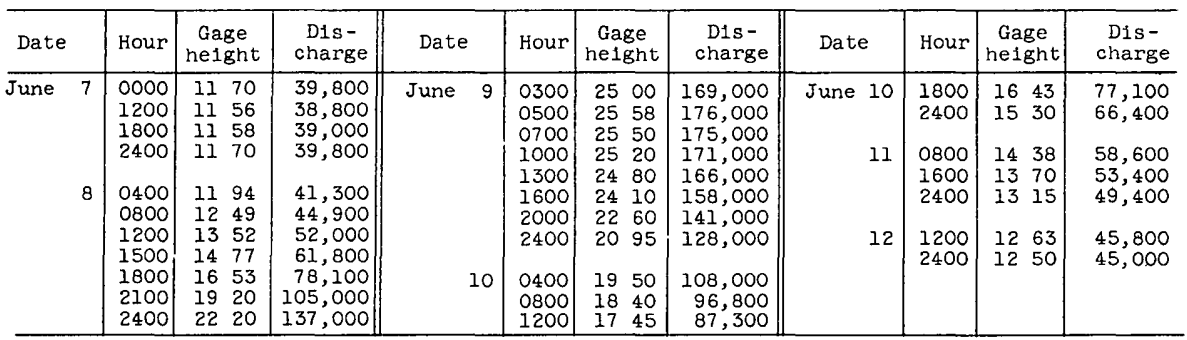

(192) 12-3639 Rock Creek near Olney, Mont

(Crest-stage station)

Location --Lat $48^{\circ} 37^{\prime}$, long $114^{\circ} 39^{\prime}$, in NW $\frac{1}{4} \sec 24, T 33 \mathrm{~N}, \mathrm{R} 24 \mathrm{~W}$, at culvert on U S H1ghway 93,6 miles northwest of olney

Drainage area $--6 \quad 18$ sq $\mathrm{mi}$

Gage-height record --Crest stages only Altitude of gage is $3,240 \mathrm{ft}$ (from topographic map)

Discharge record --Stage-discharge relation defined by current-meter measurements

Maxima --June 1964 Discharge, $11 \mathrm{cfs}$ June 8 (gage height, $081 \mathrm{ft}$ )

1961 to May 1964 Discharge, $25 \mathrm{cfs}$ May 2, 1964 (gage height, $129 \mathrm{ft}$ ) 
(193) 12-3650 Stillwater River near Whitefish, Mont

(Gaging station, discontinued 1950)

Location --Lat $48^{\circ} 19^{\prime} 10^{\prime \prime}$, long $114^{\circ} 23^{1} 00^{\prime \prime}$, in $N E \frac{1}{4} S W^{\frac{1}{4}} \sec 34, \mathrm{~T} 30 \mathrm{~N}, \mathrm{R} 22 \mathrm{~W}$, on right bank $600 \mathrm{ft}$ downstream from highway bridge, 7 miles southwest of Whitefish, and 10 miles upstream from Whitefish Creek

Drainage area $--524 \mathrm{sq} \mathrm{mi}$

Gage-helght record --High-water marks at gage site Alt1tude of gage is 2,950 $\mathrm{ft}$ (by barometer)

Discharge record --Stage-discharge relation defined by current-meter measurements Maxima --June 1964 Discharge, 1,480 cfs about June 9 (gage helght, $1098 \mathrm{ft}$, from f'loodmarks)

1930-50, Discharge, 4,330 cfs May 26, 1948 (gage helght, $2090 \mathrm{ft}$, from floodmark)

(194) 12-3660 Wh1tef1sh River near Kalispell, Mont

(Gaging station, discontinued 1950, formerly published as Whitefish Creek) Location --Lat $48^{\circ} 19^{\prime} 10^{\prime \prime}$, long $114^{\circ} 16^{\prime} 30^{\prime \prime}$, in SE $\frac{1}{4} N W \frac{1}{4} \sec 34, \mathrm{~T} 30 \mathrm{~N}, \mathrm{R} 21 \mathrm{~W}$, on left bank 8 miles upstream from mouth and 8 miles north of Kalispeli

Drainage area $--170 \mathrm{sq} \mathrm{mi}$

Gage-height record --High-water marks at gage site Datum of gage 1s $2,96952 \mathrm{ft}$ above mean sea level, datum of 1929 , supplementary adjustment of 1947 (levels by Corps of Englneers)

D1scharge record --Stage-discharge relation defined by current-meter measurements

Maxima --June 1964 Discharge, 1,400 cfs about June 9 (gage height, $368 \mathrm{ft}$, from floodmarks )

1928-50 Discharge, 1,290 cfs May 30, 1948 (gage height, $441 \mathrm{ft}$ ), gage

he1ght, $445 \mathrm{ft}$ June 26,1950

(195) Swan River at Stroms Store, near Condon, Mont

(M1scellaneous site, published as "at Rumble Creek" In 1948)

Location --Lat $47^{\circ} 31^{\prime}$, long $113^{\circ} 42^{\prime}$, near center of sec $1, T 20 \mathrm{~N}, \mathrm{R} 17 \mathrm{~W}$, half a mile downstream from Cooney Creek, three-quarters of a mile upstream from Glacier Creek, three-quarters of a mile southeast of Stroms Store, and $3 \frac{1}{2}$ miles southeast of Condon

Drainage area $--146 \mathrm{sq} \mathrm{ml}$

Maxima --June 1964 D1scharge, 1,670 cfs June 8, from slope-area measurement 1948 D1scharge, 1,350 cfs May 24, from slope-area measurement

\section{(196) 12-3700 Swan River near Bigfork, Mont}

Location --Lat $48^{\circ} 01^{\prime} 30^{\prime \prime}$, long $113^{\circ} 58^{14} 40^{\prime \prime}$, in SE $\frac{1}{4} S W^{\frac{1}{4}} \sec 11, \mathrm{~T} 26 \mathrm{~N}, \mathrm{R} 19 \mathrm{~W}$, on left bank at outlet of Swan Lake, 1,000 ft downstream from Johnson Creek and 5 miles southeast of Bigfork

\section{Dra1nage area $--671 \mathrm{sq} \mathrm{m} 1$}

Gage-helght record --Water-stage recorder graph, except 1800 hours June 9 to 1900 hours June 11, for which graph was reconstructed on basis of high-water marks Datum of gage is $3,0626 \mathrm{ft}$ above mean sea level, datum of 1929 (from riverprofile survey)

D1scharge record --Stage-discharge relation defined by current-meter measurements

Maxima --June 1964 Discharge, $8,100 \mathrm{cfs}$ about 1200 hours June 10 (gage he1ght, $698 \mathrm{ft}$, from floodmarks)

1922 to May 1964 Discharge, $8,400 \mathrm{cfs}$ May 24, 1948 (gage he1ght, $712 \mathrm{ft}$, from graph based on gage readings) 
Mean discharge, in cublc feet per second, 1964, of Swan R1ver near Bigfork, Mont

\begin{tabular}{|c|c|c|c|c|c|c|c|c|}
\hline Day & May & June & Day & May & June & Day & May & June \\
\hline $\begin{array}{r}1 \\
2 \\
3 \\
4 \\
5 \\
6 \\
7 \\
8 \\
9 \\
10\end{array}$ & $\begin{array}{l}1,300 \\
1,560 \\
1,770 \\
1,900 \\
2,000 \\
2,000 \\
1,970 \\
1,900 \\
1,860 \\
1,860\end{array}$ & $\begin{array}{l}3,410 \\
3,500 \\
3,700 \\
4,080 \\
4,480 \\
4,610 \\
4,690 \\
5,220 \\
6,860 \\
8,020\end{array}$ & $\begin{array}{l}11 \\
12 \\
13 \\
14 \\
15 \\
16 \\
17 \\
18 \\
19 \\
20\end{array}$ & $\begin{array}{l}1,930 \\
2,000 \\
2,040 \\
2,110 \\
2,170 \\
2,230 \\
2,350 \\
2,630 \\
2,980 \\
3,340\end{array}$ & $\begin{array}{l}7,560 \\
6,560 \\
5,760 \\
5,280 \\
5,060 \\
4,900 \\
4,880 \\
4,840 \\
4,650 \\
4,320\end{array}$ & $\begin{array}{l}21 . \\
22 \\
23 \\
24 \\
25 \\
26 \\
27 \\
28 . \\
29 \\
30 \\
31\end{array}$ & $\begin{array}{l}3,770 \\
4,290 \\
4,270 \\
3,810 \\
3,280 \\
2,910 \\
2,620 \\
2,600 \\
2,860 \\
3,190 \\
3,350 \\
\end{array}$ & $\begin{array}{r}3,980 \\
3,680 \\
3,460 \\
3,430 \\
3,610 \\
3,930 \\
4,040 \\
4,000 \\
3,850 \\
3,610 \\
-\quad-\quad- \\
\end{array}$ \\
\hline $\begin{array}{l}\text { Monthly } \\
\text { Runoff, } \\
\text { Runoff, }\end{array}$ & $\begin{array}{l}\text { mean discha } \\
\text { in inches } \\
\text { in acre-fee }\end{array}$ & e, In cub & feet & second & . & - & $\begin{array}{r}2,544 \\
437 \\
156,400 \\
\end{array}$ & $\begin{array}{r}4,666 \\
7 \quad 76 \\
277,600 \\
\end{array}$ \\
\hline
\end{tabular}

Gage he1ght, in feet, and discharge, in cub1c feet per second, at Indicated time, 1964

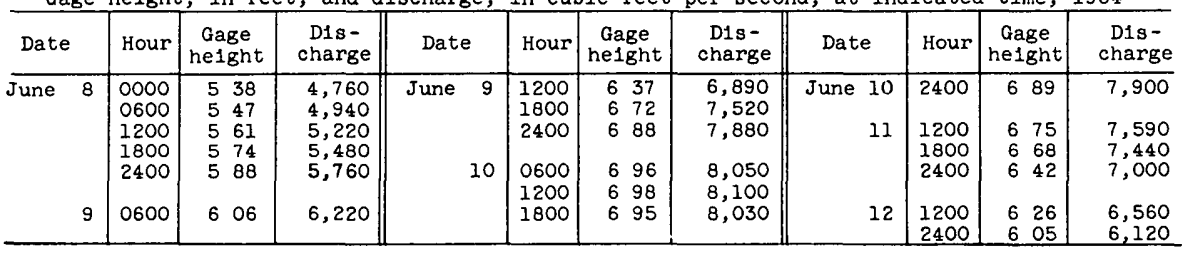

(197) 12-3705 Dayton Creek near Proctor, Mont

(Crest-stage station)

Location --Lat $47^{\circ} 55^{\prime}$, long $114^{\circ} 20^{\prime}$, in $N{ }^{\frac{1}{4}} \sec 20$, T $25 \mathrm{~N}, \mathrm{R} 21 \mathrm{~W}$, at culvert on county road, $2 \frac{1}{2}$ miles northwest of proctor

Drainage area $--209 \mathrm{sq} \mathrm{ml}$

Gage-helght record --Crest stages only Alt1tude of gage is 3,350 ft (from topographic map)

Discharge record --Stage-discharge relation defined by current-meter measurements below $30 \mathrm{cfs}$ and by flow-through-culvert measurements at $51 \mathrm{cfs}$ and $93 \mathrm{cfs}$

Maxima --June 1964 Discharge, 29 cfs June 8 (gage he1ght, $106 \mathrm{ft}$ ) 1959 to May 1964 D1scharge, $93 \mathrm{cfs}$ May 27, 1961 (gage helght, $300 \mathrm{ft}$ )

\section{(198) 12-3709 Teepee Creek near Polson, Mont \\ (Crest-stage station)}

Location --Lat $47^{\circ} 49^{\prime}$, long $114^{\circ} 01^{\prime}$, In $\mathrm{SW}^{\frac{1}{4}} \sec 23, \mathrm{~T} 24 \mathrm{~N}, \mathrm{R} 19 \mathrm{~W}$, at culvert on State H1ghway 35 , and 11 miles northeast of Polson

Drainage area $--255 \mathrm{sq} \mathrm{mi}$

Gage-he1ght record --Crest stages only Alt1tude of gage is $2,920 \mathrm{ft}$ (from topographic map)

D1scharge record --Peak discharge by flow-through-culvert measurement

Maxima --June 1964 Discharge, $44 \mathrm{cfs}$ June 8 (gage helght, $215 \mathrm{ft}$ )

1960 to May 1964 Discharge, $22 \mathrm{cfs}$ June 2, 1961 (gáge height, 0 90 ft)

(199) 12-3711 Hell Roaring Creek near Polson, Mont

(Gaging station, discontinued 1932, crest-stage station beginning 1960)

Location --Lat $47^{\circ} 42^{\prime}$, long $114^{\circ} 03^{\prime}$, in $\mathrm{NW} \frac{1}{4} \sec 4, \mathrm{~T} 22 \mathrm{~N}, \mathrm{R} 19 \mathrm{~W}$, at powerhouse, $5 \frac{1}{2}$ miles east of Polson

Drainage area $--641 \mathrm{sq} \mathrm{mi}$

Gage-he1ght record --Crest stages only Altitude of gage is $3,150 \mathrm{ft}$ (by barometer)

Discharge record --Peak discharge defined by slope-area measurement

Maxima - June 1964 D1scharge, $98 \mathrm{cfs}$ June 8 (gage height, $173 \mathrm{ft}$ )

1917-32, 1948, 1960 to May 1964 Discharge observed, 104 cfs June 9, 1917

(gage helght, $24 \mathrm{ft}$, site and datum then in use) 
(200) 12-3715 Flathead Lake at Somers, Mont

(Previously published as 12-3710)

Location --Lat $48^{\circ} 04^{1} 30^{\prime \prime}$, long $114^{\circ} 13^{\prime} 30^{\prime \prime}$, in SE $\frac{1}{4} \mathrm{NE} \frac{1}{4} \sec 26, \mathrm{~T} 27 \mathrm{~N}, \mathrm{R} 21 \mathrm{~W}$, at steamboat dock at Somers

Drainage area $--7,086 \mathrm{sq} \mathrm{ml}$

Gage-height record --Water-stage recorder graph adjusted to compensate for changes in elevation indicated by the lake gage at outlet at Polson Datum of gage is at mean sea level (Somers datum) Subtract $100 \mathrm{ft}$ to convert Somers datum to datum of 1929, supplemental adjustment of 1947

Discharge record --Inflow determined from change in contents adjusted for outflow at poison

Maxima --June 1964 Contents, 1,952,000 acre-ft 1230 hours June 12 (elevation, $2,89427 \mathrm{ft}$ ) Rate of inflow, $128,000 \mathrm{cfs} 0600$ hours June 10 1909 to May 1964 Contents, 2,208,000 acre-ft June 19, 1933 (elevation, $2,89626 \mathrm{ft}$ )

Lake reached an elevation of $2,900 \mathrm{ft}$ during flood in June 1894

Remarks --Natural storage in Flathead Lake increased by construction of Kerr Dam 4 miles downstream from natural lahe outlet, storage began Apr 11, 1938 Usable capacity, 1,791,000 acre-ft at controlled spillway elevation $(2,893 \mathrm{ft})$ Dead storage unknown below $2,878 \mathrm{ft}$ (elevation of natural outlet) Minimum operating level, $2,883 \mathrm{ft}$ for on-site power generation (usable contents, 572,300 acre-ft) Water is used for power production, flood control, recreation, and irrigation Figures given herein represent usable contents

Elevation, In feet, at 2400 hours, adjusted change in contents, in equivalent cubic feet per second, and computed inflow, in cubic feet per second, on indicated day, 1964

\begin{tabular}{|c|c|c|c|c|c|c|}
\hline \multirow[b]{2}{*}{ Day } & \multicolumn{3}{|c|}{ May } & \multicolumn{3}{|c|}{ June } \\
\hline & Elevation & $\begin{array}{l}\text { Adjusted } \\
\text { change in } \\
\text { contents }\end{array}$ & Inflow & Elevat1on & $\begin{array}{l}\text { Adjusted } \\
\text { change in } \\
\text { contents }\end{array}$ & Inflow \\
\hline $\begin{array}{l}1 \\
2 \\
3 \\
4 \\
5\end{array}$ & $\begin{array}{ll}2,884 & 78 \\
2,884 & 97 \\
2,885 & 12 \\
2,885 & 25 \\
2,885 & 37\end{array}$ & $\begin{array}{r}+3,900 \\
+7,300 \\
+10,800 \\
+7,900 \\
+9,100\end{array}$ & $\begin{array}{l}13,900 \\
17,100 \\
17,400 \\
20,000 \\
21,200\end{array}$ & $\begin{array}{ll}2,891 & 22 \\
2,891 & 40 \\
2,891 & 48 \\
2,891 & 58 \\
2,891 & 67\end{array}$ & $\begin{array}{r}+5,600 \\
+10,000 \\
+6,300 \\
+5,600 \\
+5,600\end{array}$ & $\begin{array}{l}38,900 \\
44,300 \\
43,000 \\
47,800 \\
50,100\end{array}$ \\
\hline $\begin{array}{r}6 \\
7 \\
8 \\
9 \\
10\end{array}$ & $\begin{array}{ll}2,885 & 53 \\
2,885 & 63 \\
2,885 & 77 \\
2,885 & 91 \\
2,886 & 11\end{array}$ & $\begin{array}{r}+9,100 \\
+7,300 \\
+8,500 \\
+8,500 \\
+14,000\end{array}$ & $\begin{array}{l}21,600 \\
20,600 \\
20,800 \\
19,300 \\
21,900\end{array}$ & $\begin{array}{ll}2,891 & 77 \\
2,891 & 88 \\
2,892 & 10 \\
2,892 & 81 \\
2,893 & 78\end{array}$ & $\begin{array}{r}+6,300 \\
+7,500 \\
+15,100 \\
+43,800 \\
+60,300\end{array}$ & $\begin{array}{r}49,800 \\
51,500 \\
64,800 \\
97,200 \\
119,000\end{array}$ \\
\hline $\begin{array}{l}11 \\
12 \\
13 \\
14 \\
15\end{array}$ & $\begin{array}{ll}2,886 & 30 \\
2,886 & 48 \\
2,886 & 67 \\
2,886 & 87 \\
2,887 & 11\end{array}$ & $\begin{array}{l}+11,600 \\
+11,000 \\
+11,600 \\
+12,100 \\
+14,100\end{array}$ & $\begin{array}{l}24,500 \\
24,000 \\
23,500 \\
24,500 \\
26,500\end{array}$ & 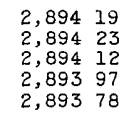 & $\begin{array}{r}+26,800 \\
+3,200 \\
-7,100 \\
-10,300 \\
-10,800\end{array}$ & $\begin{array}{l}89,500 \\
67,500 \\
57,000 \\
52,800 \\
51,600\end{array}$ \\
\hline $\begin{array}{l}16 \\
17 \\
18 \\
19 \\
20\end{array}$ & $\begin{array}{ll}2,887 & 33 \\
2,887 & 65 \\
2,887 & 98 \\
2,888 & 46 \\
2,888 & 98\end{array}$ & $\begin{array}{l}+12,600 \\
+20,100 \\
+20,700 \\
+29,200 \\
+31,300\end{array}$ & $\begin{array}{l}24,000 \\
27,400 \\
31,700 \\
38,200 \\
40,300\end{array}$ & $\begin{array}{ll}2,893 & 64 \\
2,893 & 47 \\
2,893 & 30 \\
2,893 & 15 \\
2,892 & 96\end{array}$ & $\begin{array}{r}-9,500 \\
-12,100 \\
-10,200 \\
-9,500 \\
-12,100\end{array}$ & $\begin{array}{l}51,800 \\
48,100 \\
48,700 \\
48,500 \\
44,900\end{array}$ \\
\hline $\begin{array}{l}21 \\
22 \\
23 \\
24 \\
25\end{array}$ & 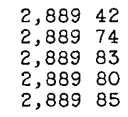 & $\begin{array}{r}+27,300 \\
+19,800 \\
+5,600 \\
-1,000 \\
+3,000\end{array}$ & $\begin{array}{l}43,500 \\
49,500 \\
41,100 \\
33,300 \\
29,400\end{array}$ & $\begin{array}{ll}2,892 & 80 \\
2,892 & 71 \\
2,892 & 93 \\
2,893 & 06 \\
2,892 & 97\end{array}$ & $\begin{array}{r}-10,800 \\
-5,700 \\
+14,000 \\
+8,300 \\
-4,400\end{array}$ & $\begin{array}{l}45,100 \\
42,200 \\
41,300 \\
45,100 \\
48,900\end{array}$ \\
\hline $\begin{array}{l}26 \\
27 \\
28 \\
29 \\
30 \\
31\end{array}$ & 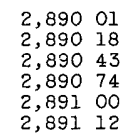 & $\begin{array}{l}+11,100 \\
+10,600 \\
+16,600 \\
+18,100 \\
+16,600 \\
+7,500\end{array}$ & $\begin{array}{l}27,900 \\
24,600 \\
29,200 \\
35,200 \\
38,300 \\
39,000\end{array}$ & $\begin{array}{ll}2,892 & 95 \\
2,892 & 94 \\
2,892 & 95 \\
2,892 & 96 \\
2,892 & 93\end{array}$ & $\begin{array}{r}-1,900 \\
0 \\
+2,500 \\
-1,900 \\
-700 \\
-\end{array}$ & $\begin{array}{l}50,000 \\
49,700 \\
42,500 \\
41,000 \\
35,000 \\
-\end{array}$ \\
\hline Change in contents & - & $+395,900$ & - & - & $+113,900$ & - \\
\hline
\end{tabular}


Elevation, in feet, and computed inflow, in cubic feet per second, at indicated time, 1964, of Flathead Lake at Somers, Mont

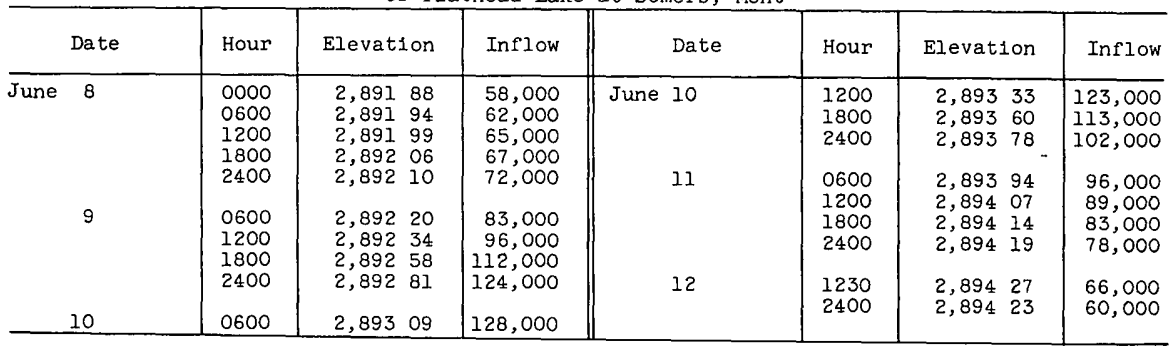

\section{(201) 12-3720 Flathead River near Polson, Mont}

Location --Lat $47^{\circ} 40^{\prime} 50^{\prime \prime}$, long $114^{\circ} 15^{\prime} 10^{\prime \prime}$, in NW $\frac{1}{4} \mathrm{SE} \frac{1}{4} \sec 11, \mathrm{~T} 22 \mathrm{~N}, \mathrm{R} 21 \mathrm{~W}$, on left bank half a mile downstream from Kerr Dam, 4 miles west of Polson, and 5 miles downstream from Flathead Lake

Drainage area $--7,096 \mathrm{sq} \mathrm{mi}$

Gage-he1ght record --Water-stage recorder punch tape Datum of gage is 2,693 $70 \mathrm{ft}$ above mean sea level (levels by The Montana Power Co )

Discharge record --Stage-discharge relation defined by current-meter measurements

Maxima --June 1964 Discharge, 66,800 0815 hours June 12 (gage helght, $1799 \mathrm{ft}$ ) 1907 to May 1964 Discharge, $82,800 \mathrm{cfs}$ May 29, 1928 (gage height, $172 \mathrm{ft}$, at site 6 miles downstream and datum of $2,62920 \mathrm{ft}$ above mean sea level (riverprofile survey)

Flood in June 1894 reached a stage of about $21 \mathrm{ft}$, present datum (discharge, about $110,000 \mathrm{cfs}$ ) from lake elevation-discharge study

Remarks --Flow regulated by Hungry Horse Reservoir since September 1951 (see

station 189), and by Flathead Lake (Kerr Dam) since April 1938 (see station 199)

Mean discharge, in cubic feet per second, 1964

\begin{tabular}{|c|c|c|c|c|c|c|c|c|}
\hline Day & May & June & Day & May & June & Day & May & June \\
\hline \multicolumn{7}{|c|}{$\begin{array}{l}\text { Monthly mean discharge, in cubic feet per second } \\
\text { Runoff, in acre-feet }\end{array}$} & $\begin{array}{r}15,270 \\
939,200 \\
\end{array}$ & $\begin{array}{r}49,790 \\
2,963,000 \\
\end{array}$ \\
\hline
\end{tabular}

Gage height, in feet, and discharge, in cubic feet per second, at indicated time, 1964

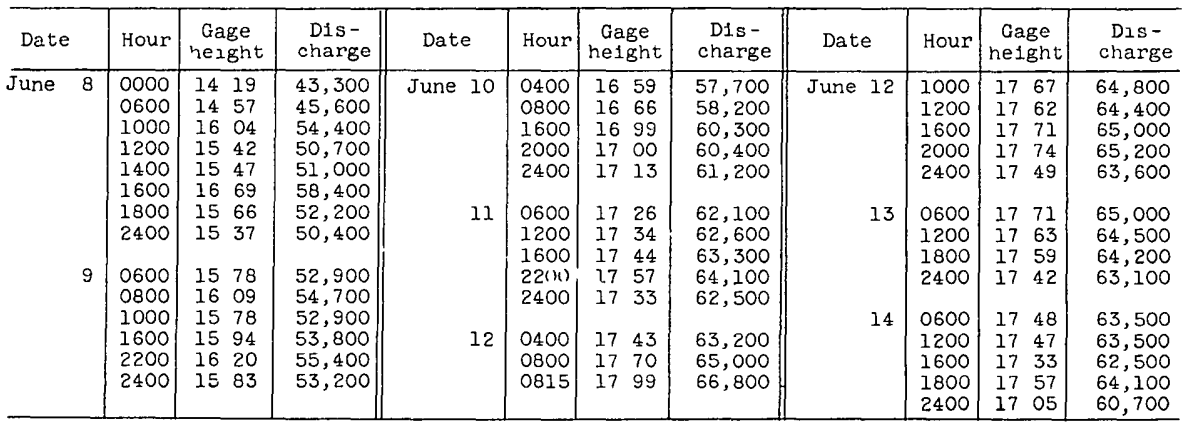




\section{(202) 12-3743 M111 Creek near Nlarada, Mont}

(Crest-stage station)

Location --Lat $47^{\circ} 50^{\prime}$, long $114^{\circ} 41^{\prime}$, in $\mathrm{NE} \frac{\mathrm{l}}{4} \sec 20, \mathrm{~T} 24 \mathrm{~N}, \mathrm{R} 24 \mathrm{~W}$, at bridge on county road, $3 \frac{1}{2}$ miles northwest of Niarada

Drainage area $--280 \mathrm{sq} \mathrm{m} 1$

Gage-helght record --Crest stages only Altitude of gage is 3,000 ft (from topographic map) $\frac{\text { D1scharge record }}{\text { below } 80 \mathrm{cfs}}-$ Stage-discharge relation defined by current-meter measurements

Maxima --June 1964 Discharge, $24 \mathrm{cfs}$ June 8 (gage height, $062 \mathrm{ft}$ )

1959 to May 1964 Discharge, $140 \mathrm{cfs}$ May 1, 1961 (gage height, $142 \mathrm{ft}$ )

(203) 12-3757 South Fork Garden Creek near Hot Springs, Mont

(Crest-stage station)

Location --Lat $47^{\circ} 39^{\prime}$, long $114^{\circ} 43^{\prime}$, in $\operatorname{SW} \frac{1}{4} \sec 20$, T $22 \mathrm{~N}, \mathrm{R} 24 \mathrm{~W}$, at bridge on county road, 3 miles north of Hot Springs

Drainage area $-329 \mathrm{sq} m 1$

Gage-helght record --Crest stages only Altitude of gage is 3,300 ft (from topograph1c map)

Discharge record --Stage-discharge relation defined by current-meter measurements below 20 cf's

Maxima --June 1964 Discharge, about $40 \mathrm{cfs}$ June 8 (gage height, $093 \mathrm{ft}$ )

1959 to May 1964 D1scharge, about $45 \mathrm{cfs}$ May 27, 1964 (gage he1ght, $102 \mathrm{ft}$ )

(204) 12-3890 Clark Fork near Plains, Mont

Location --Lat $47^{\circ} 25^{\prime} 50^{\prime \prime}$, long $114^{\circ} 51^{\prime} 20^{\prime \prime}$, In SW $\frac{1}{4} \sec 1$, T $19 \mathrm{~N}, \mathrm{R} 26 \mathrm{~W}$, on right bank 2 miles southeast of Plains and 6 miles downstream from Flathead River

Drainage area $--19,958 \mathrm{sq} \mathrm{mi}$

Gage-he1ght record --Water-stage recorder graph Datum of gage is $2,44934 \mathrm{ft}$ above mean sea level, datum of 1929 (levels by Corps of Engineers)

Discharge record --Stage-discharge relation defined by current-meter measurements $\frac{\text { Maxima }}{17} 48 \mathrm{ft}$ ) 1964 Discharge, $128,000 \mathrm{cfs} 2100$ hours June 11 (gage helght,

1910 to May 1964 Discharge, $134,000 \mathrm{cfs} J u n e$ 5, 1948 (gage height, $1917 \mathrm{ft}$ )

Remarks --Flow partly regulated by Hungry Horse Reservolr and Flathead Lake (see stations 189,200$)$ Many diversions above stations

Mean discharge, in cub1c feet per second, 1964

\begin{tabular}{|c|c|c|c|c|c|c|c|c|}
\hline Day & May & June & Day & May & June & Day & May & June \\
\hline \multicolumn{7}{|c|}{$\begin{array}{l}\text { Monthly mean discharge, in cubic feet per second } \\
\text { Runoff, in acre-feet }\end{array}$} & $\begin{array}{r}35,410 \\
2,177,000\end{array}$ & $\begin{array}{r}90,860 \\
5,406,000\end{array}$ \\
\hline
\end{tabular}


Gage height, in feet, and discharge, in cub1c feet per second, at indicated time, 1964, of

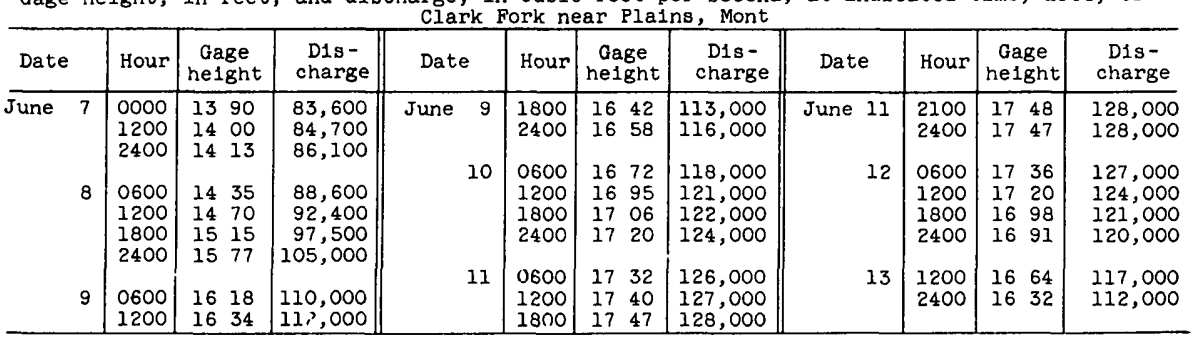




\section{SELECTED REFERENCES}

Bodhaine, G L , 1963, Indirect measurement of peak discharge through culverts U S Geol Survey open-file rept, $49 \mathrm{p}$

Corbett, D M and others, 1943, Stream-gaging procedure, a manual describing methods and practices of the Geological Survey U S Geol Survey WaterSupply Paper $888,245 \mathrm{p}$

Corps of Engineers, U S Army, 1964a, Report on flood of June 1964, upper Flathead River basin, upper Clark Fork basin U S Army Engıneer Dist, Seattle, Wash , $13 \mathrm{p}$

1964b, Report on the flood of June 1964 in the upper Missourl River basin in Montana U S Army Engineer Dist, Omaha, Nebr, $23 \mathrm{p}$

Dalrymple, Tate, and others, 1937, Major Texas floods of 1936 U S Geol Survey Water-Supply Paper 816, $146 \mathrm{p}$

Department of Northern Affairs and National Resources, 1953, Flood of June 1953 In the south Saskatchewan River basin Water Resources Paper 113F, Ottawa, Canada, $228 \mathrm{p}$

Dickson, $R$ R, 1964, The weather and clrculation of June 1964 U S Weather Bur, Monthly Weather Rev, $v$ 92, no 9, p 428-432

Dightman, R A, 1950, Montana Marias basin rainstorm, June 16-17, 1948 U S Weather Bur, Monthly Weather Rev, $\mathrm{v} 78$, no $1, \mathrm{p}$ 6-12

Farnes, P E, and Cook, S E, 1964, Special snow surveys as of June 16-18, 1964 Water Supply Outlook, Federal-State-Private Coop Snow Surveys for Montana, $4 \mathrm{p}$

Fulks, J R, 1935, Rate of precipitation from adiabatically ascending air U S Weather Bur, Monthly Weather Rev, $v 63$, no 10

Haltiner, G J, and Martin, F L , 1957, Dynamical and physical meteorology New York, McGraw-Hill Book Co , 470 p

Johnson, Holl1ster, 1936, The New York State flood of July 1935 U S Geol Survey Water-Supply Paper 773-E, p 233-268

Kindsvater, C E, and others, 1953, Computation of peak discharge at contractions U S Geol Survey Circ 284, $34 \mathrm{p}$

Petterssen, Sverre, 1956, Weather analysis and forecasting, v 2 New York, McGraw-Hill Book Co , 266 p

Soll Conservation Service, 1964, Summary of snow survey and soil moisture measurements for Montana, 1922-64 U S Department of Agriculture, $217 \mathrm{p}$

Thompson, J C , and Collins, G O, 1953, A generallzed study of precipitation forecasting U S Weather Bur, Monthly Weather Rev, v 81, no 4

Tracy, H J, 1957, Discharge characteristics of broad-crested weirs U S Geol Survey Circ 397, $15 \mathrm{p}$

U S Geological Survey, 1949, Floods of May-June 1948 in Columbia River basin U S Geol Survey Water-Supply Paper 1080, $476 \mathrm{p}$

1957, Floods of May-June 1953 in Missouri River basin in Montana U S Geol Survey Water-Supply Paper 1320-B, p 81-86

1959, Floods of May 18-23 in the Kootenal and the Flathead River basins, Montana and Idaho US Geol Survey Water-Supply Paper 1370-C, p 215-217

1964, Magnitude and frequency of floods in the United States, Part 12, Pacific slope basins in Washington and upper Columbia River basin U S Geol Survey Water-Supply Paper 1687, $337 \mathrm{p}$

1966, Magnitude and frequency of floods in the United States, Part 6-A, Missouri River basin above Sioux City Iowa U S Geol Survey Water-Supply Paper $1679,471 \mathrm{p}$

U S Weather Bureau and U S Army Corps of Engineers, 1945, Storm rainfall in the United States, Depth-Area-Duration Data

U S Weather Bureau, 1960a, Climates of the States, Montana Climatography of the United States No $60-24,20 \mathrm{p}$ 
$1960 \mathrm{~b}$, Generalized estimates of probable maximum precipitation for the United States west of the 105th meridian for areas to 400 square miles and durations to 24 hours Tech Paper $38,66 \mathrm{p}$

1961 , Synoptic meteorology as practiced by the National Meteorological Center The NAWAC Manual, pt 11, p 33-34

1964, Climatological data, Montana U S Weather Bur, v 67, no 5

Wolman, M G , and Eiler, J P, 1958, Reconnaissance study of erosion and deposition produced by the flood of August 1955 in Connecticut Am Geophys Union Trans, v 39, no $1, \mathrm{p}$ 1-14 
- 


\section{INDEX}

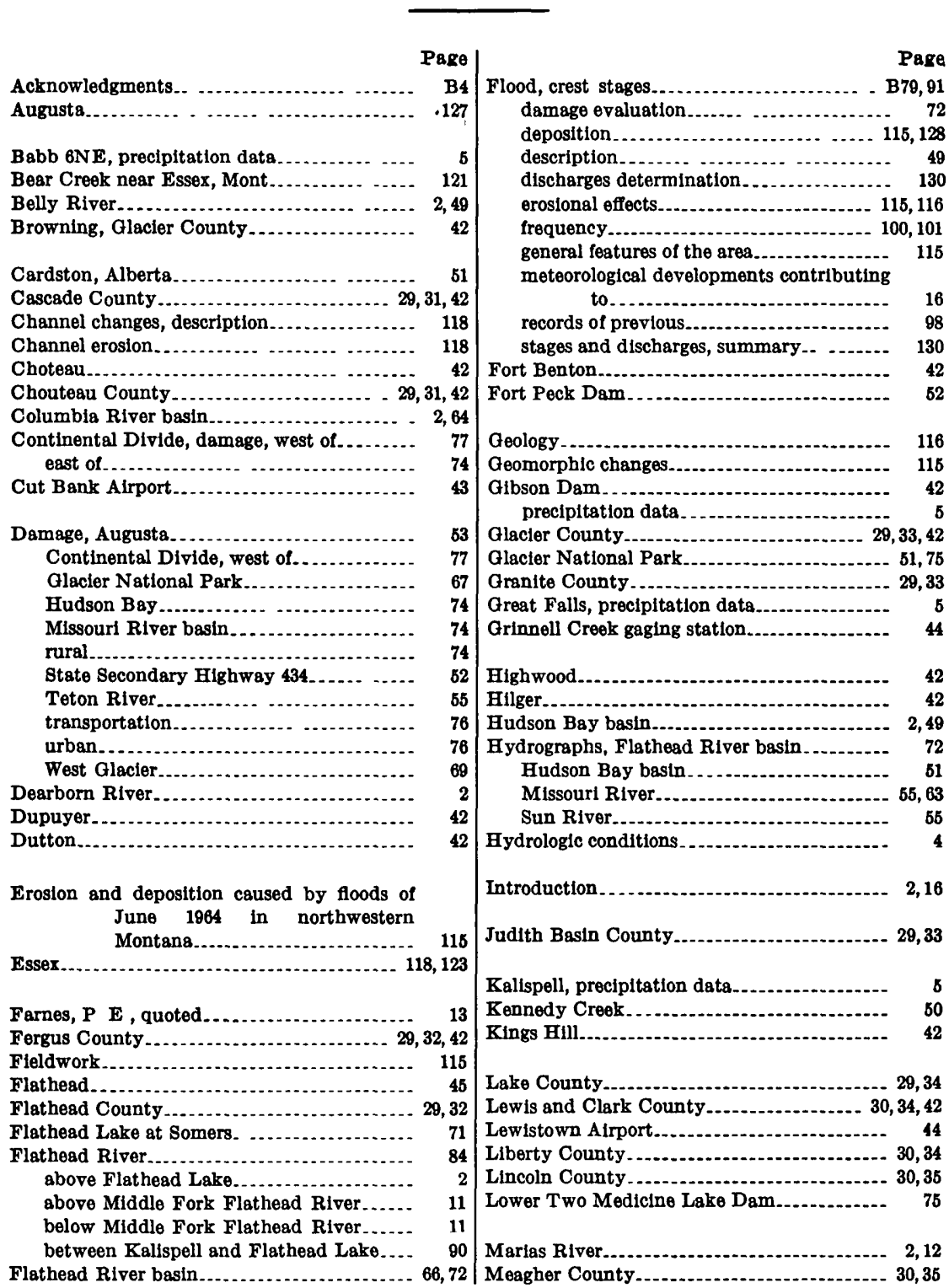




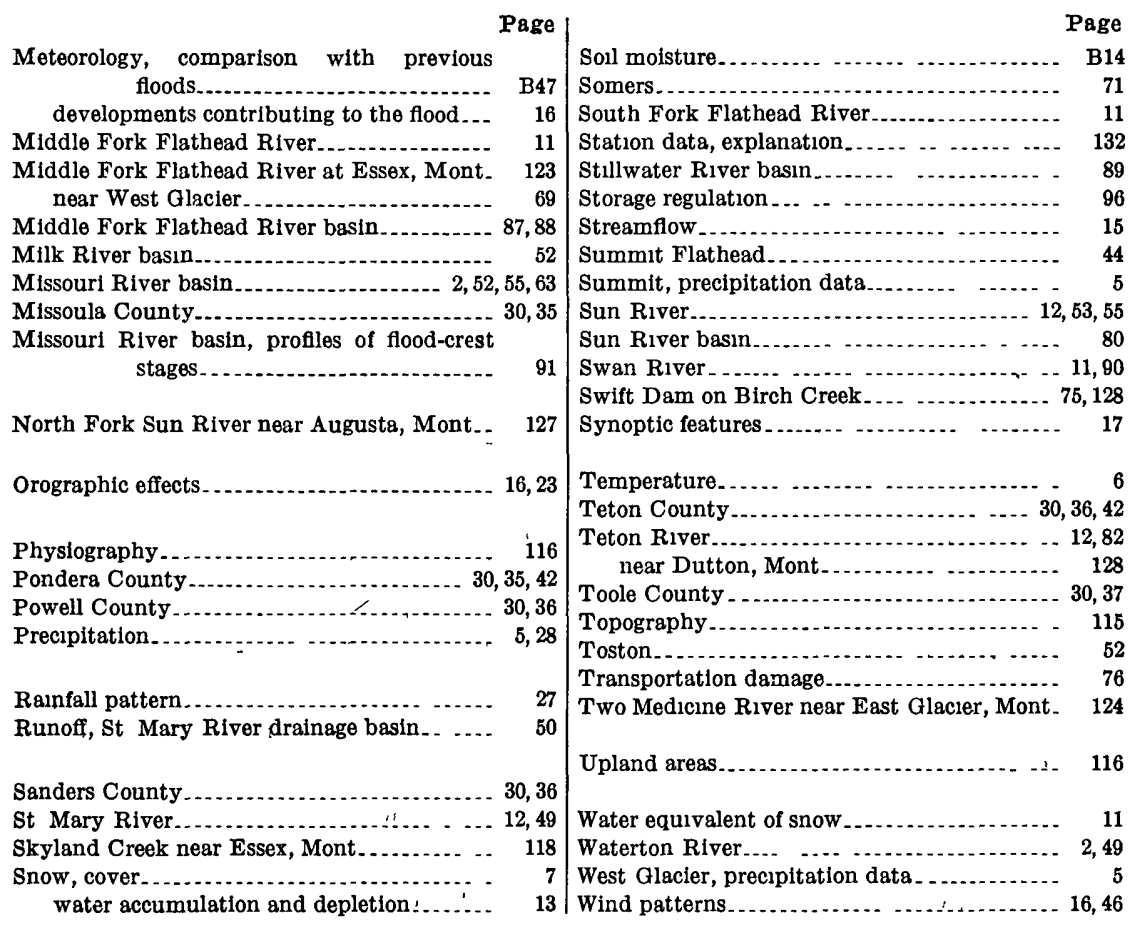

